\title{
Environmental Report 2000
}

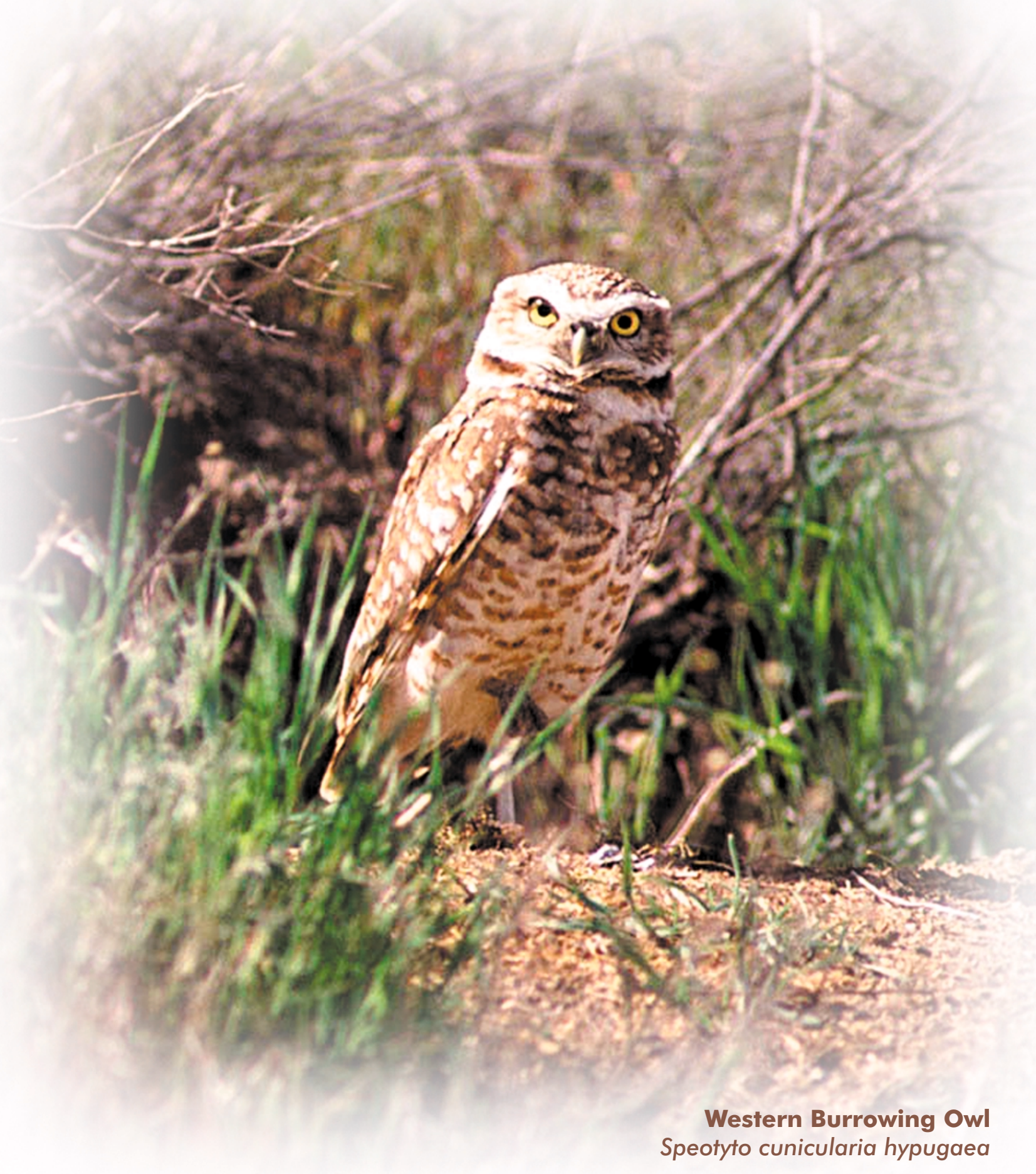

Lawrence Livermore National Laboratory 


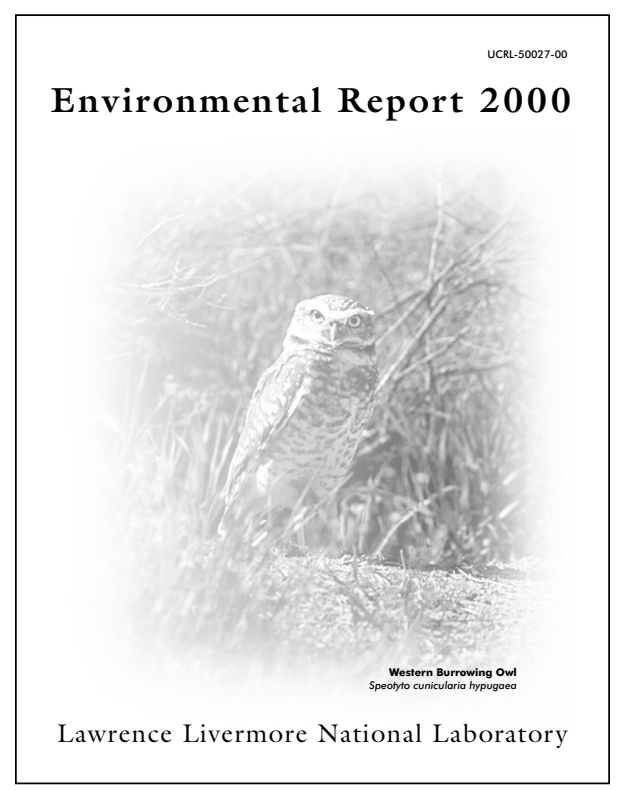

\section{Composition}

Beverly L. Chamberlain

\section{Art and Design}

Brett S. Clark

\section{Cover}

The western burrowing owl (Speotyto cunicularia hypugaea) is listed as a species of Concern on both a state and federal level and has nearly vanished from its historic range in the San Francisco Bay Area. This small owl, approximately 9 inches tall, has cryptic coloration and can be found nesting underground in prairie, agricultural, and desert habitats of western North America. The owl commonly perches on top of the mound outside its burrow and may be visible in the day or at night. The diet of the burrowing owl in the Bay Area typically consists of beetles and Jerusalem crickets in the summer and mice during the winter.

Site 300 hosts a small but significant population of burrowing owls that have adapted to the grassland habitat of the Altamont Pass area with its steeply angled slopes and ground features. Owl pairs on site express strong fidelity toward nest sites. In the spring, they can be found nesting in inactive badger dens and guarding a 2 - to 3 -acre foraging territory surrounding the den. The owl is protected at both Site 300 and the Livermore main site; exclusion zones are posted annually around active burrows to prevent adverse impacts from laboratory activities. Owls nesting in the northern buffer zone of the main site have not been sighted in several years.

Owls in northern California are considered migratory while other populations in central and southern California are predominately nonmigratory. Site 300 appears to be in a transition zone and both migratory and nonmigratory owls are thought to be present. LLNL wildlife biologists have recently color-banded some breeding owls at Site 300 to collect information on pair bonds and distribution unique to this area.

Cover photo: Nova Development Corporation

For further information about this report contact: Bert Heffner, LLNL Public Affairs Department, P.O. Box 808, Livermore, CA 94550, (510) 424-4026. This report can be accessed on the Internet at http://www.llnl.gov/saer. It is also available to DOE employees and DOE contractors from: Office of Scientific and Technical Information, P.O. Box 62, Oak Ridge, TN 37831 and to the public from: National Technical Information Service, U.S. Department of Commerce, 5285 Port Royal Road, Springfield, VA 22161.

This document was prepared as an account of work sponsored by an agency of the United States Government. Neither the United States Government nor the University of California nor any of their employees makes any warranty, express or implied, or assumes any legal liability or responsibility for the accuracy, completness, or usefulness of any information, apparatus, product, or process disclosed, or represents that its use would not infringe on privately owned rights. References herein to any specific commercial product, process, or service by trade name, trademark, manufacturer, or otherwise does not necessarily constitute or imply its endorsement, recommendation, or favoring by the United States Government

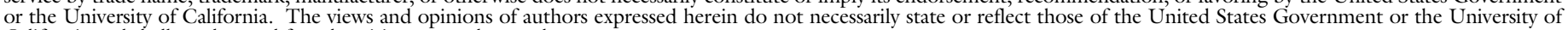
California and shall not be used for advertising or product endorsement purposes. 


\section{Environmental Report 2000}

\section{Authors}

Arthur H. Biermann

Paris E. Althouse

Nicholas A. Bertoldo

Allen R. Grayson

Richard G. Blake

Robert J. Harrach

Jennifer M. Larson

Shari L. Brigdon

Donald H. MacQueen

Richard A. Brown

Sandra Mathews

Chris G. Campbell

Barbara Nisbet

Eric Christofferson

$S$. Ring Peterson

Lucinda M. Clark

Michael J. Taffet

Karen J. Folks

Gretchen M. Gallegos

Paula J. Tate

Robert J. Vellinger

Robert A. Williams

\section{Editors}

Nancy J. Woods

Laurel L. Powers

September 1, 2001

Lawrence Livermore National Laboratory UCRL-50027-00

Distribution Category UC-702 



\section{Department of Energy \\ Oakland Operations Office \\ 1301 Clay Street \\ Oakland, California 94612-5208}

OCT 092001

Distribution:

Subject: $\quad 2000$ Site Annual Environmental Report (SAER) for the Lawrence Livermore National Laboratory (LLNL)

This report, prepared by LLNL for the Department of Energy, Oakland Operations Office (DOEOAK), provides a comprehensive summary of the environmental program activities at LLNL for calendar year 2000. Site Annual Environmental Reports (SAERs) are prepared annually for all DOE sites with significant environmental activities, and distributed to relevant external regulatory agencies and other interested organizations or individuals.

To the best of my knowledge, this report accurately summarizes the results of the 2000 environmental monitoring, compliance, impacts assessment, and restoration program at LLNL. This assurance can be made based on DOE-OAK and LLNL review of the SAER, and quality assurance protocols applied to monitoring and data analyses at LLNL.

A reader survey form is provided with the SAER to provide comments or suggestions for future versions of the report. Your response is appreciated.

Sincerely,

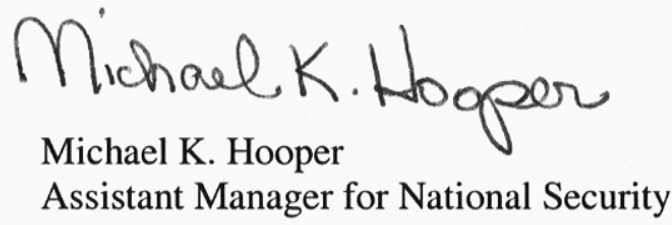





\section{Preface}

The Environmental Report 2000 is prepared for the U.S. Department of Energy (DOE), as required by DOE Order 5400.1 and DOE Order 231.1, by the Environmental Protection Department at Lawrence Livermore National Laboratory (LLNL). The results of LLNL's environmental monitoring and compliance efforts and an assessment of the impact of LLNL operations on the public and the environment are presented in this publication.

To produce a more readable and useful document for our diverse readership, which includes regulators, scientists and engineers, educators, the media, public interest groups, and interested citizens, this report is divided into two volumes: main volume and Data Supplement. The main volume describes LLNL's environmental impact and compliance activities and features descriptive and explanatory text, summary data tables, and plots showing data trends. The summary data include measures of the central tendency of the data (i.e. mean and median), their spread or variability, and their extreme values. The main volume contains the Executive Summary and the Compliance Summary; it features individual chapters on monitoring of air, sewage, surface water, groundwater, soil and sediment, vegetation and foodstuff, and environmental radiation; and it contains chapters on site overview, environmental program information, groundwater investigation and remediation, radiological dose assessment, and quality assurance. Information on both the Livermore site and Site 300 is presented in each chapter. The main volume contains the information of interest to most of our readers and will be distributed. The distribution list for the 2000 report can be accessed from the LLNL Site Annual Environmental Report (SAER) homepage on the Internet at the address provided below. Requests for additions to or deletions from the list can be made on the distribution list webpage.

The Data Supplement provides individual data points, where applicable, some summary data, and more detailed accounts of sample collection and analytical methods. The Data Supplement will be sent only upon request; a card for this purpose is included on the last page of this volume.

Environmental reports covering calendar years 1994 through 2000 can be accessed on the Internet at the address of the LLNL SAER homepage: http://www.llnl.gov/saer. Both the main volume and data supplement volume of each individual report can be viewed in its most up-todate form.

This document is the responsibility of LLNL's Operations and Regulatory Affairs Division of the Environmental Protection Department. Monitoring data were obtained through the combined efforts of the Operations and Regulatory Affairs Division, Environmental Restoration Division, the Chemistry and Materials Science Environmental Services Laboratories, and the Hazards Control Department. Special recognition is deserved for the dedication and professionalism of the technicians who carried out environmental monitoring- 
Gary A. Bear, David J. Castro, Paul C. Dickinson, David Macedo, Charles Hunt, Renee Needens, Terrance W. Poole, Donald G. Ramsey, Terri Crippen, and Robert Williams - and to the data management personnel- Kimberly A. Stanford, Louise Morris, Beth Schad, Jean Seymour, Suzanne Chamberlain, Connie Wells, Della Burruss, Susan Lambaren, Nancy Montez, Lisa Graves, and Sheila Hodgson. Judy Kelly provided secretarial support and collated and distributed drafts.
Special thanks go to Bill Hoppes for his strong support of the project and careful and timely reviews of all the drafts; C. Susi Jackson and Charlene Grandfield for reviewing the chapters; and Karen Folks and Paula Kato for their comments and coordination efforts. In addition, the following people contributed significantly to this report: Keith V. Gilbert, Albert L. Lamarre, Patricia L. Ottesen, Duane W. Rueppel, Nona Sanford, Carol Stoker, Sharlene Markow, and Kim Heyward. 


\section{Table of Contents}

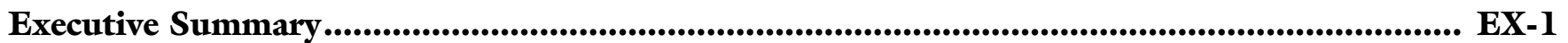

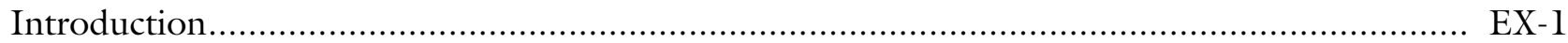

Environmental Monitoring Results .............................................................................. EX-2

Air Surveillance Monitoring ……………................................................................ EX-2

Air Effluent Monitoring ....................................................................................... EX-2

Sewerable Water Monitoring …………………………......................................... EX-3

Surface Water Monitoring ...................................................................................... EX-3

Groundwater Monitoring ………………………............................................... EX-4

Soil and Sediment Monitoring ............................................................................. EX-4

Vegetation and Foodstuff Monitoring ...................................................................... EX-5

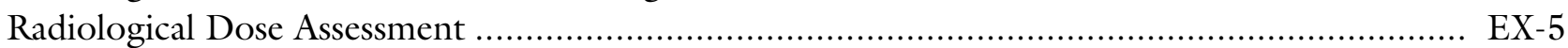

Environmental Compliance and Program Activities ................................................................ EX-6

Groundwater Remediation............................................................................. EX-6

Waste Minimization and Pollution Prevention ……….............................................. EX-6

Air, Wastewater, and Water Compliance........................................................................ EX-7

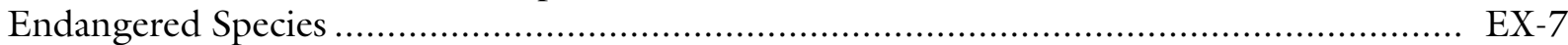

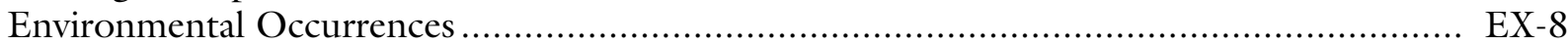

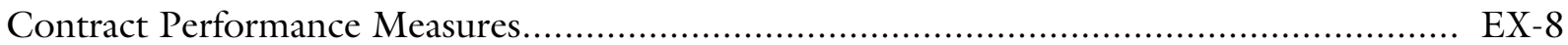

Integrated Safety Management and Work Smart Standards ............................................ EX-8

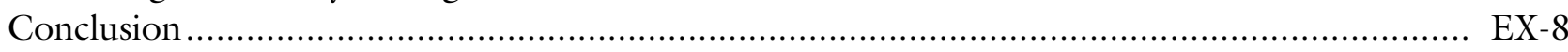

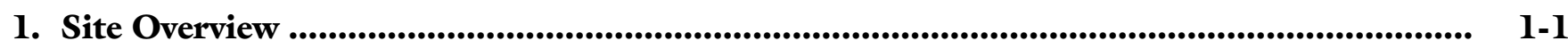

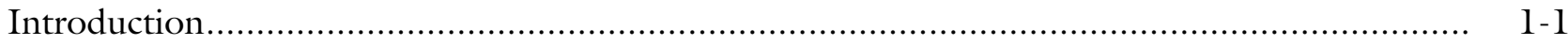

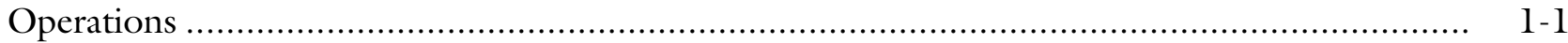

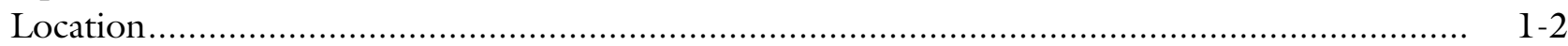

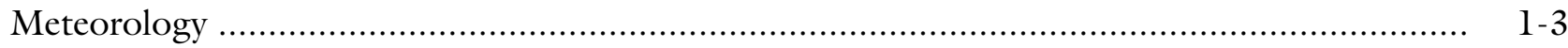

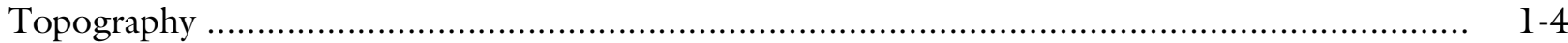

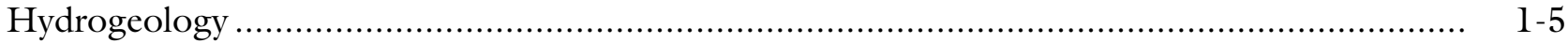

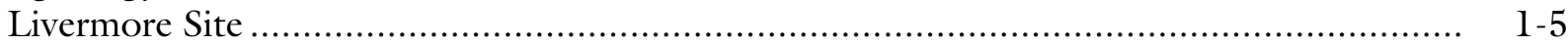

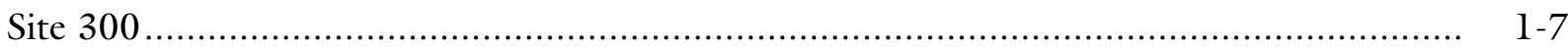

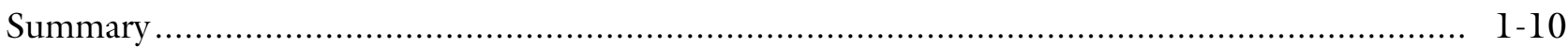

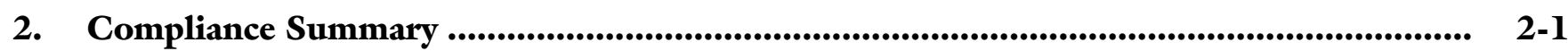

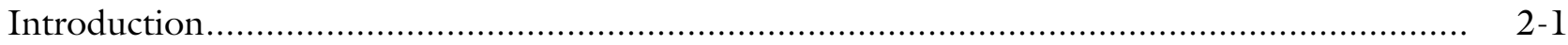

Comprehensive Environmental Response, Compensation and Liability Act ............................... 2-1

Livermore Site Groundwater Project...................................................................... 2-2

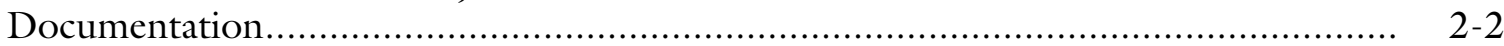

Milestones and Activities .............................................................................. 2-2

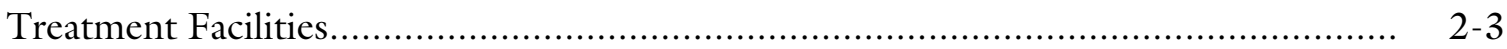

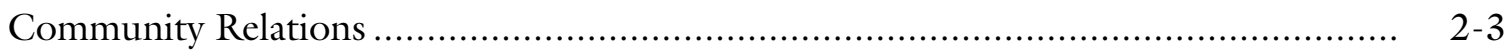


Site 300 CERCLA Project ................................................................................. 2-3

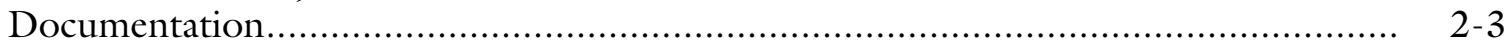

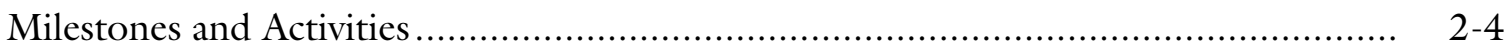

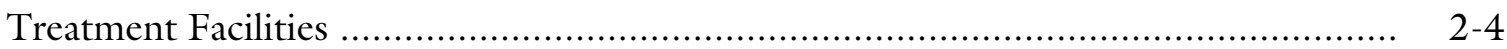

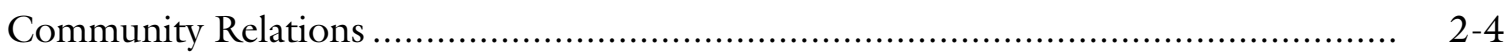

Site Evaluations Prior to Construction ……............................................................... 2- 2-4

Agency for Toxic Substances and Disease Registry Assessment ................................................ 2. 2-4

Superfund Amendment and Reauthorization Act, Title III................................................... 2- 2-5

Clean Air Act—Air Quality Management Activities …………............................................... 2 2-5

National Emission Standards for Hazardous Air Pollutants............................................. 2 2-5

Clean Water Act and Related State Programs .................................................................. 2-11

Groundwater and Surface Water …………........................................................... 2-12

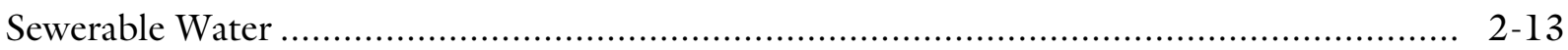

Streambed Alteration Agreements and Nationwide Permits ............................................ 2-15

Tank Management............................................................................................. 2-15

Resource Conservation and Recovery Act and Related State Laws ......................................... 2-15

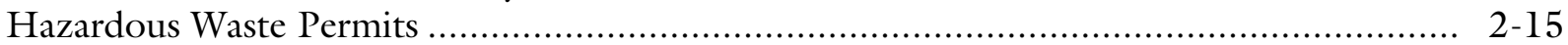

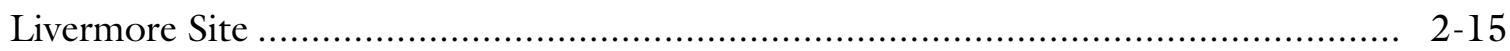

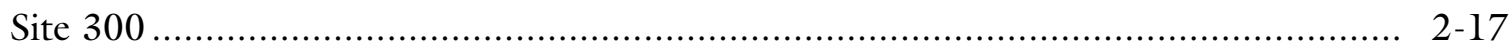

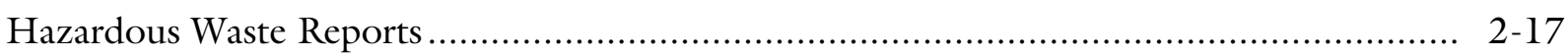

Hazardous Waste Transport Registration ……………................................................ 2-17

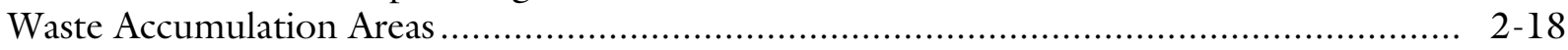

California Medical Waste Management Act ........................................................................ 2-18

Federal Facility Compliance Act................................................................................... 2-18

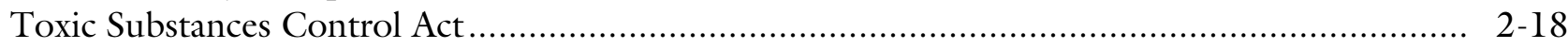

National Environmental Policy Act ........................................................................... 2-19

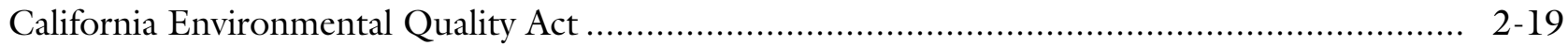

National Historic Preservation Act.............................................................................. 2-19

Endangered Species Acts and Sensitive Natural Resources .................................................... 2-20

Antiquities Act (of 1906): Paleontological Resources ……………….................................. 2-22

Environmental Occurrences.................................................................................... 2-22

Contributing Authors Acknowledgment ………………............................................... 2-24

3. Environmental Program Information ......................................................................................... 3-1

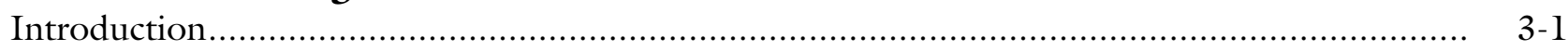

Integrated Environment, Safety, and Health Management System ......................................... 3-1

Work Smart Standards ............................................................................................. $3-2$

Environmental Protection Department ................................................................. $3-3$

Operations and Regulatory Affairs Division ........................................................... $3-4$

Hazardous Waste Management Division ..................................................................... $3-4$

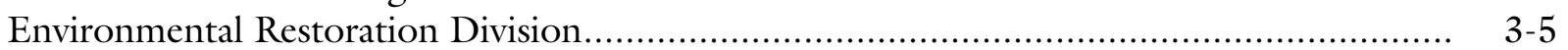

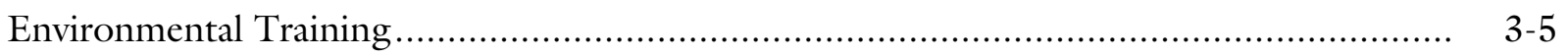

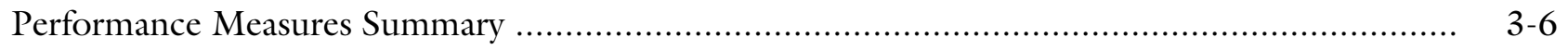

DOE Pollution Prevention Goals................................................................................... $\quad 3-7$

Pollution Prevention Reporting ............................................................................... $\quad 3-7$

Waste Minimization/Pollution Prevention................................................................ $\quad 3-7$

Nonhazardous Solid Waste Minimization.......................................................... 3-10

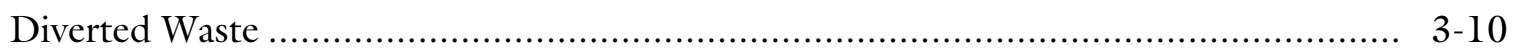


Source Reduction and Pollution Prevention ........................................................ 3-12

Toxic Reporting Inventory Information ....................................................... $3-12$

Current Return-on-Investment Projects ......................................................... 3-12

Review of New Processes or Experiments .................................................... 3-12

Design for Environment .................................................................................. $3-13$

Implementing P2 Employee Training and Awareness Programs................................. 3-13

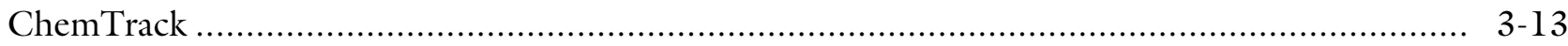

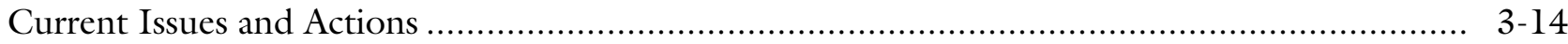

Leaking Underground Fuel Tank Studies......................................................... 3-14

Evaluation of the Use of Ethanol to Replace MTBE in Gasoline................................... 3-14

Initiative to Improve Volatile Organic Compound Process by Using Historical

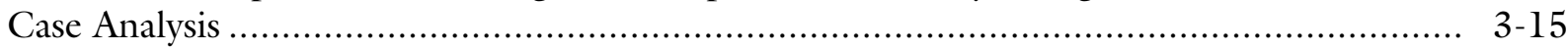

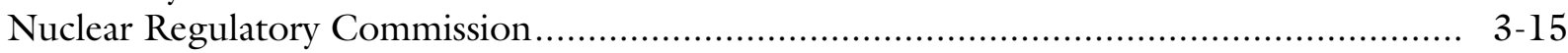

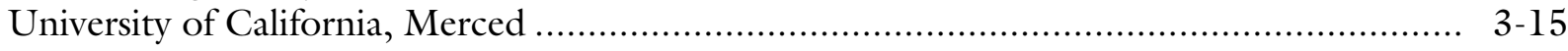

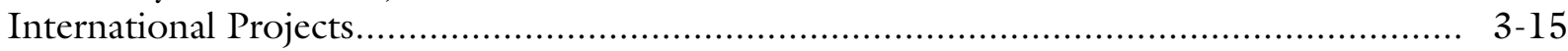

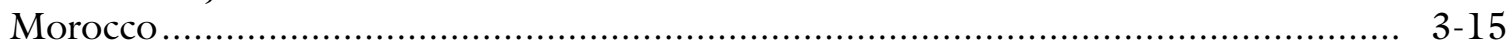

Former Soviet Union/International Science Centers ...................................... 3-16

Response to Spills and Other Environmental Emergencies ......................................... 3-16

LLNL's Other Environmental Programs .................................................................. 3-17

Contributing Authors Acknowledgment ................................................................. 3-17

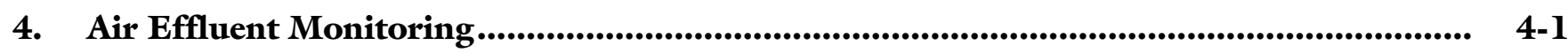

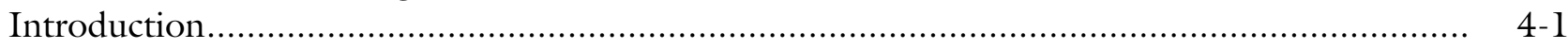

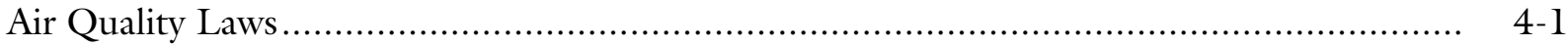

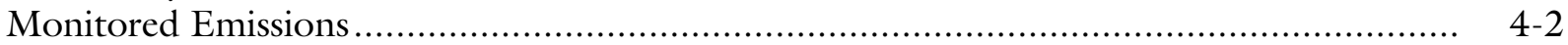

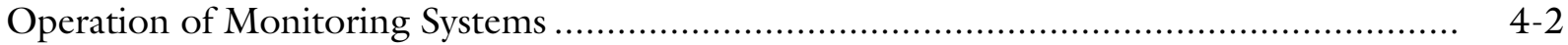

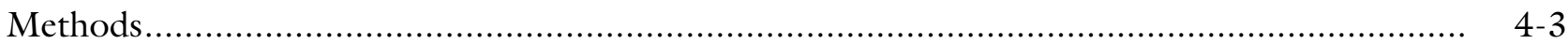

Measured Radioactive Air Emissions ......................................................................... $4-5$

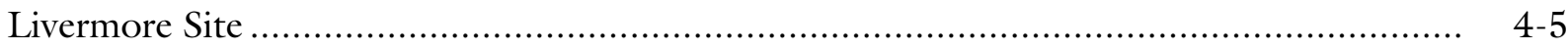

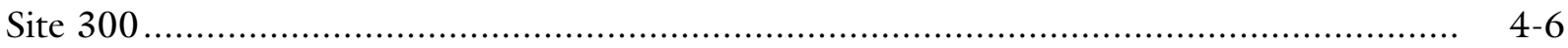

All Potential Sources of Radioactive Air Emissions ....................................................... $4-6$

Nonradioactive Air Emissions ................................................................................... $4-7$

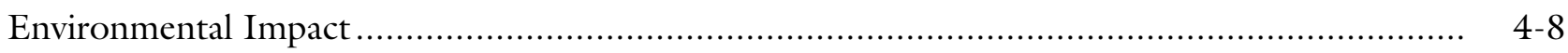

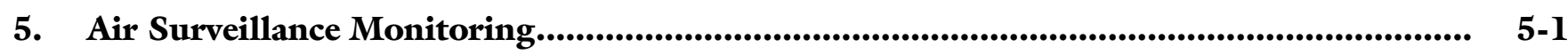

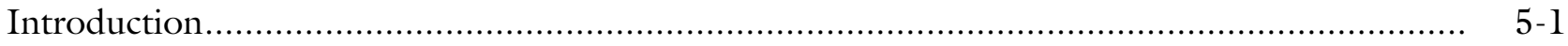

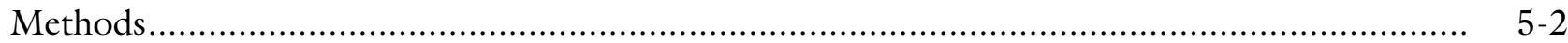

Air Particulate Sampling Locations ................................................................... $5-2$

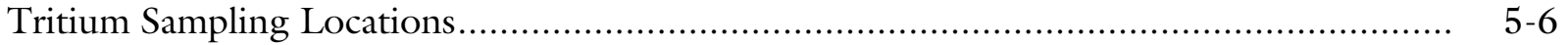

Radiological Analysis ............................................................................. 5

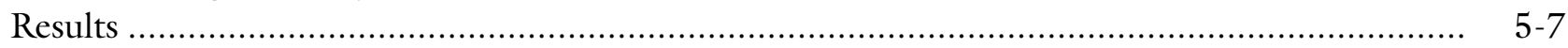

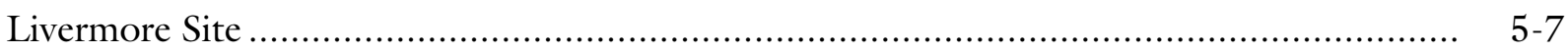

Airborne Radioactivity ................................................................... $5-7$

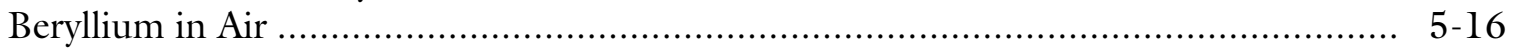

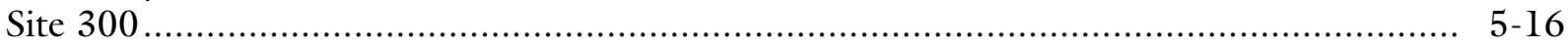

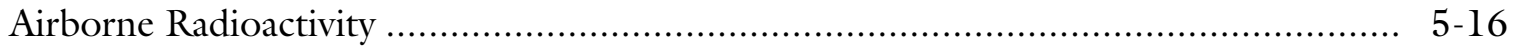

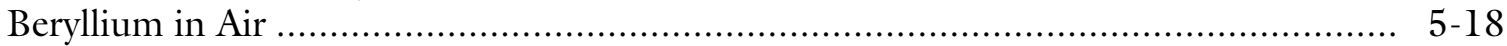


Environmental Impact

5-18

Radoactive Materials

$5-18$

Nonradioactive Materials

5-19

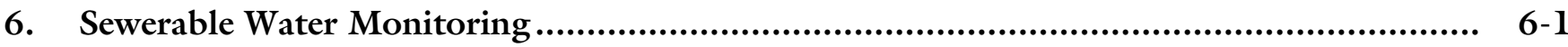

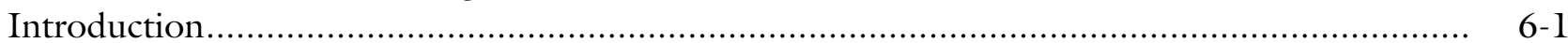

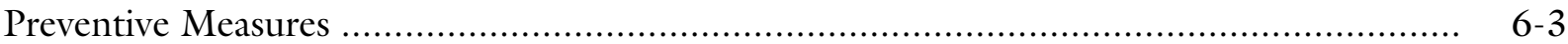

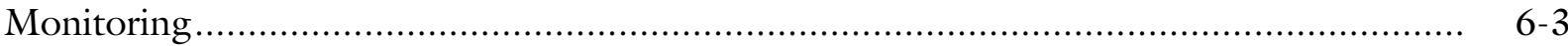

Monitoring at the Sewer Monitoring Station .............................................. $6-3$

Monitoring at the Upstream pH Monitoring Station.................................. $6-4$

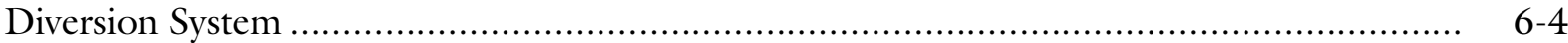

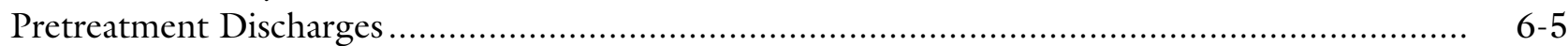

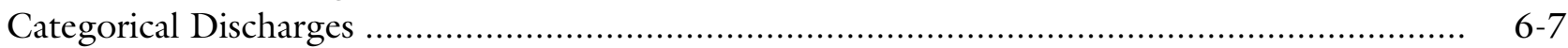

Discharges of Treated Groundwater........................................................................ $6-7$

Radioactive Pollutants in Sewage ................................................................................ 6

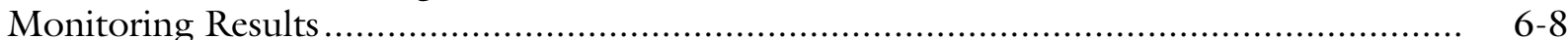

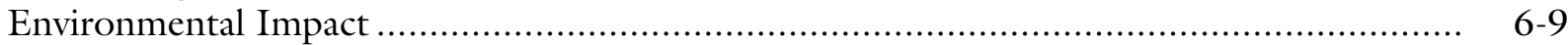

Nonradioactive Pollutants in Sewage ................................................................. 6-13

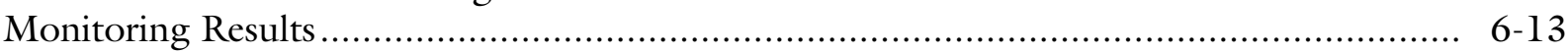

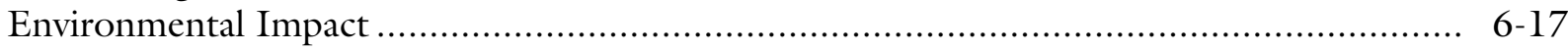

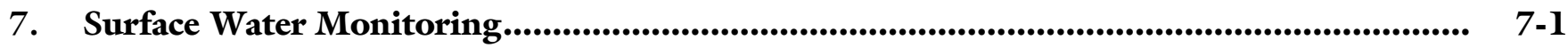

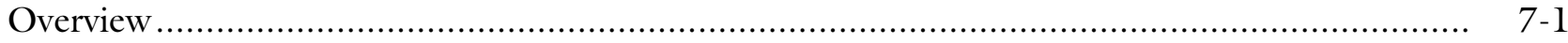

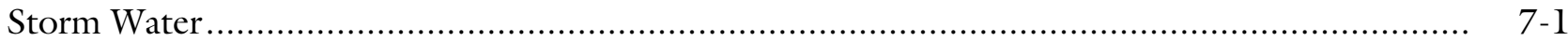

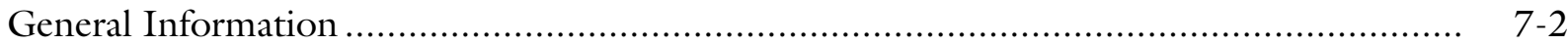

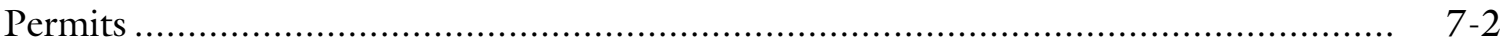

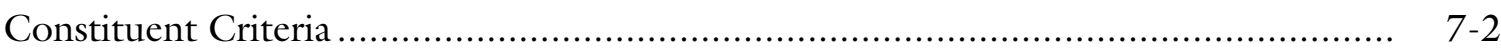

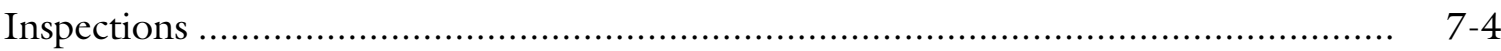

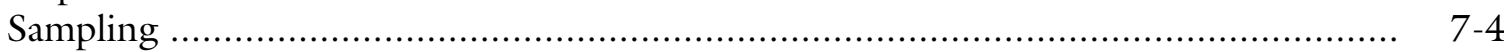

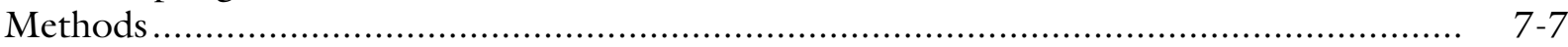

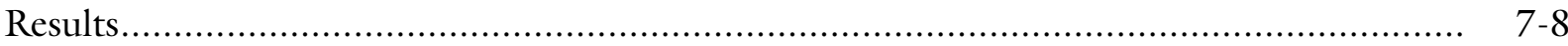

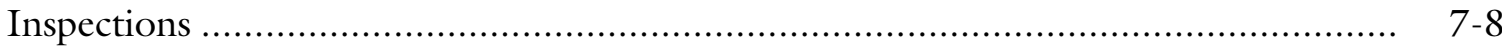

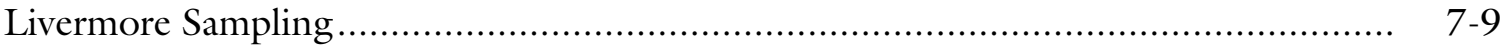

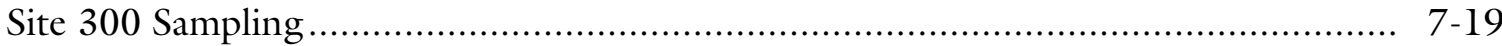

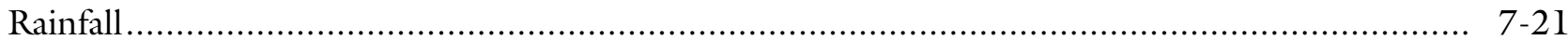

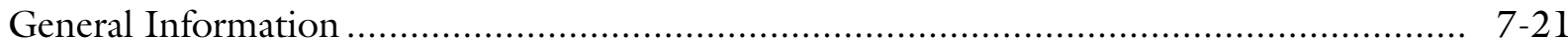

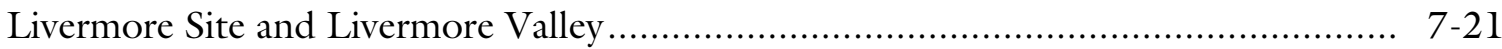

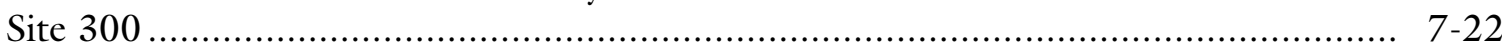

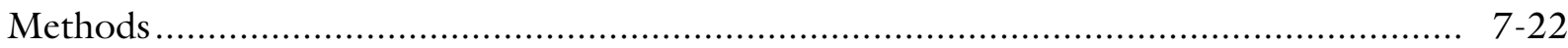

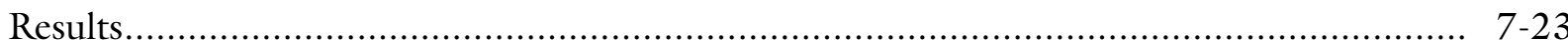

Livermore Site and Livermore Valley ...................................................... $7-23$

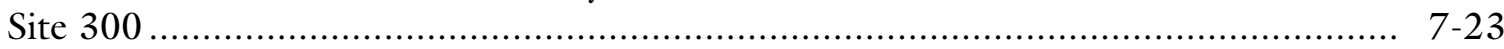

Livermore Site Drainage Retention Basin ............................................................. $\quad 7-23$

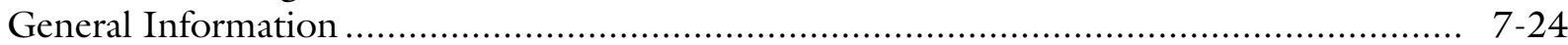

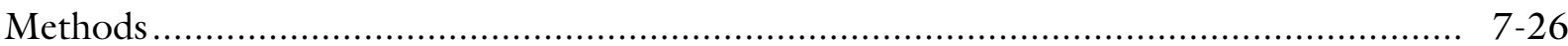

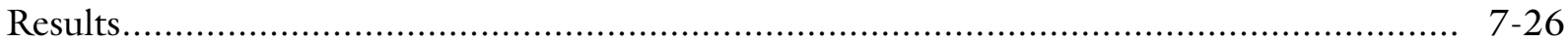

Chemical and Physical Monitoring .................................................................. 7-28

Biological Monitoring .................................................................................... 7-30

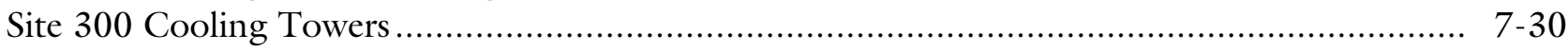

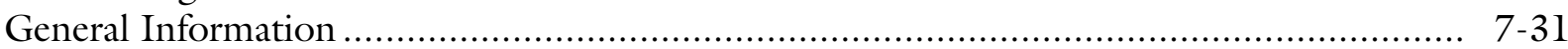


Methods

Results

Site 300 Drinking Water System Discharges................................................................

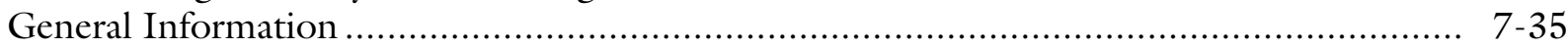

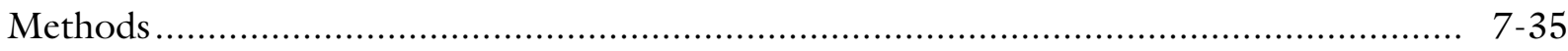

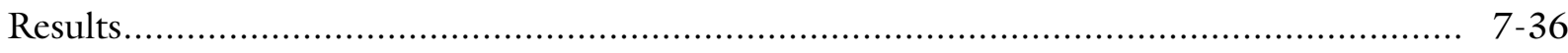

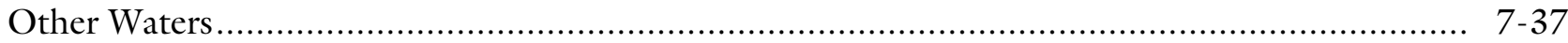

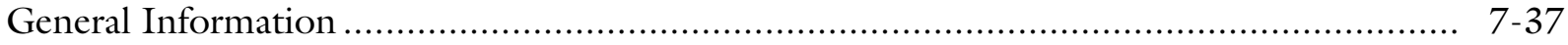

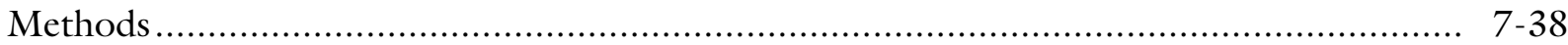

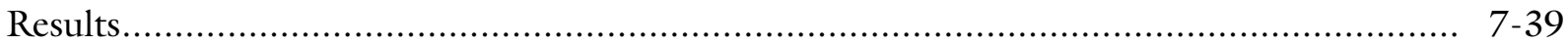

Arroyo Las Positas Maintenance Project....................................................................... $7-40$

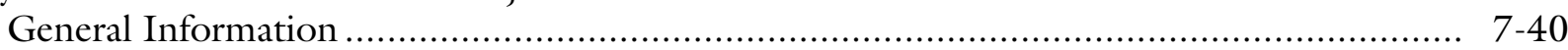

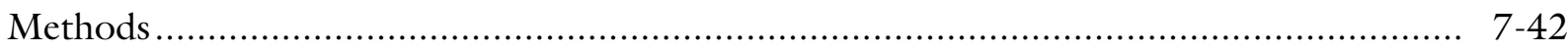

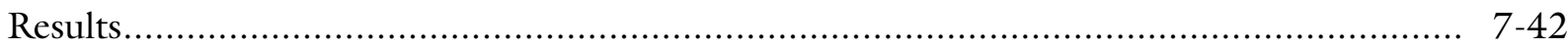

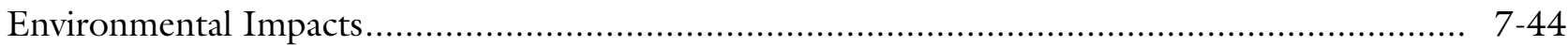

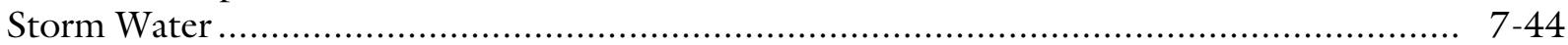

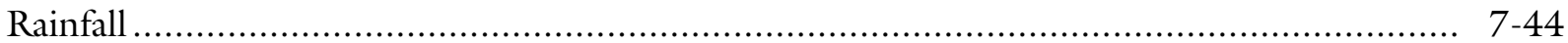

Livermore Site and Livermore Valley ......................................................... $7-44$

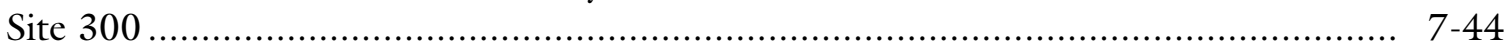

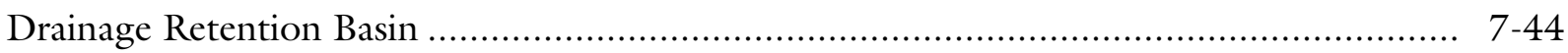

Cooling Towers ............................................................................................ $7-45$

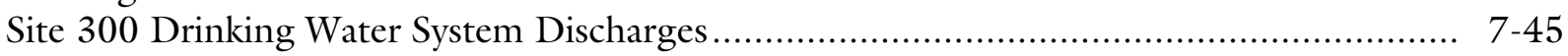

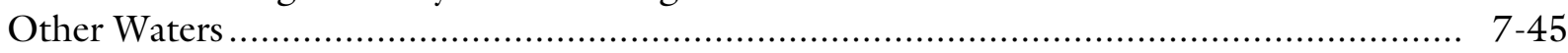

Arroyo Las Positas Maintenance Project ......................................................... $7-45$

8. Groundwater Investigation and Remediation....................................................... 8-1

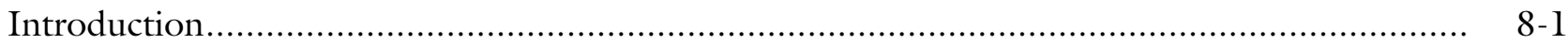

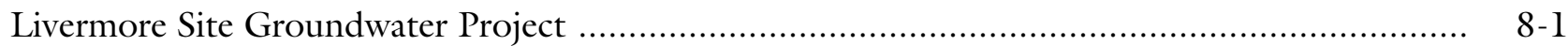

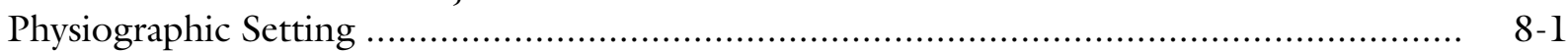

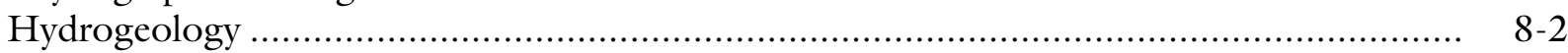

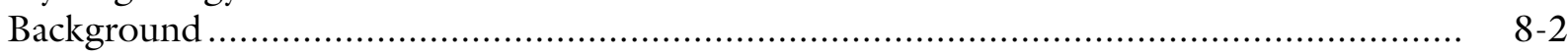

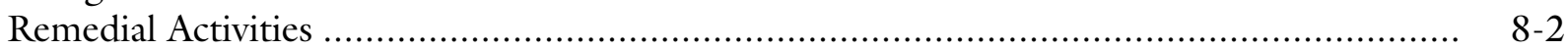

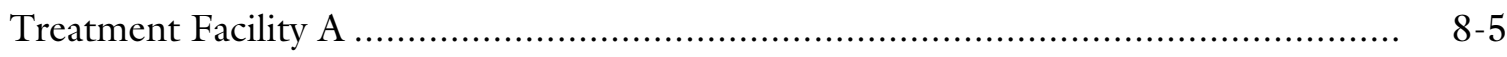

Treatment Facility B ..................................................................... $8-6$

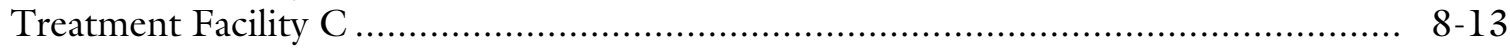

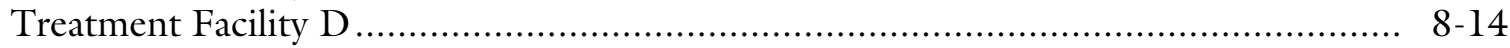

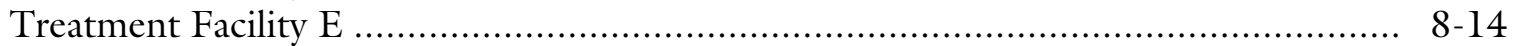

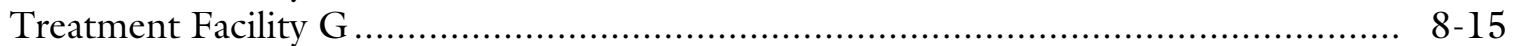

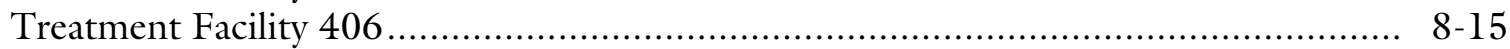

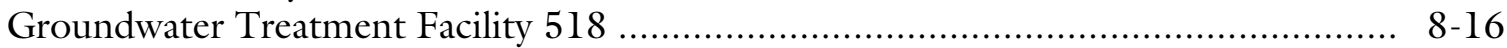

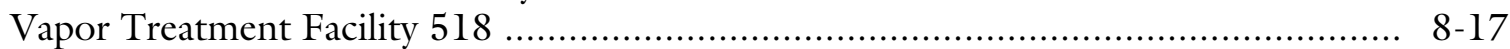

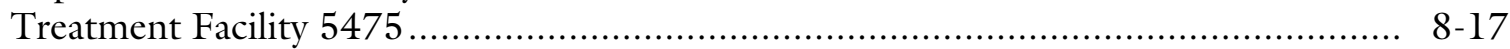

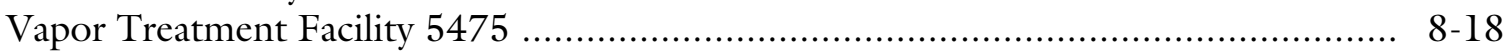

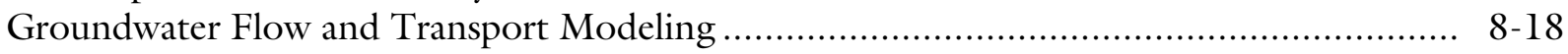

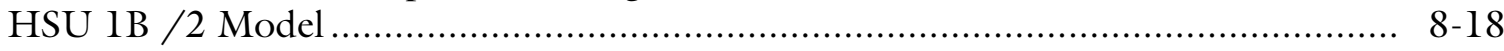

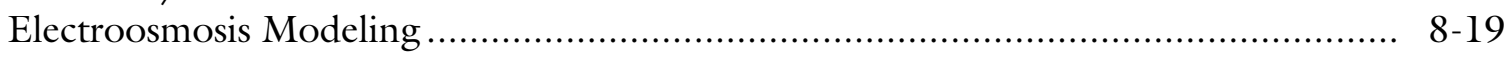

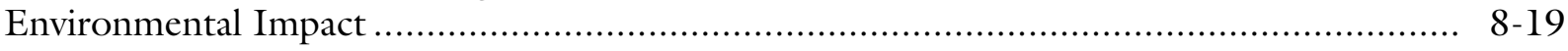

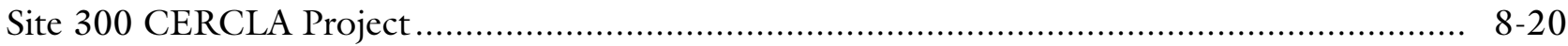

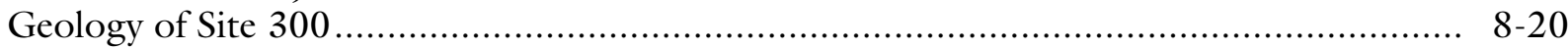




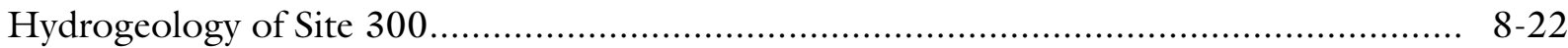

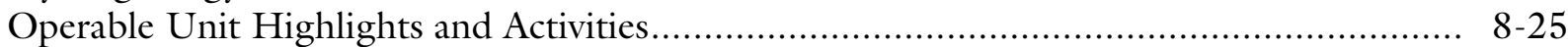

General Services Area Operable Unit .............................................................. 8-25

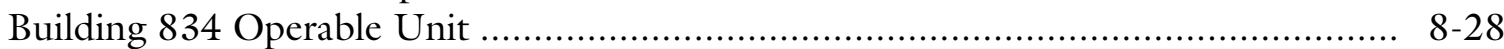

High Explosives Process Area Operable Unit...................................................... 8- 8-30

Building 850/Pits 3 \& 5 Operable Unit ......................................................... 8-32

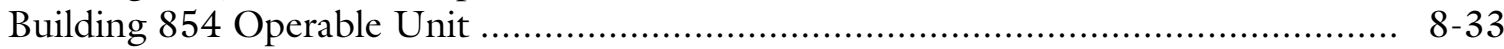

Pit 6 Operable Unit .................................................................................. 8 8 34

Building 832 Canyon Operable Unit...................................................... 8 - 35

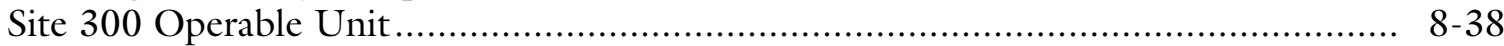

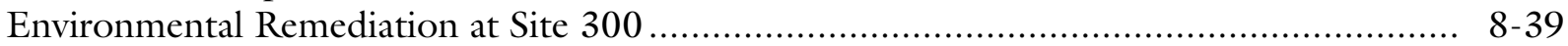

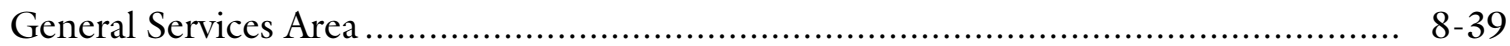

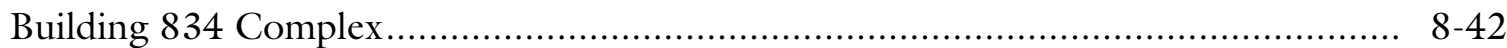

High Explosives Process Area ..................................................................... 8-42

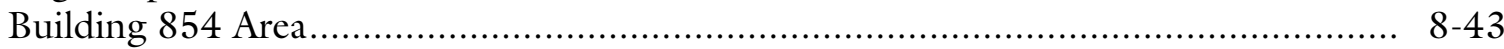

Building 832 Canyon........................................................................ $8-43$

East and West Firing Areas ..................................................................... 8- 8-44

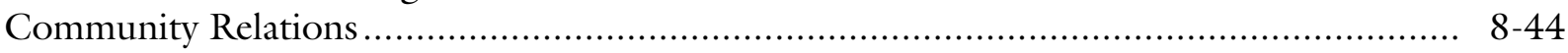

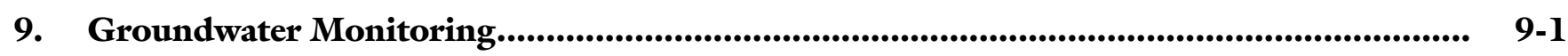

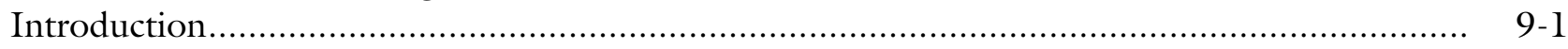

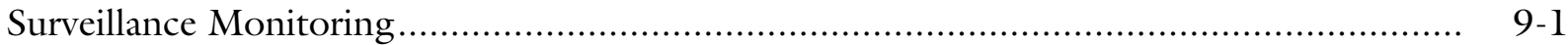

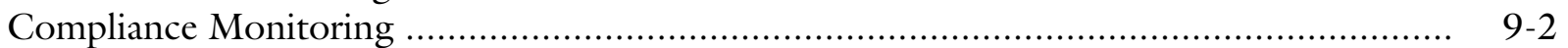

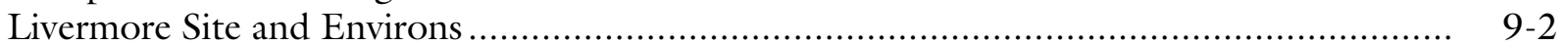

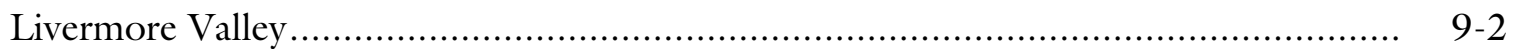

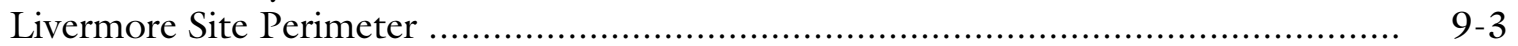

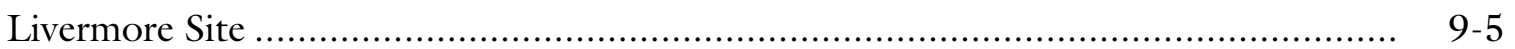

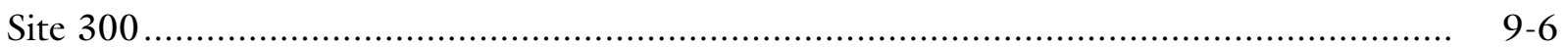

Elk Ravine Drainage Area ...................................................................... 9-8

Corral Hollow Creek Drainage Area............................................................ 9-12

Sampling and Analytical Methods ....................................................................... 9-19

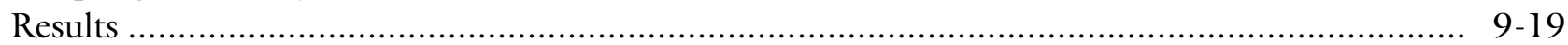

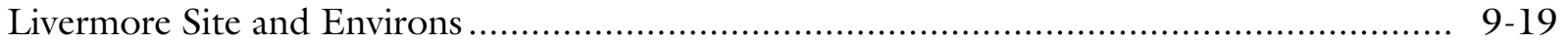

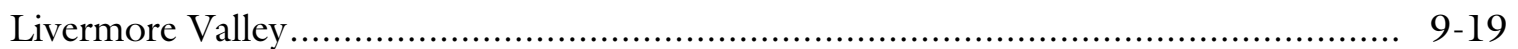

Livermore Site Perimeter ....................................................................... 9-20

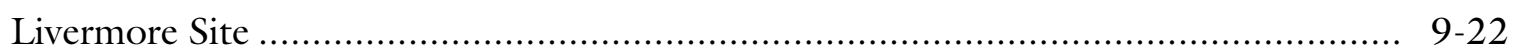

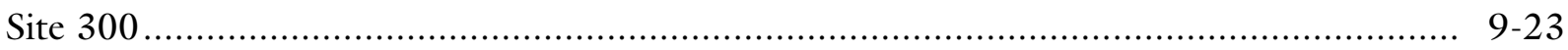

Elk Ravine Drainage Area ............................................................... 9-23

Corral Hollow Creek Drainage Area..................................................... 9-25

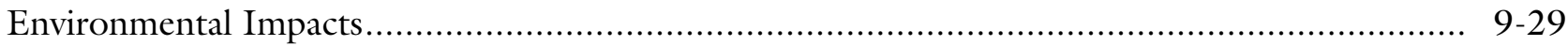

Livermore Site and Environs ..................................................................... 9-29

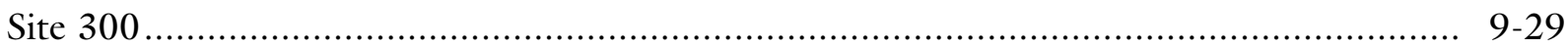

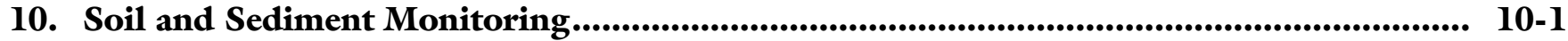

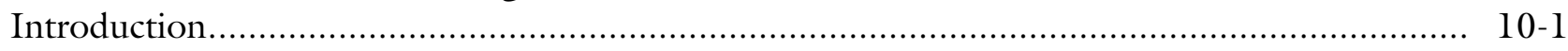

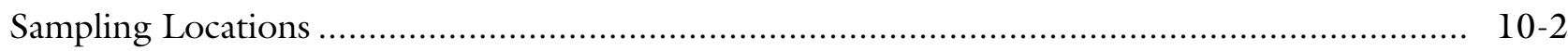

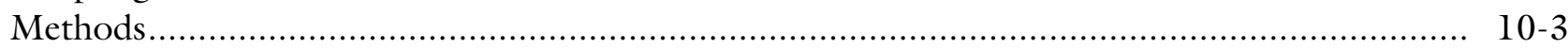

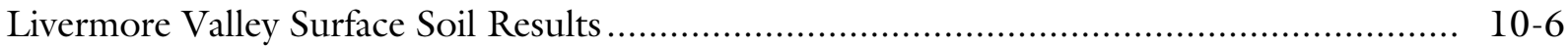

Livermore Site Sediment Results .................................................................... 10-8 
Livermore Site Vadose Zone Soil Results ............................................................ 10-8

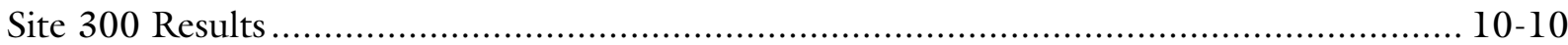

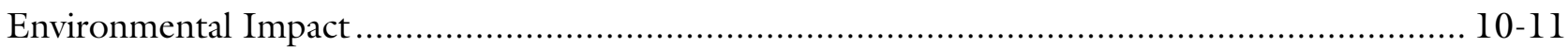

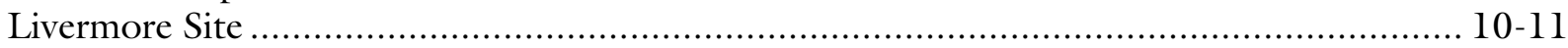

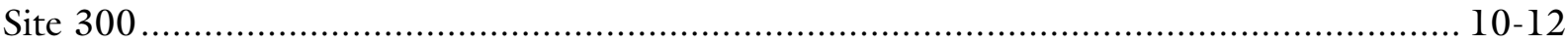

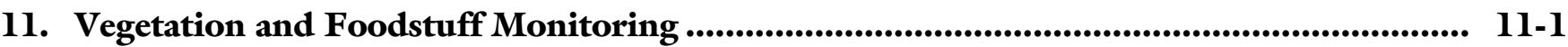

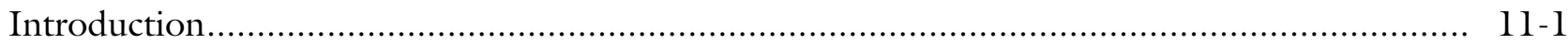

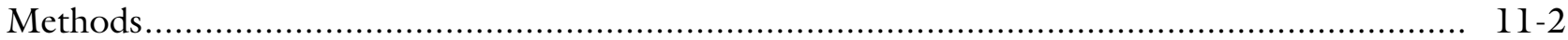

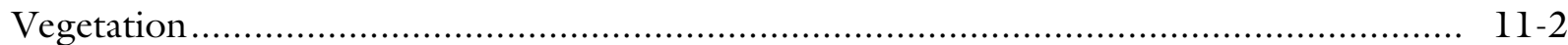

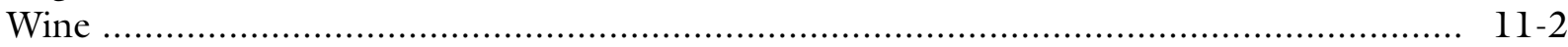

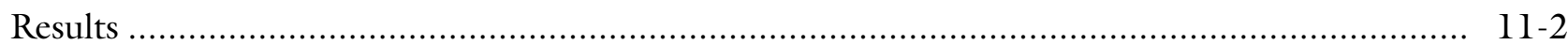

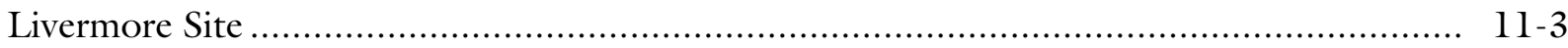

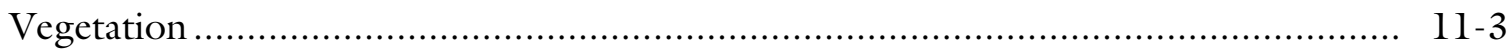

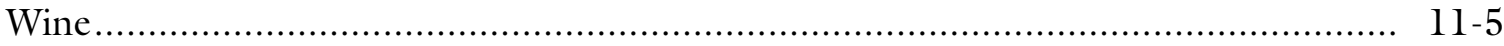

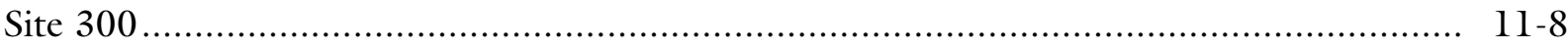

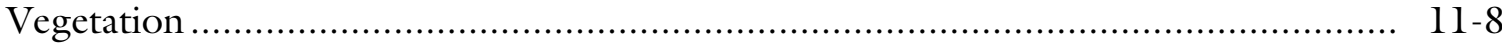

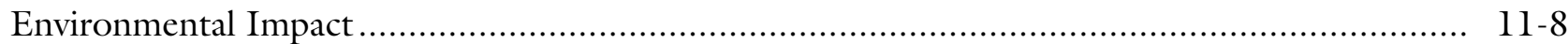

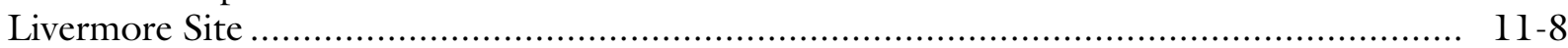

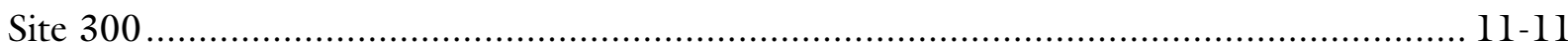

12. Environmental Radiation Monitoring ................................................................ 12-1

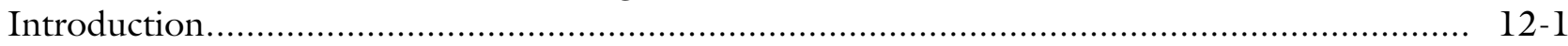

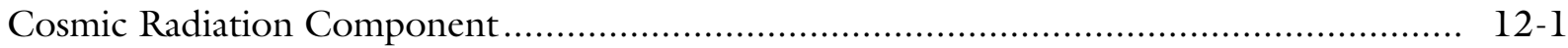

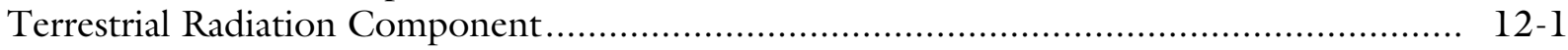

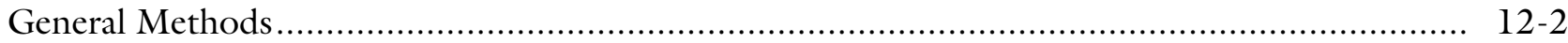

Monitoring Locations....................................................................................... 12-2

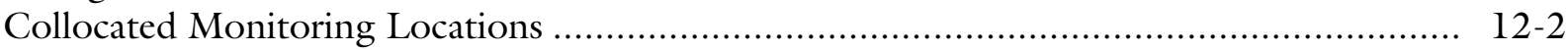

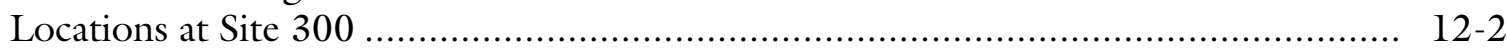

Results of Gamma Monitoring................................................................................... 12-4

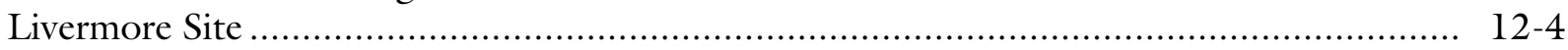

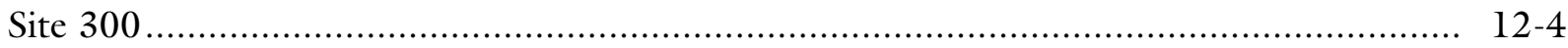

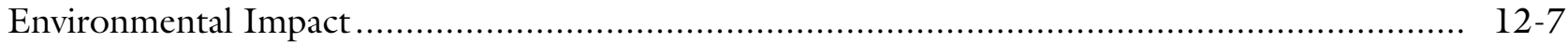

13. Radiological Dose Assessment ........................................................................... 13-1

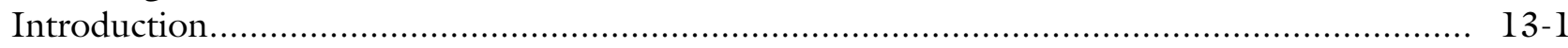

Background Information .......................................................................... $13-1$

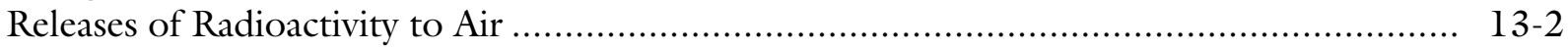

Air Dispersion and Dose Models ........................................................... 13-2

Radiation Protection Standards ........................................................................ 13-3

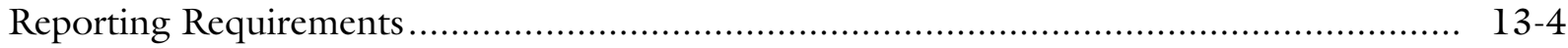

Evaluation of Sources of Radioactive Emissions..................................................... $13-4$

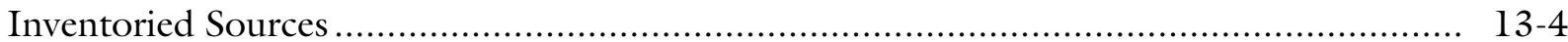

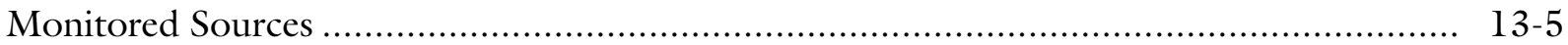

Stack Effluent Monitoring....................................................................... 13-5

Surveillance Air Monitoring .................................................................. 13-6

Determinations of Dose ...................................................................................... 13-6

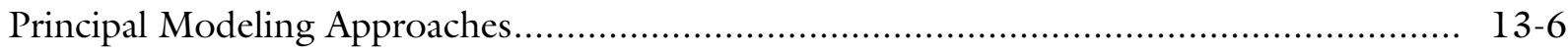

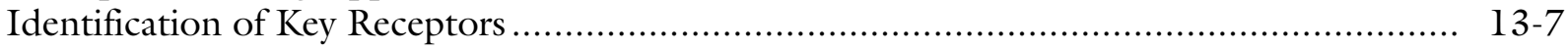

Assessment Assumptions Regarding Tritium …................................................ $13-8$ 
Relative Contributions to Dose from HTO and HT Emissions ........................... 13-8

Dose-Rate-Conversion Factor for Tritium ......................................................... 13-9

Overestimate of Ingestion Dose for Tritium .................................................. 13-9

Contribution from Ingestion of Organically Bound Tritium ............................... 13-9

New LLNL Tritium Model That Distinguishes Doses from HTO, HT, and OBT ...... 13-9

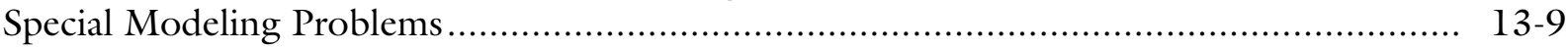

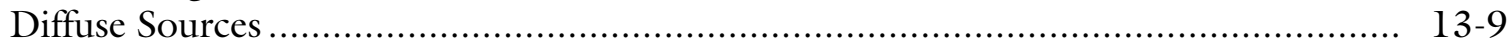

Modeling Dose Impacts from Explosives Experiments at Site 300 ....................... 13-10

Radiological Doses to the Public from 2000 LLNL Operations.......................................... 13-11

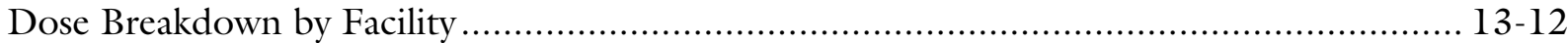

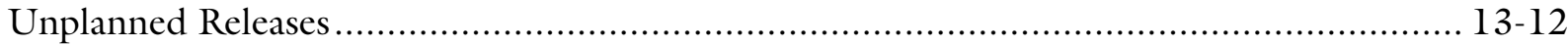

Doses to Public Site-Wide Maximally Exposed Individuals ........................................... 13-12

Comparison of Modeling Results to Monitoring Data ............................................. 13-16

Temporal Trends in Dose to the SW-MEI .............................................................. 13-19

Collective Doses to Potentially Exposed Populations................................................ 13-19

Doses to the Public Placed in Perspective ............................................................. 13-21

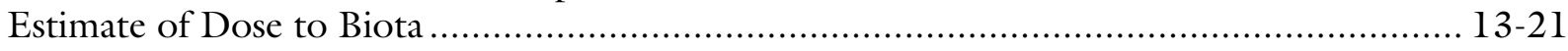

Summary and Conclusion .................................................................................... 13-23

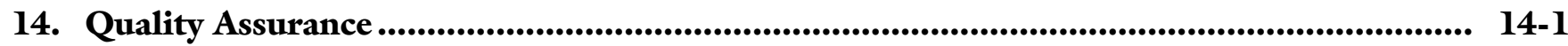

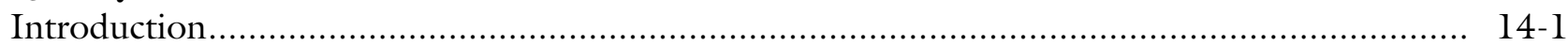

Quality Assurance Activities ............................................................................. 14-2

Analytical Laboratories ......................................................................... 14-2

Participation in Laboratory Intercomparison Studies .............................................. $14-2$

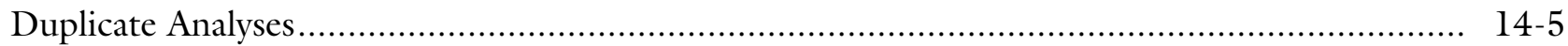

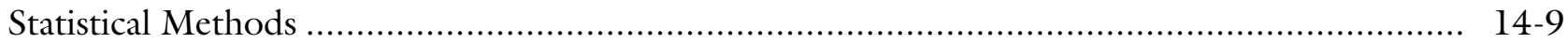

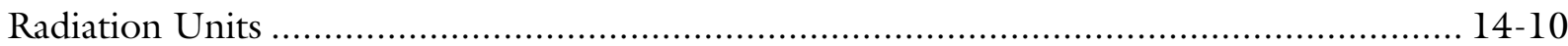

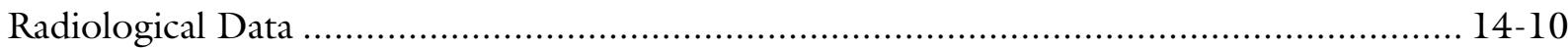

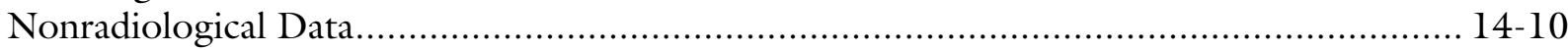

Statistical Comparisons ............................................................................. 14-10

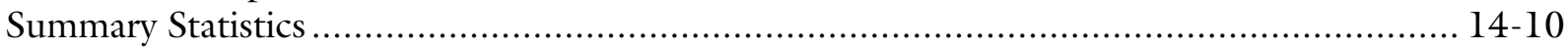

Quality Assurance Process for the Environmental Report ............................................. 14-11

Appendix A. Methods of Dose Calculations ................................................................... A-1

Appendix B. Environmental DOE Orders in Work Smart Standards................................... B-1

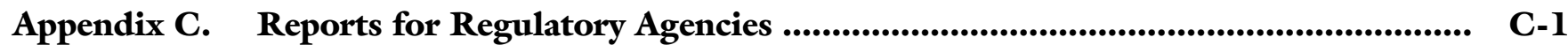

Appendix D. Supplementary Topics on Radiological Dose..................................................... D-.

D-1: Radiation Basics .............................................................................. D-1

D-2: Radiation Control Measures at LLNL.............................................. D-4

Appendix E. Errata............................................................................................................... E-1

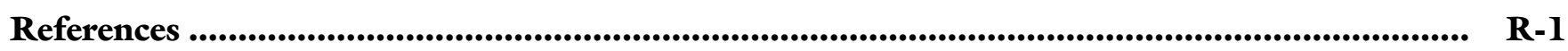

Acronyms and Abbreviations ......................................................................................... AC-1

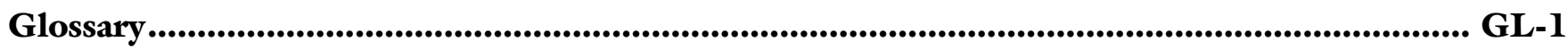




\section{List of Figures}

Figure 1-1. Locations of LLNL Livermore site and Site 300

Figure 1-2. Wind rose showing the frequency of occurrence for wind speed and direction at the Livermore site, 2000 .

Figure 1-3. Wind rose showing the frequency of occurrence for wind speed and direction at Site 300,2000 .

Figure 1-4. 2000 approximate groundwater and surface elevation contours, Livermore site and vicinity

Figure 1-5. 2000 approximate groundwater elevations in the principal continuous water-bearing zone at Site 300

Figure 4-1. Facilities at the Livermore site with air monitoring systems for effluent gas streams during all or part of 2000 .

Figure 4-2. Tritium Facility combined HTO and HT emissions from 1981 through 2000.

Figure 5-1. Air particulate and tritium sampling locations on the Livermore site, 2000 ....

Figure 5-2. Air particulate and tritium sampling locations in the Livermore Valley, 2000.

Figure 5-3. Air particulate and tritium sampling locations at Site 300 and off site, 2000

Figure 5-4. Monthly median gross alpha concentrations in particulate air samples from the LLNL perimeter, Livermore Valley, and Site 300 sampling locations, 2000.

Figure 5-5. Monthly median gross beta concentrations in particulate air samples from the LLNL perimeter, Livermore Valley, and Site 300 sampling locations, 2000.

Figure 5-6. Annual median plutonium-239+240 concentrations in air particulate samples at two locations, SALV (on-site) and FCC (upwind, off-site), 1982-2000

Figure 5-7. Median concentration of beryllium in air particulate samples taken at the

Livermore site perimeter, $1975-2000 \ldots \ldots \ldots \ldots \ldots \ldots \ldots \ldots \ldots \ldots \ldots \ldots \ldots \ldots \ldots \ldots \ldots \ldots \ldots \ldots \ldots \ldots \ldots \ldots$
LLNL sanitary sewer system, monitoring stations, and diversion facility

Figure 6-1.

Historical trend in tritium concentration in LLNL sewage

Historical trends in average monthly plutonium and cesium concentrations in

Figure 6-4. metals in LLNL sanitary sewer effluent showing trends from 1994 to 2000 ....

Figure 6-5.

Results as percentages of effluent pollutant limits (EPLs) for eight of the nine regulated metals in LLNL sewage, 2000

Figure 7-1. Surface waterways in the vicinity of the Livermore site

Figure 7-2. Storm water runoff and Drainage Retention Basin discharge sampling locations, Livermore site, 2000

Figure 7-3. Stormwater and rainwater sampling locations at Site 300, 2000

Figure 7-5. Gross alpha activities in Arroyo Seco storm water at the Livermore site compared with the LLNL site-specific threshold shown in Table 7-2.

Figure 7-6. Gross alpha activities in Arroyo Las Positas storm water at the Livermore site compared with the LLNL site-specific threshold shown in Table 7-2. 
Figure 7-7. Gross beta activities in Arroyo Seco storm water at the Livermore site compared with the LLNL site-specific threshold shown in Table 7-2 .

Figure 7-8. Gross beta activities in Arroyo Las Positas storm water at the Livermore site compared with the LLNL site-specific threshold shown in Table 7-2 .....

Figure 7-9. Tritium activity in Livermore site storm water at the outflow location WPDC compared with the drinking water maximum contaminant level (MCL)...

Figure 7-10. Sampling locations for the special tritium studies performed at Livermore site $7-17$

Figure 7-11. Tritium activity in Livermore site storm water at the locations near Building 343 where the transportainer was last located....

Figure 7-12. Tritium activity in Livermore storm water at location 3726 near Building 343 compared with the drinking water maximum contaminant level (MCL).

Figure 7-13. Correlations between selected parameters and specific conductance in storm water .......

Figure 7-14. Rain sampling locations, Livermore site and Livermore Valley, 2000 ......

Figure 7-15. Trend of median tritium activity in rain and trend of total stack emissions of HTO. From 1989 to 1995 the emissions are from the Livermore site and Sandia/California. Emissions from 1996 to 2000 are from LLNL only....

Figure 7-16. Sampling locations within the Drainage Retention Basin, 2000

Figure 7-17. Monthly chlorophyll-a in the Drainage Retention Basin, 2000

Figure 7-18. Turbidity in Drainage Retention Basin, 1994-2000

Figure 7-19. Nutrient levels in the Drainage Retention Basin, 2000

Figure 7-20. Cooling tower locations and receiving water monitoring locations, Site 300,2000

Figure 7-21. Site 300 surface waters, drinking water tanks, and receiving water monitoring locations.....

Figure 7-22. Surface and drinking water sampling locations, Livermore Valley, 2000

Figure 7-23. Annual median tritium activity in Livermore Valley surface and drinking water, 1988 to 2000

Figure 7-24. Arroyo Las Positas maintenance zones.

Figure 8-1. Map and cross section of the Livermore site showing hydrostratigraphic units and the locations of the treatment facilities.

Figure 8-2. Total VOC mass removed from the subsurface of the Livermore site, 1989-2000 ........

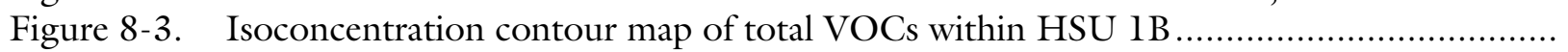

Figure 8-4. Isoconcentration contour map of total VOCs within HSU 2

Figure 8-11. Approximate groundwater elevations in the principal continuous water-bearing zone at Site 300 .

Figure 8-12. Extent of groundwater contamination at Site 300

Figure 8-13. Total VOC concentrations in groundwater in the eastern GSA and vicinity (4th quarter, 2000).

Figure 8-14. Total VOC concentrations in groundwater in the central GSA (4th quarter, 2000). Monitoring wells are completed in the Qt-Tnsc hydrologic unit.

Figure 8-15. Distribution of total VOCs in groundwater in the Qt-Tpsg hydrologic unit at the Building 834 complex (4th quarter, 2000) 
Figure 8-16. Trichloroethene (TCE) isoconcentration contour map in the Tnbs 2 aquifer in the HE Process Area (2nd quarter, 2000)

Figure 8-17. Distribution of tritium in groundwater in the first water-bearing zone in the Building 850/Pits 3 and 5 Operable Unit (2nd quarter, 2000)

Figure 8-18. Distribution of TCE in groundwater in the Building 854 area (4th quarter, 2000) ...... 8-35

Figure 8-19. Distribution of TCE in groundwater in the Pit 6 area (4th quarter, 2000)................. 8-36

Figure 8-20. Distribution of TCE in groundwater in the Building 832 Canyon

(4th quarter, 2000).

Figure 9-1. Locations of off-site tritium monitoring wells in the Livermore Valley....

Figure 9-2. Locations of routine surveillance groundwater monitoring wells at the Livermore site.

Figure 9-3. Locations of surveillance groundwater wells, Barcads, and springs at Site $300 \ldots$

Figure 9-10. Locations of compliance groundwater monitoring wells in the Explosives

Figure 9-11. Sewage evaporation and percolation ponds, compliance groundwater monitoring wells, and wastewater monitoring locations

Figure 9-12. Trend of tritium activity in Livermore Valley wells, 1988 to 2000. Drinking water MCL of $740 \mathrm{~Bq} / \mathrm{L}$ is also shown .....

Figure 10-1. Surface soil sampling locations, Livermore Valley, 2000

Figure 10-4. Median plutonium-239+240 activities in surface soils, 1976-2000. Upwind and downwind designations are relative to the center of the Livermore site .......

Figure 11-3. Median tritium concentrations in Livermore site and Livermore Valley plant water samples, 1971-2000 (For Far vegetation for 1998 and 1999, the values are the lowest positive) .

Figure 11-4. Mean tritium concentrations in retail wines decay-corrected from the sampling year to the vintage year

Figure 11-5. Median tritium concentrations in plant water at Site 300 sampling locations, 1971-2000. When the median is negative (e.g., all other locations for 1998 and 1999), the lowest positive concentration has been substituted.

Figure 12-1. Gamma dosimeter locations, Livermore site, 2000

Figure 12-4. Quarterly gamma dose measurements at the Livermore site perimeter, Livermore Valley, and Site 300, 1988-2000

Figure 13-1. Annual dose to the site-wide maximally exposed individual member of the public, 1990 to 2000 
Figure 14-1. Air tritium concentrations from collocated samples. These samples lie close to a line with slope equal to 1 and intercept equal to 0 .

Figure 14-2. Air uranium concentrations from collocated samples showing an outlier.... $14-9$

Figure 14-3. Sewer gross alpha concentrations from collocated samples showing a lot of scatter...... 


\section{List of Tables}

Table 1-1. Wind rose data for LLNL's Livermore site at the 10-m level for 2000. Values are frequency of occurrence (in percent)

Table 1-2. Wind rose data for LLNL's Site 300 at the $10-\mathrm{m}$ level for 2000. Values are frequency of occurrence (in percent)

Table 2-1.

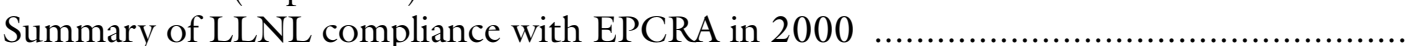

Table 2-2. Livermore site, SARA, Title III, Section 31 1, Chemical List, 2000 .......................... 2-7

Table 2-3. Site 300, SARA, Title III, Section 311, Chemical List, 2000 ...................................... 2-8

Table 2-4. Inspections and tours of the Livermore site and Site 300 by external agencies in $2000 \ldots \quad 2-9$

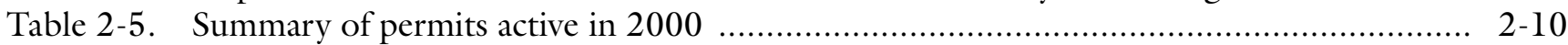

Table 2-6. Summary of NPDES permit nonconformance ..................................................... 2-13

Table 2-7. Summary of nonconformance with LWRP permit limits for discharges

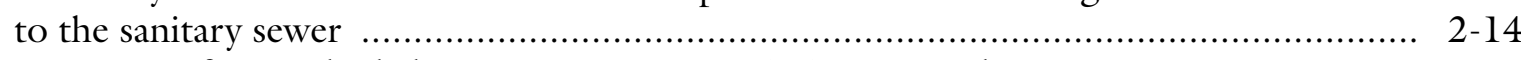

Table 2-8. Summary of streambed alteration agreements, 404 nationwide permits, and 401 waivers or WDRs

Table 2-9. Summary of in-service tanks, December 31, 2000 ......................................... 2-16

Table 2-10. Tabulation of environmental occurrences reported under the Occurrence Reporting (OR) System, 2000

Table 3-1. UC Contract 48 environmental protection performance measures for environmental performance in FY2000

Table 3-2. Pollution Prevention and Energy Efficiency Leadership Goals at

Department of Energy Facilities

Table 3-3. Routine waste generation totals (tons), 1993-2000

Table 3-4 Routine waste reduction, 2000

Table 4-3. Nonradioactive air emissions, Livermore site and Site 300, 2000

Table 5-1. Sampling locations listed by monitoring network

Table 5-2. Gross alpha and gross beta concentration in air particulate samples summarized by month, 2000

Table 5-3. Gamma activity in air particulate samples, Livermore site perimeter and Site 300, 2000 .

Table 5-4.

Table 5-5.

Table 5-6.

Table 5-7.

\section{Plutonium-239+240 activity in air particulate samples $\left(10^{-9} \mathrm{~Bq} / \mathrm{m}^{3}\right), 2000$}

Uranium mass concentration in air particulate samples, 2000

Tritium in air samples, 2000

Beryllium in particulate samples for Livermore site perimeter and

Site 300 locations, 2000
$5-11$

5-12

5-14

5-15 
Table 6-1. LLNL's internal discharge guidelines for pollutants in wastewater ............................ 6-4

Table 6-2. Permit discharge limits for nonradioactive pollutants in LLNL wastewaters ................. 6-6

Table 6-3. Estimated total radioactivity in LLNL sanitary sewer effluent, 2000 .......................... 6-8

Table 6-4. Tritium in sanitary sewer effluents, LLNL and LWRP, 2000.................................. 6-9

Table 6-5. Cesium and plutonium in sanitary sewer effluents, LLNL and LWRP, 2000 ............... 6-11

Table 6-6. Radioactive liquid effluent releases from the Livermore site, 1991-2000 _................... 6-13

Table 6-7. Average monthly results for regulated metals in LLNL sanitary sewer effluent $(\mathrm{mg} / \mathrm{L}), 2000$

Table 6-8. Monthly monitoring results for physical and chemical characteristics of the LLNL sanitary sewer effluent, 2000 .

Table 7-1. Analyses conducted on storm water samples, 2000

Table 7-2. Threshold criteria for selected water quality parameters. The sources of values above these are examined to determine if any action is necessary. ............................ $7-4$

Table 7-3. Fish chronic toxicity test results, Livermore site, 2000 .....

Table 7-4. Algae chronic toxicity test results, Livermore site, 2000

Table 7-5. Radioactivity in storm water from the Livermore site, 2000.

Table 7-6. Nonradioactive water quality parameters from the Livermore site in 2000 above the threshold comparison criteria shown in Table 7-2

Table 7-7. Total suspended solids in storm water samples from Site 300 in 2000

Table 7-8. Tritium activities in rainfall for the Livermore site, Livermore Valley, and Site 300, 2000

Table 7-9. Summary of Drainage Retention Basin monitoring not meeting management action levels

Table 7-10. Summary data from compliance monitoring of primary cooling towers, Site 300, 2000

Table 7-11. Summary data from operational monitoring of primary cooling towers, Site 300,2000

Table 7-12. Measured residual chlorine and $\mathrm{pH}$ values in flush water, Building 801, Pressure Zone 3

Table 7-13. Radioactivity in surface and drinking water in the Livermore Valley, 2000

Table 7-14. Arroyo Las Positas maintenance project monitoring data, 2000

Table 8-1. 2000 extraction wells and extraction rates

Table 8-2. Volatile organic compounds (VOCs) removed from groundwater and soil at the Livermore site

Table 8-3. Wells installed in 2000

Table 8-4. Major contaminants of concern found in soil, rock, and groundwater at Site 300

Table 8-5. Volatile organic compounds (VOCs) removed from groundwater and soil vapor at Site 300

Table 8-6. General Services Area groundwater treatment system surface discharge permit requirements

Table 9-1. Concentration ranges for three major anions in shallow background and western perimeter monitoring wells

Table 10-1. Summary of surface soil and sediment radioanalytical data, 2000

Table 11-1. Concentrations of tritium in plant water $(\mathrm{Bq} / \mathrm{L}), 2000$

Table 11-2. Tritium in retail wine $(\mathrm{Bq} / \mathrm{L}), 2000$

Table 12-1. Summary of dose calculations for gamma-monitoring locations $(\mathrm{mSv})$ at all LLNL sites, 2000 
Table 13-1. Sources of radiation dose from LLNL releases (measured and potential) to air: stacks and other exhaust pathways from buildings containing radiological operations, and diffuse area sources

Table 13-2. Doses calculated for the SW-MEI for the Livermore site and Site 300, 1990 to 2000

Table 13-3. Annual dose to the SW-MEI from explosives experiments on firing tables at Site 300, 1990-2000, related to the total quantity of depleted uranium used in the experiments and the total quantity of high explosives driving the detonations

Table 13-4. Major contributors to LLNL's radiation dose to the site-wide maximally exposed (public) individual (SW-MEI) via releases to air, 2000

Table 13-5. Comparison of measured and modeled annual-average concentrations of tritiated water vapor (HTO) in air at selected Livermore site locations, 2000.

Table 13-6. Comparison of background (natural and man-made) and LLNL radiation doses, 2000

Table 14-1. Sampling completeness in 2000 for the Livermore site and Site 300 14-3

Table 14-2. Quality assurance collocated sampling. Summary statistics for analytes with more than eight pairs in which both results were above the detection limit

Table 14-3. Quality assurance collocated sampling. Summary statistics for selected analytes with eight or fewer pairs in which both results were above the detection limit

Table 14-4. Quality assurance duplicate sampling. Summary statistics for analytes with at least four pairs in which one or both results were below the detection limit 



\section{Executive Summary}

Arthur H. Biermann

\section{Introduction}

Lawrence Livermore National Laboratory (LLNL), a U.S. Department of Energy (DOE) facility operated by the University of California (UC), serves as a national resource of scientific, technical, and engineering capabilities. The Laboratory's mission focuses on nuclear weapons and national security, and over the years has been broadened to include areas such as strategic defense, energy, the environment, biomedicine, technology transfer, the economy, and education. The Laboratory carries out this mission in compliance with local, state, and federal environmental regulatory requirements. It does so with the support of the Environmental Protection Department, which is responsible for environmental monitoring and analysis, hazardous waste management, environmental restoration, and assisting Laboratory organizations in ensuring compliance with environmental laws and regulations.

LLNL comprises two sites: the Livermore site and Site 300. The Livermore site occupies an area of 3.28 square kilometers on the eastern edge of Livermore, California. Site 300, LLNL's experimental testing site, is located 24 kilometers to the east in the Altamont Hills and occupies an area of 30.3 square kilometers. Meteorological and environmental monitoring activities are conducted at both sites as well as in surrounding areas.

This summary provides an overview of LLNL's environmental activities in 2000 , including radiological and nonradiological surveillance, effluent and compliance monitoring, remediation, assessment of radiological releases and doses, and determination of the impact of LLNL operations on the environment and public health. 


\section{Environmental Monitoring Results}

During 2000, the Environmental Protection Department sampled air, sewerable water, surface water, groundwater, soil and sediment, and vegetation and foodstuff. Samples were analyzed for radioactive and nonradioactive substances using (1) standard methods approved by the U.S. Environmental Protection Agency (EPA), (2) special systems such as the continuous monitoring system for Livermore site sewage, or (3) special analytical techniques designed to measure very low levels of radionuclides. Environmental radiation was also measured directly using dosimeters. More than 13,000 environmental samples were taken, and more than 260,000 analytical results were obtained.

\section{Air Surveillance Monitoring}

Ambient air was monitored for various airborne radionuclides (including particles and tritiated water vapor) and beryllium at the Livermore site, Site 300, and off-site locations throughout the Livermore Valley and Tracy areas. Concentrations of all monitored radionuclides and beryllium at all of these locations were well below levels that would endanger the environment or public health, according to current regulatory standards. For example, in 2000, the highest median plutonium concentration for samples collected at any air monitoring station was $0.025 \%$ of the federal Derived Concentration Guide (DCG). The DCG specifies the concentration of radionuclides in air or water that could be inhaled or ingested continuously 365 days a year without exceeding the DOE radiation protection standard for the public. Median concentrations of tritiated water vapor collected at Livermore Valley sampling locations showed a highest median value of $0.0004 \%$ of the DCG, while the highest median values on the Livermore site perimeter and within the site boundaries were, respectively, $0.002 \%$ and $0.09 \%$ of the DCG. The highest concentrations of beryllium on the Livermore site and Site 300 were $0.38 \%$ and $0.26 \%$, respectively, of the guideline level established by the Bay Area Air Quality Management District and the EPA and are representative of naturally occurring levels.

\section{Air Effluent Monitoring}

In 2000, LLNL operated 76 samplers for measuring radioactivity in air effluent at six facilities at the Livermore site. These samplers extracted a measured volume of air from the exhaust stack of a facility or process and collected particles or vapor in a collection medium. Measured radiological air emissions from Livermore site operations remained well below levels of health and environmental concern. Building 331 emissions accounted for $23 \%$ of the estimated total tritium emissions from the site in 2000. The emissions in this facility during 2000 were lower than in 1999 and remained at a level far below those of the 1980s. Radiological emissions from the other monitored facilities were very low.

Nonradioactive air emissions from exempt and permitted sources at LLNL were quite small and typical of values in previous years. For example, total emission of nitrogen oxides from the Livermore site in 2000 was 54 kilograms per day, which is $0.07 \%$ of the quantity of this air pollutant released daily over the entire San Francisco Bay Area; corresponding numbers for reactive organics were 20 kilograms per day and $0.02 \%$. The total emission of criteria air pollutants (nitrogen oxides, volatile organics, sulfur oxides, particulate matter, carbon monoxide, and lead) was 93 kilograms per day for the Livermore site and about 3.6 kilograms per day for Site 300 . 


\section{Sewerable Water Monitoring}

Discharges of radioactive and hazardous material to the combined sanitary and industrial sewer at the Livermore site are controlled by use of administrative and engineering controls, including limiting the disposal of those materials and routing some discharged material to retention tanks for later characterization and treatment. Flow-proportional and instantaneous samples of the site's wastewater are regularly collected and analyzed (for metals, radioactivity, toxic chemicals, and water-quality parameters) to ensure that LLNL's sewage effluent meets the requirements of the permit granted by the City of Livermore. In addition, the site effluent is monitored continuously for $\mathrm{pH}$, regulated metals, and radioactivity. If concentrations are detected above warning levels, an alarm sounds and the effluent is automatically contained by LLNL's sewer diversion system. The diversion system captures all but the initial minutes of wastewater flow that causes a metal or radiation alarm, thereby protecting the Livermore Water Reclamation Plant (LWRP) and minimizing any required cleanup. Additional monitoring and diversion capability for $\mathrm{pH}$ allows the containment on site of even the initial minutes of a $\mathrm{pH}$-related release.

In 2000, the Livermore site discharged an average of 0.97 million liters per day of wastewater to the City of Livermore sewer system, an amount that constituted $3.9 \%$ of the total flow to the system (about 16\% of the Livermore site effluent was generated by Sandia National Laboratories / California). The Livermore site's sanitary sewer effluent was monitored continuously and sampled daily, weekly, and monthly to satisfy various permit compliance requirements.

LLNL achieved greater than 99\% compliance with LWRP permit limits covering discharges into the sanitary sewer during 2000. However, three notices of violation (NOVs) were written for violations that occurred. One was for a silver exceedance, a second for a cyanide exceedance, and a third for excess chromium and nickel in categorical process wastewater. Two inadvertent discharges were detected by the continuous monitoring system in 2000 , one involving a metal and the other a base; both of these instances warranted sewage diversion. During 2000, no sewer releases exceeded discharge limits for radioactive materials.

\section{Surface Water Monitoring}

Surface water sampling and analysis are a large part of the LLNL surveillance and compliance monitoring effort for the Livermore site, Site 300, and their surrounding areas. The waters monitored include storm water runoff, rainfall, water in the Livermore site Drainage Retention Basin, wastewater discharges from cooling towers and springs at Site 300 , and a variety of other water that includes off-site reservoirs and ponds, drinking water taps both on and off site, and the Livermore site swimming pool.

Radioactivity detected in the storm water was all at small percentages of the levels allowed in drinking water (referred to as the maximum contaminant level, or MCL). The maximum tritium concentration in storm water effluent at the Livermore site was $3.7 \%$ of the MCL. Plutonium activities were not above the detection limit in the liquid phase of any storm water samples.

Livermore site storm water samples were also analyzed for chemical constituents. For those chemicals showing concentrations higher than our internal comparison criteria, most concentrations were lower at the effluent sample locations than the influent locations. Acute and chronic fish toxicity tests conducted on the storm water samples demonstrated no toxicity to the test species. 
Results from monitoring in the Drainage Retention Basin provided additional evidence that water releases do not have a significant environmental impact.

At Site 300, tritium activities in storm water runoff samples were below the minimum detectable activity. Site 300 storm water contained levels of total suspended solids higher than our comparison criteria; however, as was the case for the Livermore site, these effluent levels were lower than the influent location.

Median tritium activities in rain samples in 2000 demonstrated a decrease compared to 1999 results. The median on-site measurement in rainfall during 2000 was $0.5 \%$ of the MCL. In drinking water sources, the maximum tritium activity was less than $0.3 \%$ of the MCL.

Overall, the results of surface water monitoring at both sites indicate compliance with established regulatory limits and negligible impact on the environment.

\section{Groundwater Monitoring}

Groundwater in the Livermore Valley and the Altamont Hills is monitored to assess the progress of remediation efforts in areas of known contamination, to measure the impact, if any, of LLNL operations on local groundwater resources, and to comply with numerous federal, state, and local permits. Groundwater samples are routinely measured for tritium, uranium, and other radioisotopes; gross radioactivity; toxic metals; a wide range of organic chemicals; and other general contaminant indicators. Special consideration is given to monitoring those dissolved elements and organic compounds that are known to be toxic in trace amounts.
The impact of Livermore site and Site 300 operations on off-site groundwater continued to be minimal in 2000. In the Livermore Valley, no monitored radioactive or inorganic nonradioactive constituent was found to exceed primary drinking water MCLs in any off-site well. In on-site wells, nitrates and chromium have been detected above their MCL, but these constituents have not been measured off site at levels above their MCL. The maximum tritium activity measured in the Livermore valley groundwater is less than $5 \%$ of the MCL.

At Site 300, tritium and depleted uranium have been released to groundwater from landfills and firing tables, but the boundaries of the slowly moving groundwater plumes lie entirely within site boundaries. The shallow groundwater plumes beneath Site 300 contain either volatile organic compounds (VOCs), tritium, nitrate, Freon, perchlorate, or depleted uranium, but they present no current health risks because this contaminated water is not used as a potable water supply for domestic, industrial, or agricultural use. LLNL is working with the regulatory agencies to contain and clean up groundwater contamination at both sites as necessary.

\section{Soil and Sediment Monitoring}

The impact of Laboratory operations on soil and sediment at the Livermore site in 2000 was insignificant and unchanged from previous years. The highest level of plutonium (isotopes 239 and 240) measured at the LWRP represented $1.3 \%$ of the National Council on Radiation Protection (NCRP) recommended screening limit for commercial or industrial sites. Other constituents of concern were measured at background or trace concentrations or were below the limit of detection. At Site 300, the concentrations of radionuclides and beryllium in 
soil samples were generally representative of background or naturally occurring levels, as in previous years. Elevated concentrations of uranium-238 found in Site 300 soils in 2000 were attributed to contamination by debris from firing-table experiments.

Sampling and analysis of the vadose zone, carried out as part of the Livermore Groundwater Management Program, showed no evidence of contamination that will significantly affect groundwater.

\section{Vegetation and Foodstuff Monitoring}

LLNL impacts on vegetation and food in the Livermore Valley remained minimal in 2000. Tritium, which is the only measurable radionuclide in the vegetation and foodstuff monitoring program, was estimated to be well below levels of concern, even when organically bound tritium was taken into account. In 2000, tritium concentrations in wines from the Livermore Valley, California, and Europe are within the range of those reported in previous years and remain low in wines from all areas. Even the highest detected tritium value in Livermore Valley wine represented only $0.3 \%$ of the amount of tritium that EPA allows in drinking water (no health standards exist for radionuclides in wine).

\section{Radiological Dose Assessment}

Radiological dose assessment of air emissions was conducted for LLNL facilities having the potential to discharge radioactivity to the atmosphere. Air effluent emissions from about 170 points were evaluated and reported in 2000. These sources were of several types: stacks and other exhaust pathways from buildings, diffuse area sources generally external to buildings, and open-air firing tables at Site $\mathbf{3 0 0}$ where explosives experiments were conducted. The dose assessments were performed using conservative EPA-mandated computer models, actual LLNL meteorology, population distributions appropriate to the two sites, and 2000 radionuclide usage inventory and monitoring data.

LLNL reports public doses resulting from air releases of radionuclides during routine operations and from accidents. The principal exposure pathways taken into account are internal exposures from inhalation of air and ingestion of foodstuff and drinking water contaminated by the air releases. Releases of radioactivity from LLNL via water do not directly contribute to the public dose because this water is not used as a potable water supply for domestic, industrial, or agricultural use.

The most significant radiological effluent for the Livermore site from the standpoint of public dose continues to be tritium, the radioactive isotope of hydrogen. The calculated total potential dose for the sitewide maximally exposed individual (SW-MEI), (i.e., a hypothetical member of the public having the greatest possible exposure from Livermore site operations in 2000) from all Livermore site operations was 0.38 microsievert (0.038 millirem). The point source contributions to the dose include gaseous tritium modeled as tritiated water vapor as directed by EPA Region IX. Trends in this SW-MEI dose for the Livermore site over the last nine years show levels in the range 1.0 to 0.4 microsievert per year $(0.1$ to 0.04 millirem per year). These small radiation quantities exhibit large percentage but small absolute value fluctuations from year to year.

At Site 300, depleted uranium (containing isotopes with atomic weights 238, 235, and 234) remains by far the principal contributor to off-site dose. The calculated total potential dose to the SW-MEI during 2000 was 0.19 microsievert (0.019 millirem). This is well within the range of doses calculated over the past 10 years. 
Conservatively calculated radiological doses to the maximally exposed public individuals from Livermore site and Site 300 emissions amounted to about $0.4 \%$ and $0.2 \%$, respectively, of the EPA National Emission Standards for Hazardous Air Pollutants regulatory standard. These doses are a small fraction (about $1 / 8000$ ) of the doses received by individuals from natural background radiation. Thus, the potential radiological doses from LLNL operations in 2000 were well within regulatory limits and were very small compared with doses from natural background radiation sources.

\section{Environmental Compliance and Program Activities}

LLNL works to ensure that its operations comply with all environmental laws and federal, state, and local regulatory guidelines. In addition to the extensive environmental monitoring, many compliance activities related to water, air, waste, waste reduction, community "right to know," and other environmental issues were addressed in 2000.

\section{Groundwater Remediation}

As a Superfund site, LLNL continued to treat groundwater at both the Livermore site and Site 300 under the jurisdiction of the Comprehensive Environmental Response, Compensation and Liability Act. LLNL's primary treatment method to remediate contaminated groundwater is pumpand-treat technology.

At the Livermore site, contaminants are removed at 11 treatment facilities, consisting of 9 groundwater and 2 soil vapor extraction facilities. Within each facility, wells are used to extract groundwater which is subsequently treated to remove volatile organic compounds (VOCs). A total of 80 groundwater extraction wells operated at an average flow of
3,640,000 liters per day and 2 vapor extraction wells operated at 841 cubic meters per day. Together the groundwater and vapor treatment facilities removed 269 kilograms of VOC mass in 2000. These efforts at control and remediation continue to reduce VOC concentrations throughout the site and reduce the plume sizes of contaminants.

In 2000, new treatment facilities were added to the Treatment Facility D (TFD), TFE, and TF518 areas at the Livermore site. Also, DOE/LLNL continued the evaluation of electroosmosis (EO) as a means to expedite the removal of VOCs from source areas characterized by high VOC concentrations in low permeability sediments. EO technology uses a grid of electrode-bearing wells to draw contaminated groundwater to the center wells. Based on studies conducted in 1999 at TF406, an EO system was installed at TFD in the summer of 2000. Preliminary data show the system to be effective at concentrating the contamination at the center wells.

Significant progress was also made at Site 300. Eight treatment facilities operated throughout 2000 and three new treatment facilities were added. Approximately 27.7 kilograms of VOCs were removed by treatment of 102,500,000 liters of groundwater and 352,905 cubic meters of soil vapor.

\section{Waste Minimization and Pollution Prevention}

LLNL continues to employ a weighted ranking system to prioritize and evaluate its waste streams. Cost, type of waste, and operational aspects are emphasized rather than simple considerations of total waste volume. Transuranic and transuranicmixed and low-level wastes continue to be of highest priority for LLNL even though their relative quantities are low. 
Comparing 2000 with the 1993 baseline, levels of waste in the four categories-radioactive, mixed, hazardous, and sanitary—have decreased by $78 \%$, $59 \%, 66 \%$, and $19 \%$ respectively. The total waste diverted from landfills in 2000 was more than 26,000 tons. Although LLNL has not yet achieved a $33 \%$ reduction goal for routine nonhazardous waste, its recycling percentage for nonhazardous waste was $85 \%$ in 2000 .

The Laboratory has a Chemical Exchange Warehouse (CHEW) that enables employees to locate needed chemicals already on site. By reducing the need to buy new chemicals, production of waste is minimized. Employees can use ChemTrack, LLNL's computerized chemical inventory system, to search for chemicals in CHEW. In 2000, ChemTrack tracked some 167,000 chemicals through the use of bar codes, hand-held bar code laser scanners, and customized software.

\section{Air, Wastewater, and Water Compliance}

LLNL continued to perform all activities necessary to comply with clean air and clean water requirements. In 2000, the Bay Area Air Quality Management District issued or renewed 129 operating permits for the Livermore site. The San Joaquin Valley Unified Air Pollution Control District issued or renewed permits for 42 air emissions sources at Site 300. LLNL has permits for underground and aboveground storage tanks and for discharge of treated groundwater, industrial and sanitary sewage, and storm water. Site 300 has additional permits for inactive landfills, cooling tower discharges, operation of the sewer lagoon, septic tanks, and leach fields. The Laboratory complies with all requirements for self-monitoring and inspections associated with these permits.

\section{Endangered Species}

LLNL meets the requirements of both the U.S. Endangered Species Act and the California Endangered Species Act as they pertain to endangered or threatened species and other species of special concern that may exist or are known to exist at the LLNL sites. In 2000, biological assessment surveys were performed for special-status species at 82 LLNL project construction (grounddisturbing) areas. Although no active San Joaquin kit fox dens were discovered, 3 occupied American badger dens were found. In addition, 11 active burrowing owl dens were discovered at Site 300; the owls were marked with leg bands to perform long-term studies, monitoring, and conservation of the species. A population of the California tiger salamander (Ambystoma californiense), a federal species of concern, was monitored at Site 300. And, at both the Livermore site population and Site 300 the federally threatened California redlegged frog (Rana aurora draytonii) was monitored and protected. In 2000, the Central Drainage Retention Basin (DRB) was drained in an effort to eradicate non-native bullfrogs ( Rana catesbeiana), which are a predator of the California red-legged frog.

Four rare plant populations were monitored at Site 300 in 2000: the large-flowered fiddleneck (Amsinckia grandiflora), a federally listed endangered plant species; the big tarplant (Blepharazonia plumosa), a California Native Plant Society "rare" plant; the diamond-petaled poppy (Eschscholzia rhombipetala); the big tarplant (Blepharazonia plumosa), a California Native Plant Society "rare" plant; and gypsum-loving larkspur (Delphinium gypsophilum ssp gypsophilum) listed on the California Native Plant Society Rare Plant 4 list. In April 2000, an area at Site 300, the Amsinckia grandiflora Reserve, was designated a critical habitat area (CHA) by declaration of the Secretary of the U.S. Department of Energy. LLNL has also 
established an experimental population within the reserve and will continue working with the U.S. Fish and Wildlife Service on the continued monitoring of the native and experimental fiddleneck populations. The number and size of the big tarplant populations increased from 2000 abundances. The number of diamond-petaled poppy plants were also observed in 2000.

\section{Environmental Occurrences}

Notification of environmental occurrences at the Laboratory is required by a number of environmental laws, regulations, and DOE orders. LLNL responded to nine incidents that required federal and/or state agency notification during 2000. None of these caused adverse impact to human health or the environment.

\section{Contract Performance Measures}

University of California's Prime Contract W-7405ENG-48 includes four performance measures related to environmental protection activities: (1) radiation dose to the public, (2) process and solid waste generation, (3) environmental violations, and (4) environmental releases. At the end of 2000, DOE assigned LLNL a score of excellent as an average for these environmental performance measures.

\section{Integrated Safety Management and Work Smart Standards}

LLNL has implemented an Integrated Safety Management System (ISMS) in accordance with the requirements of the University of California's Prime Contract. ISMS is designed to ensure the systematic integration of Environment, Safety, and Health considerations into management and work practices so that missions are accomplished while protecting the public, workers, and the environment. The Work Smart Standard (WSS) process is an integral part of ISMS whereby safety and environmental professionals identify ES\&H hazards and establish standards of operation appropriate to the particular work being performed. The final WSS set of standards was approved in 1999 and is included in the Prime Contract. The WSS set includes more than 250 requirements directly related to the environment.

\section{Conclusion}

The current techniques LLNL uses for environmental monitoring are very sensitive, allowing detection of extremely low levels of constituents. The combination of surveillance and effluent monitoring, source characterization, and dose assessment shows that radiological doses to the public caused by LLNL operations are less than $1 \%$ of regulatory standards and are about 8000 times smaller than the doses received from natural background radiation. The analytical results and evaluations generally show continuing low contaminant levels, reflecting the responsiveness of the Laboratory in controlling pollutants.

In 2000, LLNL successfully engaged in environmental compliance activities related to water, air, waste, waste reduction, and other environmental issues. Some key examples include groundwater remediation activities, waste minimization efforts, and recycling efforts that diminished the quantity of waste sent to landfills. Actions to protect endangered species at both LLNL sites also continued.

In summary, the results of the 2000 environmental programs demonstrate that LLNL is committed to protecting the environment and ensuring that its operations are conducted in accordance with applicable federal, state, and local laws and regulations. The environmental impacts of LLNL operations are minimal and pose no threat to the public or the environment. 


\section{Site Overview}

\section{Introduction}

Meteorology and geography play primary roles in how the environment is affected by human actions. Dispersal of particles in air, for example, is influenced by the wind and rain, which in turn are influenced by geographical characteristics. Similarly, the movement of groundwater is constrained by the particular geology of a site. Thus, knowledge of wind, rainfall, geology, and geographical characteristics is used to model the effects that operations at Lawrence Livermore National Laboratory might have on the surrounding environment. Some history and a description of these characteristics help us understand the importance of the Laboratory's meteorological and geographic setting.

\section{Operations}

Lawrence Livermore's mission is to apply science and technology in the national interest, with a focus on global security, global ecology, and bioscience. Laboratory employees are working with industrial and academic partners to increase national economic competitiveness and improve science education. The Laboratory's mission is dynamic and has changed over the years to meet new national needs.
LLNL is a full-service research laboratory with the infrastructure-engineering, maintenance, and waste management activities, as well as security, fire, health and safety, and medical departmentsnecessary to support its operations and about 9000 personnel. 


\section{Location}

LLNL consists of two sites - the main laboratory site located in Livermore, California (Livermore site) in Alameda County, and the Experimental
Test Site (Site 300) located near Tracy, California, in San Joaquin and Alameda counties

(Figure 1-1). Each site is unique, requiring a different approach for environmental monitoring and protection.

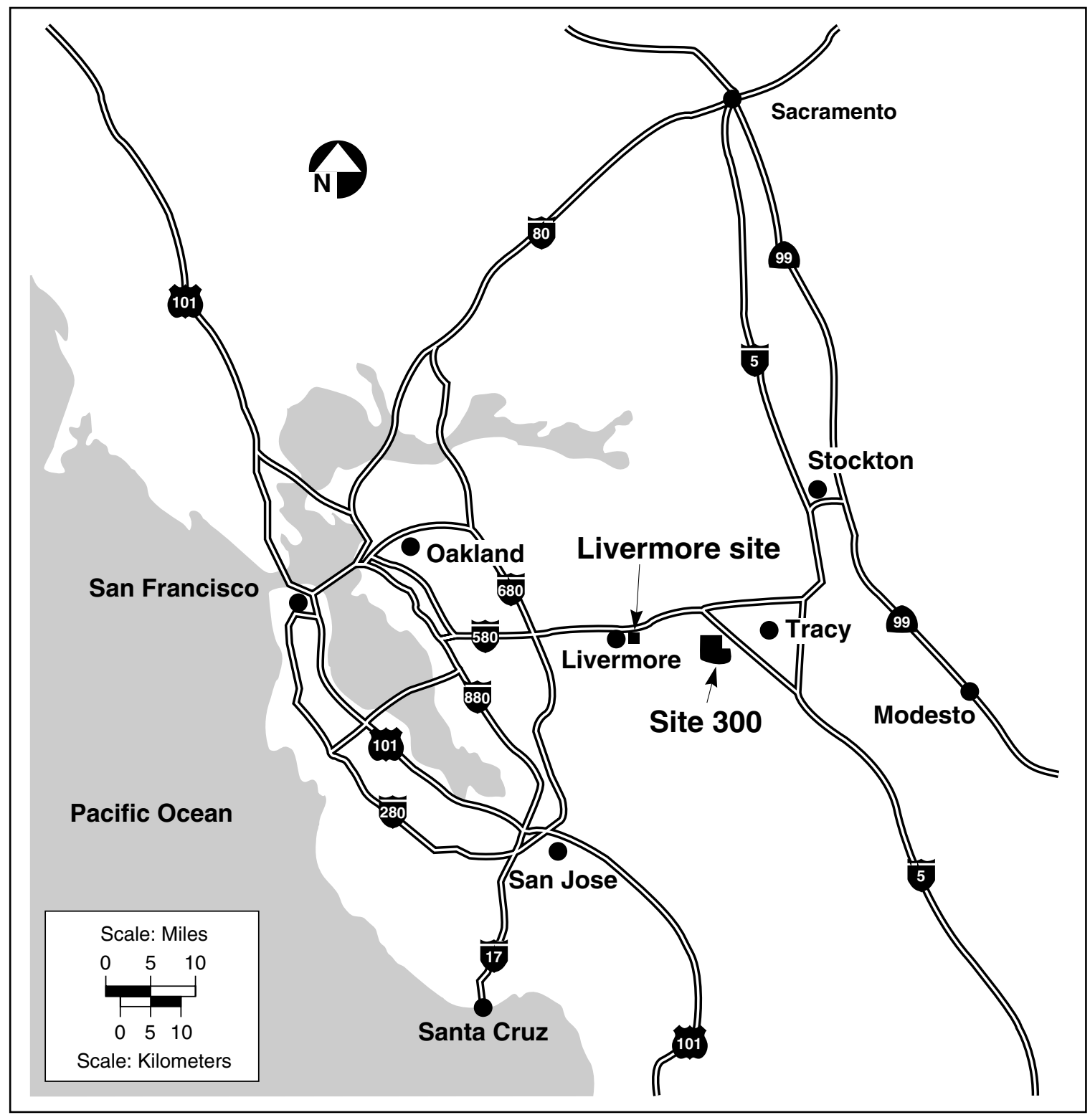

Figure 1-1. Locations of LLNL Livermore site and Site 300 
LLNL was founded at the Livermore site in 1952 at a former U.S. Navy training base. At that time the location was relatively isolated, being approximately $1.6 \mathrm{~km}$ from the Livermore city limits. Over time, Livermore evolved from a small town of fewer than 7000 people when the Laboratory began to its present population which, based on the 2000 census, is about 73,345. The economy, which had been primarily agricultural, diversified to include light industry and business parks. Within the last few years, low-density, single-family residential developments have begun to fill the formerly vacant fields. Livermore residences are now near LLNL's western boundary.

LLNL's Livermore site occupies an area of $3.28 \mathrm{~km}^{2}$, including the land that serves as a buffer zone around the site. Immediately to the south is Sandia National Laboratories/California (Sandia/ California), operated by Lockheed-Martin under Department of Energy (DOE) contract. Sandia/ California engages in research and development associated with nuclear weapons systems engineering as well as related national security tasks. Although their primary missions are similar, LLNL and Sandia/California are separate entities, each with its own management and each reporting to a different DOE operations office.

To the south of LLNL, there are also some lowdensity residential areas and agricultural areas devoted to grazing, orchards, and vineyards. A business park lies to the southwest. Farther south, property is primarily open space and ranchettes, with some agricultural use. High-density residential development lies to the west. A very small amount of low-density residential development lies to the east of the Livermore site, and agricultural land extends to the foothills that define the eastern margin of the Livermore Valley. A business park is located to the north, and a 200-hectare parcel of open space to the northeast has been rezoned to allow development of light industry.
Major population centers near Livermore include the nearby communities of Pleasanton and Tracy, and the more distant metropolitan areas of Oakland, San Jose, and San Francisco, as well as Stockton in the San Joaquin Valley. There are 6.9 million residents within an $80-\mathrm{km}$ radius of the Livermore site.

Site 300, LLNL's Experimental Test Facility, is located $20 \mathrm{~km}$ east of the Livermore site in San Joaquin and Alameda counties in the Altamont Hills of the Diablo Range; it occupies an area of $30.3 \mathrm{~km}^{2}$. SRI International operates a testing site located approximately $1 \mathrm{~km}$ south of Site 300. A test site owned by Primex Physics International and located east of Site 300 is no longer in operation. The Carnegie State Vehicular Recreation Area is located south of the western portion of Site 300, and wind turbine generators line the hills to the northwest. The remainder of the surrounding area is in agricultural use, primarily as grazing land for cattle and sheep. The nearest residential area is the town of Tracy (population 56,529), located $10 \mathrm{~km}$ to the northeast. Within $80 \mathrm{~km}$ of Site 300 , there are 6 million residents, many of whom are located in the metropolitan areas of Oakland, San Jose, and Stockton.

\section{Meteorology}

Meteorological data (including wind speed, wind direction, rainfall, humidity, solar radiation, and air temperature) are continuously gathered at both the Livermore site and Site 300. Mild, rainy winters and warm, dry summers characterize the climate. A detailed review of the climatology for LLNL can be found in Climatology of Lawrence Livermore National Laboratory (Gouveia and Chapman 1989). The mean annual temperature for both sites in 2000 was $15^{\circ} \mathrm{C}$. Temperatures range from $-5^{\circ} \mathrm{C}$ during some predawn winter mornings to $40^{\circ} \mathrm{C}$ during some summer afternoons. 
Both rainfall and wind exhibit strong seasonal patterns. These wind patterns tend to be dominated by the thermal draw of the warm San Joaquin Valley that results in wind blowing from the cool ocean toward the warm valley, increasing in intensity as the valley heats up. The wind blows from the northeast primarily during the winter storm season. Most precipitation occurs between October and April, with very little rainfall during the warmer months.

Annual wind data for the Livermore site are given in Figure 1-2 and Table 1-1. These data show that about $50 \%$ of the wind comes from the southwest to westerly direction. This prevailing pattern

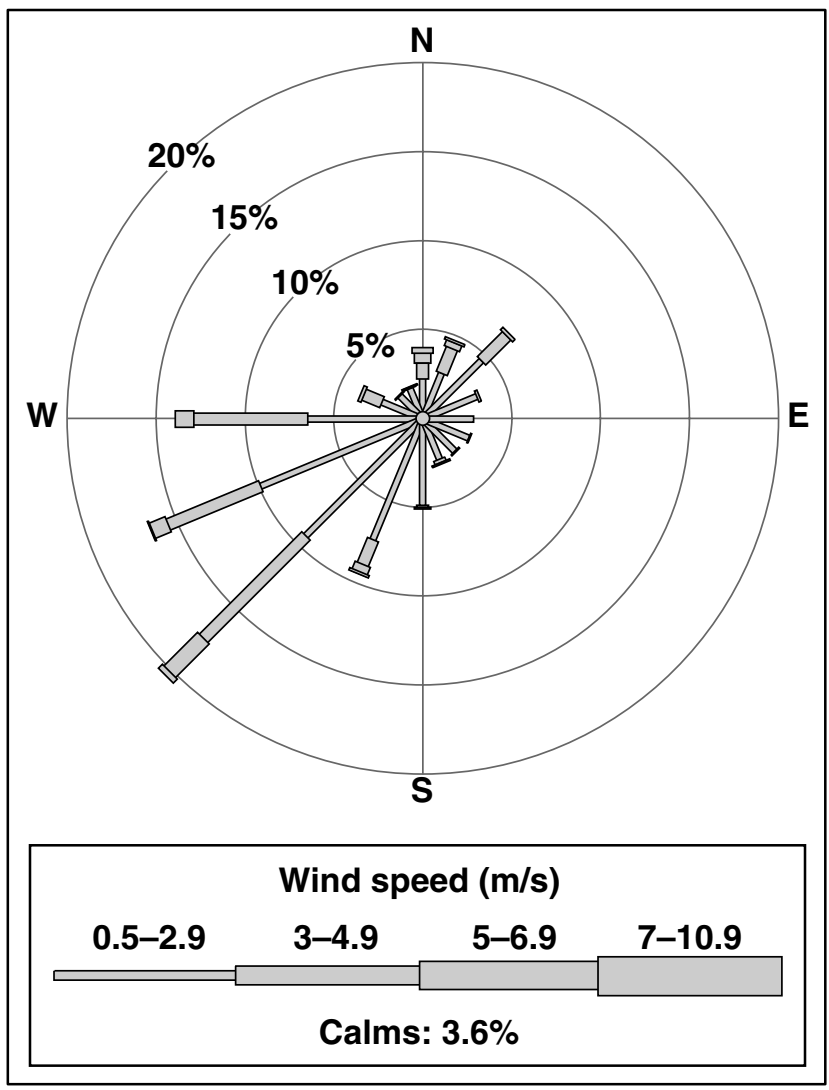

Figure 1-2. Wind rose showing the frequency of occurrence for wind speed and direction at the Livermore site, 2000 occurs primarily during the summer. During the winter, the wind often blows from the northeast. Based on a ten-year record, the highest and lowest annual rainfalls were 541 and $211 \mathrm{~mm}$, and the average annual rainfall was $360 \mathrm{~mm}$. In 2000, the Livermore site received $295 \mathrm{~mm}$ of rain.

The meteorological conditions at Site 300, while generally similar to those at the Livermore site, are modified by higher elevation and more pronounced topological relief. The complex topography of the site significantly influences local wind and temperature patterns. Annual wind data are presented in Figure 1-3 and Table 1-2. The data show that winds are more consistently from the west-southwest and reach greater speeds than at the Livermore site. The increased wind speed and elevation of much of Site 300 result in afternoon temperatures that are typically lower than those for the Livermore site. Rainfall for 2000 was $250 \mathrm{~mm}$ at Site 300 . As in the case for the Livermore site, precipitation is seasonal, with most rainfall occurring between October and April.

\section{Topography}

The Livermore site is located in the southeastern portion of the Livermore Valley, a topographic and structural depression oriented east-west within the Diablo Range of the California Coast Range Province. The Livermore Valley, the most prominent valley in the Diablo Range, is an east-west trending structural and topographic trough that is bounded on the west by Pleasanton Ridge and on the east by the Altamont Hills. The valley floor is covered by alluvial, lake, and swamp deposits consisting of gravels, sands, silts, and clays, at an average thickness of about $100 \mathrm{~m}$. The valley is approximately $25-\mathrm{km}$ long and averages $11-\mathrm{km}$ in width. The valley floor is at its highest elevation of $220 \mathrm{~m}$ above sea level along the eastern margin and gradually dips to $92 \mathrm{~m}$ at the southwest corner. The major streams passing through the Livermore 
Table 1-1. Wind rose data for LLNL's Livermore site at the 10-m level for 2000. Values are frequency of occurrence (in percent)

\begin{tabular}{|l|c|c|c|c|c|c|}
\hline \multirow{2}{*}{ Direction } & \multicolumn{7}{|c|}{ Wind speed range (m/s) } \\
\cline { 2 - 7 } NNE & $0.0-0.4$ & $0.5-2.9$ & $3.0-4.9$ & $5.0-6.9$ & $\geq 7.0$ & Total $^{\text {(a) }}$ \\
NE & 0.24 & 2.43 & 1.47 & 0.35 & 0.11 & 4.6 \\
ENE & 0.24 & 4.28 & 1.98 & 0.17 & 0.00 & 6.7 \\
E & 0.24 & 2.94 & 0.09 & 0.00 & 0.00 & 3.3 \\
ESE & 0.24 & 2.47 & 0.00 & 0.00 & 0.00 & 2.7 \\
SE & 0.24 & 2.45 & 0.01 & 0.00 & 0.00 & 2.7 \\
SSE & 0.24 & 2.19 & 0.06 & 0.00 & 0.00 & 2.5 \\
S & 0.24 & 2.08 & 0.20 & 0.05 & 0.02 & 2.6 \\
SSW & 0.24 & 4.46 & 0.15 & 0.01 & 0.00 & 4.9 \\
SW & 0.24 & 6.90 & 1.50 & 0.43 & 0.16 & 9.2 \\
WSW & 0.24 & 8.81 & 8.11 & 2.65 & 0.33 & 20.1 \\
W & 0.24 & 9.38 & 5.59 & 0.97 & 0.04 & 16.2 \\
WNW & 0.24 & 5.99 & 6.38 & 1.05 & 0.00 & 13.7 \\
NW & 0.24 & 2.06 & 1.10 & 0.15 & 0.00 & 3.6 \\
NNW & 0.24 & 1.43 & 0.02 & 0.00 & 0.00 & 1.7 \\
N & 0.24 & 1.47 & 0.04 & 0.02 & 0.00 & 1.8 \\
Total (a) & 0.24 & 1.83 & 0.90 & 0.56 & 0.31 & 3.8 \\
\hline
\end{tabular}

a Columns and rows may not exactly sum to the listed totals because of rounding

Valley are Arroyo del Valle and Arroyo Mocho, which drain the southern highlands and flow intermittently. Major arroyos are depicted in Chapter 7 (Figure 7-1).

The topography of Site 300 is much more irregular than that of the Livermore site; a series of steep hills and ridges is oriented along a generally northwest-southeast trend and is separated by intervening ravines. The Altamont Hills, where Site 300 is located, are part of the California Coast Range Province and separate the Livermore Valley to the west from the San Joaquin Valley to the east.
The elevation ranges from approximately $538 \mathrm{~m}$ above sea level at the northwestern corner of the site to approximately $150 \mathrm{~m}$ in the southeast portion.

\section{Hydrogeology}

\section{Livermore Site}

The hydrogeology and movement of groundwater in the vicinity of the Livermore site have been the subjects of several investigations (Stone and Ruggieri 1983; Carpenter et al. 1984; WebsterScholten and Hall 1988; and Thorpe et al. 1990). 


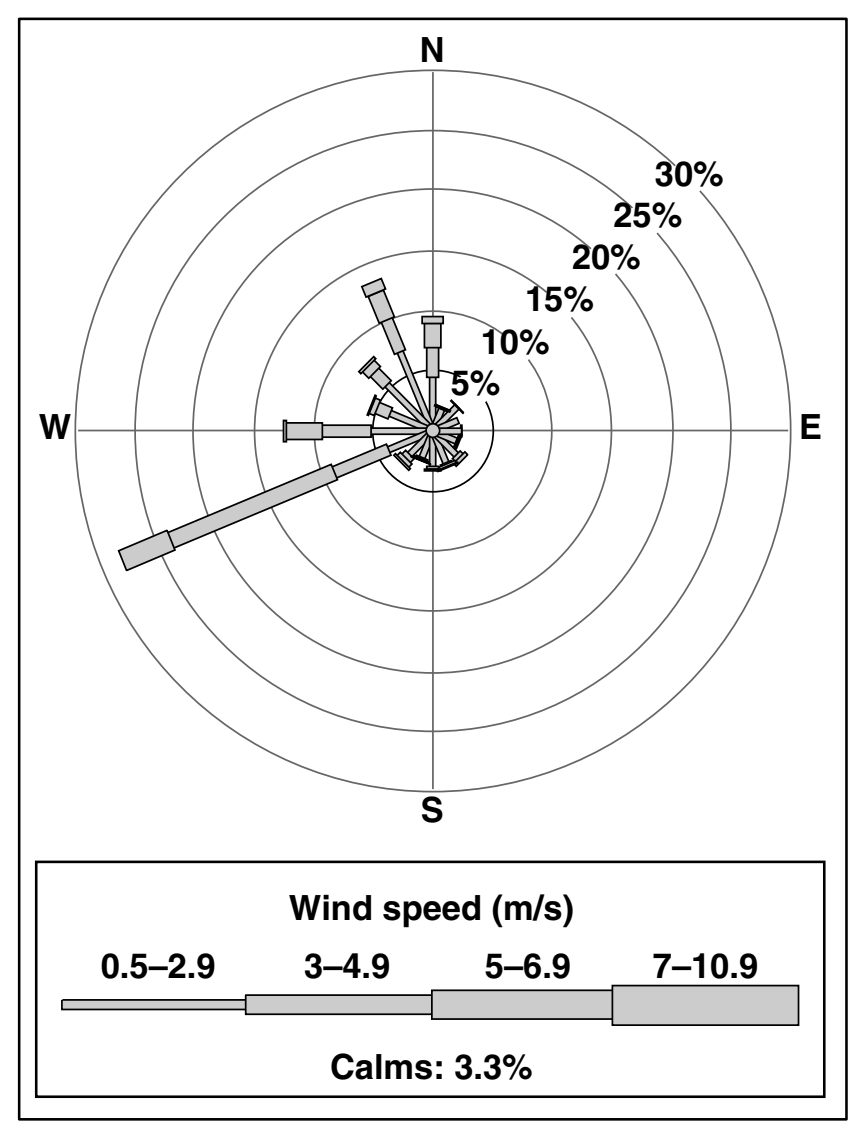

Figure 1-3. Wind rose showing the frequency of occurrence for wind speed and direction at Site 300, 2000

This section has been summarized from the reports of these investigations and from data supplied by Alameda County Flood Control and Water Conservation District Zone 7, the agency responsible for groundwater management in the Livermore Valley basin (SFBRWQCB 1982a,b).

The Livermore Formation (and overlying alluvial deposits) contains the aquifers of the Livermore Valley groundwater basin, an important waterbearing formation. Natural recharge occurs primarily along the fringes of the basin and through the arroyos during periods of winter flow. Artificial recharge, if needed to maintain groundwater levels, is accomplished by releasing water from Lake Del Valle or from the South Bay Aqueduct into arroyo channels in the east. Groundwater flow in the valley generally moves toward the central east-west axis of the valley and then westward through the central basin. Groundwater flow in the basin is primarily horizontal, although a significant vertical component probably exists in fringe areas, under localized sources of recharge, and in the vicinity of heavily used extraction (production) wells.

Beneath the Livermore site, the water table varies in depth from the surface from about 10 to $40 \mathrm{~m}$. Figure 1-4 shows a contour map of water table elevations (meters above mean sea level) for the Livermore site area. Although water table elevations vary slightly with seasonal and year-to-year differences in both natural and artificial recharge, the qualitative patterns shown in Figure 1-4 are generally maintained. At the eastern edge of the Livermore site, groundwater gradients (change in vertical elevation per unit of horizontal distance) are relatively steep, but under most of the site and farther to the west, the contours flatten to a gradient of approximately 0.003 .

Groundwater flow under most of the site is southwesterly. This flow direction diverges from the generally westward regional flow and from flow patterns demonstrated for the site in the 1980s. This shift in flow direction is a consequence of groundwater recovery and remediation in the southwest portion of the site and agricultural pumping. Aquifer tests on monitoring wells in the vicinity of the Livermore site indicate that the hydraulic conductivity (a measure of the rate of flow) of the permeable sediments ranges from 1 to $16 \mathrm{~m} /$ day (Isherwood et al. 1991). This, in combination with the observed water table gradients, yields an estimated average groundwater velocity of $20 \mathrm{~m} / \mathrm{y}$ (Thorpe et al. 1990). The range in these values reflects the heterogeneity typical of the more permeable alluvial sediments that underlie the area. 
Table 1-2. Wind rose data for LLNL's Site 300 at the 10-m level for 2000. Values are frequency of occurrence (in percent)

\begin{tabular}{|l|c|c|c|c|c|c|}
\hline \multirow{2}{*}{ Direction } & \multicolumn{7}{|c|}{ Wind speed range (m/s) } \\
\cline { 2 - 7 } & $0.0-0.4$ & $0.5-4.9$ & $5.0-6.9$ & $7.0-10.9$ & $\geq 11.0$ & Total $^{(\mathbf{a})}$ \\
\hline NNE & 0.22 & 1.40 & 0.05 & 0.05 & 0.00 & 1.7 \\
NE & 0.22 & 2.28 & 0.00 & 0.01 & 0.00 & 2.5 \\
ENE & 0.22 & 1.71 & 0.00 & 0.00 & 0.00 & 1.9 \\
E & 0.22 & 1.83 & 0.03 & 0.00 & 0.00 & 2.1 \\
ESE & 0.22 & 1.61 & 0.10 & 0.09 & 0.00 & 2.0 \\
SE & 0.22 & 2.29 & 0.34 & 0.28 & 0.00 & 3.1 \\
SSE & 0.22 & 2.35 & 0.11 & 0.20 & 0.08 & 3.0 \\
S & 0.22 & 2.40 & 0.27 & 0.13 & 0.00 & 3.0 \\
SSW & 0.22 & 1.88 & 0.10 & 0.07 & 0.02 & 2.3 \\
SW & 0.22 & 2.27 & 0.40 & 0.38 & 0.16 & 3.4 \\
WSW & 0.22 & 3.46 & 4.90 & 14.87 & 4.39 & 27.8 \\
W & 0.22 & 4.63 & 4.11 & 2.98 & 0.24 & 12.2 \\
WNW & 0.22 & 3.31 & 1.20 & 0.46 & 0.02 & 5.2 \\
NW & 0.22 & 4.83 & 1.49 & 0.84 & 0.14 & 7.5 \\
NNW & 0.22 & 6.55 & 2.82 & 2.45 & 1.00 & 13.0 \\
N & 3.82 & 46.7 & 18.4 & 24.8 & 6.66 & 100 \\
\hline Total (a) & 0.22 & 3.44 & 2.03 & 0.61 & 9.2 \\
\hline
\end{tabular}

a Columns and rows may not exactly sum to the listed totals because of rounding

\section{Site 300}

Gently dipping sedimentary bedrock dissected by steep ravines generally underlies Site 300 . The bedrock is made up primarily of interbedded sandstone, siltstone, and claystone. Most groundwater occurs in the Neroly Formation upper and lower blue sandstone aquifers. Significant groundwater is also locally present in permeable Quaternary alluvium valley fill. Much less groundwater is present within perched aquifers in the unnamed Pliocene nonmarine unit. Perched aquifers contain unconfined water separated from an underlying main body of water by impermeable layers; normally they are discontinuous and highly localized. Because water quality generally is poor and yields are low, these perched water-bearing zones do not meet the State of California criteria for aquifers that are potential water supplies.

Fine-grained siltstone and claystone interbeds may confine the groundwater and act as aquitards, confining layers, or perching horizons. Groundwater is present under confined conditions in parts of the deeper bedrock aquifers but is generally unconfined elsewhere. 


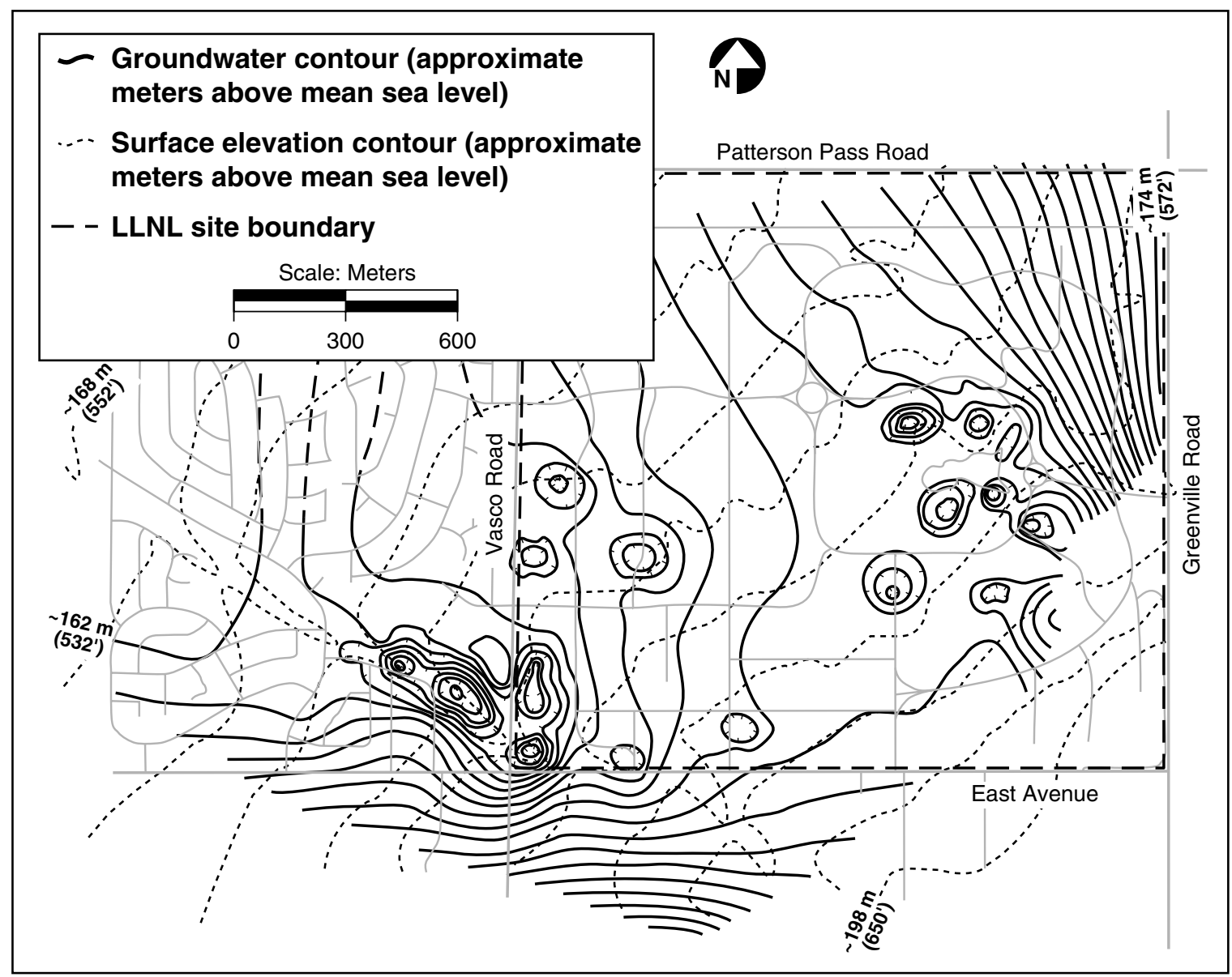

Figure 1-4. 2000 approximate groundwater and surface elevation contours, Livermore site and vicinity

Groundwater flow in most aquifers follows the attitude of the bedrock. In the northwest part of Site 300, groundwater in bedrock generally flows northeast except where it is locally influenced by the geometry of alluvium-filled ravines. In the southern half of Site 300, groundwater in bedrock flows roughly south-southeast, approximately coincident with the attitude of bedrock strata.

The thick Neroly lower blue sandstone, stratigraphically near the base of the formation, generally contains confined water. Wells located in the western part of the General Services Area (GSA) are completed in this aquifer and are used to supply drinking and process water.
Figure 1-5 shows the elevation contours for groundwater in the regional aquifer at Site 300 . This map of the piezometric surface (the elevation at which water stabilizes in a well that penetrates a confined or unconfined aquifer) is based primarily on water levels in the Neroly lower blue sandstone aquifer.

Recharge occurs predominantly in locations where saturated alluvial valley fill is in contact with underlying permeable bedrock or where permeable bedrock strata crop out because of structure or topography. Local recharge also occurs on hilltops, creating some perched water-bearing zones. Low 


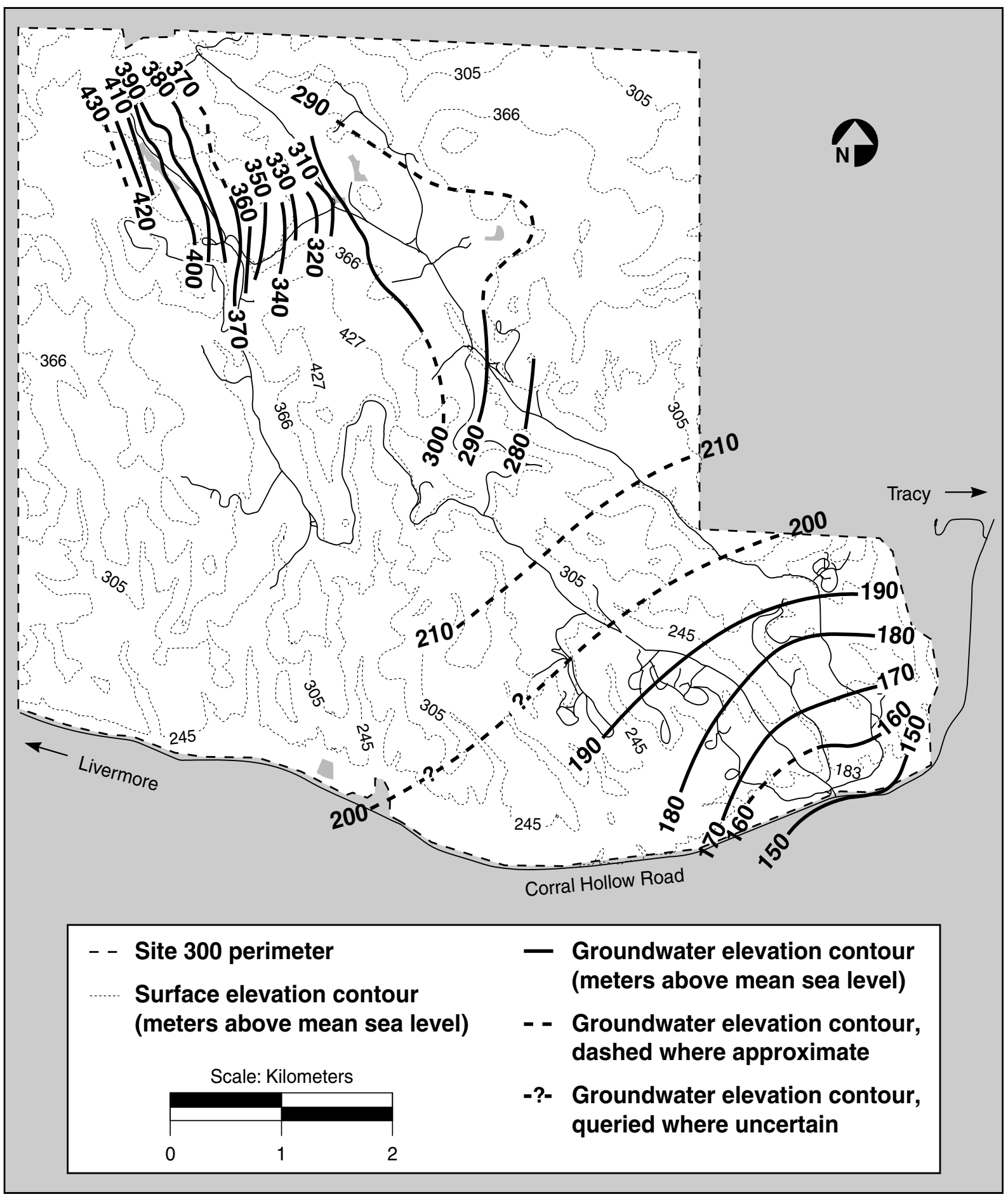

Figure 1-5. 2000 approximate groundwater elevations in the principal continuous waterbearing zone at Site 300 
rainfall, high evapotranspiration, steep topography, and intervening aquitards generally preclude direct vertical recharge of the bedrock aquifers.

Further information on the hydrology of both the Livermore site and Site 300 can be found in the groundwater monitoring and remediation information in Chapters 8 and 9.

\section{Summary}

LLNL recognizes the importance of our geology, hydrogeology, climate, and geographical relationships with our neighbors in assessing potential impacts of operations at the Livermore site and
Site 300. Each year we gain additional informationthat allows us to better predict, interpret, and avoid potential impacts. Each environmental medium that is discussed in this document-air, soil, water, vegetation, and foodstuff-may be affected differently. The environmental scientists at LLNL take into account the unique locations of the Livermore site and Site 300 to tailor sampling and analysis programs for each method used to monitor the environment.

We acknowledge the work of Art Biermann, Richard Blake, Frank Gouveia, Robert Harrach, William Hoppes, and Michael Taffet, in preparing this chapter. 


\section{Compliance Summary}

\section{Introduction}

During 2000, Lawrence Livermore National Laboratory (LLNL) participated in numerous activities to comply with federal, state, and local environmental regulations as well as internal requirements and applicable Department of Energy (DOE) orders. This chapter, which is organized according to the various laws and regulations that drive LLNL's compliance activities, describes those activities the Laboratory carried out related to air, water, waste, waste reduction, community "right to know," protection of sensitive resources, and other environmental issues at the Livermore site and Site 300. A wide range of compliance activities is summarized in this chapter. Compliance activities specific to the applicable DOE orders are discussed in the chapters that follow. Applicable DOE orders are those identified in LLNL's Work Smart Standards (WSS), a set of environmental, safety, and health standards specific to operations at the Laboratory (see Chapter 3). Other environmental program information, including the Environment, Safety, and Health Management System and pollution prevention and waste minimization activities, is also discussed in Chapter 3. Many documents concerned with these activities and other environmental topics are available for public viewing at the LLNL Visitors Center and the Livermore and Tracy public libraries.

\section{Comprehensive Environmental Response, Compensation and Liability Act}

The Livermore Site Groundwater Project (GWP) and the Site 300 CERCLA Project are under the jurisdiction of the Comprehensive Environmental Response, Compensation and Liability Act (CERCLA)/Superfund Amendments and Reauthorization Act, Title 1. As part of work on these projects, DOE and LLNL also continued with environmental restoration and community relations activities. These projects and activities are described in the following sections.

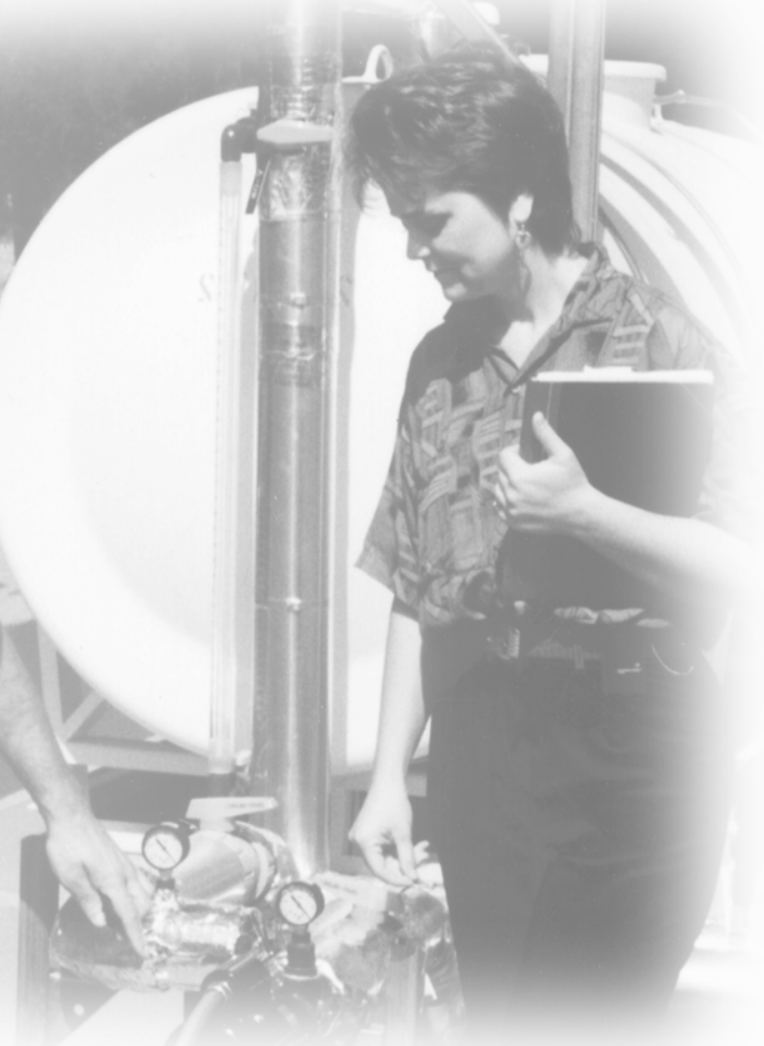




\section{Livermore Site Groundwater Project}

The GWP at the Livermore site complies with provisions specified in a federal facility agreement (FFA) entered into by the U.S. Environmental Protection Agency (EPA), DOE, the California EPA's Department of Toxic Substances Control (DTSC), and the San Francisco Bay Regional Water Quality Control Board (SFBRWQCB). As required by the FFA, the project addresses compliance issues by investigating potential contamination source areas (such as suspected old release sites, solvent-handling areas, and leaking underground tank systems), continuous monitoring, and remediation of groundwater. The groundwater contaminants (constituents of concern) are volatile organic compounds (VOCs), primarily trichloroethene (TCE) and tetrachloroethene (PCE). For the most part, these contaminants are present within the site boundary and to some extent at the site boundary and beyond, mainly to the west and south of the site (see Figures 8-3 to 8-8). In 2000, GWP activities included preparing the required CERCLA documents, meeting milestones, operating groundwater treatment facilities, and maintaining liaison with community groups.

In 2000, DOE and LLNL submitted documents required by the CERCLA and the Livermore Site FFA. In addition, DOE and LLNL continued environmental restoration and community activities as discussed below.

\section{Documentation}

As required by the FFA, DOE and LLNL issued the Ground Water Project 1999 Annual Report (Aarons et al. 2000) on schedule on March 31, 2000. DOE and LLNL also issued six final Remedial Project Managers' (RPMs') meeting summaries. Quarterly self-monitoring data were reported in letter reports (Bainer and Joma 2000a; Bainer and Abbott, 2000a,b, 2001).
An Explanation of Significant Differences was issued on February 28, 2000, that described a change to the groundwater treatment system at Trailer 5475 to allow groundwater containing both VOCs and tritium above their maximum contaminant levels (MCLs) to pass through an aboveground facility to treat VOCs (Berg 2000). Treated water still containing tritium is subsequently recharged back into the same hydrostratigraphic unit (HSU) via two adjacent recharge wells.

DOE and LLNL also issued an Action Memorandum on March 6, 2000, for a time-critical removal action that documented the removal of soil containing residual polychlorinated biphenyls (PCBs) from the East Traffic Circle (Joma 2000).

\section{Milestones and Activities}

Three milestones were completed ahead of schedule and one was delayed three months with regulatory concurrence to accommodate an adjacent construction project unrelated to GWP activities. For the first milestone, LLNL began operation of Treatment Facility 518 North solar treatment unit on January 26, 2000. With regulatory approval, LLNL began operation of Treatment Facility D Southshore miniature treatment unit (MTU) three months late on June 30, 2000. In addition, two other milestones were achieved by beginning operation of Treatment Facility E Southeast MTU on June 27, 2000, and Treatment Facility 5475-3 catalytic reductive dehalogenation unit on September 27, 2000.

Other activities related to the Livermore CERCLA project included the investigation and analysis of data associated with recently discovered high VOC concentrations in a perched water-bearing zone in the Building 518 area. LLNL also destroyed five offsite wells on property north of East Avenue, south of Arroyo Seco, and west of Vasco Road to accommodate a new housing development. 


\section{Treatment Facilities}

DOE and LLNL operated all facilities in treatment facilities TFA, TFB, TFC, TFD, TFE, TFG, TF406, TF518, and TF5475 areas in 2000. A total of 80 groundwater extraction wells operated at 25 separate locations at an average flow rate of 3,641,170 L/day. Vapor treatment facilities VTF518 and VTF5475 operated at an average flow of $841 \mathrm{~m}^{3} /$ day. Together, the groundwater and vapor treatment facilities removed approximately $269 \mathrm{~kg}$ of VOC mass in 2000. Since initial operation, approximately 5.4 billion $\mathrm{L}$ of groundwater and $695,000 \mathrm{~m}^{3}$ of vapor have been treated, removing more than $1,021 \mathrm{~kg}$ of VOCs.

\section{Community Relations}

The Community Work Group (CWG) met twice in 2000 to discuss the DOE budget, long-term stewardship, technology deployments, and progress of the Livermore site cleanup. Correspondence and communication continued with CWG members throughout the year. DOE and LLNL met twice with members of Tri-Valley Communities Against a Radioactive Environment (CAREs) and their scientific advisor as part of the activities funded by an Environmental Protection Agency Technical Assistance Grant.

Other Livermore site community relations activities in 2000 included communicating and meeting with neighbors, local, regional and national interest groups, and other community organizations; giving public presentations including those to local Realtors; producing and distributing the Environmental Community Letter; maintaining the information repositories and the administrative record; conducting tours of the site environmental activities; and responding to public and news media inquiries. In addition, community questions were addressed by telephone and electronic mail. Documents, letters, and public notices were posted on a public website at the following address: http://www-envirinfo.llnl.gov.

\section{Site 300 CERCLA Project}

Investigations and remedial activities are ongoing at Site 300, which became a CERCLA/Superfund site in 1991, when it was placed on the National Priorities List. Investigations and remedial activities are conducted under the joint oversight of the EPA, the Central Valley Regional Water Quality Control Board (CVRWQCB), California EPA's DTSC, and the authority of an FFA for the site. (There are separate FFAs for Site 300 and the Livermore site.)

During 2000, LLNL submitted all required regulatory documents (see Chapter 8 ) on or ahead of schedule, performed all actions stipulated in the FFA, and maintained liaison with community groups. Results and status for Site 300 environmental restoration operable units are discussed in Chapter 8. Background information for LLNL environmental characterization and restoration activities at Site 300 can be found in the Final SiteWide Remedial Investigation Report, Lawrence Livermore National Laboratory Site 300 (WebsterScholten 1994).

\section{Documentation}

LLNL submitted all required documentation to oversight agencies on time in 2000. The Final Proposed Plan for Environmental Cleanup at Lawrence Livermore National Laboratory Site 300 (Dresen et al. 2000), Draft Final Interim Site-Wide Record of Decision for Lawrence Livermore National Laboratory Site 300 (U.S. DOE 2000), quarterly reports, and work plans were among the documents submitted.

On November 3, 2000, DOE issued a Finding of No Significant Impact (FONSI) for the Environmental Assessment of the Remediation of Environmental Contaminants at the Lawrence Livermore National Laboratory Experimental Test Facility, Site 300, which was prepared by LLNL. 


\section{Milestones and Activities}

LLNL has completed all the 2000 FFA milestones for Site 300 on or ahead of schedule. For a detailed list of these milestones and corresponding dates, see Table 8-2.

\section{Treatment Facilities}

VOCs (primarily TCE) are the main contaminants at Site 300. High explosives, tritium, depleted uranium, organosilicate oil, nitrate, and perchlorate are also found in groundwater. Eight treatment facilities that remove and treat VOCs operated throughout 2000. Additionally, three new treatment facilities were constructed and began operation at Site 300 during 2000. These facilities are discussed in more detail in Chapter 8 . Fourteen wells that extract groundwater only and 25 wells that extract both groundwater and soil vapor operated during 2000, treating about 102.5 million L of groundwater. The 25 wells that extract both vapor and groundwater together removed $352,905 \mathrm{~m}^{3}$ of vapor. In 2000 , the Site 300 treatment facilities removed approximately $27.7 \mathrm{~kg}$ of VOCs. Since remediation efforts began in 1990 , more than 702 million $\mathrm{L}$ of groundwater and approximately 2.21 million $\mathrm{m}^{3}$ of vapor have been treated, to yield about $185 \mathrm{~kg}$ of removed VOCs. See Chapter 8 for maps of the operable units and details of the distribution of contaminants in groundwater at Site 300 .

\section{Community Relations}

The Site 300 CERCLA project maintains proactive communication with the surrounding communities of Tracy and Livermore. Community relations activities in 2000 included maintenance of the information repositories and administrative records; off-site, private well-sampling activities; mailings to stakeholders; and interviews with the news media. Meetings were held with Tri-Valley CAREs, which receives an annual technical assistance grant from EPA to independently evaluate CERCLA activities at Site 300.
On May 5, 2000, the remedial project managers held a public meeting to present to the community the preferred remedial alternatives outlined in the Final Proposed Plan for Environmental Cleanup (Dresen et al. 2000). Prior to the meeting, LLNL held a public workshop to help the public understand the proposed plan.

\section{Site Evaluations Prior to Construction}

Before any construction begins, the CERCLA Record of Decision (ROD) for the Livermore site requires that the project site be evaluated to determine if soil or rubble (concrete and asphalt) is contaminated. Soil is sampled and analyzed for potential radioactive and/or hazardous contamination. Depending on the analytical results, soil may be reused on site or disposed of according to established procedures. Depending on the potential for radioactive contamination, rubble may be either surveyed or analyzed for radioactivity. During 2000, soil and rubble were evaluated at 51 construction sites.

\section{Agency for Toxic Substances and Disease Registry Assessment}

The Agency for Toxic Substances and Disease Registry (ATSDR) is a federal public health agency whose mission is to prevent adverse human health effects and diminished quality of life associated with exposure to hazardous substances from waste sites, unplanned releases, and other sources of pollution in the environment. ATSDR is mandated by Congress to conduct public health assessments (PHAs) of communities such as Livermore that are adjacent to hazardous waste sites. During the PHA process, in response to ATSDR queries, members of the Livermore community expressed specific concerns related to the environmental monitoring and dose evaluation of tritium at a meeting on April 19. To address these concerns, in 2000 ATSDR convened a panel of five experts in the 
fields of tritium analysis and dosimetry to complete a health consultation on tritium related to LLNL operations.

The health consultation, which will be part of the final PHA for LLNL, will assess concerns related to tritium releases from the Laboratory. The health consultation, while based on the findings of the expert panel, will recommend action if there is any doubt that risks to the public are not being adequately assessed.

ATSDR reports and other related regulatory documents can be viewed in the "Off-site Environmental Studies (Livermore Site)" section of the Environmental Community Relations website at the following address: http://www-envirinfo.llnl.gov.

\section{Superfund Amendment and Reauthorization Act, Title III}

Title III of the Superfund Amendment and Reauthorization Act (SARA) is known as the Emergency Planning and Community Right-to-Know Act (EPCRA). It requires owners or operators of facilities that handle certain hazardous chemicals on site to provide information on the release, storage, and use of those chemicals to organizations responsible for emergency response planning. Executive Order 13148 directs all federal agencies to comply with the requirements of EPCRA, including SARA 313, Toxic Release Inventory Program.

EPCRA requirements and LLNL compliance are summarized in Table 2-1. Tables 2-2 and 2-3 identify those chemicals and their hazards reported during 2000 by LLNL for the Livermore site and Site 300, respectively, under Title III, Section 311.

\section{Clean Air Act-Air Quality Management Activities}

Air permits are obtained from the Bay Area Air Quality Management District (BAAQMD) for the Livermore site and from the San Joaquin Valley Unified Air Pollution Control District (SJVUAPCD) for Site 300. In 2000, LLNL operated 129 air emission sources for the Livermore site. BAAQMD inspectors found no deficiencies at the Livermore site (see Table 2-4). Also in 2000, LLNL applied for a Synthetic Minor Operating Permit as required by BAAQMD Regulation 2-6312. The purpose of the document is to provide BAAQMD with an accounting of data about the potential to emit regulated pollutants from LLNL operations, a list of the permitted and exempt sources on site, a proposed limit on any regulated pollutant that exceeds the limits set in the regulation, and an explanation of how LLNL will comply with the conditions set forth in the permit.

BAAQMD received and accepted the permit application on October 20,2000, and committed to making a final decision on the application no later than April 18, 2001. In 2000, SJVUAPCD issued or renewed air permits for 42 air emission sources for Site 300 (see Table 2-5). At Site 300 SJVUAPCD conducted an inspection of emission sources and observed a leak test of the vapor recovery system for the Site $\mathbf{3 0 0}$ gasoline fuel tank; no deficiencies were found (see Table 2-4).

\section{National Emission Standards for Hazardous Air Pollutants}

To demonstrate compliance with the National Emissions Standards for Hazardous Air Pollutants (NESHAPs) for radiological emissions (40 Code of Federal Regulations [CFR] 61, Subpart H), LLNL is required to monitor certain air release points and evaluate all potential sources of radionuclide air emissions to determine the possible effective dose 
Table 2-1. Summary of LLNL compliance with EPCRA in 2000

\begin{tabular}{|c|c|c|}
\hline EPCRA requirement & Brief description & Compliance \\
\hline $\begin{array}{l}302 \text { Planning } \\
\text { Notification }\end{array}$ & $\begin{array}{l}\text { Operator must notify SERC } \\
\text { extremely hazardous substances. } \\
\text { In California, operator must notify CEPRC } \\
\text { of presence of extremely hazardous } \\
\text { substances above threshold planning } \\
\text { quantities. }\end{array}$ & Originally submitted May 1987. \\
\hline $\begin{array}{l}303 \text { Planning } \\
\text { Notification }\end{array}$ & $\begin{array}{l}\text { Operator must designate a facility repre- } \\
\text { sentative to serve as emergency response } \\
\text { coordinator. }\end{array}$ & $\begin{array}{l}\text { Updates submitted March 23, 2000, } \\
\text { and August } 8,2000 .\end{array}$ \\
\hline $\begin{array}{l}304 \text { Release Notifica- } \\
\text { tion }\end{array}$ & $\begin{array}{l}\text { Releases of certain hazardous substances } \\
\text { must be reported to SERC and LEPC. (c) }\end{array}$ & $\begin{array}{l}\text { No EPCRA-listed extremely hazardous } \\
\text { substances were released above } \\
\text { reportable quantities. }\end{array}$ \\
\hline $\begin{array}{l}311 \operatorname{MSDS}^{(\mathrm{d})} / \\
\text { Chemical Inventory }\end{array}$ & $\begin{array}{l}\text { Operator must submit MSDSs or chemical } \\
\text { list to SERC, LEPC, and Fire Department. }\end{array}$ & $\begin{array}{l}\text { Tables } 2-2 \text { and } 2-3 \text {. } \\
\text { Updated March 23, 2000, and } \\
\text { August } 8,2000 .\end{array}$ \\
\hline $\begin{array}{l}312 \text { MSDS/Chemical } \\
\text { Inventory }\end{array}$ & $\begin{array}{l}\text { Operator must submit hazardous chemical } \\
\text { inventory to local administering agency } \\
\text { (county). }\end{array}$ & $\begin{array}{l}\text { Business plans and chemical inventory } \\
\text { submitted to San Joaquin County } \\
\text { (January 14, 2000) and Alameda } \\
\text { County (March 1, 2000, August 11, } \\
\text { 2000). }\end{array}$ \\
\hline $\begin{array}{l}313 \text { Toxic Release } \\
\text { Inventory }\end{array}$ & $\begin{array}{l}\text { Operator must submit Form R to U.S. EPA } \\
\text { and California EPA for toxic chemicals } \\
\text { released. }\end{array}$ & $\begin{array}{l}\text { Form R for Freon } 113 \text { submitted } \\
\text { June } 21,2000 \text {, to DOE; DOE } \\
\text { forwarded it to U.S. EPA and } \\
\text { California EPA on June 27, } 2000 .\end{array}$ \\
\hline \multicolumn{3}{|c|}{ a $\quad$ SERC $=$ State Emergency Response Commission } \\
\hline \multicolumn{3}{|c|}{ b CEPRC $=$ Chemical Emergency Planning and Response Commission } \\
\hline \multicolumn{3}{|c|}{ c $\quad$ LEPC $=$ Local Emergency Planning Committee } \\
\hline \multicolumn{3}{|c|}{ d MSDS = material safety data sheet } \\
\hline
\end{tabular}

equivalent to the maximally exposed individual of the public. These evaluations include modeling (using EPA-sanctioned computer codes) based on radionuclide inventory data, air effluent (source emission) monitoring, or air surveillance monitoring.

The LLNL NESHAPs 2000 Annual Report (Gallegos et al. 2001), submitted to DOE and EPA, reported that the estimated total site-wide maximally exposed individual radiological doses for the Livermore site and Site 300 were $0.38 \mu \mathrm{Sv}$ $(0.038 \mathrm{mrem})$ and $0.19 \mu \mathrm{Sv}(0.019 \mathrm{mrem})$, respectively, for 2000. Disregarding the EPAmandated assumption that gaseous tritium be treated as though it were tritiated water yielded a slightly lower dose of $0.37 \mu \mathrm{Sv}$ ( $0.037 \mathrm{mrem})$ for Livermore site operations.

The reported doses include contributions from both point and diffuse sources. The totals were well below the $100 \mu \mathrm{Sv} / \mathrm{y}(10 \mathrm{mrem} / \mathrm{y})$ dose limits defined by the NESHAPs regulations. The details of these data are included in this report (see Chapter 13). 
Table 2-2. Livermore site, SARA, Title III, Section 311, Chemical List, 2000

\begin{tabular}{|c|c|c|c|c|c|}
\hline \multirow{2}{*}{ Livermore site chemicals } & \multicolumn{3}{|c|}{ Physical hazard $(a)$} & \multicolumn{2}{|c|}{ Health hazard $(a)$} \\
\hline & Fire & Pressure & Reactivity & Acute & Chronic \\
\hline Ammonium hydroxide & & & & $\bullet$ & \\
\hline Argon & & $\bullet$ & & $\bullet$ & \\
\hline Carbon, activated & $\bullet$ & & & & \\
\hline Carbon dioxide & & $\bullet$ & $\bullet$ & $\bullet$ & \\
\hline Chlorine & & $\bullet$ & $\bullet$ & $\bullet$ & \\
\hline Chromium(III) chloride & & & & $\bullet$ & • \\
\hline Cobalt & • & & & $\bullet$ & • \\
\hline Diesel fuel & - & & & - & - \\
\hline Freon 11 & & $\bullet$ & & • & \\
\hline Freon 113 & & & & $\bullet$ & \\
\hline Gasoline & • & & & $\bullet$ & • \\
\hline Glass cleaner & & - & & - & \\
\hline Helium & & $\bullet$ & & $\bullet$ & \\
\hline Hydrochloric acid & & & & $\bullet$ & - \\
\hline Hydrofluoric acid & & (b) & • & • & • \\
\hline Hydrogen & • & $\bullet$ & & $\bullet$ & \\
\hline Hydrogen peroxide (<52\%) & & & $\bullet$ & & \\
\hline Insulating oil, inhibiting & $\bullet$ & & & & \\
\hline Lead (bricks and ingots) & & & & • & • \\
\hline Lithium hydride & • & & $\bullet$ & • & \\
\hline Methane & • & • & & • & \\
\hline Methyl alcohol & $\bullet$ & & & $\bullet$ & \\
\hline Methylene chloride & & & & $\bullet$ & • \\
\hline Nitric acid & • & & • & $\bullet$ & $\bullet$ \\
\hline Nitric oxide & • & $\bullet$ & $\bullet$ & • & \\
\hline Nitrogen & & • & & & \\
\hline Oil, DTE-26 & $\bullet$ & & & & \\
\hline Oxygen & & $\bullet$ & • & & \\
\hline Paint & $\bullet$ & & & & \\
\hline Potassium cyanide & & & & $\bullet$ & \\
\hline Potassium hydroxide & & & $\bullet$ & $\bullet$ & • \\
\hline
\end{tabular}


Table 2-2. Livermore site, SARA, Title III, Section 311, Chemical List, 2000 (continued)

\begin{tabular}{|c|c|c|c|c|c|}
\hline \multirow{2}{*}{ Livermore site chemicals } & \multicolumn{3}{|c|}{ Physical hazard ${ }^{(a)}$} & \multicolumn{2}{|c|}{ Health hazard $(a)$} \\
\hline & Fire & Pressure & Reactivity & Acute & Chronic \\
\hline Propane & $\bullet$ & $\bullet$ & & $\bullet$ & \\
\hline Sodium hypochlorite & & & & $\bullet$ & \\
\hline Sulfuric acid & & & $\bullet$ & $\bullet$ & $\bullet$ \\
\hline Tantalum & & & & $\bullet$ & \\
\hline Thinner, lacquer & • & & & • & • \\
\hline
\end{tabular}

a Physical and health hazard information obtained primarily from material safety data sheets

b Some containers have a pressure hazard.

Table 2-3. Site 300, SARA, Title III, Section 311, Chemical List, 2000

\begin{tabular}{|c|c|c|c|c|c|}
\hline \multirow{2}{*}{ Site 300 chemicals } & \multicolumn{3}{|c|}{ Physical hazard(a) } & \multicolumn{2}{|c|}{ Health hazard(a) } \\
\hline & Fire & Pressure & Reactivity & Acute & Chronic \\
\hline Argon & & • & & • & \\
\hline Carbon, activated & - & & & & \\
\hline Chlorine & & $\bullet$ & $\bullet$ & • & \\
\hline $\begin{array}{l}\text { Bis(2,2-dinitro-2-fluoroethyl) formal in } \\
\text { methylene chloride }\end{array}$ & $-^{(b)}$ & & - $^{\text {(b) }}$ & • & • \\
\hline Diesel fuel & • & & & • & - \\
\hline Gasoline & $\bullet$ & & & - & - \\
\hline High explosives & & & - & & \\
\hline Lead (bricks) & & & & - & - \\
\hline Nitrogen & & $\bullet$ & & & \\
\hline Oil, hydraulic & $\bullet$ & & & - & \\
\hline Oil, inhibited insulating & $\bullet$ & & & & \\
\hline Oil, transformer & $\bullet$ & & & & \\
\hline Phosphorous trichloride & & & • & • & \\
\hline Sulfuric acid & & & - & - & - \\
\hline
\end{tabular}

a Physical and health hazard information obtained primarily from material safety data sheets

b Dangerous fire or explosion risk in neat form (solvent evaporates) 
Table 2-4. Inspections and tours of the Livermore site and Site 300 by external agencies in 2000

\begin{tabular}{|c|c|c|c|c|}
\hline Medium & Description & Agency ${ }^{(a)}$ & Date & Finding $^{(a)}$ \\
\hline \multicolumn{5}{|c|}{ Livermore Site $^{(b)}$} \\
\hline Air & Emission sources & BAAQMD & $\begin{array}{l}5 / 4 \\
5 / 25 \\
6 / 15 \\
6 / 29\end{array}$ & No violations \\
\hline \multirow{2}{*}{$\begin{array}{l}\text { Sanitary } \\
\text { sewer }\end{array}$} & Annual compliance sampling & LWRP & $11 / 6$ & No violations \\
\hline & Categorical sampling & & $\begin{array}{l}10 / 19 \\
11 / 2\end{array}$ & $\begin{array}{l}\text { No outstanding deficiencies at time of } \\
\text { sampling. However, one notice of } \\
\text { violation was received in January } \\
2001 \text { as a result of a sample collected } \\
\text { on } 11 / 2 \text {. }\end{array}$ \\
\hline \multirow[t]{2}{*}{ Waste } & Hazardous waste facilities & DTSC & $\begin{array}{l}3 / 21 \\
3 / 22 \\
3 / 23 \\
3 / 24 \\
4 / 18\end{array}$ & $\begin{array}{l}\text { Received an SOV with five initial find- } \\
\text { ings but have not received final SOV }\end{array}$ \\
\hline & Medical waste & ACDEH & $9 / 6$ & No violations \\
\hline $\begin{array}{l}\text { Storage } \\
\text { tanks }\end{array}$ & $\begin{array}{l}\text { Compliance with underground } \\
\text { storage tank upgrade require- } \\
\text { ments and operating permits. }\end{array}$ & $\mathrm{ACHCS}$ & $\begin{array}{l}2 / 15 \\
10 / 4 \\
11 / 2\end{array}$ & No violations \\
\hline $\begin{array}{l}\text { Waste } \\
\text { minimiza- } \\
\text { tion }\end{array}$ & $\begin{array}{l}\text { Compliance with Section } 6002 \text { of } \\
\text { RCRA }\end{array}$ & EPA & $2 / 17$ & No violations \\
\hline $\begin{array}{l}\text { Ground- } \\
\text { water }\end{array}$ & Three remediation sites & $\begin{array}{l}\text { SFBRWQCB, } \\
\text { EPA, DTSC }\end{array}$ & $6 / 9$ & No violations \\
\hline \multicolumn{5}{|c|}{ Site 300} \\
\hline Air & $\begin{array}{l}\text { Emission sources } \\
\text { Witness leak test of vapor recovery } \\
\text { system for fuel tank }\end{array}$ & SJVUAPCD & $\begin{array}{l}4 / 20 \\
9 / 26\end{array}$ & No violations \\
\hline Water & Permitted operations & CVRWQCB & $\begin{array}{l}3 / 17 \\
4 / 18 \\
10 / 20\end{array}$ & $\begin{array}{l}\text { No violations; however, as a result of } \\
\text { the } 10 / 20 \text { inspection, the CVRWQCB } \\
\text { requested LLNL prepare work plan for } \\
\text { repair of overflowing cooling tower } \\
\text { percolation pit at Building } 827 \mathrm{~A}\end{array}$ \\
\hline Waste & Various facilities & DTSC & $6 / 28-6 / 29$ & One violation ${ }^{(c)}$ \\
\hline $\begin{array}{l}\text { Storage } \\
\text { tanks }\end{array}$ & $\begin{array}{l}\text { Compliance with underground } \\
\text { storage tank upgrade require- } \\
\text { ments and operating permits. }\end{array}$ & SJCEHD & $2 / 14$ & No violations \\
\hline
\end{tabular}

a See Acronyms and Abbreviations for list of acronyms

b There were no water agency inspections at the Livermore site in 2000.

c DTSC determined that Site 300 returned to compliance on $8 / 15 / 00$. 
Table 2-5. Summary of permits active in $2000^{(a, b)}$

\begin{tabular}{|c|c|c|}
\hline $\begin{array}{l}\text { Type of } \\
\text { permit }\end{array}$ & Livermore site & Site 300 \\
\hline Air & $\begin{array}{l}\text { BAAQMD issued } 129 \text { permits for operation of various } \\
\text { types of equipment, including boilers, emergency } \\
\text { generators, cold cleaners, ultrasonic cleaners, } \\
\text { degreasers, printing press operations, manual wipe- } \\
\text { cleaning operations, metal machining and finishing } \\
\text { operations, silk-screening operations, silk-screen } \\
\text { washers, paint spray booths, adhesives operations, } \\
\text { image tube fabrication, optic coating operations, } \\
\text { storage tanks containing VOCs in excess of } 1.0 \% \text {, } \\
\text { plating tanks, drum crusher, semiconductor opera- } \\
\text { tions, diesel air-compressor engines, groundwater air } \\
\text { strippers/dryers, ovens, material-handling equip- } \\
\text { ment, sewer diversion system, oil and water separator, } \\
\text { fire test cells, gasoline-dispensing operation, paper- } \\
\text { pulverizer system, and firing tanks. }\end{array}$ & $\begin{array}{l}\text { SJVUAPCD issued } 42 \text { permits for operation of } \\
\text { various types of equipment, including boilers, } \\
\text { emergency generators, paint spray booth, } \\
\text { groundwater air strippers, soil vapor extraction } \\
\text { units, woodworking cyclone, gasoline-dispensing } \\
\text { operation, explosive waste treatment units, and } \\
\text { drying ovens. }\end{array}$ \\
\hline Water & $\begin{array}{l}\text { WDR Order No. 88-075 for discharges of treated } \\
\text { groundwater from Treatment Facility A to percolation } \\
\text { pits and recharge basin. } \\
\text { WDR Order No. 95-174, NPDES Permit } \\
\text { No. CA0030023 for discharges of storm water associ- } \\
\text { ated with industrial activities and low-threat nonstorm } \\
\text { water discharges to surface waters. } \\
\text { WDR Order No. 99-08-DWQ, NPDES California } \\
\text { General Construction Activity Permit No. CASO00002, } \\
\text { DWTF Site ID No. 201S305140, Soil Reuse Project ID } \\
\text { No. } 2015305529 \text { and National Ignition Facility, Site } \\
\text { ID No. } 201 \text { S306762, for discharges of storm water } \\
\text { associated with construction activities affecting two } \\
\text { hectares or more. } \\
\text { WDR Order No. } 99-086 \text { for the Arroyo Las Positas } \\
\text { Maintenance Project. } \\
\text { Two ongoing projects permitted under streambed } \\
\text { alteration agreements. } \\
\text { Nationwide Permit } 18 \text { for the Arroyo Las Positas } \\
\text { Maintenance Project. } \\
\text { FFA for groundwater investigation/remediation. }\end{array}$ & $\begin{array}{l}\text { WDR Order No. 99-08-DWQ, NPDES California } \\
\text { General Construction Activity Permit No. } \\
\text { CAS000002, Contained Firing Facility/Chemistry } \\
\text { Magazine Loop, Site ID No. 5B39S307131 for } \\
\text { discharges of storm water associated with } \\
\text { construction activities impacting two hectares or } \\
\text { more. } \\
\text { WDR Order No. 93-100 for post-closure moni- } \\
\text { toring requirements for two Class I landfills. } \\
\text { WDR Order No. } 94-131 \text {, NPDES Permit } \\
\text { No. CA0081396 for discharges of storm water } \\
\text { associated with industrial activities and from } \\
\text { cooling towers. (Rescinded August } 2000 \text { ) } \\
\text { WDR Order No. } 96-248 \text { for operation of two } \\
\text { Class II surface impoundments, a domestic } \\
\text { sewage lagoon, and percolation pits. } \\
\text { WDR Order No. } 97-03-D W Q, \text { NPDES California } \\
\text { General Industrial Activity General Permit No. } \\
\text { CASO00002 for discharge of storm water associ- } \\
\text { ated with industrial activities } \\
\text { WDR Order No. } 97-242, \text { NPDES Permit } \\
\text { No. CA0082651 for discharges of treated } \\
\text { groundwater from the eastern General Services } \\
\text { Area treatment unit. } \\
\text { WDR Order No. 5-00-175, NPDES Permit No. } \\
\text { CA0082651 for large volume discharges from the } \\
\text { drinking water system that reach surface waters. } \\
\text { One ongoing project permitted under a stream- } \\
\text { bed alteration agreement. } \\
\text { FFA for groundwater investigation/remediation. } \\
57 \text { registered Class V injection wells. }\end{array}$ \\
\hline
\end{tabular}


Table 2-5. Summary of permits active in $2000^{(a, b)}$ (continued)

\begin{tabular}{|c|c|c|}
\hline $\begin{array}{l}\text { Type of } \\
\text { permit }\end{array}$ & Livermore site & Site 300 \\
\hline $\begin{array}{l}\text { Hazardous } \\
\text { waste }\end{array}$ & $\begin{array}{l}\text { EPA ID No. CA2890012584. } \\
\text { Authorization to mix resin in Units CE231-1 under } \\
\text { conditional exemption tiered permitting. } \\
\text { Final Closure Plan submitted to DTSC for the } \\
\text { Building } 419 \text { interim status unit (February } 2001 \text { ). } \\
\text { Authorizations to construct the permitted units of } \\
\text { Building } 280 \text {, Building } 695 \text {, and additions to } \\
\text { Building } 693 \text {. } \\
\text { Authorization under hazardous waste permit to } \\
\text { operate } 18 \text { waste storage units and } 14 \text { waste treat- } \\
\text { ment units. } \\
\text { Continued authorization to operate seven waste } \\
\text { storage units and eight waste treatment units under } \\
\text { interim status. }\end{array}$ & $\begin{array}{l}\text { EPA ID No. CA2890090002. } \\
\text { Part B Permit-Container Storage Area } \\
\text { (Building 883) and Explosives Waste Storage } \\
\text { Facility (issued May 23, 1996). } \\
\text { Part B Permit-Explosives Waste Treatment Facility } \\
\text { (issued October 9, 1997). } \\
\text { Docket HWCA 92/93-031. Closure and } \\
\text { Post-Closure Plans for Landfill Pit } 6 \text { and the } \\
\text { Building } 829 \text { Open Burn Facility. } \\
\text { Post Closure Permit Application submitted for } \\
\text { Building } 829 \text { Open Burn Facility (September } \\
\text { 2000) }\end{array}$ \\
\hline $\begin{array}{l}\text { Sanitary } \\
\text { sewer }\end{array}$ & $\begin{array}{l}\text { Discharge Permit No. } 1250(00 / 01) \text { for discharges of } \\
\text { wastewater to the sanitary sewer. } \\
\text { Permit } 1510 G(00) \text { for discharges of sewerable } \\
\text { groundwater from CERCLA restoration activities. }\end{array}$ & \\
\hline $\begin{array}{l}\text { Storage } \\
\text { tanks }\end{array}$ & 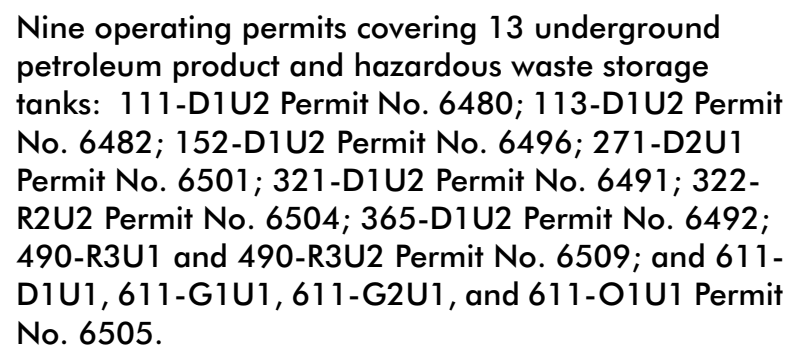 & 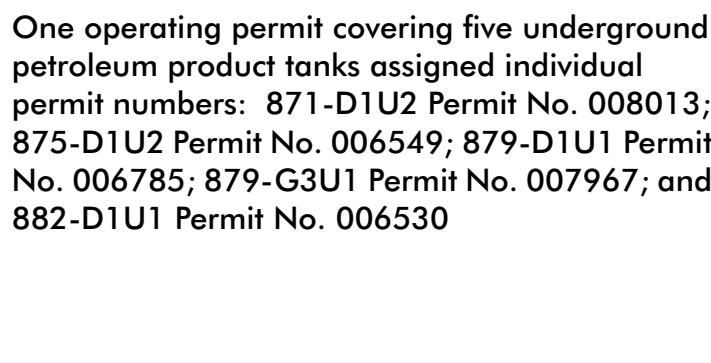 \\
\hline
\end{tabular}

a Permit numbers are based on actual permitted units or activities maintained and renewed by LLNL during 2000.

b See Acronyms and Abbreviations for list of acronyms.

c A second unit, CE443-1, which was authorized to mix resins under conditional exemption tiered permitting, was officially closed on July 6, 2000.

In 2000, LLNL continuously monitored radionuclide emissions from Building 331 (the Tritium Facility), Building 332 (the Plutonium Building), and portions of four other facilities (see Chapter 4 ). There were no unplanned atmospheric releases at the Livermore site or at Site 300 in 2000.

\section{Clean Water Act and Related State Programs}

Preserving clean water is one objective of local, state, and federal regulations. The National
Pollutant Discharge Elimination System (NPDES) under the Federal Clean Water Act establishes permit requirements for discharges into waters of the United States. In addition, the State of California, under the Porter Cologne Water Quality Control Act, requires permits, known as Waste Discharge Requirements (WDRs), for any waste discharges affecting the beneficial uses of waters of the state. The regional water quality control boards are responsible for issuing and enforcing both permits. 
Several agencies issue other water-related permits. The Livermore Water Reclamation Plant (LWRP) requires permits for discharges of sewerable water to the city sanitary sewer system. The Army Corps of Engineers (ACOE) issues permits for work in navigable waterways below the ordinary high-water mark and for controlling fill operations in waters of the United States. The State Water Resources Control Board (SWRCB) can issue water quality certifications or WDRs. The California Department of Fish and Game (CDFG) under the Fish and Game Code Section 1601 et seq. requires streambed alteration agreements for any work that may disturb or impact rivers, streams, or lakes. The Safe Drinking Water Act requires registration with the EPA and management of injection wells to protect underground sources of drinking water. The Clean Water Act also requires facilities meeting specific storage requirements to have and implement Spill Prevention Control and Countermeasure (SPCC) plans for oil-containing equipment and tanks. Finally, Alameda County Health Care Services (ACHCS) and San Joaquin County Environmental Health Services issue permits for operating underground storage tanks containing hazardous materials or hazardous waste as required under the California Health and Safety Code. Water-related permits are summarized in Table 2-5 and discussed in detail in Chapters 6, 7, and 9.

\section{Groundwater and Surface Water}

In 2000, LLNL discharged storm water associated with industrial activities, low-threat equipment wastewater, process wastewater, sanitary sewage, treated groundwater, and domestic drinking water to surface waters, percolation pits, surface impoundments, septic systems, and a sewage lagoon under six NPDES permits, four WDRs, waivers, and agreements developed under CERLCA (Table 2-5). Details about surface water discharges are found in Chapter 7 of this report and in quarterly and annual compliance monitoring reports. Details about groundwater monitoring and discharges from CERCLA remediation actions are found in Chapters 8 and 9 of this report and in quarterly and annual compliance monitoring and groundwater program reports.

In August 2000, the CVRWQCB rescinded WDR 94-131 as part of their permit management strategy to reduce individual NPDES permits for discharges to surface waters by covering these discharges through applicable existing general permits. In July 2000, LLNL submitted two Notices of Intent to permit storm water discharges associated with industrial activities under WDR 97-03-DWQ and large domestic water system discharges to surface waters under WDR 5-00-175. At the same time, LLNL also submitted a Report of Waste Discharge to the CVRWQCB requesting that several low threat equipment discharges going to ground be added to WDR 96-248. The low threat discharges include serveral discharges previously believed to be discharging to surface waters. The CVRWQCB is currently in the process of amending WDR 96-248 to include these discharges. In addition, to simplify the various administrative mechanism that currently cover wastewater discharges occurring at Site 300, LLNL requested that discharges covered by waivers of WDRs be consolidated into WDR 96-248.

WDR 95-174 expired in August 2000. LLNL submitted a Report of Waste Discharge and a technical report to the SFBRWQCB requesting they renew WDR 95-174. In November 2000, the SFBRWQCB issued an administrative continuance of WDR 95-174 for storm water discharges associated with industrial activity and several low threat non-storm water discharges to surface waters.

During 2000, LLNL continued construction of four projects that were covered by the California General Construction Activity permit (see Table 2-5). Continuing operations included 
construction of the Decontamination and Waste Treatment Facility (DWTF), the Soil Reuse Project, and the National Ignition Facility (NIF) at the Livermore site and the Contained Firing Facility/Chemistry Magazine Loop Project at Site 300.

LLNL received no Notices of Violation (NOVs) in 2000 from the regional water quality control boards that issued the NPDES permits and WDRs; however, LLNL identified administrative nonconformances with one of the six NPDES permits (see Table 2-6). These events are documented in the annual compliance certification required by NPDES CAS000002 and were reported to the SFBRWQCB at its request. In addition, LLNL was unable to comply with prohibitions in WDR 96-248 on four occasions and had occasional readings exceeding receiving water quality criteria during arroyo maintenance activities covered in WDR 99-086. These discharges were reported to the applicable regional boards and are discussed further in Chapters 7 and 9.
The CVRWQCB inspected the Site 300 permitted facilities in March, April, and October 2000. No violations were found during these inspections (see Table 2-4). However, the CVRWQCB requested that LLNL eliminate discharges from an overflowing percolation pit designed to receive coolingtower discharges from B827A. The CVRWQCB requested that the percolation pit be repaired to eliminate discharges by April 15, 2001.

\section{Sewerable Water}

The Livermore site's sanitary sewer discharges are sampled continuously, daily, weekly, and monthly to satisfy various permit requirements. The monitoring results for the LLNL effluent were reported monthly to the LWRP. In 2000, LLNL had three discharges in violation of the LWRP permit covering wastewater discharges to the sanitary sewer (see

Table 2-7).

Table 2-6. Summary of NPDES permit nonconformance

\begin{tabular}{|c|c|c|c|c|}
\hline $\begin{array}{l}\text { Permit } \\
\text { No. }\end{array}$ & Outfall & Nonconformance & $\begin{array}{l}\text { Date(s) of } \\
\text { non- } \\
\text { conformance }^{(b)}\end{array}$ & $\begin{array}{l}\text { Description- } \\
\text { solution }\end{array}$ \\
\hline CAS000002 & $\begin{array}{l}\text { Arroyo Las Positas } \\
\text { (Livermore site) }\end{array}$ & $\begin{array}{l}\text { Decontamination and } \\
\text { Waste Treatment Facility- } \\
\text { Failure to update SWPPP(a) } \\
\text { by deadline. }\end{array}$ & $\begin{array}{l}11 / 17 / 99- \\
12 / 13 / 99\end{array}$ & $\begin{array}{l}\text { Construction operations were } \\
\text { suspended and the site was } \\
\text { stabilized when the deadline for } \\
\text { the SWPPP amendment } \\
\text { occurred. The SWPPP was } \\
\text { revised prior to re-commencing } \\
\text { construction activities. }\end{array}$ \\
\hline CAS000002 & $\begin{array}{l}\text { Arroyo Las Positas } \\
\text { (Livermore site) }\end{array}$ & $\begin{array}{l}\text { National Ignition Facility- } \\
\text { Failure to date inspection } \\
\text { forms. }\end{array}$ & 10/99-4/00 & $\begin{array}{l}\text { Revised form to include an } \\
\text { inspection date field. }\end{array}$ \\
\hline
\end{tabular}

a SWPPP $=$ Storm Water Pollution Prevention Plan

b These dates reflect the construction reporting period of June 1999 through May 2000. The actual nonconformance may not have occurred over the entire time; however, specific nonconformance dates cannot be determined. 
Table 2-7. Summary of nonconformance with LWRP permit limits for discharges to the sanitary sewer

\begin{tabular}{|c|c|c|c|}
\hline $\begin{array}{l}\text { Permit } \\
\text { No }\end{array}$ & Nonconformance & $\begin{array}{c}\text { Date(s) of } \\
\text { nonconformance }\end{array}$ & Description-solution \\
\hline \multirow[t]{3}{*}{1250} & $\begin{array}{l}\text { Cyanide in the January monthly effluent } \\
\text { sample exceeded the permit limit. LWRP issued } \\
\text { a notice of violation dated March 9, } 2000 .\end{array}$ & $1 / 5 / 00$ & $\begin{array}{l}\text { An effluent sample collected March } 1 \text {, } \\
2000 \text {, confirmed LLNL's return to } \\
\text { compliance. }\end{array}$ \\
\hline & $\begin{array}{l}\text { Silver in the June } 26,2000 \text { daily composite } \\
\text { sample exceeded the permit limit. LWRP issued } \\
\text { a notice of violation dated July } 31,2000 \text {. }\end{array}$ & $6 / 26 / 00$ & $\begin{array}{l}\text { The daily composite sample for June } 27 \text {, } \\
2000 \text {, confirmed effluent discharges } \\
\text { returned to compliance. }\end{array}$ \\
\hline & $\begin{array}{l}\text { Discharges from a water jet process exceeded } \\
\text { categorical process discharge limits for chro- } \\
\text { mium and nickel. LWRP issued a notice of viola- } \\
\text { tion dated January } 12,2001 \text {. }\end{array}$ & $11 / 2 / 00-1 / 8 / 01$ & $\begin{array}{l}\text { Discharges were discontinued on } \\
\text { January } 8,2001 \text {. Additional settling and } \\
\text { filtration was added to the wastewater } \\
\text { treatment system. Return to compliance } \\
\text { was demonstrated on February 1, 2001. }\end{array}$ \\
\hline
\end{tabular}

Self-monitoring continued during 2000 , as required in the permit. Two samples collected in 2000 had constituents that exceeded permit effluent limits. The January monthly effluent sample collected on January 5, 2000, exceeded the discharge limit for cyanide. The LWRP issued an NOV for this discharge dated March 9, 2000.

On June 26, 2000, LLNL's real-time sewer monitoring station identified and diverted wastewater containing silver concentrations above alarm levels. The wastewater was diverted to the LLNL Sewer Diversion Facility for 10 minutes. The daily composite sample collected for June 26 was analyzed and confirmed silver concentrations in the discharge for that day exceeded the permit discharge limit. The daily composite sample for June 27 was analyzed and confirmed LLNL's return to compliance. On July 31, 2000, the LWRP issued an NOV for this incident.

On November 6, 2000, the LWRP collected split samples of site effluent as part of the annual compliance sampling. Sample results confirmed compliance with effluent discharge limits. LLNL and LWRP also inspected and sampled identified federally regulated processes and their wastestreams on October 19 and November 2. No outstanding facility deficiencies were noted during any of the inspections (Table 2-4). However, subsequent to the November inspection, analytical data received for a sample collected at a water jet process exceeded the chromium and nickel federal categorical discharge limits. LLNL discontinued discharges from the process on January 8, 2001. The LWRP issued an NOV for the November 2, 2000, sample on January 12, 2001. LLNL promptly began upgrading the wastewater treatment system for the discharge. Several follow-up samples were collected during 2001 with the sample collected February 1, 2001 , confirming that the discharge from the water jet complied with federal categorical discharge limits.

In addition, LLNL conducts self-monitoring of federally regulated processes and reports results to the LWRP semiannually.

LLNL monitors discharges from groundwater treatment facilities to sanitary sewer under Permit 1510G (2000) as they occur. Data are reported annually to the LWRP. In 2000, LLNL complied with all the terms and conditions of Permit 1510G. Chapter 6 discusses the self-monitoring programs and the analytical results for the site effluent, categorical processes, and discharges from groundwater treatment facilities. 


\section{Streambed Alteration Agreements and Nationwide Permits}

CDFG, SFBRWQCB, and ACOE all issue permits for work in streambeds (Table 2-8). ACOE issued Nationwide Permit (NWP) 18 for the installation of check dams associated with the Arroyo Las Positas Maintenance Project in 2000. Prior to issuing this permit in August 2000, the ACOE staff visited the Livermore site to evaluate permitting requirements for the project. LLNL continued operations allowed under a five-year streambed alteration agreement and WDR issued for the Arroyo Las Positas Maintenance Project. Operations also continued under a streambed alteration agreement issued for vegetation management in Arroyo Seco. No projects at Site 300 required permits from ACOE during 2000.

\section{Tank Management}

LLNL manages its underground and aboveground storage tanks through the use of underground tank permits, monitoring programs, operational plans, closure plans and reports, leak reports and followup activities, and inspections. At LLNL, underground storage tanks contain diesel fuel gasoline, waste oil, and process wastewater; aboveground storage tanks contain diesel fuel, insulating oil, and process wastewater. Some wastewater systems are a combination of underground storage tanks and aboveground storage tanks. Table 2-9 shows the status of tanks at the Livermore site and Site 300 as of December 31, 2000. All regulated underground storage tanks at the Livermore site were inspected by the regulating agency in 2000 , and no violations were found (see Table 2-4).

In December 1998, LLNL performed the triennial review and evaluation of the SPCC plans for Site 300 and the Livermore site. No significant changes were made to the technology or practices documented in the Spill Prepention Control and
Countermeasures Plan (Campbell 1995). The changes noted in the review reflect a reduction in the number of oil-containing tanks and equipment managed at the Livermore site and Site 300. The Site 300 SPCC was updated in December 1999. The Livermore site SPCC will be amended in 2001.

\section{Resource Conservation and Recovery Act and Related State Laws}

The Resource Conservation and Recovery Act (RCRA) and its corresponding regulations provide the framework at the federal level for regulating the generation and management of solid wastes, including wastes designated as hazardous. Similarly, the California Hazardous Waste Control Act (HWCA) and the California Code of Regulations (CCR) Title 22, set requirements for managing hazardous wastes in California. RCRA and HWCA also regulate hazardous waste treatment, storage, and disposal facilities, including permit requirements. Because RCRA program authorization was delegated to the State of California in 1992, LLNL works with DTSC on compliance issues and in obtaining hazardous waste permits.

\section{Hazardous Waste Permits}

\section{Livermore Site}

The hazardous waste management facilities at the Livermore site consist of permitted units (located in Area 612 and Buildings 695 and 693 of the DWTF) and units that operate under interim status (Area 514 Facility and the Building 233 Container Storage Facility). Permitted and interim status waste management units include container storage, tank storage, and various treatment processes (e.g., wastewater filtration, blending, and size reduction). A final closure plan for the Building 419 Interim Status Facility has been submitted to DTSC for approval. 
Table 2-8. Summary of streambed alteration agreements, 404 nationwide permits, and 401 waivers or Waste Discharge Requirements

\begin{tabular}{|l|l|l|c|}
\hline \multicolumn{1}{|c|}{ Project } & \multicolumn{1}{|c|}{ Location } & \multicolumn{1}{c|}{ Agency/type of permit } & Year submitted \\
\hline $\begin{array}{l}\text { Storm-generated debris removal and } \\
\text { vegetation management (five-year } \\
\text { agreement) }\end{array}$ & Arroyo Seco & CDFG/SAA & 1999 \\
\hline $\begin{array}{l}\text { Arroyo Las Positas Maintenance Project } \\
\text { (five-year agreement) }\end{array}$ & Arroyo Las Positas & $\begin{array}{l}\text { CDFG/SAA } \\
\text { SFBRWQCB/WDR }\end{array}$ & 1998 \\
& & ACOE/NWP 18 & 1999 \\
\end{tabular}

a See Acronyms and Abbreviations for list of acronyms.

Table 2-9. Summary of in-service tanks, December 31, 2000

\begin{tabular}{|c|c|c|c|c|c|c|}
\hline \multirow[b]{2}{*}{ Tank type } & \multicolumn{3}{|c|}{ Livermore site } & \multicolumn{3}{|c|}{ Site 300} \\
\hline & Permitted & $\begin{array}{l}\text { Permits } \\
\text { not } \\
\text { required }\end{array}$ & Total & Permitted & $\begin{array}{l}\text { Permits not } \\
\text { required }\end{array}$ & Total \\
\hline \multicolumn{7}{|c|}{ Underground storage tanks } \\
\hline Diesel fuel & 7 & 0 & 7 & 4 & 0 & 4 \\
\hline Gasoline & 2 & 0 & 2 & 1 & 0 & 1 \\
\hline Waste oil & 1 & 0 & 1 & 0 & 0 & 0 \\
\hline Process wastewater & 3 & 31 & 34 & 0 & 7 & 7 \\
\hline Subtotal & 13 & 31 & 44 & 5 & 7 & 12 \\
\hline \multicolumn{7}{|c|}{ Aboveground storage tanks } \\
\hline Diesel fuel & 0 & 26 & 26 & 0 & 6 & 6 \\
\hline Insulating oil & 0 & 1 & 1 & 0 & 3 & 3 \\
\hline Process wastewater & $10^{(a)}$ & 56 & 66 & 0 & 11 & 11 \\
\hline Subtotal & 10 & 83 & 93 & 0 & 20 & 20 \\
\hline TOTAL & 23 & 114 & 137 & 5 & 27 & 32 \\
\hline
\end{tabular}

a These 10 tanks are located at the LLNL Treatment and Storage Facility.

In accordance with the document, Transition Plan: Transfer of Existing Waste Treatment Units to the Decontamination and Waste Treatment Facility (EPD 1997), operations in the Area 514 Facility will eventually be replaced by those in the new DWTF, and Area 514 will be closed. The Building 233 Container Storage Facility will be closed. 
In May 1998, DTSC conducted a compliance evaluation inspection of the hazardous waste storage and treatment facilities at the Livermore site. On April 25, 2000, LLNL received notification of a Summary of Violations (SOV) resulting from this inspection.

In May 1999, DTSC signed the hazardous waste permit and issued a Notice of Final Permit Decision for DWTF. In July 1999, Tri-Valley CAREs et al. filed a petition for review to appeal the permit decision. The appeal was denied by the DTSC in November 1999, and the permit immediately became effective. Tri-Valley CAREs et al. filed a California Environmental Quality Act (CEQA) lawsuit in December 1999, which challenges many of the environmental impact evaluations made in the DTSC initial study, which formed the basis of the CEQA Negative Declaration determination. The lawsuit was not resolved in 2000 .

In June, July, and August 1999, DTSC conducted a compliance evaluation inspection of the hazardous waste storage and treatment facilities at the Livermore site. In August 1999, LLNL responded to DTSC's SOV. LLNL received the final inspection report and SOV in December 1999. On February 15, 2000, LLNL responded to DTSC regarding the alleged violations and information request. LLNL has not received a response from DTSC.

On March 21-24; and April 17 and 18, 2000, DTSC conducted a compliance inspection of the hazardous waste storage and treatment facilities at the Livermore site. A preliminary report of findings was received by LLNL. LLNL responded to DTSC and did not receive a final SOV in 2000.

\section{Site $\mathbf{3 0 0}$}

A post closure permit application for the Building 829 Open Burn Facility was submitted to DTSC for approval in September 2000. The Open Burn
Facility was replaced by the Explosives Waste Treatment Facility (EWTF) in 1999.

On June 28 and 29, 2000, DTSC conducted a compliance evaluation inspection of Site 300 hazardous waste generator areas, the Building 883 Container Storage Area, Explosives Waste Storage Facility (EWSF), and EWTF. As a result of the inspection, on August 15, 2000, DTSC issued an SOV under the category of "Minor Violations/ Notice to Comply" for failing to provide initial "Explosives Waste Storage and Treatment Operations" training to the facility manager within six months of the date hired (see Table 2-4). LLNL provided the required training on August 3, 2000 , and submitted a certification of course completion to DTSC on August 9, 2000. After reviewing the submittal, DTSC issued a letter, dated August 15, 2000, stating that Site 300 is again in compliance.

\section{Hazardous Waste Reports}

LLNL completed two annual hazardous waste reports, one for the Livermore site and the other for Site 300, which address the 2000 transportation, storage, disposal, and recycling of hazardous wastes. The annual reports, required under 22 CCR 66262.41, were completed and submitted to meet DTSC's April 1, 2001, deadline. These same reports, 2000 Hazardous Waste Report-Mainsite and 2000 Hazardous Waste Report-Site 300 (Galles and Gilbert 2000a, b), were submitted to the EPA under Sections 3002 and 3004 of RCRA, which requires a biennial reporting of hazardous wastes. DTSC is authorized to receive the reports for EPA.

\section{Hazardous Waste Transport Registration}

Transportation of hazardous waste over public roads (e.g., from one LLNL site to another) requires DTSC registration (22 CCR 66263.10). 
Conditions for registration may include annual inspections of transport vehicles and trailers by the California Highway Patrol (CHP), biennial terminal inspections, and special training and annual physical examinations for drivers. DTSC renewed LLNL's registration in November 2000. The CHP opted not to conduct inspections of LLNL vehicles in 2000.

\section{Waste Accumulation Areas}

In January 2000, there were 20 waste accumulation areas (WAAs) at the Livermore site. One WAA and three temporary WAAs were put into service, and two temporary WAAs were taken out of service. Program representatives conducted formal inspections at least weekly at all WAAs to ensure that they were operated in compliance with regulatory requirements. Approximately 1093 formal WAA inspections were conducted at the Livermore site.

One WAA was in operation at Site 300 during 2000. Program representatives conducted 52 formal inspections of the WAA at Site 300 .

\section{California Medical Waste Management Act}

All LLNL medical waste management operations comply with the California Medical Waste Management Act, Health and Safety Code Sections 117600-118360, Chapters 1-11. The Medical Waste Management Act establishes a comprehensive program for regulating the management, transport, and treatment of medical wastes that contain substances that may potentially infect humans. The program is administered by the State Department of Health Services (DHS) and is enforced by the Alameda County Department of Environmental Health (ACDEH).
LLNL is registered with the ACDEH as a generator of medical waste and has a treatment permit. The September 2000 ACDEH inspection of buildings at Health Services and the Biology and Biotechnology Research Program did not result in any compliance issues or violations (see Table 2-4).

\section{Federal Facility Compliance Act}

LLNL is continuing to work with DOE to maintain compliance with the Federal Facilities Compliance Act Site Treatment Plan (STP) for Lawrence Livermore National Laboratory that was signed in February 1997. A milestone extension was requested for one waste stream that contains classified mixed waste. The extension was granted to allow time to develop the procedures necessary to handle and treat this waste. All other milestones for 2000 were completed on time. Reports and certification letters were submitted to DOE as required. LLNL continued to pursue the use of commercial treatment and disposal facilities that are permitted to accept mixed waste. These facilities provide LLNL greater flexibility in pursuing the goals and milestones set forth in the STP.

\section{Toxic Substances Control Act}

The Federal Toxic Substances Control Act (TSCA) and implementing regulations found in Title 49, Code of Federal Regulations, Parts 700-789, govern the uses of newly developed chemical substances and TSCA-governed waste by establishing requirements for recordkeeping, reporting, disposal standards, employee protection, compliance and enforcement, and cleanup standards.

In 2000, LLNL generated TSCA PCB waste from CERCLA cleanup projects, PCB oil drained from electrical equipment, electrical equipment contaminated with PCBs, liquid PCBs used to 
calibrate analytical equipment, and TSCA-regulated asbestos from building demolition or renovation projects.

All TSCA-regulated waste was disposed of in accordance with TSCA, state, and local disposal requirements except for radioactively contaminated PCB waste. Radioactive PCB waste, typically known as transuranic (TRU) mixed waste or mixed waste, is currently stored at one of LLNL's hazardous waste storage facilities until the Waste Isolation Pilot Project, or other approved facility, accepts this waste for final disposal.

\section{National Environmental Policy Act}

The National Environmental Policy Act (NEPA; 42 U.S. Code [USC] 4321 et seq.) established federal policy for protecting environmental quality. The major method for achieving established NEPA goals is the requirement of preparing an environmental impact statement (EIS) for any major federal or federally funded project that may have significant impact on the quality of the human environment. If the need for an EIS is not clear, or if the project does not meet DOE's criteria for requiring an EIS, an environmental assessment (EA) is prepared. A Finding Of No Significant Impact (FONSI) is issued when an EIS is determined to be unnecessary.

Certain groups of actions that do not have a significant effect on the environment either individually or cumulatively can be categorically excluded from a more in-depth NEPA review (i.e., preparation of either an EA or EIS). DOE NEPA implementing procedures (61 FR 36222 and 57 FR 15122) identify those categorical exclusions and the eligibility criteria for their application. If a proposed project does not clearly fit one of the exclusion categories, DOE determines which type of assessment document may be needed.
In 2000, one FONSI for the EA of the Site 300 CERCLA Remediation Project was issued by DOE. Preparation of another EA for the decommissioning and demolition of Buildings 222 and 412 was continued from 1999. Thirty-nine categorical exclusion applications were approved by DOE, and there were no proposed actions at LLNL that required separate DOE floodplain or wetlands assessments under DOE regulations in 10 CFR 1022. In March 1999, DOE issued a Supplement Analysis (U.S. DOE 1999) that concluded that the 1992 Final Environmental Impact Statement and Environmental Impact Report for Continued Operation of Lawrence Livermore National Laboratory and Sandia National Laboratories, Livermore (1992 EIS/EIR) (U.S. DOE and UC 1992a,b) did not need to be supplemented and remained adequate.

\section{California Environmental Quality Act}

In November 1992, the University of California (UC) and LLNL made a commitment to implement 67 mitigation measures identified by the 1992 EIS/EIR and to provide annual reports on their implementation. The measures are being implemented in accordance with the approved 1992 Mitigation Monitoring and Reporting Program associated with that joint DOE/UC EIS/EIR. The 1997-1999 fiscal year Mitigation Monitoring reports will be published in 2001 .

\section{National Historic Preservation Act}

The National Historic Preservation Act of 1966 (NHPA), as amended through 1992, requires federally operated and funded installations such as LLNL to balance agency missions with cultural values by integrating historic preservation into federal agency programs. Federal agencies must take into account the effects their projects may 
have on "historic properties" (cultural resources), and they must allow a reasonable time period for the Advisory Council on Historic Preservation (the Council) to comment. LLNL has three significant types of cultural resources: (1) prehistoric, (2) historic (turn-of-the-century homesteading, ranching, and industrial), and (3) historic (World War II and Cold War science and technology).

A draft programmatic agreement (PA) was developed by LLNL in 1997 in consultation with the U.S. Department of Energy Oakland Office (DOE/OAK), the Council, and the California State Historic Preservation Office (SHPO) to help LLNL implement applicable federal and state cultural resource laws and regulations. Activities included cultural overviews, development of theme and context for significance evaluation, research designs, archaeological site identification and evaluation methods, and records and collection management. The activities will also generate needed data and methods in order to develop a Cultural Resource Management Plan (CRMP), the final objective of the PA.

As a result of continuing consultation with DOE/ OAK, the Council, and SHPO, a revised PA was prepared in 2000 and is undergoing internal LLNL review. Based upon input from the Council and SHPO, the PA has been expanded and reorganized to focus efforts on undertaking the historic building inventory for the Main site and Site 300, and mitigating impacts to any historic buildings that may be proposed for demolition, while at the same time protecting known and potential archaeological resources. DOE extended invitations to participate in the PA process to Alameda and San Joaquin counties, the cities of Tracy and Livermore, to LLNL, and Native American representatives (Ohlone/Costanoan, Northern Valley Yokut, and Bay Minok).
During 2000, LLNL completed a historic evaluation of one building (Building 177 Chemistry/ Physics Development Laboratory) and initiated evaluations for four additional buildings. Based on the historic evaluation of Building 177, the building is not eligible for listing in the National Register of Historic Places.

\section{Endangered Species Acts and Sensitive Natural Resources}

LLNL must meet the requirements of the U.S. Endangered Species Act, the California Endangered Species Act, and the California Native Plant Protection Act as they pertain to Endangered or Threatened species and their habitats, other species of special concern, and critical habitats that may exist or are known to exist at the LLNL sites. For example, in implementing the 1992 Mitigation Monitoring and Reporting Program in 2000, biological assessment surveys were performed for special-status species at 82 LLNL Site 300 project construction (ground-disturbing) areas. Presence data for the San Joaquin kit fox (Vulpes macrotis mutica), American badger (Taxidea taxus), and western burrowing owl (Speotyto cunicularia bypugaea) were collected at each project location, and other applicable mitigation measures were implemented where appropriate.

During 2000, at Site 300, no active San Joaquin kit fox dens were discovered, but three potential dens were found. Three occupied American badger dens were discovered, and ten unoccupied dens were identified. Eleven active burrowing owl dens were discovered and monitored throughout the breeding and wintering season. For the second year, owls were marked with aluminum leg bands to initiate long-term studies, monitoring, and conservation of the species in the rugged topography of Site 300. Also, Site 300 populations of 
the federally-listed threatened California redlegged frog (Rana aurora draytonii) and a federal species of concern, the California tiger salamander (Ambystoma californiense), were monitored at wetland locations sitewide.

A critical habitat area (CHA) was formally designated by the U.S. Fish and Wildlife Service for the Alameda whipsnake (Masticophis lateralis euryxanthus) and includes about one-third of the Site 300 property in the southwest corner of the site. CHA was designated by the U.S. Fish and Wildlife Service for the California red-legged frog and roughly $80 \%$ of Site 300 lies within this CHA.

Livermore site populations of the California redlegged frog were monitored in accordance with the 1997 and 1998 amended Service Biological Opinion for the Arroyo Las Positas Maintenance Project. One-hundred- to three-hundred-foot checkerboard sections in the Arroyo were managed for excess in-stream vegetation and 64 California red-legged frogs were protected from harm in project locations during the maintenance process. A CHA for the California red-legged frog was proposed by the U.S. Fish and Wildlife Service that encompasses parts of the Livermore site and surrounding areas.

The DRB was drained in a proactive attempt to eradicate recently discovered non-native bullfrogs (Rana catesbeiana), which are a predator of the California red-legged frog. The project successfully dried the DRB during December 2000 and halted further colonization of habitat onsite.

At the Livermore site, one pair of white-tailed kites (Elanus leucurus), a state-listed protected bird-ofprey, attempted to nest. The nest was abandoned for unknown reasons shortly after the nestlings hatched. No other nests were recorded in 2000. This low nesting success trend was observed state- wide and is probably due to cyclical climatic variations and the reduction of prey items such as rodents.

Four rare plant populations were monitored at Site 300 in 2000. These were the large-flowered fiddleneck (Amsinckia grandiflora, a federallylisted endangered plant species), the big tarplant (Blepharizonia plumosa ssp plumosa, listed on the California Native Plant Society Rare Plant 1B List), the diamond-petaled poppy (Eschscholzia rhombipetala, a plant thought to be extinct until rediscovered in 1993 and thus on the California Native Plant Society 1A list) and the gypsum-loving larkspur (Delphinium gypsophilum ssp gypsophilum, listed on the California Native Plant Society Rare Plant 4 list). The results of the work on these four plant species is described in more detail in an annual progress report (Carlsen et al. 2001).

Two of the three known natural populations of the large-flowered fiddleneck (Amsinckia grandiflora), a federally-listed endangered plant species, occur at Site 300. A portion of Site 300 has been designated as CHA for the plant. In April 2000, this area was designated the Amsinckia grandiflora Reserve through a declaration by Secretary of the U.S. Department of Energy. A memorandum of agreement was signed between the DOE and the U.S. Fish and Wildlife Service concerning activities within the reserve. LLNL has also established an experimental population within the reserve. LLNL is working with the U.S. Fish and Wildlife Service on continued monitoring of native and experimental Amsinckia populations, and to further develop habitat restoration and maintenance techniques. The annual progress report prepared by LLNL will be submitted to the U.S. Fish and Wildlife Service in May 2001 (Carlsen et al. 2001).

The smaller of the two on-site native populations of fiddleneck was extirpated in 1997 when the bank containing the population washed away. No plants 
have been observed at this site since 1998. The number of fiddleneck plants in the larger native population remain low (40 plants in 2000) but is up from the six plants observed in 1999. The number of fiddleneck plants observed in the experimental population ( 45 plants) is similar to that observed during the past two years (42 plants in 1999 and 61 plants in 1998). The experimental population was expanded in 2000 to investigate more fully the use of fire as a management tool. Of the 200 Amsinckia grandiflora seedlings transplanted into twenty native bunch grass-restored plots, a total of 178 survived to flowering.

The low numbers of Amsinckia grandiflora plants observed over the past several years at Site 300 have also been observed in other existing natural and experimental populations of the fiddleneck. A dramatic increase in nutlet predation by small rodents was observed in the Site 300 experimental population in 1998 and 1999. However, nutlet predation was much reduced in 2000. During a two week experimental removal period, only one rodent was trapped, indicating the numbers of this primary seed predator to be very low. The experimental population will be monitored next year to determine if the reduction in nutlet predation results in an increase in plant numbers.

Monitoring of the big tarplant (Blepharazonia plumosa), and the diamond-petaled poppy (Eschscholzia rhombipetala) continued in 2000. The big tarplant remained widespread throughout Site 300, with the number and size of the populations increasing from 1999. Detailed monitoring of populations located in areas undergoing controlled burning is also being conducted to determine the impacts of fire on the population dynamics of this species. A total of 273 diamondpetaled poppy plants were observed in 2000 (a dramatic increase from the nine plants observed in 1999). The majority of these plants produced seed-bearing pods.
In addition, this year populations of the gypsumloving larkspur (Delphinium gypsophilum ssp gypsophilum) were mapped. Two locations of this species were confirmed. It was determined that a more common species of larkspur had been misidentified as the gypsum-loving larkspur in many locations during previous surveys.

\section{Antiquities Act (of 1906): Paleontological Resources}

During soil excavation for the National Ignition Facility at the Livermore site in 1997, a molar from a 14,000-year-old mammoth was found at a depth of about $10 \mathrm{~m}$ below the surface. After this discovery, LLNL obtained an excavation permit from the Department of Interior under the provisions of the Antiquities Act of 1906 and removed bones from the construction area in late 1997 and early 1998. The bones (including 11 ribs, 3 vertebrae, 1 humerus, 1 complete and 1 partial tusk, and a partial skull with palate, jawbone, and molars) were accessioned into the UC Berkeley Museum of Paleontology collection in 1999 and have been partially prepared for possible later presentation at LLNL. The bones were displayed for the public during Family Days at LLNL in October, 2000.

\section{Environmental Occurrences}

Notification of environmental occurrences is required under a number of environmental laws and regulations as well as DOE Order 232.1, Occurrence Reporting and Processing of Operations Information. DOE Order 232.1 provides guidelines to contractor facilities regarding categorization and reporting of environmental occurrences to DOE and divides occurrences into two categories: unusual occurrences and off-normal occurrences. Operational emergencies are also reported under DOE Order 232.1; however, DOE Order 151.1, 


\section{Categorization and Classification of Operational}

Emergencies, defines the criteria for categorization

and classification of operational emergency events.

The Environmental Protection Department's (EPD) response to environmental occurrences is part of the larger LLNL on-site emergency response organization that also includes representatives from Hazards Control (including the LLNL Fire Department), Health Services, Plant Engineering, Public Affairs, Safeguards and Security, and Site 300. In 2000, nine environmental incidents were reportable under DOE Order 232.1 and were categorized as off-normal occurrences according to DOE Order 232.1.

None of the environmental occurrences, summarized in Table 2-10, caused any adverse impact to the public or the environment. Agencies notified of these incidents included DOE and DTSC.

Table 2-10. Tabulation of environmental occurrences reported under the Occurrence Reporting (OR) System, 2000

\begin{tabular}{|c|c|c|}
\hline Date ${ }^{(a)}$ & $\begin{array}{l}\text { Occurrence } \\
\text { category }\end{array}$ & Description $^{(b)}$ \\
\hline March 13 & Off-Normal & $\begin{array}{l}\text { LLNL received an NOV on March } 13,2000 \text {, from the LWRP. The NOV was issued because } \\
\text { LLNL exceeded the permit limit for cyanide. The January compliance sampling result for } \\
\text { cyanide indicated a concentration of } 0.051 \mathrm{mg} / \mathrm{L} \text { in the sanitary effluent. The LLNL limit is } \\
0.04 \mathrm{mg} / \mathrm{L} \text {. Receiving an NOV meets the requirements of an Off-Normal Occurrence. } \\
\text { OR } 2000-0012 \text {. }\end{array}$ \\
\hline March 16 & Off-Normal & $\begin{array}{l}\text { Two oil-filled transformers leaked approximately } 55 \text { gallons of oil into a waste container. } \\
\text { An estimated } 15 \text { gallons of the oil leaked onto the paved area in the salvage yard. It was } \\
\text { determined that the amount of oil released did not exceed any reporting limits. However, } \\
\text { there was a chance that the oil could have been transported offsite within the container. } \\
\text { This was reported under the Off-Normal category. OR 2000-0014 }\end{array}$ \\
\hline March 28 & Off-Normal & $\begin{array}{l}\text { A Hazardous Waste technician was processing laboratory waste from the Biology and } \\
\text { Biotechnology Research Program at Building } 612 \text { (Hazardous Waste Yard). The waste } \\
\text { was labeled }>99 \% \text { laboratory trash (paper, plastic, and rubber) with 2-mercaptoethanol, } \\
\text { phenol and chloroform. The waste bag also contained at least two hypodermic needles } \\
\text { that were not listed on the waste label. One of the needles penetrated the bag and stuck } \\
\text { the Hazardous Waste technician in the arm. This was reported under the Off-Normal } \\
\text { category. OR 2000-0016. }\end{array}$ \\
\hline April 19 & Off-Normal & $\begin{array}{l}\text { LLNL was notified by DTSC of an SOV on April } 18 \text {. The SOV resulted from a CEI } \\
\text { conducted by DTSC on March 20-24. The SOV was issued for: (1) failure to mark the } \\
\text { date on a waste container, (2) storage of incompatible wastes, (3) storage of a waste } \\
\text { container for more than one year, (4) failure to follow the waste analysis plan, and (5) } \\
\text { failure to record required information. Receiving an SOV meets the requirements of an } \\
\text { Off-Normal Occurrence. OR 2000-0022 }\end{array}$ \\
\hline April 26 & Off-Normal & $\begin{array}{l}\text { LLNL was notified by DTSC of an SOV on April } 25 \text {. The SOV resulted from a CEI } \\
\text { conducted two years earlier on May } 26 \text { and } 27 \text {, and July } 7,1998 \text {. Receiving an SOV } \\
\text { meets the requirements of an Off-Normal Occurrence. OR 2000-0028 }\end{array}$ \\
\hline June 12 & Off-Normal & $\begin{array}{l}\text { On June 1,2000, an HWM technician was verifying the contents of a } 55 \text {-gallon drum } \\
\text { containing four carboys at the } 883 \text { Waste Accumulation Area. While the technician was } \\
\text { visually inspecting the drum, the drum lid popped up and flipped over. Pressure and a } \\
\text { visible light grey cloud escaped from the drum. The waste in the drum resulted from } \\
\text { synthesis work with phosphorus trichloride. This was reported under the Off-Normal } \\
\text { category. OR 2000-0035 }\end{array}$ \\
\hline
\end{tabular}


Table 2-10. Tabulation of environmental occurrences reported under the Occurrence Reporting (OR) System, 2000 (continued)

\begin{tabular}{|l|l|l|}
\hline Date & $\begin{array}{l}\text { Occurrence } \\
\text { category }\end{array}$ & \multicolumn{1}{c|}{ Description ${ }^{(b)}$} \\
\hline June 30 & Off- Normal & $\begin{array}{l}\text { On June 20, 2000, an empty container used to store low-level waste was surveyed for } \\
\text { radioactivity. This survey was conducted for the purpose of releasing the container from } \\
\text { Building 332 for disposal. The container had been unused and was in storage for } \\
\text { approximately 5 years. The survey detected the presence of a radioactive isotope at } \\
\text { approximately 800 cpm alpha activity. This incident was reported under the Facility Cate- } \\
\text { gory D: loss of Radioactive Material/Spread of Radioactive Contamination as an Off- } \\
\text { Normal Occurrence. OR 2000-0044 }\end{array}$ \\
\hline July 27 & Off-Normal & $\begin{array}{l}\text { On July 27, 2000, DTSC issued LLNL an SOV. The SOV was a result of a CEI conducted } \\
\text { by DTSC on July 12, 2000. The SOV was issued for failure to provide all required } \\
\text { training to new personnel within six months of the date hired. Receiving an SOV meets } \\
\text { the requirements of an Off-Normal Occurrence. OR 2000-0050 }\end{array}$ \\
\hline July 31 & Off-Normal & $\begin{array}{l}\text { LLNL received an NOV from the LWRP. The NOV was issued because LLNL exceeded its } \\
\text { permit limit for silver on June 26, 2000. Analysis of the daily compliance sample for June } \\
26 \text { indicated silver at 0.31 mg/L; LLNL's permit limit is } 0.20 \text { mg/L. Receiving an NOV } \\
\text { meets the requirements of an Off-Normal Occurrence. OR 2000-0053 }\end{array}$ \\
\hline
\end{tabular}

a The date indicated is the date when the occurrence was categorized, not the date of its discovery.

b See Acronyms and Abbreviations for list of acronyms

\section{Contributing Authors Acknowledgment}

Many authors significantly contributed to this large and diverse chapter. We acknowledge here the work of Richard Blake, Shari Brigdon, John Buchanan, Winifred Burks-Houck, Tina Carlsen, Steve Cerruti, Dixie Finley, Karen Folks, Gretchen Gallegos, Keith Gilbert, Charlene Grandfield,
Robert Harrach, Steve Harris, Bert Heffner, Rod Hollister, Bill Hoppes, Susi Jackson, Paula Kato, Albert Lamarre, Saverio Mancieri, Sandra Mathews, Willie Montemayor, Barbara Nisbet, Kathy Pandrea, Ring Peterson, Victoria Salvo, Bill Schwartz, Judy Steenhoven, Michael Taffet, Stan Terusaki, Mike van Hattem, Charlotte Van Warmerdam, Joseph Woods, Jim Woollett, Jr., and Kenneth Zahn. 


\section{ENVIRONMENTAL \\ Program Information}

\section{Introduction}

Lawrence Livermore National Laboratory is committed to operating in a manner that preserves the quality of the environment. The Environmental Protection Department (EPD) leads this effort in the areas of environmental compliance and accountability. This chapter begins with a brief description of LLNL's integrated Environment, Safety, and Health (ES\&H) Management System Work Smart Standards (WSS), and the missions and activities of EPD and its three divisions. Performance measures (PMs) used by the U.S.

Department of Energy (DOE) to evaluate the Laboratory's environmental protection efforts are then summarized. The bulk of the chapter is devoted to an account of LLNL's activities and progress in waste minimization and pollution prevention in 2000. Following descriptions of current issues and actions in the environmental program arena, this chapter concludes with a brief discussion of spill response.

\section{Integrated Environment, Safety, and Health Management System}

In accordance with the requirements of the University of California's (UC's) Prime Contract W-7405-ENG-48, Clause 6.7, LLNL has implemented an Integrated Safety Management System
(ISMS). The LLNL ISMS is designed to ensure the systematic integration of ES\&H considerations into management and work practices so that missions are accomplished safely. "Safety" used in this context is synonymous with environment, safety, and health to encompass protection of the public, workers, and the environment (including pollution prevention and waste minimization). The core requirements of ISMS are based on the DOE's Seven Guiding Principles and Five Core Functions.

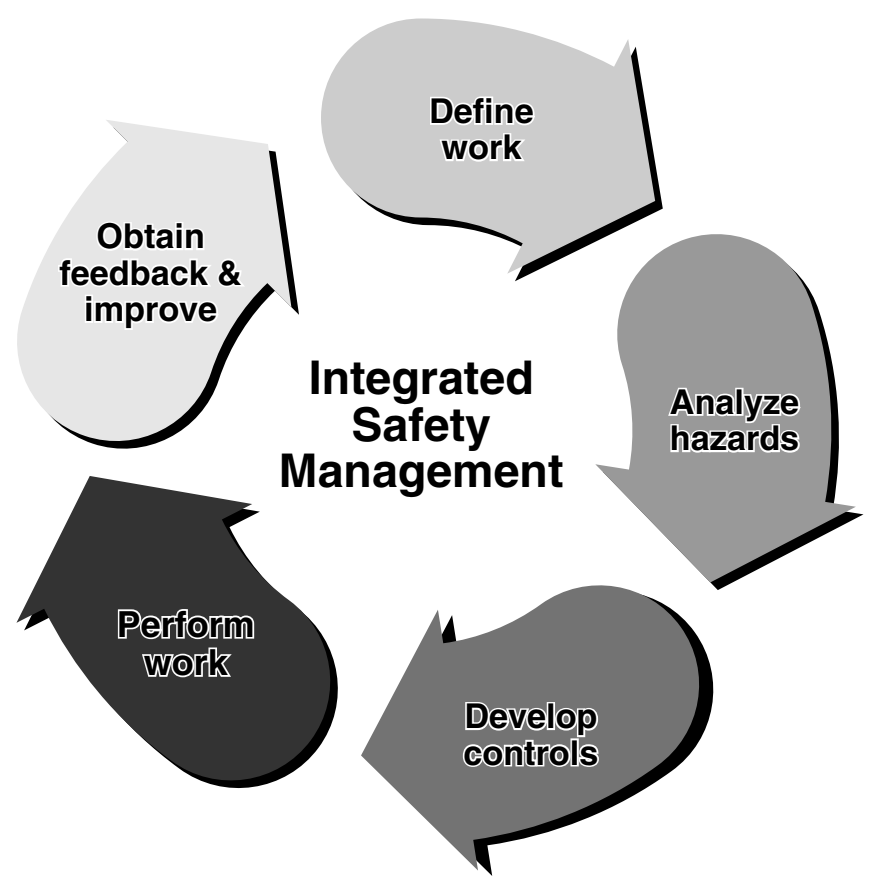


The Seven Guiding Principles can be summarized as: (1) line management is responsible for ensuring the protection of employees, the public, and the environment; (2) clear roles and responsibilities for $E S \& H$ are established and maintained; (3) personnel competence is commensurate with their responsibilities; (4) resources are effectively allocated to address ES\& $\mathrm{H}$, programmatic, and operational considerations with balanced priorities; (5) safety standards and requirements are established that ensure adequate protection of the employees, the public, and the environment; (6) administrative and engineering controls to prevent and mitigate ES\& $H$ hazards are tailored to the work being performed; and (7) operations are authorized.

The Five C ore Functions that describe how LL N L manages and performs work are summarized as: (1) define the scope of work; (2) identify and analyze the hazards associated with the work; (3) develop and implement hazards controls; (4) perform work within the controls; and (5) provide feedback on the adequacy of the controls for continuous improvement.

The implementation of a management system based on these principles and functions results in accountability at all levels of the organization, project planning with protection in mind, and excellence in program execution. The ISM S Program at LLNL employs a process of assessing hazards and the environmental implications of work; designing and implementing standards-based methods intended to control risks; and complying with applicable ES\&H requirements. This process is implemented using a graded approach, which increases the level of risk management as hazards increase. The complete description of LLNL's ISM S can be found in I ntegrated Safety M anage ment System D escription (Clough 2000).
DOE initiated a verification review of $L L N L$ 's implementation of ISM S on N ovember 29, 1999, and the results of the verification were presented on December 9, 1999. DOE recommended approval of the LLN L ISM S description after the completion of several action items.

\section{Work Smart Standards}

Work Smart Standards (WSS) are an integral part of an ISM S, whereby safety professionals identify ES\& $\mathrm{H}$ hazards and establish standards of operation appropriate for the particular work environment.

The WSS process requires an understanding of the work, an analysis of the hazards associated with the work, and the selection of standards from which hazard controls are developed. This process empowers the L aboratory and local DOE staffs, through consensus, to focus on the work being performed and to select sitewide ES\& $\mathrm{H}$ standards based on the actual work being conducted and its associated hazards and threats to the environment.

WSS were approved at the management level closest to and with the most expertise in the work. The LLNL Director and DOE/ OAK M anager approved the final set of sitewide standards on August 5, 1999, after they were confirmed by an independent panel of external experts in $M$ arch 1999. The WSS set was essentially considered part of the $U \mathrm{C}$ contract once it was signed by the LLNL Director and the DOE/ OAK M anager. Reaching these agreements with DOE on new work-based standards aligns the Laboratory with industry practice, establishes common ES\& $\mathrm{H}$ expectations for DOE and $U C$, and facilitates the tailoring of requirements to streamline and increase the effectiveness of management at the $L$ aboratory. LL N L's existing ES\& $\mathrm{H}$ methodologies and documentation have been modified to incorporate the newly identified set of standards and to reflect the requirements of ISM S. 
The WSS set currently identified to satisfy the ES\&H needs of the LLNL work environment are in the UC contract, Appendix G and can be viewed at: http://labs.ucop.edu/internet/wss/wss.html. The DOE orders applicable to the environment that are included in the WSS are listed in Appendix $\mathrm{B}$ of this report.

Meeting new expectations for integrated ES\&H management at the Laboratory will take several years, but the WSS approach, coupled with enhanced, integrated management, promises further safety improvements and lower costs.

\section{Environmental Protection Department}

As the lead organization at LLNL for providing environmental expertise and guidance on operations at LLNL, EPD is responsible for environmental monitoring, environmental regulatory interpretation and implementation guidance, environmental restoration, environmental community relations, and hazardous waste management in support of the Laboratory's programs. EPD prepares and maintains environmental plans, reports, and permits; maintains the environmental portions of the ESerH Manual; informs management about pending changes in environmental regulations pertinent to LLNL; represents the Laboratory in day-to-day interactions with regulatory agencies and the public; and assesses the effectiveness of pollution control programs.

EPD monitors air, sewerable water, groundwater, surface water, soil, sediments, vegetation, and foodstuff, as well as direct radiation; evaluates possible contaminant sources; and models the impact of LLNL operations on humans and the environment. In 2000, 13,483 samples were taken, and 260,158 analytes were tested. The type of samples collected at a specific location depends on the site and the potential pollutants to be monitored; see the specific chapters of this report for discussions of each environmental medium.

A principal part of EPD's mission is to work with LLNL programs to ensure that operations are conducted in a manner that limits environmental impacts and is in compliance with regulatory guidelines. EPD helps LLNL programs manage and minimize hazardous, radioactive, and mixed wastes; determines the concentrations of environmental contaminants remaining from past activities; cleans up environmental contamination to acceptable standards; responds to emergencies in order to minimize and assess any impact on the environment and the public; and provides training programs to improve the ability of LLNL employees to comply with environmental regulations.

LLNL programs are supported by the Hazards Control Department's five ES\&H teams and by EPD's five environmental support teams (ESTs). The ESTs are integrated into the ES\&H teams through environmental analysts, who also chair the ESTs. Each EST includes representatives from environmental specialties within the Operations and Regulatory Affairs Division (ORAD), the ES\&H teams, and a field technician from the Hazardous Waste Management (HWM) Division. Some ESTs also include a representative from the Environmental Restoration Division (ERD) or the organizations supported by the ESTs. These teams evaluate operations, determine potential environmental impacts, and provide guidance on environmental regulations and applicable DOE orders for existing and proposed projects. ESTs assist programs in planning, implementing, and operating projects and in understanding and meeting their environmental obligations. When permits are obtained from regulatory agencies, ESTs aid the programs in evaluating the permit conditions and implementing requirements. 


\section{Operations and Regulatory Affairs Division}

ORAD currently consists of seven groups that specialize in environmental compliance and monitoring and provide Laboratory programs with a wide range of information, data, and guidance to make more informed environmental decisions.

ORAD prepares the environmental permit applications and related documents for submittal to federal, state, and local agencies; provides the liaison between LLNL and regulatory agencies conducting inspections; tracks chemical inventories; prepares National Environmental Policy Act (NEPA) documents; conducts related field studies for DOE; oversees wetland protection and floodplain management requirements; coordinates cultural and wildlife resource protection and management; facilitates and provides support for the pollution prevention and recycling programs; teaches environmental training courses; coordinates the tank environmental compliance program; conducts compliance and surveillance monitoring; and provides environmental impact modeling and analysis, risk assessment, and reporting.

ORAD also actively assists in responding to environmental emergencies such as spills. During normal working hours, an environmental analyst from the ORAD Environmental Operations Group (EOG) responds to environmental emergencies and notifies a specially trained environmental duty officer. Environmental duty officers are on duty 24 hours a day, 7 days a week, and coordinate emergency response with LLNL's ES\&H team and other first responders or environmental specialists.

\section{Hazardous Waste Management Division}

All hazardous, radioactive, and mixed wastes generated at LLNL facilities are managed by the HWM
Division in accordance with state and federal requirements. HWM processes, stores, packages, solidifies, treats, and prepares waste for shipment and disposal, recycling, or discharge to the sanitary sewer.

As part of its waste management activities, HWM tracks and documents the movement of hazardous, mixed, and radioactive wastes from waste accumulation areas (WAAs) located near the waste generator to final disposition; develops and implements approved standard operating procedures; decontaminates LLNL equipment; ensures that containers for shipment of waste meet the specifications of the U.S. Department of Transportation (DOT) and other regulatory agencies; responds to emergencies; and participates in the cleanup of potential hazardous and radioactive spills at LLNL facilities. HWM prepares numerous reports, including the annual and biennial hazardous waste reports required by the state and federal environmental protection agencies (see Appendix C). HWM also prepares waste acceptance criteria documents, safety analysis reports, and various waste guidance and management plans.

HWM meets regulations requiring the treatment and disposal of LLNL's mixed waste in accordance with the requirements of the Federal Facility Compliance Act. The schedule for this treatment is negotiated with the State of California and involves developing new on-site treatment options as well as finding off-site alternatives.

HWM is responsible for implementing a program directed at eliminating the backlog of legacy waste (waste that is not at present certified for disposal). This effort includes a large characterization effort to identify all components of the waste and a certification effort that will provide appropriate documentation for the disposal site. 


\section{Environmental Restoration Division}

ERD was established to evaluate and remediate soil and groundwater contaminated by past hazardous materials handling and disposal processes and from leaks and spills that have occurred at the Livermore site and Site 300, both prior to and during LLNL operations. ERD conducts field investigations at both the Livermore site and Site 300 to characterize the existence, extent, and impact of contamination. ERD evaluates and develops various remediation technologies, makes recommendations, and implements actions for site restoration. ERD is responsible for managing remedial activities, such as soil removal and groundwater extraction, and for assisting in closing inactive facilities in a manner designed to prevent environmental contamination.

As part of its responsibility for Comprehensive Environmental Response, Compensation, and Liability Act (CERCLA) compliance issues, ERD plans, directs, and conducts assessments to determine both the impact of past releases on the environment and the restoration activities needed to reduce contaminant concentrations to protect human health and the environment. ERD interacts with the community on these issues through Environmental Community Relations. Public meetings are held each year and information is provided to the public as required in the ERD CERCLA Community Relations Plans. To comply with CERCLA groundwater remedial actions at the Livermore site, ERD has to date designed, constructed, and operated five fixed groundwater treatment facilities and associated pipeline networks and wells, 19 portable groundwater treatment units, two catalytic dehalogenation units, and two soil vapor extraction facilities (see Chapter 8 ). ERD also installed an electroosmosis system to improve our ability to remove contaminants from fine grained sediments. At Site 300, ERD has designed, constructed, and operated three soil vapor extraction facilities and eleven groundwater extraction and treatment facilities. In addition, ERD has capped and closed four landfills and the High Explosives Rinse Water Lagoons and Burn Pits, excavated and closed numerous waste water disposal sumps, and removed contaminated waste and soil to prevent further impacts to groundwater at Site 300.

ERD is actively designing, testing, and applying innovative remediation and assessment technologies to contaminant problems at the Livermore site and Site 300. ERD provides the sampling and data management support for groundwater surveillance and compliance monitoring activities.

\section{Environmental Training}

The LLNL Environmental Protection Training Program (EPTP) provides Laboratory workers the appropriate training support to assure that they have the knowledge, skills, and abilities to competently, safely, and effectively carry out the jobrelated environmental protection responsibilities of their work assignments. In 2000, EPTP provided nearly 10,000 hours of environmental protection training to over 3,100 Laboratory workers involved in science related work at LLNL. EPTP also provided over 3,000 additional hours of specialized training to LLNL environmental professionals involved with activities related to the management of waste and other environmental protection activities. The environmental training developed and delivered to our Laboratory workers during 2000 addressed the requirements of the National Environmental Policy Act, the Resource Conservation and Recovery Act, the Superfund Amendment and Reauthorization Act, the Occupational Safety and Health Administration and other Federal and California State regulatory requirements. Training subjects included hazardous waste management, low-level waste generation and certification, transuranic waste generation and certification, spill 
prevention, control, and countermeasures, and other similar environmental protection related topics. The EPTP staff is supported in the development and delivery of training by environmental protection subject matter experts (SMEs) from the three EPD divisions. In close coordination, the divisions provide the assessment and interpretation of training to be given to Laboratory workers and to internal Department environmental protection specialists. In addition, the divisions supply SMEs and personnel who are trained and qualified to be instructors for the EPTP. The EPTP staff consists of technical and administrative personnel familiar with the various environmental regulations and requirements and cognizant in Laboratory operations requiring environmental protection training.

\section{Performance Measures Summary}

Since 1992, UC's contract to manage and operate LLNL for DOE has contained performance objectives, criteria, and measures. Four of these performance measures (PMs) are used to evaluate LLNL's environmental protection activities.

At the end of 2000, DOE gave LLNL an average score of excellent for its environmental performance in FY2000. DOE scores for individual performance measures are shown in Table 3-1. Performance measure data for FY2000 will be included in the annual self-assessment and evaluation conducted in 2001.

Table 3-1. UC Contract 48 environmental protection performance measures for environmental performance in FY2000

\begin{tabular}{|c|c|c|c|}
\hline $\begin{array}{c}\text { PM } \\
\text { designator }\end{array}$ & Performance measure & Location in Environmental Report & Score \\
\hline 1.2.b & $\begin{array}{l}\text { Radiation dose to the public } \\
\text { Public radiation doses to the maximally } \\
\text { exposed individual from DOE operations } \\
\text { will be measured or calculated and } \\
\text { controlled to ensure that doses are kept } \\
\text { as low as reasonably achievable } \\
\text { (ALARA). }\end{array}$ & $\begin{array}{l}\text { Environmental Report } 1999 \text { and } \\
\text { Environmental Report 2000: } \\
\text { Chapter 13, Radiological Dose Assessment, } \\
\text { section on Radiological Doses to the Public } \\
\text { from LLNL Operations. } \\
\text { Chapter 2, Compliance Summary, section on } \\
\text { National Emission Standards for Hazardous } \\
\text { Air Pollutants. }\end{array}$ & Outstanding \\
\hline $1.2 . \mathrm{g}$ & $\begin{array}{l}\text { Process and solid waste generation } \\
\text { (Waste reduction and recycling) } \\
\text { The Laboratory continues to progress } \\
\text { toward meeting the DOE pollution } \\
\text { prevention goal for the year } 2005 \text {. }\end{array}$ & $\begin{array}{l}\text { Environmental Report } 1999 \text { and } \\
\text { Environmental Report 2000: } \\
\text { Chapter 3, Environmental Program } \\
\text { Information, section on Waste Minimization/ } \\
\text { Pollution Prevention. }\end{array}$ & Outstanding \\
\hline 1.2.h & $\begin{array}{l}\text { Environmental violations } \\
\text { The rate of validated environmental } \\
\text { violations, determined from inspections } \\
\text { and reporting requirements from regula- } \\
\text { tory agencies is kept low. }\end{array}$ & $\begin{array}{l}\text { Environmental Report 1999: Chapter 2, } \\
\text { Compliance Summary, Tables 2-5 and 2-9 } \\
\text { Environmental Report 2000: Chapter 2, } \\
\text { Compliance Summary, Tables 2-5 and 2-10 }\end{array}$ & Excellent \\
\hline $1.2 . \mathrm{i}$ & $\begin{array}{l}\text { Environmental releases } \\
\text { The Laboratory controls and reduces the } \\
\text { number of occurrences of environmental } \\
\text { releases and the number of releases that } \\
\text { result in violations. }\end{array}$ & $\begin{array}{l}\text { Environmental Report 1999: Chapter 2, } \\
\text { Compliance Summary, Table 2-9. } \\
\text { Environmental Report 2000: Chapter 2, } \\
\text { Compliance Summary, Table 2-10. }\end{array}$ & Outstanding \\
\hline
\end{tabular}




\section{DOE Pollution Prevention Goals}

In a memo dated N ovember 12, 1999, the Secretary of E nergy issued a new and challenging set of pollution prevention and energy efficiency (P2/ E2) goals for the D OE Complex in response to the President's Executive O rders for G reening the Federal Government. The DOE P2/ E2 Leadership goals, presented in Table 3-2 have expanded the scope of the P2 goals in place during the 1990s by including the following: building and facility energy efficiency; reduction of releases of toxic chemicals, ozone-depleting substances, and greenhouse gases; increased vehicle fleet efficiency and use of alternative fuels; and the required purchasing of environmentally preferable products and services. The new P2/ E 2 goals continue to use 1993 as a baseline and have interim measurement points in 2005 and 2010.

The D O E P2/ E 2 L eadership Goals are intended to be achieved on a $D$ epartment-wide basis. DOE field offices, such as the $O$ akland Field $O$ ffice are responsible for developing and incorporating appropriately adapted goals for each of their sites into annual performance agreements for each site. For $L L N L$, past $D O E P 2$ goals were reflected in U C C ontract performance measure 1.2.g. $\mathrm{H}$ owever, the new P2/ E2 goals have not yet been formally incorporated into $L L N L$ performance measures.

\section{Pollution Prevention Reporting}

Typically $L L N L$ has prepared a P2 Plan to meet the requirements of (1) DOE O rders 435.1 and 5400.1; (2) Resource Conservation and Recovery Act of 1976 (RCRA) Sections 3002(b) and 3005(h); and (3) Title 22 of the California Code of Regulations. This plan, updated every three years, has reviewed past and current pollution prevention activities and defined the objectives of LLN L's waste minimization and pollution prevention efforts. The plan was last updated and submitted to DOE in M ay 1997 (Celeste 1997). While preparation of an update was expected in 2000 , the timeline was deferred per DOE guidance. During the latter half of 2000, L LN L P2 personnel focused efforts on a different report, the LLN L R eport on Pollution Prevention and Energy Efficiency Leadership Goals. Due for completion and submission to DOE in early 2001, this report provides information on how $L L N L$ intends to accomplish the new DOE P2/ E2 goals. It is expected that this report will take the place of the usual triennial P2 Plan.

LLNL is required by $U \mathrm{C}$ C ontract performance measure 1.2.g to annually review its waste generation in terms of pollution prevention opportunities and to propose implementation projects. During 2000, the LLNL P2 staff prepared the 1999 Comprehens ve O ppor tunity A ssessment for Pollution Prevention, Energy Efficiency, and Water Conservation at Lawrence Livermore $\mathrm{N}$ ational Laboratory, Livermore Site (PRAG 2001). The report identified and cataloged opportunities for pollution prevention throughout the Livermore site using fiscal year 1999 data from routinely generated hazardous, mixed, and radioactive waste; non-hazardous solid waste; and industrial solid waste databases. The report recorded previously evaluated alternatives and current or planned programs for particular waste streams and potential projects in the energy efficiency and water conservation areas. It differed from the previous 1997 Comprehensive O ppor tunity A ssessment (C eleste 1997) report by reviewing only current routinely generated wastes.

Waste Minimization/Pollution Prevention

The P2 Program at L L N L strives to systematically reduce solid, hazardous, radioactive, and mixedwaste generation and eliminate or minimize pollutant releases to all environmental media from all aspects of the site's operations. These efforts 
Table 3-2. Pollution Prevention and Energy Efficiency Leadership Goals at Department of Energy Facilities

\begin{tabular}{|c|c|}
\hline Goal $^{(a)}$ & Detail \\
\hline \multirow[t]{5}{*}{$\begin{array}{l}\text { Reduce Waste } \\
\text { and Recycling }\end{array}$} & $\begin{array}{l}\text { Reduce waste from routine operations by } 2005 \text {, using a } 1993 \text { baseline, for these waste types: } \\
\text { Hazardous by } 90 \% \\
\text { Low Level Radioactive by } 80 \% \\
\text { Low Level-Mixed Radioactive by } 80 \% \\
\text { Transuranic (TRU) by } 80 \%\end{array}$ \\
\hline & $\begin{array}{l}\text { Reduce releases of toxic chemicals subject to Toxic Chemical Release Inventory reporting by } \\
90 \% \text { by } 2005 \text {, using a } 1993 \text { baseline. }\end{array}$ \\
\hline & $\begin{array}{l}\text { Reduce sanitary waste from routine operations by } 75 \% \text { by } 2005 \text { and } 80 \% \text { by } 2010 \text {, using a } \\
1993 \text { baseline. }\end{array}$ \\
\hline & Recycle $45 \%$ of sanitary wastes from all operations by 2005 and $50 \%$ by 2010 . \\
\hline & $\begin{array}{l}\text { Reduce waste resulting from cleanup, stabilization, and decommissioning activities by } 10 \% \text { on } \\
\text { an annual basis. }\end{array}$ \\
\hline $\begin{array}{l}\text { Buy Items with } \\
\text { Recycled Content }\end{array}$ & $\begin{array}{l}\text { Increase purchases of EPA-designated items with recycled content to } 100 \% \text {, except when not } \\
\text { available competitively at reasonable price or that do not meet performance standards. }\end{array}$ \\
\hline \multirow[t]{2}{*}{$\begin{array}{l}\text { Improve Energy } \\
\text { Usage }\end{array}$} & $\begin{array}{l}\text { Reduce energy consumption through life-cycle cost effective measures by: } \\
40 \% \text { by } 2005 \text { and } 45 \% \text { by } 2010 \text { per gross square foot for buildings, using a } 1985 \text { baseline } \\
20 \% \text { by } 2005 \text { and } 30 \% \text { by } 2010 \text { per gross square foot, or per other unit as applicable, for } \\
\text { laboratory and industrial facilities, using a } 1990 \text { baseline. }\end{array}$ \\
\hline & $\begin{array}{l}\text { Increase the purchase of electricity from clean energy sources: } \\
\text { (a) Increase purchase of electricity from renewable energy sources by including provisions } \\
\text { for such purchase as a component of our requests for bids in } 100 \% \text { of all future DOE } \\
\text { competitive solicitations for electricity. } \\
\text { (b) Increase the purchase of electricity from less greenhouse gas-intensive sources including } \\
\text { but not limited to new advanced technology fossil energy systems, hydroelectric, and } \\
\text { other highly efficient generating technologies. }\end{array}$ \\
\hline \multirow{3}{*}{$\begin{array}{l}\text { Reduce Ozone } \\
\text { Depleting Substances } \\
\text { and Greenhouse } \\
\text { Gases }\end{array}$} & $\begin{array}{l}\text { Retrofit or replace } 100 \% \text { of chillers greater than } 150 \text { tons of cooling capacity and } \\
\text { manufactured before } 1984 \text { that use class I refrigerants by } 2005 \text {. }\end{array}$ \\
\hline & $\begin{array}{l}\text { Eliminate use of class I ozone depleting substances by } 2010 \text {, to the extent economically } \\
\text { practicable, and to the extent that safe alternative chemicals are available for DOE class I } \\
\text { applications. }\end{array}$ \\
\hline & $\begin{array}{l}\text { Reduce greenhouse gas emissions attributed to facility energy use through life-cycle cost- } \\
\text { effective measures by } 25 \% \text { by } 2005 \text { and } 30 \% \text { by } 2010 \text {, using } 1990 \text { as a baseline. }\end{array}$ \\
\hline \multirow[t]{3}{*}{$\begin{array}{l}\text { Increase Vehicle } \\
\text { Fleet Efficiency and } \\
\text { Use of Alternative Fuels }\end{array}$} & $\begin{array}{l}\text { Reduce our entire fleet's annual petroleum consumption by at least } 20 \% \text { by } 2005 \text { in compar- } \\
\text { ison to } 1999 \text {, including improving the fuel economy of new light duty vehicle acquisitions and } \\
\text { by other means. }\end{array}$ \\
\hline & $\begin{array}{l}\text { Acquire each year at least } 75 \% \text { of light duty vehicles as alternative fuel vehicles, in accordance } \\
\text { with the requirements of the Energy Policy Act of } 1992 \text {. }\end{array}$ \\
\hline & $\begin{array}{l}\text { Increase usage rate of alternative fuel in departmental alternative fuel vehicles to } 75 \% \text { by } \\
2005 \text { and } 90 \% \text { by } 2010 \text { in areas where alternative fuel infrastructure is available. }\end{array}$ \\
\hline
\end{tabular}

a From DOE P2/E2 leadership goals, dated November 12, 1999 
help protect public health and the environment by reducing or eliminating waste management and compliance costs, improving resource usage, reducing inventories and releases of hazardous chemicals, and minimizing civil and criminal liabilities under environmental laws. In accordance with EPA guidelines and DOE policy, the P2 Program uses a hierarchical approach to waste reduction (i.e., source elimination or reduction, material substitution, reuse and recycling, and treatment and disposal) applied where feasible to all types of waste.

The P2 staff tracks waste generation using the HWM Division's Total Waste Management System (TWMS) database.

By reviewing this database, the P2 staff can identify waste streams with potential problems for each directorate and address issues in a timely manner.
Routine waste generation by waste category, from 1993 through 2000, is shown in Table 3-3. The trend from 1993 on shows a dramatic reduction in all waste categories, which is the result of LLNL's proactive P2 program.

Table 3-4 presents the percent reductions in routine waste generation for 2000 compared with the 1993 baseline. With the decreases in routine radioactive and hazardous waste generation, the Laboratory met the UC Contract performance measures goal of $50 \%$ in 1997 . Current reductions are $78 \%$ and $66 \%$ respectively. The $50 \%$ reduction goal for low-level mixed waste was achieved in 2000, largely because of an improved treatment technology and a decrease in programmatic generation. Reduction of the sanitary waste stream from the baseline of 1993 is currently at 19\%. Further discussion of the sanitary waste stream occurs in the following section.

Table 3-3. Routine waste generation totals (tons), 1993-2000

\begin{tabular}{|l|c|c|c|c|c|c|c|c|}
\hline $\begin{array}{c}\text { Waste } \\
\text { category }\end{array}$ & $\begin{array}{c}1993^{(\mathbf{a})} \\
\text { (baseline) }\end{array}$ & CY1994 & CY1995 & CY1996 & CY1997 & CY1998 & CY1999 & FY2000(b) \\
\hline Low-level radioactive & 256 & 181 & 136 & 91 & 68 & 73 & 66 & 56 \\
Low-level mixed & 34 & 26 & 36 & 23 & 21 & 25 & 20 & 14 \\
Hazardous & 628 & 510 & 368 & 360 & 240 & 232 & 188 & 212 \\
Sanitary & 2600 & 2246 & 2246 & 2001 & 2017 & 2201 & 2210 & 2103 \\
LLNL totals & 3518 & 2963 & 2786 & 2475 & 2346 & 2531 & 2484 & 2385 \\
\hline
\end{tabular}

a Baseline values 1993 through 1997 adjusted per agreement between DOE/OAK and LLNL on February 20, 1998

b In 2000 the format for reporting waste generation for UC Contract performance measures changed from a calendar year (CY) to a fiscal year (FY) basis. To keep numbers consistent with the published performance measures, FY waste generation is reported for 2000. 
Table 3-4. Routine waste reduction, 2000

\begin{tabular}{|l|c|}
\hline \multicolumn{1}{|c|}{ Waste category } & $\begin{array}{c}\text { Reduction } 2000 \text { vs. } 1993 \\
(\%)\end{array}$ \\
\hline Radioactive & 78 \\
Mixed & 59 \\
Hazardous & 66 \\
Sanitary & 19 \\
\hline
\end{tabular}

\section{Nonhazardous Solid Waste Minimization}

In 2000, LLNL sent 4605 tons of routine and nonroutine, nonhazardous waste (also designated as sanitary waste) to a landfill. The routine portion was 2096 tons and the nonroutine portion was 2509 tons. The breakdown for routine and nonroutine waste is shown in Table 3-5.

Table 3-5. Total nonhazardous waste sent to landfills, $\mathbf{2 0 0 0}$

\begin{tabular}{|c|c|}
\hline Nonhazardous waste & $\begin{array}{l}2000 \text { total } \\
\text { (tons) }\end{array}$ \\
\hline \multicolumn{2}{|l|}{ Routine } \\
\hline Compacted & 1828 \\
\hline Industrial (TWMS) ${ }^{(a)}$ & 268 \\
\hline Routine subtotal & 2096 \\
\hline \multicolumn{2}{|l|}{ Nonroutine } \\
\hline $\begin{array}{l}\text { Construction demonstration } \\
\text { (noncompacted) }\end{array}$ & 2363 \\
\hline Industrial (TWMS) & 146 \\
\hline Nonroutine subtotal & 2509 \\
\hline LLNL total & 4605 \\
\hline
\end{tabular}

\section{Diverted Waste}

The total waste diverted from landfills in 2000 was 26,563 tons (see Table 3-6). This 2000 relative decrease in total diversions with respect to previous years was due to a decreased quantity of soil leaving the site.
Table 3-6. Diverted waste totals, 1996-2000

\begin{tabular}{|c|c|}
\hline Date & $\begin{array}{c}\text { Diverted waste totals } \\
\text { (tons) }\end{array}$ \\
\hline 1996 & 20,266 \\
1997 & $323,465^{(a)}$ \\
1998 & 31,513 \\
1999 & $47,161.5$ \\
2000 & 26,563 \\
\hline
\end{tabular}

a The 1997 solid waste diversion total of 323,465 reflects an increase in soil reuse, predominately driven by construction of the National Ignition Facility.

Table 3-7 shows a breakdown of waste diversion categories for 2000 , reflecting the variety of diversion programs in place at LLNL. Soil, a major contributor to diversion totals, is reused both on site and at the landfill for daily cover. Asphalt and concrete are reused as road base material at the landfill. Wood waste, created by broken pallets, shipping crates, and demolition or construction scrap, cannot be cost-effectively reused on site, so it is gathered in a collection yard for recycling by a vendor at a cost lower than that of other disposal alternatives. Intact pallets and other reusable wood remain on site for internal reuse.

Composting landscape clippings from the site's lawns, trees, shrubs, and annual plantings is another waste reduction method. Once it is properly aged, the compost is used on site as a soil amendment. By generating its own soil builders, LLNL benefits twice: by eliminating an organic waste stream (with no tipping fees or hauling required), and by saving the purchase cost of new material. In one activity that both reduces waste and helps conserve water, gardeners chip office Christmas trees at the end of the holiday season to create mulch that is used yearround, reducing the amount of dry-season irrigation necessary in tree wells. 
Table 3-7. Diverted waste summary, 2000

\begin{tabular}{|c|c|}
\hline Waste description & $\begin{array}{c}\text { Cumulative } \\
2000 \text { total } \\
\text { (tons) }\end{array}$ \\
\hline Asphalt/concrete & 3,872 \\
\hline Batteries & 48 \\
\hline Cardboard & 186 \\
\hline Compost & 513 \\
\hline Cooking grease/food & 4.5 \\
\hline Diverted soil & 19,476 \\
\hline HWM recycled materials & 178 \\
\hline $\begin{array}{l}\text { Magazines, newspapers, and } \\
\text { phone books }\end{array}$ & 22 \\
\hline Metals & 1,504 \\
\hline Paper & 310 \\
\hline Tires and scrap & 30 \\
\hline Toner cartridges & 2 \\
\hline Wood & 402 \\
\hline Beverage containers & 15 \\
\hline LLNL diversion total & 26,563 \\
\hline
\end{tabular}

Another well-developed and highly visible component of the LLNL recycling effort is the officepaper collection and reclamation project. The Laboratory operates a full-site program, with more than 122 facility collection points. Unclassified paper is transported to a contract firm, where it is shredded and recycled into toilet paper and egg cartons. Classified paper is preprocessed at the Livermore site using a hammer mill destruction process. Additionally, LLNL collects and recycles external and internal phone books, newspapers, and magazines by placing recycling bins on site for pickup by a local vendor. If a recycling bin is not easily accessible, employees may also mail these items to a central collection point. These items would otherwise contribute to the solid waste stream.
LLNL continues to look for diversion opportunities. A beverage container recycling program initiated in late 1999 was increasingly successful in 2000. This program, which serves all three on-site cafeterias, collected 15 tons of aluminum, glass, and plastic containers and steel food cans, which were taken off site for recycling by a local vendor.

According to its management contract with UC, LLNL's goal was to reduce the generation of routine sanitary (nonhazardous) waste by $33 \%$ by December 31, 1999. As shown in Table 3-5, after recycling, LLNL generated 2096 tons of routine nonhazardous waste in 2000, a reduction of $19 \%$ with respect to the baseline. Because the 33\% reduction goal has not yet been achieved, despite an impressive $85 \%$ recycling rate for nonhazardous waste, the Laboratory has a strong incentive to continue to identify new nonhazardous-waste reduction measures. The LLNL Report on Pollution Prevention and Energy Efficiency Leadership Goals discusses several ideas that could help LLNL in this effort. The most ambitious ideas involve the design, building, and operation of an onsite Materials Recovery Facility (MRF). At MRF, LLNL's commingled solid-waste stream would be manually sorted, increasing the diversion of recyclable and reusable materials. Given the cost, building an MRF will be possible only if specific funding for this project is received from DOE.

Cities and counties have been required by California law to reduce nonhazardous solid waste by $25 \%$ and $50 \%$ between the baseline year of 1990 , and 1995 and 2000, respectively. LLNL contributes to this effort by tracking and reporting its waste diversions to the County of Alameda. Significant reductions have been achieved. Compared with the 1990 baseline, by 1995 LLNL reduced its nonhazardous waste by 46\% (see Table 3-8), which compared favorably with unincorporated 
Table 3-8. Nonhazardous solid waste summary, 1990-2000

\begin{tabular}{|l|c|c|c|}
\hline & 1990 & 1995 & 2000 \\
\hline $\begin{array}{l}\text { Nonhazardous solid waste } \\
\text { (routine and nonroutine) } \\
\text { (tons) } \\
\begin{array}{l}\text { Percent reduction } \\
\hline\end{array}\end{array}$ & $8332^{\text {(a) }}$ & 4560 & 4605 \\
\hline
\end{tabular}

a The 1990 baseline weight is an estimated figure. A conversion factor was used to convert the recorded volume of landfilled waste to a weight value. LLNL waste was not weighed at the landfill until 1994.

Alameda County (8.9\% reduction) and the City of Livermore (13.8\% reduction) for 1995. Additional details are discussed in Assessing the Nonhazardous Solid Waste Stream at Lawrence Livermore National Laboratory (Wilson 1999). Generating a total of 4605 tons in 2000, LLNL's 45\% nonhazardous waste reduction remains fairly consistent with the 1995 reduction.

\section{Source Reduction and Pollution Prevention}

LLNL P2 staff continue to survey on-site operations for opportunities to eliminate, reduce, recover, or recycle potential pollutants to all media, including air, water, soil, sediments, and biota.

\section{Toxic Reporting Inventory Information}

The Reporting Year 1999 Toxic Reporting Inventory (TRI) FORM R Report for Freon 113 (1,1,2trichloro-1,2,2-trifluoroethane, also known as CFC 113) was submitted to the Department of Energy on June 21, 2000. All other chemicals are present in quantities below the threshold reporting levels or are in a form that does not require reporting.

Freon 113, which is used in parts cleaning operations and as a coolant or refrigerant, is an ozonedepleting substance whose consumption and production are slated for elimination by the year 2000. For this reason, the replacement and recy- cling of Freon 113 is a high priority at LLNL. During 2000, LLNL decreased its inventory of Freon 113 as equipment from the Atomic Vapor Laser Isotope Separation (AVLIS) program was decommissioned.

\section{Current Return-on-Investment Projects}

The DOE funds P2 projects through the HighReturn-on-Investment (ROI) P2 Program. LLNL prepared and received funding for two high ROI P2 project proposals in 2000. The two high ROI projects that received funding and began in 2000 are listed in Table 3-9. Also listed is an on-going project funded in 1999.

\section{Table 3-9. High return-on-investment projects, 2000}

\begin{tabular}{|l|l|}
\hline \multicolumn{1}{|c|}{ Operation } & \multicolumn{1}{c|}{ Project } \\
\hline $\begin{array}{l}\text { Conversion from } \\
\text { aerosol to } \\
\text { aqueous brake } \\
\text { cleaning at LLNL } \\
\text { auto mainte- } \\
\text { nance facilities }\end{array}$ & $\begin{array}{l}\text { This project funded the conversion } \\
\text { from the use of solvent aerosol } \\
\text { spray cans for brake cleaning to an } \\
\text { aqueous system in two LLNL auto- } \\
\text { motive facilities. }\end{array}$ \\
\hline $\begin{array}{l}\text { LLNL Fuel Incen- } \\
\text { tive Program }\end{array}$ & $\begin{array}{l}\text { To promote use of car- and } \\
\text { vanpooling by LLNL commuters, } \\
\text { this project provided the startup } \\
\text { costs for a program giving regis- } \\
\text { tered vanpool and carpool drivers } \\
\text { the opportunity to purchase } \\
\text { discounted gas for their pool vehi- } \\
\text { cles at the Lab's two fuel stations. }\end{array}$ \\
\hline $\begin{array}{l}\text { Low-Hg Fluores- } \\
\text { cent Lighting } \\
\text { Pilot at LBNL and } \\
\text { LLNL }\end{array}$ & $\begin{array}{l}\text { This project studies the benefits } \\
\text { and drawbacks of converting to } \\
\text { low-Hg fluorescent tubes in office } \\
\text { and shop space (lt received } \\
\text { funding in 1999. Work on this ROI } \\
\text { project was ongoing in 2000.) }\end{array}$ \\
\hline
\end{tabular}

\section{Review of New Processes or Experiments}

Many organizations at LLNL use a "front-end" review process that applies to new programs, projects, or experiments that could have a significant impact on the environment. In this review, 
hazardous materials projected to be used are identified and wastes expected to be generated are estimated. The possibilities for chemical substitution, process changes, and recycling are then addressed. If an opportunity for P2 is identified, the Pollution Prevention staff assists the generator in evaluating the options. Researchers and project managers are encouraged to implement reasonable P2 opportunities that have been identified.

\section{Design for Environment}

Design for environment is a concept that involves developing an understanding of potential environmental impacts over the lifetime of a project, with the goal of minimizing or mitigating those potential impacts through modifications to the project at the design stage.

In 1997, the Pollution Prevention Team and National Ignition Facility (NIF) project management completed a design-for-environment evaluation of the opportunities within the NIF project. Based on this evaluation, the laboratory implemented recycling programs during NIF construction, prepared a Pollution Prevention Plan for NIF, and implemented aqueous cleaning concepts in the design for parts and optics cleaning. The NIF Pollution Prevention and Waste Minimization Plan (Cantwell and Celeste 1998), which was completed in 1998, included pollution prevention opportunity assessments (PPOAs) on the predicted waste streams identified in the preliminary environmental impact statement. In 2000, a follow up document was completed, the NIF Pollution Prevention and Waste Minimization 2000 Supplement, which updated the PPOAs as needed, accounting for two years of design progress and process development. This work continues with the aim of developing and implementing waste minimization options before NIF becomes operational.

\section{Implementing P2 Employee Training and Awareness Programs}

General P2 awareness for LLNL employees is promoted through new employee training and orientation, posters, articles in Newsline (LLNL's weekly newspaper), and administrative briefings and memos. The Pollution Prevention Team also sponsors a yearly Earth Expo event open to employees, their families, and the local community to provide awareness of environmentally sound technologies and LLNL waste diversion initiatives. P2 information directed at technical employees is found in LLNL's ESerH Manual (Volume III, Part 7), is covered in the EPD training course Hazardous Waste Generation and Certification. This information is also disseminated to employees by means of organizing conferences and workshops, and making formal presentations to groups such as the ES\&H Working Group's Environmental Subcommittee.

\section{ChemTrack}

ChemTrack, which is a computerized chemical inventory system, serves as an important tool for ensuring that LLNL complies with the Superfund Amendment and Reauthorization Act (SARA) Title III and California Business Plan reporting requirements and for improving the overall management of hazardous materials. ChemTrack enhances LLNL's ability to obtain the toxic release information necessary to complete SARA 313 submittals, to improve emergency response capabilities and management of material safety data sheets (MSDSs), to more closely track specific high-hazard chemicals and other regulated substances, and to screen selected LLNL facilities for preliminary hazard analyses. ChemTrack currently contains records of approximately 178,000 chemical containers ranging from $210-\mathrm{L}$ drums to gram-quantity vials. 


\section{Current Issues and Actions}

Many current issues and actions are described in this report according to chapter subjects. This section lists several not covered elsewhere.

\section{Leaking Underground Fuel Tank Studies}

As part of continuing state-funded leaking underground fuel tank (LUFT) studies, LLNL is continuing to work with the California State Water Resources Control Board (SWRCB) to identify groundwater resources that may be vulnerable to methyl tertiary-butyl ether (MTBE) impact. As part of this effort, LLNL has developed a pilot geographic information system (GIS) to assess the vulnerability of public drinking water sources from fuel hydrocarbon releases, including MTBE, and assist in managing the public risk that may be associated with these releases. The working pilot GIS, called GeoTracker, can be viewed at: http://geotracker.llnl.gov.

GeoTracker gives users the ability to assess potential threats to their drinking water sources. It determines the distance between contaminant sites and sensitive drinking water sources. The tools built into GeoTracker can quickly identify and display the number of LUFT sites within various distances of wells. Further, a set of on-line tools allows the user to integrate well-specific and contaminant site-specific information to give users the potential to analyze various aspects of vulnerability.

\section{Evaluation of the Use of Ethanol to Replace MTBE in Gasoline}

On March 25, 1999, California Governor Gray Davis issued Executive Order D-5-99, calling for the removal of MTBE from gasoline at the earliest possible date but no later than December 31, 2002. To assist the SWRCB, LLNL has led a team of researchers in evaluating the potential groundwater and surface water impacts that may occur if ethanol is used to replace MTBE. These findings are reported in Health and Environmental Assessment of the Use of Ethanol as a Fuel Oxygenate (Rice and Cannon 1999). This document has been presented to the California Environmental Policy Council and can be viewed at: http://www-erd.llnl.gov/ethanol/.

The presence of ethanol in groundwater may alter micobially mediated benzene, toluene, ethylbenzene and xylene (BTEX) fate and transport processes and could contribute to increased benzene plume lengths. Several abiotic and biotic processes or mechanisms that affect the fate of ethanol and ethanol-gasolines in the subsurface are continuing to be studied by LLNL.

During evaluation of groundwater and surfacewater impacts, LLNL began to develop a comprehensive life-cycle model. Work continued on a lifecycle model that systematically addresses impacts from fugitive and accidental releases associated with the production, distribution, and use of ethanolcontaining gasoline. LLNL also continued to examine the salient environmental properties of alkylates, which are nonoxygenated compounds likely to be used in greater amounts in gasoline after MTBE is phased out.

Several modeling efforts evaluating the behavior of benzene groundwater plumes in the presence of ethanol indicate that benzene plumes are likely to increase in length, but the amount of this increase is not well known. A number of recommendations have been made to address knowledge gaps in the potential groundwater and surface-water impacts associated with using ethanol to replace MTBE. 


\section{Initiative to Improve Volatile Organic Compound Cleanup Process by Using Historical Case Analysis}

The goal of this initiative is to evaluate a large number of nationwide historical cases to identify common volatile organic compound (VOC) release conditions that pose low risks and can be managed with minimal effort and cost, versus release conditions that pose higher risks and warrant larger expenditures. The key to this initiative is a crosscutting evaluation of the large amount of VOC case data that is available.

This study is ongoing, and LLNL is continuing to gather chlorinated VOC historical case data to improve the evaluation of the behavior of chlorinated VOC plumes. A Phase 1 final report, entitled, Historical Case Analysis of Chlorinated Volatile Organic Compound Plumes (McNab et al. 1999), has been completed and can be viewed on the Internet at: http://www-erd.llnl.gov/library/ AR-133361.html.

\section{Nuclear Regulatory Commission}

Since the spring of 2000, the Operations and Regulatory Affairs Division (ORAD) has been providing technical assistance to the Nuclear Regulatory Commission (NRC). Much of ORAD's work is in preparing NRC staff for responding to license renewal requests due from more than 100 US nuclear power plant operators in 2006, and in preparing the extensive NEPA documentation to support its decisions.

ORAD staff also leads a team of experienced LLNL staff in supporting NRC in a variety of activities, including participating in planning processes and public interactions, developing leaders from LLNL staff to manage NRC technical support, and providing expertise to $\mathrm{NRC}$ in preserving natural resources and addressing environmental policy issues.
ORAD also supports NRC in programs at LLNL, such as assisting in the maintenance and updating of an existing Geographical, Environmental \& Siting Information system, a project managed within NRC's contract with the Fission Energy and Systems Safety Program (FESSP) at LLNL.

\section{University of California, Merced}

LLNL is supporting the new University of California campus at Merced (UCM), which is scheduled to open for students in 2004 , by helping UCM solidify its commitment to building a strong environmental program and protecting its sensitive natural resources. Through several programs, such as Partnerships for the Future, LLNL is helping UCM strengthen its research, teaching and outreach mission in the Central Valley and support its research programs that will focus on critical issues such as population growth and development impacts in California.

EPD, along with counterparts from Lawrence Berkeley and Los Alamos National Laboratory, will also be assisting UCM in several areas of environmental responsibility. These include advising in permitting and building design, identifying best management practices for sensitive wetlands habitat, and providing expertise and assessments on specific subjects of environmental concern.

\section{International Projects}

\section{Morocco}

EPD has provided support to Morocco's National Center for Nuclear Energy Sciences and Techniques (CNESTEN), as part of a Sister Lab Agreement between the United States and the government of Morocco. CNESTEN has consulted EPD about several areas of environmental monitoring and management, such as the development of analysis reports, waste management, environmental monitoring and modeling, 
and in the identification of salinity sources and their impact on drinking water resources.

\section{Former Soviet Union/International Science Centers}

EPD personnel are supporting U.S. non-proliferation and arms control programs by participating in environmental projects sponsored by two nonproliferation research centers in the former Soviet Union. These two centers, the International Science and Technology Center (ISTC) in Moscow and Science and Technology Center of Ukraine (STCU) in Kiev, sponsor development of novel environmental technologies that are an important component in the conversion of former Soviet scientists from weapons to nonweapons work.

By participating as auditors and collaborators, the EPD team has had the opportunity to review environmental monitoring, restoration, and waste management projects that may lead to unique solutions to environmental problems in the former Soviet Union and elsewhere. In addition, EPD has recognized a potential for applying the principles of these projects to EPD missions.

\section{Response to Spills and Other Environmental Emergencies}

\author{
All spills and leaks (releases) at LLNL that are \\ potentially hazardous to the environment are inves- \\ tigated and evaluated. The release response process \\ includes identifying the release, shutting off the \\ source (if it is safe to do so), eliminating ignition \\ sources, contacting appropriate emergency \\ personnel, cordoning off the area containing the \\ released material, absorbing and neutralizing the \\ released material, assisting in cleanup, determining \\ if a release must be reported to regulatory agencies, \\ and verifying that cleanup (including decontami- \\ nating and replenishing spill equipment) is
}

complete. Environmental analysts provide guidance to the programs on preventing spill recurrence.

To maximize efficient and effective emergency environmental response, EPD established a 7-daya-week, 24-hour-a-day, on-call rotational position entitled the environmental duty officer (EDO). Specialized EDO training includes simulated incidents to provide the response personnel with the experience of working together to mitigate an environmental emergency, determine any reporting requirements to regulatory agencies and DOE, and resolve environmental and regulatory issues within the LLNL emergency response organization. The on-duty EDO can be reached by pager or cellular phone at any time.

During normal work hours, Laboratory employees report all environmental incidents to the Environmental Operations Group (EOG) environmental analyst assigned to support their program area. The EOG environmental analyst then notifies the on-duty EDO of the incident, and together they determine applicable reporting requirements to local, state, and federal regulatory agencies and to DOE. The EDO and the EOG environmental analyst also notify and consult with program management and have 7-day-a-week, 24-hour-aday access to the office of Laboratory Counsel for questions concerning regulatory reporting requirements.

During off hours, Laboratory employees report all environmental incidents to the Fire Dispatcher, who, in turn, notifies the EDO and the Fire Department, if required. The EDO then calls out additional EPD support to the incident scene as necessary, and follows the same procedures as outlined above for normal work hours. 


\section{LLNL's Other Environmental Programs}

While EPD plays a central role, every directorate at LLNL is responsible for environmental compliance and minimizing the impacts of its operations. Several directorates have taken particularly noteworthy steps in this direction. Some examples include the plans for Defense Nuclear Technologies Program's Contained Firing Facility at Site 300 that will move explosive tests inside a facility where the debris is contained, the Laser Program's efforts to design the National Ignition Facility to have minimal environmental impact, Engineering's Metal Finishing Group's continuing efforts to reduce waste and substitute less hazardous chemicals in many of its processes, and the Education Program's efforts to enhance environmental education. Additionally, general waste minimization and pollution activities have been integral to the overall Defense Programs Directorate.

Integral to LLNL's environmental efforts is the ongoing research and development activities of the Energy and Environmental Programs Directorate. This directorate conducts multidisciplinary research to assess and mitigate environmental and human risk from natural and man-made hazards and to develop and demonstrate new tools and technologies for environmental restoration. This work primarily involves state of the art groundwater modeling and advanced hydrogeologic tracer studies; in situ environmental remediation using natural and engineered processes; pathway, dosimetry, and risk analysis of radioactive and toxic substances; atmospheric dispersion modeling and dynamics; subsurface imaging and characterization; and seismic processes.

\section{Contributing Authors Acknowledgment}

Major contributors to this diverse chapter were Mo Bissani, Winifred A. Burks-Houck, Katharine Gabor, Charlene Grandfield, Steve Harris, C. Susi Jackson, Paula Kato, Saverio Mancieri, Barbara Nisbet, Ellen Raber, David Rice, George Sanford, Kris Surano, Charlotte van Warmerdam, Joseph Woods, and Kenneth Zahn. 



\section{Air Effluent MONITORING}

Paula J. Tate Arthur H. Biermann

Barbara Nisbet

\section{Introduction}

Lawrence Livermore National Laboratory performs continuous air effluent sampling of atmospheric discharge points at several facilities. LLNL assesses air effluent emissions from facility operations to evaluate compliance with local, state, and federal regulations and to ensure that human health and the environment are protected from hazardous and radioactive air emissions.

\section{Air Quality Laws}

LLNL complies with local, state, and federal environmental air quality laws and Department of Energy (DOE) regulations. Applicable sections of DOE Orders 5400.1, General Environmental Protection Program, and 5400.5, Radiation Protection of the Public and the Environment, define standards for controlling exposures to the public from operations at DOE facilities. Subpart $\mathrm{H}$ of the National Emission Standards for Hazardous Air Pollutants (NESHAPs), 40 Code of Federal Regulations (CFR) 61, requires the continuous monitoring of certain discharge points and the estimation of dose to the public resulting from operations at DOE facilities. Guidance on air effluent sampling is provided in the Environmental Regulatory Guide for Radiological Effluent Monitoring and Environmental Surveillance (U.S. DOE 1991), 40 CFR 60, and NESHAPs-cited American National Standards Institute (ANSI) standards. The Environmental Protection Agency (EPA)
Region IX has oversight responsibility for LLNL compliance with regulations regarding radiological air emissions.

Enforcement authority of the Clean Air Act regulations for nonradiological air emissions have been delegated to the local air districts: the Bay Area Air Quality Management District (BAAQMD) for the Livermore site and the San Joaquin Valley Unified Air Pollution Control District (SJVUAPCD) for Site 300. 
Applicable regulations and permitting requirements are contained in the BAAQMD Regulations 1-12 for the Livermore site and the SJVUAPCD Regulations Rules 1010-9120 for Site 300.

\section{Monitored Emissions}

LLNL uses a variety of radioisotopes-including uranium, transuranics, biomedical tracers, tritium, and mixed-fission products - for research purposes. The major radionuclide released to the atmosphere from the Livermore site is tritium. In addition to effluent sampling for tritium, a number of facilities at the Livermore site have air effluent samplers to detect the release of uranium and transuranic aerosols. The air effluent sampling systems described in this chapter apply to stationary and point source discharges. LLNL also monitors diffuse, or nonpoint, sources to fulfill NESHAPs requirements. Sampling methods to evaluate LLNL diffuse sources are described in Chapter 5 of the Data Supplement. Summary data from these diffuse sources can be found in Chapter 5 of this volume.

Assessment of air effluent emissions and resulting dose to the public is performed by monitoring emissions and/or evaluating potential emissions. Currently, the air effluent sampling program measures only radiological emissions. LLNL has operations with nonradiological discharges; however, permits for these operations are obtained through local agencies, BAAQMD, and SJVUAPCD, and monitoring of the effluent is not required. The California Air Toxics "Hot Spots" legislation requires facilities to prepare an air toxics emissions inventory and risk assessment, which LLNL has completed. Based on the assessment, BAAQMD and SJVUAPCD have ranked LLNL as a low-risk facility for nonradiological air emissions.
Historically, monitoring of radionuclide air effluents at LLNL has been implemented according to the DOE as low as reasonably achievable (ALARA) policy. This policy is meant to ensure that DOE facilities are capable of monitoring routine and nonroutine radiological releases, so that the dose to members of the public can be assessed, and so that doses are ALARA. In addition, the NESHAPs 40 CFR 61, Subpart H, regulations require that facility radiological air effluents must be continuously monitored if the potential off-site dose equivalent is greater than $1 \mu \mathrm{Sv} / \mathrm{y}(0.1 \mathrm{mrem} / \mathrm{y})$, as calculated using the EPA-mandated air dispersion dose model and assuming that there are no emission control devices. The results from monitoring the air discharge points provide the actual emission source information for modeling, which is used to ensure that the NESHAPs standard, $100 \mu \mathrm{Sv} / \mathrm{y}$ (10 mrem/y) total site effective dose equivalent, is not exceeded. Discharges from non-monitored operations with the potential to release radionuclides are also evaluated according to NESHAPs regulations. To determine radiological NESHAPs compliance, corresponding doses are added to those obtained by modeling monitored emissions.

\section{Operation of Monitoring Systems}

Air effluent monitoring of atmospheric discharge points is used to determine the actual radionuclide releases from individual facilities and processes during routine and nonroutine operations, to confirm the operation of facility emission control systems, and to corroborate and aid in the resolution of air surveillance measurement results for the site. (The relationship can also work the other way as well-air surveillance measurements can corroborate effluent monitoring.) Measurements made by the air surveillance samplers located on and off site are reported in Chapter 5 . 


\section{Methods}

Air effluent monitoring involves the extraction of a measured volume of air from the exhaust of a facility or process and subsequent collection of particles by filters or of vapors by a collection medium. After collection, the various radionuclides in the sample are measured by appropriate analytical methods.

In 2000, LLNL operated 76 sampling systems for radioactivity from air exhausts at 6 facilities at the Livermore site (see Figure 4-1). These systems are listed in Table 4-1 along with the analytes of

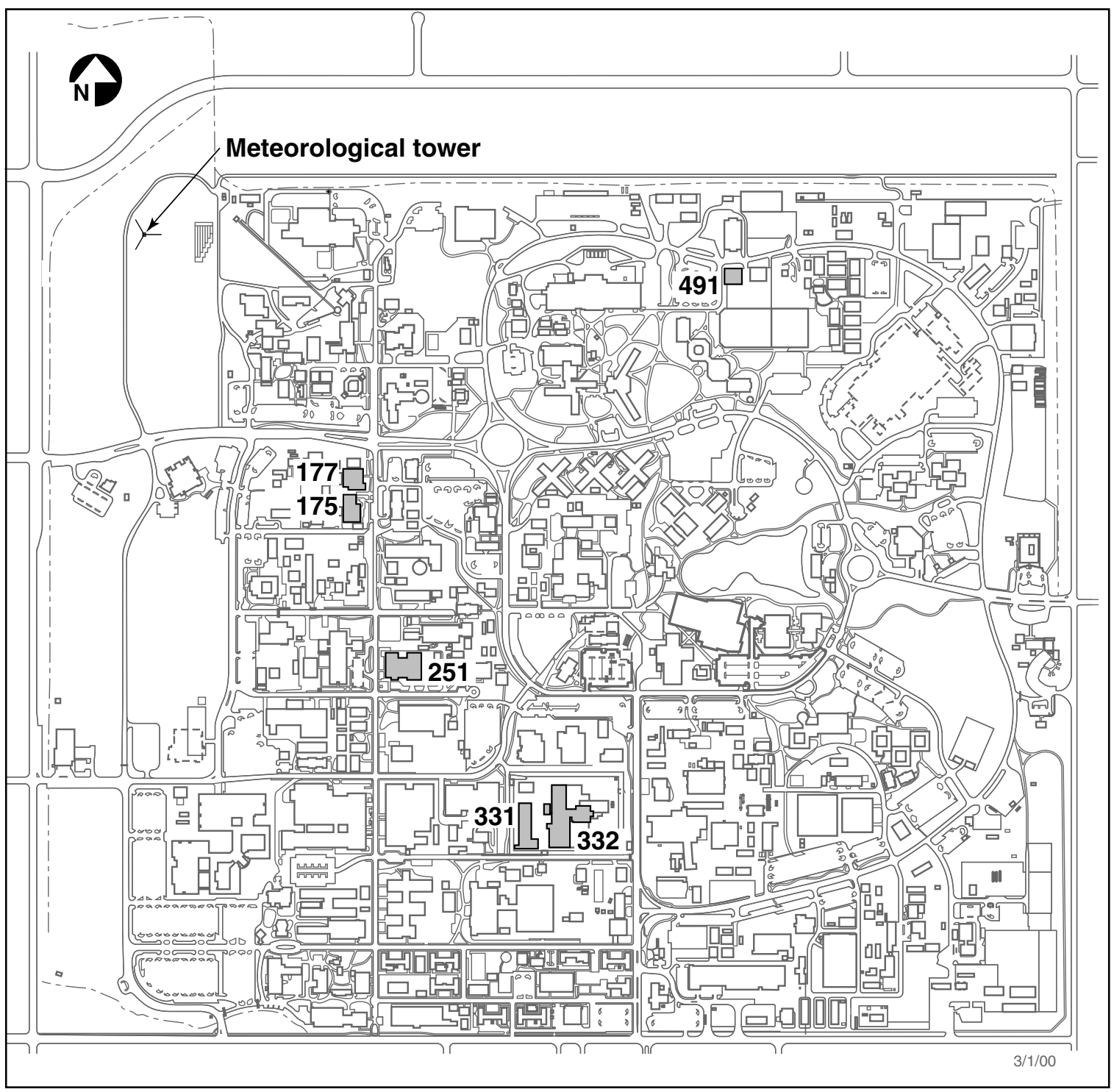

Figure 4-1. Facilities at the Livermore site with air monitoring systems for effluent gas streams during all or part of $\mathbf{2 0 0 0}$ 
Table 4-1. Air effluent sampling locations and sampling systems

\begin{tabular}{|c|c|c|c|c|}
\hline Building & Facility & Analytes & $\begin{array}{l}\text { Sampler } \\
\text { type }\end{array}$ & $\begin{array}{c}\text { Number } \\
\text { of } \\
\text { samplers }\end{array}$ \\
\hline 175 & MARS & Gross $\alpha, \beta$ on particles & Filter & 6 \\
\hline 177 & Extractor Test Facility & Gross $\alpha, \beta$ on particles & Filter & 1 \\
\hline 251 & Heavy elements & Gross $\alpha, \beta$ on particles & Filter & 32 \\
\hline \multirow[t]{2}{*}{331} & Tritium & Tritium & $\begin{array}{l}\text { lonization } \\
\text { chamber }^{(a)}\end{array}$ & 4 \\
\hline & & $\begin{array}{l}\text { Gaseous tritium and triti- } \\
\text { ated water vapor }\end{array}$ & Molecular sieves & 4 \\
\hline \multirow[t]{2}{*}{332} & Plutonium & Gross $\alpha, \beta$ on particles & $\operatorname{CAM}^{(a, b)}$ & 12 \\
\hline & & Gross $\alpha, \beta$ on particles & Filter & 16 \\
\hline 491 & Laser isotope separation & Gross $\alpha, \beta$ on particles & Filter & 1 \\
\hline
\end{tabular}

interest, the type of sampler, and the number of samplers. LLNL reassesses the need for continuous monitoring on an annual basis, and more often if warranted by new operations or changes in operations. From NESHAPs assessments of operations during 2000, no additional discharge points were found to require continuous sampling.

In the past, sampling operations performed in Buildings 175, 177, 490, and 491 have supported research and development for the separation of uranium isotopes under the Advanced VaporLaser Isotope Separation (AVLIS) Program. In 1999 the AVLIS Program was shut down, and samplers on a Building 490 exhaust system were deactivated because the operation of the ventilation system was stopped. Air effluent sampling systems at Buildings 175,177 , and 491 continue to operate as part of the maintenance and surveillance shutdown plan for AVLIS facilities.

Sampling for particles containing radioactivity was conducted in five of the facilities and sampling for tritium was conducted in the Tritium Facility (Building 331). All sampling systems operated continuously. Samples were collected weekly or biweekly depending on the facility. Most air samples for particulate emissions were extracted downstream of high-efficiency particulate air (HEPA) filters and before the emissions were discharged to the atmosphere. Particles in the extracted air were collected on sample filters and analyzed for gross alpha and beta activity. Tritium is collected using molecular sieves. In addition to sample collection for environmental reporting, some facilities used real-time alarm monitors (listed in Table 4-1) at discharge points to provide faster notification in the event of a release of radioactivity.

Analytical results from the continuous samplers are reported as a measured concentration per volume of air, or as less than the minimum detection concentration (MDC) when no activity is detected. In all cases, the MDC is more than adequate for demonstrating compliance with the pertinent regulatory requirements for radionuclides that are present or may be present in the sampled air. Further details of LLNL air effluent sampling systems are included in Chapter 4 of the Environmental Monitoring Plan (Tate et al. 1999). 


\section{Measured Radioactive Air Emissions}

This section discusses the radiological air emissions from facilities that have continuously monitored discharge points.

\section{Livermore Site}

In 2000 , a total of $1.5 \mathrm{TBq}(40 \mathrm{Ci}$ ) of tritium was released from the Tritium Facility (Building 331). Of this, approximately $1.3 \mathrm{TBq}(35 \mathrm{Ci})$ were released as tritiated water vapor (HTO). The remaining tritium released, $0.18 \mathrm{TBq}(5 \mathrm{Ci})$, was elemental tritium gas (HT). HTO emissions from the facility ranged from $137 \mathrm{~Bq} / \mathrm{m}^{3}$ $\left(3.7 \times 10^{-9} \mathrm{Ci} / \mathrm{m}^{3}\right)$ to $4.3 \times 10^{4} \mathrm{~Bq} / \mathrm{m}^{3}$

$\left(1.2 \times 10^{-6} \mathrm{Ci} / \mathrm{m}^{3}\right)$, while HT emissions ranged from $0 \mathrm{~Bq} / \mathrm{m}^{3}\left(0 \mathrm{Ci} / \mathrm{m}^{3}\right)$ to $5.6 \times 10^{3} \mathrm{~Bq} / \mathrm{m}^{3}$ $\left(1.5 \times 10^{-7} \mathrm{Ci} / \mathrm{m}^{3}\right)$. The highest single weekly stack emission from the facility was $0.3 \mathrm{TBq}$ (8.1 Ci), of which $0.28 \mathrm{TBq}(7.7 \mathrm{Ci})$ was HTO. The emissions from Building 331 accounted for approximately $80 \%$ of the estimated potential tritium emissions from the Livermore site.

Emissions from Building 331 for 2000 continued to remain considerably lower than those during the 1980s and much lower than 1999 emissions.

Figure 4-2 illustrates the HTO and HT emissions from the facility since 1981 .

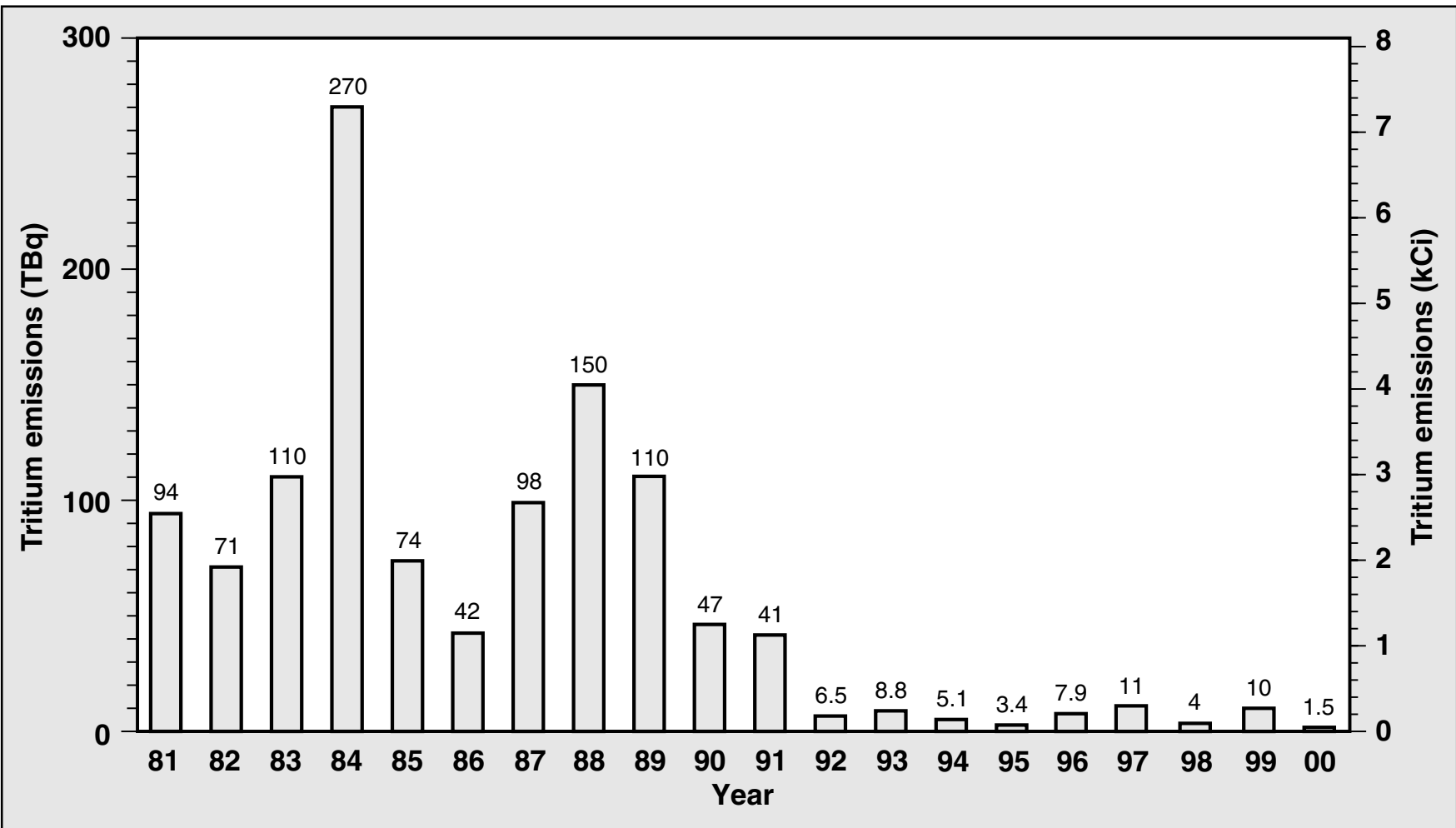

Figure 4-2. Tritium Facility combined HTO and HT emissions from 1981 through 2000 
Most sample results from the continuously sampled discharge points that have the potential for releasing particulate radionuclides were below the MDC of the analysis. Sometimes as few as one to four samples (out of 25 to 50 samples per year) exhibited concentrations greater than the MDC. Generally, these few samples with results above the MDC were only marginally above the MDC. In addition, because of the way some exhaust systems were configured, the monitoring systems sometimes sampled air from the ambient atmosphere and HEPA-filtered air from facility operations, which means that background atmospheric radioactivity was also collected. LLNL uses zero values for these results based on knowledge of the facility, the use of HEPA filters in all significant release pathways, and alpha-spectroscopy-based isotopic analyses of selected air sampling filters. These analyses demonstrate the presence of naturally occurring radionuclides, such as radon daughters, like polonium. Even if LLNL used the MDC values to calculate the emission estimates for these facilities (which would be an extremely conservative approach), the total dose to a member of the public attributable to LLNL activities would not be significantly affected.

Of all of the facilities monitored for gross alpha and beta, Building 251 was the only facility with emissions in 2000. At Building 251, one discharge point yielded gross alpha results greater than the MDC on a significant number of samples collected throughout the year. We use gross alpha as the primary indicator of potential emissions for operations, such as those at Building 251 that involve the use of uranium and transuranic materials. We use gross beta results to further corroborate those gross alpha results with concentrations above the MDC. The gross alpha and gross beta activity emissions for Building 251 were $2.6 \times 10^{2} \mathrm{~Bq} / \mathrm{y}$ $\left(7.0 \times 10^{-9} \mathrm{Ci} / \mathrm{y}\right)$ and $3.7 \times 10^{3} \mathrm{~Bq} / \mathrm{y}\left(9.9 \times 10^{-8}\right.$ $\mathrm{Ci} / \mathrm{y})$, respectively. Because of the number of samples with values above the MDC, we have taken a conservative approach and are reporting gross alpha and gross beta measurements as actual emissions.

The gross alpha monitoring concentrations for Building 251 ranged from $-9.3 \times 10^{-5} \mathrm{~Bq} / \mathrm{m}^{3}$ $\left(-2.5 \times 10^{-15} \mathrm{Ci} / \mathrm{m}^{3}\right)$ to $7.0 \times 10^{-4} \mathrm{~Bq} / \mathrm{m}^{3}$ $\left(1.9 \times 10^{-14} \mathrm{Ci} / \mathrm{m}^{3}\right)$. The Building 251 facility was in a standby, limited mode of operation throughout 2000, so emissions were not anticipated. Also, the gross alpha and gross beta average activity concentrations do not significantly differ from those of the low-volume air particulate surveillance samplers (see Chapter 5 ). Therefore, it is likely that Building 251 measurements were caused by naturally occurring or background radioactivity and by the facility exhaust configuration, as previously mentioned. In any case, the gross alpha and gross beta emissions from operations did not significantly contribute to the radiological dose to the public.

Table 4-2 lists total radiological emissions as determined from the continuous sampling of facility exhausts for 2000. Radioactive effluent concentrations from individual discharge points at all monitored facilities are reported in Chapter 4, Data Supplement.

\section{Site 300}

Currently, there is no requirement for air effluent monitoring of facilities at Site 300 . Air surveillance monitoring is performed for Site 300, and results are reported in Chapter 5 .

\section{All Potential Sources of Radioactive Air Emissions}

This section discusses the evaluation of all potential sources of radionuclide emissions to air at the Livermore site and Site 300. LLNL evaluates all discharge points with the potential to release radionuclides to the air according to 40 CFR 61, 
Subpart H, of the NESHAPs regulations. LLNL uses radionuclide usage inventories and/or monitoring data, along with EPA-accepted release factors for operations and EPA-suggested reduction factors for emission control devices, to estimate the potential release for each individual discharge point. Potential emissions are calculated using radionuclide usage inventories as distinguished from emissions-based air effluent sampling. We conduct this evaluation annually to assess both the potential dose to the public from all LLNL operations and the need for continuous sampling of individual discharge points.

For 2000, LLNL evaluated potential emissions of radionuclides from approximately 50 facilities and/or diffuse sources to determine their contribution of dose to a member of the public. Potential emissions were estimated based on radionuclide usage inventories specific to individual discharge points, physical state of the materials involved in the processes, and reductions caused by emission control systems. The effective dose equivalent (EDE) to a member of the public from specific operations at the Livermore site and Site 300 were published in LLNL NESHAPs 2000 Annual Report (Gallegos et al. 2001) and are summarized in Chapter 13 of this report.

The radionuclide isotope responsible for the majority of the 2000 EDE was tritium. Emissions from the Tritium Facility in the form of HTO accounted for $23 \%$ of the potential EDE to the maximally exposed member of the public from the Livermore site. A discussion of the relative dose impacts from HTO and HT is given in Chapter 13 in the section entitled "Assessment Assumptions Regarding Tritium." The other measured emissions shown in Table 4-2 (Building 251) contributed negligibly to the EDE for the maximally exposed member of the public.
Table 4-2. Measured radiological air effluent emissions for the Livermore site, 2000

\begin{tabular}{|c|l|c|c|}
\hline \multicolumn{5}{|c|}{ Tritium } \\
\hline $\begin{array}{c}\text { Build- } \\
\text { ing }\end{array}$ & Facility & $\begin{array}{c}\text { Elemental, HT } \\
\text { (Bq) }\end{array}$ & $\begin{array}{c}\text { Tritiated } \\
\text { water, HTO } \\
\text { (Bq) }\end{array}$ \\
\hline 331 & Tritium & $1.8 \times 10^{11}$ & $1.3 \times 10^{12}$ \\
\hline \multicolumn{4}{|c|}{ Gross alpha and gross beta } \\
\hline $\begin{array}{c}\text { Build- } \\
\text { ing }\end{array}$ & Facility & $\begin{array}{c}\text { Gross alpha } \\
\text { (Bq) }\end{array}$ & $\begin{array}{c}\text { Gross beta } \\
\text { (Bq) }\end{array}$ \\
\hline 251 & $\begin{array}{l}\text { Heavy } \\
\text { element }\end{array}$ & $2.6 \times 10^{2}$ & $3.7 \times 10^{3}$ \\
\hline
\end{tabular}

When determining if continuous sampling is needed at a discharge point, LLNL evaluates operations to determine if the potential dose to the maximally exposed member of the public will exceed $0.1 \mathrm{mrem}$ for the calendar year. This evaluation is similar to the evaluation of EDE previously described, except no credit is allowed for emission control systems (according to the regulations). For 2000, LLNL reported more than 200 potential discharge points and/or discharges at the Livermore site and Site 300. As a result of the evaluation, no additional discharge points, other than those already being continuously sampled, were found to require continuous sampling.

\section{Nonradioactive Air Emissions}

The Livermore site currently emits approximately $93 \mathrm{~kg} /$ day of criteria air pollutants (e.g., nitrogen oxides, sulfur oxides, particulate matter [PM-10], carbon monoxide, and lead, as defined by the Clean Air Act). The largest sources of criteria pollutants from the Livermore site are surfacecoating operations, internal combustion engines, solvent operations, and, when grouped together, boilers (oil and natural gas fired). Table 4-3 lists the estimated Livermore site 2000 total airborne releases for criteria pollutants. 
Table 4-3. Nonradioactive air emissions, Livermore site and Site 300, 2000

\begin{tabular}{|l|c|c|}
\hline \multirow{2}{*}{\multicolumn{1}{|c|}{ Pollutant }} & \multicolumn{2}{|c|}{$\begin{array}{c}\text { Estimated releases } \\
\text { (kg/day) }\end{array}$} \\
\cline { 2 - 3 } & $\begin{array}{c}\text { Livermore } \\
\text { site }\end{array}$ & Site 300 \\
\hline Organics/volatile organics & 19.6 & 0.4 \\
Nitrogen oxides & 53.7 & 2.3 \\
Carbon monoxide & 13.9 & 0.5 \\
Particulates (PM-10) & 5.5 & 0.2 \\
Oxides of sulfur & 0.6 & 0.2 \\
\hline
\end{tabular}

When comparing the estimated releases from exempt and permitted sources of air pollutants at the Livermore site with daily releases of air pollutants for the entire B ay Area, LLNL emissions are very low. For example, the total emissions of nitrogen oxides released in the Bay Area for 2000 were approximately $8.1 \times 10^{4} \mathrm{~kg} /$ day, compared with an estimate for $L L N L$ releases of $54 \mathrm{~kg} /$ day for the Livermore site $(0.07 \%$ of total B ay Area emissions from stationary sources). The BAAQ M D estimate for reactive organic emissions was $1.1 \times 10^{5} \mathrm{~kg} /$ day for 2000 , versus the Livermore site's estimated releases of $20 \mathrm{~kg} /$ day $10.02 \%$ of total Bay Area emissions from stationary sources) in 2000.

Certain operations at Site 300 require permits from SJVU APCD. The total estimated air emissions during 2000 from operations (permitted and exempt air sources) at Site 300 are given in Table 4-3. The largest sources of criteria pollutants at Site 300 include internal combustion engines, boilers, a gasoline-dispensing operation, open burning, paint spray booths, drying ovens, and soil vapor extraction operations.

\section{Environmental Impact}

$M$ easured radiological air emissions from the Livermore site operations for 2000 are well below levels that would cause concern for public health according to existing regulatory standards for radioactive dose. The dose to the hypothetical maximally exposed member of the public caused by the measured air emissions reported here (that is, caused by emissions from monitored stacks) is $0.084 \mu \mathrm{Sv} / \mathrm{y}(0.0084 \mathrm{mrem} / \mathrm{y})$. Including the measured $\mathrm{HT}$ emissions (with $\mathrm{HT}$ emissions modeled as H TO emissions as mandated by EPA), the dose to the hypothetical maximally exposed member of the public is $0.095 \mu \mathrm{Sv} / \mathrm{y}$ $(0.0095 \mathrm{mrem} / \mathrm{y})$. In either case, the dose is far below the NESH APs standard of $100 \mu \mathrm{Sv} / \mathrm{y}$ (10 mrem/ y) and doses from naturally occurring radiation. Thus, the estimated radiological dose caused by measured air emissions from LL N L operations is minimal. See Table 13-2 in Chapter 13 for a summary of all doses, monitored or otherwise. N onradioactive air effluents, which are also very small compared with emissions in surrounding areas, are well below standards and are not a threat to the environment or public health. 


\section{Air Surveillance MONITORING}

\section{Introduction}

Lawrence Livermore National Laboratory performs air surveillance monitoring to evaluate its compliance with local, state, and federal laws and regulations and to ensure that human health and the environment are protected from hazardous and radioactive air emissions. Federal environmental air quality laws and U.S. Department of Energy (DOE) regulations include Title 40 of the Code of Federal Regulations (CFR) Part 61, the National Emissions Standards for Hazardous Air Pollutants (NESHAPs) section of the Clean Air Act, and applicable portions of DOE Orders 5400.1 and 5400.5. The Environmental Regulatory Guide for Radiological Effluent Monitoring and Environmental Surveillance (U.S. DOE 1991) provides the guidance for implementing DOE Orders 5400.1 and 5400.5. In general, the constituents for which LLNL monitors are at levels far below the regulatory standards.

LLNL conducts surveillance monitoring of ambient air to determine if airborne radionuclides or hazardous materials are being released by Laboratory operations, what the concentrations are, and what the trends are in the LLNL environs. In the air monitoring program, LLNL collects particles on filters and chemically traps vapors on a collection medium. Concentrations of various airborne radionuclides (including particles and tritiated water vapor) and beryllium are measured at the
Livermore site, Site 300, and at off-site locations throughout the Livermore Valley and in the City of Tracy. In addition, some point sources and diffuse, or nonpoint sources, are monitored to fulfill NESHAPs requirements (Gallegos et al. 2000). 


\section{Methods}

Several monitoring networks were established for surveillance of air particulates and tritium in the environs of LLNL and Site 300, as well as in the surrounding Livermore Valley and in the City of Tracy. The sampling locations for each monitoring network are listed in Table 5-1 and shown on

Figures 5-1, 5-2, and 5-3. All monitoring networks use continuously operating samplers. The radiological high-volume sampling networks use glass-fiber filters; the beryllium high-volume networks use cellulose filters; and the low-volume network uses Millipore filters. The collection medium for tritium is silica gel.

Particulate filters are changed each week at all locations, and tritium samples are changed every two weeks. Duplicate quality control samplers operate in parallel with the permanent sampler at a given site, and these samples are analyzed to confirm results.

\section{Air Particulate Sampling Locations}

All air samplers are positioned to provide reasonable probability that, if there were any significant concentration of radioactive or beryllium effluents from LLNL operations, it would be detected.

The Livermore site radiological air surveillance sampling network (see Figure 5-1) consists of seven samplers at the perimeter with one (CRED) serving as the sitewide maximally exposed individual (SW-MEI) for NESHAPs reporting purposes. CRED is also located in the southeast quadrant in an area of known plutonium contamination attributed to historic operations, which included the operation of solar evaporators for plutonium-containing liquid waste.
The Livermore Valley network (see Figure 5-2) consists of air particulate samplers located in all compass directions from the Livermore site. For the purposes of data analysis, four samplers (FCC, FIRE, HOSP, and CHUR) located in the least prevalent wind directions are considered to be upwind or representative of background locations. An additional upwind sampler is located in another area of special interest, the Livermore Water Reclamation Plant (LWRP), because of a 1967 and earlier plutonium releases to the sanitary sewer system with subsequent soil contamination and potential resuspension (see the "Livermore Valley Surface Soil Results" section of Chapter 10 for a discussion of this). Four samplers (PATT, ZON7, TANK, and AMON) are located in the most prevalent downwind directions that are considered most likely to be affected by Laboratory operations.

Livermore site beryllium monitoring continued in 2000 at the six perimeter locations (see

Figure 5-1). To satisfy beryllium reporting requirements and determine the effects of the Laboratory's beryllium operations, LLNL conducted a technical assessment of the beryllium monitoring locations at Site 300 in 1997. Although there is no requirement to sample for beryllium at Site 300 , as a best management practice, LLNL has decided to continue beryllium monitoring at three locations on site $(801 \mathrm{E}$, EOBS, GOLF) and at one location in the City of Tracy (TFIR) (see Figure 5-3).

The Site 300 radiological air particulate monitoring network includes eight sampling units placed around the site boundary and near on-site firing tables and one in downtown Tracy (see

Figure 5-3). Due to the remoteness of Site 300 and the difficulties with weekly access, monitoring sites were chosen based on safety, power, and access considerations. A new location, identified as COHO, was added in April 2000 and serves as the 
Table 5-1. Sampling locations listed by monitoring network

\begin{tabular}{|c|c|c|c|}
\hline $\begin{array}{l}\text { High-volume radiological } \\
\text { (glass fiber filters) }\end{array}$ & $\begin{array}{l}\text { High-volume beryllium } \\
\text { (cellulose filters) }\end{array}$ & $\begin{array}{l}\text { Low-volume gross alpha } \\
\text { and beta (millipore filters) }\end{array}$ & $\begin{array}{c}\text { Tritium } \\
\text { (silica gel) }\end{array}$ \\
\hline \multicolumn{4}{|c|}{ Livermore site } \\
\hline CAFE & CAFE & & $B 292^{(a)}$ \\
\hline cow & cow & & B33 $1^{\text {(a) }}$ \\
\hline $\operatorname{CRED}^{(\mathrm{a})}$ & MESQ & & B514 $4^{(\mathrm{a})}$ \\
\hline MESQ & MET & & $\mathrm{B} 624^{(\mathrm{a})}$ \\
\hline MET & SALV & & CAFE \\
\hline SALV & VIS & & cow \\
\hline \multirow[t]{5}{*}{ VIS } & & & MESQ \\
\hline & & & MET \\
\hline & & & POOL \\
\hline & & & SALV \\
\hline & & & VIS \\
\hline \multicolumn{4}{|c|}{ Livermore Valley } \\
\hline AMON & & FCC & AMON \\
\hline CHUR & & HOSP & FIRE \\
\hline FCC & & & HOSP \\
\hline FIRE & & & VET \\
\hline HOSP & & & XRDS \\
\hline LWRP & & & ZON7 \\
\hline PATT & & & \\
\hline TANK & & & \\
\hline ZON7 & & & \\
\hline \multicolumn{4}{|c|}{ Site 300} \\
\hline $801 E$ & $801 \mathrm{E}$ & & $\mathrm{COHO}{ }^{(b)}$ \\
\hline $\mathrm{COHO}(\mathrm{b})$ & EOBS & & \\
\hline $\mathrm{ECP}$ & GOLF & & \\
\hline EOBS & & & \\
\hline GOLF & & & \\
\hline NPS & & & \\
\hline WCP & & & \\
\hline WOBS & & & \\
\hline \multicolumn{4}{|c|}{ Site $\mathbf{3 0 0}$ off site } \\
\hline TFIR & TFIR & & PRIM $^{(b)}$ \\
\hline
\end{tabular}

a These locations are in areas of diffuse sources and are monitored to fulfill NESHAPs requirements.

b Location PRIM was removed January 26, 2000. Replacement location COHO was added April 2000. 


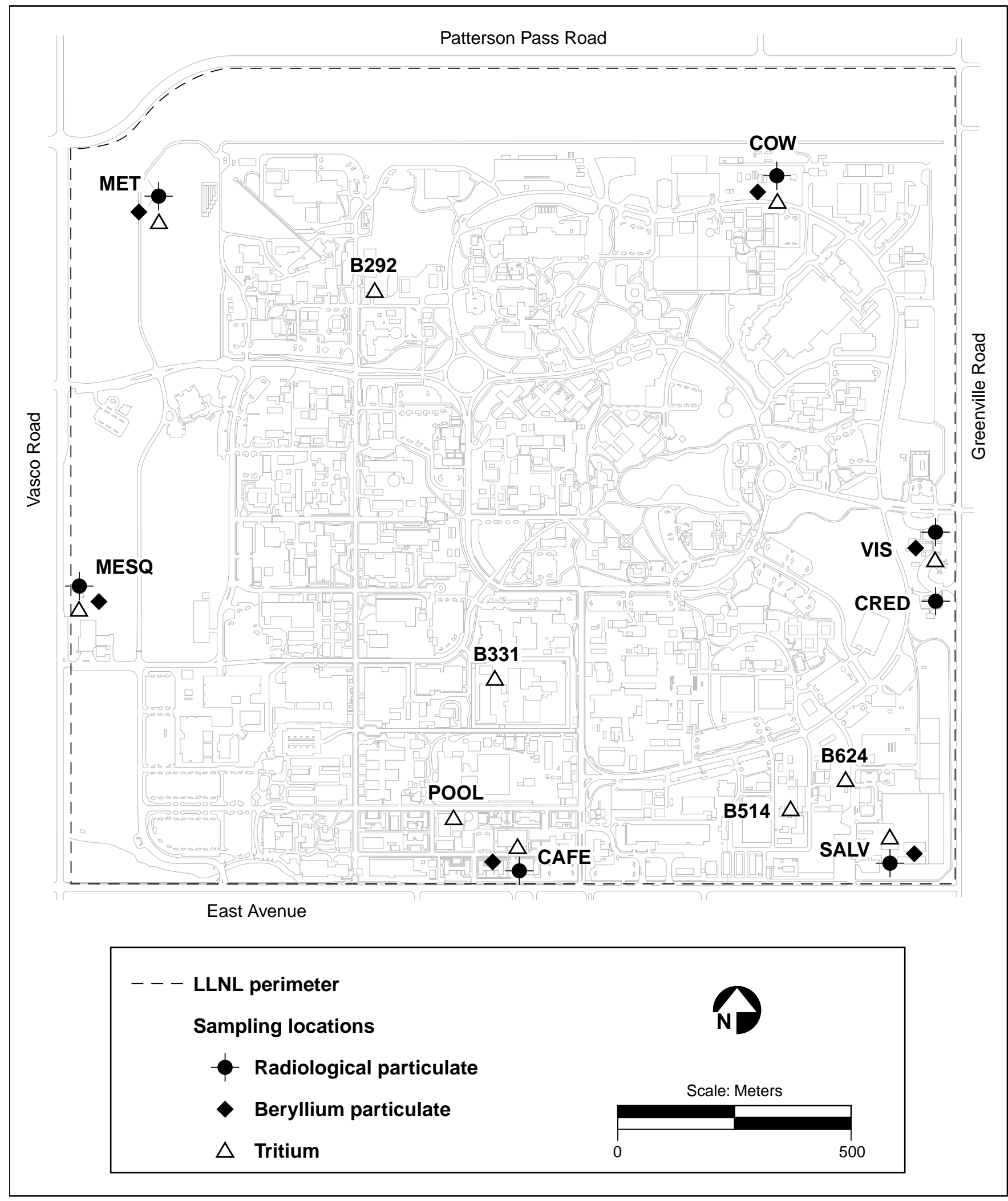

Figure 5-1. Air particulate and tritium sampling locations on the Livermore site, 2000 


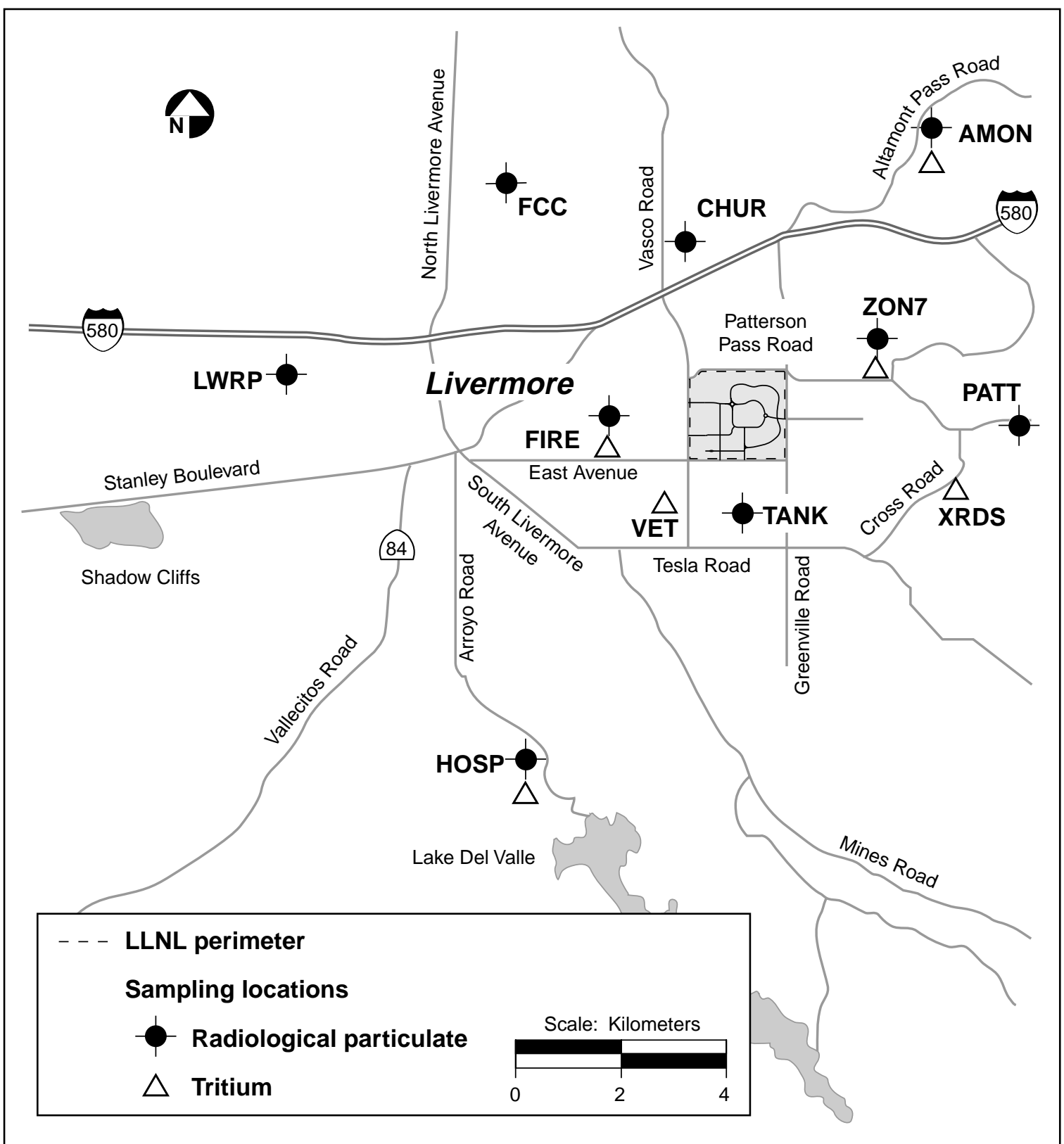

Figure 5-2. Air particulate and tritium sampling locations in the Livermore Valley, 2000

SW-M EI for NESH APs reporting purposes. In addition to air particulate, air tritium is also analyzed at $\mathrm{COHO}$.

Two sampling systems were added in July 1997 as part of the new low-volume radiological air surveillance sampling network. The samplers are situated at the FCC and H OSP locations, sites that are generally upwind of the Livermore site. The results are used to establish background levels of gross alpha and beta activity for direct comparison to results from the air effluent samplers (see Chapter 4). The sampling systems are very similar to the air-effluent samplers used in facilities, 


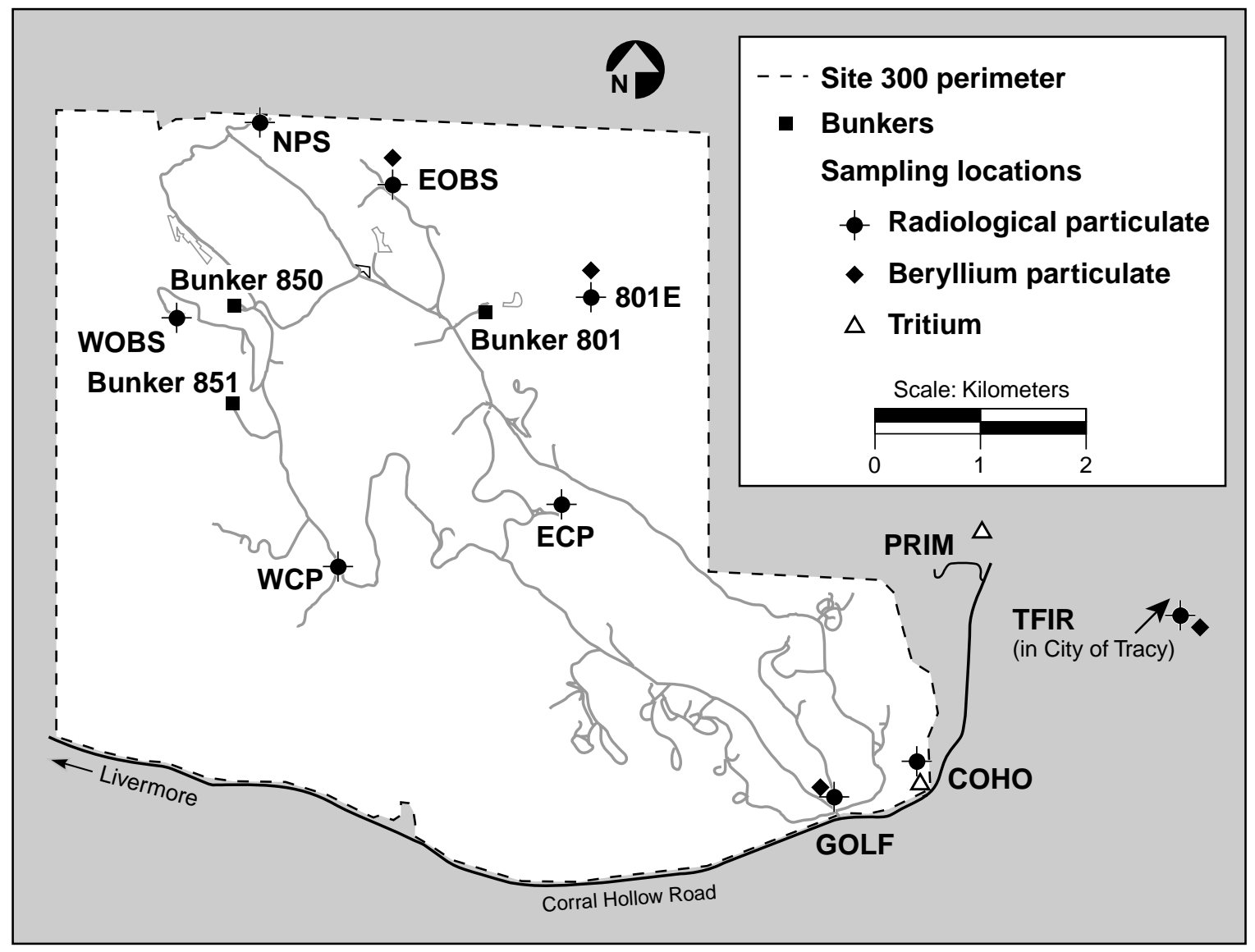

Figure 5-3. Air particulate and tritium sampling locations at Site 300 and off-site, 2000

including sampling system design, sampler operation, filter media, sample tracking, sample analysis, and processing of results.

\section{Tritium Sampling Locations}

LLNL also maintains 11 continuously operating, airborne tritium samplers on the L ivermore site (see Figure 5-1), 6 samplers in the L ivermore Valley (see Figure 5-2), and 1 sampler at Site 300 (see Figure 5-3) to assess historical and current activities that influence environmental impacts. Four of the Livermore site locations (B331, B292, B514, and B624) monitor diffuse tritium emissions.

\section{Radiological Analysis}

As outlined in Environmental R egulatory Guidefor $R$ adiological Effluent Monitoring and Environmental Surveillance(U.S. DOE 1991), gross alpha and gross beta air filter results are used as trend indicators; specific radionuclide analysis is done for plutonium, uranium, and gamma emitters. Radiological analytical results are reported as a measured concentration per volume of air. When the activity is less than the minimum detection concentration (MDC) the calculated value is reported (see Chapter 14 for further details). Particle size distributions are not determined because the estimated effective dose equivalent to the maximally exposed individual (from the total particulate) is well below 
the $0.01-\mathrm{mSv}$ (1-mrem) allowable limit as discussed in the above-mentioned environmental regulatory guide.

In January 2000, there was a change in the laboratory performing the air particulate analysis. This change resulted in an increase in the detection limit for plutonium, uranium, and gamma isotopes; however, all detection limits are adequate for determining environmental and health concerns. Gross alpha and gross beta activities are determined by gas-flow proportional counting; plutonium and uranium isotopes by alpha spectrometry; gamma emitters by gamma spectroscopy; and tritium by liquid scintillation. Further details of the surveillance monitoring methods are included in Chapter 5, Data Supplement.

\section{Results}

This section discusses the air monitoring results from all air surveillance locations at the Livermore site, Site 300 , and all off-site surveillance locations.

In April 1997, the radiological air particulate sampling filter media were changed from cellulose to glass fiber; however, blank glass-fiber filters contain nontrivial amounts of some naturally occurring radiological isotopes (Althouse 1998) including uranium-235, uranium-238, potassium40 , radium-226, radium-228, and thorium-228. In fact, the amounts of these naturally occurring isotopes contained in these filters is often greater than the amounts of the isotopes being filtered from the air. LLNL adjusts the gross measured concentrations of these isotopes according to U.S. Environmental Protection Agency (EPA) procedures (Eadie and Bernhardt 1976). LLNL staff subtracts the appropriate blank filter content from the gross analytical result to obtain a corrected net result. This subtraction of the background filter content, coupled with the higher detection limit and uncertainty, resulted in highly variable uranium-235 to uranium 238 ratios. Historically, these ratios have been used to determine the presence of naturally occurring uranium; however, this variability made the ratio results useless. Therefore, the ratios are not reported.

\section{Livermore Site}

\section{Airborne Radioactivity}

Table 5-2 summarizes the monthly gross alpha and gross beta results for the LLNL perimeter, Livermore Valley, Site 300, and Site 300 off-site sampling locations. Detection frequencies, median concentrations, interquartile ranges (IQR), and maximum concentration values for each network are included. (See Data Supplement Tables 5-1, 5-2, and 5-3 for detailed location results for all high-volume networks for gross alpha and gross beta concentrations.)

Typical gross alpha activity (median value) for the LLNL perimeter is $6.9 \times 10^{-5} \mathrm{~Bq} / \mathrm{m}^{3}$ $\left(1.9 \times 10^{-15} \mathrm{Ci} / \mathrm{m}^{3}\right)$; for both the upwind and downwind Livermore Valley stations, the value is $6.8 \times 10^{-5} \mathrm{~Bq} / \mathrm{m}^{3}\left(1.8 \times 10^{-15} \mathrm{Ci} / \mathrm{m}^{3}\right)$. Typical gross beta activity (median value) for the LLNL perimeter is $1.9 \times 10^{-4} \mathrm{~Bq} / \mathrm{m}^{3}$ $\left(5.1 \times 10^{-15} \mathrm{Ci} / \mathrm{m}^{3}\right)$; for the upwind Livermore Valley stations, the value is $4.1 \times 10^{-4} \mathrm{~Bq} / \mathrm{m}^{3}$ $\left(1.1 \times 10^{-14} \mathrm{Ci} / \mathrm{m}^{3}\right)$; and for the downwind Livermore stations, the value is $4.0 \times 10^{-4} \mathrm{~Bq} / \mathrm{m}^{3}$ $\left(1.1 \times 10^{-14} \mathrm{Ci} / \mathrm{m}^{3}\right)$. Negative values occur when the activity of the analytical background is higher than the activity on the filters being analyzed. The primary sources of the alpha and beta activities are the naturally occurring radioisotopes of uranium and thorium, and any residual fallout from atmospheric weapons testing and the 1986 Chernobyl reactor accident. The monthly median gross alpha and gross beta concentrations are plotted in Figures 5-4 and 5-5, respectively. The gradual increase in gross alpha and gross beta activity throughout the summer was most likely caused by 
Table 5-2. Gross alpha and gross beta concentration in air particulate samples summarized by month, 2000

\begin{tabular}{|c|c|c|c|c|c|c|c|c|}
\hline \multirow[b]{2}{*}{ Month } & \multicolumn{4}{|c|}{ Gross alpha $\left(10^{-6} \mathrm{~Bq} / \mathrm{m}^{3}\right)$} & \multicolumn{4}{|c|}{ Gross beta $\left(10^{-6} \mathrm{~Bq} / \mathrm{m}^{3}\right)$} \\
\hline & $\begin{array}{c}\text { Detection } \\
\text { frequency (a) }\end{array}$ & Median & IQR (b) & Maximum & $\begin{array}{l}\text { Detection } \\
\text { frequency }^{(a)}\end{array}$ & Median & $I Q R^{(b)}$ & Maximum \\
\hline \multicolumn{9}{|c|}{ LLNL perimeter locations } \\
\hline Jan & $25 / 30$ & 64.6 & 70.9 & 396 & $30 / 30$ & 483 & 227 & 1830 \\
\hline Feb & $17 / 28$ & 29.5 & 26.4 & 84.4 & $28 / 28$ & 228 & 98.0 & 463 \\
\hline Mar & $11 / 28$ & 20.9 & 25.8 & 50.5 & $28 / 28$ & 278 & 61.8 & 423 \\
\hline Apr & $32 / 35$ & 52.8 & 51.8 & 132 & $35 / 35$ & 308 & 181 & 530 \\
\hline May & $23 / 28$ & 33.0 & 27.7 & 87.6 & $28 / 28$ & 254 & 174 & 704 \\
\hline Jun & $19 / 28$ & 45.5 & 44.5 & 126 & $28 / 28$ & 371 & 138 & 528 \\
\hline Jul & $35 / 35$ & 80.2 & 33.2 & 132 & $35 / 35$ & 312 & 116 & 506 \\
\hline Aug & $28 / 28$ & 76.2 & 28.0 & 124 & $28 / 28$ & 387 & 65.3 & 491 \\
\hline Sep & $35 / 35$ & 123 & 47.3 & 181 & $35 / 35$ & 711 & 160 & 1020 \\
\hline Oct & $25 / 28$ & 76.7 & 48.9 & 163 & $28 / 28$ & 637 & 217 & 760 \\
\hline Nov & $27 / 27$ & 99.3 & 56.7 & 259 & $24 / 24$ & 780 & 862 & 1670 \\
\hline Dec & $24 / 24$ & 147 & 145 & 351 & $28 / 28$ & 937 & 548 & 2060 \\
\hline \multicolumn{9}{|c|}{ Livermore Valley upwind locations } \\
\hline Jan & $16 / 20$ & 54.4 & 84.6 & 309 & $20 / 20$ & 431 & 236 & 1460 \\
\hline Feb & $14 / 16$ & 30.2 & 10.7 & 57.0 & $16 / 16$ & 237 & 117 & 455 \\
\hline Mar & $8 / 16$ & 26.4 & 13.6 & 38.0 & $16 / 16$ & 272 & 50.8 & 414 \\
\hline Apr & $18 / 20$ & 50.0 & 36.8 & 88.8 & $20 / 20$ & 296 & 120 & 573 \\
\hline May & $8 / 16$ & 25.6 & 32.5 & 103 & $15 / 16$ & 216 & 128 & 694 \\
\hline Jun & $13 / 16$ & 49.4 & 40.4 & 107 & $16 / 16$ & 384 & 126 & 530 \\
\hline Jul & $16 / 18$ & 78.4 & 35.9 & 122 & $18 / 18$ & 314 & 138 & 460 \\
\hline Aug & $16 / 16$ & 86.1 & 11.8 & 191 & $16 / 16$ & 416 & 83.0 & 633 \\
\hline Sep & $20 / 20$ & 125 & 34 & 201 & $20 / 20$ & 711 & 163 & 971 \\
\hline Oct & $14 / 16$ & 85.2 & 36.9 & 117 & $16 / 16$ & 627 & 130 & 746 \\
\hline Nov & $16 / 16$ & 99.4 & 61.9 & 150 & $16 / 16$ & 1040 & 902 & 1820 \\
\hline Dec & $16 / 16$ & 157 & 169 & 347 & $16 / 16$ & 1110 & 695 & 1970 \\
\hline \multicolumn{9}{|c|}{ Livermore Valley downwind locations ${ }^{(c)}$} \\
\hline Jan & $23 / 25$ & 62.2 & 52.6 & 385 & $25 / 25$ & 422 & 286 & 1750 \\
\hline Feb & $14 / 20$ & 35.2 & 26.2 & 75.1 & $20 / 20$ & 268 & 142 & 429 \\
\hline Mar & $12 / 20$ & 31.3 & 9.65 & 48.1 & $20 / 20$ & 281 & 102 & 378 \\
\hline Apr & $21 / 25$ & 58.6 & 58.6 & 117 & $25 / 25$ & 341 & 158 & 542 \\
\hline May & $16 / 20$ & 35.7 & 30.5 & 98.0 & $20 / 20$ & 272 & 197 & 709 \\
\hline Jun & $15 / 20$ & 45.6 & 37.9 & 77.8 & $20 / 20$ & 383 & 101 & 591 \\
\hline Jul & $25 / 25$ & 72.0 & 26.2 & 132 & $24 / 24$ & 333 & 104 & 522 \\
\hline Aug & $18 / 18$ & 99.0 & 33.7 & 149 & $16 / 16$ & 445 & 65.5 & 544 \\
\hline Sep & $20 / 20$ & 134 & 59.3 & 205 & $20 / 20$ & 678 & 129 & 1060 \\
\hline Oct & $16 / 16$ & 78.5 & 40.6 & 148 & $16 / 16$ & 631 & 188 & 769 \\
\hline Nov & $16 / 16$ & 92.7 & 55.8 & 154 & $16 / 16$ & 1040 & 901 & 1750 \\
\hline Dec & $16 / 16$ & 125 & 149 & 380 & $16 / 16$ & 1000 & 1140 & 1960 \\
\hline
\end{tabular}


Table 5-2. Gross alpha and gross beta concentration in air particulate samples summarized by month, 2000 (continued)

\begin{tabular}{|c|c|c|c|c|c|c|c|c|}
\hline \multirow[b]{2}{*}{ Month } & \multicolumn{4}{|c|}{ Gross alpha $\left(10^{-6} \mathrm{~Bq} / \mathrm{m}^{3}\right)$} & \multicolumn{4}{|c|}{ Gross beta $\left(10^{-6} \mathrm{~Bq} / \mathrm{m}^{3}\right)$} \\
\hline & $\begin{array}{l}\text { Detection } \\
\text { frequency }(a)\end{array}$ & Median & IQR (b) & Maximum & $\begin{array}{l}\text { Detection } \\
\text { frequency } \\
(a)\end{array}$ & Median & $I Q R^{(b)}$ & Maximum \\
\hline \multicolumn{9}{|c|}{ Site 300 locations $(d)$} \\
\hline Jan & $31 / 35$ & 77.3 & 78.0 & 374 & $35 / 35$ & 507 & 269 & 1620 \\
\hline Feb & $17 / 28$ & 30.6 & 46.7 & 111 & $29 / 29$ & 226 & 198 & 566 \\
\hline Mar & $16 / 27$ & 32.3 & 20.4 & 59.5 & $27 / 27$ & 341 & 98.5 & 468 \\
\hline Apr & $32 / 41$ & 54.4 & 50.6 & 137 & $40 / 41$ & 370 & 198 & 666 \\
\hline May & $34 / 37$ & 44.8 & 29.3 & 94.8 & $36 / 36$ & 338 & 207 & 741 \\
\hline Jun & $29 / 36$ & 55.5 & 35.1 & 84.3 & $36 / 36$ & 460 & 228 & 619 \\
\hline Jul & $42 / 43$ & 92.9 & 23.9 & 159 & $42 / 44$ & 406 & 145 & 755 \\
\hline Aug & $37 / 37$ & 103 & 34.7 & 163 & $37 / 37$ & 489 & 85.0 & 681 \\
\hline Sep & $44 / 44$ & 123 & 47.0 & 248 & $43 / 43$ & 818 & 353 & 1110 \\
\hline Oct & $30 / 37$ & 91.9 & 65.2 & 181 & $37 / 37$ & 678 & 325 & 1070 \\
\hline Nov & $35 / 36$ & 90.6 & 55.3 & 210 & $36 / 36$ & 931 & 763 & 2080 \\
\hline Dec & $36 / 36$ & 152 & 134 & 331 & $36 / 36$ & 1160 & 540 & 1940 \\
\hline \multicolumn{9}{|c|}{$\begin{array}{l}\text { Detection frequency is the number of samples with calculated results greater than the uncertainty divided by the number of } \\
\text { samples. }\end{array}$} \\
\hline \multicolumn{9}{|c|}{$I Q R=$ Interquartile range } \\
\hline \multicolumn{9}{|c|}{ Livermore Valley downwind locations include data from the special interest location LWRP, see Figure $\mathbf{5 - 2 .}$} \\
\hline \multicolumn{9}{|c|}{ Site 300 locations includes data from one off-site location (TFIR), see Figure 5-3. } \\
\hline
\end{tabular}

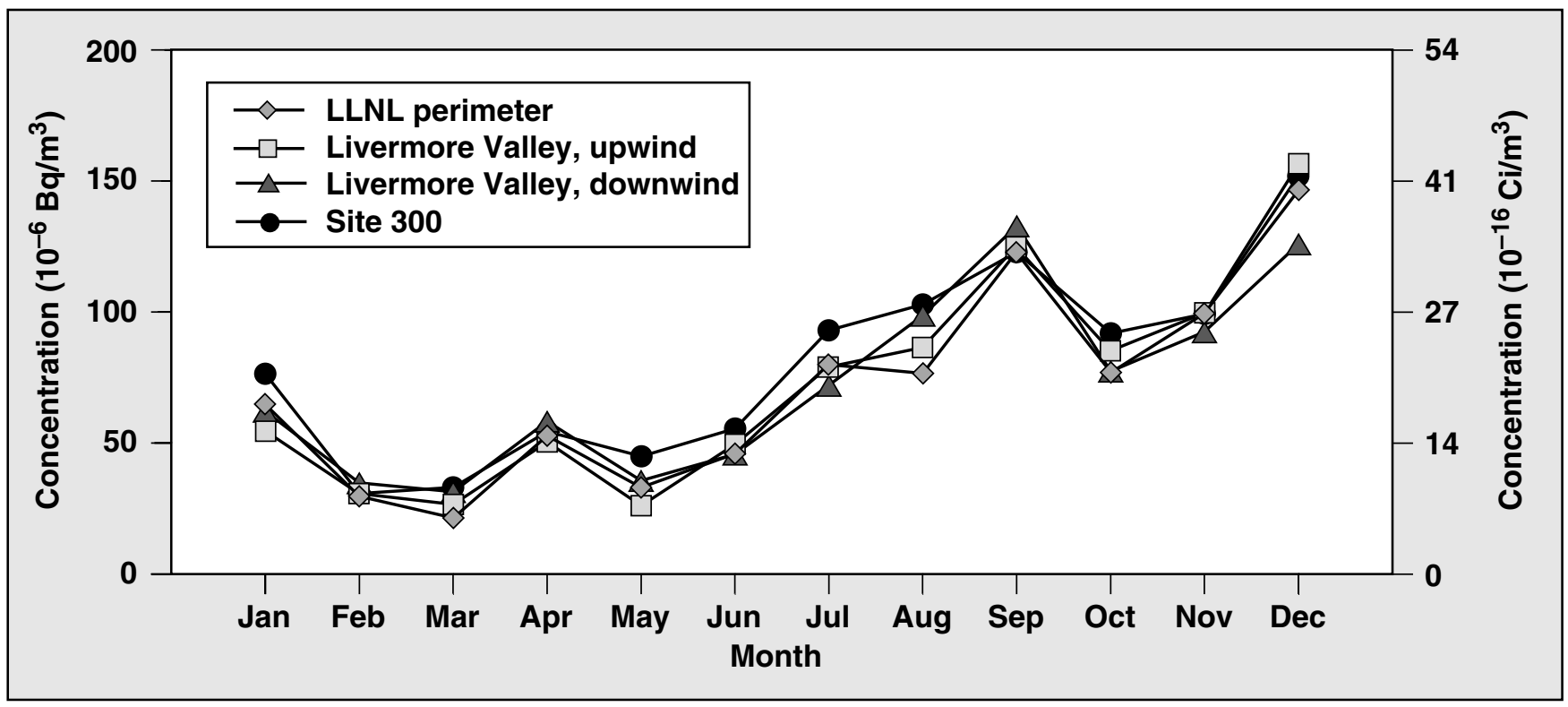

Figure 5-4. Monthly median gross alpha concentrations in particulate air samples from the LLNL perimeter, Livermore Valley, and Site 300 sampling locations, 2000 
an increase in resuspension of soils that occurs during the dry season. December values are also elevated because of low rainfall during that month. These data follow a similar pattern to the lowvolume gross alpha and gross beta data.

Gamma-emitting radionuclide concentrations in air that contribute to the activity in the Livermore site perimeter samples are summarized in Table 5-3. (See Data Supplement Table 5-4 for monthly gamma activity data.) Of the nuclides identified, all were naturally occurring, with the exception of cesium-137. The primary source of cesium-137 is long-term global fallout and fallout resuspension.

By analyzing air samples for gamma-emitting radionuclides, LLNL verifies that there is no evidence of a release of the small inventories of mixed fission products and radiochemical tracers used at LLNL and also obtains baseline data on global fallout. The Derived Concentration Guides (DCGs) for these radionuclides are shown in Table 5-3. For air, DCGs specify the concentrations of radionuclides that could be inhaled continuously 365 days a year without exceeding the DOE primary radiation protection standard for the public, which is $1 \mathrm{mSv} / \mathrm{y}(100 \mathrm{mrem} / \mathrm{y})$ effective dose equivalent (DOE Order 5400.5). (Chapter 13 provides an explanation of this and other units of dose.) Table 5-3 also presents the percent of the DCGs, which demonstrates that the level of gamma activity present in air at the Livermore site perimeter was far below the DCGs.

Table 5-4 shows the concentrations of airborne plutonium-239+240 on air filters from the LLNL perimeter locations. In September, the plutonium concentrations reported were above the minimum detectable limit for nearly all locations (including a trip blank sample). While many of these values exceeded the action level established by the

Environmental Monitoring Plan (Tate et al. 1999), none of them exceeded the DCG. However, because the concentrations were unusually high, the analytical laboratory was asked to investigate the possibility of laboratory contamination. The analytical laboratory confirmed that the high values were likely the result of internal laboratory contamination and has since implemented protocol to reduce the chance of reoccurrance. Six similar samples, colocated at the onsite LLNL locations, were subsequently analyzed by another laboratory using the same methodology. Of these six samples, only one sample (SALV) result was above the detection limit and its value was six times less than the original value. Both data sets are shown in Table 5-5, Data Supplement. For conservative measures, and because only onsite colocated samples were available for reanalysis, all summary statistics were performed using the higher of the two values.

Data Supplement Table 5-5 shows the monthly data by location. The highest concentration was registered at location CRED in September 2000; the concentration value is reported as $5.8 \times 10^{-7} \mathrm{~Bq} / \mathrm{m}^{3}\left(1.6 \times 10^{-17} \mathrm{Ci} / \mathrm{m}^{3}\right)$, which represents $0.025 \%$ of the DCG. The highest median concentration onsite, at location SALV, was $1.5 \times 10^{-8} \mathrm{~Bq} / \mathrm{m}^{3}\left(4.1 \times 10^{-19} \mathrm{Ci} / \mathrm{m}^{3}\right)$, which is similar to that for the previous year.

Table 5-4 also shows the detection frequency, median concentration, IQR, maximum concentration, and percent of DCG for the concentration of plutonium on air filter samples collected in the Livermore Valley. The highest concentration was registered at location FCC in October; the value of $3.7 \times 10^{-6} \mathrm{~Bq} / \mathrm{m}^{3}\left(1.0 \times 10^{-16} \mathrm{Ci} / \mathrm{m}^{3}\right)$, which exceeded the action level established by the Environmental Monitoring Plan, represents 0.50\% of the DCG. Because this sampling location is upwind of LLNL and plutonium activity is unlikely, this data was investigated. Plutonium analysis using the new laboratory is performed by digesting a filter, removing an aliquot from the digestate, 


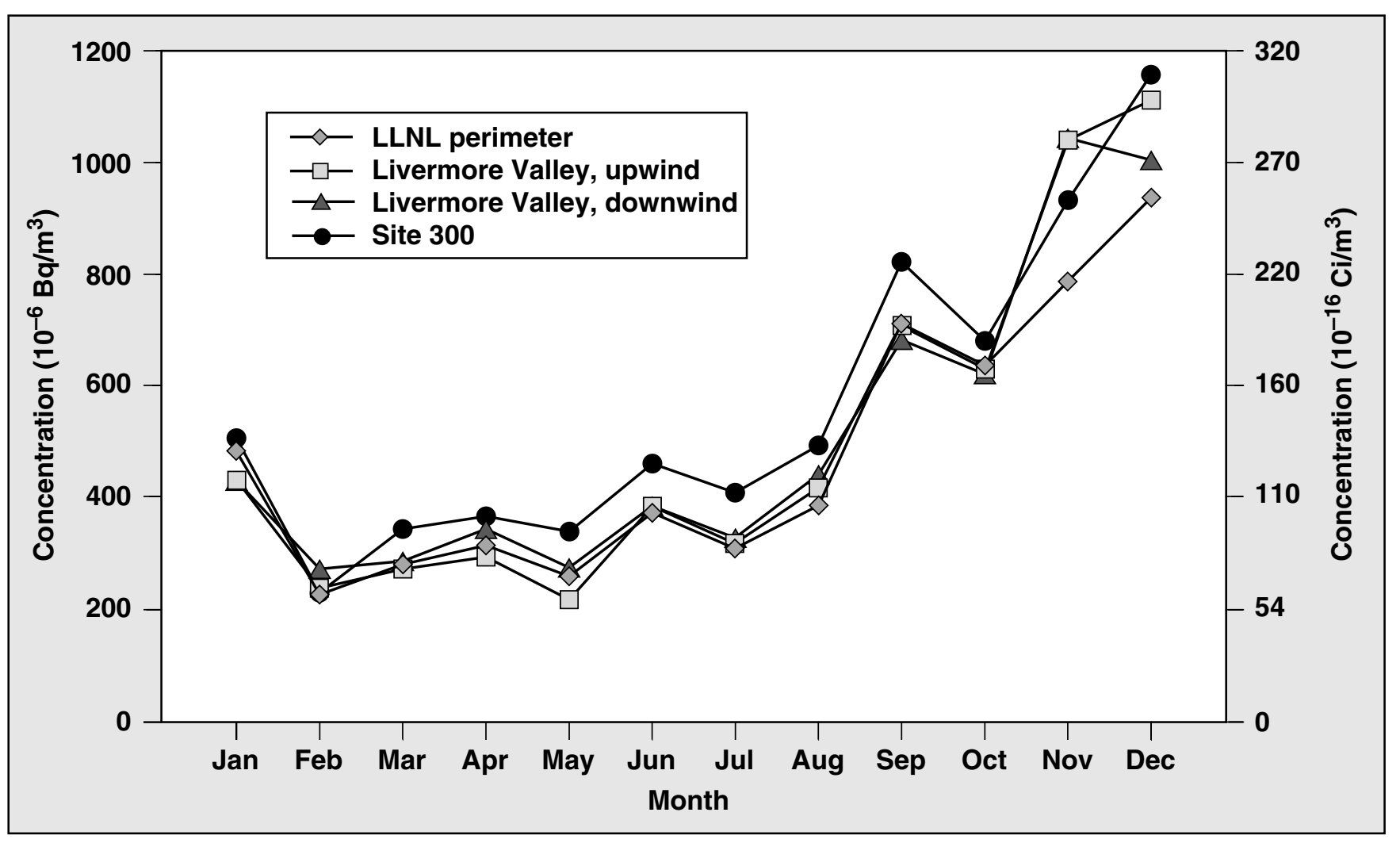

Figure 5-5. Monthly median gross beta concentrations in particulate air samples from the LLNL perimeter, Livermore Valley, and Site 300 sampling locations, 2000

Table 5-3. Gamma activity in air particulate samples, Livermore site perimeter and Site 300, 2000

\begin{tabular}{|c|c|c|c|c|c|c|c|}
\hline & ${ }^{7} \mathrm{Be}$ & ${ }^{137} \mathrm{Cs}$ & ${ }^{40} K$ & ${ }^{22} \mathrm{Na}$ & ${ }^{226} \mathrm{Ra}$ & ${ }^{228} \mathrm{Ra}$ & ${ }^{228} \mathrm{Th}$ \\
\hline & $\left(10^{-3} \mathrm{~Bq} / \mathrm{m}^{3}\right)$ & \multicolumn{6}{|c|}{$\left(10^{-6} \mathrm{~Bq} / \mathrm{m}^{3}\right)$} \\
\hline \multicolumn{8}{|c|}{ Livermore perimeter } \\
\hline Median & 0.87 & -0.051 & -1.1 & 0.46 & -0.89 & -0.68 & -0.12 \\
\hline Interquartile range & 0.48 & 0.43 & 18 & 0.35 & 2.0 & 1.9 & 3.6 \\
\hline Maximum & 1.7 & 1.3 & 32 & 1.4 & 3.0 & 2.3 & 4.7 \\
\hline Percent of DCG(a) & $5.8 \times 10^{-5}$ & $8.7 \times 10^{-6}$ & $3.2 \times 10^{-6}$ & $1.2 \times 10^{-6}$ & $2.7 \times 10^{-3}$ & $6.2 \times 10^{-3}$ & 0.31 \\
\hline \multicolumn{8}{|c|}{ Site 300} \\
\hline Median & 0.91 & 0.018 & -0.85 & 0.26 & -1.3 & -1.01 & -0.22 \\
\hline Interquartile range & 0.98 & 0.60 & 14 & 0.40 & 1.7 & 3.6 & 2.1 \\
\hline Maximum & 2.1 & 1.1 & 23 & 0.78 & 1.4 & 1.5 & 1.1 \\
\hline Percent of DCG(a) & $6.0 \times 10^{-5}$ & $1.2 \times 10^{-7}$ & $7.0 \times 10^{-5}$ & $7.0 \times 10^{-7}$ & $1.3 \times 10^{-3}$ & $4.1 \times 10^{-3}$ & 0.073 \\
\hline $\operatorname{DCG}\left(\mathrm{Bq} / \mathrm{m}^{3}\right)$ & $1.5 \times 10^{3}$ & 15 & 33 & 37 & 0.11 & 0.037 & $1.5 \times 10^{-3}$ \\
\hline
\end{tabular}

a Percent of Derived Concentration Guide (DCG) is calculated from the median value unless median value is negative. When median value is negative, the maximum value is used. 
Table 5-4. Plutonium-239+240 activity in air particulate samples $\left(10^{-9} \mathrm{~Bq} / \mathrm{m}^{3}\right), 2000$

\begin{tabular}{|c|c|c|c|c|c|}
\hline $\begin{array}{l}\text { Sampling } \\
\text { locations (a) }\end{array}$ & $\begin{array}{c}\text { Detection } \\
\text { frequency }(b)\end{array}$ & Median & $\begin{array}{c}\text { Interquartile } \\
\text { range }\end{array}$ & Maximum & $\begin{array}{l}\text { Percent } \\
\text { of DCG (c) }\end{array}$ \\
\hline \multicolumn{6}{|c|}{ LLNL perimeter locations } \\
\hline CAFE & $3 / 13$ & 9.07 & 9.30 & 108 & $1.23 \times 10^{-3}$ \\
\hline cow & $7 / 13$ & 8.25 & 7.82 & 120 & $1.11 \times 10^{-3}$ \\
\hline CRED & $5 / 12$ & 6.92 & 18.3 & 582 & $9.34 \times 10^{-4}$ \\
\hline MESQ & $5 / 13$ & 8.56 & 17.2 & 145 & $1.16 \times 10^{-3}$ \\
\hline MET & $2 / 13$ & 3.93 & 7.58 & 57.7 & $5.31 \times 10^{-4}$ \\
\hline SALV & $7 / 13$ & 15.2 & 25.5 & 183 & $2.05 \times 10^{-3}$ \\
\hline VIS & $4 / 13$ & 8.36 & 19.0 & 78.5 & $1.13 \times 10^{-3}$ \\
\hline \multicolumn{6}{|c|}{ Livermore Valley upwind locations } \\
\hline CHUR & $7 / 12$ & 8.98 & 15.7 & 206 & $1.21 \times 10^{-3}$ \\
\hline FCC & $5 / 12$ & 3.92 & 15.9 & 3720 & $5.30 \times 10^{-4}$ \\
\hline FIRE & $5 / 12$ & 0.00 & 15.6 & 572 & $7.73 \times 10^{-2}$ \\
\hline HOSP & $2 / 12$ & 2.88 & 15.1 & 409 & $3.89 \times 10^{-4}$ \\
\hline LWRP & $7 / 12$ & 9.03 & 15.6 & 88.9 & $1.22 \times 10^{-3}$ \\
\hline \multicolumn{6}{|c|}{ Livermore Valley downwind locations } \\
\hline AMON & $5 / 5$ & 11.1 & 23.8 & 34.8 & $1.50 \times 10^{-3}$ \\
\hline PATT & $6 / 12$ & 9.25 & 22.1 & 159 & $1.25 \times 10^{-3}$ \\
\hline TANK & $3 / 12$ & 6.81 & 18.2 & 215 & $9.20 \times 10^{-4}$ \\
\hline ZON7 & $5 / 12$ & 5.79 & 15.8 & 87.7 & $7.82 \times 10^{-4}$ \\
\hline \multicolumn{6}{|c|}{ Site $\mathbf{3 0 0}$ on-site location composite } \\
\hline S300 composite & $2 / 12$ & 1.34 & 4.34 & 18.6 & $1.80 \times 10^{-4}$ \\
\hline
\end{tabular}

a See Figures 5-1, 5-2, and 5-3 for sampling locations.

b Detection frequency is the number of samples with the calculated results greater than the uncertainty divided by the number of samples.

c $\quad$ DCG $=$ Derived Concentration Guide of $7.4 \times 10^{-4} \mathrm{~Bq} / \mathrm{m}^{3}$ for plutonium-239+240 activity in air. Percent DCG is calculated on the median concentrations unless median value negative. When median value is negative or zero, the maximum value is used.

then plating the plutonium on a planchet for counting. This sample was recounted using another aliquot from the same digestate and the value was confirmed. It is believed that there was laboratory contamination during the digesting processing of the filter and therefore, the recount also detected plutonium. An undigested portion of this sample was also sent to another laboratory where plutonium was not detected. The remainder of
2000 data from FCC was less than the detection limit. See Data Supplement Table 5-6 for monthly data.

Figure 5-6 shows the annual median concentrations of plutonium-239+240 for locations SALV (on-site) and FCC (off-site) from 1982 to 2000. Location FCC represents a typical upwind background location, and SALV represents a typical 


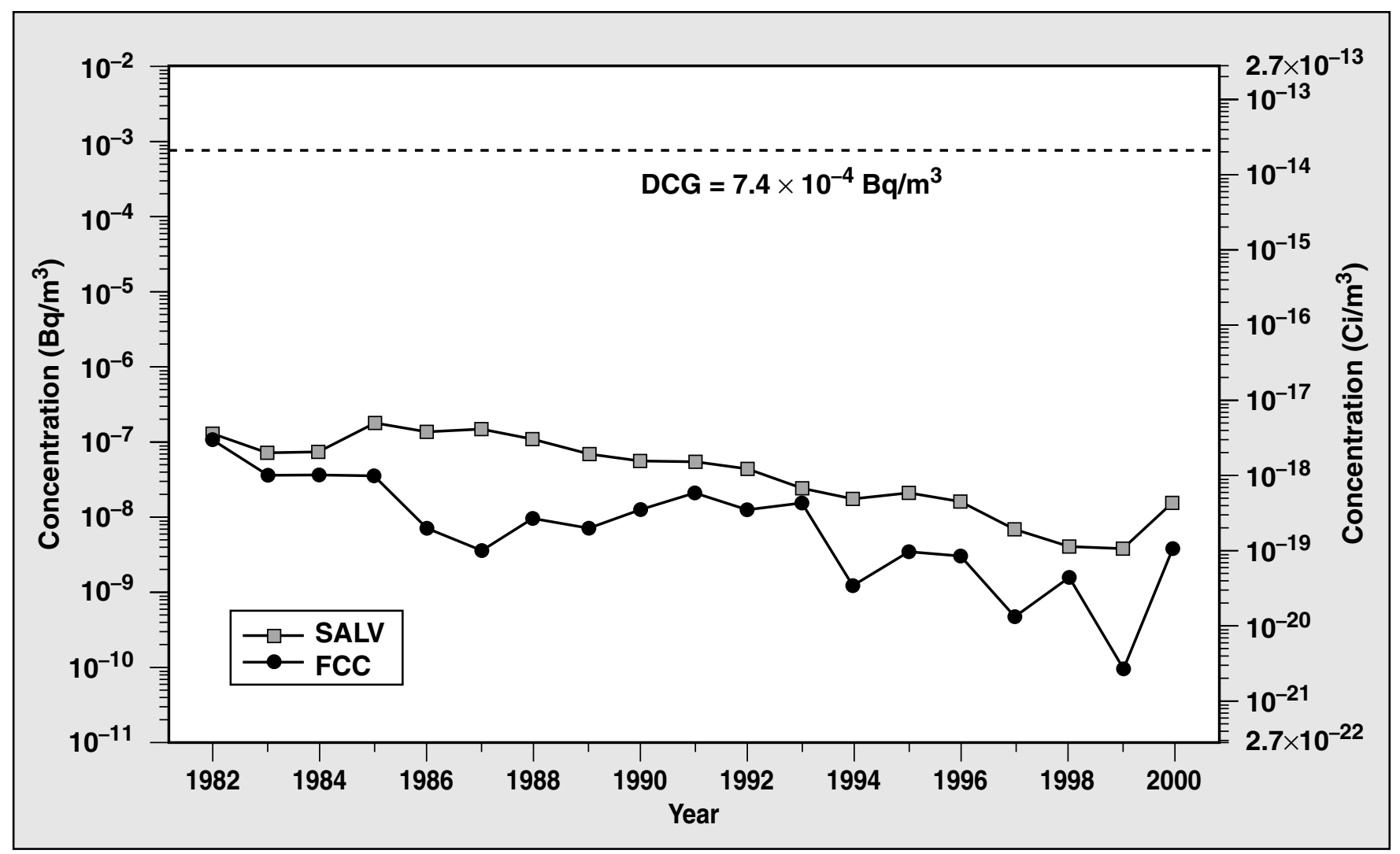

Figure 5-6. Annual median plutonium-239+240 concentrations in air particulate samples at two locations, SALV (on-site) and FCC (upwind, off-site), 1982-2000

perimeter location. The annual median concentration for FCC was $3.9 \times 10^{-9} \mathrm{~Bq} / \mathrm{m}^{3}$ $\left(1.1 \times 10^{-19} \mathrm{Ci} / \mathrm{m}^{3}\right)$; this value includes the high value for October discussed previously.

Figure 5-6 uses a log scale and, for the years in which a negative median concentration was calculated, the positive value closest to the median was plotted. The higher values in the past at SALV may be attributed to historical activities at LLNL. The general downward trend at both locations is likely the result of decreasing residual global fallout. The increase at both locations this year is most likely the result of the change in the analytical laboratory.
As the result of a network assessment, starting January 2000, Livermore perimeter site-specific uranium analysis was eliminated because there are no significant sources of uranium on-site. Instead a composite from six perimeter locations (CAFE, COW, MESQ, MET, SALV, and VIS) is created to determine uranium activities at LLNL. These data are shown in Table 5-5. The maximum uranium-235 and uranium-238 concentration was less than $0.01 \%$ of the DCG for each isotope.

The low-volume radiological air sampling locations FCC and HOSP have an annual median for gross alpha and gross beta activity of $4.1 \times 10^{-5} \mathrm{~Bq} / \mathrm{m}^{3}$ $\left(1.1 \times 10^{-15} \mathrm{Ci} / \mathrm{m}^{3}\right)$ and $4.4 \times 10^{-4} \mathrm{~Bq} / \mathrm{m}^{3}$ $\left(1.2 \times 10^{-14} \mathrm{Ci} / \mathrm{m}^{3}\right)$, respectively. (See Data 
Table 5-5. Uranium mass concentration in air particulate samples, 2000

\begin{tabular}{|c|c|c|}
\hline $\begin{array}{l}\text { Sampling } \\
\text { location (a) }^{(2)}\end{array}$ & $\begin{array}{c}{ }^{235} \mathrm{U}^{(\mathrm{b})} \\
\left(10^{-7} \mu \mathrm{g} / \mathrm{m}^{3}\right)\end{array}$ & $\begin{array}{c}{ }^{238} \mathrm{U}^{(\mathrm{c})} \\
\left(10^{-5} \mu \mathrm{g} / \mathrm{m}^{3}\right)\end{array}$ \\
\hline \multicolumn{3}{|l|}{$801 E$} \\
\hline Median & 1.32 & 3.79 \\
\hline Interquartile range & 8.47 & 4.05 \\
\hline Maximum & 16.1 & 17.7 \\
\hline Percent of DCG (d) & $2.81 \times 10^{-4}$ & $1.26 \times 10^{-2}$ \\
\hline \multicolumn{3}{|l|}{ COHO } \\
\hline Median & 0.773 & 0.952 \\
\hline Interquartile range & 7.53 & 7.92 \\
\hline Maximum & 8.30 & 5.79 \\
\hline Percent of DCG (d) & $1.64 \times 10^{-4}$ & $3.17 \times 10^{-3}$ \\
\hline \multicolumn{3}{|l|}{ ECP } \\
\hline Median & 2.70 & 3.06 \\
\hline Interquartile range & 6.24 & 3.55 \\
\hline Maximum & 13.6 & 13.5 \\
\hline Percent of DCG ${ }^{(d)}$ & $5.73 \times 10^{-4}$ & $1.02 \times 10^{-2}$ \\
\hline \multicolumn{3}{|l|}{ EOBS } \\
\hline Median & 1.42 & 3.71 \\
\hline Interquartile range & 2.88 & 3.51 \\
\hline Maximum & 33.0 & 44.6 \\
\hline Percent of DCG (d) & $3.01 \times 10^{-4}$ & $1.24 \times 10^{-2}$ \\
\hline \multicolumn{3}{|l|}{ GOLF } \\
\hline Median & 1.67 & 3.98 \\
\hline Interquartile range & 10.9 & 3.90 \\
\hline Maximum & 25.0 & 35.0 \\
\hline Percent of DCG ${ }^{(d)}$ & $3.54 \times 10^{-4}$ & $1.33 \times 10^{-2}$ \\
\hline \multicolumn{3}{|l|}{ NPS } \\
\hline Median & 0.486 & 2.18 \\
\hline Interquartile range & 5.64 & 2.06 \\
\hline Maximum & 21.8 & 5.64 \\
\hline Percent of DCG (d) & $1.03 \times 10^{-4}$ & $7.25 \times 10^{-3}$ \\
\hline \multicolumn{3}{|l|}{ TFIR } \\
\hline Median & 4.82 & 7.48 \\
\hline Interquartile range & 4.60 & 4.15 \\
\hline Maximum & 8.75 & 15.3 \\
\hline Percent of DCG ${ }^{(d)}$ & $1.03 \times 10^{-3}$ & $2.49 \times 10^{-2}$ \\
\hline \multicolumn{3}{|l|}{ WCP } \\
\hline Median & -0.782 & 2.96 \\
\hline Interquartile range & 3.88 & 4.94 \\
\hline Maximum & 5.42 & 5.73 \\
\hline Percent of DCG $(\mathrm{d})$ & $1.15 \times 10^{-3}$ & $9.87 \times 10^{-3}$ \\
\hline
\end{tabular}

Table 5-5. Uranium mass concentration in air particulate samples, 2000 (continued)

\begin{tabular}{|c|c|c|c|}
\hline & $\begin{array}{l}\text { Sampling } \\
\text { location(a) }\end{array}$ & $\begin{array}{c}{ }^{235} \mathrm{U}^{(\mathrm{b})} \\
\left(10^{-7} \mu \mathrm{g} / \mathrm{m}^{3}\right)\end{array}$ & $\begin{array}{c}{ }^{238} \mathrm{U}^{(\mathrm{c})} \\
\left(10^{-5} \mu \mathrm{g} / \mathrm{m}^{3}\right)\end{array}$ \\
\hline \multicolumn{4}{|c|}{ WOBS } \\
\hline & Median & 1.59 & 1.79 \\
\hline & Interquartile range & 7.40 & 3.60 \\
\hline & Maximum & 11.7 & 32.4 \\
\hline & Percent of DCG ${ }^{(d)}$ & $3.38 \times 10^{-4}$ & $5.97 \times 10^{-3}$ \\
\hline \multicolumn{4}{|c|}{ Livermore Composite } \\
\hline & Median & -4.24 & -4.85 \\
\hline & Interquartile range & 7.23 & 8.98 \\
\hline & Maximum & 9.68 & 14.3 \\
\hline & Percent of DCG (d) & $2.06 \times 10^{-3}$ & $4.77 \times 10^{-2}$ \\
\hline \multicolumn{4}{|c|}{ a See Figures 5-1 and 5-3 for sampling locations. } \\
\hline \multicolumn{4}{|c|}{$\begin{array}{l}\text { b Derived Concentration Guide }=0.047 \mu \mathrm{g} / \mathrm{m}^{3} \text { for uranium- } \\
235 \text { activity in air. Uranium- } 235 \text { activities in } \mathrm{Bq} / \mathrm{m}^{3} \text { can be } \\
\text { determined by dividing the weight in } \mu \mathrm{g} / \mathrm{m}^{3} \text { by } 12.5 \text {. }\end{array}$} \\
\hline \multicolumn{4}{|c|}{$\begin{array}{l}\text { Derived Concentration Guide }=0.3 \mu \mathrm{g} / \mathrm{m}^{3} \text { for uranium-238 } \\
\text { activity in air. Uranium- } 238 \text { activities in } \mathrm{Bq} / \mathrm{m}^{3} \text { can be deter- } \\
\text { mined by dividing the weight in } \mu \mathrm{g} / \mathrm{m}^{3} \text { by } 80.3 \text {. }\end{array}$} \\
\hline \multicolumn{4}{|c|}{$\begin{array}{l}\text { dercent of Derived Concentration Guide (DCG) is calculated } \\
\text { from the median value. When median value is negative, the } \\
\text { percent DCG is calculated from the maximum value. }\end{array}$} \\
\hline
\end{tabular}

Supplement Tables 5-8 and 5-9 for monthly median data.) These gross alpha values are similar to those reported from the high-volume sampling systems at the same locations.

Table 5-6 shows the median concentrations of tritiated water vapor for the Livermore Valley sampling locations. (See Data Supplement Table 5-10 for biweekly data for each location.) The highest annual median concentration was observed at location ZON7. At approximately $1.4 \times 10^{-2} \mathrm{~Bq} / \mathrm{m}^{3}\left(3.8 \times 10^{-13} \mathrm{Ci} / \mathrm{m}^{3}\right)$, this concentration represents $0.0004 \%$ of the DCG. The highest biweekly concentration was observed in July at ZON7. If it were a yearly average, this concentration of $8.9 \times 10^{-2} \mathrm{~Bq} / \mathrm{m}^{3}\left(2.4 \times 10^{-12}\right.$ $\mathrm{Ci} / \mathrm{m}^{3}$ ) would be $0.002 \%$ of the DCG. The 2000 tritium values were lower than those reported last year because of lower emissions from the Tritium Facility (Building 331). 
Table 5-6. Tritium in air samples, 2000

\begin{tabular}{|c|c|c|c|c|c|c|}
\hline $\begin{array}{l}\text { Sampling } \\
\text { location (a) }\end{array}$ & $\begin{array}{l}\text { Detection } \\
\text { frequency }\end{array}$ & $\begin{array}{c}\text { Median } \\
\left(10^{-3}\right. \\
\left.\mathrm{Bq} / \mathrm{m}^{3}\right)\end{array}$ & $\begin{array}{c}I Q R^{(c)} \\
\left(10^{-3}\right. \\
\left.B q / m^{3}\right)\end{array}$ & $\begin{array}{c}\text { Maximum } \\
\left(10^{-3}\right. \\
\left.\mathrm{Bq} / \mathrm{m}^{3}\right)\end{array}$ & $\begin{array}{l}\text { Percent of } \\
\text { DCG }^{(d)}\end{array}$ & $\begin{array}{c}\text { Median } \\
\text { dose }(m S v))^{(e)}\end{array}$ \\
\hline \multicolumn{7}{|c|}{ Livermore Valley locations } \\
\hline AMON & $3 / 17$ & 7.99 & 6.88 & 16.8 & $2.2 \times 10^{-4}$ & $1.7 \times 10^{-6}$ \\
\hline FIRE & $3 / 26$ & 5.70 & 7.86 & 27.1 & $1.5 \times 10^{-4}$ & $1.2 \times 10^{-6}$ \\
\hline HOSP & $0 / 24$ & 0.762 & 8.41 & 27.6 & $2.1 \times 10^{-5}$ & $1.6 \times 10^{-7}$ \\
\hline VET & $5 / 23$ & 7.84 & 13.5 & 29.5 & $2.1 \times 10^{-4}$ & $1.6 \times 10^{-6}$ \\
\hline XRDS & $0 / 7$ & 0.755 & 7.35 & 10.5 & $2.0 \times 10^{-5}$ & $1.6 \times 10^{-7}$ \\
\hline ZON7 & $9 / 24$ & 14.1 & 10.6 & 89.2 & $3.8 \times 10^{-4}$ & $2.9 \times 10^{-6}$ \\
\hline \multicolumn{7}{|c|}{ Livermore perimeter locations } \\
\hline CAFE & $21 / 26$ & 40.5 & 42.2 & 129 & $1.1 \times 10^{-3}$ & $8.4 \times 10^{-6}$ \\
\hline cow & $22 / 23$ & 33.6 & 22.7 & 1370 & $9.1 \times 10^{-4}$ & $7.0 \times 10^{-6}$ \\
\hline MESQ & $15 / 26$ & 20.9 & 17.0 & 66.2 & $5.6 \times 10^{-4}$ & $4.3 \times 10^{-6}$ \\
\hline MET & $11 / 23$ & 17.9 & 22.3 & 186 & $4.8 \times 10^{-4}$ & $3.7 \times 10^{-6}$ \\
\hline POOL & $26 / 26$ & 76.6 & 74.7 & 343 & $2.1 \times 10^{-3}$ & $1.6 \times 10^{-5}$ \\
\hline SALV & $18 / 23$ & 27.3 & 21.6 & 55.1 & $7.4 \times 10^{-4}$ & $5.7 \times 10^{-6}$ \\
\hline VIS & $24 / 24$ & 47.4 & 31.3 & 248 & $1.3 \times 10^{-3}$ & $9.8 \times 10^{-6}$ \\
\hline \multicolumn{7}{|c|}{ Diffuse on-site sources locations } \\
\hline B292 & $19 / 23$ & 55.1 & 38.1 & 137 & $1.5 \times 10^{-3}$ & $1.1 \times 10^{-5}$ \\
\hline B331 & $26 / 26$ & 446 & 697 & 2100 & $1.2 \times 10^{-2}$ & $9.3 \times 10^{-5}$ \\
\hline B514 & $25 / 25$ & 1850 & 1830 & 8470 & $5.0 \times 10^{-2}$ & $3.8 \times 10^{-4}$ \\
\hline B624 & $26 / 26$ & 3280 & 2040 & 5920 & $8.9 \times 10^{-2}$ & $6.8 \times 10^{-4}$ \\
\hline \multicolumn{7}{|c|}{ Site 300 location } \\
\hline $\mathrm{COHO}$ & $0 / 25$ & -2.27 & 10.3 & 7.62 & $2.1 \times 10^{-4(f)}$ & $1.6 \times 10^{-6(\mathrm{~g})}$ \\
\hline
\end{tabular}

a See Figures 5-1, 5-2, and 5-3 for sample locations.

b Detection frequency is the number of samples with results above the detection limit divided by the number of samples.

c $I Q R=$ Interquartile range

d $\quad D C G=$ Derived Concentration Guide of $3.7 \times 10^{3} \mathrm{~Bq} / \mathrm{m}^{3}$. Percent calculated from the median concentration.

e $1 \mathrm{mSv}=100 \mathrm{mrem}$

$f$ The percent of DCG was determined by using the maximum value because the median value was negative.

g The dose was determined by using the maximum value because the median value was negative. 
Table 5-6 also shows the median concentrations of tritiated water vapor that were observed at the Livermore site perimeter sampling locations. (See Data Supplement Table 5-11 for biweekly data.) The highest annual median concentration was observed at location POOL, which was $7.7 \times 10^{-2} \mathrm{~Bq} / \mathrm{m}^{3}\left(2.1 \times 10^{-12} \mathrm{Ci} / \mathrm{m}^{3}\right)$, or $0.002 \%$ of the DCG. The highest biweekly concentration, $1.4 \mathrm{~Bq} / \mathrm{m}^{3}\left(3.8 \times 10^{-11} \mathrm{Ci} / \mathrm{m}^{3}\right)$, was observed in August at location COW. A transportainer containing tritium-contaminated waste was stored near the COW location for several days before being shipped offsite for disposal.

Diffuse sources of tritium on the Livermore site are monitored at air tritium sampling locations B292, B331, B514, and B624. Table 5-6 shows the median concentrations of tritiated water vapor for these sampling locations. (See Data Supplement Table 5-12 for biweekly data.) The highest median concentration was observed at location B624. This concentration was $3.3 \mathrm{~Bq} / \mathrm{m}^{3}$ $\left(8.9 \times 10^{-11} \mathrm{Ci} / \mathrm{m}^{3}\right)$ and represents $0.09 \%$ of the DCG. The highest biweekly tritium concentration, $8.5 \mathrm{~Bq} / \mathrm{m}^{3}\left(2.3 \times 10^{-10} \mathrm{Ci} / \mathrm{m}^{3}\right)$, was observed in April at location B514. If it were a yearly average, this concentration would represent $0.2 \%$ of the DCG.

The B514 sampling location is in a hazardous waste management area where tritium-contaminated waste is treated, and the B292 location is near an underground retention tank that had previously leaked. The concentrations in air at the B514 sampling location are variable because of the changing concentrations of tritium in the waste stream. The 2000 median concentrations at B292 and B514 are similar to the median concentrations in 1999.

The B331 location is near the Tritium Facility (Building 331), where LLNL personnel have reduced operations in recent years and performed significant inventory reduction and cleanup activities. During this process, tritium-contaminated equipment slated for disposal was stored in an area outside Building 331 before being sent to Hazardous Waste Management facilities. Although this area is no longer used for storage of tritium-contaminated equipment, Building 331 is still considered a diffuse source and monitoring will continue. During 2000, an estimated $1.9 \times 10^{11} \mathrm{~Bq}(5.2 \mathrm{Ci})$ of tritium was released to the atmosphere outside Building 331.

\section{Beryllium in Air}

The median concentrations of airborne beryllium for the Livermore site perimeter sampling locations are shown in Table 5-7. (See Data Supplement Table 5-13 for monthly data.) The highest value of $38.2 \mathrm{pg} / \mathrm{m}^{3}$ was found in the March composite at location MESQ. The median concentration for this location is $0.11 \%$ of the monthly ambient concentration limit (ACL) of $10,000 \mathrm{pg} / \mathrm{m}^{3}$ established by the Bay Area Air Quality Management District (BAAQMD) and the EPA.

Figure 5-7 is a plot of the median beryllium concentration at the Livermore site perimeter from 1975 through 2000 . The decrease in median concentration in 1993 and the increase in 1999 were the result of a change in the analytical laboratory used to perform this analysis. The overall median concentration from 1975 through 2000 was calculated to be $0.18 \%$ of the ACL. Unless there is a change in LLNL's operations, the beryllium levels are expected to remain unchanged.

\section{Site $\mathbf{3 0 0}$}

\section{Airborne Radioactivity}

Table 5-2 shows the detection frequency and the monthly gross alpha and gross beta median, IQR, and maximum for sampling locations at Site 300. (See Data Supplement Table 5-14 for monthly data.) The monthly median gross alpha and gross 
Table 5-7. Beryllium in particulate samples for Livermore site perimeter and Site 300 locations, 2000

\begin{tabular}{|l|c|c|c|c|}
\hline $\begin{array}{c}\text { Sampling } \\
\text { location }\end{array}$ & $\begin{array}{c}\text { Detection } \\
\text { frequency }\end{array}$ & $\begin{array}{c}\text { Median } \\
\left(\mathbf{p g} / \mathbf{m}^{3}\right)\end{array}$ & $\begin{array}{c}\text { Interquartile } \\
\text { range } \\
\left(\mathbf{p g} / \mathbf{m}^{3}\right)\end{array}$ & $\begin{array}{c}\text { Maximum } \\
\left(\mathbf{p g} / \mathbf{m}^{3}\right)\end{array}$ \\
\hline \multicolumn{5}{|c|}{ Livermore perimeter locations } \\
\hline CAFE & $11 / 12$ & 16.4 & 11.4 & 28.2 \\
COW & $8 / 12$ & 10.3 & 12.3 & 24.0 \\
MESQ & $11 / 12$ & 11.1 & 8.81 & 38.2 \\
MET & $9 / 12$ & 9.30 & 7.66 & 20.0 \\
SALV & $8 / 12$ & 9.00 & 11.0 & 22.3 \\
VIS & $9 / 12$ & 10.3 & 9.03 & 20.0 \\
\hline & \multicolumn{5}{|c|}{ Site 300 locations } & & \\
\hline $801 E$ & $8 / 12$ & 7.46 & 8.84 & 25.7 \\
EOBS & $5 / 12$ & 4.82 & 7.36 & 11.7 \\
GOLF & $9 / 12$ & 10.2 & 8.44 & 17.6 \\
TFIR & $8 / 9$ & 15.9 & 16.7 & 30.4 \\
\hline
\end{tabular}

a See Figures 5-1 and 5-3 for sampling locations.

b Detection frequency is the number of samples with results above the detection limit divided by the number of samples.

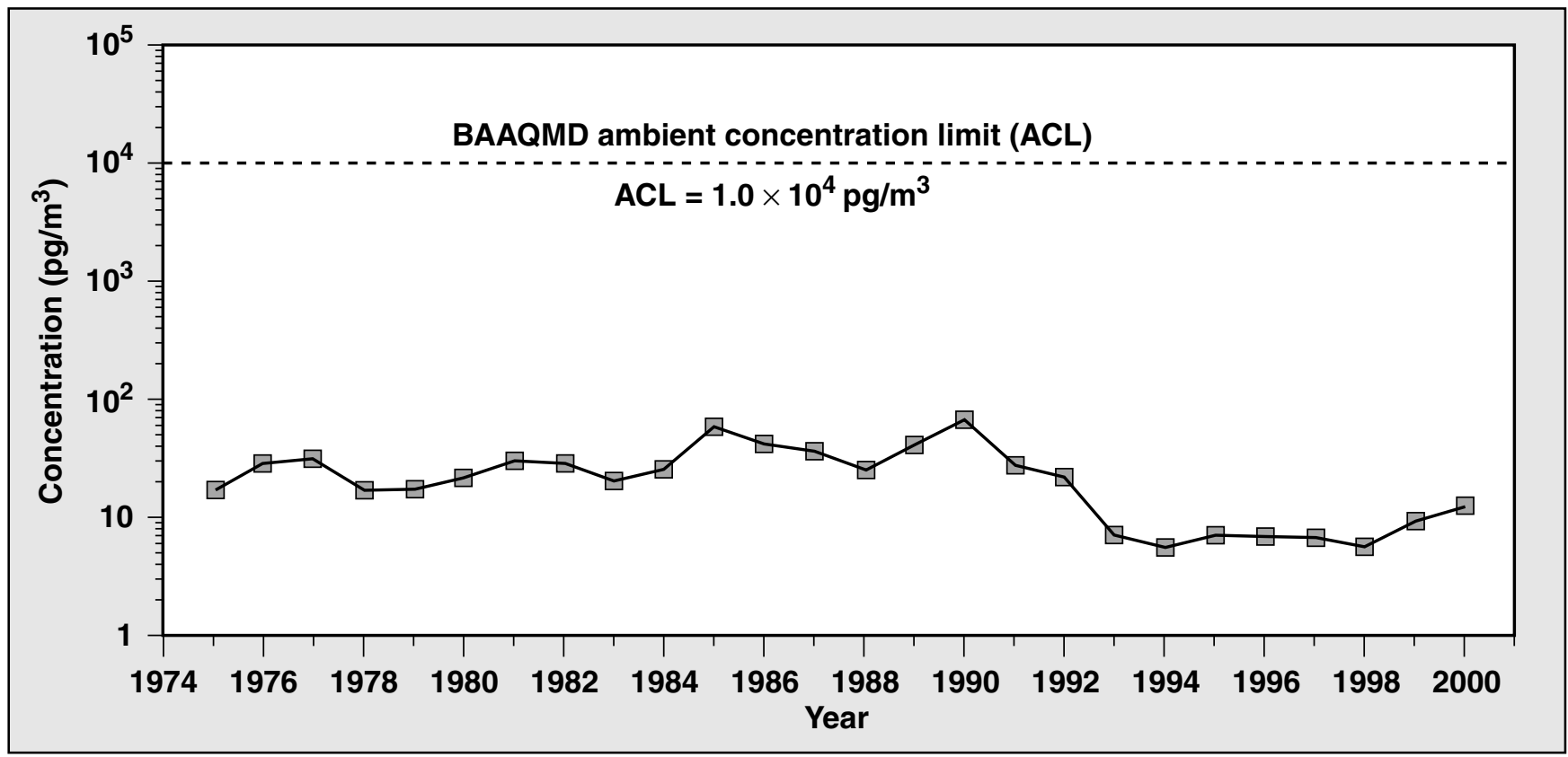

Figure 5-7. Median concentration of beryllium in air particulate samples taken at the Livermore site perimeter, 1975-2000 
beta concentrations are shown in Figures 5-4 and 5-5. The Site 300 gross alpha and gross beta results show a similar pattern to those found at the Livermore site. The median gross alpha activity is $8.2 \times 10^{-5} \mathrm{~Bq} / \mathrm{m}^{3}\left(2.2 \times 10^{-15} \mathrm{Ci} / \mathrm{m}^{3}\right)$. The median gross beta activity is $5.0 \times 10^{-4} \mathrm{~Bq} / \mathrm{m}^{3}$ $\left(1.3 \times 10^{-14} \mathrm{Ci} / \mathrm{m}^{3}\right)$. These values are similar to those obtained from previous monitoring data during the past several years.

The primary sources of observed gross alpha and gross beta activity are naturally occurring radioisotopes of uranium and thorium, their decay products, and any residual fallout from atmospheric weapons testing and the 1986 Chernobyl reactor accident.

Table 5-3 lists the annual median activities, detection frequencies, IQR, maximum, the percent of the DCG, as well as the DCG, of gamma-emitting radionuclides in samples from Site 300. (See Data Supplement Table 5-15 for monthly data.) All these radionuclides were measured at concentrations significantly below the DCGs. Of the nuclides identified, all are naturally occurring, with the exception of cesium-137. The primary source of cesium-137 normally is long-term global fallout and resuspension.

Table 5-4 shows the median concentration of plutonium-239+240 on air-filter samples collected from Site 300. (See Data Supplement Table 5-16 for monthly data.) The highest concentration of plutonium-239+240 was recorded in the April composite at a level of $1.9 \times 10^{-8} \mathrm{~Bq} / \mathrm{m}^{3}\left(5.1 \times 10^{-19} \mathrm{Ci} / \mathrm{m}^{3}\right)$, or $0.003 \%$ of the DCG.

As the result of a network assessment, and because Site 300 has uranium sources (from explosive testing and resuspension of this residue in these soils), the uranium analysis was expanded to all Site 300 locations (including TFIR). Table 5-5 shows the median concentration of uranium-235 and uranium-238 for the air samples from the Site 300 network. (See Data Supplement Table 5-17 for monthly data.) The highest concentrations of uranium-235 $\left(3.3 \times 10^{-6} \mu \mathrm{g} / \mathrm{m}^{3}\right)$ and uranium-238 $\left(4.5 \times 10^{-4} \mu \mathrm{g} / \mathrm{m}^{3}\right)$ were observed in April at location EOBS. These concentrations represent less than $0.01 \%$ of the DCG for both isotopes.

Table 5-6 shows the median concentration of tritiated water vapor that was observed at the new sampling location (COHO) near Site 300. (See Data Supplement Table 5-18 for biweekly data.) The annual median concentration is $-2.3 \times 10^{-3} \mathrm{~Bq} / \mathrm{m}^{3}\left(-6.2 \times 10^{-14} \mathrm{Ci} / \mathrm{m}^{3}\right)$. The maximum concentration at location $\mathrm{COHO}$ of $7.9 \times 10^{-3} \mathrm{~Bq} / \mathrm{m}^{3}$ is $0.0002 \%$ of the DCG.

\section{Beryllium in Air}

The detection frequency, median concentration, IQR, and maximum concentrations of airborne beryllium for the Site 300 sampling locations are shown in Table 5-7. (See Data Supplement Table 5-19 for monthly data.) The highest beryllium concentration of $30.4 \mathrm{pg} / \mathrm{m}^{3}$ occurred in September at location TFIR. The median concentration for this location is $0.16 \%$ of the federal and state ambient concentration limit, which is $10,000 \mathrm{pg} / \mathrm{m}^{3}$.

\section{Environmental Impact}

The environmental impacts from both radioactive and nonradioactive effluents are described in this section.

\section{Radioactive Materials}

LLNL operations involving radioactive materials had little impact on radionuclide concentrations in ambient air during 2000. Radionuclide 
concentrations in air at the Livermore site and in the Livermore Valley were well below the levels that would cause concern for the environment or public health according to existing regulatory standards.

The diffuse tritium sources at B292, B331, B514, and B624 had a localized effect; elevated concentrations such as those found at diffuse sources were not bound at perimeter or off-site locations.

The concentrations of radionuclides measured around Site 300 and in the City of Tracy were well below the levels that would cause concern for the environment or public health according to existing regulatory standards.

\section{Nonradioactive Materials}

The concentrations of beryllium at both sites can be attributed to resuspension of surface soil containing naturally occurring beryllium. Local soils contain approximately 1 ppm of beryllium, and the air of the Livermore area and the Central Valley typically contains 10 to $100 \mu \mathrm{g} / \mathrm{m}^{3}$ of particulates. Using a value of $50 \mu \mathrm{g} / \mathrm{m}^{3}$ for an average dust load and $1 \mathrm{ppm}$ for beryllium content of dust, a conservative airborne beryllium concentration of $50 \mathrm{pg} / \mathrm{m}^{3}$ can be predicted. The overall annual medians for the Livermore site and Site 300 are $11.5 \mathrm{pg} / \mathrm{m}^{3}$ and $8.4 \mathrm{pg} / \mathrm{m}^{3}$, respectively. These data are lower than predicted, well below standards, and do not indicate the presence of a threat to the environment or public health. 



\section{Sewerable Water MONITORING}

\section{Introduction}

In 2000, the Livermore site discharged an average of 0.97 million liters (ML) per day of wastewater to the City of Livermore sewer system, an amount that constituted $3.9 \%$ of the total flow to the system. This volume includes wastewater generated by Sandia National Laboratories/California, which is discharged to the LLNL collection system and combines with LLNL sewage before it is released at a single point to the municipal collection system (Figure 6-1). In 2000, Sandia/California generated approximately $16 \%$ of the total effluent discharged from the Livermore site. LLNL's wastewater contains sanitary sewage and industrial wastewater and is discharged in accordance with permit requirements and the City of Livermore Municipal Code, as discussed below in the "Pretreatment Discharges" and "Categorical Discharges" sections.

The effluent is treated at the Livermore Water Reclamation Plant (LWRP). As part of the Livermore-Amador Valley Wastewater Management Program, the treated sanitary wastewater is transported out of the valley through a pipeline and discharged into San Francisco Bay. A small portion of this treated wastewater is used for summer irrigation of the municipal golf course adjacent to the LWRP. Sludge from the treatment process is disposed of in sanitary landfills.
LLNL receives water from two suppliers. LLNL's primary water source is the Hetch-Hetchy Aqueduct. Secondary or emergency water deliveries are taken from the Alameda County Flood Control and Water Conservation District Zone 7 . This water is a mixture of groundwater and water from the South Bay Aqueduct of the State Water Project. Water quality parameters for the two sources are obtained from the suppliers and are used to evaluate compliance with the discharge permit conditions that limit changes in water quality between receipt and discharge.

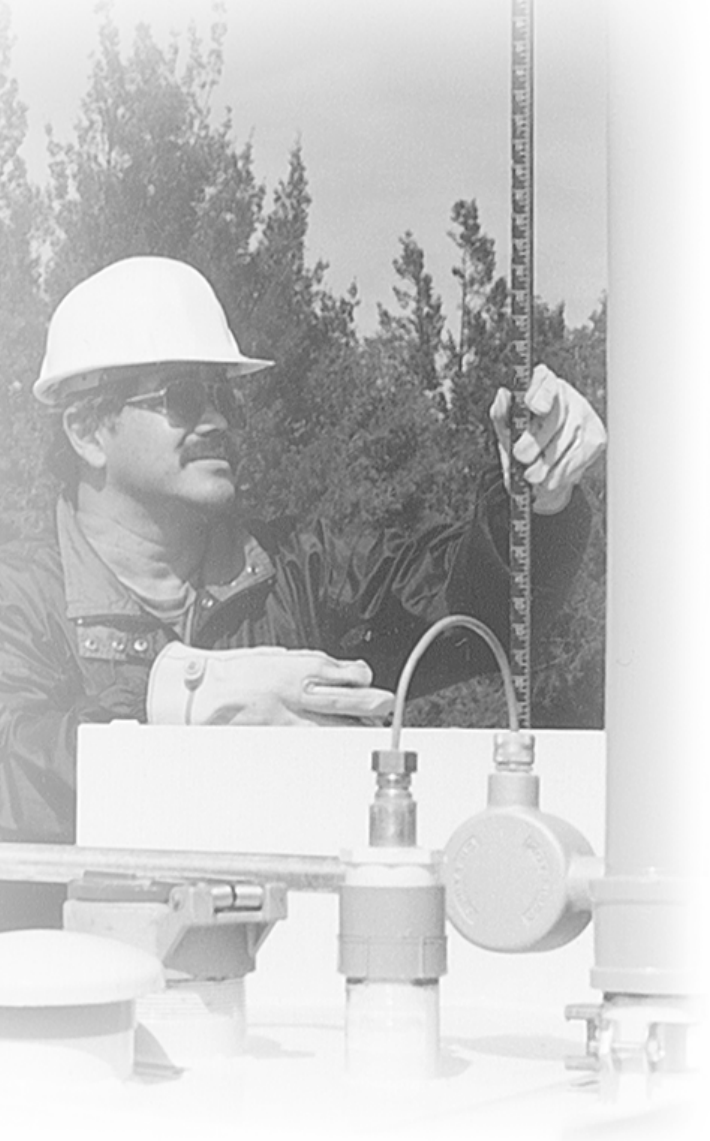


To City of Livermore Collection System

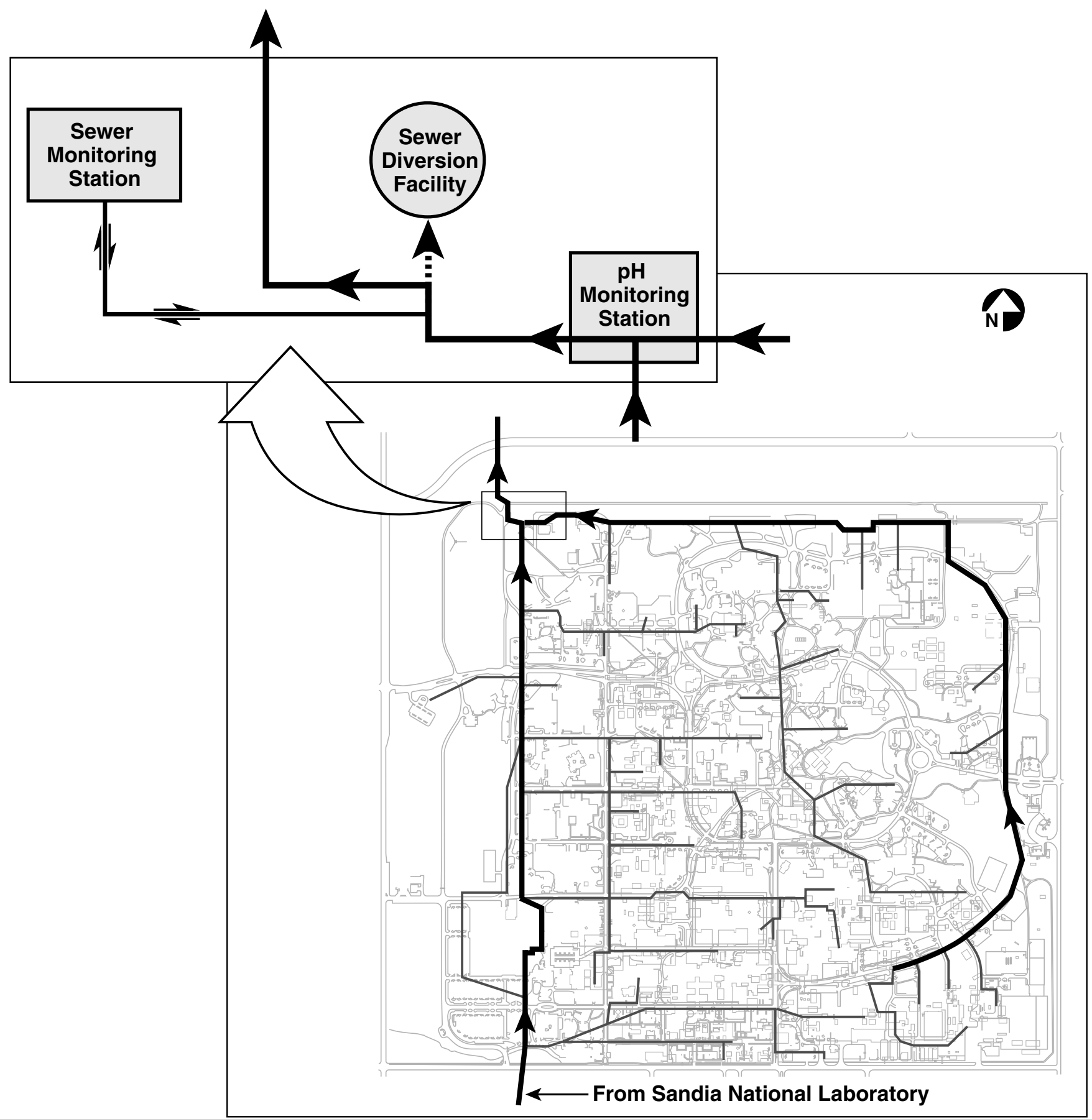

Figure 6-1. LLNL sanitary sewer system, monitoring stations, and diversion facility 


\section{Preventive Measures}

Administrative and engineering controls at the Livermore site are designed to prevent potentially contaminated wastewater from being discharged directly to the sanitary sewer. Waste generators receive training on proper waste handling. LLNL personnel review facility procedures and inspect processes to ensure appropriate discharges. Retention tanks collect wastewater from processes that might release contaminants in quantities sufficient to disrupt operations at the LWRP. Wastewater that cannot be discharged into one or more of the surface water collection units at LLNL's Experimental Test Site (Site 300) is transported to LLNL's Livermore site and managed under Livermore site retention tank administrative controls. Groundwater (generated from startup operations associated with new, portable groundwater treatment units, tests of experimental treatment units, and maintenance of existing treatment facilities) is analyzed for pollutants of concern and must meet permitted criteria, or LWRP approval must be obtained before it can be discharged to the sanitary sewer. Finally, to verify the success of training and control equipment, wastewater is sampled and analyzed not only at the significant points of generation, as defined by type and quantity of contaminant generated, but also at the point of discharge to the municipal sewer system.

For facilities with installed retention tank systems, collected wastewater is discharged to the sanitary sewer only if analytical laboratory results show that pollutant levels are within allowable limits (Grandfield 1989). LLNL developed internal discharge guidelines for specific sources and operations to ensure that sewer effluent for the entire site complies with LLNL's wastewater discharge permit. Process wastewater generation and discharge frequency from retention tanks vary from monthly to yearly, depending upon the process. During 2000, there were approximately 33 waste retention tank systems in use at the Livermore site, with an average of nine wastewater retention tanks discharged each month, averaging a volume of 8200 L per tank.

Table 6-1 shows LLNL's internal discharge guidelines for wastewater discharged to the sewer. Any processes that discharge to the sanitary sewer are subject to the general pretreatment self-monitoring program specified in the Wastewater Discharge Permit issued by the LWRP and, as such, are managed by LLNL using these internal discharge guidelines as applied at the point of discharge into the LLNL sewer.

If pollutant levels exceed internal permissible concentrations, the wastewater is treated to reduce pollutants to the lowest levels practical and below LLNL guidelines, or it is shipped to an off-site treatment or disposal facility. Liquids containing radioactivity are handled on site and may be treated using processes that reduce the activity to levels well below those required by DOE Order 5400.5, or they are shipped to an off-site treatment or disposal facility.

For the year as a whole, the monitoring data reflect the success of LLNL's discharge control program in preventing any adverse impact on the operations of Livermore's treatment plant and are generally consistent with past values.

\section{Monitoring}

\section{Monitoring at the Sewer Monitoring Station}

LLNL's sanitary sewer discharge permit requires continuous monitoring of the effluent flow rate and $\mathrm{pH}$. Samplers collect flow-proportional composite samples and instantaneous grab samples that are analyzed for metals, radioactivity, toxic chemicals, and water-quality parameters. In addition, as a best management practice, the outflow to the municipal collection system is sampled 
Table 6-1. LLNL's internal discharge guidelines for pollutants in wastewater

\begin{tabular}{|c|c|c|}
\hline \multicolumn{3}{|c|}{ Nonradioactive pollutants in wastewaters } \\
\hline \multicolumn{2}{|c|}{ Constituent } & $\begin{array}{l}\text { Discharge } \\
\text { guidelines }\end{array}$ \\
\hline \multicolumn{2}{|l|}{ Metals (mg/L) } & \\
\hline \multicolumn{2}{|l|}{ Arsenic } & $0.06^{(a)}$ \\
\hline \multicolumn{2}{|l|}{ Cadmium } & 0.9 \\
\hline \multicolumn{2}{|l|}{ Copper } & 10 \\
\hline \multicolumn{2}{|c|}{ Chromium (total) } & 4.9 \\
\hline \multicolumn{2}{|c|}{ Lead } & 4.9 \\
\hline \multicolumn{2}{|l|}{ Mercury } & 0.05 \\
\hline \multicolumn{2}{|l|}{ Nickel } & 5 \\
\hline \multicolumn{2}{|l|}{ Silver } & 1 \\
\hline \multicolumn{2}{|l|}{ Zinc } & 15 \\
\hline \multicolumn{2}{|l|}{ Cyanide $(\mathrm{mg} / \mathrm{L})^{(\mathrm{b})}$} & 5 \\
\hline \multicolumn{2}{|c|}{ Oil and grease $(\mathrm{mg} / \mathrm{L})$} & 500 \\
\hline \multicolumn{2}{|c|}{ Total toxic organics (TTO) $(\mathrm{mg} / \mathrm{L})^{(\mathrm{c})}$} & 4.57 \\
\hline \multicolumn{2}{|c|}{$\mathrm{pH}$ (pH units) } & $5-10$ \\
\hline \multicolumn{3}{|c|}{ Radioisotopes in wastewaters ${ }^{(d)}$} \\
\hline Parameter & $\begin{array}{l}\text { Individual } \\
\text { discharge }\end{array}$ & $\begin{array}{l}\text { Total daily } \\
\text { limit for site }\end{array}$ \\
\hline Gross alpha & $\begin{array}{l}11.1 \mathrm{~Bq} / \mathrm{L} \\
(300 \mathrm{pCi} / \mathrm{L})\end{array}$ & $\begin{array}{l}185 \mathrm{kBq} \\
(5.0 \mu \mathrm{Ci})\end{array}$ \\
\hline Gross beta & $\begin{array}{l}111 \mathrm{~Bq} / \mathrm{L} \\
(3000 \mathrm{pCi} / \mathrm{L})\end{array}$ & $\begin{array}{c}1.85 \mathrm{MBq} \\
(50.0 \mu \mathrm{Ci})\end{array}$ \\
\hline Tritium & $\begin{array}{l}185 \mathrm{kBq} / \mathrm{L} \\
(5.0 \mu \mathrm{Ci} / \mathrm{L})\end{array}$ & $\begin{array}{l}3.7 \mathrm{GBq} \\
(100.0 \mathrm{mCi})\end{array}$ \\
\hline
\end{tabular}

a No specific internal discharge limit was developed for this constituent; therefore, the discharge limit in LLNL's wastewater discharge permit is used as a guideline for this parameter.

b Limits apply to cyanide discharges other than cyanide salts. Cyanide salts are classified by the State of California as "extremely hazardous waste" and cannot be discharged to the sewer.

c Total toxic organics are defined by the Livermore Municipal Code as the sum total of all detectable organic compounds that are on the Environmental Protection Agency's (EPA's) current priority pollutant list and that are present in concentrations of $0.01 \mathrm{mg} / \mathrm{L}$ or greater. Analysis of samples using EPA Methods 624 and 625 satisfies this requirement. A listing of the specific compounds included may be found in the Data Supplement, Chapter 6 .

d There is no gross gamma limit; DOE Order 5400.5 isotopespecific limits apply. continuously and analyzed in real time for conditions that might upset the LWRP treatment process or otherwise impact the public welfare. The effluent is continuously analyzed for $\mathrm{pH}$, regulated metals, and radioactivity. If concentrations above warning levels are detected, an alarm is registered at the LLNL Fire Dispatcher's Station, which is attended 24 hours a day, and the site effluent is diverted to the Sewer Diversion Facility (SDF). The monitoring system provides a continuous check on sewage control, and the LWRP is notified of contaminant alarms. Trained staff respond to all alarms to evaluate the cause and take appropriate action.

\section{Monitoring at the Upstream pH Monitoring Station}

In addition to the continuous monitoring at the Sewer Monitoring Station (SMS), LLNL monitors $\mathrm{pH}$ at the upstream $\mathrm{pH}$ Monitoring Station (pHMS) (see Figure 6-1 for a system diagram). The pHMS continuously monitors $\mathrm{pH}$ between 7 a.m. and 7 p.m. during the work week and diverts $\mathrm{pH}$ discharges outside the permitted 5 to 10 range to the SDF. The pHMS duplicates the $\mathrm{pH}$ monitoring and diversion capabilities of the SMS, but because it is located upstream of the SDF it is able to initiate diversion earlier. Earlier detection allows LLNL to divert all of the unpermitted site effluent.

\section{Diversion System}

LLNL operates and maintains a diversion system that activates automatically when either the SMS continuous monitoring system or the pHMS sounds an alarm. For SMS-activated alarms, the SDF ensures that all but the first few minutes of the potentially affected wastewater flow is retained at LLNL, thereby protecting the LWRP and minimizing any required cleanup. During $\mathrm{pH}$ excursions activated by the pHMS, even the first few minutes of affected wastewater flow are retained. 
Up to $775,000 \mathrm{~L}$ of potentially contaminated sewage can be held pending analysis to determine the appropriate handling method. The diverted effluent may be returned to the sanitary sewer (if it meets LLNL's wastewater discharge permit limits), shipped for off-site disposal, or treated at LLNL's Hazardous Waste Management (HWM) Facility. The majority of all diverted sewage in 2000 was returned to the sanitary sewer.

\section{Pretreatment Discharges}

The general pretreatment regulations establish both general and specific standards for the discharge of prohibited substances (40 CFR 403.5) that apply to all industrial users. These regulations apply even if LLNL is subject to other federal, state, or local pretreatment standards. The pretreatment standards contain prohibitions intended to protect the LWRP and its operations from interference with its treatment processes or pass-through that would cause the LWRP to violate its own effluent limitations. The LWRP, under the authorization of the San Francisco Bay Regional Water Quality Control Board (SFBWQCB), requires self-monitored pretreatment programs at both the Livermore site and Site 300. The sampling and monitoring of nondomestic, industrial sources covered by pretreatment standards defined in 40 CFR 403 are required in the 2000-2001 Wastewater Discharge Permit No. 1250 issued for the discharge of wastewater from LLNL into the City of Livermore sewer system. Permit 1250 lists all the self-monitoring parameters that are applied at the SMS before wastewater enters the municipal collection system at LLNL's effluent outfall (see Figure 6-1). Parameters with numerical limits are listed in Table 6-2. The additional discharge limits shown in Table 6-2 are discussed in the "Categorical Discharges" and "Discharges of Treated Groundwater" sections. Other required parameters such as flow rate, biological oxygen demand, total dissolved solids, total suspended solids, and tributyltin are also monitored at the SMS but have no specific numerical limits.

In 2000 and early 2001, LLNL received a total of three Notices of Violation (NOVs) from the LWRP for exceeding permit limits in 2000. The first was for discharging wastewater that exceeded the effluent discharge limit for cyanide. The second NOV was for an excess of silver above the discharge permit limit. (See the "Nonradioactive Pollutants in Sewage" section of this chapter for more details on these events.) The third NOV received was issued for excess chromium and nickel found during compliance sampling of effluent from a water-jet process. (Details of this event are provided in the "Categorical Discharges" section of this chapter.)

Two additional pieces of correspondence were received from the LWRP for calendar year 2000. One letter, dated January 8, 2001, was in regard to acetone results for compliance sampling of a regulated retention tank on October 19, 2000, and LLNL site effluent on November 7, 2000. Although acetone is not one of the priority pollutants listed for the total toxic organics (TTO) discharge limit, the LWRP letter encouraged LLNL to reduce the concentration of acetone in future discharges because the values LLNL measured in the retention tank and the site effluent were 8900 and $500 \mu \mathrm{g} / \mathrm{L}$, respectively. As requested, LLNL reviewed the handling and disposal procedures for acetone from processes contributing to the retention tank. The required written response to the LWRP letter was submitted on January 31, 2001.

The other letter, received in March 2000 from the LWRP, requested detailed LLNL tritium discharge data. LLNL provided the requested data in April 2000 as part of an ongoing, joint LLNL and LWRP project to investigate and quantify tritium 
Table 6-2. Permit discharge limits for nonradioactive pollutants in LLNL wastewaters

\begin{tabular}{|c|c|c|c|c|}
\hline \multirow{3}{*}{ Parameter } & \multicolumn{4}{|c|}{ Permit discharge limits } \\
\hline & \multicolumn{3}{|c|}{ Permit 1250} & \multirow{2}{*}{$\begin{array}{c}\text { Permit 1510G } \\
\text { Treated } \\
\text { groundwater }\end{array}$} \\
\hline & Outfall(a) & $\begin{array}{c}\text { Metal } \\
\text { finishing }^{(b)}\end{array}$ & $\begin{array}{c}\text { Electric } \\
\text { component }^{(b)}\end{array}$ & \\
\hline \multicolumn{5}{|l|}{ Metals (mg/L) } \\
\hline Arsenic & 0.06 & 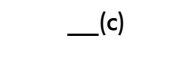 & 0.83 & 0.06 \\
\hline Cadmium & 0.14 & 0.07 & $-^{(c)}$ & 0.14 \\
\hline Chromium (total) & 0.62 & 1.71 & $-^{(c)}$ & 0.62 \\
\hline Copper & 1.0 & 2.07 & - (c) $^{\text {(c) }}$ & 1.00 \\
\hline Lead & 0.20 & 0.43 & 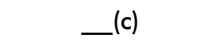 & 0.20 \\
\hline Mercury & 0.01 & 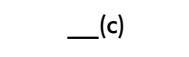 & 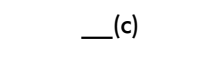 & 0.01 \\
\hline Nickel & 0.61 & 2.38 & - (c) & 0.61 \\
\hline Silver & 0.20 & 0.24 & - (c) $^{\text {(c) }}$ & 0.20 \\
\hline Zinc & 3.0 & 1.48 & $-^{(c)}$ & 3.00 \\
\hline \multicolumn{5}{|l|}{ Organics (mg/L) } \\
\hline $\mathrm{TTO}^{(\mathrm{d})}$ & 1.00 & 2.13 & 1.37 & 1.00 \\
\hline \multicolumn{5}{|l|}{ Other (mg/L) } \\
\hline Cyanide $^{(e)}$ & 0.04 & 0.65 & $-^{(c)}$ & $0.04^{(f)}$ \\
\hline Oil and grease & 100 & 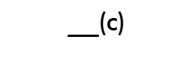 & -(c) $^{(1)}$ & 100 \\
\hline pH (pH units) & $5-10$ & -(c) $^{\text {(c) }}$ & -(c) $^{\text {(c) }}$ & $5-10$ \\
\hline
\end{tabular}

a These standards apply at the SMS (the point of discharge to the municipal sewer). All other standards in this table apply at the point of discharge into LLNL's sanitary sewer system.

b Values shown for these categorical standards were specified by EPA. By regulation, the EPA or City of Livermore limit is used, whichever is lower. The internal limits in Table 6-1 are applied by LLNL where no other standard is specified.

c There is no specific categorical limit for this parameter; therefore, the Table 6-1 internal discharge limits apply.

d Total toxic organics is defined by the Livermore Municipal Code as the sum total of all detectable organic compounds that are on EPA's current priority pollutant list and that are present in concentrations of $0.01 \mathrm{mg} / \mathrm{L}$ or greater. Analysis using EPA Methods 624 and 625 satisfies this requirement. A listing of the specific compounds included may be found in the Data Supplement, Chapter 6.

e Limits apply to cyanide discharges other than cyanide salts. Cyanide salts are classified by the State of California as "extremely hazardous waste" and cannot be discharged to the sewer.

f Although Permit $1510 \mathrm{G}$ lists a discharge limit for cyanide, sample collection is not required by the selfmonitoring program. 
in the LWRP liquid effluent. LLNL efforts for this project in the year 2000 included providing the LWRP with technical input and low-level chemical analysis for tritium.

\section{Categorical Discharges}

The Environmental Protection Agency (EPA) publishes categorical standards as regulations separate from the general pretreatment regulations and developed for broad categories of specific industrial processes determined to be the most significant contributors to point-source water pollution. These standards contain specific numerical limits for the discharge of industry-specific pollutants from individual processes. The number of processes at LLNL using these pollutants is subject to change as programmatic requirements dictate. During 2000, the LWRP identified 17 specific LLNL wastewater-generating processes that fall under the definition of two categorical standards: Electrical and Electronic Components (40 CFR 469), and Metal Finishing (40 CFR 433). The discharge limits for these standards are shown in Table 6-2. Under the terms in Permit 1250, only those processes that discharge to the sanitary sewer require sampling, inspection, and reporting. Three of the 17 identified processes meet these criteria. In 2000, LLNL analyzed samples for all regulated parameters from these three processes and, with one exception, demonstrated compliance with all Federal Categorical Discharge limits.

The first of the three categorical processes that discharge directly into the sanitary sewer system is an abrasive jet machine (or water-jet) that is regulated under the Metal-Finishing Point Source Category; the filtered water from this process is discharged to the sanitary sewer. In January 2001, LLNL received a Notice of Violation from the LWRP for discharging wastewater from this process with concentrations of chromium and nickel in excess of established Federal Pretreatment
Categorical Limits on November 2, 2000; split samples of the process wastewater showed concentrations of 14.0 and $8.2 \mathrm{mg} / \mathrm{L}$ for chromium and 4.9 and $3.6 \mathrm{mg} / \mathrm{L}$ for nickel. After changes to the process, follow-up sampling conducted on January 18 and February 1, 2001, demonstrated a return to compliance. The LWRP conducted a corrective action review and determined that no fines or penalties were required.

The other two discharging categorical processes are both regulated under the Federal Electrical and Electronic Component Point Source Category. One is a series of processes clustered within a single building that houses research-scale microfabrication laboratories used for developing prototype semiconductor devices. These laboratories discharge into a building wastewater retention system, and because they are housed within the same building with no diluting flow, they share a single point of compliance. The other categorical process is a small gallium arsenide cutting operation; this process discharges directly to the sanitary sewer.

The nondischarging processes, all regulated under the Metal-Finishing Point Source Category (40 CFR 433), were printed circuit board manufacturing, electrolysis plating, chemical etching, electroplating, anodizing, coating, painting, cleaning, electrical discharge machining, irridite processing, and abrasive jet machining (water-jet). The wastewater from these processes was contained for removal and off-site shipment by LLNL's Hazardous Waste Management Division (HWM).

\section{Discharges of Treated Groundwater}

LLNL's groundwater discharge permit (1510G, 2000) allows treated groundwater from site-wide cleanup activities under the Comprehensive Environmental Response, Compensation and Liability 
Act (CERCLA) of 1980 to be discharged in the City of Livermore sanitary sewer in compliance with Table 6-2 effluent limitations taken from the Livermore Municipal Code.

During 2000, the volume of groundwater discharged to the sanitary sewer was approximately 18,556 L. Water discharges during this period were related to well purging and maintenance of an existing treatment facility (TFD). Three separate discharges were sampled and discharged to the sewer during this period, all in compliance with self-monitoring permit provisions and discharge limits of Permit 1510G. Monitoring data are presented in the Data Supplement, Chapter 6.

\section{Radioactive Pollutants in Sewage}

\section{Monitoring Results}

LLNL determines the total radioactivity released from tritium, alpha emitters, and beta emitters based either on the measured radioactivity in the effluent or on the limit of sensitivity, whichever is higher (see Table 6-3). The 2000 combined releases of alpha and beta sources was $0.28 \mathrm{GBq}$ $(0.0076 \mathrm{Ci})$. The combined total is based on the alpha and beta results shown in Table 6-3. The tritium total was $5.0 \mathrm{GBq}(0.14 \mathrm{Ci})$, and the annual mean concentration of tritium in LLNL sanitary sewer effluent was $0.014 \mathrm{~Bq} / \mathrm{mL}$ $(0.38 \mathrm{pCi} / \mathrm{mL})$.

Table 6-3. Estimated total radioactivity in LLNL sanitary sewer effluent, 2000

\begin{tabular}{|l|c|c|}
\hline $\begin{array}{c}\text { Radioactive } \\
\text { emitter }\end{array}$ & $\begin{array}{c}\text { Estimate based } \\
\text { on effluent } \\
\text { activity }(\mathrm{GBq})\end{array}$ & $\begin{array}{c}\text { Limit of } \\
\text { sensitivity } \\
\text { (GBq) }\end{array}$ \\
\hline Tritium & 5.0 & 3.9 \\
Alpha sources & 0.040 & 0.033 \\
Beta sources & 0.24 & 0.043 \\
\hline
\end{tabular}

a $\quad 37 \mathrm{GBq}=3.7 \times 10^{10} \mathrm{~Bq}=1 \mathrm{Ci}$
Summary results for tritium measured in the sanitary sewer effluent from LLNL and LWRP are presented in Table 6-4. The monthly tritium numbers are based on the flow-weighted average of the individual daily sample results for a given month. The total annual result is based on the multiplication of each daily sample result or the limit of sensitivity, whichever is greater, by the total flow volume over which the sample was collected, and summing up over all samples. (All other total annual results presented in this chapter for radioactive emitters are also calculated conservatively; the limit of sensitivity or minimum detectable concentration is used to determine the total annual activity when the limit of sensitivity is greater than the sample result.) Also included in the table are fractions of LWRP, Department of Energy (DOE), and 10 CFR 20 limits, discussed in the "Environmental Impact" section.

The historical trend in the monthly average concentration of tritium is shown in Figure 6-2. Also included in the figure are the limit of sensitivity (LOS) values for the tritium analysis and the DOE tritium limit $(370 \mathrm{~Bq} / \mathrm{mL})$, discussed in the "Environmental Impact" section of this chapter. The trend indicates a well-controlled tritium discharge, orders of magnitude below the DOE tritium limit. (Note that for 2000 data, only results above the LOS are plotted.)

The concentrations of plutonium-239 and cesium-137 measured in the sanitary sewer effluent from LLNL and LWRP are presented in

Table 6-5. The plutonium and cesium numbers are the direct results for analyses of monthly composite samples of LLNL and LWRP effluent, and quarterly composites of LWRP sludge. At the bottom of the table, the total annual activity released is given by radioisotope. Also included in the table are fractions of DOE limits, discussed in the "Environmental Impact" section. 
Table 6-4. Tritium in sanitary sewer effluents, LLNL and LWRP, 2000

\begin{tabular}{|c|c|c|c|}
\hline \multicolumn{4}{|c|}{ Monitoring results } \\
\hline & \multicolumn{2}{|c|}{ LLNL } & \multirow{2}{*}{$\begin{array}{c}\text { LWRP } \\
\text { Weekly }\end{array}$} \\
\hline & Daily & Monthly average & \\
\hline Maximum $(\mathrm{Bq} / \mathrm{mL})$ & $0.107 \pm 0.007^{(a)}$ & $0.016^{(b)}$ & $0.0080^{(c)}$ \\
\hline Median $(\mathrm{Bq} / \mathrm{mL})$ & 0.001 & 0.004 & $<-0.0004^{(d)}$ \\
\hline $\mathrm{IQR}^{(\mathrm{e})}(\mathrm{Bq} / \mathrm{mL})$ & 0.005 & 0.005 & (d) $^{(\mathrm{n}}$ \\
\hline LLNL annual total (GBq) & \multicolumn{3}{|c|}{5.0} \\
\hline \multicolumn{4}{|c|}{ Discharge limits for LLNL effluent } \\
\hline & \multirow{2}{*}{$\begin{array}{l}\text { Discharge } \\
\text { limit }\end{array}$} & Monitoring results as & percentage of limit \\
\hline & & LLNL maximum & LLNL median \\
\hline $\begin{array}{l}\text { LWRP permit daily discharge limit } \\
(\mathrm{Bq} / \mathrm{mL})\end{array}$ & 12 & 0.89 & 0.0083 \\
\hline $\begin{array}{l}\text { DOE annualized discharge limit for } \\
\text { application of } B A T^{(f)}(B q / m L)\end{array}$ & 370 & $0.0043^{(g)}$ & $0.0011^{(\mathrm{g})}$ \\
\hline 10 CFR 20 annual total (GBq) & 185 & \multicolumn{2}{|c|}{2.7} \\
\hline
\end{tabular}

a This daily result is for a June sample; the detection limit for the analysis was $0.008 \mathrm{~Bq} / \mathrm{mL}$. See the Data Supplement, Chapter 6, for all daily results.

b This is the monthly average for February. All year 2000 monthly averages greater than the LOS are plotted in Figure 6-2.

c This is a weekly result for a March sample. The result was not above the detection limit $(0.011 \mathrm{~Bq} / \mathrm{mL})$ for the analysis. None of the LWRP weekly monitoring results were greater than the detection limits for the analyses; a detection limit is the smallest concentration of radioactive material that can be detected with a large degree of confidence. (See Chapter 14.) The detection limits ranged from 0.008 to $0.012 \mathrm{~Bq} / \mathrm{mL}$. See the Data Supplement, Chapter 6, for all weekly results.

d Because of the large number of nondetects, the central tendency is reported as less than the median value, and the interquartile range is not calculated. See Chapter 14.

e $\quad I Q R=$ Interquartile range

$f$ The DOE annualized discharge limit for application of best available technology (BAT) is five times the derived concentration guide (DCG: ingested water) for each radionuclide released.

g Monitoring results as a percentage of limit are calculated using LLNL monthly average results and the DOE annualized discharge limit.

Figure 6-3 shows the average monthly plutonium and cesium concentrations in sewage since 1991. For 2000, the annual mean concentration of cesium-137 was $2.6 \times 10^{-6} \mathrm{~Bq} / \mathrm{mL}$ $\left(7.0 \times 10^{-5} \mathrm{pCi} / \mathrm{mL}\right)$; the annual mean concentration of plutonium-239 was $2.7 \times 10^{-7} \mathrm{~Bq} / \mathrm{mL}$ $\left(7.3 \times 10^{-6} \mathrm{pCi} / \mathrm{mL}\right)$.

\section{Environmental Impact}

During 2000, no inadvertent discharges exceeded any discharge limits for release of radioactive materials to the sanitary sewer system. 


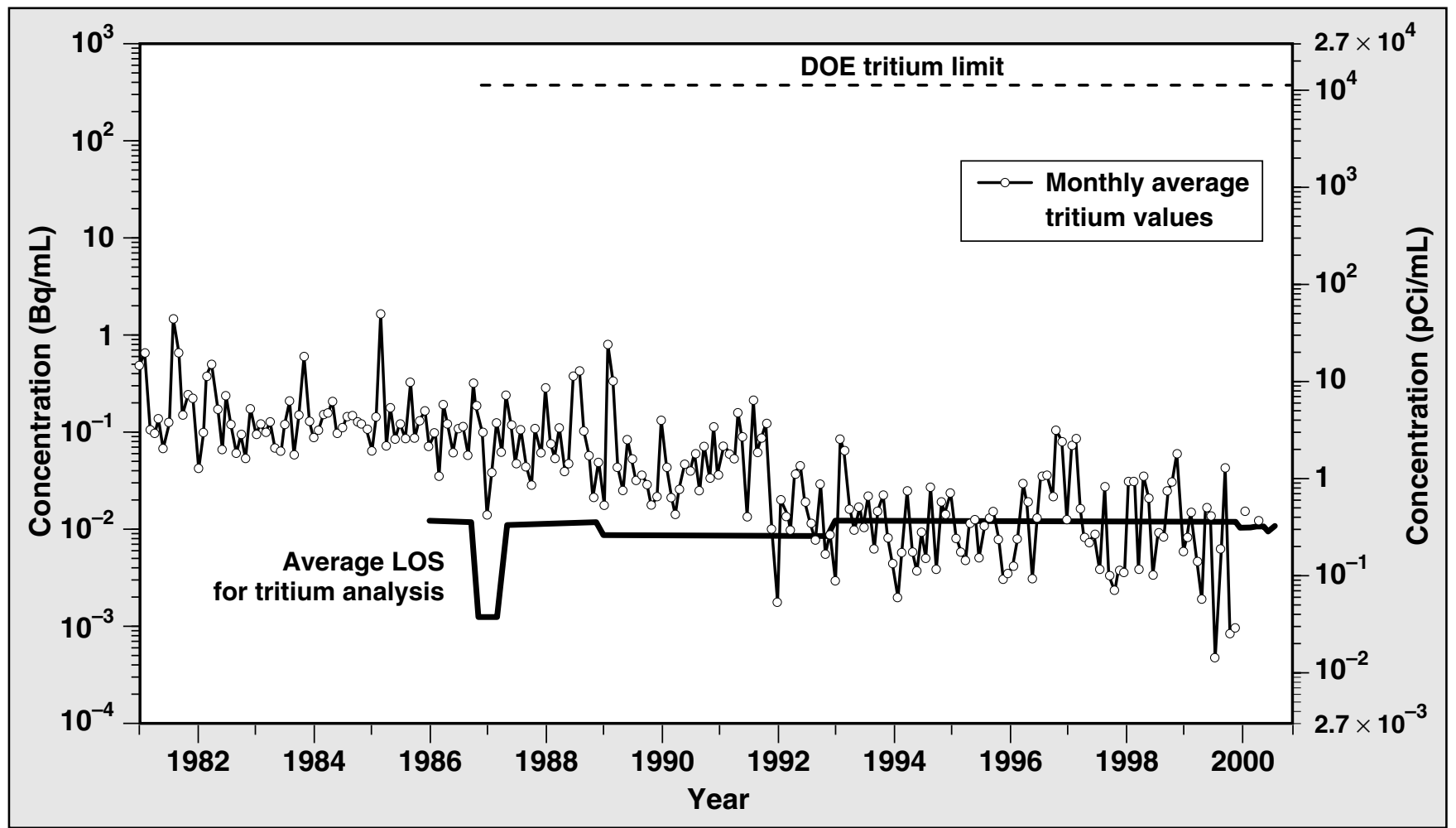

Figure 6-2. Historical trend in tritium concentration in LLNL sewage

In 1999, the Work Smart Standards (WSS) developed for LLNL became effective. Included in the WSS are the standards selected for sanitary sewer discharges. For radioactive material releases, complementary (rather than redundant) sections from DOE Order 5400.5, Radiation Protection of the Public and Environment, and Title 10 of the Code of Federal Regulations, Part 20, are both part of the standards.

From DOE Order 5400.5, the WSS for sanitary sewer discharges include the criteria DOE established for the application of best available technology to protect public health and minimize degradation of the environment. These criteria (the Derived Concentration Guides, or DCGs) limit the concentration of each radionuclide discharged to publicly owned treatment works. If a measurement of the monthly average concentration of a radioisotope exceeds its specific concentration limit, LLNL is required to improve discharge control measures until concentrations are again below the DOE limits. Tables 6-4 and 6-5 include the DCGs for the specific radioisotopes of most interest at LLNL.

The median monthly average concentration of tritium in LLNL sanitary sewer effluent was $1.1 \times 10^{-5}$, that is, $0.0011 \%$ of the DOE DCG, and the maximum monthly average concentration of tritium was $4.3 \times 10^{-5}(0.0043 \%)$ of the DCG (see Table 6-4). 
Table 6-5. Cesium and plutonium in sanitary sewer effluents, LLNL and LWRP, 2000

\begin{tabular}{|c|c|c|c|c|c|c|c|c|c|c|}
\hline \multirow{3}{*}{ Month } & \multicolumn{4}{|c|}{${ }^{137} \mathrm{Cs}(\mu \mathrm{Bq} / \mathrm{mL})$} & \multicolumn{4}{|c|}{${ }^{239} \mathrm{Pu}(\mathrm{nBq} / \mathrm{mL})$} & \multirow{2}{*}{\multicolumn{2}{|c|}{$\frac{{ }^{239} \mathrm{Pu}(\mathrm{mBq} / \mathrm{dry} \mathrm{g})}{\text { LWRP sludge }}$}} \\
\hline & \multicolumn{2}{|l|}{ LLNL } & \multicolumn{2}{|l|}{ LWRP } & \multicolumn{2}{|l|}{ LLNL } & \multicolumn{2}{|l|}{ LWRP } & & \\
\hline & $\begin{array}{l}\text { Radio- } \\
\text { activity }\end{array}$ & MDC & $\begin{array}{l}\text { Radio- } \\
\text { activity }\end{array}$ & MDC & $\begin{array}{l}\text { Radio- } \\
\text { activity }\end{array}$ & MDC & $\begin{array}{l}\text { Radio- } \\
\text { activity }\end{array}$ & MDC & $\begin{array}{l}\text { Radio- } \\
\text { activity }\end{array}$ & MDC \\
\hline Jan & $2.0 \pm 3.0$ & 2.8 & $0.79 \pm 2.61$ & 2.37 & $278 \pm 44$ & 10 & $-0.47 \pm 4.63$ & 11.9 & & \\
\hline Feb & $-0.94 \pm 3.34$ & 2.90 & $-0.24 \pm 2.60$ & 2.29 & $118 \pm 29$ & 6 & $4.2 \pm 5.8$ & 8.1 & & \\
\hline Mar & $0.31 \pm 2.86$ & 2.56 & $0.33 \pm 2.56$ & 2.30 & $262 \pm 45$ & 5 & $-6.7 \pm 5.5$ & 21.3 & $0.17 \pm 0.02$ & 0.00 \\
\hline Apr & $2.5 \pm 3.1$ & 2.9 & $-0.29 \pm 2.99$ & 2.56 & $155 \pm 29$ & 8 & $4.1 \pm 9.1$ & 12.4 & & \\
\hline May & $-0.61 \pm 3.06$ & 2.61 & $-0.89 \pm 2.46$ & 2.06 & $142 \pm 29$ & 12 & $0.99 \pm 3.67$ & 8.51 & & \\
\hline Jun & $1.0 \pm 2.9$ & 2.6 & $1.0 \pm 2.7$ & 2.4 & $43.7 \pm 19.5$ & 17.5 & $-2.0 \pm 3.8$ & 11.0 & $0.16 \pm 0.03$ & 0.01 \\
\hline Jul & $0.24 \pm 2.19$ & 2.01 & $-2.3 \pm 2.8$ & 2.4 & $75.1 \pm 18.5$ & 8.7 & $0.8 \pm 10.3$ & 15.3 & & \\
\hline Aug & $1.1 \pm 2.4$ & 2.2 & $1.6 \pm 2.4$ & 2.3 & $23.6 \pm 15.7$ & 15.6 & $-12.0 \pm 9.5$ & 19.1 & & \\
\hline Sep & $2.3 \pm 1.8$ & 2.2 & $-0.83 \pm 2.90$ & 2.57 & $1550 \pm 140$ & 16 & $-0.88 \pm 3.25$ & 8.66 & $0.080 \pm 0.016$ & 0.006 \\
\hline Oct & $0.88 \pm 2.70$ & 2.52 & $-0.38 \pm 2.63$ & 2.36 & $297 \pm 50$ & 12 & $-2.1 \pm 2.1$ & 8.5 & & \\
\hline Nov & $1.3 \pm 2.9$ & 2.8 & $-0.08 \pm 2.74$ & 2.48 & $219 \pm 32$ & 8 & $-2.5 \pm 6.0$ & 15.6 & & \\
\hline Dec & $0.39 \pm 2.73$ & 2.52 & $-0.70 \pm 2.53$ & 2.25 & $78 \pm 22$ & 12 & $-5.2 \pm 6.7$ & 17.8 & $2.98 \pm 0.16$ & 0.01 \\
\hline \multirow{3}{*}{$\begin{array}{l}\text { Median } \\
\mathrm{IQR}^{(\mathrm{c})}\end{array}$} & \multirow{2}{*}{\multicolumn{2}{|c|}{$\begin{array}{c}<0.9^{\text {(b) }} \\
\text { - }^{\text {(d) }}\end{array}$}} & \multirow{2}{*}{\multicolumn{2}{|c|}{$\begin{array}{c}<-0.3^{(b)} \\
\ldots^{(d)}\end{array}$}} & \multicolumn{2}{|l|}{149} & \multicolumn{2}{|c|}{$<-1.45^{(b)}$} & \multicolumn{2}{|l|}{0.17} \\
\hline & & & & & \multicolumn{2}{|l|}{189} & $-^{(d)}$ & & \multicolumn{2}{|l|}{0.73} \\
\hline & \multicolumn{8}{|c|}{$\mathrm{pCi} / \mathrm{mL}^{(\mathrm{e})}$} & \multicolumn{2}{|c|}{ pCi/dry $\mathbf{g}^{(\mathrm{e})}$} \\
\hline $\begin{array}{l}\text { Median } \\
\operatorname{IQR}^{(c)}\end{array}$ & \multicolumn{2}{|c|}{$\begin{array}{c}<2.6 \times 10^{-5} \\
\text { — (d) }^{\text {(d) }}\end{array}$} & \multicolumn{2}{|c|}{$\begin{array}{c}<-7.2 \times 10^{-6} \\
\text {-(d) }^{\text {(d) }}\end{array}$} & \multicolumn{2}{|c|}{$\begin{array}{l}4.2 \times 10^{-6} \\
5.1 \times 10^{-6}\end{array}$} & \multicolumn{2}{|c|}{$\begin{array}{c}<-3.9 \times 10^{-8} \\
\text { (d) }^{\text {(d) }}\end{array}$} & \multicolumn{2}{|l|}{$\begin{array}{l}0.0045 \\
0.0198\end{array}$} \\
\hline & & & \multicolumn{8}{|c|}{ Annual LLNL total discharges by radioisotope } \\
\hline & & & \multicolumn{4}{|c|}{${ }^{137} \mathrm{Cs}$} & \multicolumn{4}{|c|}{${ }^{239} \mathrm{Pu}$} \\
\hline \multirow{3}{*}{$\begin{array}{l}\mathrm{Bq} / \mathrm{y} \\
\mathrm{Ci} / \mathrm{y}\end{array}$} & & & \multicolumn{4}{|c|}{$9.1 \times 10^{5}$} & \multicolumn{4}{|c|}{$9.6 \times 10^{4}$} \\
\hline & & & \multicolumn{4}{|c|}{$2.5 \times 10^{-5}$} & \multicolumn{4}{|c|}{$2.6 \times 10^{-6}$} \\
\hline & & & & & & raction & of limit ${ }^{(f)}$ & & & \\
\hline DOE annu & ed discharge li & $\mathrm{it}^{(\mathrm{g})}$ & & $4.6>$ & $0^{-6}$ & & & $7.3>$ & $10^{-7}$ & \\
\hline
\end{tabular}

Note: Results in this table are reported as radioactivity (the measured concentration and a $\pm 2 \sigma$ counting uncertainty) along with the detection limit or minimum detectable concentration (MDC). A measure concentration exhibiting a $2 \sigma$ counting uncertainty greater than or equal to $100 \%$ is considered to be a nondetection. See Chapter 14 .

a Sludge from LWRP digesters is dried before analysis. The resulting data indicate the plutonium concentration of the sludge prepared by LWRP workers for disposal at the Vasco Road Landfill in Alameda County.

b Because of the large number of nondetects, the central tendency is reported as less than the median value. See Chapter 14.

c $I Q R=$ Interquartile range

d Because of the large number of nondetects, the interquartile range is not calculated. See Chapter 14.

e $1 \mathrm{Ci}=3.7 \times 10^{10} \mathrm{~Bq}$

$f$ Fraction of limit calculations are based on the annual total discharge for a given isotope and the corresponding concentration-based limit ( 0.56 and $0.37 \mathrm{~Bq} / \mathrm{mL}$ for cesium-137 and plutonium-239, respectively) multiplied by the annual volume of Livermore site effluent.

g The DOE annualized discharge limit for application of best available technology (BAT) is five times the derived concentration guide (DCG: ingested water) for each radionuclide released. 


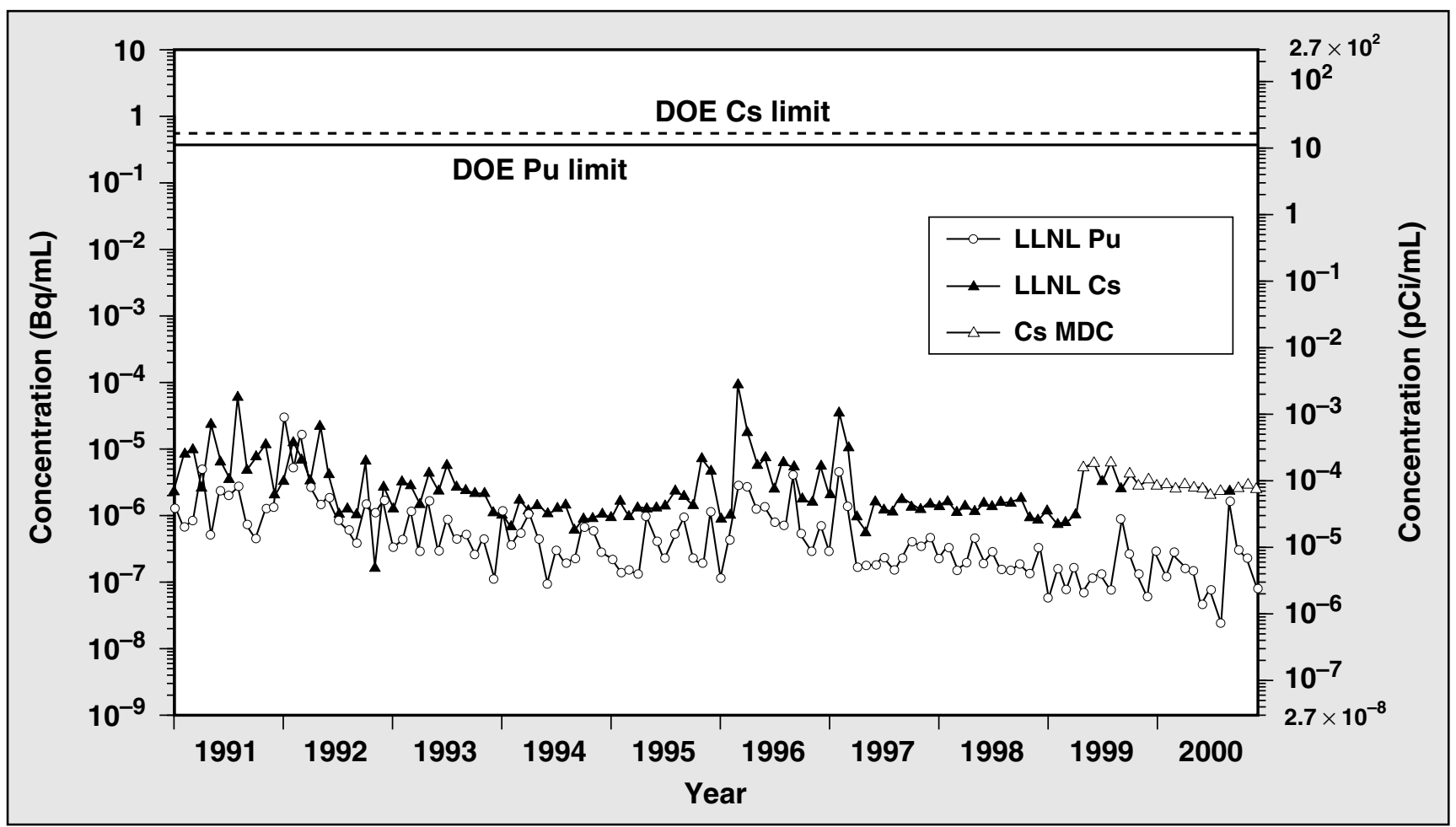

Figure 6-3. Historical trends in average monthly plutonium and cesium concentrations in LLNL sewage

The annual average concentration of cesium-137 was $4.6 \times 10^{-6}(0.00046 \%)$ of the DOE DCG; and the annual average plutonium-239 concentration was $7.3 \times 10^{-7}(0.000073 \%)$ of the plutonium-239 DOE DCG. These results are shown at the end of Table 6-5.

From 10 CFR 20, the numerical discharge limits for sanitary sewer discharges in the WSS include the annual discharge limits for radioactivity: $185 \mathrm{GBq}(5 \mathrm{Ci})$ of tritium, $37 \mathrm{GBq}(1 \mathrm{Ci})$ of carbon-14, and $37 \mathrm{GBq}$ (1 Ci) of all other radionuclides combined.

The 10 CFR 20 limit on total tritium activity (185 GBq) dischargeable during a single year overrides the DOE Order 5400.5 concentration-based limit for tritium for facilities such as LLNL that generate wastewater in large volumes. In 2000, the total LLNL tritium release was $2.7 \%$ of this Title 10 limit. Total LLNL releases (see Table 6-3), in the form of alpha and beta emitters (excluding tritium), were $0.76 \%$ of the corresponding Title 10 limit.

In addition to the DOE average concentration discharge limit for tritium and the 10 CFR 20 annual total discharge limit for tritium, the LWRP established in 1999 an effluent concentration discharge limit for LLNL daily releases of tritium. This limit is more stringent than the DOE discharge limit: it is a factor of $\mathbf{3 0}$ smaller and applies to a daily rather than an annualized concentration. The maximum daily concentration for tritium in 2000 was $0.89 \%$ of the permit discharge limit. Table 6-4 shows this result and the daily effluent discharge limit for tritium.

LLNL also compares annual discharges with historical values to evaluate the effectiveness of ongoing discharge control programs. Table 6-6 
summarizes the radioactivity in liquid effluent released over the past 10 years. During 2000, a total of $5.0 \mathrm{GBq}(0.14 \mathrm{Ci})$ of tritium was discharged to the sanitary sewer, an amount that is well within environmental protection standards and is comparable to the amounts reported since 1991. Moreover, the total tritium released by LLNL in 2000 continues the 1992 to 1999 trend of significantly smaller releases than those in the years prior to 1992.

Table 6-6. Radioactive liquid effluent releases from the Livermore site, 1991-2000

\begin{tabular}{|c|c|c|}
\hline \multirow{2}{*}{ Year } & \multicolumn{2}{|c|}{ Liquid effluent (GBq) } \\
\cline { 2 - 3 } & ${ }^{3} \mathrm{H}$ & ${ }^{339} \mathrm{Pu}$ \\
\hline 1991 & 32 & $6.1 \times 10^{-4}$ \\
1992 & 8 & $1.9 \times 10^{-3}$ \\
1993 & 13 & $2.6 \times 10^{-4}$ \\
1994 & 6.9 & $1.9 \times 10^{-4}$ \\
1995 & 6.0 & $1.2 \times 10^{-4}$ \\
1996 & $12^{\text {(a) }}$ & $4.2 \times 10^{-4}$ \\
1997 & 9.1 & $2.1 \times 10^{-4}$ \\
1998 & 10 & $7.7 \times 10^{-5}$ \\
1999 & 7.1 & $6.8 \times 10^{-5}$ \\
2000 & 5.0 & $9.6 \times 10^{-5}$ \\
\hline
\end{tabular}

a In 1995, Sandia National Laboratories/California ceased all tritium facility operations. Therefore, the annual tritium totals beginning with the 1996 value do not include contributions from Sandia/California.

Figure 6-3 summarizes the plutonium-239 monitoring data over the past 10 years. The historical levels observed since 1991 average $1 \mu \mathrm{Bq} / \mathrm{mL}$ $\left(3 \times 10^{-5} \mathrm{pCi} / \mathrm{mL}\right)$. These historical levels generally are three-millionths $(0.000003)$ of the DOE DCG for plutonium-239. The greatest part of the plutonium discharged in LLNL effluent is ultimately concentrated in LWRP sludge, which is dried and disposed of at a landfill. The median plutonium concentration observed in 2000 sludge (Table 6-5), $0.17 \mathrm{mBq} / \mathrm{dry} \mathrm{g}$, is approximately 550 times lower than the EPA preliminary remediation goal for residential soil $(93 \mathrm{mBq} / \mathrm{dry} \mathrm{g})$ and is nearly 2200 times lower than the remediation goal for industrial or commercial soil (370 mBq/dry g).

As first discussed in the Environmental Report 1991 (Gallegos et al. 1992), plutonium and cesium concentrations were slightly elevated during 1991 and 1992 over the lowest values seen historically. As was established in 1991, the overall upward trend was related to sewer cleaning with new, more-effective equipment. The concentrations in 1996 and the first quarter of 1997 were also slightly higher than the lowest values seen historically, although slightly lower than those of 1990 through 1992. In fact, the cyclic nature of the data points in Figure 6-3 suggests a potential frequency relationship in LLNL sewer lines for radionuclide buildup and subsequent liberation by line cleaning. The higher plutonium and cesium concentrations are all well below applicable DOE DCGs. In general, the plutonium and cesium concentrations for 2000 are comparable to the lowest values seen historically, and are well below the applicable DOE DCGs. (Note that because MDC values for cesium analysis increased in May 1999, most analytical results are below their respective MDCs; see

Table 6-5.)

\section{Nonradioactive Pollutants in Sewage}

\section{Monitoring Results}

Table 6-7 presents monthly average concentrations for all regulated metals in LLNL's sanitary sewer effluent for 2000 . The averages were obtained by a flow-proportional weighting of the analytical results for the weekly composite samples collected each month. Each result was weighted by the total flow volume for the period during which the sample was 
Table 6-7. Average monthly results for regulated metals in LLNL sanitary sewer effluent (mg/L), 2000

\begin{tabular}{|c|c|c|c|c|c|c|c|c|c|}
\hline Month & $\mathbf{A g}$ & As & $\mathrm{Cd}$ & $\mathrm{Cr}$ & Cu & $\mathrm{Hg}$ & $\mathrm{Ni}$ & $\mathrm{Pb}$ & $\mathrm{Zn}$ \\
\hline Jan & 0.011 & 0.0035 & $<0.0060$ & 0.032 & 0.17 & 0.00032 & 0.0090 & 0.016 & 0.38 \\
\hline Feb & $<0.010$ & 0.0045 & $<0.010$ & 0.023 & 0.19 & 0.00038 & 0.011 & 0.017 & 0.37 \\
\hline Mar & $<0.010$ & 0.0027 & $<0.0094$ & 0.034 & 0.24 & 0.0013 & 0.012 & 0.031 & 0.60 \\
\hline Apr & $<0.010$ & 0.0047 & $<0.0057$ & 0.057 & 0.19 & 0.00054 & 0.0090 & 0.027 & 0.35 \\
\hline May & $<0.010$ & 0.0072 & $<0.0059$ & 0.13 & 0.33 & 0.00048 & 0.010 & 0.046 & 0.61 \\
\hline Jun & 0.022 & 0.0065 & $<0.0053$ & 0.13 & 0.48 & 0.00048 & 0.0042 & 0.042 & 0.71 \\
\hline Jul & 0.022 & 0.0064 & $<0.0050$ & 0.10 & 0.51 & 0.00015 & 0.026 & 0.048 & 0.79 \\
\hline Aug & $<0.010$ & 0.0055 & $<0.0050$ & 0.062 & 0.30 & 0.00045 & 0.010 & 0.026 & 0.48 \\
\hline Sep & 0.012 & 0.0050 & $<0.0050$ & 0.098 & 0.51 & 0.00085 & 0.013 & 0.058 & 0.72 \\
\hline Oct & 0.012 & 0.0086 & $<0.0050$ & 0.15 & 0.52 & 0.0012 & 0.021 & 0.047 & 0.95 \\
\hline Nov & $<0.010$ & 0.0039 & $<0.0050$ & 0.12 & 0.40 & 0.00081 & 0.011 & 0.031 & 0.74 \\
\hline Dec & $<0.010$ & 0.0020 & $<0.0071$ & 0.040 & 0.22 & 0.00041 & 0.010 & 0.012 & 0.36 \\
\hline Median & $<0.010$ & 0.0049 & $<0.0055$ & 0.080 & 0.32 & 0.00048 & 0.011 & 0.031 & 0.61 \\
\hline$I Q R^{(a)}$ & - (b) $^{\text {(b) }}$ & 0.0026 & $-^{(b)}$ & 0.084 & 0.28 & 0.00042 & 0.0025 & 0.023 & 0.35 \\
\hline $\mathrm{EPL}^{(\mathrm{c})}$ & 0.2 & 0.06 & 0.14 & 0.62 & 1 & 0.01 & 0.61 & 0.2 & 3.0 \\
\hline $\begin{array}{l}\text { Median fraction } \\
\text { of EPL }\end{array}$ & $<0.05$ & 0.08 & $<0.04$ & 0.13 & 0.32 & 0.05 & 0.020 & 0.16 & 0.20 \\
\hline
\end{tabular}

Note: Monthly values are presented with less-than signs when all weekly composite sample results for the month are below the detectable concentration.

a $\quad I Q R=$ Interquartile range

b Because of the large number of nondetects, the interquartile range cannot be calculated for these metals. See Chapter 14 .

c Effluent pollutant limit (LLNL Wastewater Discharge Permit 1999-2000 and 2000-2001)

collected. The results are generally typical of the values seen from 1994 to 1999. Figure 6-4 presents historical trends for the monthly 24-hour composite sample results from 1994 through 2000 for eight of the nine regulated metals; cadmium is not presented because this metal is typically not detected. Trends for chromium and copper continue to show the elevated average monthly concentrations observed in mid-1999, as compared with the previous years. The other metals have no discernible trends in their concentrations.

The concentrations measured in the routine analysis of LLNL sewage samples collected once a week (seven-day composite sample) and once a month (24-hour composite samples) are presented for eight of nine regulated metals as a percentage of the corresponding effluent pollutant limit (EPL) in Figure 6-5; cadmium is not present because it was detected in less than $5 \%$ of the samples, with a maximum detected value of no more than $4 \%$ of the discharge limit. The EPL is equal to the maximum pollutant concentration allowed per 24-hour composite sample, as specified by the LLNL wastewater discharge permit. When a weekly sample concentration is at or above $50 \%$ of its EPL, all daily (24-hour composite) samples collected in the SMS corresponding to the weekly sample period must be analyzed to determine if any of their concentrations are above the EPL. As 


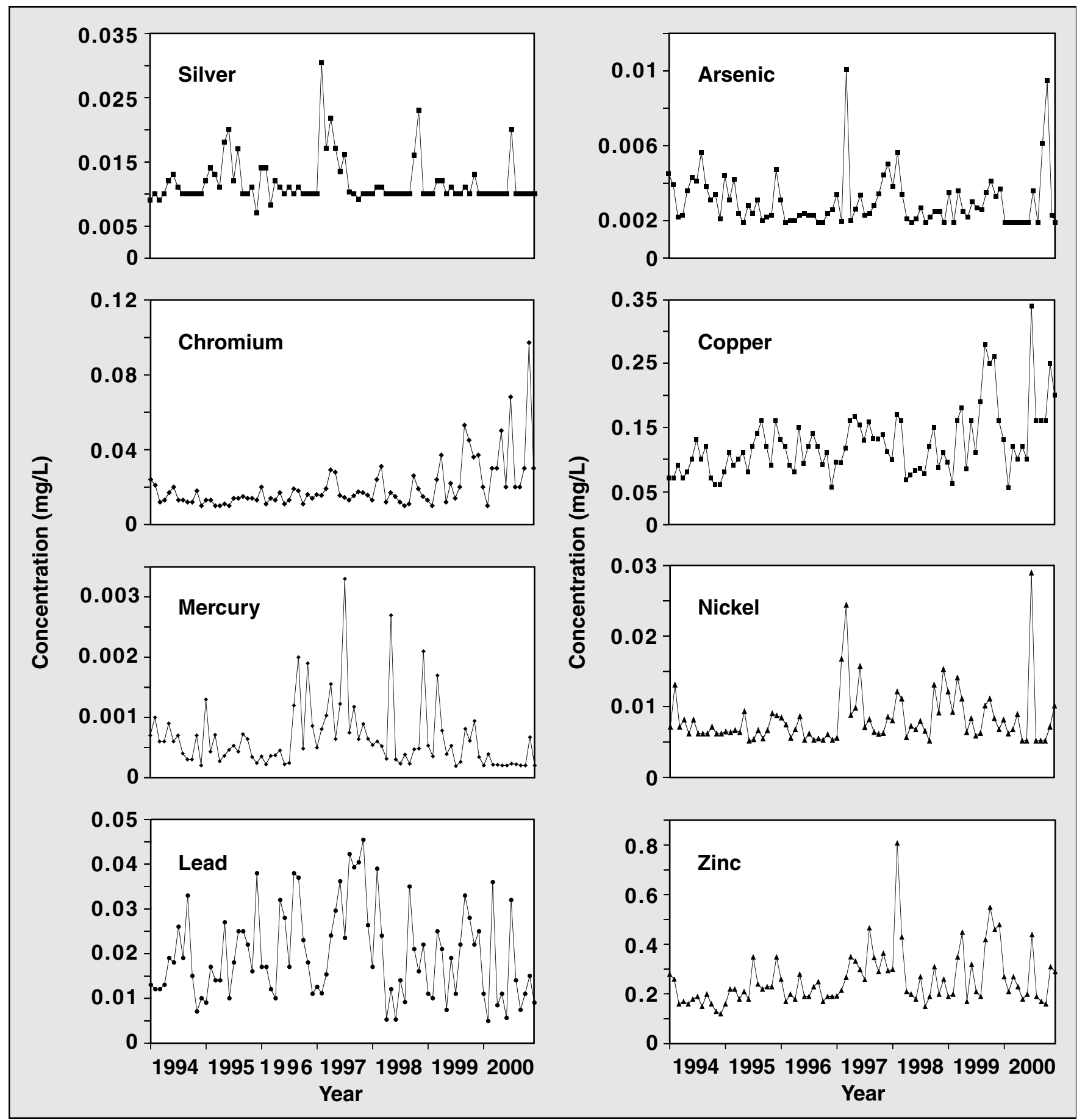

Figure 6-4. Monthly 24-hour composite sample concentrations for eight of the nine regulated metals in LLNL sanitary sewer effluent showing trends from 1994 to 2000 


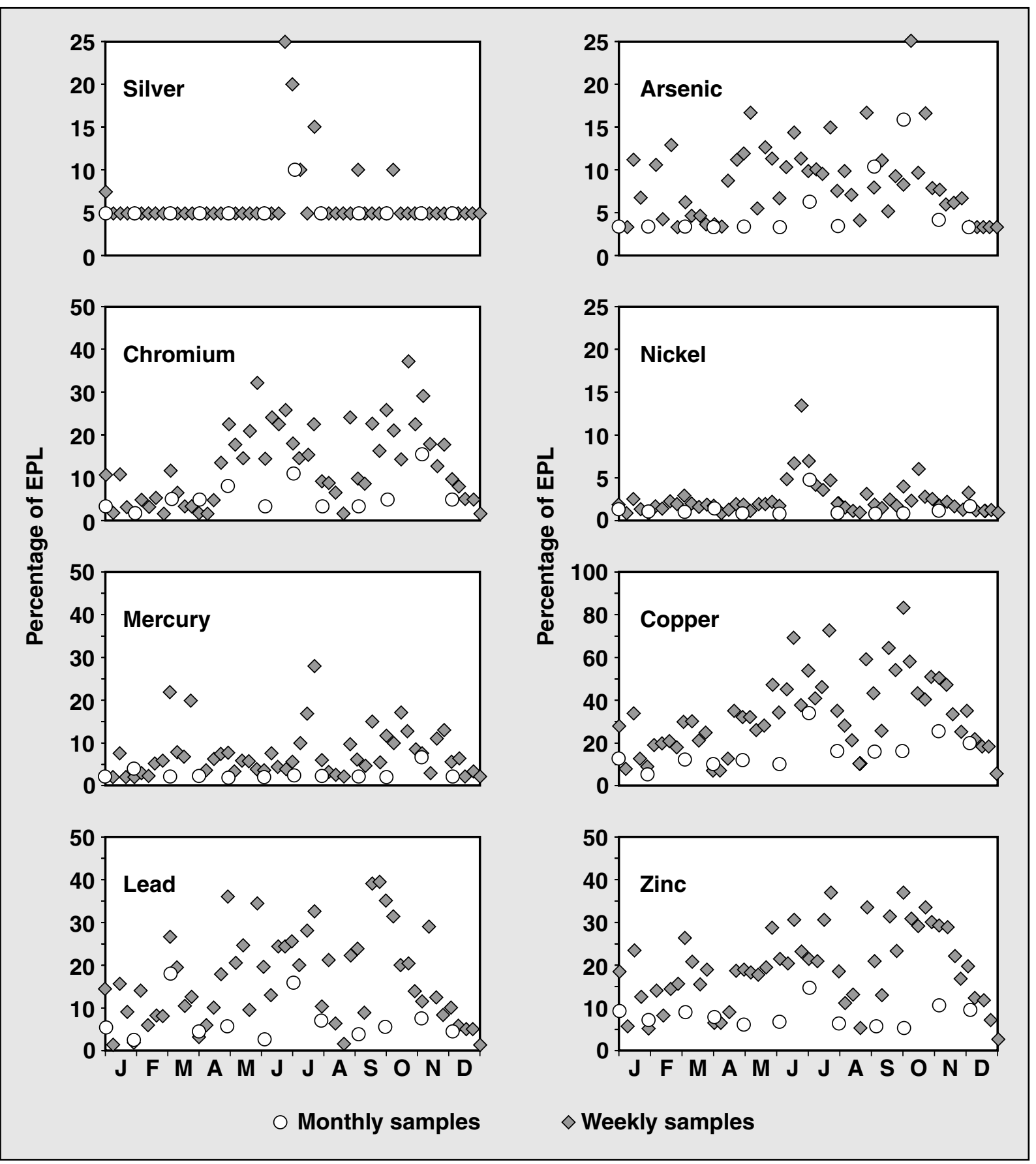

Figure 6-5. Results as percentages of effluent pollutant limits (EPLs) for eight of the nine regulated metals in LLNL sewage, 2000 
discussed further in the "Environmental Impact" section, ten weekly sample concentrations met the action level in 2000, and no monthly sample concentrations were greater than the EPL.

Detections of anions, metals, and organic compounds and summary data concerning other physical and chemical characteristics of the sanitary sewer effluent are provided in Table 6-8. (All analytical results are provided in the Data Supplement, Table 6-7.) Although samples were analyzed for bromide, nitrite (as $\mathrm{N}$ ), carbonate alkalinity (as $\mathrm{CaCO}_{3}$ ), and hydroxide alkalinity (as $\mathrm{CaCO}_{3}$ ), those analytes were not detected in any sample acquired during 2000, and so are not presented in Table 6-8. The results are quite typical of those seen in previous years except for the maximum cyanide concentration. See the "Environmental Impact" section for further discussion.

\section{Environmental Impact}

Table 6-7 presents monthly average concentrations and summary statistics for all regulated metals monitored in LLNL's sanitary sewer effluent. At the bottom of the table, the annual median concentration for each metal is compared with the discharge limit. In 2000, the metals closest to the discharge limits were copper, zinc, and lead at $32 \%$, $20 \%$, and $16 \%$, respectively.

Although monthly 24-hour composite sample results for chromium and copper have been slightly elevated since 1999 (see Figure 6-4), all of the individual weekly and monthly results for 2000 were less than $50 \%$ of the corresponding discharge limits, except for ten weekly concentrations. The daily samples that correspond to the appropriate weekly composite sampling periods were submitted for analysis. All of the analytical results for the daily samples were less than the effluent pollutant limit; no sample had a copper concentration greater than $0.35 \mathrm{mg} / \mathrm{L}$.
Table 6-8 presents summary results and statistics for monthly monitoring of physical and chemical characteristics of LLNL's sanitary sewer effluent. Although the results are generally similar to typical values seen in previous years for both the three regulated parameters (total toxic organics [TTO], cyanide, and oil and grease) and all other nonregulated parameters, there is one notable exception in the maximum value shown for cyanide.

The January 2000 semiannual compliance grab sample that was analyzed for cyanide had a concentration of $0.051 \mathrm{mg} / \mathrm{L}$. The LWRP issued an NOV to LLNL for this result because it exceeded the discharge limit of $0.04 \mathrm{mg} / \mathrm{L}$. Subsequent sampling performed in March demonstrated a return to compliance with a concentration of $<0.020 \mathrm{mg} / \mathrm{L}$. No corrective actions were required.

In 2000, the SMS continuous monitoring system detected two inadvertent discharges: one for $\mathrm{pH}$ and the other for silver. (For comparison, 4, 2, and 13 such diversions occurred in 1999, 1998, and 1997, respectively.) Neither incident represented a threat to the integrity of the operations at the LWRP. (Uncontained $\mathrm{pH}$ and metals releases of sufficient concentration and duration outside the effluent pollutant limit range could disrupt treatment plant operations or cause the treated wastewater to exceed allowable concentration limits for discharge to the San Francisco Bay.) On July 28, 2000 , the release of a caustic contaminant raised the $\mathrm{pH}$ of the LLNL effluent above the permitted value of 10 for 11 minutes during which the maximum $\mathrm{pH}$ was 11.3. The incident was not considered an enforceable exceedance of permit conditions because it did not exceed the duration criteria of 40 CFR 401.17. The event was of sufficient concentration and duration to warrant a sewage diversion, although not all effluent was captured because of a pHMS controller error (see the "Monitoring" section of this chapter); of the 
Table 6-8. Monthly monitoring results for physical and chemical characteristics of the LLNL sanitary sewer effluent, $2000^{(a)}$

\begin{tabular}{|c|c|c|c|c|c|}
\hline & $\begin{array}{c}\text { Detection } \\
\text { frequency }\end{array}$ & Minimum & Maximum & Median & $\mathrm{IQR}^{(\mathrm{c})}$ \\
\hline \multicolumn{6}{|c|}{ 24-hour composite sample parameter $(\mathrm{mg} / \mathrm{L})$} \\
\hline \multicolumn{6}{|l|}{ Alkalinity } \\
\hline Bicarbonate alkalinity $\left(\mathrm{as} \mathrm{CaCO}_{3}\right.$ ) & $12 / 12$ & 115 & 241 & 210 & 33 \\
\hline Total alkalinity $\left(\mathrm{as} \mathrm{CaCO}_{3}\right)$ & $12 / 12$ & 115 & 241 & 210 & 38 \\
\hline Anions & & & & & \\
\hline Bromide & $3 / 12$ & $<0.1$ & 0.4 & $<0.1$ & $-^{(\mathrm{d})}$ \\
\hline Chloride & $12 / 12$ & 17 & 87 & 46 & 24 \\
\hline Fluoride & $9 / 12$ & $<0.050$ & 0.28 & 0.068 & 0.05 \\
\hline Orthophosphate & $12 / 12$ & 0.90 & 20 & 16 & 4.3 \\
\hline Sulfate & $12 / 12$ & 5.9 & 16 & 9.5 & 3.3 \\
\hline \multicolumn{6}{|l|}{ Nutrients } \\
\hline Ammonia nitrogen (as $\mathrm{N}$ ) & $12 / 12$ & 20 & 56 & 40 & 14 \\
\hline Total Kjeldahl nitrogen & $12 / 12$ & 28 & 90 & 56 & 6 \\
\hline Total phosphorus (as P) & $12 / 12$ & 5.4 & 9.9 & 8.3 & 1.8 \\
\hline \multicolumn{6}{|l|}{ Oxygen demand } \\
\hline Biochemical oxygen demand & $12 / 12$ & 88 & 760 & 223 & 111 \\
\hline Chemical oxygen demand & $12 / 12$ & 260 & 910 & 486 & 208 \\
\hline \multicolumn{6}{|l|}{ Solids } \\
\hline Total dissolved solids & $12 / 12$ & 183 & 367 & 233 & 45 \\
\hline Total suspended solids & $12 / 12$ & 91 & 450 & 252 & 244 \\
\hline Volatile solids & $12 / 12$ & 74 & 474 & 220 & 257 \\
\hline \multicolumn{6}{|l|}{ Total metals } \\
\hline Calcium & $12 / 12$ & 9.2 & 30 & 14 & 7.3 \\
\hline Magnesium & $12 / 12$ & 2.1 & 3.7 & 2.5 & 0.83 \\
\hline Potassium & $12 / 12$ & 12 & 22 & 18 & 3.5 \\
\hline Total organic carbon & $12 / 12$ & 41 & 72 & 55 & 20 \\
\hline Tributyltin (ng/L) ${ }^{(\mathrm{f})}$ & $2 / 2$ & 40 & 250 & 145 & $-^{(d)}$ \\
\hline
\end{tabular}


Table 6-8. Monthly monitoring results for physical and chemical characteristics of the LLNL sanitary sewer effluent, $2000^{(a)}$ (continued)

\begin{tabular}{|c|c|c|c|c|c|}
\hline & $\begin{array}{l}\text { Detection } \\
\text { frequency }^{(b)}\end{array}$ & Minimum & Maximum & Median & $I Q R^{(c)}$ \\
\hline \multicolumn{6}{|c|}{ Grab sample parameter } \\
\hline \multicolumn{6}{|l|}{ Semivolatile organic compounds ( $\mu \mathrm{g} / \mathrm{L}$ ) } \\
\hline Benzoic acid & $6 / 12$ & $<10$ & 120 & 25 & - (d) $^{(\mathrm{n}}$ \\
\hline Benzyl alcohol & $10 / 12$ & $<2.0$ & 32 & 6.5 & $-^{(d)}$ \\
\hline Bis(2-ethylhexyl)phthalate ${ }^{(e)}$ & $10 / 12$ & $<5.0$ & 93 & 13 & 7 \\
\hline Butyl benzyl phthalate ${ }^{(\mathrm{e})}$ & $2 / 12$ & $<2.0$ & 20 & 2.0 & $-^{(d)}$ \\
\hline Diethylphthalate & $11 / 12$ & 4.2 & 22 & 12 & 8.4 \\
\hline $\mathrm{m}$ - and $\mathrm{p}$ - Cresol & $9 / 12$ & $<2.0$ & 60 & 13 & 22 \\
\hline Total cyanide (mg/L)(f) & $2 / 3$ & $<0.02$ & $<0.051^{(\mathrm{g})}$ & 0.030 & $-^{(d)}$ \\
\hline Oil and grease $(\mathrm{mg} / \mathrm{L})^{(\mathrm{f})}$ & $2 / 2$ & 11 & 17 & 14 & $-^{(d)}$ \\
\hline \multicolumn{6}{|l|}{ Volatile organic compounds ( $\mu \mathrm{g} / \mathrm{L}$ ) } \\
\hline 1,4-Dichlorobenzene & $8 / 12$ & $<0.50$ & 1.1 & 0.62 & 0.24 \\
\hline Acetone & $12 / 12$ & 74 & 550 & 145 & 183 \\
\hline Chloroform & $12 / 12$ & 5.1 & 15 & 12 & 4.6 \\
\hline Ethanol & $3 / 12$ & $<1000$ & $<4100$ & $<1000$ & $-^{(d)}$ \\
\hline Tolvene & $6 / 12$ & $<0.50$ & $<1.5$ & $<0.50$ & $-^{(d)}$ \\
\hline
\end{tabular}

a The monthly sample results plotted in Figures 6-5 and nondetected values reported in the Data Supplement, Chapter 6, are not reported in this table.

b The number of times an analyte was positively identified, followed by the number of samples that were analyzed (generally 12 , one sample for each month of the year).

c $\quad I Q R=$ Interquartile range

d When the detection frequency is less than or equal to $50 \%$, there is no range, or there are less than four results for a sample parameter, the interquartile range is omitted.

e Priority toxic pollutant parameter used in assessing compliance with the total toxic organic (TTO) permit limit of $1 \mathrm{mg} / \mathrm{L}$ $(1000 \mu \mathrm{g} / \mathrm{L})$ issued by the Livermore Water Reclamation Plant.

f Sampling for this parameter is required on a semiannual rather than a monthly basis. An additional cyanide sample was taken in March to demonstrate return to compliance.

g See the "Environmental Impact" subsection of the "Nonradioactive Pollutants in Sewage" section for a discussion of this result. 
approximately 17,000 L of effluent with $\mathrm{pH}$ greater than 10 , about $7600 \mathrm{~L}$ were captured. Subsequent analysis of all diverted effluent showed that the average $\mathrm{pH}$ was acceptable for release of the wastewater back to the sanitary sewer.

In the case of a June 26, 2000, inadvertent discharge of silver detected by the SMS, the LWRP issued an NOV for an excess of silver $(0.31 \mathrm{mg} / \mathrm{L})$ in the daily composite sample. The discharge permit limit is $0.2 \mathrm{mg} / \mathrm{L}$. This incident initiated a tenminute diversion during which approximately $8000 \mathrm{~L}$ of effluent were contained by the SDF. The diverted effluent was shipped off site for disposal.
Unlike 1999, monitoring results for $2000 \mathrm{did}$ not reflect a perfect year for LLNL's sewerable water discharge control program and Livermore site personnel. Nonetheless, LLNL achieved greater than $99 \%$ compliance with the provisions of its wastewater discharge permit. 


\section{Surface Water MONITORING}

\section{Overview}

Lawrence Livermore National Laboratory monitors surface water at the Livermore site, in surrounding regions of the Livermore Valley and Altamont Hills, and at Site 300. At the Livermore site and vicinity, LLNL monitors reservoirs and ponds, the Livermore site swimming pool, the Drainage Retention Basin (DRB), rainfall, tap water, storm water runoff, and receiving waters. At Site 300 and vicinity, surface water monitoring encompasses rainfall, cooling tower discharges, drinking water system discharges, storm water runoff, and receiving waters.

Given the diverse activities and environmental conditions at the LLNL sites and in the surrounding areas, the water samples are analyzed for several water quality parameters including radionuclides, high explosives, residual chlorine, total organic carbon, total organic halides, total suspended solids, conductivity, $\mathrm{pH}$, chemical oxygen demand, total dissolved solids, oil and grease, metals, minerals, anions, temperature, nutrients, and a wide range of organic compounds. In addition, bioassays are performed annually on water entering and leaving the Livermore site via the Arroyo Las Positas, discharges from the DRB, and water contained in the DRB.

\section{Storm Water}

This section provides a general introduction to the storm water program at LLNL, including information on permits, constituent comparison criteria, building inspections, as well as sampling methods and results. The goals of the storm water runoff monitoring program are to demonstrate compliance with permit requirements, aid in implementing the Storm Water Pollution Prevention 
Plans (SWPPPs) (Eccher et al. 1994a and b), assess the risk of storm water contamination from various potential sources, and evaluate the effectiveness of Best Management Practices (BMPs) for preventing storm water contamination.

\section{General Information}

\section{Permits}

To assess compliance with permit requirements, LLNL monitors storm water at the Livermore site in accordance with Waste Discharge Requirements (WDR 95-174), National Pollutant Discharge Elimination System permit (NPDES Permit No. CA0030023), issued in 1995 by the San Francisco Bay Regional Water Quality Control Board (SFBRWQCB 1995). In August 2000, the Central Valley Regional Water Quality Control Board (CVRWQCB) rescinded WDR 94-131, NPDES Permit No. CA0081396 for Site 300. LLNL submitted a Notice of Intent (NOI) to the State Water Resources Control Board (SWRCB) to cover storm water discharges at Site 300 previously permitted by WDR 94-131 under the Statewide General NPDES Permit for Storm Water Discharges Associated with Industrial Activity (WDR 97-03-DWQ, NPDES Permit No. CAS000001, SWRCB). In addition, Site 300 storm water monitoring meets the requirements of the Post-Closure Plan for the Pit 6 Landfill Operable Unit (Ferry et al. 1998). These permits include specific monitoring and reporting requirements. In addition to the storm water quality constituents required by the permits, LLNL monitors other constituents to provide a more complete water quality profile. The current list of analyses provided for storm water samples is given in Table 7-1.

Storm water monitoring follows the requirements in the Environmental Regulatory Guide for Radiological Effluent Monitoring and Environmental Surveillance (U.S. DOE 1991) and meets the applicable requirements of DOE Order 5400.1, General Environmental Protection Program, and DOE Order 5400.5, Radiation Protection of the Public and the Environment.

NPDES permits for storm water require that LLNL sample effluent two times per year. In addition, LLNL is required to visually inspect the storm drainage system monthly during the wet season, whenever significant storms occur, and twice during the dry season to identify any dry weather flows. Influent sampling is also required at the Livermore site. LLNL monitors up to two more storm events each year at the Livermore site (a total of four sampling events) in support of DOE Orders 5400.1 and 5400.5. In addition, annual facility inspections are required to ensure that the BMPs are adequate and implemented.

LLNL also meets the storm water compliance monitoring requirements of the Statewide General NPDES Permit for Storm Water Discharges Associated with Construction Activity (Order 99-08DWQ, NPDES Permit No. CAS000002) for construction projects that disturb two hectares of land or more (SWRCB 1999).

\section{Constituent Criteria}

Currently, there are no numeric criteria that limit concentrations of specific constituents in LLNL's storm water effluent. The Environmental Protection Agency (EPA) established parameter benchmark values, but stressed that these concentrations were not intended to be interpreted as effluent limits (U.S. EPA 2000). Rather, the values are levels that the EPA has used to determine if storm water discharged from any given facility merits further monitoring. Although these criteria are not directly applicable, they are used as comparison criteria to help evaluate LLNL's storm water management program. To further evaluate the storm water management program, LLNL established or calculated site-specific threshold 
Table 7-1. Analyses conducted on storm water samples, 2000

\begin{tabular}{|l|l|}
\hline \multicolumn{1}{|c|}{ Livermore site } & \multicolumn{1}{|c|}{ Site $\mathbf{3 0 0}$} \\
\hline Specific conductance & Specific conductance \\
Total suspended solids (TSS) & Total dissolved solids (TDS) \\
$\mathrm{pH}$ & TSS \\
Chemical oxygen demand (COD) & pH \\
Fish bioassay (fathead minnow) & Potassium \\
Anions & Beryllium \\
General minerals & Mercury \\
Metals & Volatile organic compounds (VOCs) \\
Volatile organic compounds (VOCs) & Semivolatile organic compounds (SVOCs) \\
Semivolatile organic compounds (SVOCs) & Pesticides \\
Pesticides & PCBs \\
Oil and grease & Total organic halides \\
PCBs & Total organic carbon \\
Total organic carbon & Dioxins \\
Gross alpha and beta & Explosives \\
Tritium & Gross alpha and beta \\
Plutonium & Tritium \\
& Uranium \\
\hline
\end{tabular}

comparison criteria for a select group of parameters. A value exceeds the threshold if it is greater than the $95 \%$ confidence limit computed for the historical mean value for a specific parameter. A value that deserves further attention would therefore be in the upper $5 \%$ of recorded values (Table 7-2). The threshold comparison criteria are used to identify out-of-the-ordinary data that merit further investigation to determine if concentrations of that parameter are increasing in the storm water runoff.

For a better understanding of how LLNL storm water data relate to other target values, water samples are also compared with criteria listed in the Water Quality Control Plan, San Francisco Bay Basin (SFBRWQCB 1995), The Water Quality
Control Plan (Basin Plan) for the California Regional Water Quality Control Board, Central Valley Region, Sacramento and San Joaquin River Basins (Longley et al. 1994), EPA maximum contaminant levels (MCLs), and ambient water quality criteria (AWQC). The greatest importance is placed on the site-specific comparison criteria calculated from historical concentrations in storm runoff.

In addition to chemical monitoring, LLNL is required by NPDES permit WDR 95-174 to conduct acute and chronic fish toxicity testing in Arroyo Las Positas (Livermore site) once per wet season (defined as October of one year through April of the following year). Currently, LLNL is not required to test for fish toxicity at Site $\mathbf{3 0 0}$. 
Table 7-2. Threshold comparison criteria for selected water quality parameters. The sources of values above these are examined to determine if any action is necessary.

\begin{tabular}{|c|c|c|}
\hline Parameter & Livermore site & Site 300 \\
\hline $\begin{array}{l}\text { Total suspended } \\
\text { solids (TSS) }\end{array}$ & $750 \mathrm{mg} / \mathrm{L}^{(\mathrm{a})}$ & $1700 \mathrm{mg} / \mathrm{L}^{\text {(a) }}$ \\
\hline $\begin{array}{l}\text { Chemical oxygen } \\
\text { demand (COD) }\end{array}$ & $200 \mathrm{mg} / \mathrm{L}^{(\mathrm{a})}$ & not monitored \\
\hline $\mathrm{pH}$ & $<6.0,>8.5^{(a)}$ & $<6.0,>9.0^{(b)}$ \\
\hline Nitrate (as $\mathrm{NO}_{3}$ ) & $10 \mathrm{mg} / \mathrm{L}^{(a)}$ & not monitored \\
\hline Orthophosphate & $2.5 \mathrm{mg} / \mathrm{L}^{(\mathrm{a})}$ & not monitored \\
\hline Mercury & above $\mathrm{RL}^{(\mathrm{c})}$ & above $\mathrm{RL}^{(\mathrm{c})}$ \\
\hline Beryllium & $0.0016 \mathrm{mg} / \mathrm{L}^{(\mathrm{a})}$ & $0.0016 \mathrm{mg} / \mathrm{L}^{(a)}$ \\
\hline Chromium(VI) & $0.016 \mathrm{mg} / \mathrm{L}^{(\mathrm{d})}$ & not monitored \\
\hline Copper & $0.013 \mathrm{mg} / \mathrm{L}^{(\mathrm{d})}$ & not monitored \\
\hline Lead & $0.015 \mathrm{mg} / \mathrm{L}^{(\mathrm{e})}$ & $0.015 \mathrm{mg} / \mathrm{L}^{(\mathrm{a})}$ \\
\hline Zinc & $0.117 \mathrm{mg} / \mathrm{L}^{(\mathrm{b})}$ & not monitored \\
\hline Diuron & $0.014 \mathrm{mg} / \mathrm{L}^{(\mathrm{a})}$ & not monitored \\
\hline Oil and grease & $9 \mathrm{mg} / \mathrm{L}^{(a)}$ & $9 \mathrm{mg} / \mathrm{L}^{(\mathrm{a})}$ \\
\hline Tritium & $36 \mathrm{~Bq} / \mathrm{L}^{(\mathrm{a})}$ & $3.17 \mathrm{~Bq} / \mathrm{L}^{(\mathrm{a})}$ \\
\hline Gross alpha & $0.34 \mathrm{~Bq} / \mathrm{L}^{(\mathrm{a})}$ & $0.90 \mathrm{~Bq} / \mathrm{L}^{(\mathrm{a})}$ \\
\hline Gross beta & $0.48 \mathrm{~Bq} / \mathrm{L}^{(\mathrm{a})}$ & $1.73 \mathrm{~Bq} / \mathrm{L}^{(\mathrm{a})}$ \\
\hline
\end{tabular}

a Site-specific value calculated from historical data and studies. Most of these values are lower than the maximum contaminent levels (MCLs) or EPA benchmark values for drinking water except for TSS, COD, and Site 300 gross alpha, which have been demonstrated to be consistent with background values.

b EPA benchmark (calculated at $100 \mathrm{mg} / \mathrm{L} \mathrm{CaCO}_{3}$ hardness for zinc)

c $\quad \mathrm{RL}=$ reporting limit $=0.0002 \mathrm{mg} / \mathrm{L}$

d Ambient water quality criteria

e EPA primary maximum contaminant level (PMCL)

\section{Inspections}

Each directorate at LLNL conducts an annual inspection of its facilities to verify implementation of the SWPPPs and to ensure that measures to reduce pollutant loadings to storm water runoff are implemented. The Laboratory's associate directors certified in 2000 that their facilities comply with the provisions of WDR 94-131, WDR 95-174, and the SWPPPs. The deputy director for operations certifies the facilities directly reporting to the Director's Office, except those facilities in the Laboratory Site Operations organization, which are certified by the Laboratory Site Manager. LLNL submits annual storm water monitoring reports to the SFBRWQCB and to the CVRWQCB with the results of sampling, observations, and inspections.

Monitoring for construction projects permitted by Order 99-08-DWQ includes visual observations of construction sites by the construction staff before, during, and after storms to assess the effectiveness of implemented BMPs. Annual compliance certifications summarize these inspections.

As in past years, the SFBRWQCB requested submission of compliance status reports for the Livermore site construction projects. (The CVRWQCB has never requested compliance status reports for projects located at Site 300.) The 2000 compliance certifications (and compliance status reports) covered the period of June 1999 through May 2000. During this period, three Livermore site projects were inspected: the Decontamination and Waste Treatment Facility (DWTF), the National Ignition Facility (NIF), and the areas associated with the Soil Reuse Project. One Site 300 project, the Contained Firing Facility, was also inspected under this program.

\section{Sampling}

For the purpose of evaluating the overall impact of Livermore site and Site 300 operations on storm water quality, storm water flows are sampled at upstream and downstream locations. Because of flow patterns at the Livermore site, storm water at sampling locations includes water running onto the site from other sources, such as neighboring agricultural land, parking lots, and landscaped areas. In contrast, storm water at Site 300 is sampled at 
locations that target specific industrial activities, with no run-on from off-site sources. These samples provide information used to evaluate the effectiveness of LLNL's storm water pollution control program.

Livermore Site: As is commonly the case in urbanized areas, the surface water bodies and runoff pathways at LLNL do not represent the historical natural conditions. The drainage at the Livermore site was altered by construction activities several times up to 1966 (Thorpe et al. 1990) so that the current northwest flow of Arroyo Seco and the westward flow of Arroyo Las Positas do not represent historical flow paths. About $1.6 \mathrm{~km}$ to the west of the Livermore site, Arroyo Seco merges with Arroyo Las Positas, which continues to the west to eventually merge with Arroyo Mocho (see Figure 7-1).

The DRB was excavated and lined in 1992 to prevent infiltration of storm water that was dispersing groundwater contaminants. It also serves storm water diversion and flood control purposes. The DRB collects about one-fourth of the surface water runoff from the site and a portion of the Arroyo Las Positas drainage (Figure 7-2). When full, the DRB discharges north to a culvert that leads to Arroyo Las Positas. The remainder of the site drains either directly or indirectly into the two arroyos by way of storm drains and swales. Arroyo Seco cuts across the southwestern corner of the site. Arroyo Las Positas follows the northeastern and northern boundaries of the site and exits the site near the northwest corner.

The routine Livermore site storm water runoff monitoring network consists of nine sampling locations (Figure 7-2). Six locations characterize storm water either entering (influent: ALPE, ALPO, ASS2, and GRNE) or exiting (effluent: ASW and WPDC) the Livermore site. Locations
$\mathrm{CDB}$ and $\mathrm{CDB} 2$ characterize runoff from the southeastern quadrant of the Livermore site entering the DRB, and location CDBX characterizes water leaving the DRB. Additional locations were sampled beginning in 1999 and continuing through 2000 as part of a tritium source investigation and are described in the Livermore Site Radioactive Constituents section in this chapter.

Site 300: Surface water at Site 300 consists of seasonal runoff, springs, and natural and man-made ponds. The primary waterway in the Site 300 area is Corral Hollow Creek, an ephemeral stream that borders the site to the south and southeast. No naturally continuously flowing streams are present in the Site 300 area. Elk Ravine is the major drainage channel for most of Site 300; it extends from the northwest portion of the site to the eastcentral area. Elk Ravine drains the center of the site into Corral Hollow Creek, which drains eastward to the San Joaquin River Basin. Some smaller canyons in the northeast portion of the site drain to the north and east toward Tracy.

There are at least 23 springs at Site 300 . Nineteen are perennial, and four are intermittent. Most of the springs have very low flow rates and are recognized only by small marshy areas, pools of water, or vegetation. Numerous artificial surface water bodies are present at Site 300. A sewage evaporation pond and a sewage percolation pond are located in the southeast corner of the site in the General Services Area (GSA), and two lined, high-explosives (HE) surface water impoundments are located to the west in the Explosives Process Area. Monitoring results associated with these facilities are reported in Chapter 9. Three wetlands created by now-discontinued flows from cooling towers located at Buildings 827, 851, and 865 are currently maintained by discharges of potable water. 


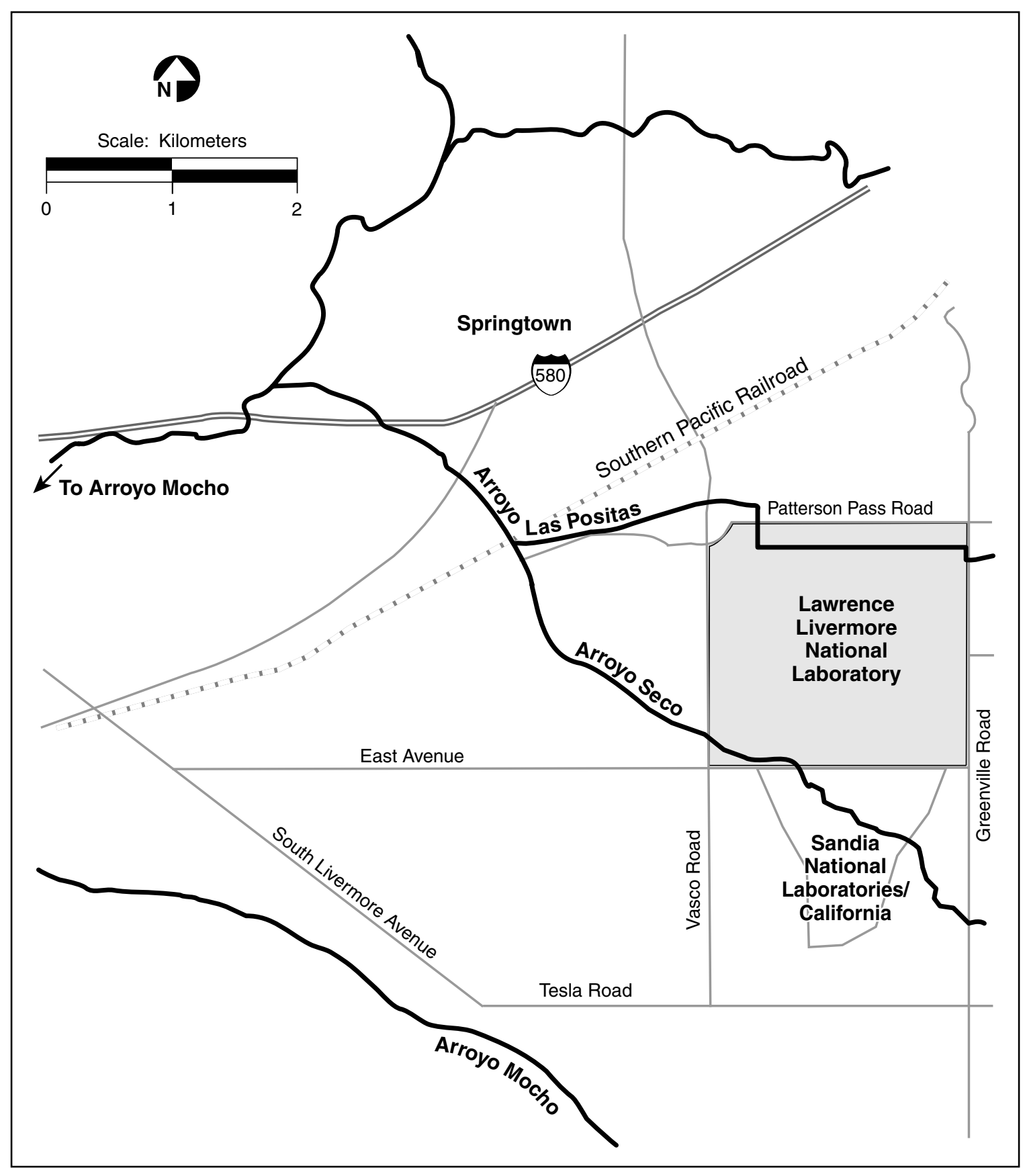

Figure 7-1. Surface waterways in the vicinity of the Livermore site 


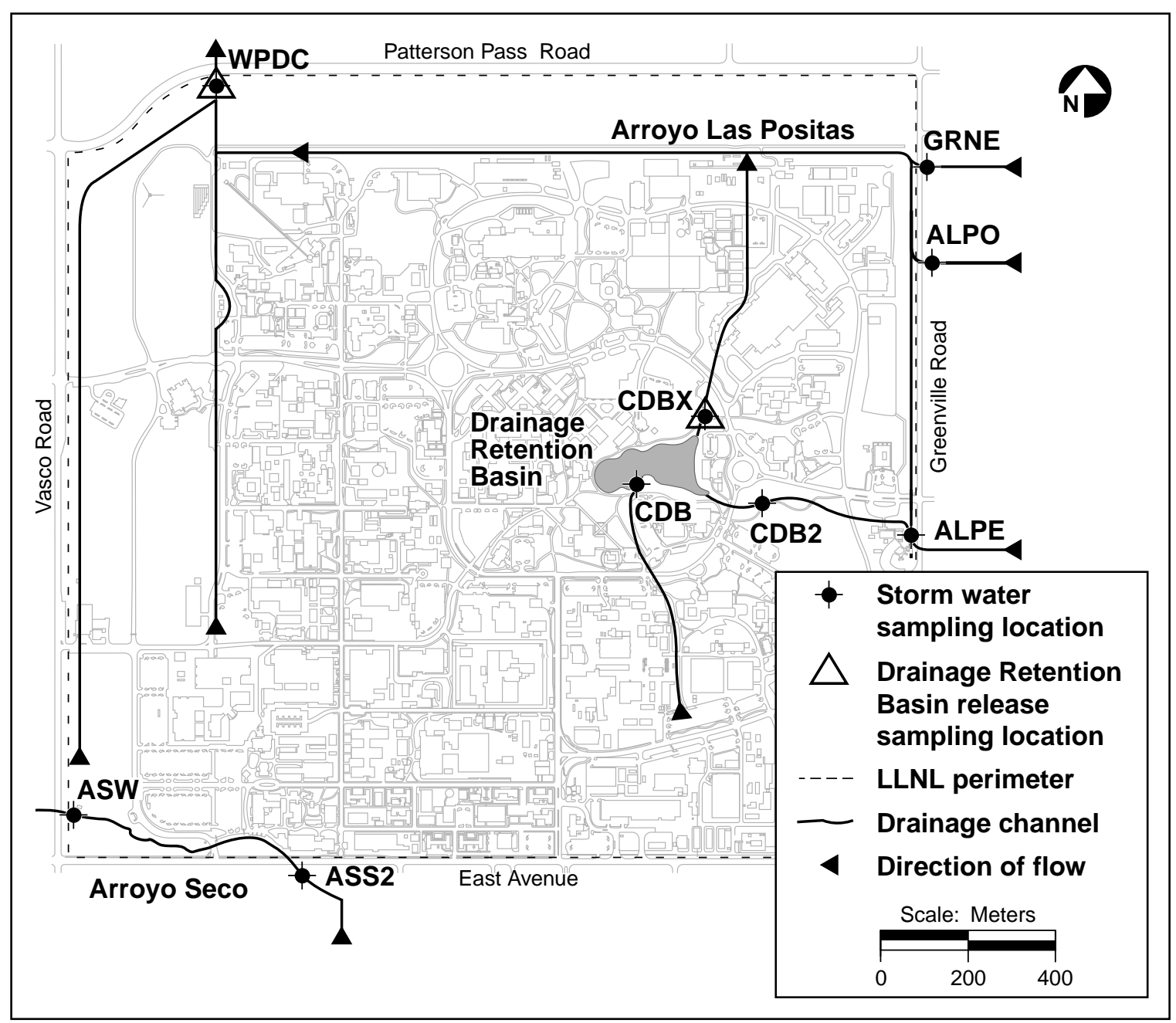

Figure 7-2. Storm water runoff and Drainage Retention Basin discharge sampling locations, Livermore site, 2000

The on-site Site 300 storm water sampling network began in 1994 with six locations and now consists of seven locations (Figure 7-3). L ocations were selected to characterize storm water runoff at locations that could be affected by specific Site 300 activities.

O ff-site location CARW is used to characterize runoff in Corral H ollow Creek upstream and therefore is unaffected by Site 300 industrial activities. Location GEOCRK is used to characterize runoff in Corral H ollow Creek, downstream of Site 300.

\section{Methods}

At all monitoring locations at both the Livermore site and Site 300, samples are collected by grab sampling from the storm runoff flowing in the stream channels. Standard sample bottle requirements, special sampling techniques, and preservation requirements for each analyte are specified in the Environmental M onitoring Plan (Tate et al. 1999) and summarized below. 


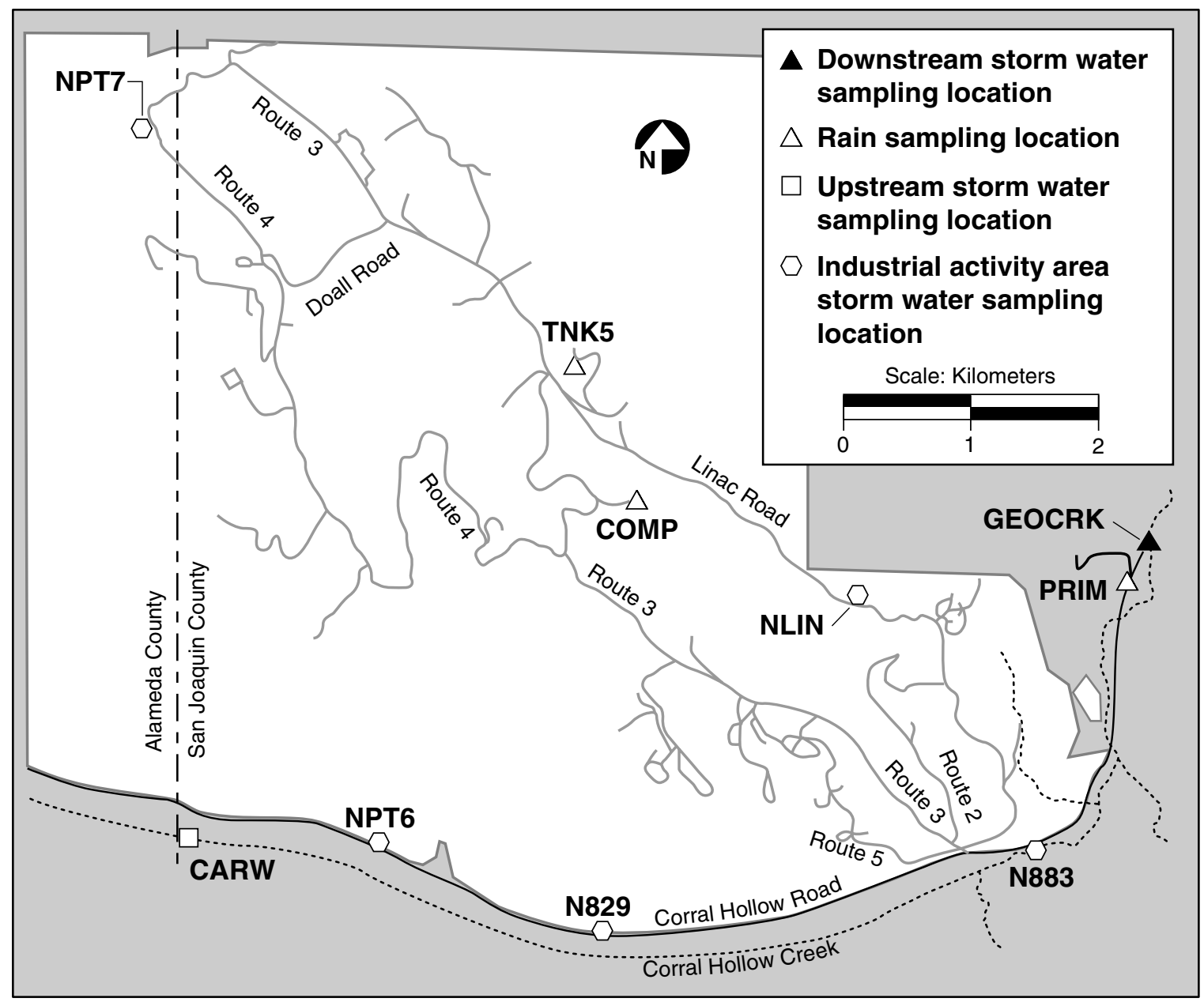

Figure 7-3. Stormwater and rainwater sampling locations at Site 300, 2000

Grab samples are collected by partially submerging sample bottles directly into the water and allowing them to fill with the sample water. If the water to be sampled is not directly accessible, a stainlesssteel bucket or an automatic water sampler is used for sampling. The bucket is triple-rinsed with the water to be sampled, then dipped or submerged into the water, and withdrawn in a smooth motion. Sampling is conducted away from the edge of the arroyo to minimize the collection of sediment with water samples. Sample vials for volatile organics are filled before sample vials for all other constituents and parameters.

\section{Results}

\section{Inspections}

In accordance with WDR 95-174 and the LLNL SWPPP, all 12 directorate-level organizations at the Livermore site conducted the permit-required annual inspections during 2000. These inspections of more than 500 facilities indicated that all BMPs were in place, implemented, and adequate to protect storm water in all but seven instances at the Livermore site. Three of the exceptions noted were the absence of BMPs for the outdoor storage of materials (stored product, as well as cans of gasoline and chemical sealant). The gasoline cans were 
removed and the chemical sealant moved indoors, while the product materials were moved to a proper location. Work is progressing to transfer and ultimately dispose of the material. Additionally, excess equipment in the Building 235 dock area, contaminated with a photo-processing chemical by-product, has been decontaminated. The need for better runoff controls and a drainage swale were identified at Trailer 6303 and Building 622, respectively. Finally, it was determined that the beryllium found to be a roof contaminant at Building 241 is not mobile and poses no threat for storm water contamination. All Site 300 inspections of more than 100 facilities indicated that the applicable BMPs were in place, implemented, and adequate to protect storm water.

Additionally, LLNL conducted the permit-required inspections before, during, and after rain events at four permitted construction sites: three at the Livermore site and one at Site 300. The findings of these inspections indicated compliance with the permit and the construction site SWPPPs, with two exceptions documented in the 1999/2000 annual compliance certifications:

- The DWTF project did not update its SWPPP by the required deadline because construction operations were suspended. The DWTF SWPPP was revised prior to the recommencement of construction operations.

- The NIF project did not have the date of inspection on some of the inspection forms as required. The NIF storm water inspection forms were revised for the $2000 / 2001$ rainy season.

\section{Livermore Sampling}

LLNL collected samples at all nine Livermore site locations on March 8, 2000. Earlier samples were collected from six locations on January 11 and February 14, 2000. The three monitoring loca- tions that were not sampled on these dates were those where storm runoff flows into and out of the DRB. The fish and algae toxicity analyses were conducted during the January 11, 2000, sampling in order to catch the first flush that occurs at the beginning of the wet season.

Toxicity Monitoring: As required by WDR 95-174, grab samples were collected and analyzed for acute and chronic toxicity using the fathead minnow (Pimephales promelas) as the test species. The acute, 96-hour survival test was observed in undiluted storm water collected from location WPDC. The permit states that an acceptable survival rate is $20 \%$ lower than the survival rate of the control sample. The testing laboratory provides water for the quality control sample. As specified by the permit, upgradient water from influent locations ALPE, ALPO, and GRNE is used as an additional control. Thus, a difference of more than $20 \%$ between location WPDC and the control sample with the lowest survival rate is considered a failed test. If the test is failed, the permit requires LLNL to conduct additional toxicity testing during the next significant storm event. If two consecutive tests fail, LLNL must perform a toxicity reduction evaluation to identify the source of the toxicity. Survival in the acute test at WPDC and all corresponding influent locations (ALPE, ALPO, and GRNE) was 100\% in 2000.

In the chronic test, storm water dilutions of 0 (laboratory control), 6.25, 12.5, 25, 50, and 100\% (undiluted storm water) were used to determine a dose-response relationship, if any, for both survival and growth of the fathead minnow (see Table 7-3). No criteria are set by the permit for this test. In addition, this test is performed only on water from the effluent location (WPDC) and not on water from influent locations, so it is difficult to determine if toxicity should be attributed to LLNL or to upgradient water quality. From the data collected for this test, no observed effect concentrations 
Table 7-3. Fish chronic toxicity test results, Livermore site, 2000

\begin{tabular}{|c|c|c|c|c|}
\hline $\begin{array}{c}\text { Sample } \\
\begin{array}{c}\text { Concen- } \\
\text { tration } \\
(\%)\end{array}\end{array}$ & \multicolumn{2}{|c|}{ 7-day survival } & \multicolumn{2}{|c|}{ 7-day weight } \\
\cline { 2 - 5 } & $\begin{array}{c}\text { Average } \\
(\%)\end{array}$ & $\begin{array}{c}\text { Standard } \\
\text { deviation }\end{array}$ & $\begin{array}{c}\text { Average } \\
\text { (mg) }\end{array}$ & $\begin{array}{c}\text { Standard } \\
\text { deviation }\end{array}$ \\
\hline Lab control & 98 & 5.0 & 0.56 & 0.046 \\
6.25 & 85 & 12.9 & 0.62 & 0.094 \\
12.5 & 95 & 5.8 & 0.57 & 0.054 \\
25 & 100 & 0 & 0.6 & 0.064 \\
50 & 98 & 5.0 & 0.65 & 0.042 \\
100 & 98 & 5.0 & 0.48 & 0.069 \\
\hline
\end{tabular}

a Weight of the fathead minnows at the end of the 7-day toxicity test

(NOECs) or lowest observed effect concentrations (LOECs) were calculated using EPA/600/4-91002. The NOECs and LOECs for survival and growth were $100 \%$. Thus, both the acute and chronic fish toxicity tests indicated that storm water had no effect on survival or growth of the fathead minnow.

In addition to the flathead minnow toxicity test required by WDR 95-174, additional chronic toxicity tests for daphnid (Ceriodaphnia dubia) and freshwater algae (Selenastrum capriocornutum) were performed for water sampled at location WPDC on January 11, 2000. These additional tests were inadvertently performed by the analytical laboratory. These toxicity tests use the same dilutions as those described for the chronic fish toxicity. The daphnid toxicity is established with a 6-day survival test, and algae toxicities established by growth (cell counts) over a 96-hour period.

Toxicity was not observed in the daphnid test. However, algae growth was inhibited in the storm runoff compared with the control sample, with an NOEC of $12.5 \%$ and an LOEC of $25 \%$

(Table 7-4). As this toxicity test was conducted only at the effluent location (WPDC), there is no clear determination of whether algae growth was inhibited by an upstream activity or by activities at LLNL. However, past water quality data have indicated moderately high herbicide concentrations, specifically diuron, at one of the influent sampling locations (GRNE) in a tributary to Arroyo Las Positas (Figure 7-4). The influent concentrations of this herbicide, such as the peaks shown at GRNE in 1997 and 1999, are often higher than the effluent waters from LLNL. One exception is the peak in January 1999 at WPDC; however, this single peak was much smaller than the other peaks measured at GRNE. Influent concentrations of diuron were higher than effluent concentrations in 2000. Therefore, if the diuron is impacting algae growth in the storm water, then the problem is likely caused by an upstream source. Monitoring of algae toxicity will continue in 2001 to determine if this problem persists.

Table 7-4. Algae chronic toxicity test results, Livermore site, 2000

\begin{tabular}{|c|c|c|}
\hline \multirow{2}{*}{$\begin{array}{c}\text { Sample } \\
\text { concentration } \\
(\%)\end{array}$} & \multicolumn{2}{|c|}{ 96-hour growth } \\
\cline { 2 - 3 } & $\begin{array}{c}\text { Count } \\
\left(10^{5} \text { cells } / \mathrm{mL}\right)\end{array}$ & $\begin{array}{c}\text { Variance } \\
(\%)\end{array}$ \\
\hline Lab control & 11.9 & 10.2 \\
6.25 & 11.6 & 9.0 \\
12.5 & 12.5 & 6.4 \\
25 & 10.1 & 9.9 \\
50 & 6.0 & 8.3 \\
100 & 5.0 & 7.7 \\
\hline
\end{tabular}

\section{Livermore Site Radioactive Constituents:}

Storm water sampling and analysis were performed for gross alpha, gross beta, plutonium, and tritium. Storm water gross alpha, gross beta, and tritium results are summarized in Table 7-5. Complete results are in Data Supplement Tables 7-1, 7-2, and 7-3. Tritium activities at effluent locations were less than $4 \%$ of the respective MCLs. Figures 7-5 through 7-8 show the historical activities of gross 


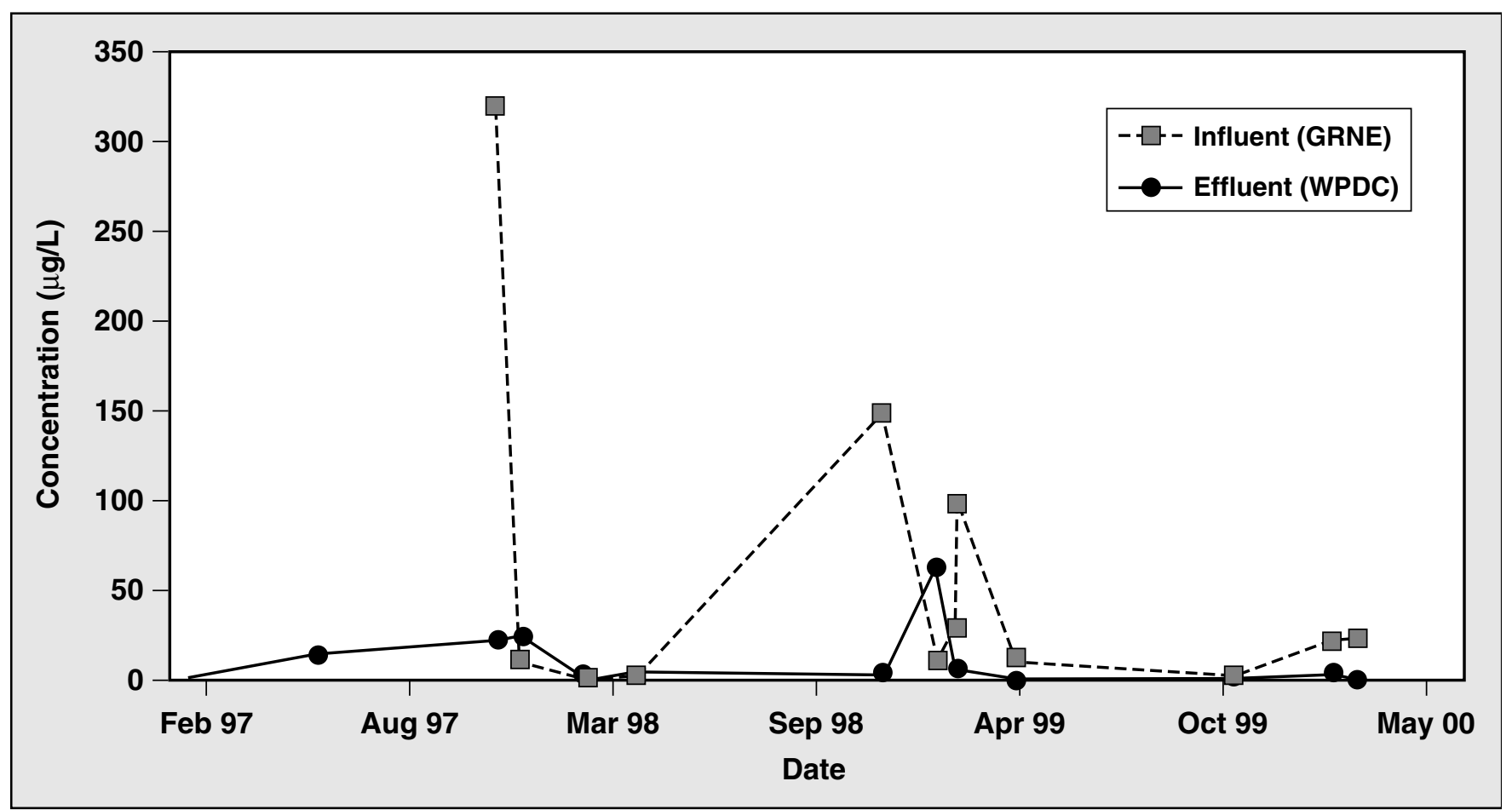

Figure 7-4. Diuron concentrations in Arroyo Las Positas storm water 1997-2000

Table 7-5. Radioactivity in storm water from the Livermore site, $2000^{(a)}$

\begin{tabular}{|l|c|c|c|}
\hline Locations & $\begin{array}{c}\text { Tritium } \\
(\mathrm{Bq} / \mathrm{L})\end{array}$ & $\begin{array}{c}\text { Gross alpha } \\
(\mathrm{Bq} / \mathrm{L})\end{array}$ & $\begin{array}{c}\text { Gross beta } \\
(\mathrm{Bq} / \mathrm{L})\end{array}$ \\
\hline MCL & 740 & 0.555 & 1.85 \\
\hline Influent & & & \\
Median & 0.316 & 0.140 & 0.278 \\
Minimum & -1.162 & 0.015 & 0.091 \\
Maximum & 2.683 & 0.685 & 1.040 \\
Effluent & & & \\
Median & 1.395 & 0.068 & 0.200 \\
Minimum & 0.129 & 0.031 & 0.189 \\
Maximum & 27.232 & 0.714 & 1.162 \\
\hline
\end{tabular}

a See Chapter 14 for a complete explanation of calculated values. alpha and gross beta, respectively, in storm runoff. There is no discernible trend in any of these figures. However, activities in water running on and off site are highly correlated.

LLNL began analyzing for plutonium in storm water in 1998. Samples were analyzed from the Arroyo Seco and Arroyo Las Positas effluent locations (ASW and WPDC). The unfiltered water was analyzed when the samples were low in suspended sediments. When the analytical laboratory determined that water samples contained sufficient sediment (as it did on January 11, 2000), a portion of the runoff was analyzed unfiltered, and the remaining runoff was filtered. The filtrate and filtered water were analyzed (three analyses total from each location). Plutonium was not found to be at activities above the detection limit for either the liquid or sediment portion of the storm water 


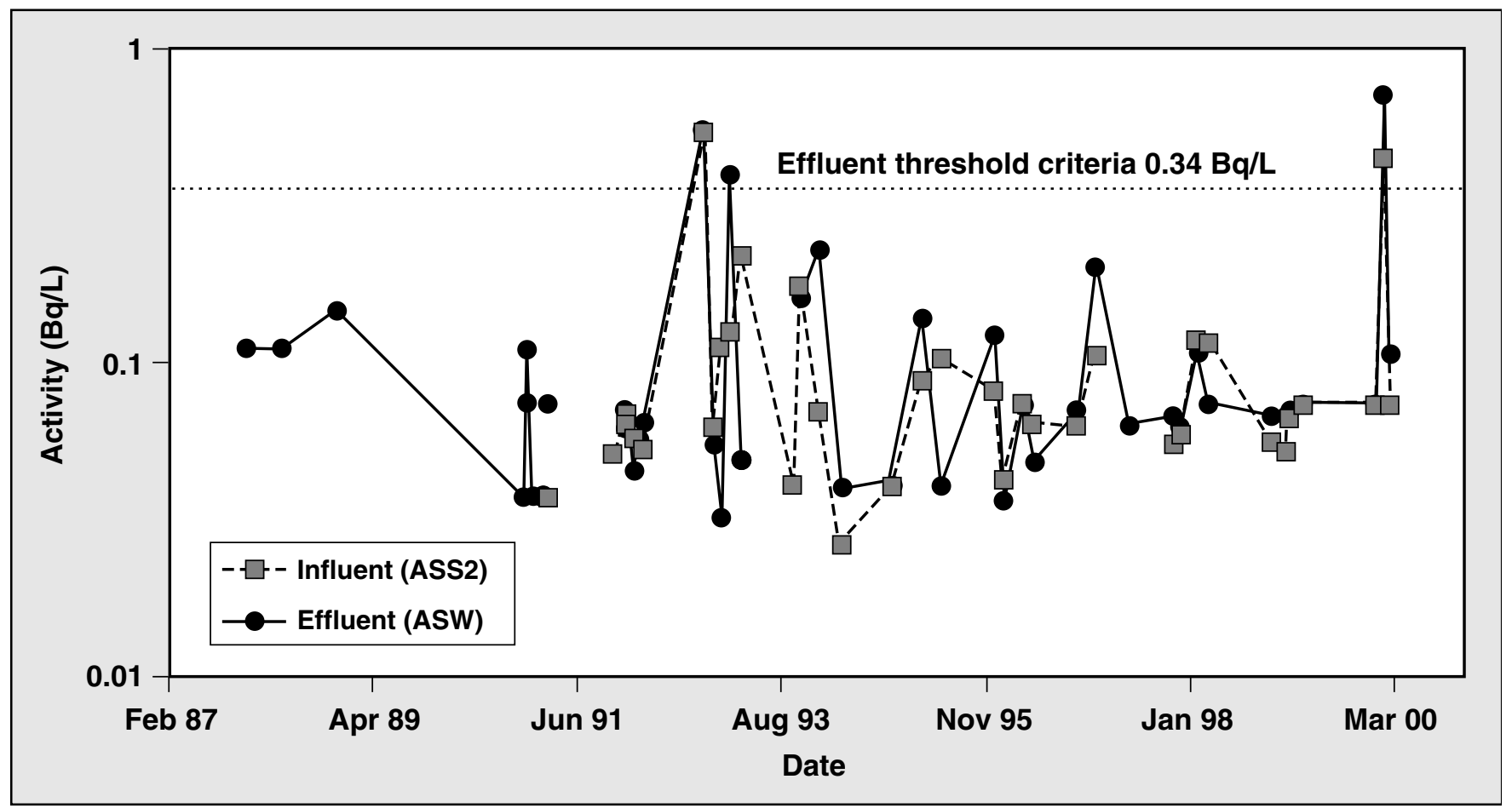

Figure 7-5. Gross alpha activities in Arroyo Seco storm water at the Livermore site compared with the LLNL site-specific threshold shown in Table 7-2

samples in 2000. Thus, there is no evidence in the data to indicate that LLNL has contributed plutonium to runoff. Complete plutonium results are found in Data Supplement Table 7-3.

Beginning with the 1996/1997 season, the tritium activity in Arroyo Las Positas was observed to be higher in storm water leaving the site than in storm water entering the site. On May 23, 1997, at location WPDC, where effluent is measured, a single higher-than-typical result for tritium in storm water (359 Bq/L) was measured. The historical trend in tritium levels at location WPDC is presented in Figure 7-9.

In response to the elevated effluent tritium levels, additional tritium investigations were initiated in the fall of 1998 to reconfirm the current evidence that effluent tritium activity is greater than influent tritium activity, and to identify potential sources of tritium to the storm runoff. These investigations included:

- Review of air tritium sampling results

- Increased frequency of rain sampling

- Increased frequency and number of locations of storm water sampling

The initial approach taken to evaluate tritium flow patterns across the Livermore site was to evaluate four locations upstream of WPDC (WPDW, 196S, WPDS, and 196E) (Figure 7-10), where the storm drainage channels join the main Arroyo Las Positas channel and leave the Livermore site. Samples were collected at these junctures on November 30, 1998, and reported in the Environmental Report 1998 (Larson et al. 1999). Tritium 


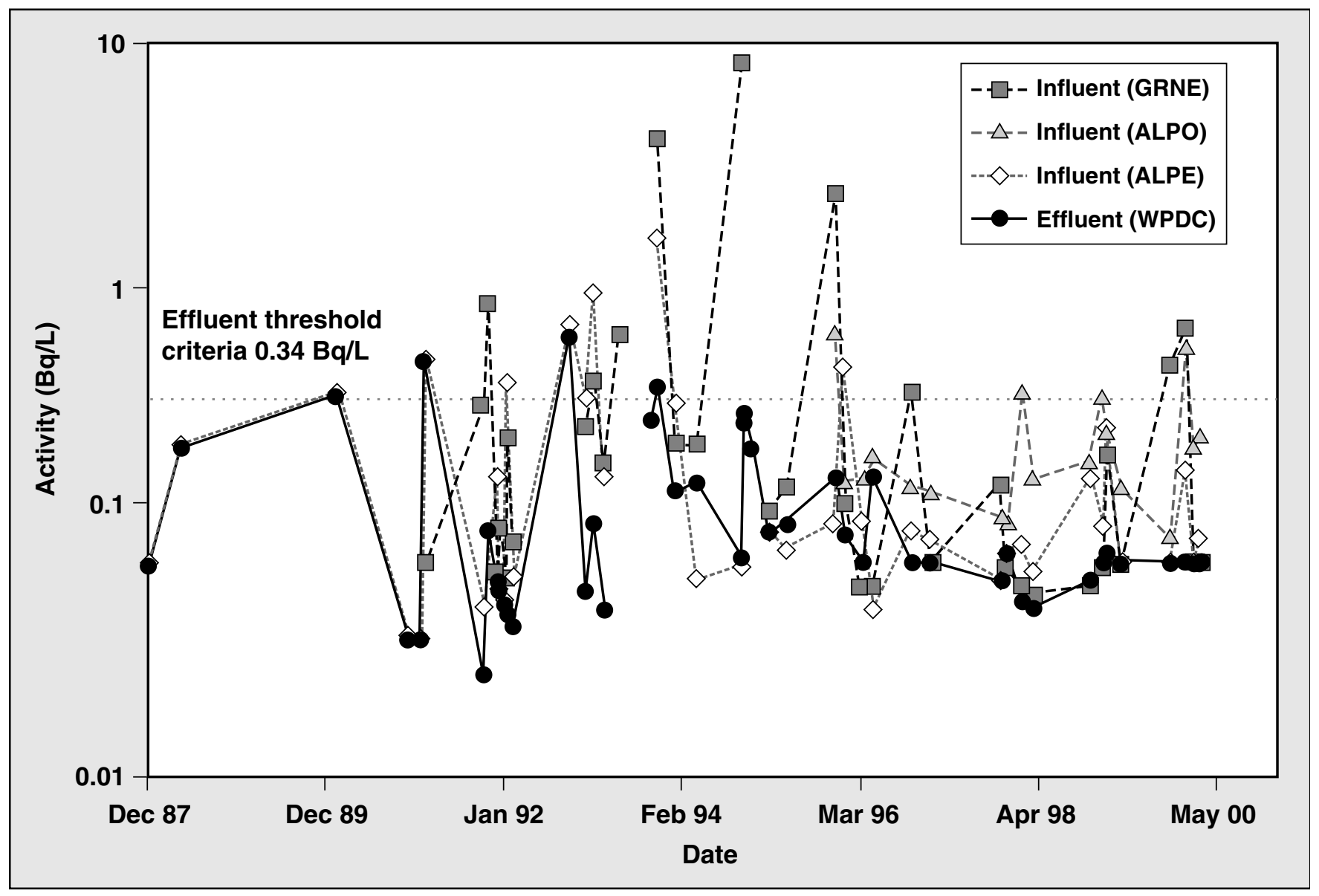

Figure 7-6. Gross alpha activities in Arroyo Las Positas storm water at the Livermore site compared with the LLNL site-specific threshold shown in Table 7-2

was not detected in the incoming channels (calculated values of 2.0 and $0.9 \mathrm{~Bq} / \mathrm{L}$ at WPDW and $196 \mathrm{~S}$, respectively), but was detected at $31 \mathrm{~Bq} / \mathrm{L}$ in the main Arroyo Las Positas channel at both WPDS and 196E.

Follow-up analyses during 1999 located a potential on-site source for the tritium in the storm water samples showing up in air samples near Building 331. On March 28, 1999, facility staff located a glove box with a faulty pump that was causing the glove box contents to vent directly to the building stack. However, continued detailed tritium observations from locations in the area (Figure 7-10) and in the north-south storm drain, found increased tritium activities revealing an additional source. Specifically, higher levels were found at locations 3726 and 2582 near buildings 331 and 343. The source of elevated tritium was tracked to a transportainer containing materials exposed to tritium. The transportainer had been placed outside Building 331 from April 1998 to April 30, 1999. It was moved to just outside Building 343, where it remained until August 2000, when it was removed and disposed of properly as radioactive waste.

Sampling of surface runoff in the vicinity of the transportainer near Building 343 found tritium concentrations as high as $41,138 \mathrm{~Bq} / \mathrm{L}$. These 


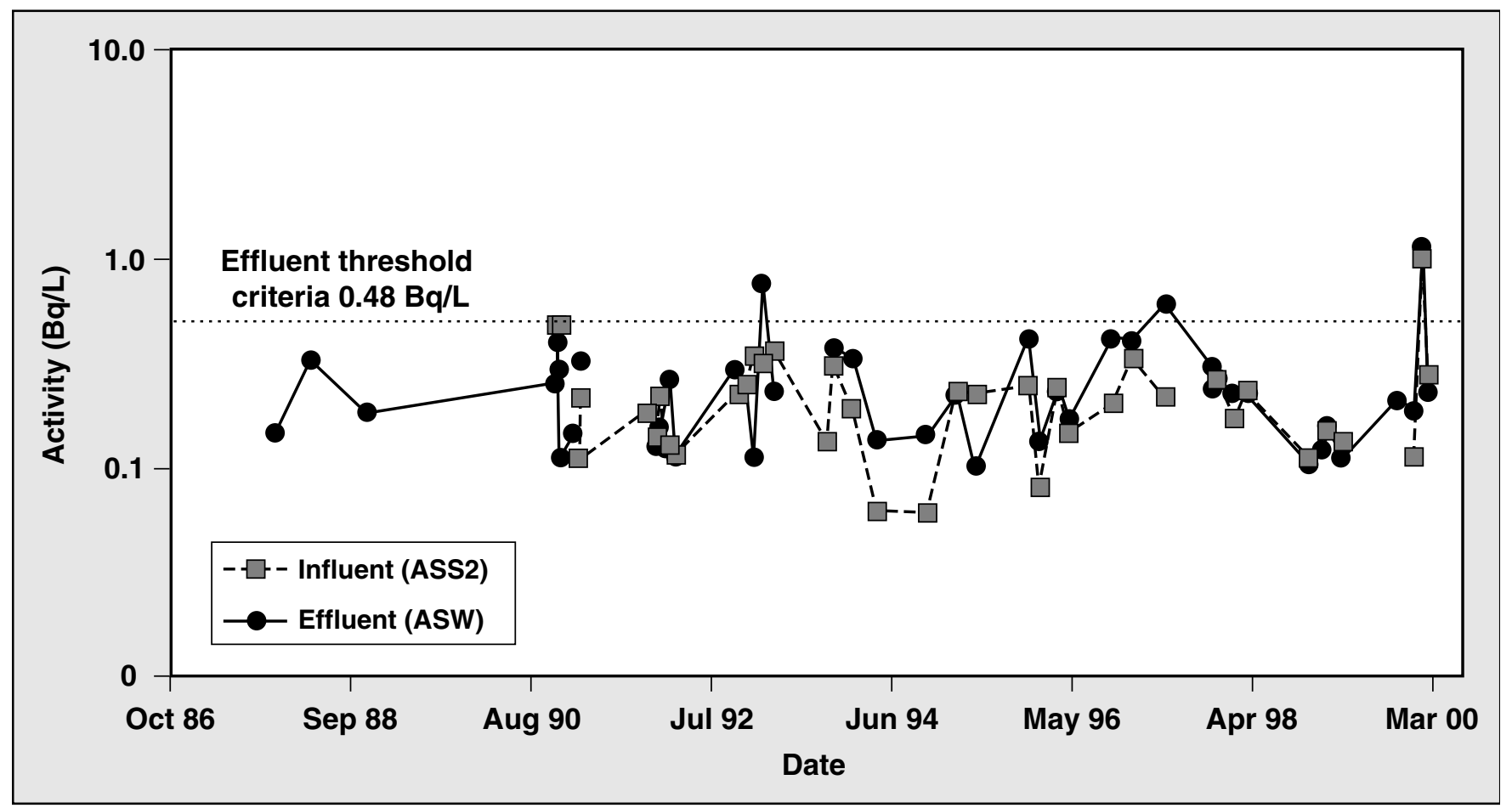

Figure 7-7. Gross beta activities in Arroyo Seco storm water at the Livermore site compared with the LLNL site-specific threshold shown in Table 7-2

samples were taken in the parking lot directly downgradient from the transportainer. This concentration was significantly diluted so that samples collected at the site outlet (WPDC) on the same day were not more than $4 \%$ of the drinking water standard for tritium $(740 \mathrm{~Bq} / \mathrm{L})$. Continued monitoring of both surface runoff near Building 343 and sampling in the storm channels have demonstrated a rapid decrease in measured tritium concentrations since the transportainer was removed in August 2000 (Figure 7-11). Monitoring of this network will continue into 2001 until tritium concentrations in the north-south storm drain near Building 343 return to background levels (Figure 7-12).

\section{Livermore Site Nonradioactive Constituents:}

In addition to data on radioactivity, the results for other water quality parameters were analyzed. Sample results were compared with the comparison criteria in Table 7-2; of greatest concern are the constituents that exceed comparison criteria at effluent points and whose concentrations are lower in influent than in effluent. If influent concentrations are higher than effluent concentrations, the source is generally assumed to be unrelated to LLNL operations; therefore, further investigation is not warranted. Constituents that exceeded comparison criteria for effluent and influent locations are listed in Table 7-6. Some of the constituents identified by this screening process (ions and metals) were not listed, as their presence has been attributed to naturally occurring concentrations transported in sediments during a previous twoyear study (Brandstetter 1998). Furthermore, many of the high effluent values that occurred were recorded at an influent tributary to Arroyo Las Positas (ALPO) on March 8, 2000. On this date, the influent total suspended solids (TSS) concentration was also high. A correlation does exist 


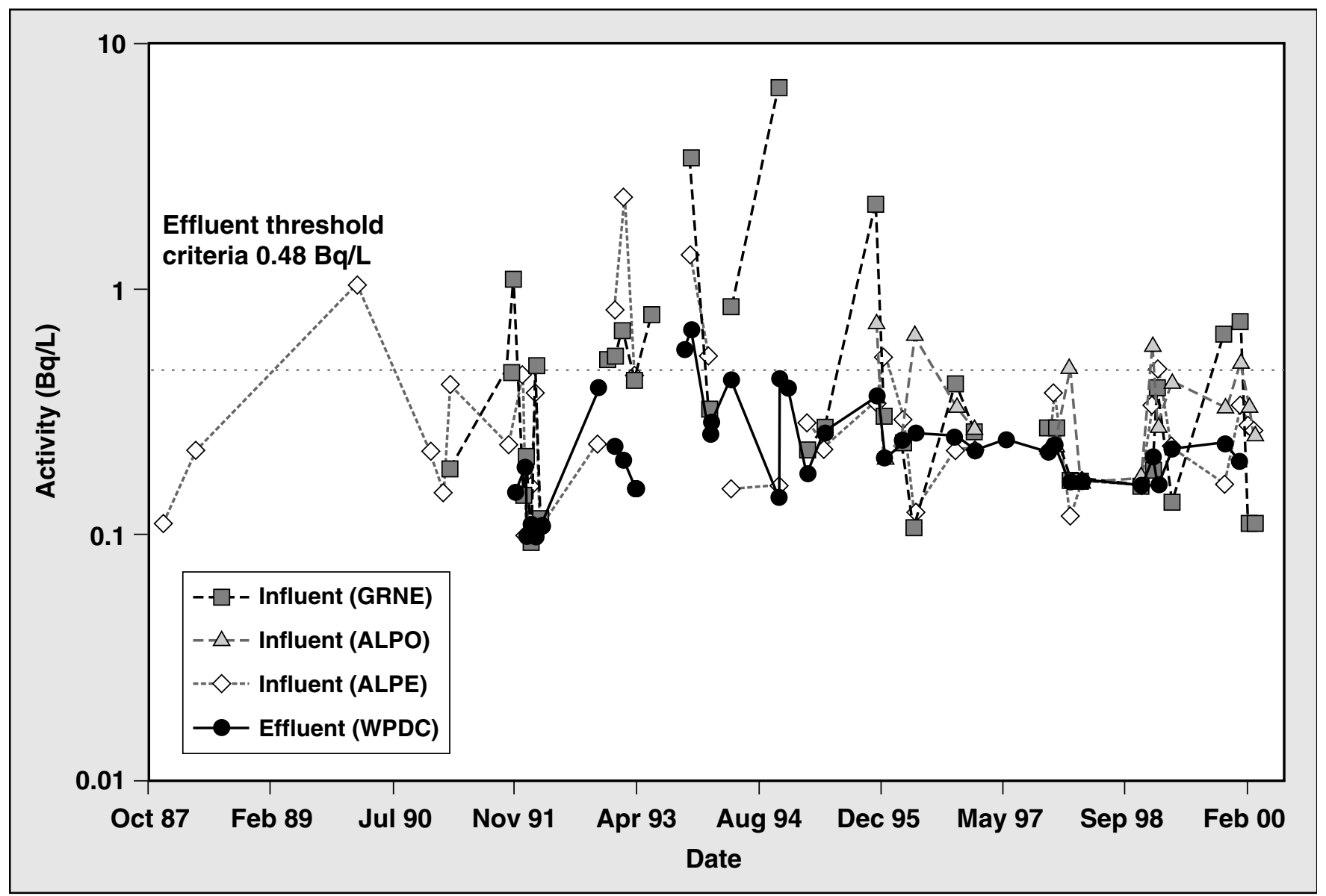

Figure 7-8. Gross beta activities in Arroyo Las Positas storm water at the Livermore site compared with the LLNL site-specific threshold shown in Table 7-2

between TSS and some metals; for example, correlation coefficients for zinc, iron, and aluminum to TSS are $0.21,0.36$, and 0.4 , respectively. In addition, correlations between these metals (zinc to iron, iron to aluminum, and aluminum to zinc) were found to range from 0.31 to 0.99 . These results suggest a natural, relatively consistent association between sediments and metals found in the storm water runoff from the Livermore site.

Using the threshold comparison criteria and the guideline that if influent values are much lower than effluent values, data from two water quality parameters from location ASW on Arroyo Seco (TSS and zinc on February 14) deserve further attention. After examining our sampling locations, it was discovered that an additional influent channel source into the arroyo was not being captured by our upstream sampling location (ASS2). Visual observations during storm flow suggested that the channel is a potential source for suspended sediment. If this is the source of the high TSS values on February 14, then it is also reasonable that, given the demonstrated correlation between TSS and zinc, the high sediment load also resulted in the high zinc concentration in the unfiltered samples. A new sampling location will be added to the newly identified channel in 2001 to test the hypothesis that it is a source for suspended sediment. 


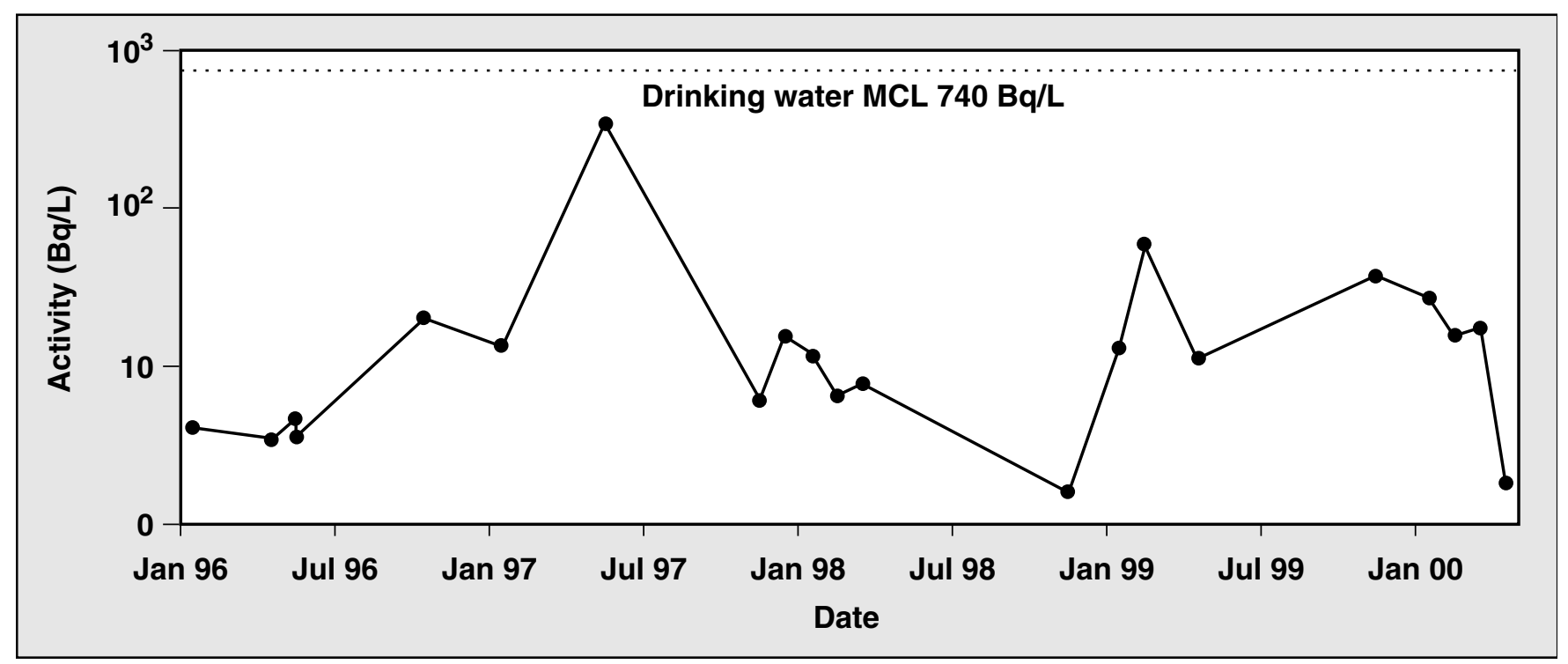

Figure 7-9. Tritium activity in Livermore site storm water at the outflow location WPDC compared with the drinking water maximum contaminant level (MCL)

Complete storm water results for nonradioactive constituents are presented in Data Supplement Tables 7-4, 7-5, and 7-6.

To build on the storm water monitoring program, LLNL began to examine the potential to use easily measured water quality parameters as indicators for those not as easily measured. Many basic chemical characteristics (e.g., pH, dissolved oxygen, and specific conductance) of storm water may be monitored in the stream channel in real time. As a precursor to designing a storm water monitoring system to collect regular data over short sampling intervals, relationships between water quality parameters and an indicator, such as specific conductance, must first be examined. To this end, LLNL performed regression analysis on the water quality data to relate specific conductance and other storm water constituents. The goal, to determine if specific conductance could be used as a indicator (or predictor) of the levels of other chemical components impacting stream water quality, will improve our understanding of runoff and solute transport in the storm water. Various parameters were compared to specific conductance and linear regression models, and the relative fits $\left(\mathrm{r}^{2}\right.$ values $)$ of that model were estimated. The results are shown in Figure 7-13.

The chemical parameters that influence the specific conductance measurement (i.e., chloride, sulfate, sodium, and fluoride) are highly correlated with $\mathrm{r}^{2}$ values ranging from 0.82 to 0.98 . There are two main potential causes for the correlations. The first is that the measurements are chemically related. Therefore, the concentration directly impacts the specific conductance, chloride for example. At the same time, a correlation between specific conductance and other parameters may result if water is consistently dominated by a single source, such as surface runoff or soil-water interflow. In this case, there may be no chemical relationship, only a consistency in where the water comes from. For example, the water could be high in specific conductance in a place that always adds dissolved oxygen because of rapid water flow. This may be the explanation for 


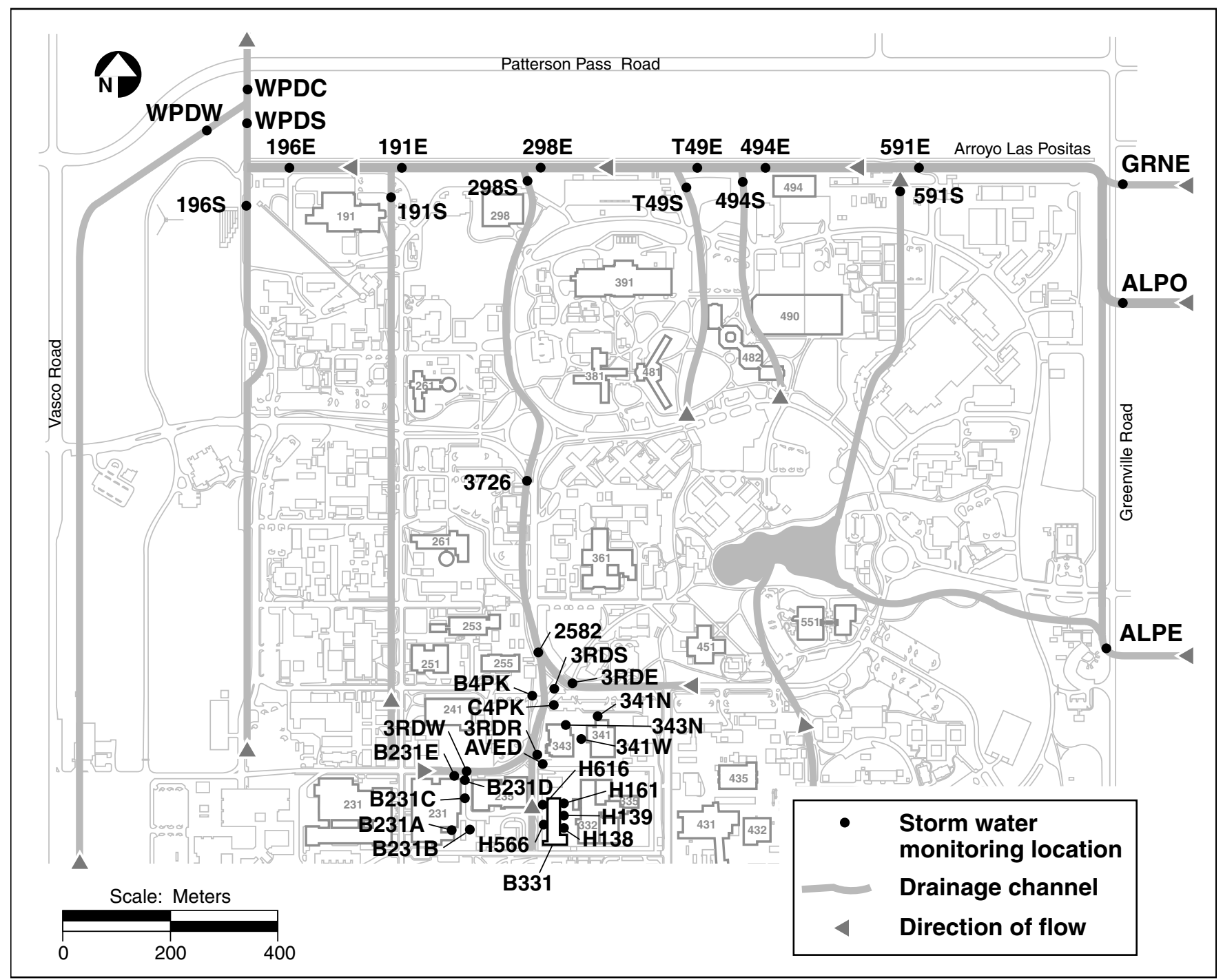

Figure 7-10. Sampling locations for the special tritium studies performed at Livermore site

the weaker relationships observed between specific conductance and $\mathrm{pH}$ or chemical oxygen demand, which have $\mathrm{r}^{2}$ values of 0.39 and 0.05 , respectively. The metals examined did not demonstrate a consistent relationship to specific conductance, so another indicator might be necessary.

There is the potential of using a few easily measurable water quality parameters to represent the transport distributions of other chemical components in storm runoff. Specific conductance is clearly a reasonable indicator for general minerals (ions) in the storm water, but is less useful for other parameters like metals. Over the next year, LLNL will continue to evaluate other indicators, specifically for metals. In addition, the potential of using continuous in-stream monitoring devices will be explored in an effort to increase our ability to assess potential environmental impacts of storm runoff from the Livermore site. 


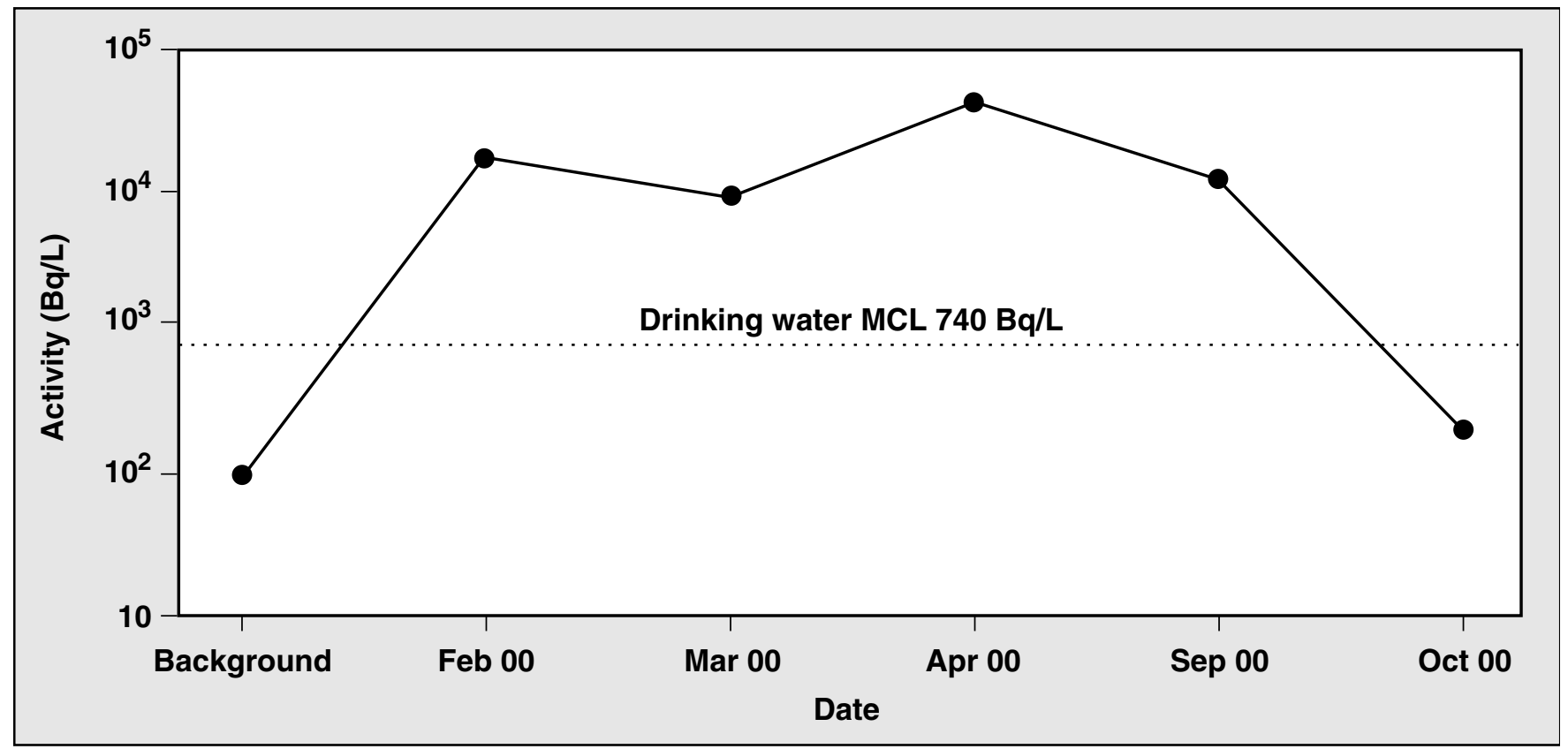

Figure 7-11. Tritium activity in Livermore site storm water at the locations near Building 343 where the transportainer was last located

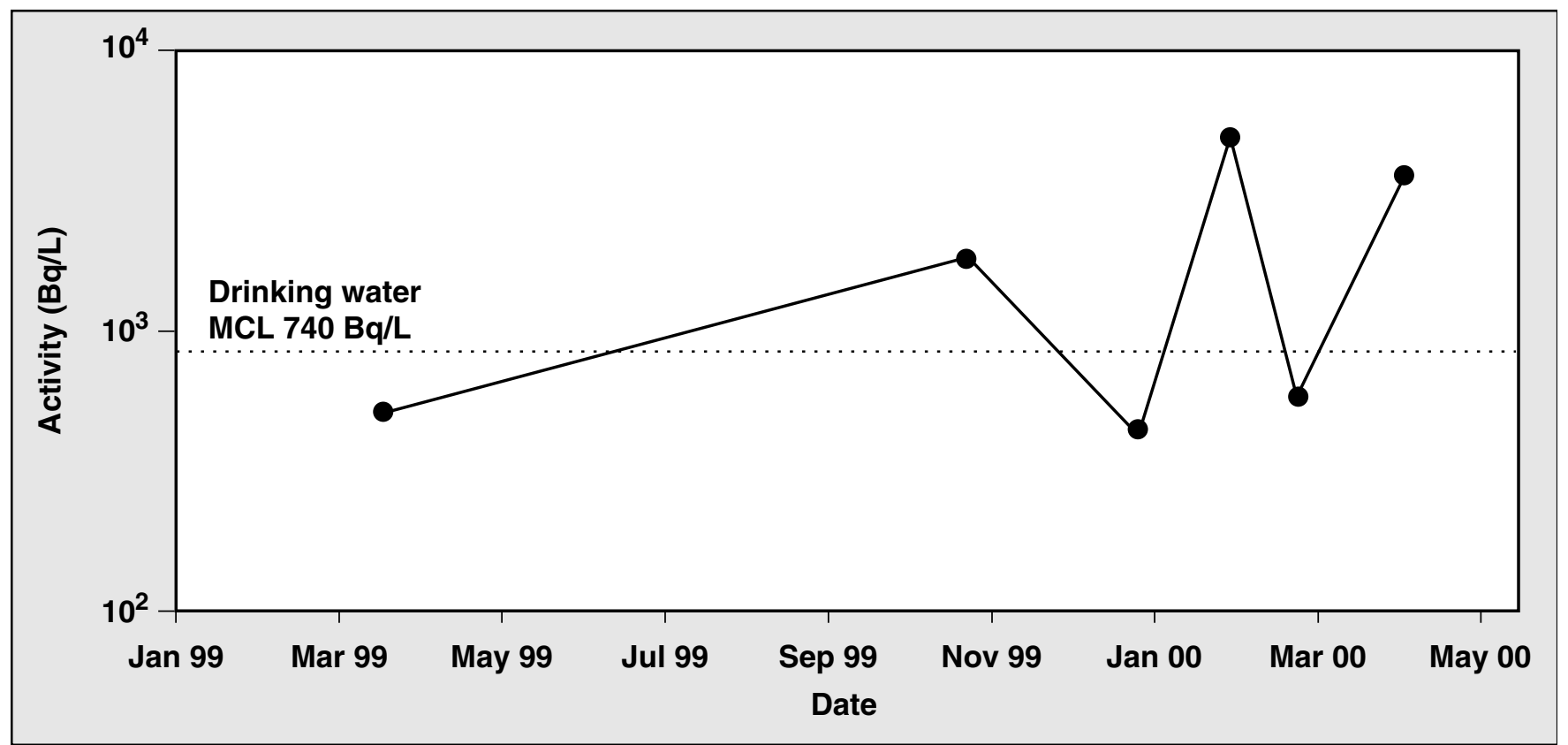

Figure 7-12. Tritium activity in Livermore storm water at location 3726 near Building 343 compared with the drinking water maximum contaminant level $(M C L)$ 
Table 7-6. Nonradioactive water quality parameters from the Livermore site in $\mathbf{2 0 0 0}$ above the threshold comparison criteria shown in Table 7-2

\begin{tabular}{|c|c|c|c|c|}
\hline Parameter & Date & Location & Influent or effluent & $\begin{array}{l}2000 \text { results/ } \\
\text { threshold criteria }\end{array}$ \\
\hline \multirow[t]{2}{*}{ Nitrate (as $\mathrm{NO}_{3}$ ) (mg/L) } & $2 / 14$ & ALPO & Influent & $13 / 10$ \\
\hline & $3 / 8$ & ALPO & Influent & $14 / 10$ \\
\hline Orthophosphate (mg/L) & $2 / 14$ & ALPE & Influent & $2.81 / 2.5$ \\
\hline Total suspended solids (mg/L) & $2 / 14$ & ASW & Effluent & $835 / 750$ \\
\hline \multirow[t]{3}{*}{ Diuron (mg/L) } & $2 / 14$ & ALPO & Influent & $0.023 / 0.014$ \\
\hline & $2 / 14$ & GRNE & Influent & $0.022 / 0.014$ \\
\hline & $3 / 8$ & GRNE & Influent & $0.024 / 0.014$ \\
\hline \multirow[t]{2}{*}{ Copper (mg/L) } & $2 / 14$ & ASS2 & Influent & $0.05 / 0.026$ \\
\hline & $2 / 14$ & ASW & Effluent & $0.058 / 0.026$ \\
\hline \multirow[t]{3}{*}{ Chromium(VI) (mg/L) } & $2 / 14$ & ALPE & Influent & $0.026 / 0.016$ \\
\hline & $2 / 14$ & ASW & Effluent & $0.017 / 0.016$ \\
\hline & $2 / 14$ & GRNE & Influent & $0.017 / 0.016$ \\
\hline \multirow[t]{3}{*}{$\mathrm{pH}$} & $3 / 8$ & ALPO & Influent & $8.53 /<6.0,>8.5$ \\
\hline & $3 / 8$ & ASS2 & Influent & $8.52 /<6.0,>8.5$ \\
\hline & $3 / 8$ & ALPE & Influent & $8.5 /<6.0,>8.5$ \\
\hline Zinc (mg/L) & $2 / 14$ & ASW & Effluent & $0.15 / 0.117$ \\
\hline
\end{tabular}

\section{Site 300 Sampling}

LLNL procedures specify sampling a minimum of two storms per rainy season from Site 300. Typically, a single storm does not produce runoff at all Site 300 locations, because Site 300 receives relatively little rainfall and is largely undeveloped. Therefore, at many locations, a series of large storms is required to saturate the ground before runoff occurs. In 2000, samples were collected at locations with flow on January 24, February 14, February 22, and March 2. There was no tritium above the minimum detectable activity in Site $\mathbf{3 0 0}$ storm water during 2000. The maximum values of all effluent gross alpha and gross beta results were 0.36 and $0.55 \mathrm{~Bq} / \mathrm{L}$, respectively, approximately
$64 \%$ and $30 \%$ of the drinking water MCLs (0.56 and $1.85 \mathrm{~Bq} / \mathrm{L})$. (See Data Supplement, Table 7-7.) The maximum gross alpha and beta values for the downstream location GEOCRK were 1.06 and $1.42 \mathrm{~Bq} / \mathrm{L}$, respectively, where the gross alpha value that exceeds the LLNL threshold may be explained by a higher value in the upstream influent (CARW) of $1.306 \mathrm{~Bq} / \mathrm{L}$. This gross alpha value was the highest recorded for the year. The corresponding gross beta value at this upstream location was $1.95 \mathrm{~Bq} / \mathrm{L}$, which is also above our comparison criteria. This is not unusual, however, as this area has had relatively high background gross alpha and beta levels in stream flow that are closely associated with suspended sediment 

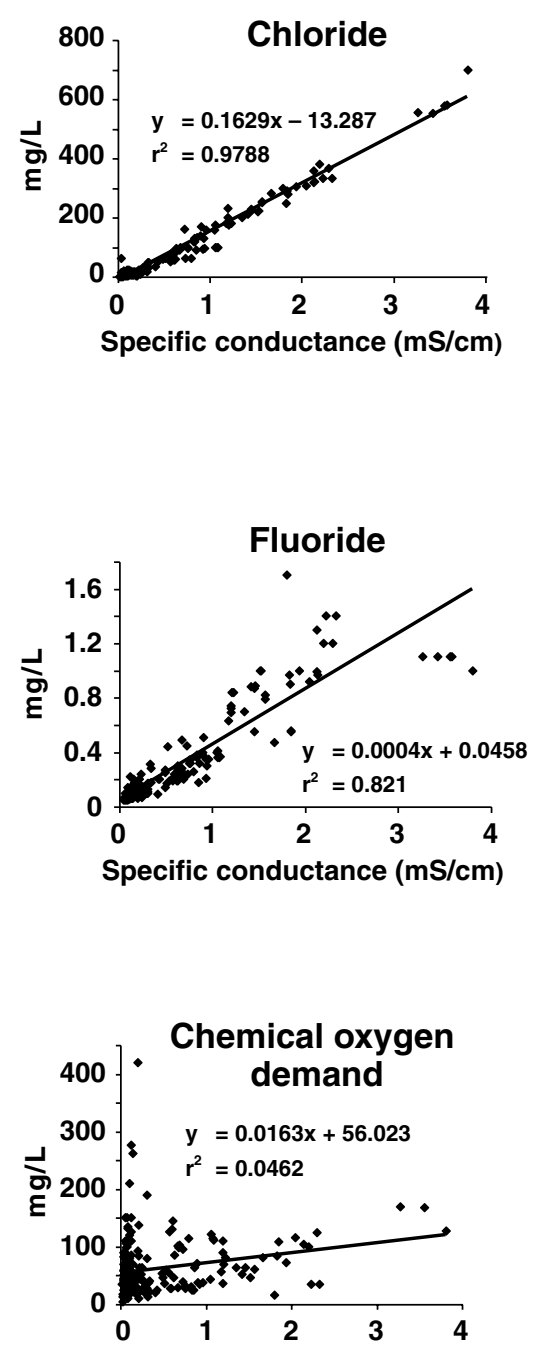

Specific conductance $(\mathrm{mS} / \mathrm{cm})$

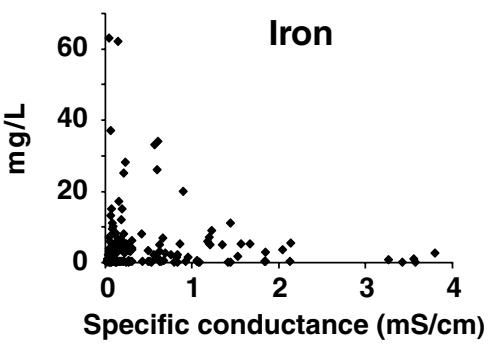

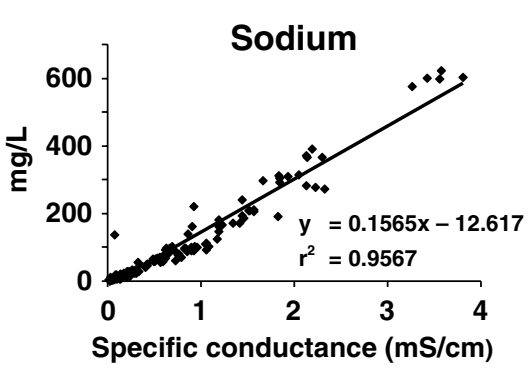

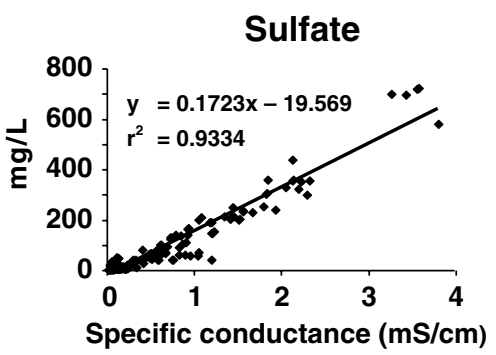

Ortho-P
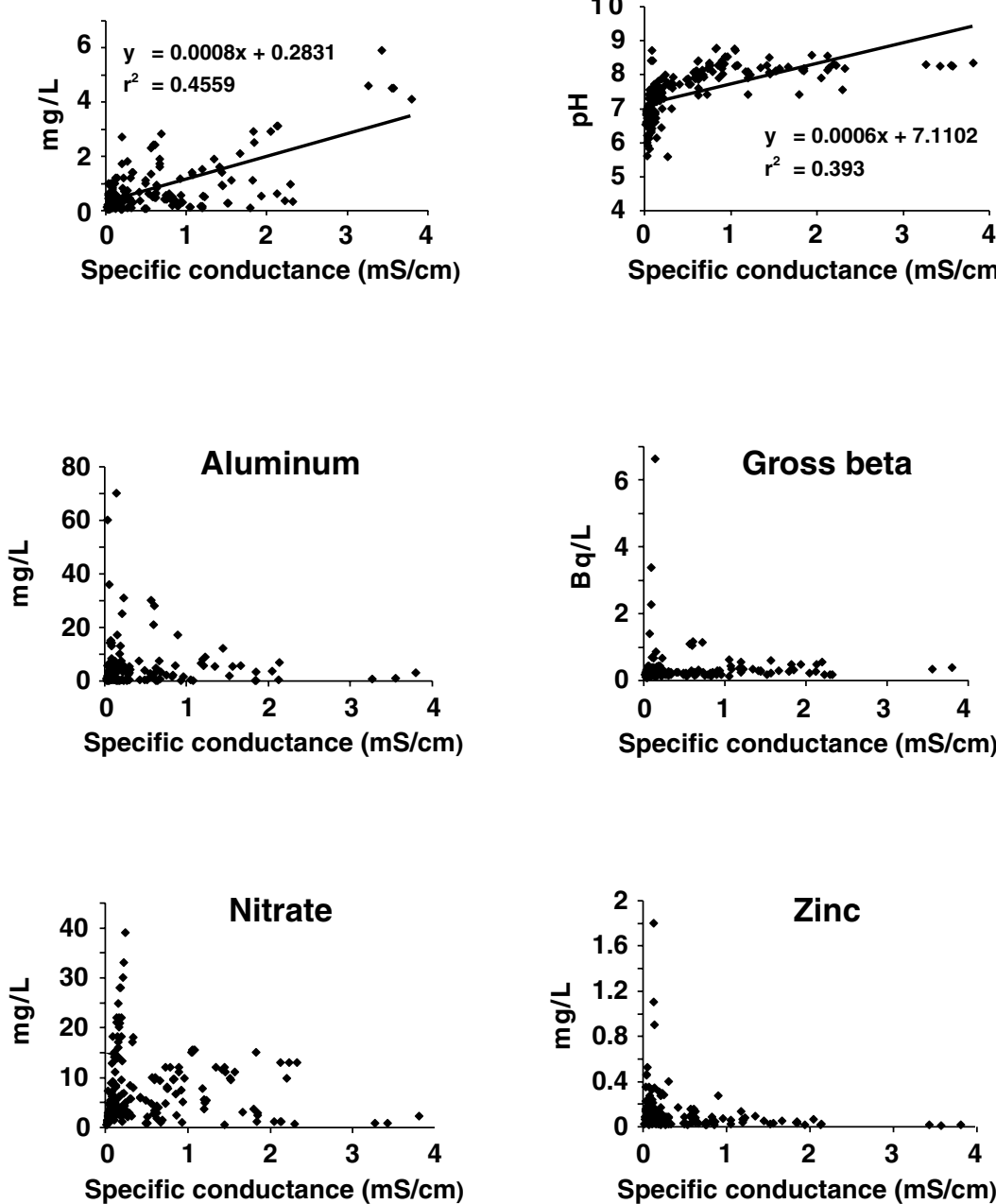

$\mathrm{pH}$

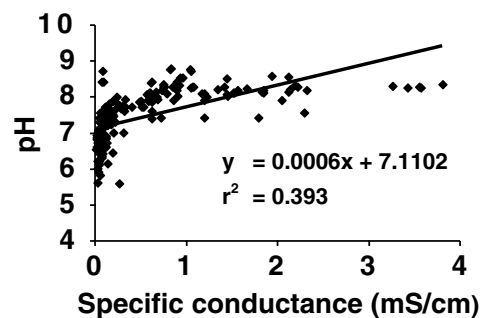

Specific conductance $(\mathrm{mS} / \mathrm{cm})$

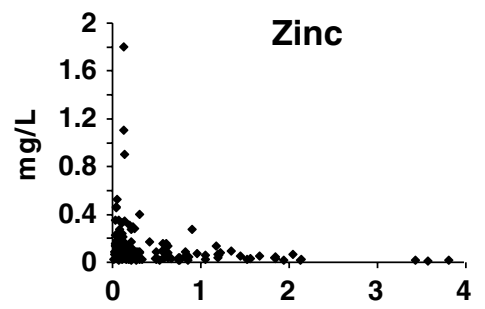

Specific conductance $(\mathrm{mS} / \mathrm{cm})$

Figure 7-13. Correlations between selected parameters and specific conductance in storm water 
(Harrach et al. 1996). As the high runoff energy of storm flow suspends sediment, it is likely that the source is natural. Regardless of the source, the upstream CARW gross alpha and beta levels are higher than the downstream point at GEOCRK, so the runoff from Site 300 is actually contributing to dilution of the upstream water, reducing the levels of TSS observed at GEOCRK (Table 7-7).

Table 7-7. Total suspended solids in storm water samples from Site $\mathbf{3 0 0}$ in $\mathbf{2 0 0 0}$

\begin{tabular}{|c|l|c|}
\hline Sampled date & Location & $\begin{array}{c}\text { Total } \\
\text { suspended } \\
\text { solids (mg/L) }\end{array}$ \\
\hline $1 / 24$ & GEOCRK & $<2$ \\
$1 / 24$ & N883 & 443 \\
$1 / 24$ & NPT7 & 18 \\
$2 / 14$ & CARW & 1710 \\
$2 / 14$ & GEOCRK & 1100 \\
$2 / 14$ & NLIN & 243 \\
$2 / 22$ & NPT7 & 64 \\
$3 / 2$ & N883 & 66.5 \\
\hline
\end{tabular}

Tables 7-8 and 7-9 in the Data Supplement list results for nonradioactive constituents and dioxins in Site 300 storm water runoff. Because of a CERCLA remedial investigation finding of past releases of polychlorinated biphenyls (PCBs) and dioxins related to activities in the vicinity of Building 850, LLNL conducted an analysis for PCBs and dioxins at location NLIN, the storm water sampling location downstream of Building 850. The intent of the sampling was to determine whether these constituents are being released from the site in storm water runoff. Dioxins and furans were detected at low levels (maximum of $470 \mathrm{pg} / \mathrm{L}$, or $4.7 \times 10^{-7} \mathrm{mg} / \mathrm{L}$ ); all concentrations were below MCLs and other comparison criteria.
Sampling at Pit 6 includes analyses required as part of the postclosure sampling; however, no storm runoff was sampled as the drains did not produce any runoff to collect in 2000 .

Specific conductance and TSS at Site 300 locations were at times above comparison criteria. However, effluent levels were lower than levels at the upstream location CARW, indicating that the levels observed in effluent are typical for the area. Suspended sediment is an issue in Coral Hollow Creek, but it is clear that activities at Site $\mathbf{3 0 0}$ are not producing a majority of that sediment. In fact, storm water from the site appears to be contributing to the dilution of the upstream water that contains higher sediment loads (Table 7-7). The valley floor is dominated by an off-road motorcycle use area and ranching activities that are potential sources for sediment. All other Site 300 results were below comparison criteria.

\section{Rainfall}

This section discusses general information about rainfall in the Livermore site, Livermore Valley, and Site 300 , as well as methods for sampling rainfall and the sampling results.

\section{General Information}

\section{Livermore Site and Livermore Valley}

Historically, the tritium activity measured in rainfall in the Livermore Valley results primarily from atmospheric emissions of tritiated water (HTO) from vent stacks at LLNL's Tritium Facility (Building 331), and from the former Tritium Research Laboratory at the Sandia National Laboratories/California (Sandia/California). The total measured atmospheric emission of HTO from LLNL facilities in 2000 was $1.60 \mathrm{TBq}$ (see Chapter 4). 
The rain sampling station locations are shown in Figure 7-14. The fixed stations are positioned to record the maximum activity expected down to background levels. The Building 343 rain sampling location is near the Tritium Facility (Building 331) and has historically recorded the maximum tritium activity in rainfall.

\section{Site $\mathbf{3 0 0}$}

One off-site location (PRIM) and two on-site locations (COMP and TNK5) are used to collect rainfall for tritium activity measurements at Site $\mathbf{3 0 0}$ (Figure 7-3).

\section{Methods}

Rainfall is sampled for tritium according to written procedures, described in Appendix B of the Environmental Monitoring Plan (Tate et al. 1999) and summarized here. Rainfall is collected in stainlesssteel buckets at specified locations. The buckets are placed in open areas and are elevated about $1 \mathrm{~m}$ above the ground to prevent collection of splashback water. Rainwater samples are decanted into 250-mL amber glass bottles with Teflon-lined lids. The tritium activity of each sample is measured by scintillation counting (EPA Method 906).

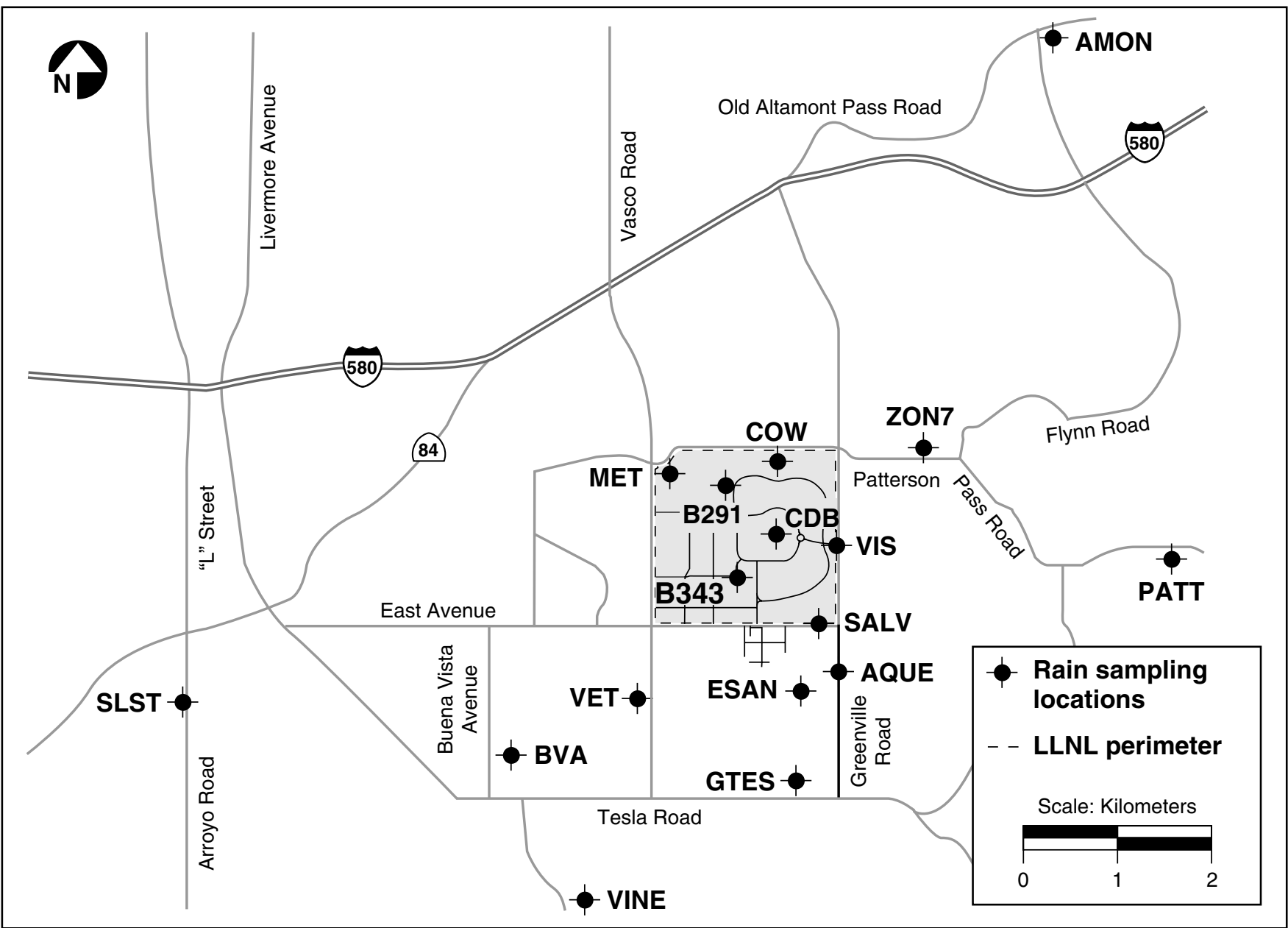

Figure 7-14. Rain sampling locations, Livermore site and Livermore Valley, 2000 


\section{Results}

\section{Livermore Site and Livermore Valley}

During 2000, LLNL collected sets of rain samples following 7 rainfall events at the Livermore site

(87 total routine samples obtained) and 4 events at Site 300 (10 total routine samples obtained). The tritium activities of the 97 routine rainwater samples obtained during 2000 are listed in Table 7-10 of the Data Supplement.

The Livermore site rainfall has exhibited elevated tritium activities in the past (Gallegos et al. 1994). During 2000, however, only one measurement of tritium activity in rainfall, obtained from one on-site location (Building 343), was above the $740 \mathrm{~Bq} / \mathrm{L}$ MCL established by the EPA for drinking water. The activities of the remaining samples were very low, and most were at background level. As in the past, the on-site rainfall sampling location $343 \mathrm{~N}$ (the sampling location nearest the Tritium Facility) showed the highest tritium activity for the year: $1413 \mathrm{~Bq} / \mathrm{L}$ (see Table 7-8) for the rainfall event that immediately preceded the March 23 collection date. The highest off-site tritium activity measured in a routine sample during 2000 was less than $7 \mathrm{~Bq} / \mathrm{L}$

Table 7-8. Tritium activities in rainfall for the Livermore site, Livermore Valley, and Site 300, 2000

\begin{tabular}{|l|c|c|c|}
\hline \multicolumn{1}{|c|}{ Parameter } & $\begin{array}{c}\text { Livermore } \\
\text { site (Bq/L) }\end{array}$ & $\begin{array}{c}\text { Livermore } \\
\text { Valley (Bq/L) }\end{array}$ & Site 300 \\
\hline Maximum & $1413 \pm 15.2$ & $6.73 \pm 1.75$ & $0.223 \pm 1.99$ \\
Minimum & $-1.33 \pm 1.52$ & $-2.11 \pm 1.44$ & $-1.64 \pm 1.97$ \\
Median & 3.70 & 0.424 & -0.0646 \\
$\begin{array}{l}\text { Interquartile } \\
\text { range }\end{array}$ & 10.2 & 2.42 & 0.548 \\
$\begin{array}{l}\text { Number of } \\
\text { samples }\end{array}$ & 43 & 44 & 10 \\
\hline
\end{tabular}

(sample collected March 23 at location ESAN). All of the off-site routine rainfall samples measured during 2000 showed tritium activities less than 1\% of the tritium MCL for drinking water.

The median tritium activity measured in rainfall at LLNL decreased from $19.0 \mathrm{~Bq} / \mathrm{L}$ in 1999 to $3.7 \mathrm{~Bq} / \mathrm{L}$ in 2000 . This was primarily because of an overall reduction of on-site HTO emissions, from a total of $8.1 \mathrm{TBq}$ for the year 1999 to a total of $1.6 \mathrm{TBq}$ for the year 2000. The median tritium activity for rainfall at LLNL during 2000 reached its lowest level in the eleven year period beginning in 1990 , when it was $65.9 \mathrm{~Bq} / \mathrm{L}$. This decrease mirrors the downward trend in total HTO emissions from LLNL's Tritium Facility (shown in Figure 7-15). HTO emissions have decreased from a total of $34.9 \mathrm{TBq}$ for year 1990 to $8.1 \mathrm{TBq}$ for year 1999 and to $1.6 \mathrm{TBq}$ for year 2000 . Values for median tritium activity shown in Figure 7-15 are derived from the on-site LLNL rain sampling locations. Similar to tritium activities observed in on-site storm runoff, the tritium activity in rainfall at LLNL decreased even more during 2000 following the removal in August of a waste container (transportainer) that contained tritium-contaminated equipment.

\section{Site $\mathbf{3 0 0}$}

As in the past, none of the ten routine rain samples obtained from monitoring locations at Site 300 during 2000 showed tritium activities above background activity there, which is approximately $2 \mathrm{~Bq} / \mathrm{L}$.

\section{Livermore Site Drainage Retention Basin}

This section discusses general information about the DRB, sampling methods, and sampling results. 


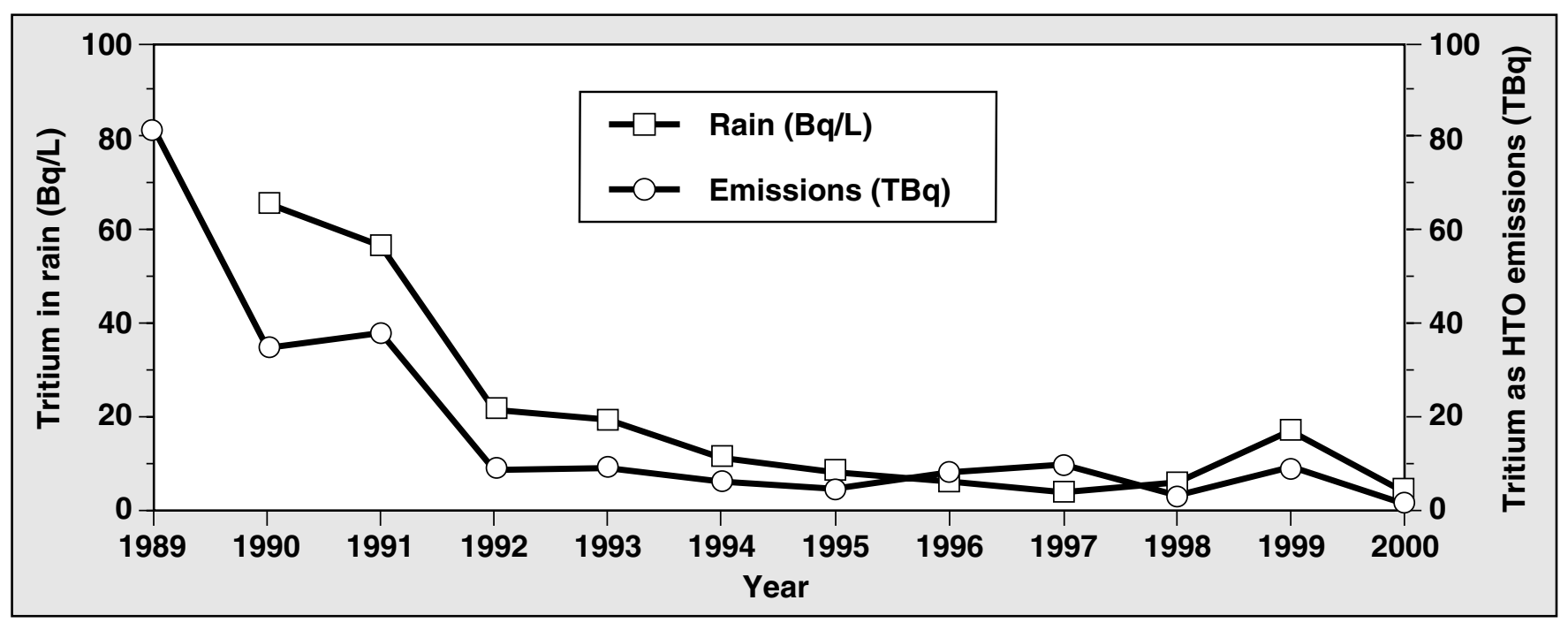

Figure 7-15. Trend of median tritium activity in rain and trend of total stack emissions of HTO. From 1989 to 1995 the emisssions are from the Livermore site and Sandia/California. Emissions from 1996 to 2000 are from LLNL only.

\section{General Information}

Previous environmental reports detail the history of the construction and management of the DRB (see Harrach et al. 1995-1997). Beginning in 1997, LLNL discharges to the DRB included routine treated groundwater from Treatment Facilities D and $\mathrm{E}$, and from related portable treatment units. These discharges contribute a year-round source of water entering and exiting the DRB. Storm runoff still dominates wet weather flows through the $\mathrm{DRB}$, but discharges from the treatment facilities now constitute a substantial portion of the total water passing through theDRB.

The SFBRWQCB regulates discharges from the DRB within the context of the Livermore site CERCLA Record of Decision (ROD) (U.S. DOE 1993), as modified by the Explanation of Significant Differences for Metals Discharge Limits at the Lawrence Livermore National Laboratory Livermore Site (Berg et al. 1997). The CERCLA ROD establishes discharge limits for all remedial activities at the Livermore site to meet applicable, relevant, and appropriate requirements derived from laws and regulations identified in the $\mathrm{ROD}$, including the Federal Clean Water Act, the Federal and State Safe Drinking Water Acts, and the California PorterCologne Water Quality Control Act.

The DRB sampling program implements requirements established by the SFBRWQCB. The program consists of monitoring wet and dry weather releases for compliance with discharge limits, monitoring internal DRB water quality to support management actions established in the Drainage Retention Basin Management Plan (DRB Management Plan) (Limnion Corporation 1991), characterizing water quality before its release, and performing routine reporting. For purposes of determining discharge monitoring requirements and frequency, the wet season is defined as October 1 through May 31, the period when rainrelated discharges usually occur (Galles 1997). Discharge limits are applied to the wet and dry seasons as defined in the Explanation of Significant Differences for Metals Discharge Limits at the Lawrence Livermore National Laboratory Livermore 
Site (Berg et al. 1997) (wet season December 1 through March 31, dry season April 1 through November 30).

To characterize wet-season discharges, LLNL samples DRB discharges (at location CDBX) and the corresponding site outfall (at location WPDC) during the first release of the rainy season, and from a minimum of one additional storm (chosen in conjunction with storm water runoff sampling). During the dry season, samples are collected, at a minimum, from each discrete discharge event. Discharge sampling locations CDBX and WPDC are shown in Figure 7-2. LLNL collects samples at CDBX to determine compliance with discharge limits. Sampling at WPDC is done to identify any change in water quality as the DRB discharges travel through the LLNL storm water drainage system and leave the site. Sampling frequencies for CDBX and WPDC and effluent limits for discharges from the DRB, applied at CDBX, are found in Table 7-11 of the Data Supplement.

The routine management constituents, management action levels, and monitoring frequencies that apply to water contained in the DRB are identified in Data Supplement Table 7-12 and were established based on recommendations made in the DRB Management Plan. LLNL collects samples at the eight locations identified in Figure 7-16 to determine whether water quality management objectives are met. Dissolved oxygen content and temperature are measured at the eight locations, while samples for the remaining chemical and physical constituents are collected from sample location

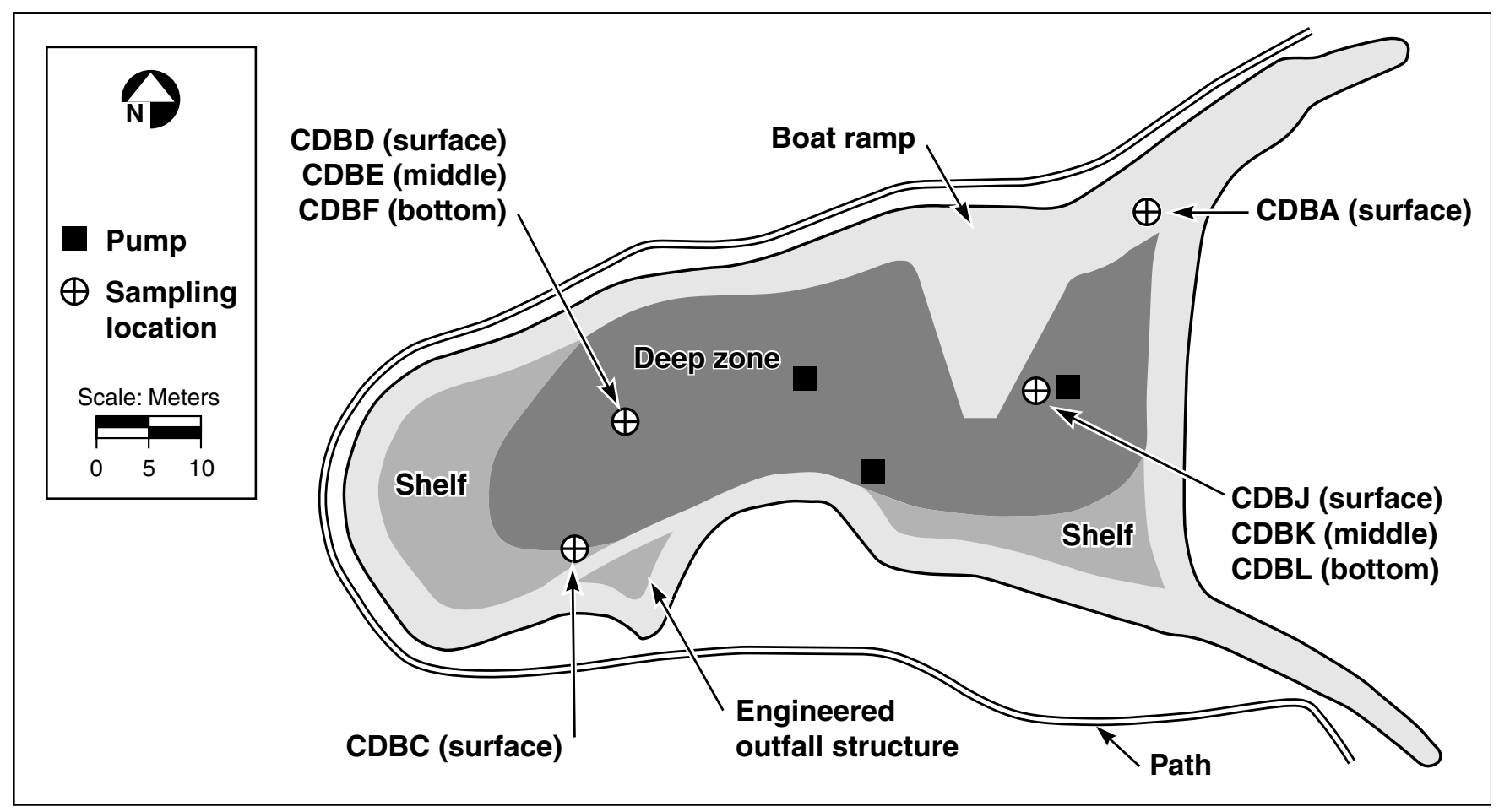

Figure 7-16. Sampling locations within the Drainage Retention Basin, 2000 
CDBE because of the limited variability for these constituents within the DRB. CDBE is located at the middle depth of the DRB.

The DRB Management Plan identifies biological and microbiological surveys that are used as the primary means to assess the long-range environmental impact of DRB operations. LLNL monitors plant and animal species at the DRB, the drainage channels discharging into the $\mathrm{DRB}$, and downstream portions of Arroyo Las Positas. LLNL's biologist conducts semiannual surveys to identify the presence or absence of amphibians, birds, and fishes, and annual surveys for mammals and plants.

LLNL drained the DRB in December 2000 for the first time since the start of operations. The draining was part of LLNL's bullfrog control strategy related to managing facility operation impacts on the California red-legged frog (Rana aurora draytonii), a federally listed threatened species. The draining was conducted following a plan submitted to and approved by the SFBRWQCB. Sediment-laden discharges were routed through sediment filter bags prior to discharging to the storm drainage system.

\section{Methods}

Sample collection procedures are discussed in Appendix B of the Environmental Monitoring Plan (Tate et al. 1999). All samples from the DRB are collected as grab samples. Field measurements for dissolved oxygen and temperature are made using a dissolved oxygen/temperature meter, and turbidity is measured using a Secchi disk. Certified laboratories analyze the collected samples.

Biological and microbiological methods are discussed in detail in the Environmental Monitoring Plan (Tate et al. 1999). Biological surveys are conducted by LLNL's biologist. Animal surveys follow standard survey protocols such as Raptor Management Techniques Manual (Pendleton et al. 1987), Inventory and Monitoring of Wildlife Habitat (Cooperrider et al. 1986), and Wildlife Management Techniques Manual (Schemnitz 1980). Vegetation surveys use protocols identified in the U.S. Army Corps of Engineers Wetlands Delineation Manual (Environmental Laboratory 1987). Because of a lack of resources, LLNL was again unable to conduct the microbiological survey.

\section{Results}

Samples collected during 2000 within the DRB at CDBE did not meet the management action levels for dissolved oxygen saturation, temperature, turbidity, nitrate (as N), total dissolved solids (TDS), total phosphorus (as P), ammonia nitrogen (as $\mathrm{N}$ ), chemical oxygen demand, $\mathrm{pH}$, and specific conductance (Table 7-9). No action was taken to adjust nutrient levels. Samples collected at CDBX and WPDC exceeded only the $\mathrm{pH}$ discharge limit (Table 7-9). All samples collected during the draining of the DRB complied with receiving water limits, except for the last sample, which exceeded the discharge limit for turbidity (the downstream receiving water turbidity reading exceeded the upstream turbidity reading by more than 10\%). This exceedance occurred when the sediment filter bag ruptured.

Data for maintenance and release monitoring at sampling locations CDBA, CDBC, CDBD, CDBE, CDBF, CDBJ, CDBK, CDBL, CDBX, and WPDC, and from the biological survey are presented in Tables 7-11 through 7-19 in the Data Supplement. Data related to the draining of the DRB can be found in LLNL Livermore Site Fourth Quarter 2000 Self-Monitoring Report (Bainer and Abbott 2001). 
Table 7-9. Summary of Drainage Retention Basin monitoring not meeting management action levels

\begin{tabular}{|c|c|c|c|c|c|c|c|}
\hline Parameter & $\begin{array}{c}\text { Management } \\
\text { action level }\end{array}$ & Jan & Feb & Mar & Apr & May & June \\
\hline \multicolumn{8}{|l|}{ Sampling location CDBE } \\
\hline Ammonia nitrogen (as N) (mg/L) & 0.1 & $-(a)$ & $-(a)$ & $-(a)$ & 0.43 & 0.2 & 0.42 \\
\hline Dissolved oxygen saturation (\%) & $<80 \%$ saturation & 72 & - $^{(a)}$ & 77 & $-^{(a)}$ & 74 & $-^{(a)}$ \\
\hline Temperature $\left({ }^{\circ} \mathrm{C}\right)^{(\mathrm{a})}$ & $<15$ and $>26$ & 12.7 & 13.2 & 14.9 & $-^{(a)}$ & -(a) $^{(\mathrm{a})}$ & $-^{(a)}$ \\
\hline Turbidity $(m)^{(a)}$ & 0.91 & 0.465 & 0.483 & 0.376 & 0.425 & 0.683 & 0.744 \\
\hline Nitrate (as N) (mg/L) & $>0.2$ & 3.3 & 1.1 & 0.88 & 0.96 & $-^{(a)}$ & 0.69 \\
\hline Specific conductance $(\mu \mathrm{S} / \mathrm{cm})$ & $>900$ & 1030 & - $^{(a)}$ & $-^{(a)}$ & $-^{(a)}$ & $-^{(a)}$ & 1080 \\
\hline Total dissolved solids (TDS) (mg/L) & $>360$ & 667 & 390 & 483 & 540 & 537 & 647 \\
\hline Total phosphorus (as P) (mg/L) & $>0.02$ & 0.11 & 0.46 & 0.38 & 0.32 & 0.3 & 0.21 \\
\hline \multirow[t]{2}{*}{ Chemical oxygen demand (mg/L) } & $>20$ & -(c) & - (a) $^{(a)}$ & -(c) & 43 & -(c) & -(c) \\
\hline & & July & Aug & Sep & Oct & Nov & Dec \\
\hline \multicolumn{8}{|l|}{ Sampling location CDBE (continued) } \\
\hline Dissolved oxygen saturation (\%) & $<80 \%$ saturation & $-^{(a)}$ & 72 & - (a) $^{(a)}$ & - (a) $^{(a)}$ & $-^{(a)}$ & - (a) $^{(a)}$ \\
\hline Temperature $\left({ }^{\circ} \mathrm{C}\right)^{(\mathrm{a})}$ & $<15$ and $>26$ & $-^{(a)}$ & $-^{(a)}$ & - (a) $^{(a)}$ & $-^{(a)}$ & 13.8 & LA \\
\hline Turbidity $(m)^{(a)}$ & 0.91 & 0.897 & 0.613 & 0.775 & - (a) $^{(a)}$ & - (a) $^{(a)}$ & - (a) $^{(a)}$ \\
\hline Nitrate (as N) (mg/L) & $>0.2$ & 0.24 & $\mathrm{NS}^{(\mathrm{d})}$ & - $^{(a)}$ & 1.1 & 2.1 & 1.4 \\
\hline $\mathrm{pH}$ (pH units) & not $<6.0$ and $>9.0$ & $-(a)$ & NS & 9.15 & - $^{(a)}$ & 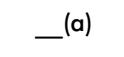 & $-(a)$ \\
\hline Specific conductance $(\mu \mathrm{S} / \mathrm{cm})$ & $>900$ & 1120 & NS & 1130 & 1160 & 1080 & 1060 \\
\hline Total dissolved solids (TDS) (mg/L) & $>360$ & 657 & NS & 693 & 673 & 650 & 627 \\
\hline Total phosphorus (as P) (mg/L) & $>0.02$ & 0.14 & NS & 0.06 & $<0.05$ & 0.05 & 0.07 \\
\hline \multirow[t]{2}{*}{ Chemical oxygen demand (mg/L) } & $>20$ & 29 & - (a) $^{(a)}$ & -(c) & 22 & $-^{(c)}$ & 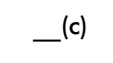 \\
\hline & Discharge limit & 8 Mar & 15 Jun & 31 Jul & 10 Aug & 12 Sep & $23 \mathrm{Oct}$ \\
\hline \multicolumn{8}{|l|}{ Sampling location CDBX } \\
\hline $\mathrm{pH}$ (pH units) & not $<6.5$ and $>8.5$ & $-^{\text {(a) }}$ & 8.56 & 8.71 & 9.12 & 9.16 & 8.8 \\
\hline Sampling location WPDC & & & & & & & \\
\hline $\mathrm{pH}$ (pH units) & not $<6.5$ and $>8.5$ & $-^{(a)}$ & 8.81 & $-^{(a)}$ & $-^{(a)}$ & $-^{(a)}$ & 8.62 \\
\hline
\end{tabular}

a Concentrations met management action level

b Monthly average, measurements taken weekly

c Chemical oxygen demand was analyzed once per quarter.

d NS = Sample not collected 


\section{Chemical and Physical Monitoring}

Monthly averages for surface-level dissolved oxygen saturationwere at or above the management action level of at least $80 \%$ oxygen saturation for 4 of 12 months. Oxygen saturation is determined by the water temperature and the dissolved oxygen concentration and represents the oxygen available to aquatic organisms. Dissolved oxygen concentrations can be manually increased using aeration pumps. These pumps are started whenever oxygen concentrations at any level of the DRB drop close to or below the critical management action level of $5 \mathrm{mg} / \mathrm{L}$.

Chemical oxygen demand was above management action levels during the second through fourth quarters of 2000. Chlorophyll-a, though below the management action levels, had one spring and one summer peak indicating two algae blooms (Figure 7-17). The spring bloom was mild. The chlorophyll-a levels can be used as an indicator of algae populations and of the duration and intensity of algae blooms. The elevated $\mathrm{pH}$ level within the DRB corresponds to the peak of the fall bloom and may be associated with the occurrence of increased photosynthesis. The highest $\mathrm{pH}$ readings seen in the DRB discharge samples (Table 7-9) also correspond to the peak of the fall bloom.

Beginning during the summer of 1994, turbidity was below the management action level of 0.914 meters. Through May 2000, it continued to be mostly below 0.914 meters clarity (Figure 7-18). However, during 2000, the turbidity in the DRB began to decrease (Secchi disk depth readings became larger), resulting in

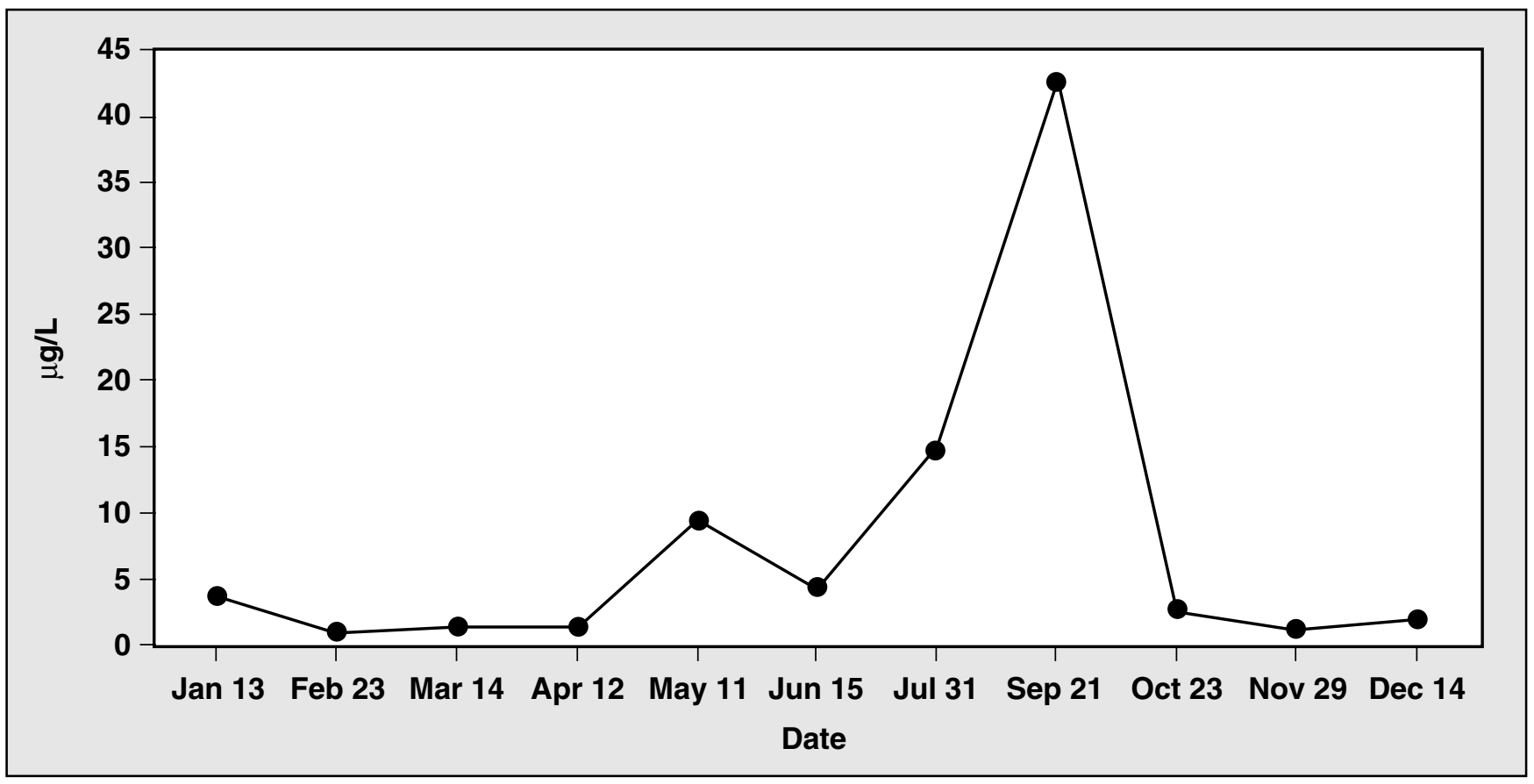

Figure 7-17. Monthly chlorophyll-a in the Drainage Retention Basin, 2000 


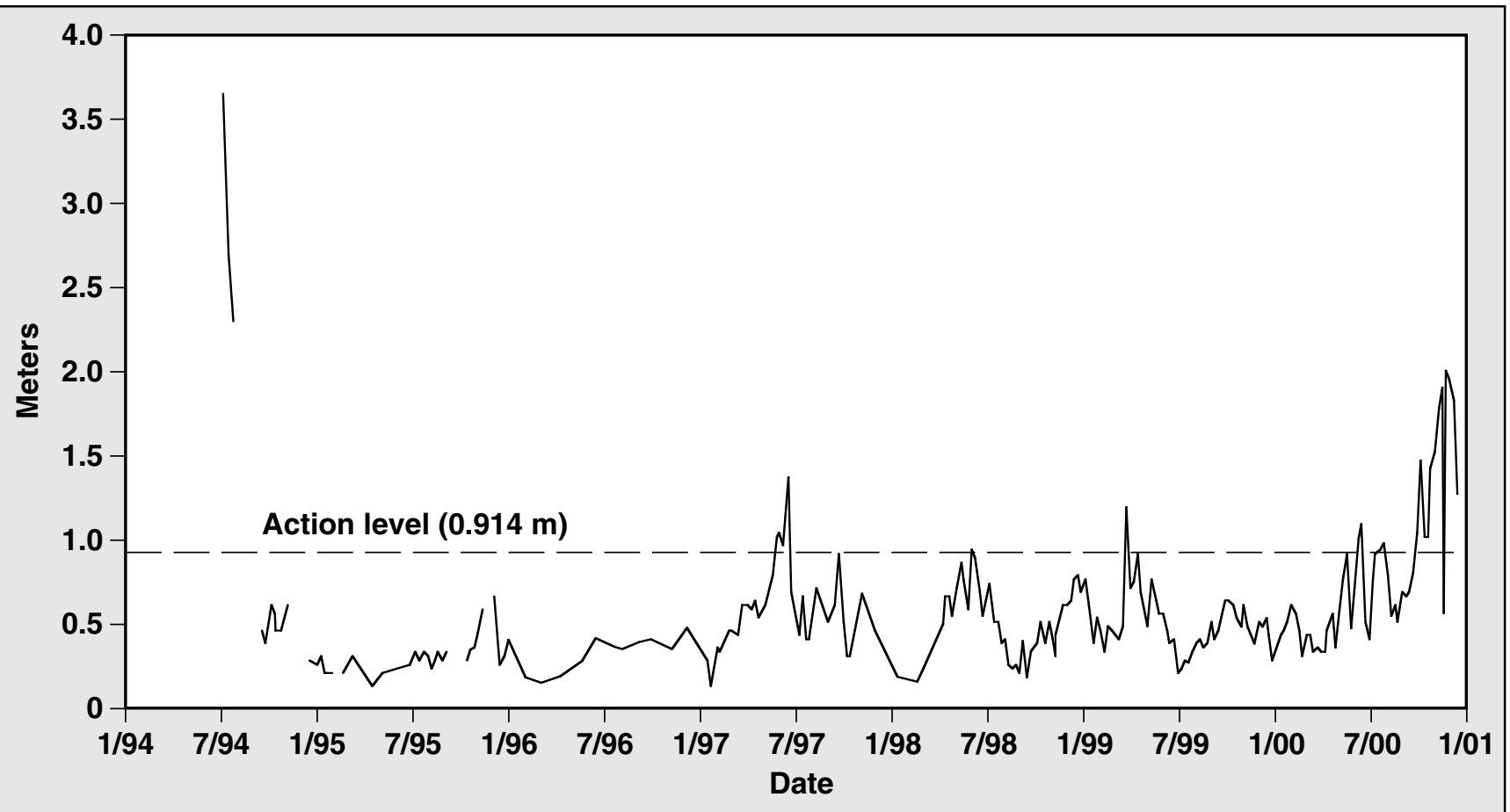

Figure 7-18. Turbidity in Drainage Retention Basin, 1994-2000

clearer water. Wet season turbidity probably results from sediments that pass through the sediment traps discharging into the DRB. Turbidity seen during the warmer summer months is most likely the result of algae growth (Harrach et al. 1996). Turbidity may also be caused by the operation of the aerators suspending sediments and preventing smaller particles from settling.

Beginning in the $1999 / 2000$ wet season and throughout 2000, LLNL began to operate the DRB to minimize the water level fluctuations and maintain the water level as much as possible between 1 and 2 feet above the shelf. This management strategy allowed both submergent and emergent vegetation to be established throughout the DRB for the first time, which may explain the trend toward increased clarity.
Nutrient levels continued to be high during 2000 (Figure 7-19). Concentrations were well above management action levels throughout the year, but decreased concentrations occurred in the periods when chlorophyll-a was high (Figure 7-17), possibly indicating an uptake of nutrients during algae growth. Total phosphorus decreased throughout 2000, ending in concentrations near the management action levels. Sources of nitrate and phosphorous include external sources, storm water runoff, treated groundwater discharges, and an internal source of nutrient cycling related to algae and plant growth. In addition, ammonia exceeded the management action level during three months of the year. Ammonia formation is normally an indication of anoxic conditions. During 2000, total dissolved solids continued to exceed the management action levels with the 


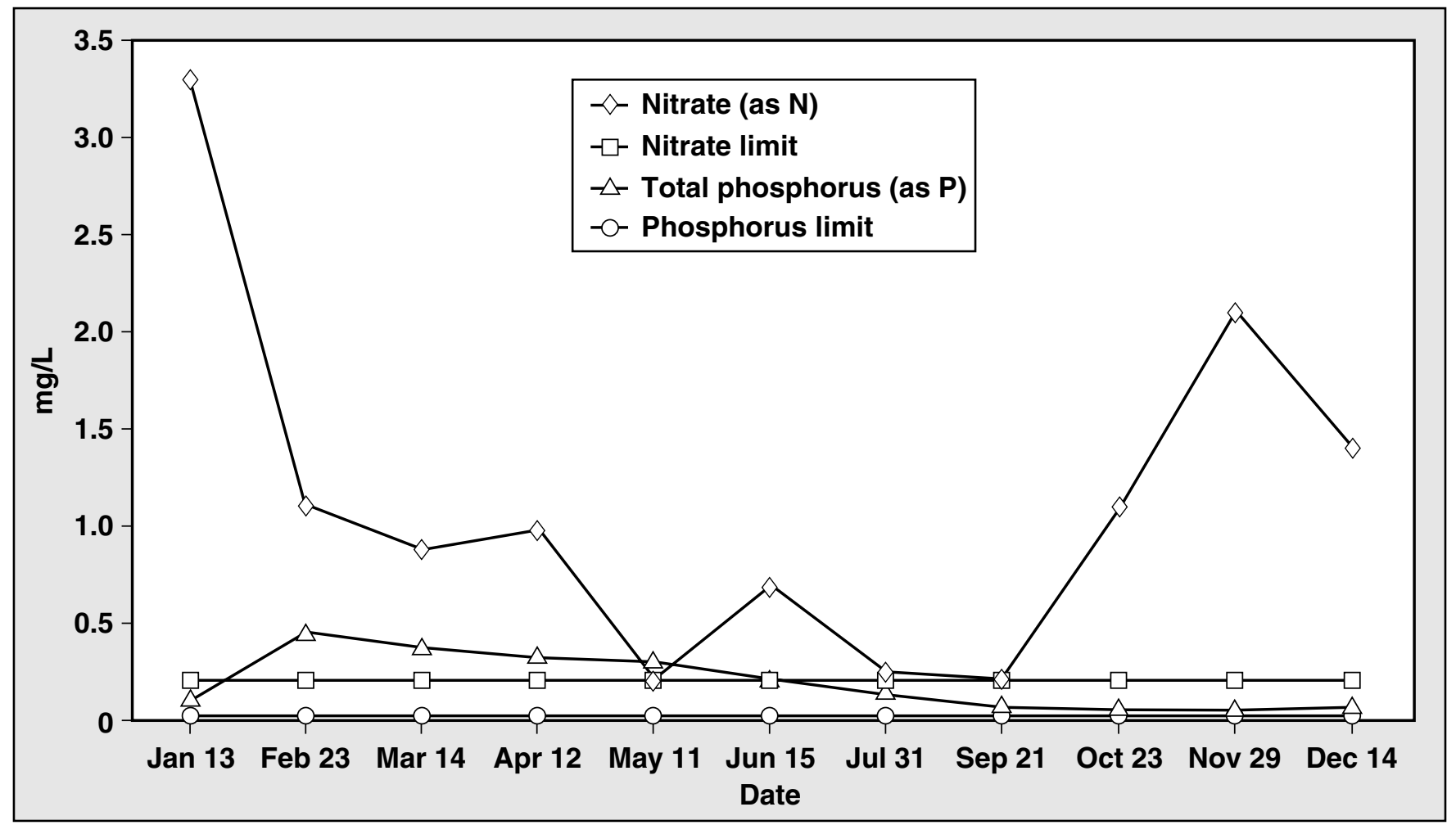

Figure 7-19. Nutrient levels in the Drainage Retention Basin, 2000

concentration exceeding $360 \mathrm{mg} / \mathrm{L}$ in all

11 months when samples were collected. Specific conductance exceeded the management action level of $900 \mu \mathrm{mhos} / \mathrm{cm}$ for 7 months, showing a relation between the increase in TDS and the increase seen in specific conductance.

LLNL collects and analyzes samples for acute fish toxicity and for the chronic toxicity of three species (fathead minnow, water flea, and algae) a minimum of once per year from sample location CDBE, and upon the first wet-season release at CDBX. In addition, LLNL collects acute fish toxicity samples from each discrete dry-season release. Samples collected in April from sample location CDBE showed very low levels of algae toxicity (2 toxic units). All other toxicity samples collected showed no toxic effects.

\section{Biological Monitoring}

Biological monitoring has not been conducted long enough to identify any trends resulting from operation of the DRB. However, biological monitoring has shown an expansion in the wetland areas in Arroyo Las Positas as a result of the continuous discharges of water from the DRB and other sources of treated groundwater throughout the dry season. The California red-legged frog is found in Arroyo Las Positas and the DRB. A number of other species routinely use the DRB, its tributaries, and receiving water; they are listed in Data Supplement Table 7-19.

\section{Site 300 Cooling Towers}

This section discusses general information about the Site 300 cooling towers, sampling methods, and sampling results. 


\section{General Information}

As discussed in the "General Information" subsection of the "Storm Water" section, the CVRWQCB rescinded WDR 94-131, NPDES Permit No. CA0081396, on August 4, 2000. Discharges from the two primary cooling towers at Site 300, with some minor plumbing modifications to the Building 836A cooling tower, were determined by CVRWQCB staff to be discharges to the ground rather than to surface water drainage courses (SWDC). Therefore, an NPDES permit for the cooling tower discharges is unnecessary and the CVRWQCB plans to incorporate the cooling tower discharges into WDR 96-248 in 2001. WDR 94-131 and its effluent limits were in effect through August 2000. Pending the incorporation of the cooling tower discharges into WDR 96-248, LLNL continues to monitor the cooling tower wastewater discharges in accordance with the WDR 94-131 monitoring and reporting program.

Compliance sampling results were reported to the CVRWQCB quarterly through the second quarter of 2000 .

Two primary cooling towers, located at Buildings 801 and 836A, regularly discharge to the ground. The 13 secondary cooling towers routinely discharge to percolation pits under a waiver of Waste Discharge Requirements from the CVRWQCB. Cooling tower locations are shown in Figure 7-20. The permit establishes separate effluent limits for the regular discharges from the primary cooling towers and secondary cooling towers, where discharges are occasionally diverted from the percolation pits for maintenance. One secondary cooling tower discharged to a surface water drainage course on two separate occasions in 2000 .
Blowdown flow is monitored biweekly from the cooling towers located at Buildings 801 and 836A. TDS and $\mathrm{pH}$ are monitored quarterly at both locations.

\section{Methods}

Sample collection procedures are discussed in Appendix B of the Environmental Monitoring Plan (Tate et al. 1999) and summarized here. To determine the effects of the cooling tower blowdown on Corral Hollow Creek, the permit requires quarterly $\mathrm{pH}$ monitoring of the creek, both upstream (background) and downstream of the cooling tower discharges, whenever the creek is flowing. CARW is the upstream sampling location, and GEOCRK is the downstream sampling location (Figure 7-20). The GEOCRK sampling location is also fed by discharges of treated groundwater from LLNL. Therefore, even when the upstream location is dry, there is often flow at GEOCRK. Field $\mathrm{pH}$ measurements, taken by LLNL technicians using calibrated meters, are used to monitor Corral Hollow Creek. These technicians also perform the required visual observations that are recorded on the field tracking forms along with the field $\mathrm{pH}$ measurements.

LLNL maintenance staff take operational TDS and $\mathrm{pH}$ measurements biweekly, using calibrated meters. LLNL reports these operational values at the request of CVRWQCB, but they are not used to determine compliance.

If the blowdown flow from one of the 13 secondary cooling towers is diverted to a surface water drainage course, the discharge is sampled for $\mathrm{pH}$ and TDS immediately. If the discharge continues, that location is monitored for the same constituents and on the same schedule as the primary cooling towers. 


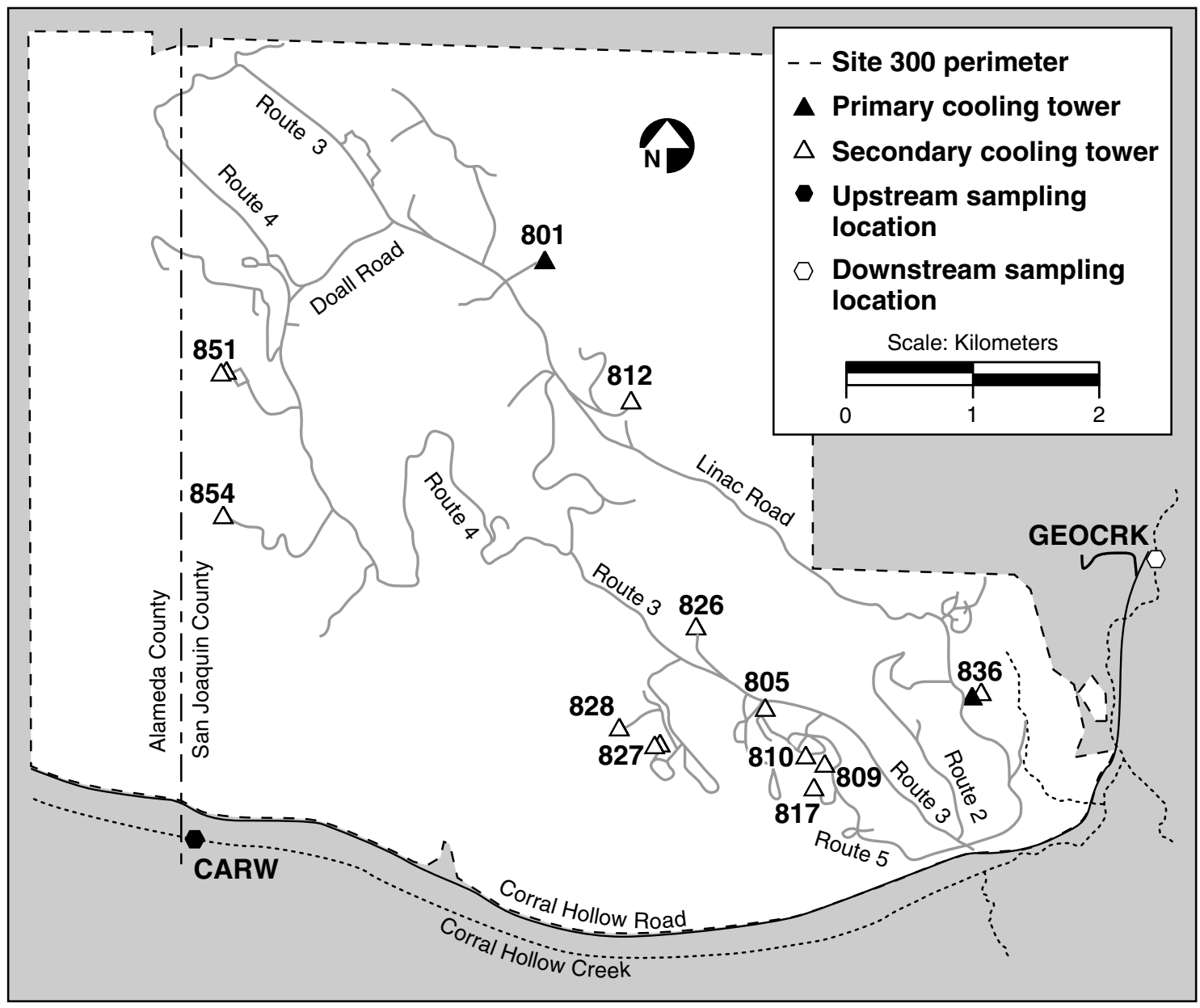

Figure 7-20. Cooling tower locations and receiving water monitoring locations, Site 300, 2000

\section{Results}

Biweekly and quarterly monitoring results are detailed in the quarterly self-monitoring report to the CVRWQCB for the first and second quarters of 2000. Although monitoring continued during the third and fourth quarters, the quarterly selfmonitoring reports were discontinued when WDR 94-131 was rescinded. Summary data from primary cooling tower compliance monitoring and operational monitoring are found in Tables 7-10 and 7-11, respectively.
All TDS concentrations at the Buildings 801 and 836A cooling towers were below both the daily maximum $(2400 \mathrm{mg} / \mathrm{L})$ and monthly average $(2000 \mathrm{mg} / \mathrm{L})$ limits. For compliance samples, all TDS concentrations at the Building 827 cooling towers were below both the daily maximum $(5000 \mathrm{mg} / \mathrm{L})$ and monthly average $(2000 \mathrm{mg} / \mathrm{L})$ limits. However, the operational monitoring data, though below the daily maximum, exceeded the monthly average on two occasions. For the period ending May 22, the operational TDSs for cooling towers $827-1$ and $827-2$ were $3000 \mathrm{mg} / \mathrm{L}$ and $2400 \mathrm{mg} / \mathrm{L}$, respectively. For the period ending December 4 , the operational TDS for cooling 
tower $827-2$ was $2500 \mathrm{mg} / \mathrm{L}$. The compliance monitoring results demonstrate that cooling tower discharges were consistently in compliance with permitted limits (Tables 7-10 and 7-11). All pH samples collected from the cooling tower discharges were below the permitted maximum of 10 .

Table 7-10. Summary data from compliance monitoring of primary cooling towers, Site 300, 2000

\begin{tabular}{|c|c|c|c|c|c|c|c|}
\hline Test & $\begin{array}{c}\text { Tower } \\
\text { no. }\end{array}$ & $\begin{array}{l}\text { Permitted } \\
\text { maximum }\end{array}$ & Minimum & Maximum & Median & $\begin{array}{c}\text { Interquartile } \\
\text { range }\end{array}$ & $\begin{array}{c}\text { Number of } \\
\text { samples }\end{array}$ \\
\hline \multirow{3}{*}{$\begin{array}{l}\text { Total dissolved solids } \\
\text { (TDS) (mg/L) }\end{array}$} & 801 & 2400 & 1100 & 1500 & 1300 & $-^{(a)}$ & 3 \\
\hline & $836 \mathrm{~A}$ & 2400 & 1200 & 1500 & 1250 & $-^{(a)}$ & 4 \\
\hline & $827^{(b)}$ & 5000 & 1300 & 1500 & 1300 & $-^{(a)}$ & 3 \\
\hline \multirow[t]{3}{*}{ Blowdown flow (L/day) } & 801 & 16276 & 3237 & 11283 & 6268 & 3651 & 20 \\
\hline & $836 \mathrm{~A}$ & 8138 & 0 & 3116 & 1071 & 1420 & 25 \\
\hline & $827^{(b)}$ & 11355 & 393 & 7774 & 3318 & 4746 & 10 \\
\hline \multirow[t]{3}{*}{ pH (pH units) } & 801 & 10 & 8.5 & 9.1 & 8.9 & $-^{(a)}$ & 3 \\
\hline & 836A & 10 & 8.3 & 9.2 & 8.9 & 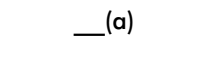 & 4 \\
\hline & $827^{(b)}$ & 10 & 8.9 & 9.0 & 9.0 & - (a) $^{-}$ & 3 \\
\hline
\end{tabular}

a Not enough data points to determine

b Combined discharge from 827-1 and 827-2

Table 7-11. Summary data from operational monitoring of primary cooling towers, Site 300, 2000

\begin{tabular}{|l|c|c|c|c|c|c|c|}
\hline \multicolumn{1}{|c|}{ Test } & $\begin{array}{c}\text { Tower } \\
\text { no. }\end{array}$ & $\begin{array}{c}\text { Permitted } \\
\text { maximum }\end{array}$ & Minimum & Maximum & Median & $\begin{array}{c}\text { Interquartile } \\
\text { range }\end{array}$ & $\begin{array}{c}\text { Number of } \\
\text { samples }\end{array}$ \\
\hline $\begin{array}{l}\text { Total dissolved solids } \\
\text { (TDS) (mg/L) }\end{array}$ & 801 & 2400 & 1050 & 1400 & 1200 & 200 \\
& $836 \mathrm{~A}$ & 2400 & 900 & 1800 & 1125 & 213 \\
& $827-1$ & 5000 & 1000 & 3000 & 1250 & 425 \\
& $827-2$ & 5000 & 700 & 2500 & 1150 & 713 \\
$\mathrm{pH}$ (pH units) & 801 & 10 & 8.7 & 9.6 & 9.2 & 0.2 \\
& $836 \mathrm{~A}$ & 10 & 8.8 & 9.6 & 9.3 & 0.3 \\
& $827-1$ & 10 & 8.7 & 9.8 & 9.4 & 0.6 \\
& $827-2$ & 10 & 8.7 & 9.9 & 9.3 & 0.5 \\
\hline
\end{tabular}


Blowdown flow at all the cooling towers was below the maximum permitted design flow for 2000. Because the Building 801 cooling tower was removed from service during the fourth quarter for installation of a new cooling tower, the summary data in Table 7-10 consist of only the first through third quarters. For the Building 827 cooling towers, the summary data include only the dates the towers discharged to SWDC. For the Building $836 \mathrm{~A}$ cooling tower, the summary data do not include flow data for the period ending June 7; a recording error made that data point unusable.

Two separate discharges occurred from the Building 827 secondary cooling tower in 2000. In March the Building 827 cooling tower percolation pit clogged with silt and overflowed to the SWDC. While evaluating the problem, LLNL allowed cooling tower blowdown to continue flowing to the percolation pit to minimize the amount of blowdown discharged to the SWDC. On May 23, the flow was diverted to the SWDC while the pit was repaired. Repairs were completed on May 24, after which flow returned to the percolation pit and LLNL discontinued routine monitoring. As required by the permit, monitoring samples for $\mathrm{pH}$ and TDS were collected immediately from both cooling towers that discharge to that pit.

However, on March 29, the LLNL sampling staff inadvertently collected biweekly $\mathrm{pH}$ and TDS samples instead of conducting biweekly flow monitoring. The results from this extra set of samples (1100 mg/L TDS and $8.9 \mathrm{pH}$ ) are not included in Table 7-10. Sampling requirements were subsequently reviewed with the sampling staff, who initiated biweekly flow monitoring on April 12. The operational flow values for this interval demonstrate compliance. For the period ending March 27 , the operational values were $2368 \mathrm{~L} /$ day for cooling tower 827-1 and $4769 \mathrm{~L} /$ day for cooling tower 827-2. These values are below the 11,355 $\mathrm{L} /$ day maximum permitted design flow.
On October 3, the Building 827 cooling tower percolation pit overflowed again and, as required by the permit, monitoring samples for $\mathrm{pH}$ and TDS were immediately collected. Analytical results were $1300 \mathrm{mg} / \mathrm{L}$ TDS and $9 \mathrm{pH}$ for the combined discharge from 827-1 and 827-2. Routine monitoring of the Building 827 cooling towers continued through March 2001, when LLNL closed the clogged percolation pit and installed a new one. Permit limits for the secondary cooling towers require that the TDS must not exceed a monthly average of $2000 \mathrm{mg} / \mathrm{L}$ or $5000 \mathrm{mg} / \mathrm{L}$ daily, $\mathrm{pH}$ must not exceed 10, and flow must not exceed the permitted design maximum. Summary data are found in Tables 7-10 (compliance monitoring) and 7-11 (operational monitoring).

First-quarter $\mathrm{pH}$ samples collected on February 14 measured a $\mathrm{pH}$ of 8.09 at CARW and 8.07 at the downstream GEOCRK location. These values are below the $8.5 \mathrm{pH}$ limit.

During the second quarter, flow was observed only at GEOCRK. This downstream flow was sampled on May 10, May 24, June 7, and June 21; the resulting $\mathrm{pH}$ measurements were 9.02, 8.96, 8.98, and 8.9 , respectively. Although these values are above the $8.5 \mathrm{pH}$ limit, cooling tower blowdown did not cause the $\mathrm{pH}$ elevation in the receiving water. In the past, it was thought that cooling tower flow could reach Corral Hollow Creek only during significant rain events. However, the recent determination by CVRWQCB staff that cooling tower flow does not reach even on-site surface waters eliminates the pathway for the cooling tower flow to reach Corral Hollow Creek.

During the third quarter, flow was observed only at GEOCRK. This downstream flow was sampled on July 6, July 19, and August 16; the resulting pH measurements were 8.9,9.31, and 8.0, respectively. Two of the three results are slightly above the 
$8.5 \mathrm{pH}$ limit. As with the second-quarter samples, there was no pathway for the cooling tower flow to reach Corral Hollow Creek.

During the fourth quarter, flow was observed only at GEOCRK. This downstream flow was sampled on October 13 and November 7; the resulting $\mathrm{pH}$ measurements were 8.69 and 8.71 , respectively.

Visual observations of Corral Hollow Creek were performed each quarter as required in the permit. The ambient $\mathrm{pH}$ did not change by more than 0.5 units, and no visible oil, grease, scum, foam, or floating suspended materials were noted in the creek during 2000.

Maintenance mechanics did not collect operational data for any cooling towers for the periods ending January 3, February 14, April 25, May 8, or September 25. Operational $\mathrm{pH}$ measurements were not taken for the period ending February 14 for any location, and for Building 801 for the period ending February 28, because of a broken pH meter. The Building 827-1 cooling tower was down for repair during the periods ending December 4 and December 18; therefore, no operational data were collected.

\section{Site 300 Drinking Water System Discharges}

This section discusses general information about the monitoring requirements for discharges from the Site 300 drinking water system, including permit information, sampling methods, and sampling results.

\section{General Information}

LLNL samples large-volume discharges from the Site 300 drinking water system that reach surface water drainage courses in accordance with the requirements of WDR 5-00-175, NPDES General
Permit No. CAG995001. LLNL obtained coverage under this general permit for drinking water system discharges to surface waters when WDR 94-131 was rescinded in August 2000. The monitoring and reporting program that LLNL developed for these discharges was approved by the CVRWQCB.

Discharges that are subject to sampling under WDR 5-00-175 include:

Drinking Water Storage Tanks: monitor all discharges that have the potential to reach surface waters.

System flushes: monitor one flush per pressure zone per year for flushes that have the potential to reach surface waters.

Deadend flushes: semi-annually monitor all flushes that have the potential to reach surface waters, and for any discharge that continues for more than four months.

Discharges must comply with the effluent limits for residual chlorine established by the permit, which require that it must not be greater than $0.02 \mathrm{mg} / \mathrm{L}$, and that the $\mathrm{pH}$ must be between 6.5 and 8.5. Discharges are also observed to ensure that no erosion results and no other pollutants are washed into surface waters. To meet the chlorine limit, drinking water system discharges with the potential to reach surface waters are dechlorinated.

\section{Methods}

Sample collection procedures are discussed in Lawrence Livermore National Laboratory Site 300 Water Suppliers' Pollution Prevention and Monitoring and Reporting Program (Mathews 2000). Grab samples are collected in accordance with Operations and Regulatory Affairs Division (ORAD) procedure EMP-W-S. Residual chlorine 
and $\mathrm{pH}$ are immediately analyzed in the field, using a spectrophotometer and calibrated $\mathrm{pH}$ meter, respectively.

Samples are collected at the point of discharge and at the point where the discharge flows into a surface water. If the discharge reaches Corral Hollow Creek, samples are collected at the upstream sampling location, CARW, and the downstream sampling location, GEOCRK (see Figure 7-21).

\section{Results}

Monitoring results are detailed in the quarterly self-monitoring reports to the CVRWQCB. Two drinking water system discharges occurred under the requirements of WDR 5-00-175 in calendar year 2000. The discharge resulted from system flushes that occurred on December 20 and 21, 2000 , at Building 801 . These data are found in Table 7-12.

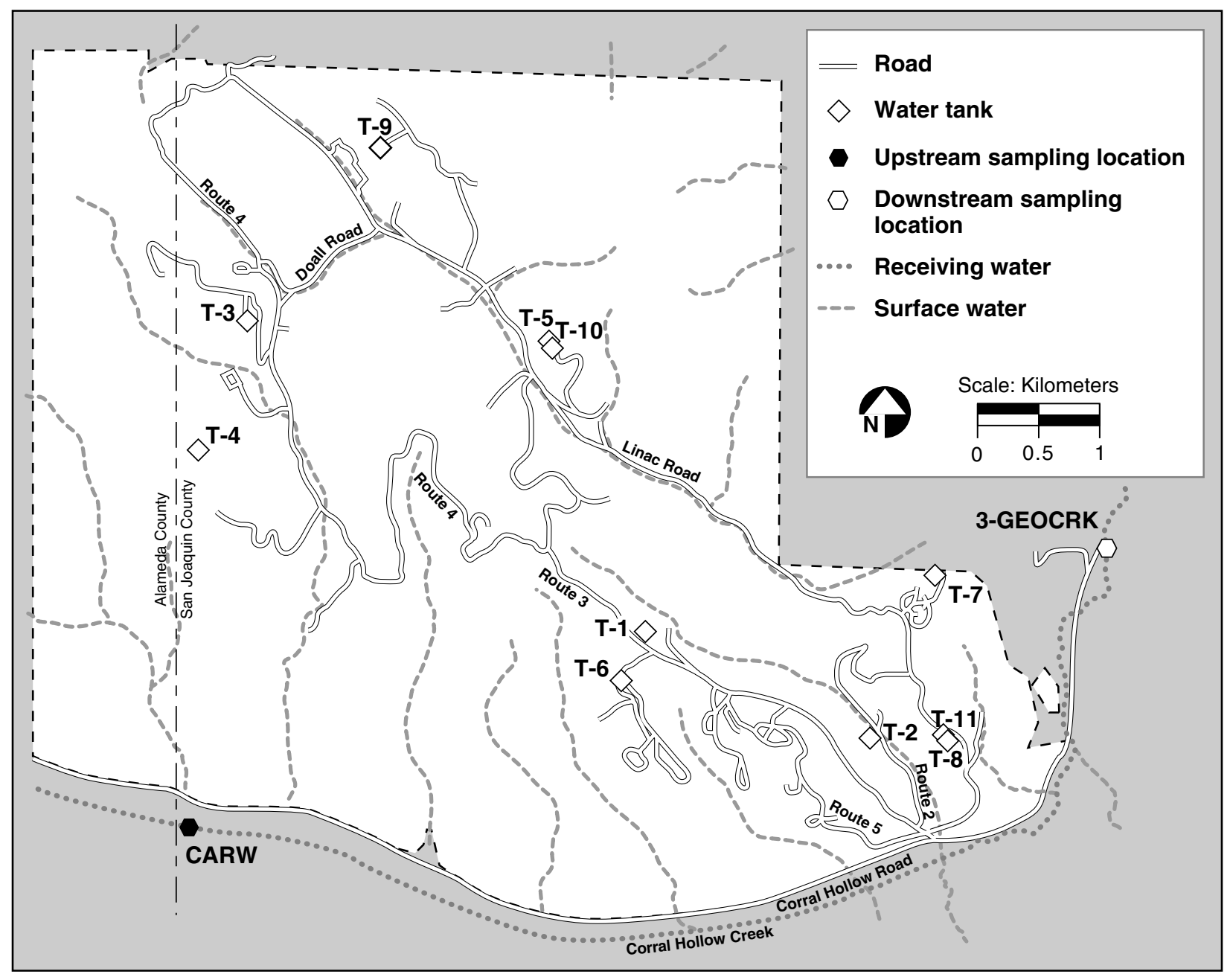

Figure 7-21. Site 300 surface waters, drinking water tanks, and receiving water monitoring locations 
Table 7-12. Measured residual chlorine and pH values in flush water, Building 801, Pressure Zone 3

\begin{tabular}{|c|c|c|c|c|c|}
\hline \multirow{2}{*}{ Date } & \multirow{2}{*}{$\begin{array}{c}\text { Volume } \\
\text { (gallons) }\end{array}$} & \multicolumn{2}{|c|}{$\mathrm{pH}$ (units) } & \multicolumn{2}{c|}{ Residual chlorine (mg/L) } \\
\cline { 3 - 6 } & Effluent & Surface water & Effluent & Surface water \\
\hline Permit limit & - & - & $\geq 6.5, \leq 8.5$ & - & 0.02 \\
$12 / 20 / 00$ & 10,000 & 8.82 & 8.45 & 0.01 & $\mathrm{NV}(\mathrm{a})$ \\
$12 / 21 / 00$ & 4,250 & 8.3 & $\mathrm{NS}^{(b)}$ & 0.01 & $\mathrm{NS}^{(\mathrm{b})}$ \\
\hline
\end{tabular}

a NV = not valid. Sample was collected, but the result was not valid because of interference; see discussion on page 7-36.

b NS = not sampled. Flush water did not reach surface water.

Residual chlorine concentrations at the point of discharge of both releases were $0.01 \mathrm{mg} / \mathrm{L}$, which is in compliance with the surface water effluent limitation of $0.02 \mathrm{mg} / \mathrm{L}$. LLNL staff experienced difficulties measuring the chlorine concentration in some of the samples using a spectrophotometer because of turbidity interference in the samples. These interferences invalidated the results of all the residual chlorine measurements, except those samples taken directly from the fire hydrant. To minimize turbidity interference in the future, LLNL plans to modify this field analysis procedure based on the spectrophotometer manufacturer's recommendations. The $\mathrm{pH}$ of the water entering the surface water on December 20 was 8.45 , which is within the permitted range of 6.5 to 8.5 . The December 21 release did not reach the surface water.

Observations of the December 20 release identified that high flow rates over a recently disturbed area resulted in turbidity in the discharge and some erosion of the stream bank. Because of the length of the travel time between the release point and the surface water, the release was completed before corrections could be made. During the second system flush that occurred on December 21, 2000, from the same release point, modifications were made to reduce the amount of mobilized sediment. These modifications included reducing the flow rate and moving the flow path by pumping the water to a different storm drainage channel. This move prevented the water from flowing through the maintenance zone where the water had picked up the majority of the sediment on the previous day.

\section{Other Waters}

This section discusses general information about monitoring network requirements, sampling methods, and sampling results.

\section{General Information}

Additional surface water monitoring is required by DOE Order 5400.1, General Environmental Protection Program, and DOE Order 5400.5, Radiation Protection of the Public and the Environment. Surface and drinking water near the LLNL Livermore site and in the Livermore Valley are sampled at locations shown in Figure 7-22. Sampling locations DEL, ZON7, DUCK, ALAG, SHAD, and CAL are surface water bodies; of these, DEL, ZON7, and CAL are drinking water sources. BELL, GAS, PALM, ORCH, and TAP are drinking water outlets. Location POOL is the on-site swimming pool. Radioactivity data from drinking water sources and drinking water outlets are used to calculate drinking water statistics (see Table 7-13) and doses. 


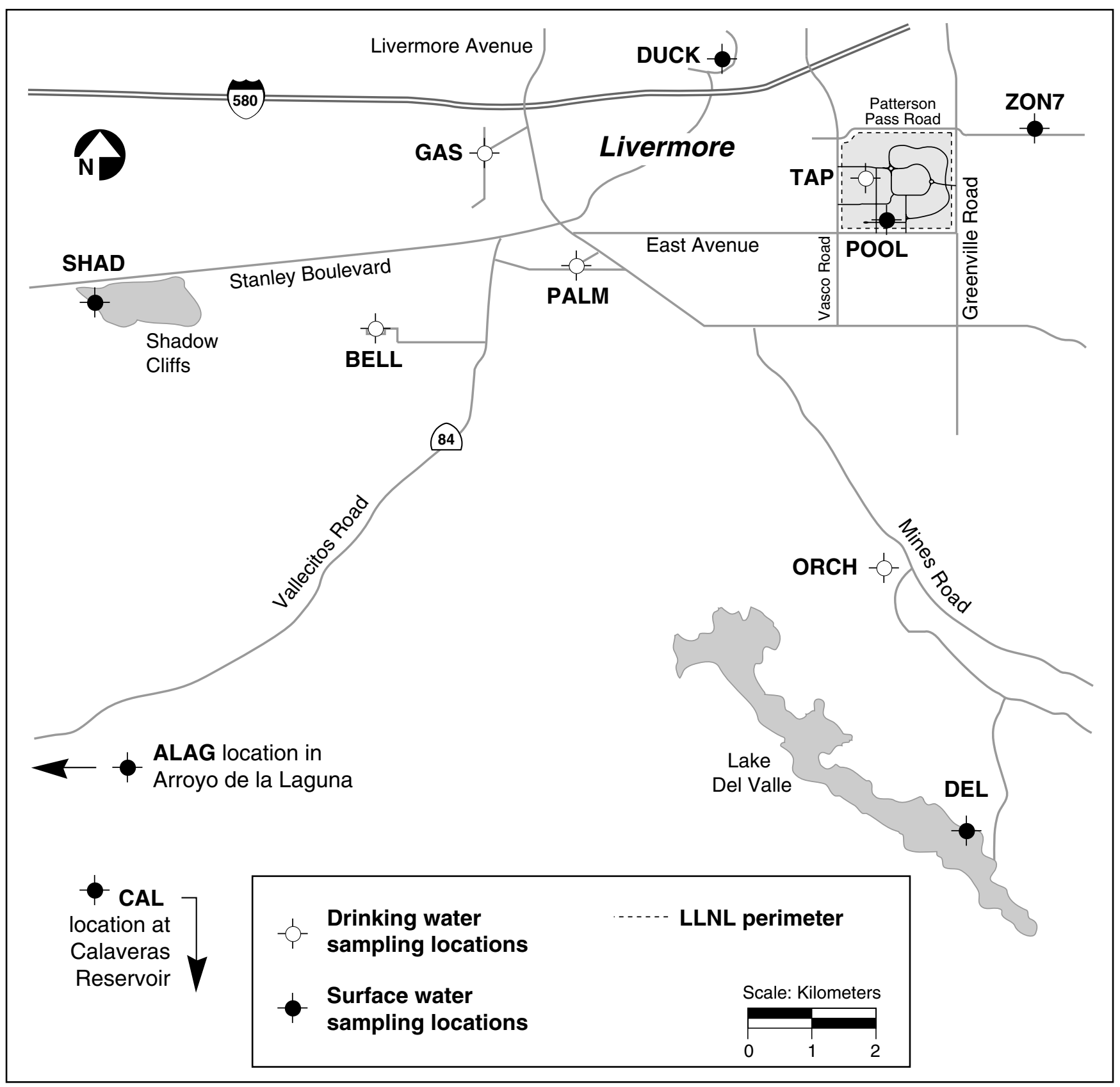

Figure 7-22. Surface and drinking water sampling locations, Livermore Valley, 2000

\section{Methods}

Samples are analyzed for gross alpha, gross beta, and tritium, according to procedures set out in Appendix B of the Environmental Monitoring Plan (Tate et al. 1999). LLNL sampled these locations semiannually, in January and July 2000, for gross alpha, gross beta, and tritium. The on-site swimming pool location (POOL) was sampled semiannually for gross alpha and gross beta, and quarterly for tritium. 
Table 7-13. Radioactivity in surface and drinking water in the Livermore Valley, 2000

\begin{tabular}{|l|c|c|c|}
\hline \multicolumn{1}{|c|}{ Locations } & Tritium (Bq/L) & Gross alpha (Bq/L) & Gross beta (Bq/L) \\
\hline All locations & & & 0.111 \\
Median & 0.372 & 0.028 & 0.029 \\
Minimum & -1.52 & 0.002 & 0.463 \\
Maximum & 4.51 & 0.235 & 0.103 \\
Interquartile range & 0.845 & 0.068 & \\
Drinking water locations & & & 0.107 \\
Median & 0.045 & 0.025 & 0.029 \\
Minimum & -0.70 & 0.007 & 0.463 \\
Maximum & 1.89 & 0.103 & 0.110 \\
Interquartile range & 0.82 & 0.024 & 1.85 \\
Drinking water MCL & 740 & 0.56 & \\
\hline
\end{tabular}

Note: Radioactivities are reported as the measured concentration and either an uncertainty $( \pm 2 \sigma$ counting error) or as being less than the detection limit. If the concentration is less than or equal to the uncertainty or the detection limit, the result is considered to be a nondetection.

\section{Results}

The median activity for tritium in surface and drinking waters, with the exception of POOL samples and one GAS sample, was estimated from calculated values below the laboratory's minimum detectable activities, or minimum quantifiable activities. The maximum tritium activity detected was less than $1 \%$ of the MCL in LLNL's on-site swimming pool. Median activities for gross alpha and gross beta radiation in surface and drinking water samples were approximately $5 \%$ of their respective MCLs. However, maximum activities detected for gross alpha and gross beta, respectively, were $0.235 \mathrm{~Bq} / \mathrm{L}$ and $0.463 \mathrm{~Bq} / \mathrm{L}$; both less than $50 \%$ of their respective MCLs (see

Table 7-13). Detailed data are in Table 7-20 of the Data Supplement. Historically, gross alpha and gross beta radiation have fluctuated around the laboratory minimum detectable activities. At these very low levels, the error measurements are nearly equal to the measured values so that no trends are apparent in the data.

Historical median tritium values in surface and drinking waters in the Livermore Valley since 1988 are shown in Figure 7-23. Water in the LLNL swimming pool has had the highest tritium activities since 1988 because it is closest to tritium sources within LLNL. The highest individual tritium activity measured in the pool was 87.3 Bq/L in a sample collected in the second quarter of 1988 , equal to about $12 \%$ of the drinking water MCL. The highest historical drinking water activity measured for tritium was $3.03 \mathrm{~Bq} / \mathrm{L}$ or about $0.4 \%$ of MCL, in a first quarter 1988 sample from location ORCH, a well used for drinking water. Tritium activities in the LLNL pool and in the other surface and drinking water locations have been decreasing since that time. 


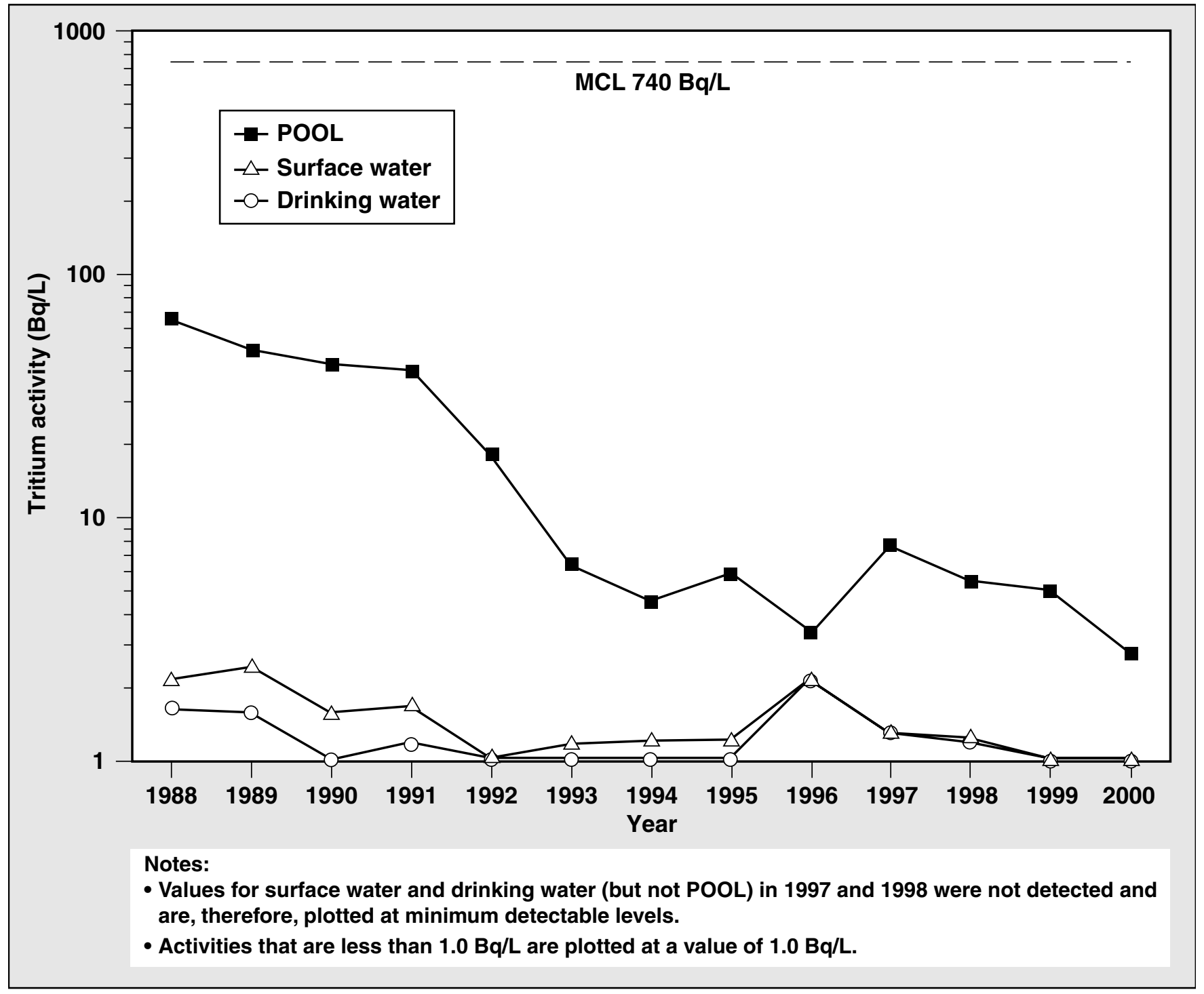

Figure 7-23. Annual median tritium activity in Livermore Valley surface and drinking water, 1988 to 2000

\section{Arroyo Las Positas Maintenance Project}

This section discusses general information about the monitoring requirements for discharges occurring during maintenance activities within Arroyo Las Positas, including permit information, sampling methods, and sampling results.

\section{General Information}

LLNL performs annual maintenance activities within the flood-control channel that diverts the flows of Arroyo Las Positas around the perimeter of the LLNL Livermore site. Maintenance activities include phased desilting of the 7000-linear-foot stretch of Arroyo Las Positas on LLNL property 
over five years, trimming cattail heights, and conducting bank stabilization/erosion control activities. These activities are regulated by:

- WDR 99-086 issued by the SFBRWQCB in 1999

- A Biological Opinion issued by U.S. Fish and Wildlife Service in 1999

- A streambed alteration agreement issued by California Department of Fish and Game in 1998
- A nationwide permit for the construction of six check dams issued by the Army Corps of Engineers in 2000

Work is done in pre-identified zones

(Figure 7-24). Each year, no more than 20 percent of the arroyo length is desilted following the pre-identified patchwork pattern. LLNL conducted maintenance work within Zone 3 during August and September 2000, with the exception of Zone 3A because California redlegged frog tadpoles were present. With agency

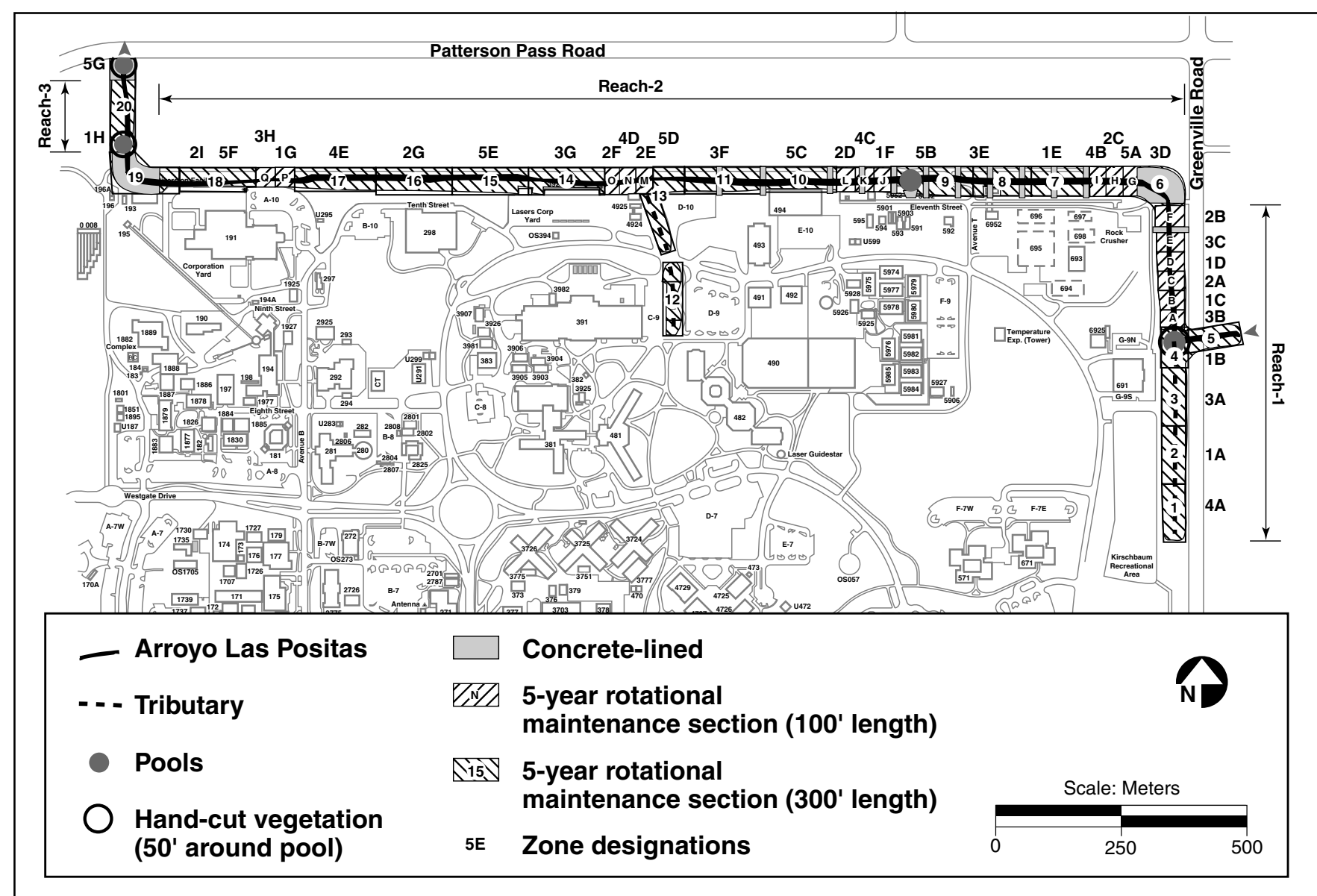

Figure 7-24. Arroyo Las Positas maintenance zones 
approvals, LLNL worked in Zones 1C, 2A, and ID instead of Zone 3A. These three sections were equal in length toZone $3 \mathrm{~A}$.

Discharges occur as a result of dewatering or water diversions, but they cannot cause the receiving water limits, specified in WDR 99-086, to be exceeded. Monitoring is conducted following requirements established in Self-Monitoring Program 99-086 to document compliance with effluent requirements and prohibitions established in WDR 99-086. LLNL submits self-monitoring reports to the SFBRWQCB annually when any receiving water limit is exceeded while work occurred.

\section{Methods}

Samples are collected following procedure EMP-W-S and Water Sampling Supplement EMP-WSS-ALP SOP, set up by the ORAD of the Environmental Protection Department at LLNL. Turbidity, $\mathrm{pH}$, and dissolved oxygen are immediately analyzed in the field using calibrated meters. Weekly duplicate samples are collected and sent to a certified laboratory for analysis.

Receiving water (downstream) samples are collected at the work site twice a day at times evenly spaced during work hours. Receiving water samples are collected no more than 50 feet downstream of the work site while water is diverted around or dewatered from the work site. Upstream samples are collected to characterize background conditions and are collected at least 500 feet above the work site. Prestart background samples are also collected to characterize the receiving water and help evaluate the impact of discharges on the receiving water.

\section{Results}

Monitoring results are detailed in the annual selfmonitoring report to the SFBRWQCB (Galles 2000c) and are presented in Table 7-14. Water diversion during desilting activities occurred only at sections $3 \mathrm{E}$ and $3 \mathrm{G}$. All other sections were dry during the work period, and monitoring was not required. Although receiving water limits were exceeded briefly at Zone $3 \mathrm{E}$ on August 28, no violations of the receiving water limits occurred and there were no failures of structural or administrative controls.

Turbidity exceeded the allowed incremental increase of $10 \%$ of background downstream, and $\mathrm{pH}$ exceeded the allowed incremental change of 0.5 units at Zone 3E on August 28, 2000. The arroyo was dry upstream of the work area. The diverted water was discharged into an isolated pool downstream of the work area. Beyond the pool, the arroyo was dry. The sample collected on August 24 from the isolated pool was used to determine background for the day, because the sample was collected prior to any water being discharged into the pool.

The increased turbidity appeared to be a result of the dewatering activity. The water was being pumped out of the work zone and discharged downstream into the standing pool of water. LLNL staff immediately implemented the corrective action identified in the Water Diversion, Desilting, and Sediment Transport Best Management Practice Plan for Arroyo Las Positas Maintenance Project (Galles 2000b) and began pumping water onto the banks of the arroyo in a manner that prevented the water from flowing back into the stream channel. This best management practice corrected for both the turbidity and the $\mathrm{pH}$. The $\mathrm{pH}$ within the standing pool returned to levels consistent with the August 2000 pH levels 
Table 7-14. Arroyo Las Positas maintenance project monitoring data, 2000

\begin{tabular}{|c|c|c|c|c|}
\hline Date & Time & $\begin{array}{l}\text { Turbidity } \\
\text { (NTU) }\end{array}$ & $\begin{array}{c}\mathrm{pH} \\
\text { (pH units) }\end{array}$ & $\begin{array}{c}\text { Dissolved oxygen } \\
\text { (mg/L) }\end{array}$ \\
\hline \multicolumn{5}{|c|}{ Location: Zone 3E, prestart (background) } \\
\hline July 31, 2000 & 1046 & 5.1 & 7.7 & 2.8 \\
\hline \multicolumn{5}{|c|}{ Location: Zone 3E, downstream } \\
\hline August 24, 2000 & 1330 & 42.2 & 7.8 & 2.35 \\
\hline August 28,2000 & 1052 & 78.5 & 8.3 & 8.8 \\
\hline August 28,2000 & 1300 & 90.2 & 8.16 & 5.4 \\
\hline August 28,2000 & 1515 & 98.3 & $-^{(\mathrm{a})}$ & - (a) $^{(2)}$ \\
\hline August 29, 2000 & 0825 & 48.1 & 8.05 & 3.6 \\
\hline August 29, 2000 & 1320 & 46.5 & 7.92 & 3.61 \\
\hline August 30, 2000 & 0955 & 41.9 & $-^{(a)}$ & - (a) $^{(2)}$ \\
\hline \multicolumn{5}{|c|}{ Location Zone 3G, prestart (background) } \\
\hline July 31, 2000 & 1021 & 120 & 8.8 & 11.2 \\
\hline \multicolumn{5}{|c|}{ Location: Zone 3G, upstream } \\
\hline August 31, 2000 & 1220 & 123 & 7.82 & 3.06 \\
\hline September 5, 2000 & 0949 & 2.9 & 7.9 & 6.35 \\
\hline September 7, 2000 & 0945 & 21.1 & 7.76 & 2.93 \\
\hline September 8, 2000 & 0841 & 26.8 & 7.87 & 3.46 \\
\hline September 11, 2000 & 0931 & 12.6 & 8.21 & 3.75 \\
\hline September 12, 2000 & 0938 & 24.3 & 8.2 & 4.13 \\
\hline September 13, 2000 & 0930 & 27.5 & 8.02 & 3.32 \\
\hline September 14, 2000 & 1000 & 10.0 & 8.16 & 3.74 \\
\hline September 15, 2000 & 0830 & 14.9 & 7.94 & 4.96 \\
\hline \multicolumn{5}{|c|}{ Location: Zone 3G, downstream } \\
\hline August 31, 2000 & 1240 & 6.7 & 8.25 & 3.88 \\
\hline August 31, 2000 & 1405 & 3.4 & 8.78 & 5.51 \\
\hline September 5, 2000 & 1015 & 4.1 & 8.1 & 6.92 \\
\hline September 5, 2000 & 1345 & 2.7 & 8.3 & 5.4 \\
\hline September 7, 2000 & 0915 & 8.0 & 8.21 & 6.31 \\
\hline September 8, 2000 & 0910 & 6.4 & 8.27 & 5.82 \\
\hline September 8, 2000 & 1514 & 8.22 & 5.23 & 3.8 \\
\hline September 11, 2000 & 0940 & 9.2 & 8.33 & 6.47 \\
\hline September 11, 2000 & 1430 & 5.1 & 8.31 & 4.46 \\
\hline September 12, 2000 & 1005 & 7.6 & 8.35 & 5.92 \\
\hline September 12, 2000 & 1340 & 3.3 & 8.83 & 4.69 \\
\hline September 13, 2000 & 0945 & 4.9 & 8.37 & 5.77 \\
\hline September 13, 2000 & 1446 & 4.1 & 7.94 & 4.23 \\
\hline September 14, 2000 & 1020 & 9.8 & 8.36 & 5.26 \\
\hline September 14, 2000 & 1515 & 3.3 & 8.25 & 4.0 \\
\hline September 15, 2000 & 0850 & 7.5 & 8.37 & 7.41 \\
\hline September 15, 2000 & 1310 & 5.4 & 8.31 & 6.24 \\
\hline
\end{tabular}

a Sample is not required because receiving water returned to background values. 
within two hours, while the turbidity returned to levels consistent with August 2000 turbidity levels by the next morning.

No measurable flow left the Livermore site during the Arroyo Las Positas maintenance project. The majority of the treated groundwater discharges were diverted from the Arroyo and held within the DRB for the duration of the project. Those treated groundwater flows occurring downstream of the DRB were not sufficient to result in a discharge off the Livermore site. Flow from Arroyo Las Positas coming onto the Livermore site was successfully held behind a strawbale cofferdam installed just upstream of Zone 3B. No flow diversions were required around Zones $1 \mathrm{C}, 1 \mathrm{D}, 2 \mathrm{~A}, 3 \mathrm{~B}$, and $3 \mathrm{C}$.

\section{Environmental Impacts}

This section discusses the environmental impacts of storm water, rainfall, the DRB, cooling towers, and other waters.

\section{Storm Water}

The potential off-site impact of tritium was estimated by determining the effective dose equivalent (EDE). (See Appendix A for the method LLNL used to calculate dose.) Median tritium activity in storm water runoff effluent (location WPDC) was $15.4 \mathrm{~Bq} / \mathrm{L}$, about $2 \%$ of the MCL. The EDE to an adult who ingested $2 \mathrm{~L} /$ day of water at the maximum storm water tritium concentration for 1 year would be less than $0.0002 \mathrm{mSv}(0.02 \mathrm{mrem})$, or $0.02 \%$ of the $1 \mathrm{mSv}$ DOE standard allowable dose for ingestion. Median effluent gross alpha and gross beta activities in Livermore site storm water were 0.20 and $0.23 \mathrm{~Bq} / \mathrm{L}$, both less than $36 \%$ of their respective MCLs.

Concentrations of some metals were above comparison criteria; this was caused by metals associated with suspended solids in the storm water.
Storm water quality runoff from Site 300 is similar to background levels. Although some 2000 storm water results were above comparison criteria at the LLNL site, there is no evidence of any impact to off-site biota. The acute and chronic fish toxicity tests conducted during 2000 showed no toxicity in LLNL storm water runoff, further supporting the conclusion that LLNL storm water has no adverse effect on off-site biota. Algae toxicity tests did reveal growth inhibition for algae in the storm water. However, it appears that this impact may not be associated with activities at LLNL. Monitoring will be continued to demonstrate that the growth inhibition is caused by activities upstream from the Livermore site.

\section{Rainfall}

\section{Livermore Site and Livermore Valley}

Tritium in rainfall had a negligible impact on the environment at the LLNL Livermore site and in the Livermore Valley. The median tritium activity measured in rainfall at LLNL decreased from $19.0 \mathrm{~Bq} / \mathrm{L}$ in 1999 to $3.7 \mathrm{~Bq} / \mathrm{L}$ in 2000 . The offsite median tritium activity for year 2000 is less than $0.5 \mathrm{~Bq} / \mathrm{L}$, which is not significantly different from atmospheric background levels.

\section{Site $\mathbf{3 0 0}$}

Tritium in rainfall had a negligible impact on the environment at Site 300. The measured tritium activities of rainfall samples taken at Site 300 were all either less than the minimum detectable activity or less than the $2 \sigma$ uncertainty. The tritium activity measured in rainfall at Site $\mathbf{3 0 0}$ has been indistinguishable from atmospheric background levels over the past 28 years.

\section{Drainage Retention Basin}

There is no evidence of adverse environmental impact resulting from releases from the DRB. Although mild toxicity to algae was observed in the 
$\mathrm{DRB}$ and in water discharged from the $\mathrm{DRB}$, there is no evidence that the discharge had an effect on the downstream receiving water. Because of the frequent dry season discharges that occurred from the DRB, discharges from groundwater treatment facilities, and the wetter rainfall years that occurred from 1997 through 1999, wetland vegetation has increased both up- and downstream of the DRB. The federally listed threatened California redlegged frog has colonized these wetland areas.

\section{Cooling Towers}

Both primary cooling towers at Site 300 that discharge to surface were within their permitted limits for $\mathrm{pH}$ and TDS. Flow from these cooling towers was below the maximum permitted design flow. Thus, data indicate no negative impact to surface waters from these cooling towers. Compliance samples for $\mathrm{pH}$, TDS, and blowdown flow from the secondary cooling tower percolation pit overflows at Building 827 were also within permitted limits. However, on two occasions the operational TDS values were below the daily maximum but above the monthly average. On both of these occasions, the receiving water, Corral Hollow Creek, was not flowing.

Because blowdown flow from the cooling towers does not reach Corral Hollow Creek, it is unlikely to have a negative impact on the receiving water.

\section{Site 300 Drinking Water System Discharges}

The two releases from the Site 300 drinking water system met the permit effluent limits for $\mathrm{pH}$ and residual chlorine, which are designed to protect aquatic life. Water from the two releases percolated into the ground within and just prior to reaching Elk Ravine, further minimizing the environmental effects of the water release.

\section{Other Waters}

The potential impact of tritium on drinking water supplies was estimated by determining the EDE (see Appendix A). Maximum tritium activity in drinking waters was $1.89 \mathrm{~Bq} / \mathrm{L}$. The EDE to an adult who ingested $2 \mathrm{~L} /$ day of water at this maximum concentration for a year would be $0.024 \mu \mathrm{Sv}$, or $0.06 \%$ of the DOE standard allowable dose of $40 \mu \mathrm{Sv}$ for drinking water systems. Gross alpha and gross beta activities (as well as tritium activies) were below their MCLs. The sample data indicate that the impact of LLNL Livermore site operations on surface and drinking waters is negligible.

\section{Arroyo Las Positas Maintenance Project}

Discharges of diverted water related to the Arroyo Las Positas maintenance project did not adversely impact receiving water quality. Though there were two instances where receiving water quality criteria were exceeded briefly (one for turbidity and one for $\mathrm{pH})$, LLNL immediately implemented corrective actions and redirected dewatering discharges away from the arroyo. The discharges went to an isolated pool within Arroyo Las Positas and did not impact the receiving waters. The isolated pool returned to background values for turbidity and $\mathrm{pH}$ by the next day. 



\section{GroundWATER INVESTIGATION AND Remediation}

\section{Introduction}

During 2000, groundwater investigations and remediations under the Comprehensive Environmental Response, Compensation and Liability Act (CERCLA) continued at both the Livermore site and Site 300. LLNL regularly samples and analyzes groundwater from areas of known or suspected contamination. Portions of the two sites that contain groundwater with concentrations of chemicals of concern are actively investigated to determine the magnitude of the contamination and its source. Remediation strategies are developed and evaluated in preparation for a CERCLA removal action or through the feasibility study process. An approved remedy for each study area is developed in consultation with the regulatory agencies and the community. This chapter reviews the distribution of contaminants in groundwater, and the progress LLNL has made in removing contaminants from groundwater and from the unsaturated zones (soil vapor) at the Livermore site and Site 300.

\section{Livermore Site Groundwater Project}

\section{Physiographic Setting}

The general topography of the Livermore site is described in Chapter 1. The Livermore Valley groundwater system is a sequence of semiconfined aquifers in which groundwater moves downslope from the valley uplands toward the east-west axis of the valley. It then flows generally westward toward the southwest portion of the basin. From there, groundwater has historically flowed south into the Sunol Valley Groundwater Basin.

The largest quantities of groundwater are pumped from the central and western portions of the Livermore Valley, where the valley fill sediment is thickest. These sediments make up two aquifers: 
the Livermore Formation and its overlying alluvium. The Livermore Formation averages about $1000 \mathrm{~m}$ in thickness and occupies an area of approximately $250 \mathrm{~km}^{2}$. The alluvium, which is about $100 \mathrm{~m}$ thick, is the principal waterproducing formation within the valley.

\section{Hydrogeology}

Sediment types at the Livermore site are grouped into four categories — clay, silt, sand, and gravel— based on dominant particle size. Groundwater flow beneath the site is primarily in alluvial sand and gravel lenses and channels, bounded by the less permeable clay and silt. The alluvial sediments have been mapped into seven hydrostratigraphic units (HSUs) beneath the Livermore site using data collected over the years. HSUs can be defined as sedimentary sequences whose permeable layers show evidence of hydraulic connection. The HSUs of concern beneath the Livermore site are the Quaternary alluvial deposits of the upper Livermore member of the Livermore Formation (see Figure 8-1). HSUs 1B, 2, 3A, 3B, 4, and 5 contain contaminants that are primarily solvents (Blake et al. 1995 and Hoffman et al. 1998).

\section{Background}

Initial releases of hazardous materials occurred at the Livermore site in the mid- to late-1940s when the site was the Livermore Naval Air Station (Thorpe et al. 1990). There is also evidence that localized spills, leaking tanks and impoundments, and landfills contributed volatile organic compounds (VOCs), fuel hydrocarbons (FHCs), lead, chromium, and tritium to the groundwater and unsaturated sediment in the post-Navy era. The Livermore site was placed on the EPA National Priorities List in 1987.

A screening of all environmental media showed that groundwater and unsaturated sediment are the only media that require remediation (Thorpe et al. 1990). The identified compounds that currently exist in groundwater at various locations beneath the site at concentrations above drinking standards are trichloroethylene (TCE), perchloroethylene (PCE), 1,1-dichloroethylene (1,1-DCE), chloroform 1, 2-dichloroethylene (1,2-DCE), 1,1-dichloroethane (1,1-DCA), 1,2-dichloroethane (1,2-DCA), trichlorotrifluoroethane (Freon 113), trichlorofluoromethane (Freon 11), and carbon tetrachloride.

\section{Remedial Activities}

In 2000, the Livermore site Groundwater Project (GWP) treated more than 1170 million liters (ML) of groundwater and removed approximately $270 \mathrm{~kg}$ of volatile organic compounds (VOCs). The GWP also brought new treatment facilities on line, installed wells, conducted hydraulic tests, developed groundwater models, published required documents, and maintained close contact with regulatory agencies and the community.

LLNL removes contaminants from groundwater and from the unsaturated zones (soil vapor) at the Livermore site through a system of 11 treatment facilities located throughout the 6 HSUs containing contaminants of concern. Within each facility, extraction wells are used to extract groundwater, which is then treated to remove VOCs. Treatment usually consists of removing VOCs with a large capacity air-stripping system, after which any VOCs present in the stripper's effluent air are removed with granular activated carbon (GAC) filters. Methods are noted in the following discussion of treatment facilities. Table 8-1 lists the extraction wells according to the HSU in which they are screened and the total flow rate for each treatment area. 


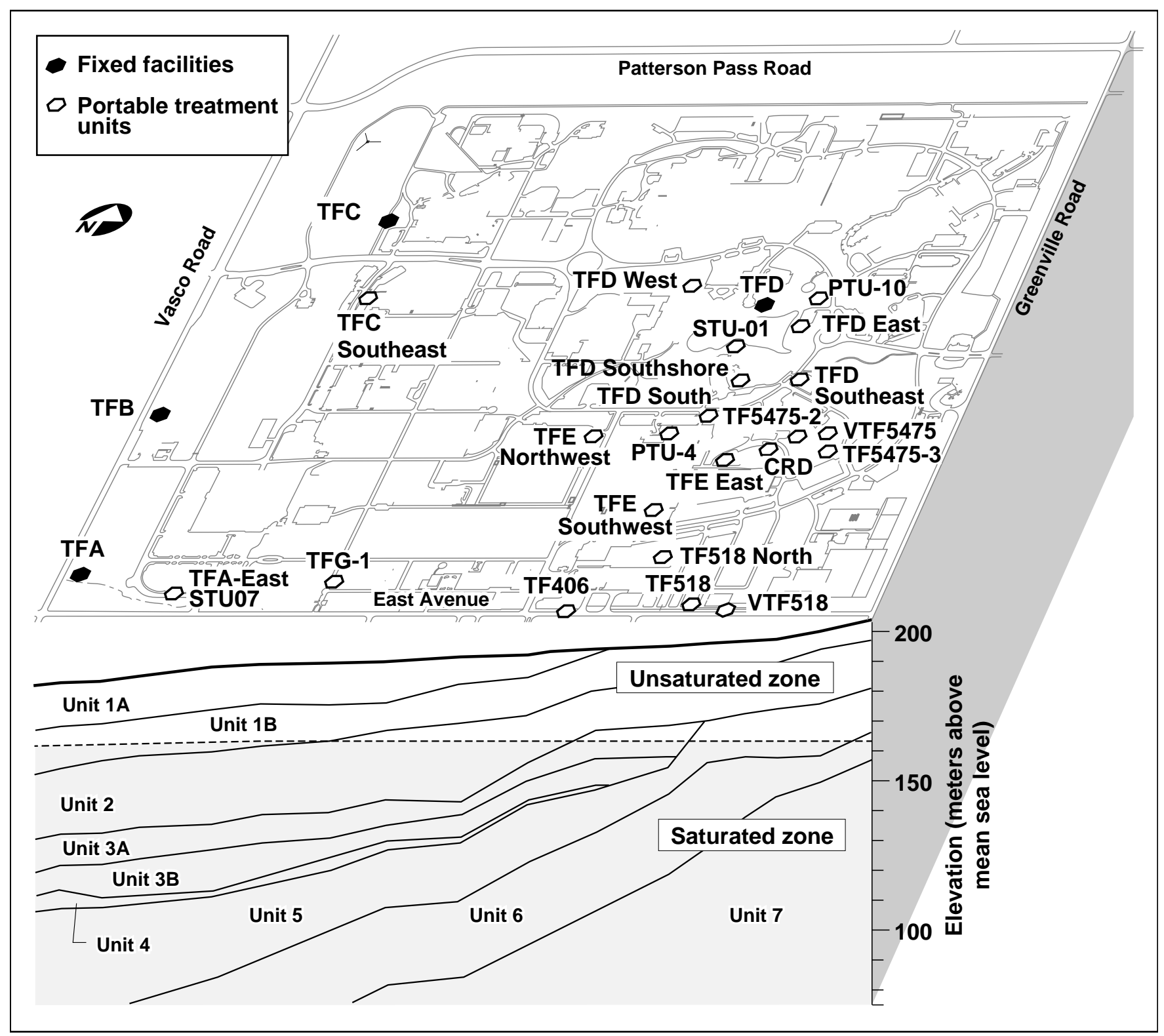

Figure 8-1. Map and cross section of the Livermore site showing hydrostratigraphic units and the locations of the treatment facilities

Of the 11 treatment facilities, 9 are groundwater treatment facilities and 2 are vapor treatment facilities (VTFs). A total of 80 groundwater extraction wells operated at 25 separate locations at an average flow rate of 2540 liters per minute ( $\mathrm{L} / \mathrm{min}$ ). A total of three vapor extraction wells operated at two separate locations at an average flow rate of 0.583 standard cubic meters per minute ( $\mathrm{scmm}$ ).
Since operations began, approximately $5413 \mathrm{ML}$ of groundwater and more than 0.695 million standard cubic meters $(\mathrm{scm})$ of vapor have been treated, and more than $1021 \mathrm{~kg}$ of VO C s have been removed.

Table 8-2 shows both the 2000 totals and the cumulative totals of groundwater and soil vapor treated at the facilities and the estimated VOCS removed from the subsurface. A graph of $\mathrm{VOC}$ 
Table 8-1. 2000 extraction wells and extraction rates

\begin{tabular}{|c|c|c|c|}
\hline $\begin{array}{l}\text { Treatment } \\
\text { facility area }\end{array}$ & $\begin{array}{c}\text { Hydrostratigraphic } \\
\text { Unit }\end{array}$ & $\begin{array}{l}\text { Extraction } \\
\text { wells }\end{array}$ & $\begin{array}{l}\text { Extraction rate } \\
\qquad(\mathrm{L} / \mathrm{min})^{(a)}\end{array}$ \\
\hline TFA & $\begin{array}{l}\text { HSU } 1 B \\
\text { HSU } 2 \\
\text { HSU 3A }\end{array}$ & $\begin{array}{l}\text { W-254, W-262, W-408, W-520, W-601, W-602, } \\
\text { W-1001, W-1004 } \\
\text { W-109, W-415, W-457, W-518, W-522, W-603, } \\
\text { W-605, W-609, W-614, W-714, W-903, W-904, } \\
\text { W-1009 } \\
\text { W-712 }\end{array}$ & $927-1306$ \\
\hline TFB & $\begin{array}{l}\text { HSU } 1 B \\
\text { HSU } 2\end{array}$ & $\begin{array}{l}\text { W-610, W-620, W-704 } \\
\text { W-357, W-621, W-655, W-1423 }\end{array}$ & 288-299 \\
\hline TFC & $\begin{array}{l}\text { HSU } 1 \mathrm{~B} \\
\text { HSU } 2\end{array}$ & $\begin{array}{l}\text { W-701, W-1015, W-1102, W-1103, W-1104, } \\
\text { W-1116 } \\
\text { W-1213 }\end{array}$ & $204-265$ \\
\hline TFD & $\begin{array}{l}\text { HSU } 2 \\
\text { HSU 3A/3B } \\
\text { HSU } 4 \\
\text { HSU } 5\end{array}$ & $\begin{array}{l}\text { W-361, W-906, W-1215, W-1216, W-1303, } \\
\text { W-1306, W-1308, W-1510, W-1550, W-1602 } \\
\text { W-1208, W-1301, W-1504, W-1551, W-1552, } \\
\text { W-1601, W-1651, W-1654 } \\
\text { W-314, W-351, W-1206, W-1307, W-1503, W-1523 } \\
\text { W-907 }\end{array}$ & $382-666$ \\
\hline TFE & $\begin{array}{l}\text { HSU } 2 \\
\text { HSU } 3 \text { A/3B } \\
\text { HSU } 4 \\
\text { HSU } 5\end{array}$ & $\begin{array}{l}\text { W-1 109, W-1409, W-1518, } \\
\text { W-1422, W-1522 } \\
\text { W-1211, W-1418, W-1520 } \\
\text { W-359, W-566 }\end{array}$ & 189-201 \\
\hline TF406 & $\begin{array}{l}\text { HSU } 4 \\
\text { HSU } 5\end{array}$ & $\begin{array}{l}\text { GSW-445, W-1309 } \\
\text { W-1310 }\end{array}$ & $71.9-114$ \\
\hline TFG & HSU 1B/2 & W-1111 & 34.1 \\
\hline TF518 & $\begin{array}{l}\text { HSU } 3 B / 4 \\
\text { HSU } 5\end{array}$ & $\begin{array}{l}W-1410 \\
W-112\end{array}$ & $18.9-34.1$ \\
\hline VTF518 & & SVI-518-201, SVI-518-303 & $0.017(\mathrm{scmm})^{(\mathrm{b})}$ \\
\hline TF5475 & $\begin{array}{l}\text { HSU } 2 \\
\text { HSU 3A }\end{array}$ & $\begin{array}{l}\text { W-1415 } \\
W-1302, W-1606, W-1608\end{array}$ & 11.4 \\
\hline VTF5475 & & SVI-EST-504 & $0.566(\mathrm{scmm})$ \\
\hline & 2000 Total & & $\begin{array}{c}2126-2931 \\
0.583(\mathrm{scmm})\end{array}$ \\
\hline
\end{tabular}

a $\mathrm{L} / \mathrm{min}=$ Liters per minute

b $\mathrm{scmm}=$ Standard cubic meters per minute 
Table 8-2. Volatile organic compounds (VOCs) removed from groundwater and soil at the Livermore site

\begin{tabular}{|c|c|c|c|c|c|}
\hline \multirow{2}{*}{$\underset{\text { facility }}{\text { Treatment }}$} & \multirow{2}{*}{$\begin{array}{l}\text { Startup } \\
\text { date }\end{array}$} & \multicolumn{2}{|c|}{2000} & \multicolumn{2}{|c|}{ Cumulative total } \\
\hline & & $\begin{array}{l}\text { Water treated } \\
(M L)^{(b)}\end{array}$ & $\begin{array}{c}\text { VOCs } \\
\text { removed }(\mathrm{kg})\end{array}$ & $\begin{array}{l}\text { Water treated } \\
\text { (ML) }\end{array}$ & $\begin{array}{c}\text { VOCs } \\
\text { removed }(\mathrm{kg})\end{array}$ \\
\hline TFA & $9 / 89$ & 536 & 13.8 & 3004 & 137 \\
\hline TFB & $10 / 90$ & 105 & 7.1 & 535 & 45 \\
\hline TFC & $10 / 93$ & 94.3 & 7.9 & 410 & 40 \\
\hline TFD & $9 / 94$ & 251 & 107 & 947 & 342 \\
\hline TFE & $11 / 96$ & 106 & 24 & 307 & 95 \\
\hline TFG & $4 / 96$ & 14.8 & 0.8 & 52.6 & 2.7 \\
\hline TF406 & $8 / 96$ & 47.3 & 1.6 & 131 & 5.8 \\
\hline TF518 & $1 / 98$ & 11 & 1.7 & 25 & 3.0 \\
\hline TF5475 & 9/98 & 0.379 & 0.9 & 1.17 & 3.2 \\
\hline \multirow[t]{2}{*}{ Total ${ }^{(c)}$} & & 1166 & 165 & 5413 & 674 \\
\hline & & $\begin{array}{c}\text { Soil vapor treated } \\
\qquad\left(10^{3} \mathrm{~m}^{3}\right)\end{array}$ & $\begin{array}{c}\text { VOCs } \\
\text { removed }(\mathrm{kg})\end{array}$ & $\begin{array}{l}\text { Soil vapor treated } \\
\qquad\left(10^{3} \mathrm{~m}^{3}\right)\end{array}$ & $\begin{array}{l}\text { VOCs } \\
\text { removed }(\mathrm{kg})\end{array}$ \\
\hline VTF518 $8^{\text {(d) }}$ & $9 / 95$ & 3.94 & 2.8 & 422 & 150.1 \\
\hline VTF5475(d) & $1 / 99$ & 214 & 102 & 273 & 197.7 \\
\hline Total $^{(c)}$ & & 218 & 105 & 695 & 348 \\
\hline
\end{tabular}

\footnotetext{
a Includes fixed and portable units

b $\quad M L=1$ million liters

c Totals rounded to nearest whole number

d Vapor treatment facility
}

mass removal at the Livermore site since 1989 is presented in Figure 8-2. Concentrations of remaining VOCs in the fourth quarter 2000 are depicted as isoconcentration maps in the six HSUs in Figures 8-3 through 8-8. The VOC plumes in HSUs $1 \mathrm{~B}, 2,3 \mathrm{~A}, 3 \mathrm{~B}, 4$, and 5 continue to be hydraulically controlled based on trends in groundwater chemistry, capture zone analysis, and the total VOC isoconcentration maps (Figures 8-3 through 8-8) for each HSU.

The numbers and associated treatment faciliy areas of new wells installed in 2000 are shown in Table 8-3. Well construction details, well closure data, and results of drawdown tests are provided in the LLNL Groundwater Project 2000 Annual Report (Aarons et al. 2001).

\section{Treatment Facility A}

Treatment Facility A (TFA) is a fixed facility located in the southwestern quadrant of the Livermore site near Vasco Road and East Avenue (Figure 8-1). Groundwater is treated using the large-capacity air-stripping system installed in June 1997. VOCs are stripped from the groundwater, and the effluent air from the stripper is passed through granular activated carbon (GAC) filters to remove VOCs. The treated effluent air is then vented to the atmosphere. The California Regional Water Quality Control Board (RWQCB) permits 


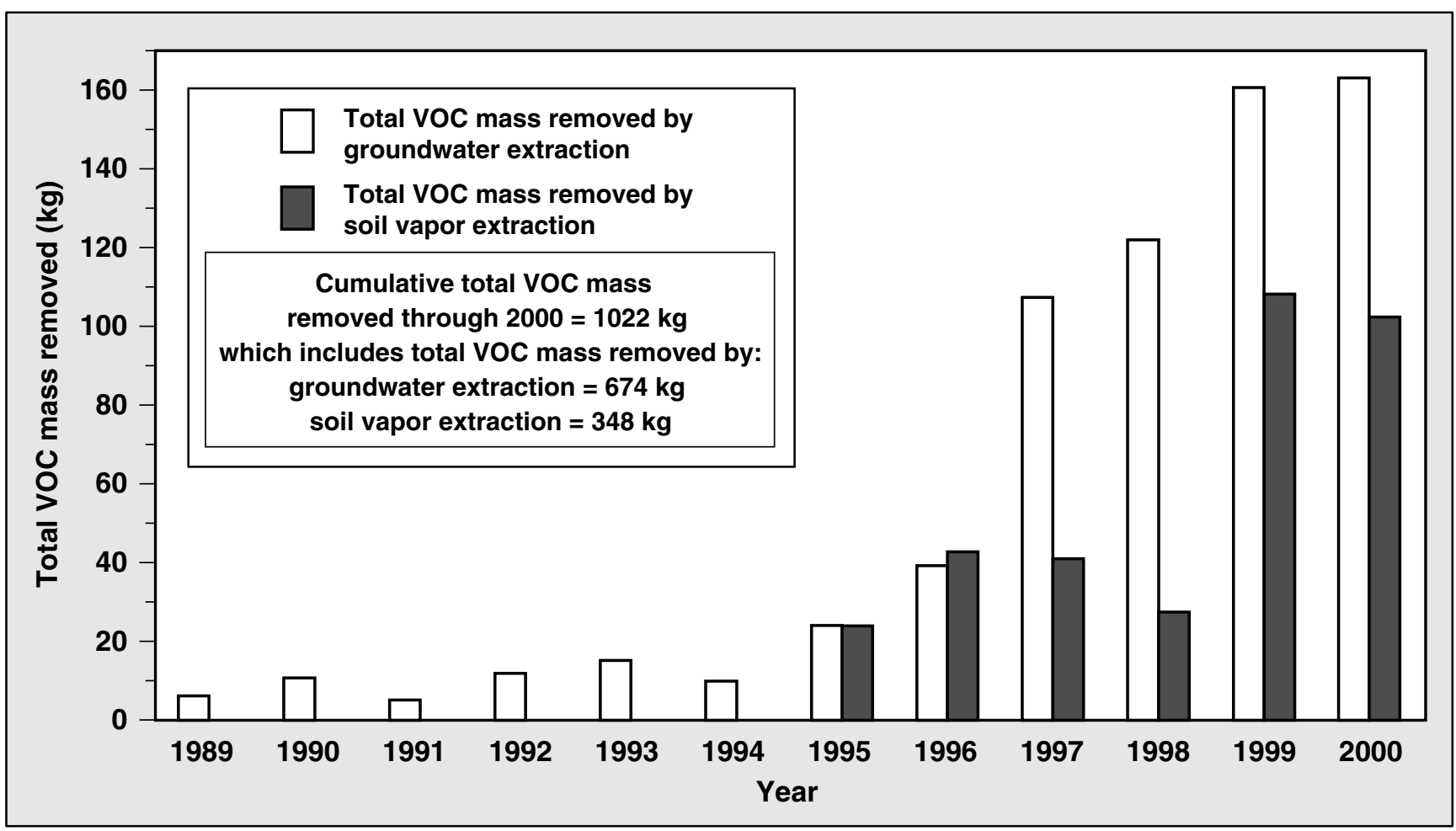

Figure 8-2. Total VOC mass removed from the subsurface of the Livermore site, 1989-2000

LLNL to treat up to $1890 \mathrm{~L} / \mathrm{min}$ of groundwater. Treated groundwater from TFA is discharged to the Recharge Basin, located about $600 \mathrm{~m}$ southeast of TFA on Department of Energy (DOE) property administered by Sandia National Laboratories/California. Since the startup of the new system, TFA has not exceeded the 5 parts per billion (ppb) total VOC discharge limit.

Solar treatment unit (STU) TFA East (TFA-E) is located east of TFA and processes VOCs in groundwater using GAC. TFA-E was in compliance with all permits through 2000 .

In 2000, wells at TFA and TFA-E pumped at a combined flow rate of about $1210 \mathrm{~L} / \mathrm{min}$ and treated $536 \mathrm{ML}$ of groundwater containing an estimated $13.8 \mathrm{~kg}$ of VOCs.
One new monitor well was installed in the TFA area in 2000 (see Table 8-3).

\section{Treatment Facility B}

Treatment Facility B (TFB) is located in the westcentral portion of the Livermore site (Figure 8-1). Groundwater is treated using the large-capacity air-stripping system installed in October 1998. This unit replaced an ultraviolet/hydrogen peroxide $\left(\mathrm{UV} / \mathrm{H}_{2} \mathrm{O}_{2}\right)$ system that had been in use since 1990. Groundwater is also treated for chromium(VI) in an ion-exchange unit during December through March, based on the current RWQCB discharge substantive requirements. Treated groundwater from TFB is discharged into the north-flowing drainage ditch parallel to Vasco Road that empties into Arroyo Las Positas to the north. 


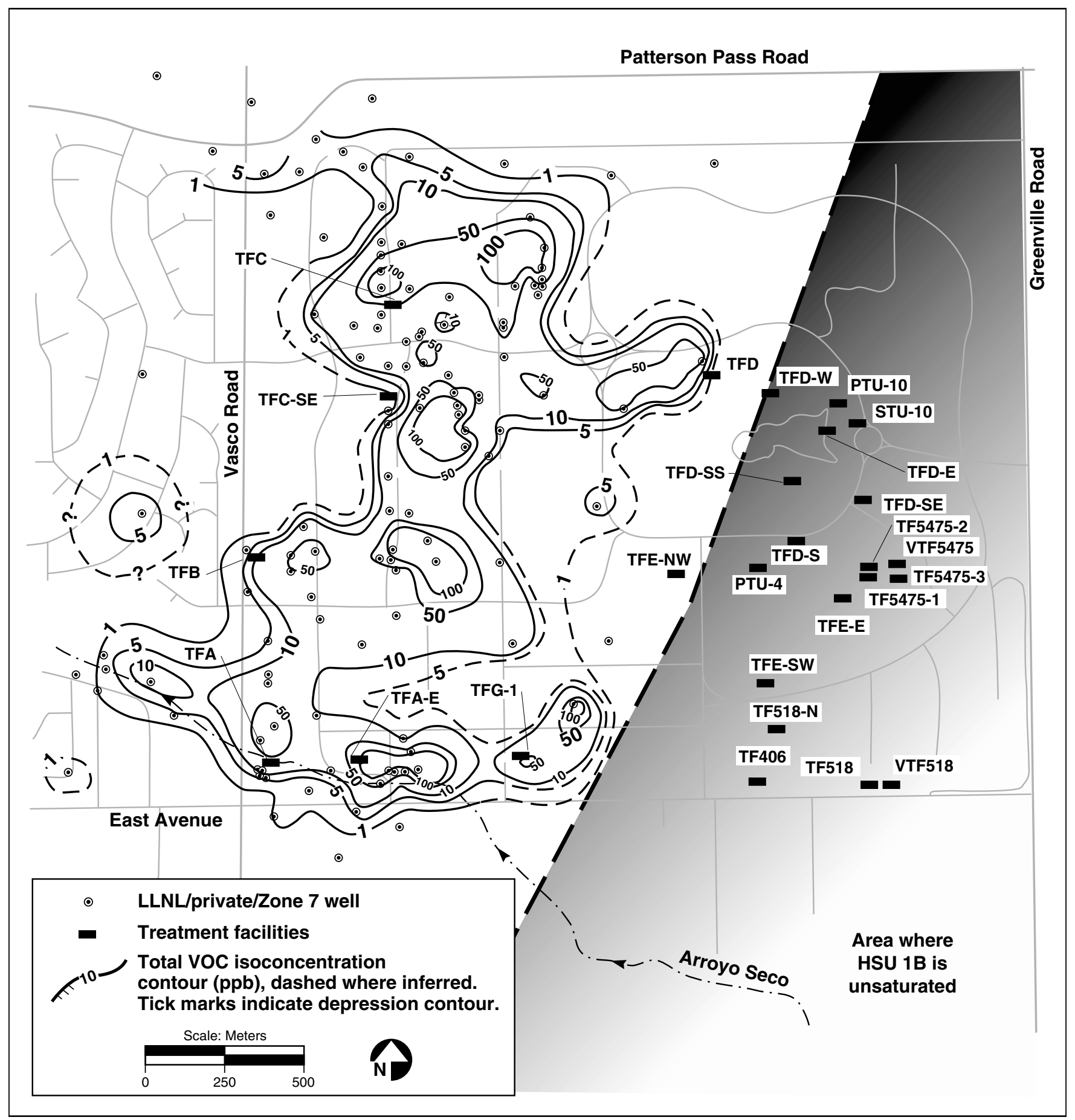

Figure 8-3. Isoconcentration contour map of total VOCs within HSU 1B 


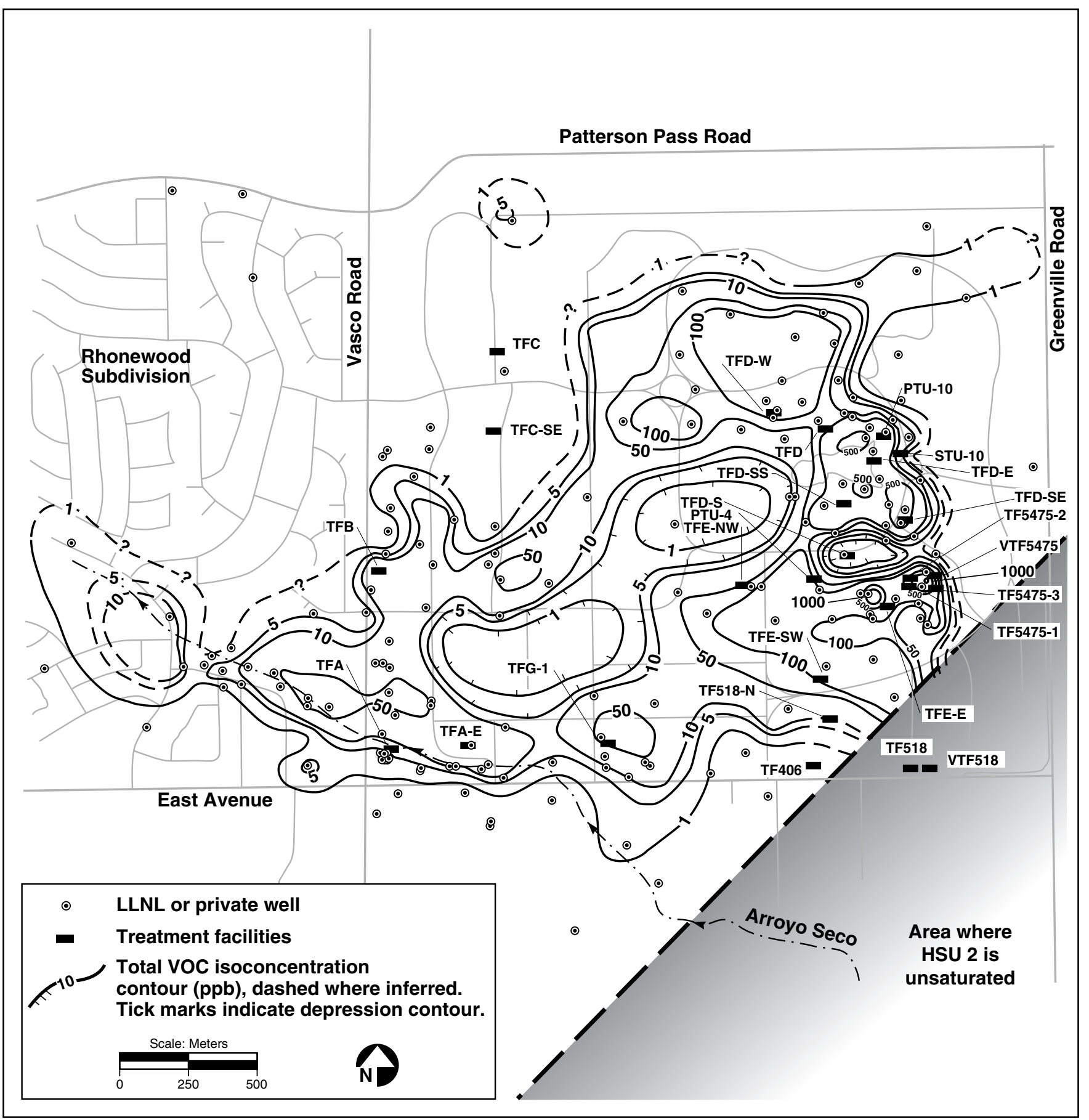

Figure 8-4. Isoconcentration contour map of total VOCs within HSU 2 


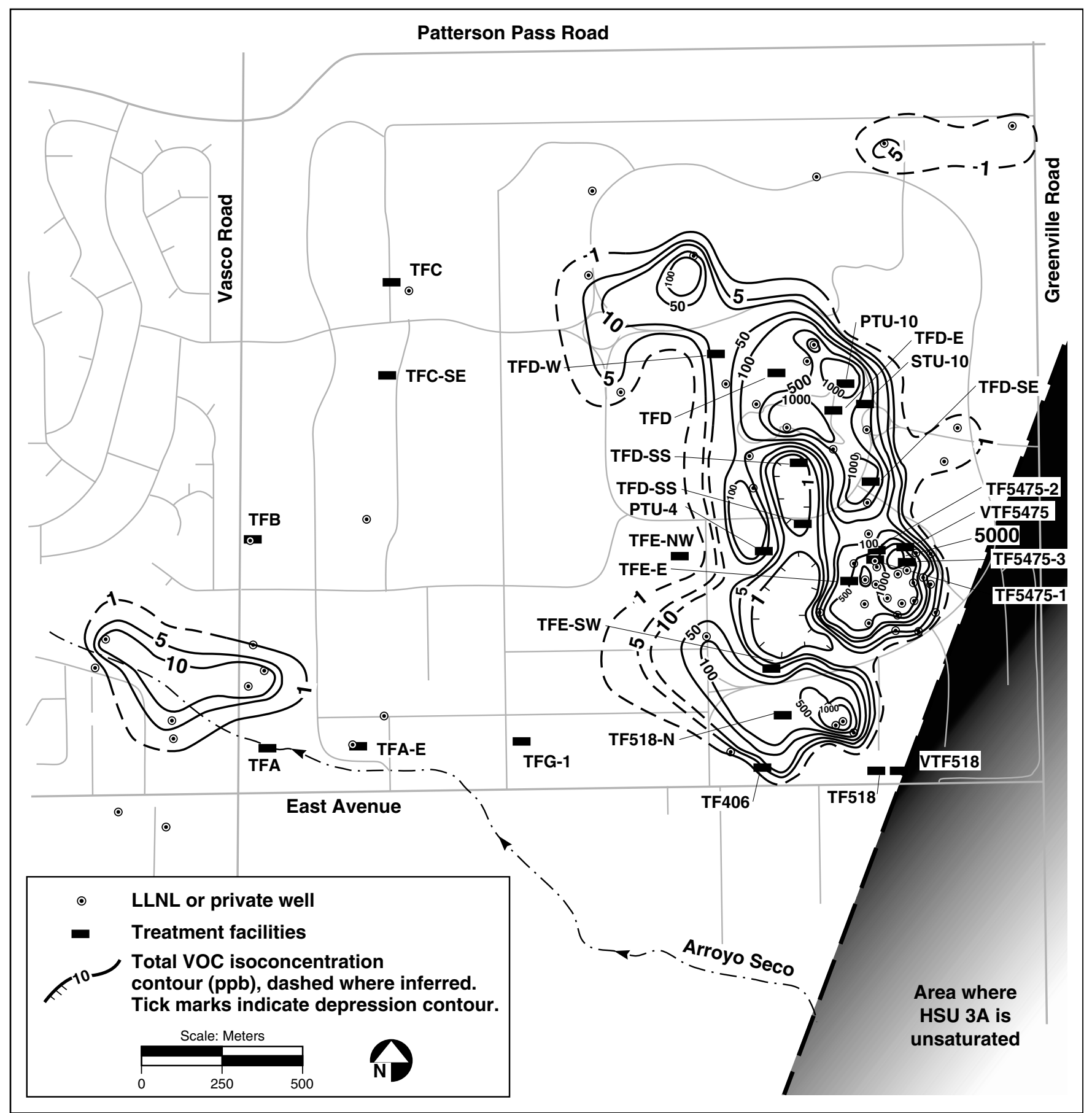

Figure 8-5. Isoconcentration contour map of total VOCs within HSU 3A 


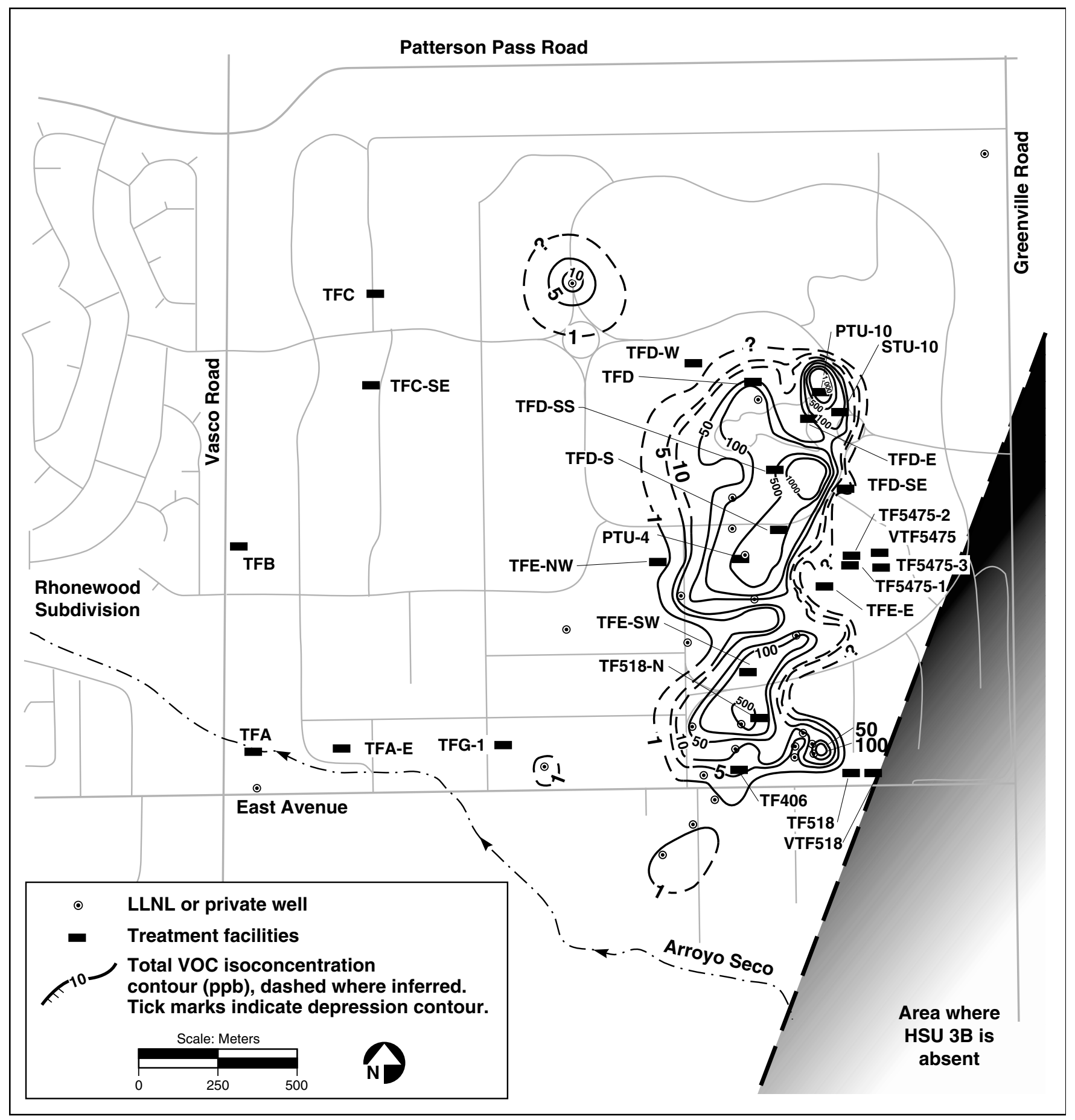

Figure 8-6. Isoconcentration contour map of total VOCs within HSU 3B 


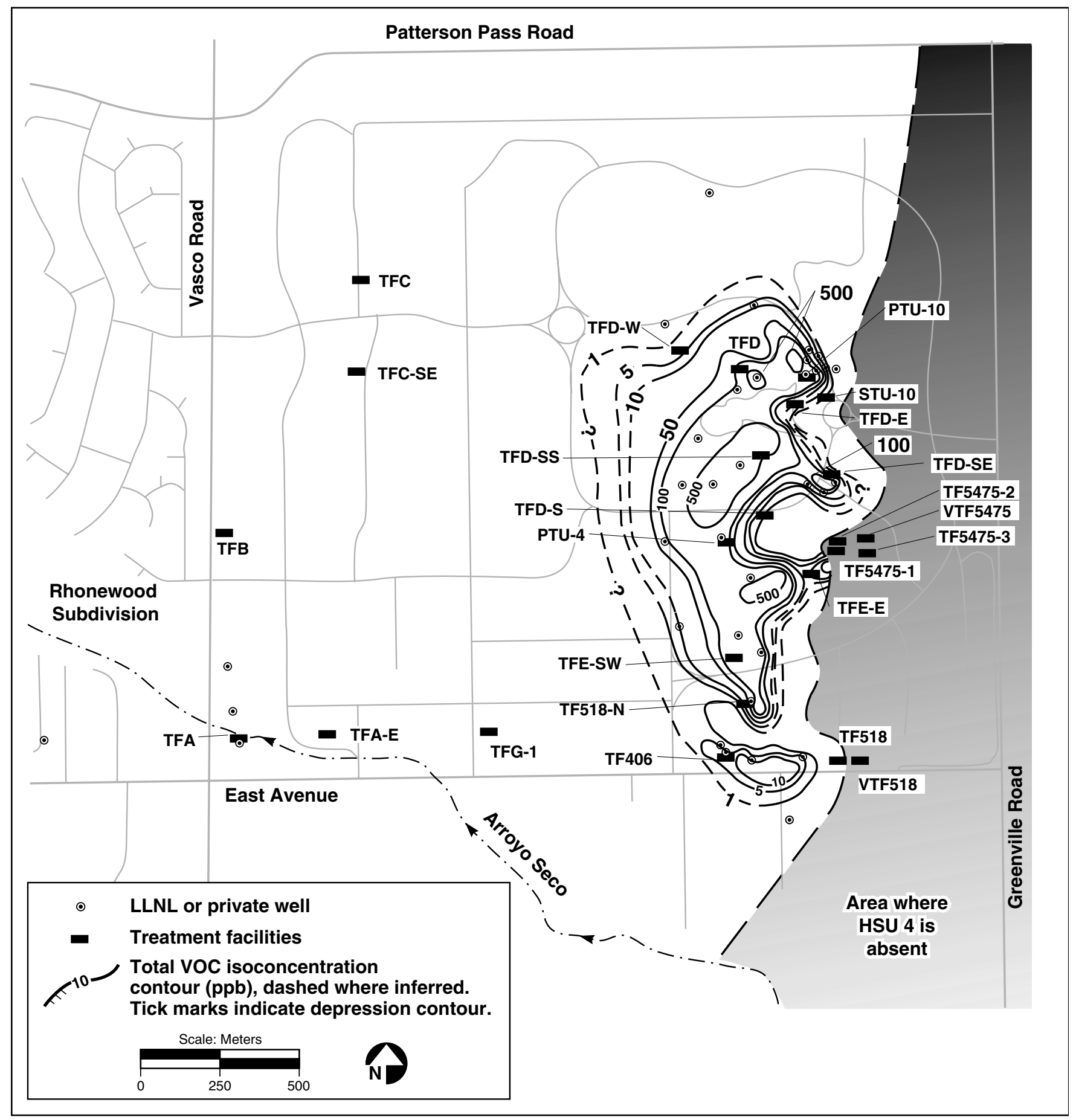

Figure 8-7. Isoconcentration contour map of total VOCs within HSU 4 


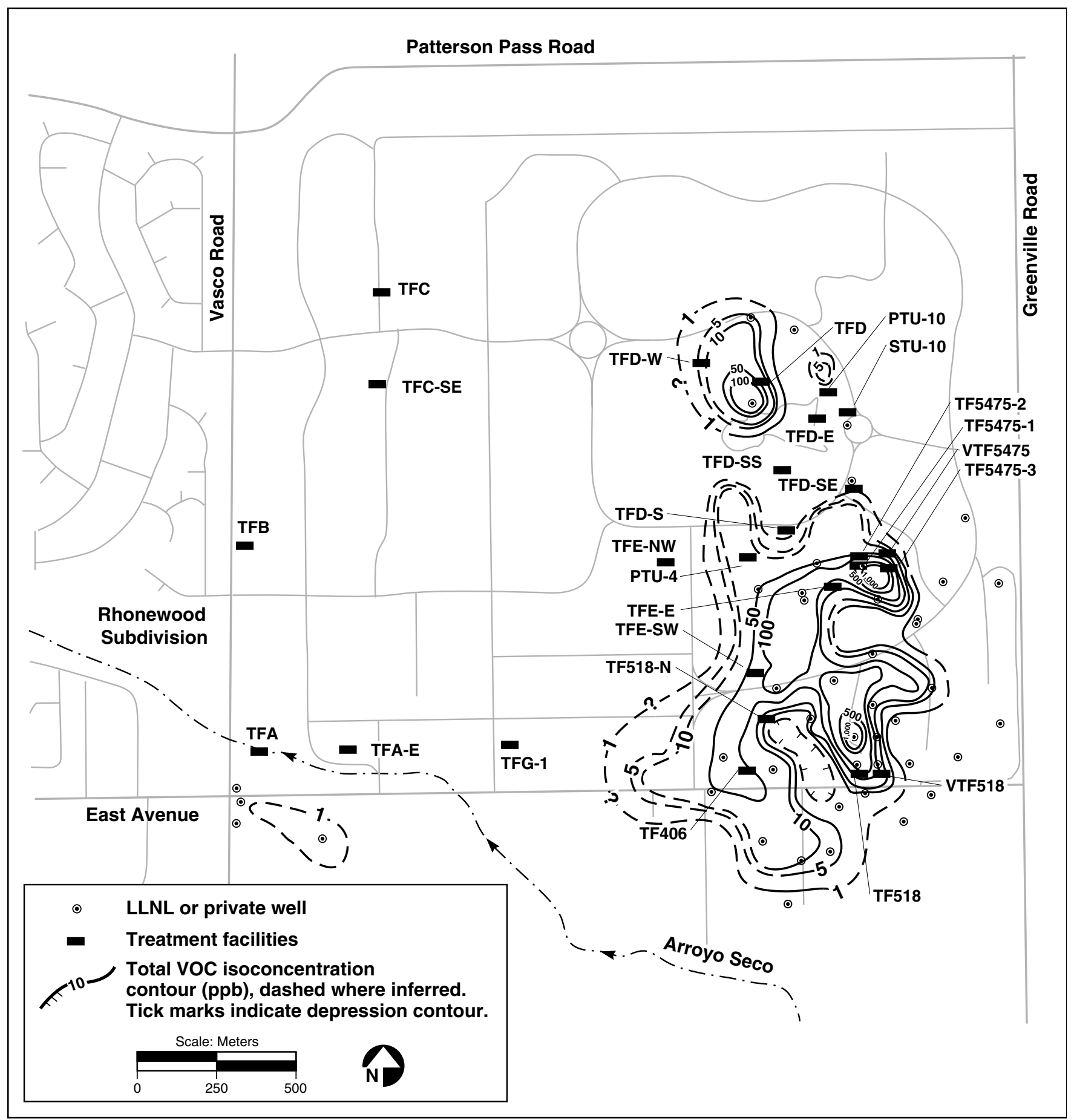

Figure 8-8. Isoconcentration contour map of total VOCs within HSU 5 
The seven wells at TFB pumped at a combined flow rate of about $269 \mathrm{~L} / \mathrm{min}$, and treated about $105 \mathrm{ML}$ of groundwater containing an estimated $7.1 \mathrm{~kg}$ of VOCs.

A control and interlock system failed that allowed the discharge of about 148,000 L of groundwater while the air stripper was off. Other than this incident, TFB was in compliance through 2000. No new wells were installed at TFB during 2000.

\section{Treatment Facility C}

Treatment Facility C (TFC) is located in the northwest quadrant of the Livermore site (Figure 8-1). Portable Treatment Unit (PTU) location TFC Southeast (TFC-SE) is located near the intersection of Avenue A and Sixth Street in the northwest quadrant of the Livermore site.

TFC and TFC-SE process VOCs in groundwater using air stripping. The effluent air from the stripper is treated with GAC prior to discharge to the atmosphere. Groundwater is treated for chro-
mium(VI) in an ion-exchange unit during December through March in order to meet the current RWQCB discharge substantive requirements. Treated groundwater from TFC is discharged into Arroyo Las Positas; from TFC-SE, groundwater is discharged into a north-flowing drainage ditch that empties into Arroyo Las Positas to the north. The TFC effluent chromium(VI) concentration was below the wet season discharge limit of $22 \mathrm{ppb}$ during 2000. TFC and TFC-SE complied with all permits throughout 2000 .

Wells in the TFC area pumped at a combined flow rate of about $212 \mathrm{~L} / \mathrm{min}$ and treated about 94.3 ML of groundwater containing an estimated $7.9 \mathrm{~kg}$ of VOCs. Since system start up in 1993, the combined TFC area facilities have treated more than $410 \mathrm{ML}$ of groundwater and removed about $40 \mathrm{~kg}$ of VOC mass from the subsurface.

No new wells were installed in the TFC area during 2000.

Table 8-3. Wells installed in 2000

\begin{tabular}{|c|c|l|}
\hline Treatment facility area & Hydrostratigraphic unit & \multicolumn{1}{|c|}{ Monitoring/extraction well } \\
\hline TFA & HSU 1B & W-1614 \\
TFB & & None \\
TFC & & None \\
TFD & HSUs 3A/3B & W-1650, W-1651, W-1652, W-1653, \\
& & W-1654, W-1655, W-1656, W-1657 \\
TFE & None \\
TF406 & HSU 3B & W-1613 \\
TFG & None \\
TF518 & HSU1B/2 & W-1615 \\
TF5475 & HSU 3A & W-1605, W-1606, W-1607, W-1608 \\
& HSU 5 & W-1609, W-1610 \\
\hline
\end{tabular}




\section{Treatment Facility D}

The Treatment Facility D (TFD) area is located in the northeast quadrant of the Livermore site (see Figure 8-1). During 2000, eight treatment facilities operated in the TFD areas. The TFD area extraction wells hydraulically control VOCs in HSUs 2, 3A, 3B, 4, and 5.

One new treatment facility located south of the Drainage Retention Basin (DRB), TFD-SS, was activated on June 30, 2000. With regulatory concurrence, this milestone was delayed three months because of an adjacent drainage and parking lot construction project.

Fixed and portable facilities operating in the TFD area process VOCs in groundwater using air stripping, although the STU uses granular activated carbon. The effluent air from the air strippers is treated with granular activated carbon prior to discharge to the atmosphere. Treated groundwater from TFD and TFD-East is discharged either into the $\mathrm{DRB}$, or into an underground pipeline downstream of the DRB weir, flowing northward to Arroyo Las Positas. Treated groundwater from TFD-West is discharged into a nearby storm sewer that also empties into Arroyo Las Positas. Treated groundwater from TFD-South and TFD-Southeast is discharged into drainage ditches, each flowing north into the DRB.

During 2000, LLNL's Environmental Restoration Department (ERD) began a pilot test to evaluate the potential of electroosmosis (EO) as a means of expediting removal of VOCs from source areas characterized by high VOC concentrations in low permeability sediments (See the section "Groundwater Flow and Transport Modeling" of this chapter.). An EO system was installed near the Helipad VOC source area during the spring and summer of 2000. The EO system consists of a grid of nine electrode-bearing groundwater wells, with screened intervals for the wells ranging from about 29 to $36 \mathrm{~m}$ below ground surface. Groundwater impacted by TCE and other VOCs is drawn by an induced direct current from the anode wells (positively charged) to the center array of wells holding negatively-charged electrodes (cathodes) by EO and hydraulic pumping. Preliminary data shows an increase in VOC concentrations at the cathode wells during EO operation.

The combined TFD facilities operated at an average flow rate of $568 \mathrm{~L} / \mathrm{min}$ in 2000. During 2000 , these units treated about $251 \mathrm{ML}$ of groundwater containing an estimated $107 \mathrm{~kg}$ of VOCs. The STU contributed about $0.38 \mathrm{ML}$ of groundwater containing an estimated $1.2 \mathrm{~kg}$ of VOCs of that total. Distal VOC plumes in the western TFD area should be hydraulically controlled once planned TFC-E and TFC-NE treatment facilities are operating; they are scheduled for January 2002 and May 2003, respectively.

All TFD facilities were in compliance through 2000. Eight wells were installed in the TFD area during 2000 (Table 8-3). In 2000, one-hour drawdown tests were conducted on TFD area wells W-1601, W-1602, W-1655, and W-1654 (Aarons et al. 2001).

\section{Treatment Facility E}

The Treatment Facility E (TFE) area is located in the southeastern quadrant of the Livermore site (Figure 8-1). In 2000, TFE-East (TFE-E) continued treating groundwater using a PTU. TFE-E is located in the east-central portion of the Livermore site and provides hydraulic containment of some portions of VOC plumes in HSUs 2, 4, and 5. TFE-Northwest treats groundwater from extraction wells in HSU 2 and HSU 4 and is located south of the Inner Loop Road, immediately west of Southgate Drive. 
TFE-E and TFE-NW treat VOCs using an air stripper. Before the effluent air is vented to the atmostphere, it is treated using granular activated carbon to remove VOCs. Treated groundwater from TFE-E is discharged into a drainage ditch that flows north into the DRB. Treated groundwater from TFE-NW is discharged into a storm drain that flows north into Arroyo Las Positas.

One new treatment facility, TFE-Southwest (TFESW), was activated on June 27, 2000, ahead of the June 30, 2000 Remedial Action Implementation Plan (RAIP) milestone date. TFE-SW is located south of the DRB and Inner Loop Road and uses a minature-treatment unit (MTU) to treat VOCs in groundwater via an air stripper. Treated groundwater is discharged into a drainage ditch that flows north into the DRB, and the effluent air is treated with GAC prior to venting to the atmosphere.

In 2000, wells at TFE pumped at a combined flow rate of about $239 \mathrm{~L} / \mathrm{min}$ and treated about $106 \mathrm{ML}$ of groundwater containing an estimated $24 \mathrm{~kg}$ of VOCs. Since system startup in 1996, the combined TFE facilities have treated more than $307 \mathrm{ML}$ of groundwater and removed about $95 \mathrm{~kg}$ of VOC mass from the subsurface.

All TFE treatment facilities were in compliance in 2000. No new wells were installed in the TFE area during 2000.

\section{Treatment Facility $\mathbf{G}$}

Treatment Facility G (TFG) is located in the southcentral portion of the Livermore site (Figure 8-1) and treats groundwater from one well at Treatment Facility G-1 (TFG-1), located near Avenue B, about $90 \mathrm{~m}$ north of East Avenue. Under the current RWQCB discharge substantive requirements, water from TFG-1 requires treatment for chromium(VI) only during December through
March. Treated groundwater from TFG- 1 is discharged to a storm drain located about $50 \mathrm{ft}$ north of TFG-1, which empties into Arroyo Seco.

Before May 1999, TFG-1 processed groundwater for VOC treatment using an air stripper, and the effluent air was treated using GAC to remove VOCs before they were vented to the atmosphere. In May 1999, the PTU at TFG-1 was replaced by a GAC treatment unit (GTU). A year-long treatability study conducted in 1998 and 1999 demonstrated that the GAC treatment was effective in the efficient removal of VOCs from TFG area groundwater. Groundwater is no longer treated for chromium(VI) because concentrations from March 1997 through November 1999 were consistently below the discharge limit of $22 \mathrm{ppb}$.

During 2000, TFG- 1 operated at an average flow rate of $32.2 \mathrm{~L} / \mathrm{min}$, treating $14.8 \mathrm{ML}$ of groundwater containing an estimated $0.8 \mathrm{~kg}$ of VOCs

(Table 8-2). Since system startup in 1996, TFG-1 has treated almost $53 \mathrm{ML}$ of groundwater and removed about $2.7 \mathrm{~kg}$ of VOC mass from the subsurface.

All TFG treatment facilities were in compliance in 2000. No new boreholes or wells were drilled and no hydraulic tests were conducted in the TFG area during 2000.

\section{Treatment Facility 406}

Treatment Facility 406 (TF406) is located east of Southgate Drive near East Avenue in the southcentral part of the Livermore site (Figure 8-1), and processes groundwater from three extraction wells . The TF406 extraction wells continue to provide significant hydraulic control of VOC plumes in HSUs 4 and 5 near the TF406 facility. The VOC plumes in HSUs 3A, 4, and 5 are being hydraulically controlled throughout the TF406 area. 
TF406 removes VOCs using an air stripper. The effluent air is passed over granular activated carbon to remove VOCs before it is vented to the atmosphere. All treated groundwater is discharged to a storm drain that flows to Arroyo Las Positas.

During 2000, TF406 operated at an average flow rate of $94.7 \mathrm{~L} / \mathrm{min}$, treating more than $47.3 \mathrm{ML}$ of groundwater containing an estimated $1.6 \mathrm{~kg}$ of VOCs (see Table 8-2). Since system startup in 1996, TF406 has treated about $131 \mathrm{ML}$ of groundwater and removed about $5.8 \mathrm{~kg}$ of VOC mass from the subsurface (see Table 8-1).

IN 1999, DOE/LLNL began evaluating electroosmosis (EO) for remediating VOCs in fine grained, low permeability sediments (See section "Groundwater Flow and Transport Modeling" of this chapter). The TF406 area was chosen as a test location because of the presence of good candidate lithologic sequences. Initial testing was conducted to determine design parameters (e.g., electrode spacing, voltage gradients), to evaluate operational issues (e.g., control of high $\mathrm{pH}$ and hydrogen gas at the cathode), and to measure electrochemical properties of the soil (e.g., electrical and electroosmotic conductivity). The results of this work will be used for subsequent analysis and modeling necessary to evaluate electroosmosis for potential deployment at LLNL. A report summarizing the results of the qualifications phase tests was issued in December 1999 (McNab 1999). In February 2000, DOE/LLNL continued its evaluation of EO and deployed the EO system in the TFD Helipad area.

TF406 was in compliance through 2000. One new well was drilled and completed at TF406 during 2000 (Table 8-3).

\section{Groundwater Treatment Facility 518}

Treatment Facility 518 (TF518) is located in the southeastern quadrant of the Livermore site, north of East Avenue and near Avenue $\mathrm{H}$, adjacent to VTF518 (Figure 8-1). The new treatment facility TF518-N, located south of the South Outer Loop Road north of Building 411, was activated on January 26, 2000, ahead of the June 28, 2000, milestone date.

In July 1998, MTU-1 was activated in the TF518 area, replacing the PTU that had processed groundwater there since January 1998. The MTU processes groundwater for VOC treatment using an air stripper, and the effluent air is treated using GAC to remove VOCs prior to venting to the atmosphere. All treated groundwater is discharged to a storm drain located about $76 \mathrm{~m}$ north of TF518, which empties into Arroyo Las Positas.

Decreased waterflow that began in 1999 at TF518 continued in 2000. As discussed in the 1999 SAER, sustainable flow rates from well W-112 decreased steadily from about $75 \mathrm{~L} / \mathrm{min}$ to about $3.8 \mathrm{~L} / \mathrm{min}$ in May 1999. TF518 periodically shut down during 1999 because of lack of sustainable flow and low water level conditions within well $\mathrm{W}-112$. Hydraulic data indicate that the cumulative pumping from HSU 5 wells at TF406, TFE, and TF518 has significantly lowered groundwater levels in the southeastern portion of the Livermore site and reduced yields observed in well W-112. Continuous pumping was discontinued from well W-112 in December 1999, because of low water levels caused by dewatering HSU-5 in the southeastern portion of the Livermore Site. In June 2000 , cyclic pumping was discontinued after water levels failed to recover sufficiently. Future operation of TF518 is planned if HSU 5 water levels recover sufficiently to provide sustainable flow in well W-112. 
During 2000, TF518 facilities operated at an average flow rate of $24.6 \mathrm{~L} / \mathrm{min}$ and treated about $11 \mathrm{ML}$ of groundwater containing an estimated $1.7 \mathrm{~kg}$ of VOCs (see Table 8-2). Since the facility started up in January 1998, TF518 facilities have processed about $25 \mathrm{ML}$ of groundwater containing an estimated $3.0 \mathrm{~kg}$ of VOCs.

TF518 was in compliance with all permits throughout 2000. One well was drilled in the TF518 area during 2000 (Table 8-3). No stepdrawdown tests were conducted in the TF518 area during 2000.

\section{Vapor Treatment Facility 518}

Vapor Treatment Facility 518 (VTF518) is located in the southeastern quadrant of the Livermore site. Soil vapor is extracted from the vadose zone and VOCs are removed from the vapor using granular activated carbon canisters. Following treatment, the effluent air is discharged to the atmosphere.

Two instrumented membrane system (IMS) sampling/monitoring wells, SEA-518-301 and SEA-518-304, continue to monitor vadose zone remediation in the VTF518 area. The IMS system is used to collect vapor pressure, soil temperature, soil moisture, and soil vapor concentration data at various discrete depths.

During 2000, VTF518 operated at an average flow rate of $0.017 \mathrm{scmm}$, treating about $3908 \mathrm{~m}^{3}$ of vapor containing an estimated $2.8 \mathrm{~kg}$ of VOCs (see Table 8-2). In addition, approximately $2460 \mathrm{~L}$ of water containing about $0.09 \mathrm{~kg}$ of VOCs were hand-bailed from the two vapor extraction wells at VTF518 in 2000. Since system startup in 1995, VTF518 has treated about $422,000 \mathrm{~m}^{3}$ of vapor and removed about $150 \mathrm{~kg}$ of of VOC mass from the subsurface (see Table 8-2).
VTF518 was in compliance with the Bay Area Air Quality Management District (BAAQMD) permit throughout 2000.

\section{Treatment Facility $\mathbf{5 4 7 5}$}

Treatment Facility 5475, located in the east-central portion of Livermore site, consists of three groundwater treatment facilities (TF5475-1, TF5475-2, and TF5475-3) (Figure 8-1).

TF5475-1 uses a catalytic reductive dehalogenation (CRD) unit (CRD-1) to treat VOCs in groundwater. CRD technology is based on the reaction of dissolved hydrogen on a palladium catalyst. When in contact with VOC-bearing groundwater, the VOCs are reduced to ethane, methane, or ethene and free chloride ions. Because of the quick reaction rates of CRD, treatment takes place during one pass through the unit. After treatment, the groundwater is returned to the same HSU from which it was extracted. This technology treats VOCs in groundwater while keeping the groundwater containing tritium in the subsurface in the T5475 area. CRD-1's destruction efficiency at TF5475-1 was over $90 \%$ in 2000 .

TF5475-1 was shut down on February 24, 2000 because of biological fouling. The unit was flushed and resumed operation from July 12, 2000, to mid November when it was shut down again for maintenance. The facility did not run from midNovember through the end of December.

TF5475-2 employs STU 5, which uses a direct current (DC)-powered pump to extract groundwater through a series of aqueous-phase GAC canisters for treatment. Treated groundwater from TF5475-2 is discharged into a storm sewer that flows north into Arroyo Las Positas. TF5475-2 was in compliance throughout 2000, although anomalous data were reported in June and July that indicated a breakthrough of VOCs from the carbon. Subsequent samples from the same carbon 
indicated no detectable VOCs. The effluent water was collected in a storage tank until the samples were analyzed and results indicated no detectable VOCs in the effluent.

TF5475-3 uses CRD-2 to treat VOCs in groundwater. CRD-2 also uses catalytic reductive dehalogenation and is similar in design to CRD-1, except that it is an above-ground treatment unit rather than deployed in a well. Because of elevated tritium concentrations in groundwater within HSU 3A, TF5475-3 is a closed-loop system. Groundwater is extracted from two wells, processed in CRD-2, and then returned to the subsurface using two reinjection wells. The destruction efficiency for CRD-2 was greater than $90 \%$ in 2000 .

During 2000, the TF5475 area facilities operated at an average flow rate of $6.44 \mathrm{~L} / \mathrm{min}$ to treat about $0.379 \mathrm{ML}$ of groundwater containing an estimated $0.9 \mathrm{~kg}$ of VOCs (see Table 8-2). Since system start up in 1998, the combined TF5475 facilities have treated more than 1.17 ML of groundwater and removed about $3.2 \mathrm{~kg}$ of VOC mass from the subsurface.

During 2000, two HSU 3A extraction wells and two HSU $3 \mathrm{~A}$ re-injection wells were installed in the TF5475 area. Two HSU 5 extraction wells were also installed in the same area (Table 8-3). An hydraulic injection test was conducted on well $\mathrm{W}-1610$ in the T5475 area during 2000.

\section{Vapor Treatment Facility $\mathbf{5 4 7 5}$}

Vapor Treatment Facility 5475 (VTF5475) is located on the northern side of Trailer T5475 in the east-central portion of the Livermore site, and it treats soil vapor from vadose zone well SVI-ETS504 (see Figure 8-1). VTF5475 began operation on January 21, 1999.
Soil vapor is extracted from the vadose zone using a vapor extraction system and is processed using GAC. Because of elevated tritium concentrations in the vadose zone, VTF5475 has been designed as a closed-loop system. Following removal of VOCs from the process air stream, the tritiated vapor is reinjected into the subsurface at soil vapor inlet well SVI-ETS-505. Because no effluent vapor from VTF5475 is released to the atmosphere, BAAQMD has granted the facility a letter of exemption for 24-hour operation. Two IMS sampling/monitoring wells, SEA-ETS-506 and SEA-ETS-507, are used to monitor vadose zone remediation in the VTF5475 area. The IMS system is used to collect vapor pressure, soil temperature, soil moisture, and soil vapor concentration data from various discrete depths.

During 2000, VTF5475 operated at an average flow rate of $0.566 \mathrm{scmm}$ and treated about $214,000 \mathrm{~m}^{3}$ of vapor containing an estimated $102 \mathrm{~kg}$ of VOCs. Since system start up in 1999, VTF5475 treated about $273,000 \mathrm{~m}^{3}$ of vapor containing an estimated $198 \mathrm{~kg}$ of VOCs (see

Table 8-2).

\section{Groundwater Flow and Transport Modeling}

Groundwater flow and transport models are used at the Livermore site to support remediation system design, performance evaluation, and ongoing subsurface characterization activities. Models also improve LLNL's ability to forecast, monitor, and interpret the progress of the groundwater remediation program.

\section{HSU 1B /2 Model}

In 2000, DOE/LLNL continued to use the threedimensional groundwater flow and contaminant transport model of HSU 1B/2 for performance evaluation and optimization of remediation systems. The HSU 1B/2 model evaluates PCE 
and TCE transport for the Treatment Facility A and $\mathrm{B}$ areas. The model proved useful during 2000 as a decision support tool, and was used to optimize well extraction rates, size pumps for wells, analyze capture zones, evaluate interference patterns and the impact of increased pumping on upgradient plumes, and forecast long-term cleanup scenarios.

\section{Electroosmosis Modeling}

In 2000, DOE/LLNL continued to evaluate the effectiveness of electroosmosis (EO) in remediating areas with high VOC concentrations in finegrained sediments. EO applies an electric field in the subsurface by placing electrodes within groundwater wells. This electric field induces migration of groundwater containing VOCs; however, the resulting electrolysis reactions also affect the $\mathrm{pH}$ in soil and groundwater. These $\mathrm{pH}$ differences can significantly change the solubility of a variety of mineral phases in the soil, affect the adsorption of various trace metals, and may result in the precipitation of metal oxyhydroxide, calcium carbonate, or magnesium carbonate minerals near the cathode. In 2000, model results were used to aid in the design of control mechanisms that will mitigate the adverse effects of these geochemical processes on system performance. To evaluate these effects, DOE/LLNL is using the reactive transport model code PHREEQC Version 2 (Parkhurst and Appelo 1999) to simulate these reactions.

A series of detailed flow and transport models was developed in 2000 for the EO remediation pilot test sites located at TFD Helipad and T5475. The models were used to calculate reasonable extraction/injection rates from wells used in the design of the EO remediation systems and for the selection of the down-hole pumps. Additionally, work began in 2000 on developing a mathematical model that can simulate flow and transport that couples the processes of groundwater flow and EO flow. The model is intended to aid in the evaluation of field data from the EO remediation pilot test sites to determine whether EO remediation can effectively reduce contamination in finegrained sediments that are not significantly impacted by groundwater extraction.

\section{Environmental Impact}

Notable results of VOC analyses of groundwater received from January through December 2000 are discussed below. Figures 8-3 through 8-8 are isoconcentration maps for total VOCs underlying the Livermore site and vicinity within HSU 1B, HSU 2, HSU 3A, HSU 3B, HSU 4, and HSU 5, respectively.

Overall, the decrease in size and concentration observed in the Livermore Site VOC plumes is consistent with the $270 \mathrm{~kg}$ of VOC removed by the groundwater extraction wells during 2000. Therefore, most of the observed trends in VOC concentrations are attributed to the active groundwater extraction system operating at the Livermore Site.

Concentrations in the HSU 1B, 2, and 3A VOC plumes along the western margin of the Livermore Site in the TFA, TFB, and TFC areas continued to decline in response to groundwater extraction.

Offsite HSU 1B wells are now below MCLs for all contaminants of concern with the exception of two wells, W-571 and W-1425, that had maximum PCE concentrations of $6.2 \mathrm{ppb}$ and $7.9 \mathrm{ppb}$ in $2000($ PCE $\mathrm{MCL}=5 \mathrm{ppb})$.

In the TFD area, VOC concentrations in parts of HSU 2 continue to decline in response to pumping the TFD extraction wells. Total VOC concentrations in HSU 2 extraction well W-906 decreased from $789 \mathrm{ppb}$ in 1995 to $100 \mathrm{ppb}$ in October 2000. In nearby HSU 2 monitor well W-355, TCE concentrations have decreased from a maximum of $3100 \mathrm{ppb}$ in April 1992 to $36 \mathrm{ppb}$ in October 2000. 
The HSU 2 Freon 11 plume in the northeastern TFD area continues to decline in response to pumping at TFD-W extraction wells W-1215 and $\mathrm{W}-1216$. Freon 11 concentrations in monitor well W-316, located near the source area, have decreased from $1100 \mathrm{ppb}$ in 1992 to $230 \mathrm{ppb}$ in August 2000.

In the southern TFD and northern TFE areas, VOC concentrations in HSU 4 are showing significant decreases because of pumping at HSU 4 extraction wells W-1418 and W-1504. Total VOC concentrations in well $\mathrm{W}-1418$ have declined from 945 ppb in 1998 to 153 ppb in November 2000. Total VOC concentrations in well W-1504 have declined from $338 \mathrm{ppb}$ in 1999 to $231 \mathrm{ppb}$ in October 2000.

In the TFE-E area, total VOC concentrations in HSU 2 extraction well W-1109 have decreased from $1744 \mathrm{ppb}$ in January 1998 to $586 \mathrm{ppb}$ in October 2000. In nearby HSU 2 monitor well $\mathrm{W}-257$, TCE concentrations have decreased from a maximum of $6400 \mathrm{ppb}$ in 1988 to $110 \mathrm{ppb}$ in May 2000.

East of TFE in the T5475 area, significant decreases in VOC concentrations in HSU 3A were observed during 2000. Total VOC concentrations in monitor well SIP-ETS-204 have decreased from $8130 \mathrm{ppb}$ in 1998 to $600 \mathrm{ppb}$ in May 2000. However, total VOC concentrations in HSU-3A monitor well W-1117 increased from $120 \mathrm{ppb}$ in 1995 to 1663 ppb in November 2000.

In the TF518 area, the offsite HSU 5 VOC plume continues to show significant decreases in VOC concentrations since the start of pumping at the TF406 and TF518 facilities in August 1996 and January 1998, respectively. Total VOC concentrations in offsite monitor well W-219 have declined from $114 \mathrm{ppb}$ in October 1997 to $3 \mathrm{ppb}$ in October 2000. Total VOC concentrations in another offsite monitor well, W-225, have declined from more than $2100 \mathrm{ppb}$ in 1987 to $4 \mathrm{ppb}$ in October 2000.

At VTF518, field investigations indicate a relatively recent development of perched water that is mobilizing VOCs from the vadose zone. Total VOC concentrations from samples of perched water in two vapor extraction wells ranged from 24,000 to $81,000 \mathrm{ppb}$ in SVI-518-204, and 7000 to 18,000 ppb in SVI-518-303.

In the TF518 North area, a significant increase in VOC concentrations was observed in HSU 3B monitor well GSW-011. Total VOC concentrations have increased from 31 ppb in February 1998 to $556 \mathrm{ppb}$ in October 2000. This VOC plume appears to be migrating out of the B419 source area located about $122 \mathrm{~m}$ to the east.

\section{Site 300 CERCLA Project}

Environmental investigations and cleanup activities at Site 300 began in 1981. Site 300 became a CERCLA/Superfund site in 1991, when it was placed on the National Priorities List (NPL). The CERCLA environmental restoration operable units (OUs) are shown in Figure 8-9. All contaminant release sites have been assigned to one of eight OUs that are based on the nature and extent of contamination, and topographic and hydrologic considerations. The major contaminants of concern are listed in Table 8-4.

\section{Geology of Site 300}

Site 300 is located in the sparsely populated Altamont Hills, which are part of the Coast Ranges Physiographic Province and separate the Livermore Valley to the west from the San Joaquin Valley to the east. Site 300 stratigraphy is shown in Figure 8-10. Rocks exposed in the region are classified into three groups: 


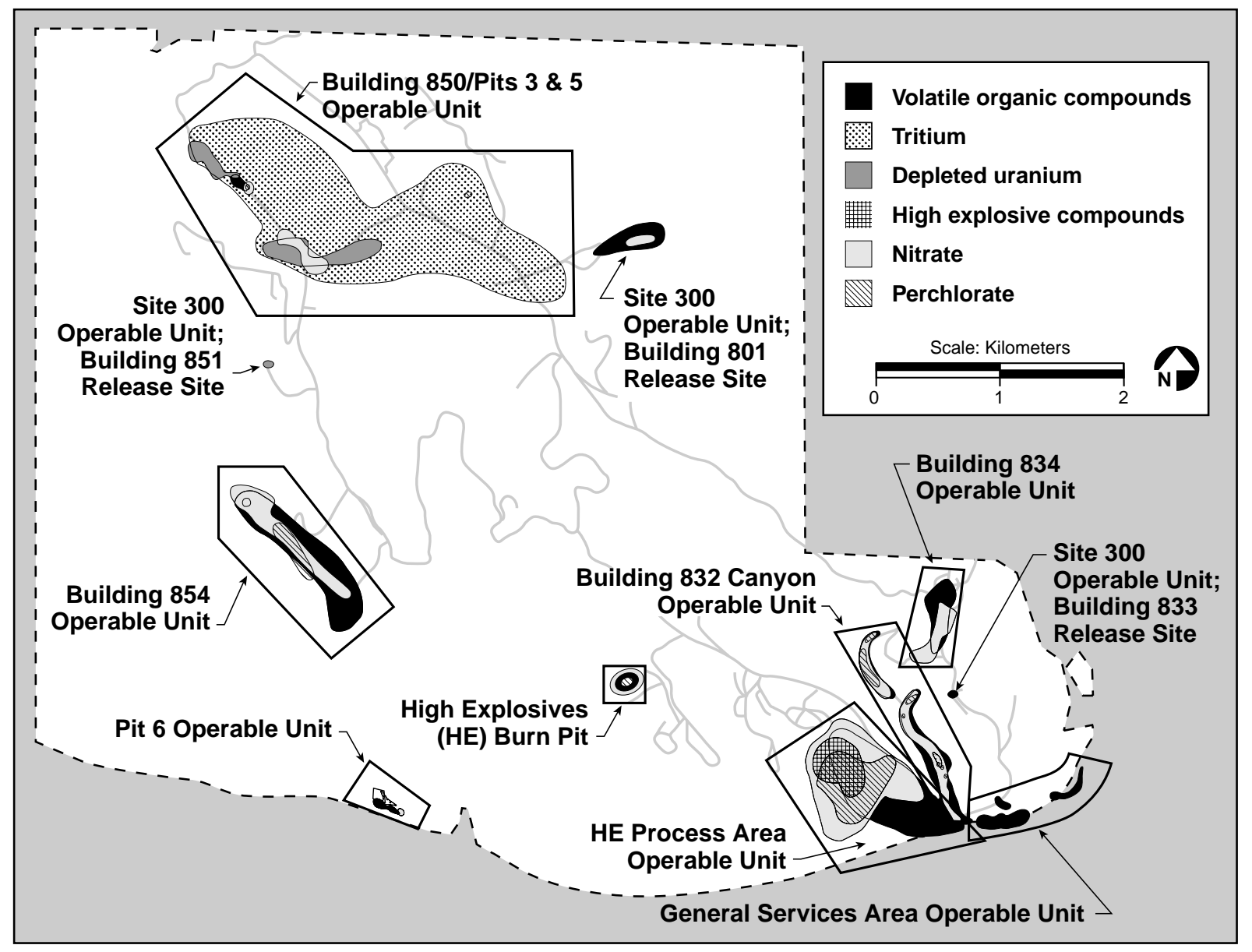

Figure 8-9. Environmental restoration operable units at Site 300

- L ate Tertiary-Q uaternary (0-5 million years ago) - alluvium and semilithified sediments, mainly of continental origin.

- Early to late Tertiary (5-65 million years ago) - shallow marine and continental sedimentary and volcaniclastic rocks.

- Jurassic-C retaceous (65-180 million years ago) - G reat Valley sequence (marine sedimentary rocks and ophiolites) and Franciscan Complex (sheared and variably metamorphosed sedimentary and igneous rocks).
D istinctive blue-gray to brown weathering volcaniclastic sandstone and sandy siltstone, interbedded with light gray weathering tuffaceous claystone and conglomerate, are exposed extensively within Site 300. These rocks are mapped as the late M iocene N eroly Formation (H uey 1948; D ibblee 1980). The N eroly Formation is also present in the subsurface beneath Site 300 .

The N eroly Formation is the principal hydrologic unit within Site 300 and has been the focus of the detailed geologic and hydrogeologic studies conducted during recent years (summarized in the Final Site-WideR emedial I nvestigation R eport, Lawrence Livermore N ational Laborator y Site 300, 
Table 8-4. Major contaminants of concern found in soil, rock, and groundwater at Site $\mathbf{3 0 0}$

\begin{tabular}{|l|l|}
\hline \multicolumn{1}{|c|}{ Operable Unit (OU) } & \multicolumn{1}{|c|}{ Contaminant of concern } \\
\hline General Services Area (GSA) (OU1) & VOCs (primarily TCE) \\
\hline Building 834 Complex (OU2) & $\begin{array}{l}\text { VOCs (primarily TCE), } \\
\text { organosilicate oil, nitrate }\end{array}$ \\
\hline High Explosives Process Area (OU4) & $\begin{array}{l}\text { VOCs (primarily TCE) } \\
\text { HE (a) (primarily HMX }{ }^{[b]} \text { ) } \\
\text { Nitrate, perchlorate }\end{array}$ \\
\hline Building 850/Pits 3 \& 5 (OU5) & $\begin{array}{l}\text { Tritium } \\
\text { Depleted uranium } \\
\text { VOCs (primarily TCE) }\end{array}$ \\
\hline Buitding 854 (OU6) & $\begin{array}{l}\text { VOCs (primarily TCE) } \\
\text { Nitrate, perchlorate }\end{array}$ \\
\hline Pit 6 (OU3) & $\begin{array}{l}\text { VOCs (primarily TCE) } \\
\text { Tritium, nitrate, perchlorate }\end{array}$ \\
\hline Building 832 Canyon (OU7) & $\begin{array}{l}\text { VOCs (primarily TCE) } \\
\text { Nitrate, perchlorate }\end{array}$ \\
\hline Site 300 (OU8) & $\begin{array}{l}\text { VOCs (primarily TCE and Freon 113) } \\
\text { Nitrate, perchlorate }\end{array}$ \\
\hline
\end{tabular}

a $\mathrm{HE}=$ high explosives

b $\mathrm{HMX}=$ octahydro-1,3,5,7-tetranitro-1,3,5,7-tetrazocine

[Webster-Scholten 1994]). The complete section of the Neroly Formation is about $150 \mathrm{~m}$ thick beneath Site 300 .

The floodplain of Corral Hollow Creek lies along the southern boundary of Site 300 and borders portions of the General Services Area (GSA), the High Explosives Process Area, and the area of closed landfill Pit 6. Floodplain alluvium consists dominantly of coarse cobble and boulder-bearing terrace gravel derived from sources to the south, with lenses and local cappings of sandy silt and silty clay.

The bedrock sequence within Site 300 has been slightly deformed into several gentle, low-amplitude folds. The locations and characteristics of these folds, in combination with the regional fault and fracture patterns, locally influence groundwater flow within the site and have therefore been studied in great detail as part of the CERCLA investigations.

\section{Hydrogeology of Site 300}

Site 300 is semiarid, with an average annual rainfall of $27 \mathrm{~cm}$. The site is underlain by gently dipping sedimentary bedrock dissected by steep ravines. The bedrock consists of interbedded conglomerates, sandstones, siltstones, and claystones (see Figure 8-10).

Groundwater primarily occurs in the Neroly Formation upper and lower blue sandstone units $\left(\mathrm{Tnbs}_{2}\right.$ and $\mathrm{Tnbs}_{1}$ ) and in the underlying Cierbo Formation (Tmss). Groundwater can also be present in permeable Quaternary alluvium valley fill (Qal) during the winter rainy season. Some 


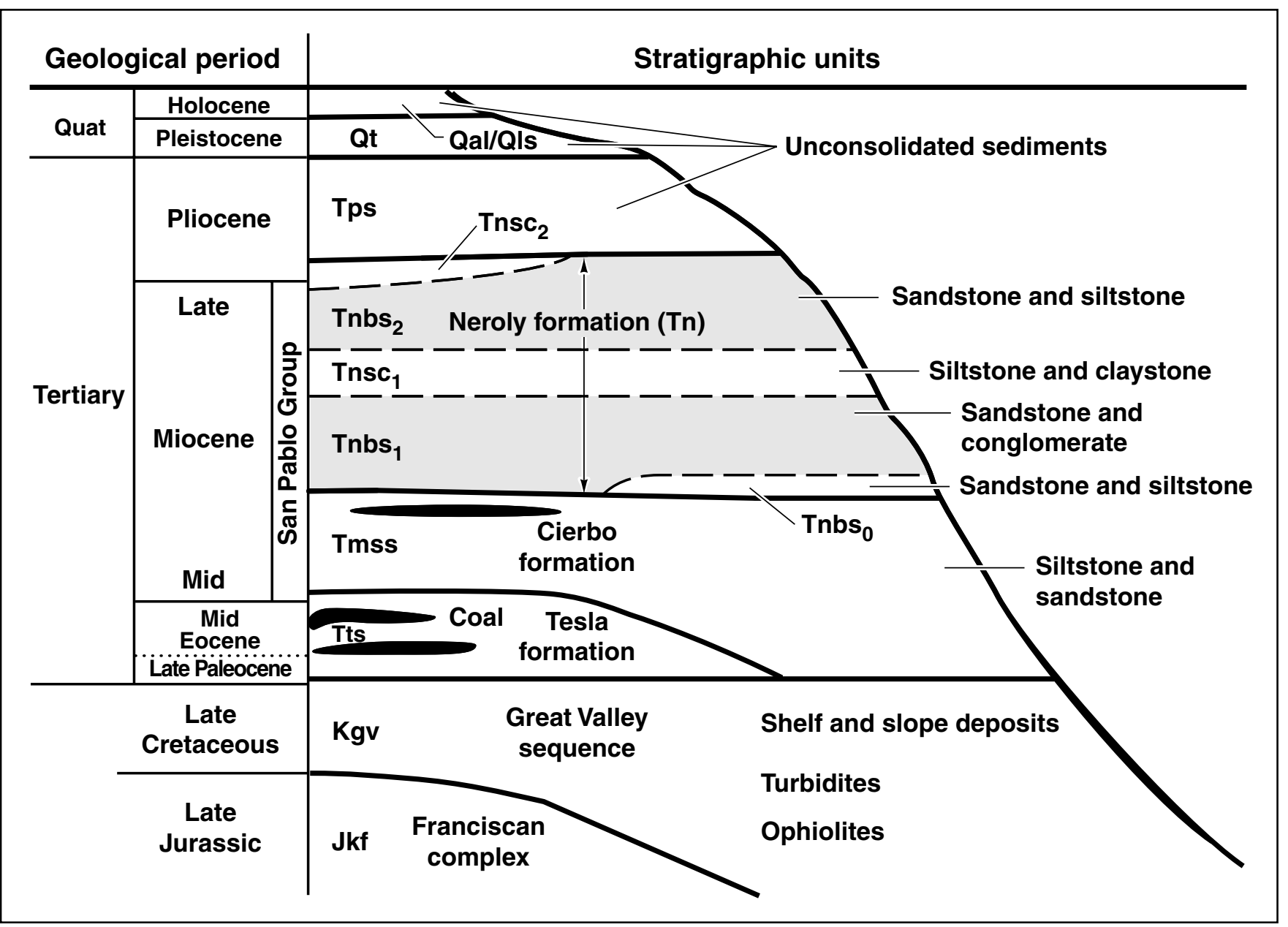

Figure 8-10. Site 300 stratigraphy (Webster-Scholten 1994)

groundwater is present as perched water-bearing zones beneath hilltops. The perched water-bearing zones primarily occur in the unconsolidated sediments of the Miocene-age nonmarine unit (Tps) in the Building 833 and 834 areas and in the Explosives Process Area. However, an extensive perched water-bearing zone occurs in $\mathrm{Tnbs}_{1}$ sandstones in the northwestern portion of the East and West Firing Area. Fine-grained siltstone and claystone interbeds in Tnbs 1 and Tmss act as aquitards, confining layers, or perching horizons. Portions of the bedrock section at Site 300 are abundantly fractured, and thus much of the groundwater flow occurs in fractures as well as in pores. Groundwater is present under confined conditions in the southern half of the site but is generally unconfined elsewhere. Figure 8-11 is a map of the potentiometric surface for the first continuous waterbearing zone at Site 300, which principally occurs in the Neroly lower blue sandstone aquifer $\left(\operatorname{Tnbs}_{1}\right)$.

Recharge occurs where saturated alluvial valley fill is in contact with underlying permeable bedrock, and where bedrock strata crop out. Local recharge occurs on hilltops, creating the perched waterbearing zones in the Building 832, 834, and 854 areas. Low rainfall, high evapotranspiration rates, steep topography, and intervening aquitards generally preclude direct vertical recharge to the deeper bedrock aquifers. 


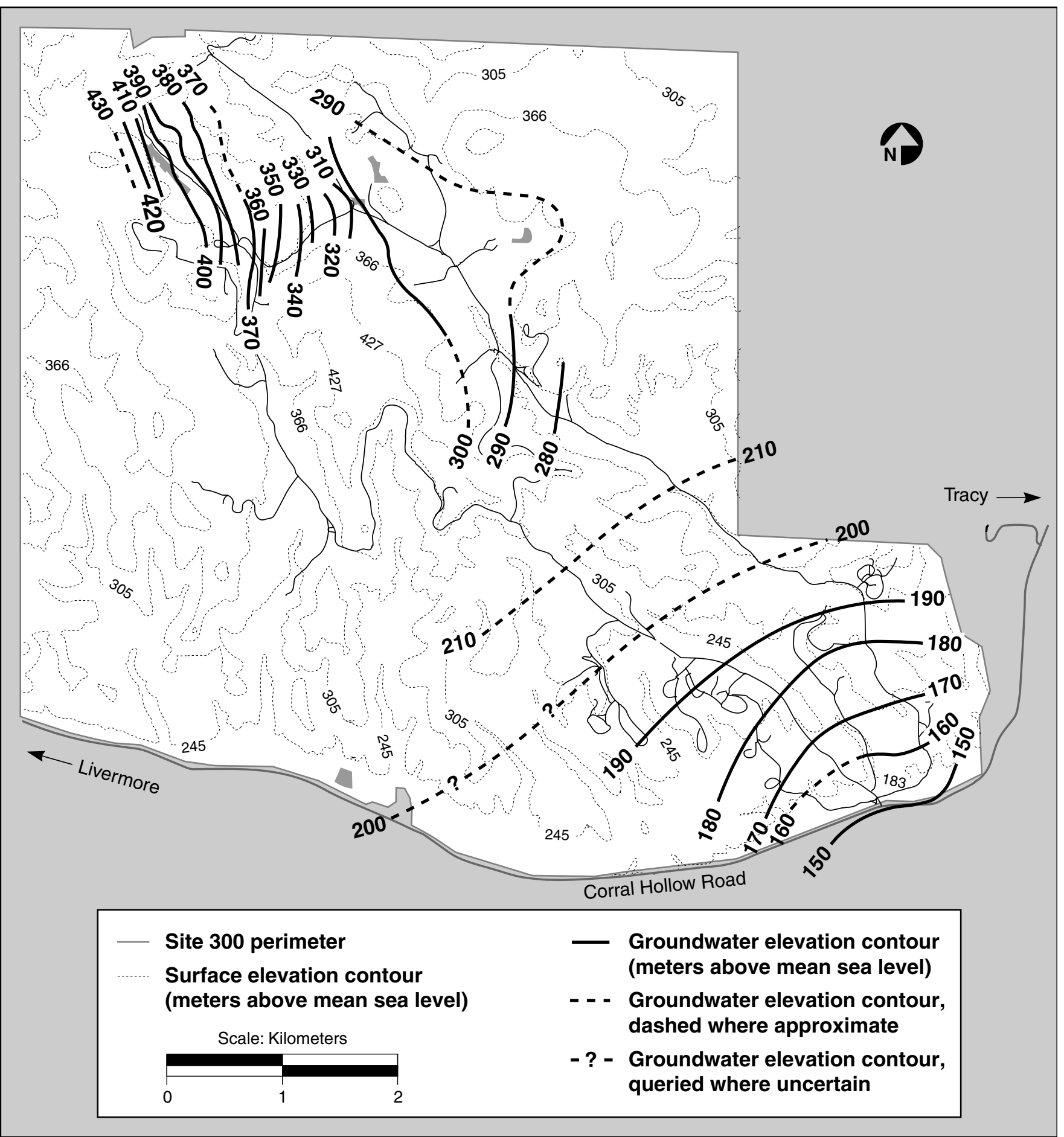

Figure 8-11. Approximate groundwater elevations in the principal continuous water-bearing zone at Site $\mathbf{3 0 0}$ 
Groundwater flow in the bedrock follows the inclination, or dip, of the layers. The tectonic forces that uplifted the Altamont $\mathrm{H}$ ills faulted, gently folded, and tilted the once-horizontal sedimentary strata. A major structure, the east-west trending Patterson anticline, occupies a central location within the site. N orth of the anticline, bedrock dips east-northeast, and groundwater flows generally east-northeast. South of the anticline, bedrock dips south-southeast, and thus groundwater flows roughly south-southeast.

The Cierbo Formation (T mss) is saturated beneath Doall Ravine, the Building 851 and 854 areas, and the southern part of the East Firing Area. The T mss unit is unsaturated or does not otherwise yield water to wells in other parts of the East and West Firing Areas. The thickness of the Cierbo Formation is not well known because most boreholes are not deep enough to completely penetrate this formation. Some of the deeper wells in the GSA penetrate the uppermost T mss. The continuity of saturation in the T mss between the north-west and southeast areas of Site 300 is undetermined. Groundwater in the Tmss occurs under unconfined to artesian conditions.

The T ps unit is the youngest bedrock unit identified at Site 300 and is generally present only on hilltops. Where present, groundwater is typically perched, discontinuous, and ephemeral. The exception to this condition exists in the Explosives Process A rea, where the extent of saturation in Tps sediments is significant. Groundwater in the T ps unit is generally unconfined, although water under confined conditions does occur locally.

Q uaternary alluvium ( $Q$ al) is present as valley fill in ravines throughout Site 300 , but is saturated only in the Corral H ollow Creek stream channel, in Doall Ravine, and in southern Elk Ravine in the vicinity of Building 850. Saturated Q uaternary terrace alluvium deposits (Qt) are present at Pit 6, in the General Services Area (GSA,) and in the Building 832 Canyon area; some of these groundwater occurrences are ephemeral. Small quantities of groundwater are present in some local landslide (Q Is) deposits.

All groundwater contaminant plumes at Site 300 occur in N eroly Formation ( $\mathrm{Tn}$ ) rocks, unnamed Pliocene nonmarine sediments (T ps), or unconsolidated Q uaternary sediments ( $\mathrm{Q}$ al , Q Is, or Q $\mathrm{t}$ ) stratigraphic units. The extent of groundwater contamination at Site 300 is shown on Figure 8-12.

\section{Operable Unit Highlights and Activities}

Background information for LLN L environmental characterization and restoration activities at Site 300 can be found in the Final SiteWideR emedial I nvestigation $R$ eport, Lawrence Livermore $\mathrm{N}$ ational Laboratory Site 300 (Webster-Scholten 1994). In 1999, LLNL submitted the D raft Final and Final SiteWide Feasibility Study for Lawrence Livermore $\mathrm{N}$ ati onal Laboratory Site 300 (Ferry et al. 1999a,b) and the Draft Final Proposed Plan for Environmental Cleanup at Lawrence Livermore $\mathrm{N}$ ational Laboratory Site 300 (D resen et al. 1999).

Background and activities for each of the study areas are described in the following sections. Groundwater remediation for Site 300 is discussed in more detail later in this chapter. See Chapter 9 for a discussion of 2000 groundwater monitoring.

General Services Area Operable Unit In the GSA, past leaks of solvents from storage areas and other facilities have resulted in several plumes of VOCs in groundwater. Two groundwater TCE plumes and two corresponding treatment facilities are present at both the eastern and central GSA. The VOC groundwater plume in the eastern GSA is present in stream channel alluvium ( $Q$ al) at 3-9 m below ground surface; the plume, as defined by the 1 ppb contaminant contour, is 


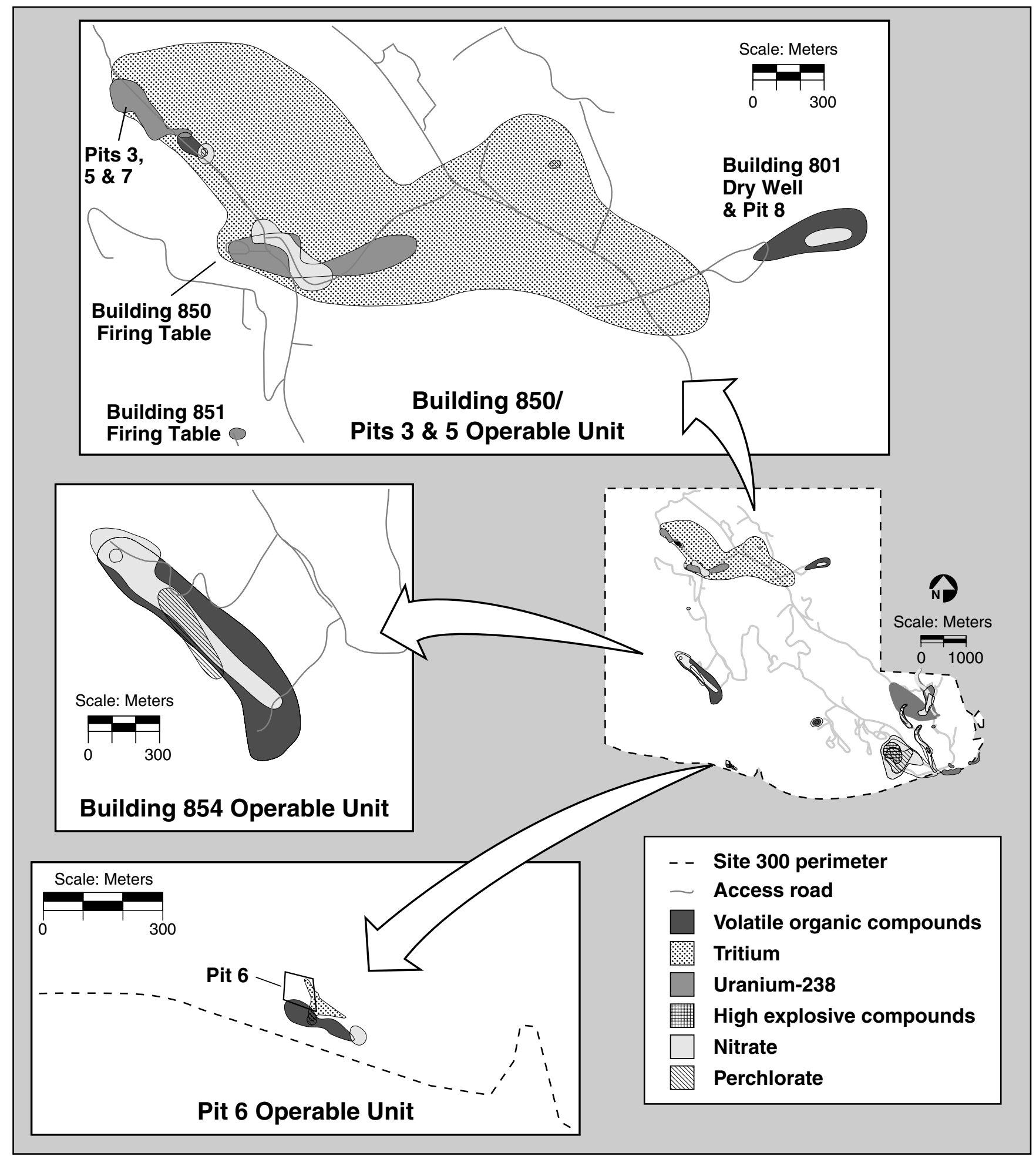

Figure 8-12. Extent of groundwater contamination at Site 300 


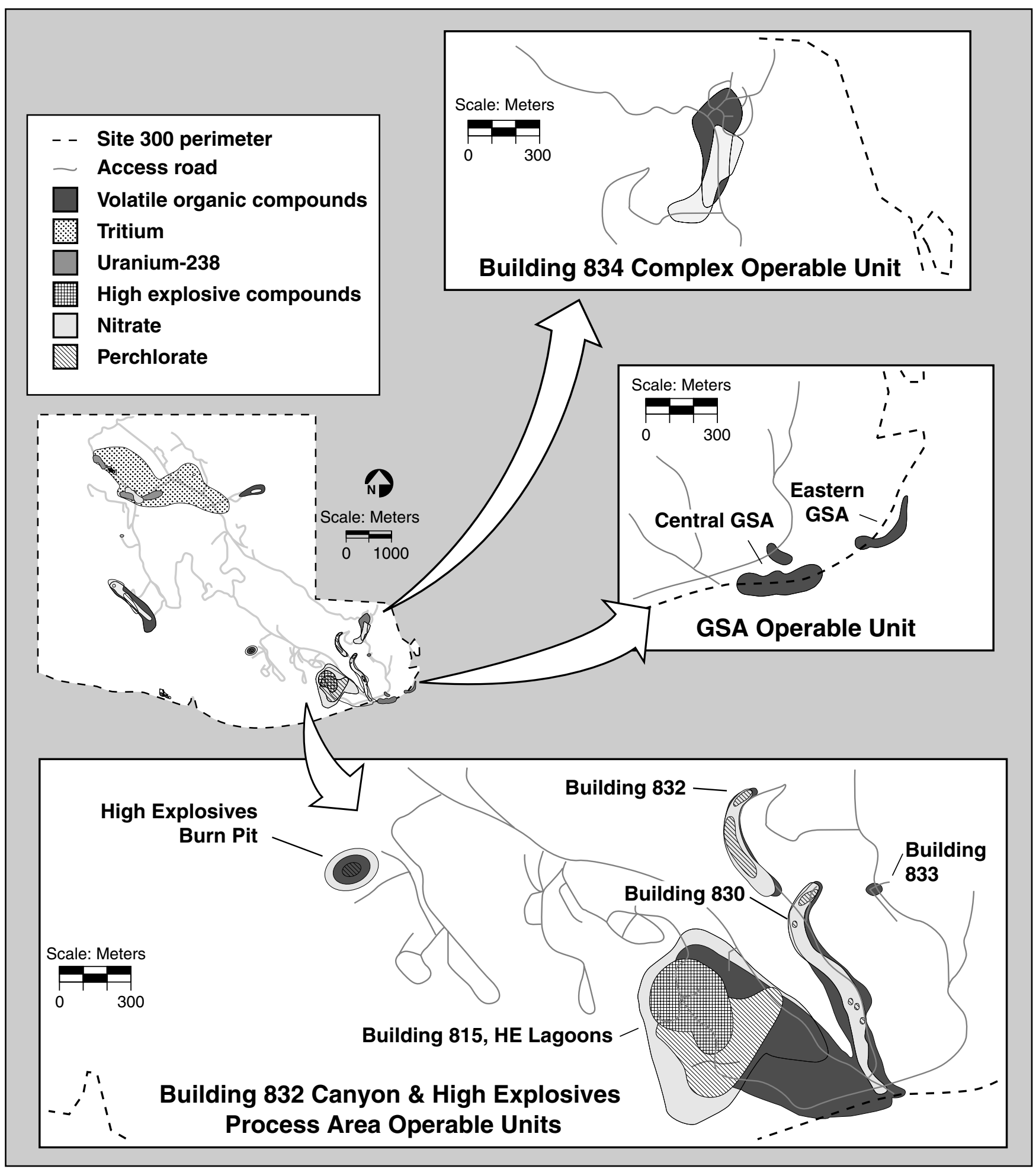


about $433 \mathrm{~m}$ long (Figure 8-13). Groundwater in the alluvium flows down Corral Hollow Creek, east and northeast. VOC groundwater concentrations from eastern GSA monitoring wells were a maximum total of $86 \mathrm{ppb}$ in the fourth quarter of 2000. The Qal alluvium is hydraulically connected to the Neroly Formation lower blue sandstone $\left(\mathrm{Tnbs}_{1}\right)$ unit.

The two VOC groundwater plumes in the central GSA are present in terrace alluvium $(\mathrm{Qt})$ and Neroly Formation upper blue sandstone $\left(\mathrm{Tnbs}_{2}\right)$, at a depth of 3-9 $\mathrm{m}$ below ground surface. These VOC plumes are about $133 \mathrm{~m}$ and $433 \mathrm{~m}$ long (Figure 8-14). Maximum fourth quarter 2000 total VOC alluvial groundwater concentrations were $1600 \mathrm{ppb}$. Deeper regional groundwater also contains total VOCs at a maximum fourth quarter 2000 concentration of $12 \mathrm{ppb}$. This groundwater occurs at depths of 11-56 m below ground surface.

Details of current and planned environmental restoration activities at the GSA are summarized in the Final Remedial Design document (Rueth et al. 1998). The remedial design document includes the Contingency Plan and Compliance Monitoring Plan for the GSA OU.

Using the results from several hydraulic tests, LLNL determined that the direction of plume migration may follow a previously unknown, now subterranean, river bed. It was observed in the fall of 1999 that the eastern GSA off-site plume (as defined by the $>5$ ppb TCE maximum contaminant level contour line) has been restricted to the Site 300 property, with the exception of one offsite well. It had previously extended more than a mile down the Corral Hollow stream channel toward the City of Tracy, before the treatment facility started up in 1991. We estimate that, through the continued efforts of source elimination and hydraulic containment, LLNL will be able to close the eastern GSA within a few years.
After determining that the eastern GSA VOC plume was primarily restricted to the site, LLNL reconsidered the need for an off-site treatment facility as originally planned for in the Record of Decision (ROD). Chemical data indicate that trichloroethylene (TCE) concentrations have decreased to near or below drinking water standards in groundwater from all off-site wells. Based on this information, LLNL has determined that an off-site extraction and treatment system is not needed or justified. The regulatory agencies have concurred that the off-site treatment system milestone can be delayed and the need will be reevaluated during the GSA Five-Year Review.

\section{Building 834 Operable Unit}

The Building 834 facility contains buildings where, in the past, TCE was used as a heat transfer fluid. Several large spills of TCE to the ground resulted in TCE contamination of a shallow perched waterbearing zone beneath the site. Natural biodegradation of the TCE has been occurring in discrete zones resulting in the formation of appreciable amounts of 1,2-DCE. An isolated, discontinuous, perched water-bearing zone occurs in Pliocene non-marine gravels (Tpsg) and occurs at a maximum depth of $9 \mathrm{~m}$ below the center of the complex. The Tpsg is underlain by a clay perching horizon (Tps) that is also nearly saturated. The perched zone Tpsg and Tps crop out on all sides of the hill housing the Building 834 complex and are isolated from the underlying regional aquifer by more than $90 \mathrm{~m}$ of vadose zone. Although the maximum VOC groundwater concentration within the Tpsg during 2000 was $120,000 \mu \mathrm{g} / \mathrm{L}$, (entirely 1,2-DCE), the highest VOC concentrations in groundwater were found in the Tps perching horizon. This perching horizon has a very low hydraulic conductivity, but does yield some groundwater. The highest concentration of VOCs in groundwater samples obtained from the Tps during 2000 was $210,000 \mu \mathrm{g} / \mathrm{L}$, and was predominantly TCE. VOC distribution within the Tpsg is 


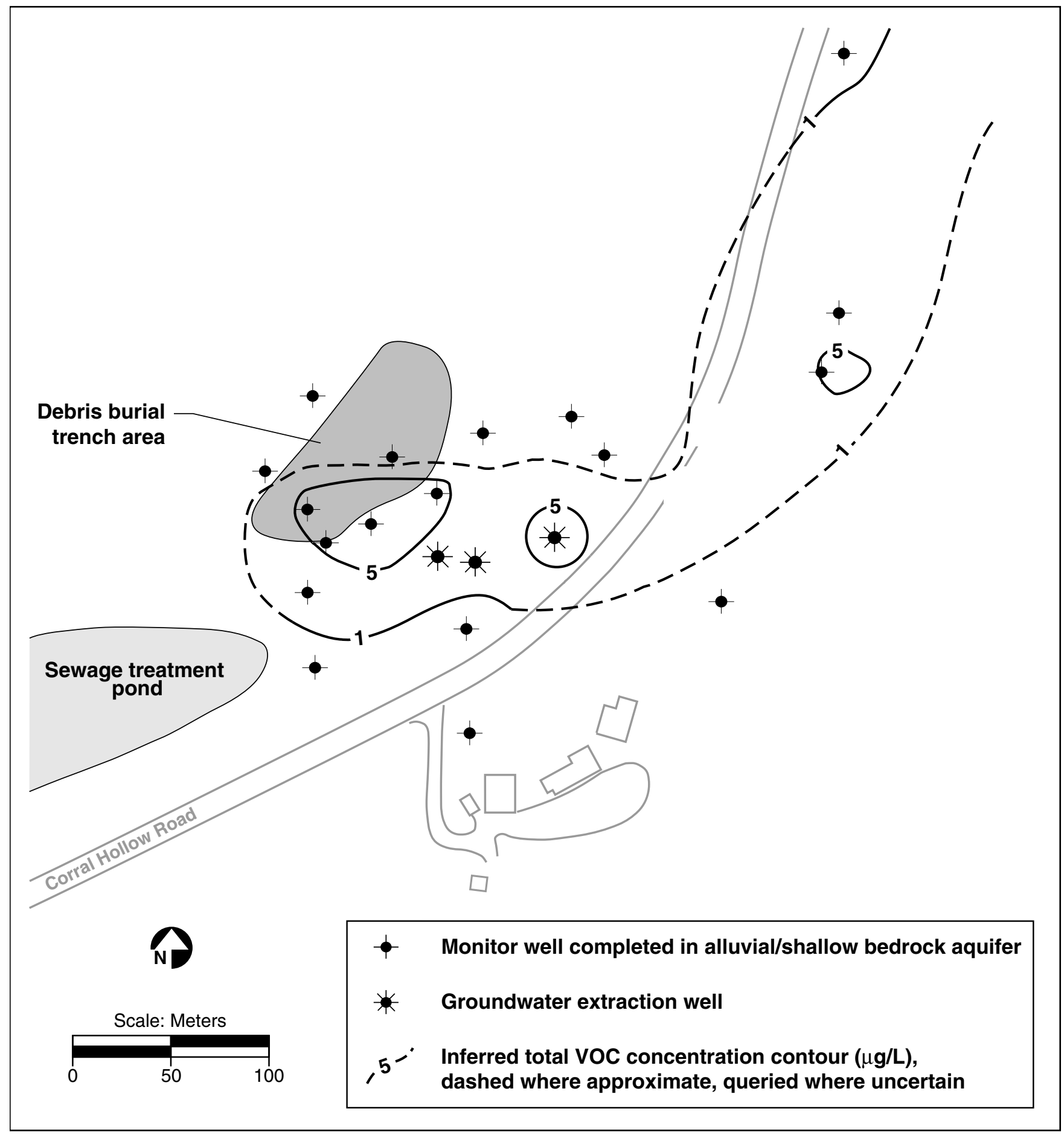

Figure 8-13. Total VOC concentrations in groundwater in the eastern GSA and vicinity (4th quarter, 2000) 


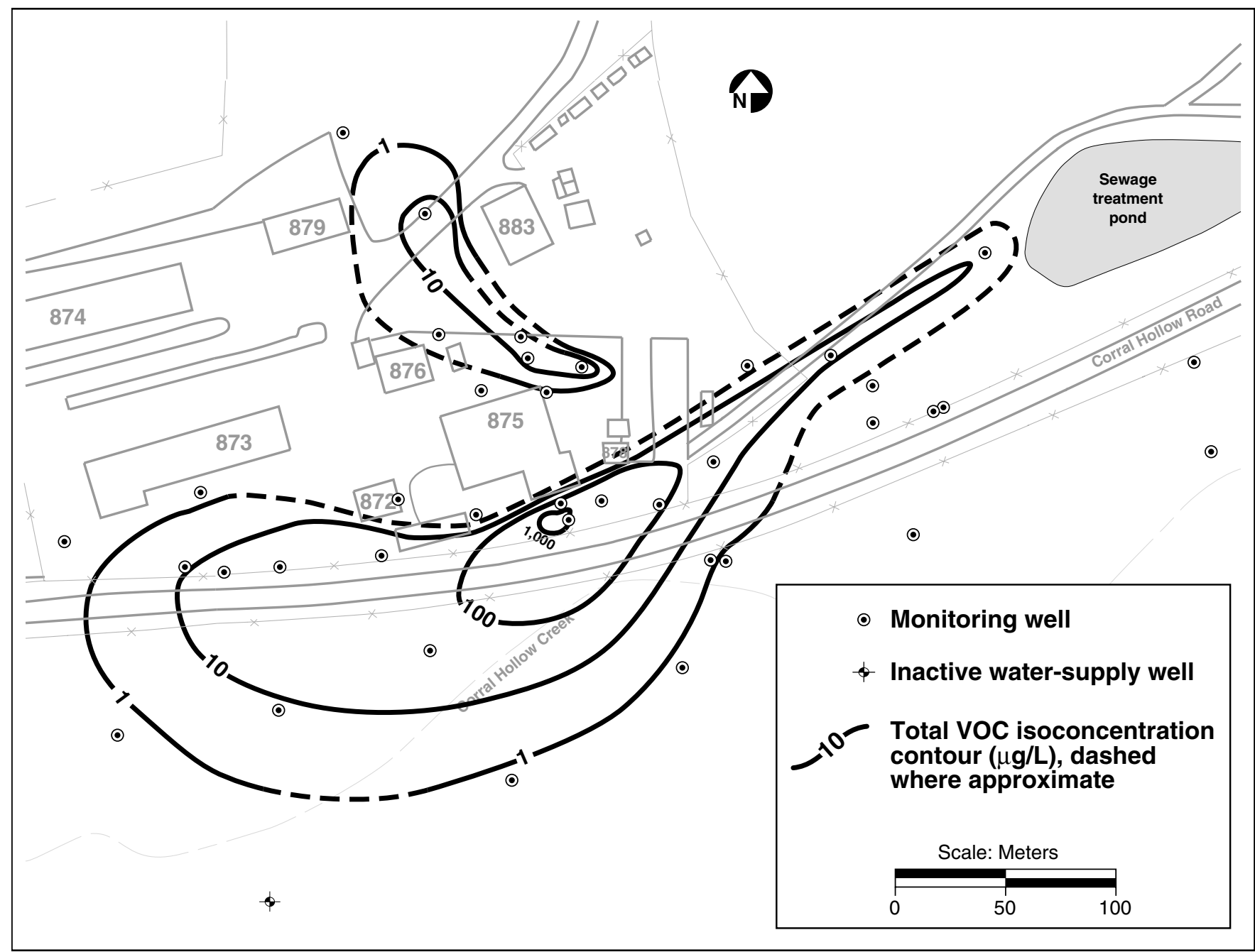

Figure 8-14. Total VOC concentrations in groundwater in the central GSA (4th quarter, 2000). Monitoring wells are completed in the Qt-Tnsc hydrologic unit.

presented in Figure 8-15. Data suggest that two, and possibly three, distinct plumes exist and may be in hydraulic communication only during or following heavy rainfall events.

The maximum groundwater nitrate concentration during 2000 from one particular well was approximately $750 \mathrm{mg} / \mathrm{L}$. This well, however, is adjacent to a leach field. The next highest nitrate concentration in groundwater was about $240 \mathrm{mg} / \mathrm{L}$. A silicate oil (tert-butyl orthosilicate) was detected at a maximum concentration of $126,000 \mu \mathrm{g} / \mathrm{L}$ during
2000. Currently, groundwater and soil vapor extraction and treatment are in progress, using airsparging and granular activated carbon (GAC), respectively. Use of liquid phase GAC for VOC removal from the groundwater is in the process of being tested to possibly replace air sparging.

\section{High Explosives Process Area Operable Unit}

The High Explosives Process Area was established in the 1950s to chemically formulate, mechanically press, and machine high explosives (HE) compounds for use in detonation devices that are 


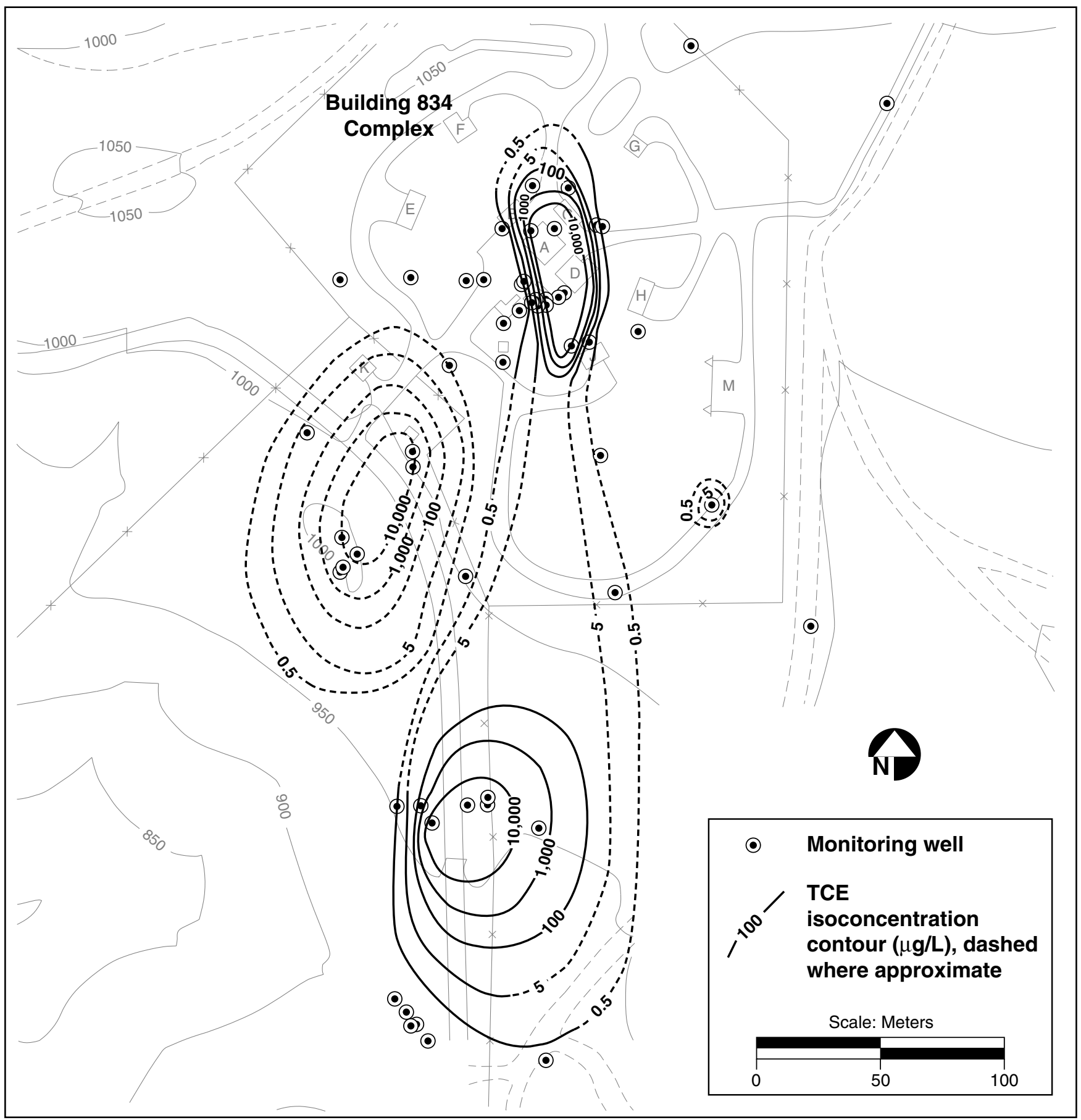

Figure 8-15. Distribution of total VOCs in groundwater in the Qt-Tpsg hydrologic unit at the Building 834 complex (4th quarter, 2000) 
tested in explosives experiments in the East and West Firing Areas of Site 300. Process wastewater from HE machining operations containing HMX, RDX, nitrate, and possibly perchlorate, was discharged to nine former unlined lagoons at concentrations high enough to impact groundwater. A TCE hardstand located near the former Building 815 steam plant is considered to be the primary source of TCE groundwater contamination. HMX and RDX are the most frequent and widespread $\mathrm{HE}$ compounds detected in soil and groundwater. TCE, nitrate, perchlorate, and RDX occur in two water-bearing zones within the $\mathrm{HE}$ Process Area. These two water-bearing zones occur in Tps sediments and Tnbs 2 sandstone, respectively. Groundwater occurs in these two zones at depths of 2-30 m, and 20-76 m, respectively. The VOC (principally TCE) plume in Tps strata is about $200 \mathrm{~m}$ long. The TCE plume in $\mathrm{Tnbs}_{2}$ strata is about $900 \mathrm{~m}$ long (Figure 8-16). The RDX plume is about $200 \mathrm{~m}$ long. The nitrate plume in $\mathrm{Tnbs}_{2}$ strata is about $700 \mathrm{~m}$ long. The perchlorate plume in $\mathrm{Tnbs}_{2}$ strata is $600 \mathrm{~m}$ long. Current 2000 maximum concentrations of TCE, RDX, nitrate, and perchlorate are 65, 220, 220, and 33 ppb, respectively. In 1999, a treatment facility (B815-DSB) was installed near the Site 300 boundary to prevent off-site migration of VOCs in groundwater. In 2000, a second treatment facility was installed in the Building 815 source area (B815-SRC). A small plume of TCE (maximum 2000 concentration of $380 \mathrm{ppb}$ ) also occurs in a local perched water-bearing zone within $\mathrm{Tnsc}_{1}$ strata at a depth of 24-30 m below the HE burn pits; this plume is less than $5 \mathrm{~m}$ long. These burn pits were closed and capped under RCRA in 1998.

\section{Building 850/Pits 3 \& 5 Operable Unit}

Explosives experiments conducted at outdoor firing tables in this area have generated wastes that in the past were disposed at several unlined landfills. Tritium has been released to groundwater from landfill Pits 3 and 5 and the Building 850 firing table (Figure 8-17). Depleted uranium has been released to groundwater from landfill Pits 5 and 7 and the Building 850 firing table. The resulting plumes occur in a perched water-bearing zone within Qal alluvium and bedrock at the base of Tnbs ${ }_{1}$. The water-bearing zone occurs at depths of 5-20 m below surface. There are three overlapping plumes of tritium in groundwater.

The maximum 2000 tritium activity is about $20,350 \mathrm{~Bq} / \mathrm{L}(550,000 \mathrm{pCi} / \mathrm{L})$. The total length of the co-mingling tritium plumes is about $3000 \mathrm{~m}$. The perched water-bearing zone is connected to the regional Tnbs ${ }_{1}$ aquifer at the Elk Ravine Fault. Maximum 2000 groundwater tritium activities in this aquifer are about $740 \mathrm{~Bq} / \mathrm{L}$ $(20,000 \mathrm{pCi} / \mathrm{L})$. There are two smaller plumes of depleted uranium (uranium-238) in groundwater, with maximum 2000 activities of less than 1.24 Bq/L (33.4 pCi/L). The depleted uranium is confined to the perched water-bearing zone; the lengths of the two uranium plumes are $370 \mathrm{~m}$ and $500 \mathrm{~m}$, respectively. Computer modeling of contaminant fate and transport indicates that by the time the tritium and uranium in groundwater reach the Site 300 boundary, these radionuclides will exist at near-background activities.

Although tritium continues to leach into groundwater from vadose zone sources at Building 850, the long-term trend in total groundwater tritium activity in this portion of the tritium plume is one of decreasing activity at approximately the radioactive decay rate of tritium. The extent of the $740 \mathrm{~Bq} / \mathrm{L}(20,000 \mathrm{pCi} / \mathrm{L}) \mathrm{MCL}$ contour for this portion of the plume is shrinking.

Nitrate and perchlorate in the Building 850/Pits 3 and 5 areas occur at maximum 2000 concentrations of less than $1200 \mathrm{ppm}$ and $5 \mathrm{ppb}$, respectively. Trace amounts of TCE (less than $5.8 \mathrm{ppb}$ ) are also present in groundwater near Pit 5. 


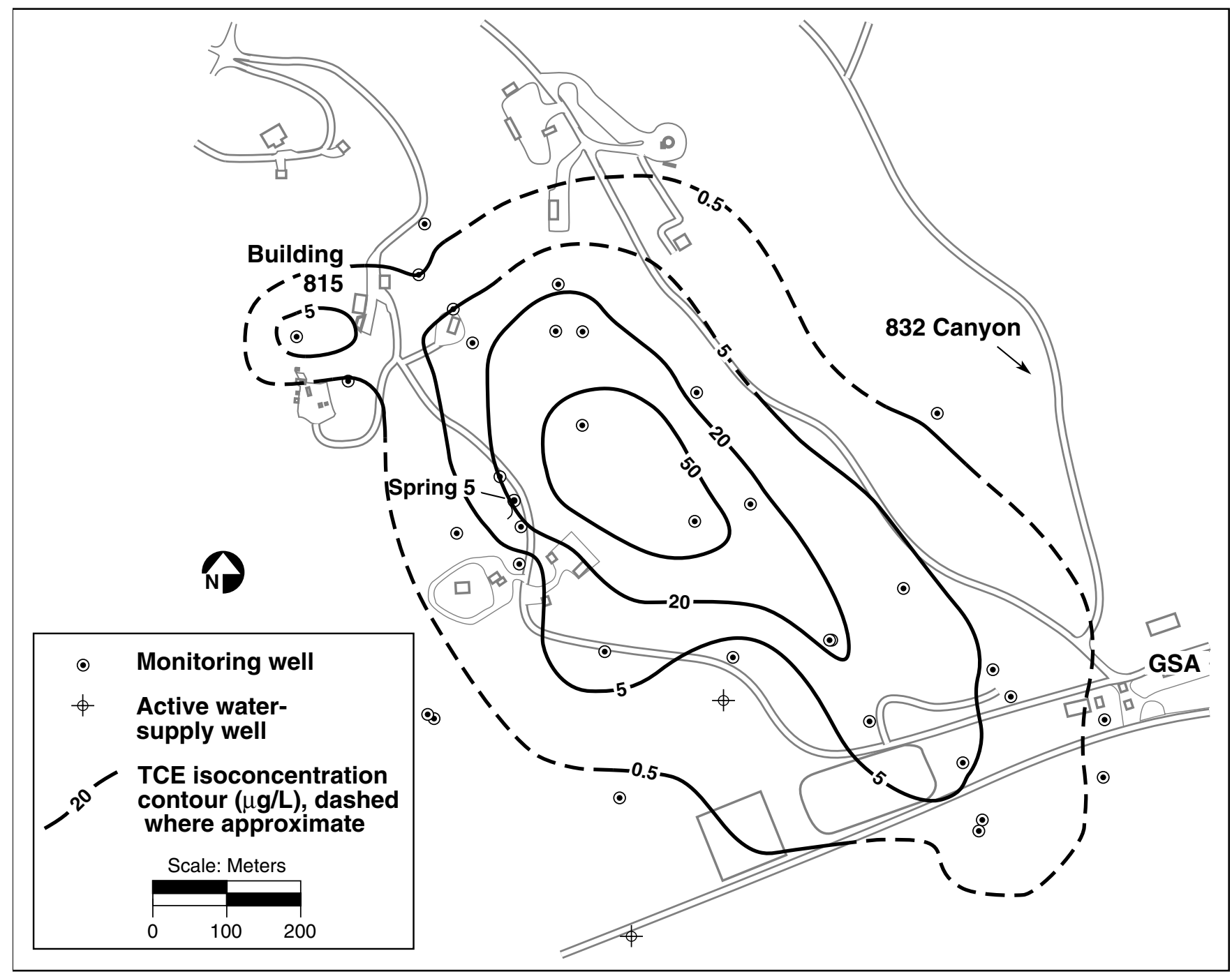

Figure 8-16. Trichloroethene (TCE) isoconcentration contour map in the Tnbs 2 aquifer in the HE Process Area (2nd quarter, 2000)

TCE also occurs in a small groundwater plume monitored by two wells at the Building 801 firing table.

\section{Building 854 Operable Unit}

Trichloroethene in groundwater was previously found to arise principally from leaks in the former overhead TCE brine system at Buildings $854 \mathrm{E}$ and 854F. Trichloroethene, nitrate, and perchlorate occur in groundwater in the Building 854 area in Neroly Formation $\mathrm{Tnbs}_{1}$ strata at maximum 2000 concentrations of $400 \mathrm{ppb}, 190 \mathrm{ppm}$, and 13.1 ppb, respectively. The affected aquifer occurs at depths of 9-50 m below ground surface. The TCE plume is about $1000 \mathrm{~m}$ long (Figure 8-18).

During 2000, LLNL continued to define the extent of TCE in groundwater. Four new monitor wells were installed along the downgradient and west sides of the groundwater TCE plume. In 1999, LLNL installed and began operating a solarpowered portable treatment unit at Building 854 


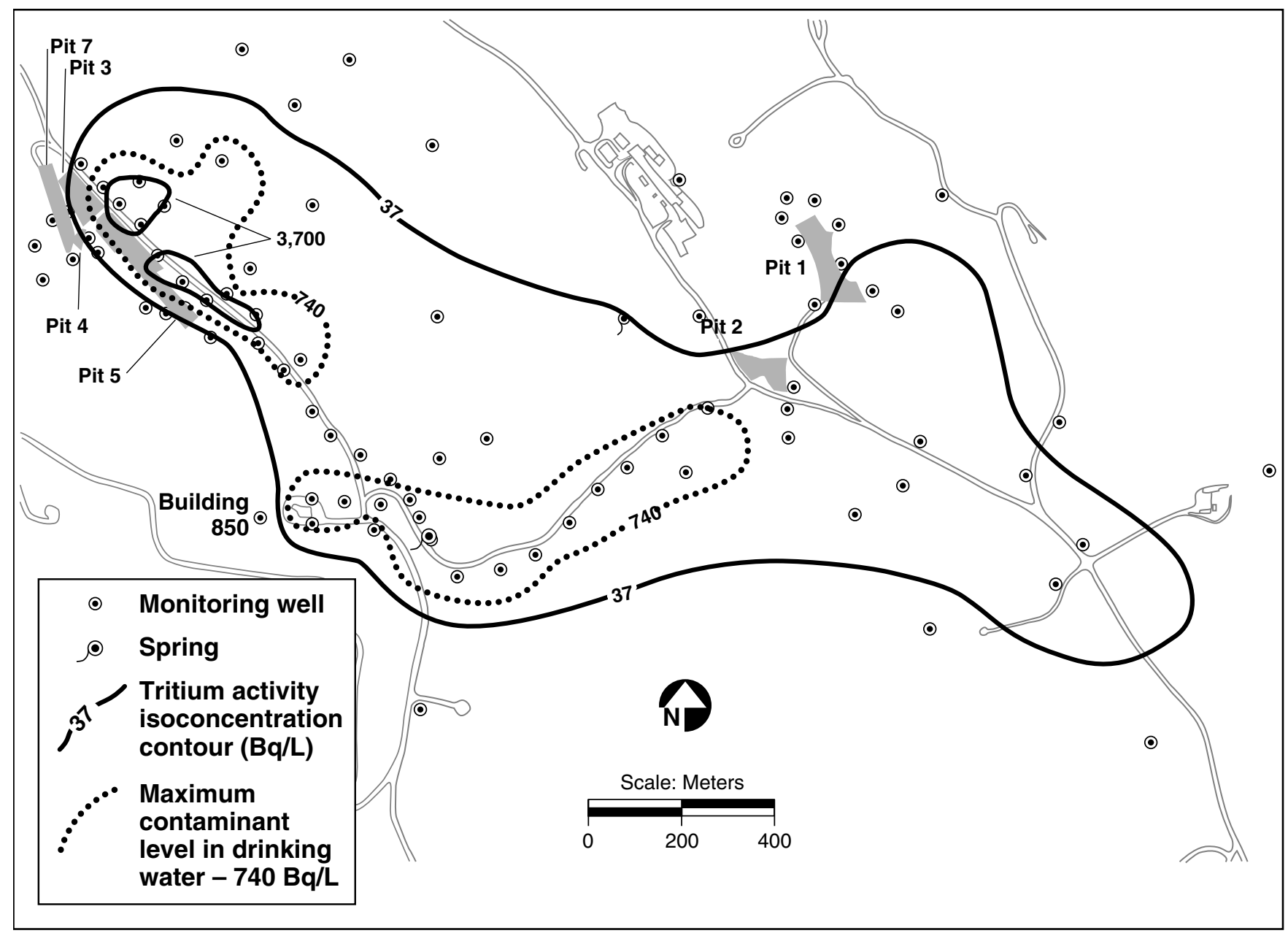

Figure 8-17. Distribution of tritium in groundwater in the first water-bearing zone in the Building 850/Pits 3 and 5 Operable Unit (2nd quarter, 2000)

to treat extracted groundwater containing VOCs and nitrate. A second treatment unit was installed in 2000. This treatment unit uses activated carbon and a containerized wetlands to treat VOCs, nitrate, and perchlorate.

\section{Pit 6 Operable Unit}

A low concentration groundwater TCE plume in perched terrace alluvium $(\mathrm{Qt})$ and in the upper part of underlying sandstone discharges to the surface at small springs at the southeastern edge of the Pit 6 area. The perched water-bearing zone occurs at depths of $0-25 \mathrm{~m}$ below ground surface. The source of the TCE plume, which is about $300 \mathrm{~m}$ long, is likely the southeast corner of the CERCLA-closed Pit 6 landfill (Figure 8-19). Concentrations of VOCs in the plume have declined by more than tenfold since 1992 . Calendar year 2000 maximum TCE concentrations are about $5.1 \mathrm{ppb}$. Tritium (at maximum activities of $126.5 \mathrm{~Bq} / \mathrm{L}(3,420 \mathrm{pCi} / \mathrm{L})$, nitrate (at maximum concentrations of $230 \mathrm{ppm}$ ), and perchlorate (at maximum concentrations of $47 \mathrm{ppb}$ ) also occur in the perched water-bearing zone. The lengths of the tritium and perchlorate plumes are 275 and $200 \mathrm{~m}$, respectively. During 


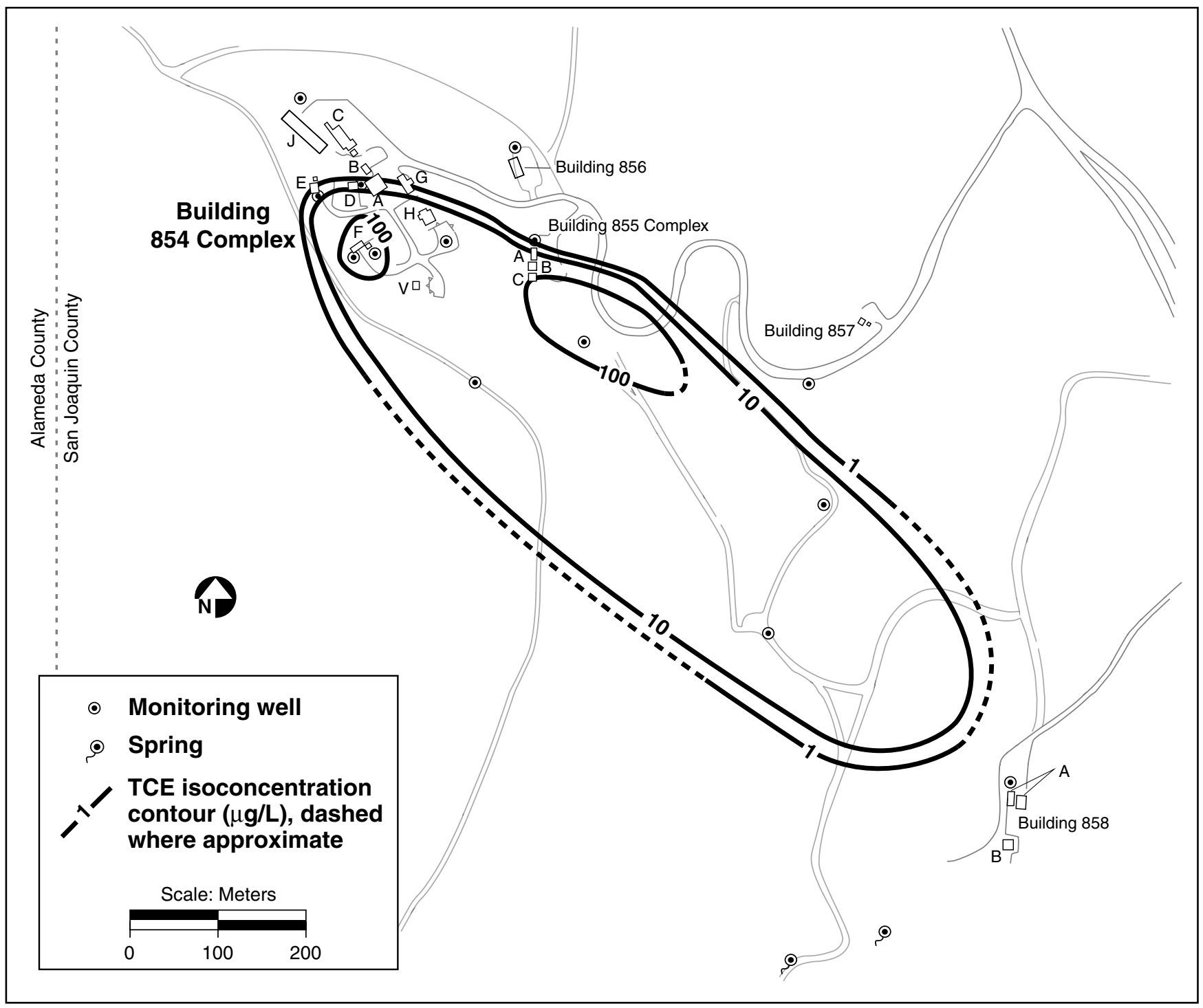

Figure 8-18. Distribution of TCE in groundwater in the Building 854 area (4th quarter, 2000)

1997, a 2.4-acre engineered cap was constructed over the landfill as a CERCLA nontime-critical removal action. During 1998, the post-closure plan (Ferry et al. 1998) for the Pit 6 cap was submitted to the regulatory agencies.

\section{Building 832 Canyon Operable Unit}

At the Building 832 Canyon area (Buildings 830 and 832 ), solvents were released from weapons component test cells in the past. TCE and nitrate occur in groundwater in Qal alluvium and in Neroly Formation sandstone units within Tnsc $_{1}$ silty-claystone strata 15-25 m beneath the Building 832 Canyon Study Area. Solvents were at maximum 2000 concentrations of $10 \mathrm{mg} / \mathrm{L}$ and $206 \mathrm{mg} / \mathrm{L}$, respectively. The TCE plume emanates from both the Building 830 and 832 areas and is about $1300 \mathrm{~m}$ long (Figure 8-20). Perchlorate 


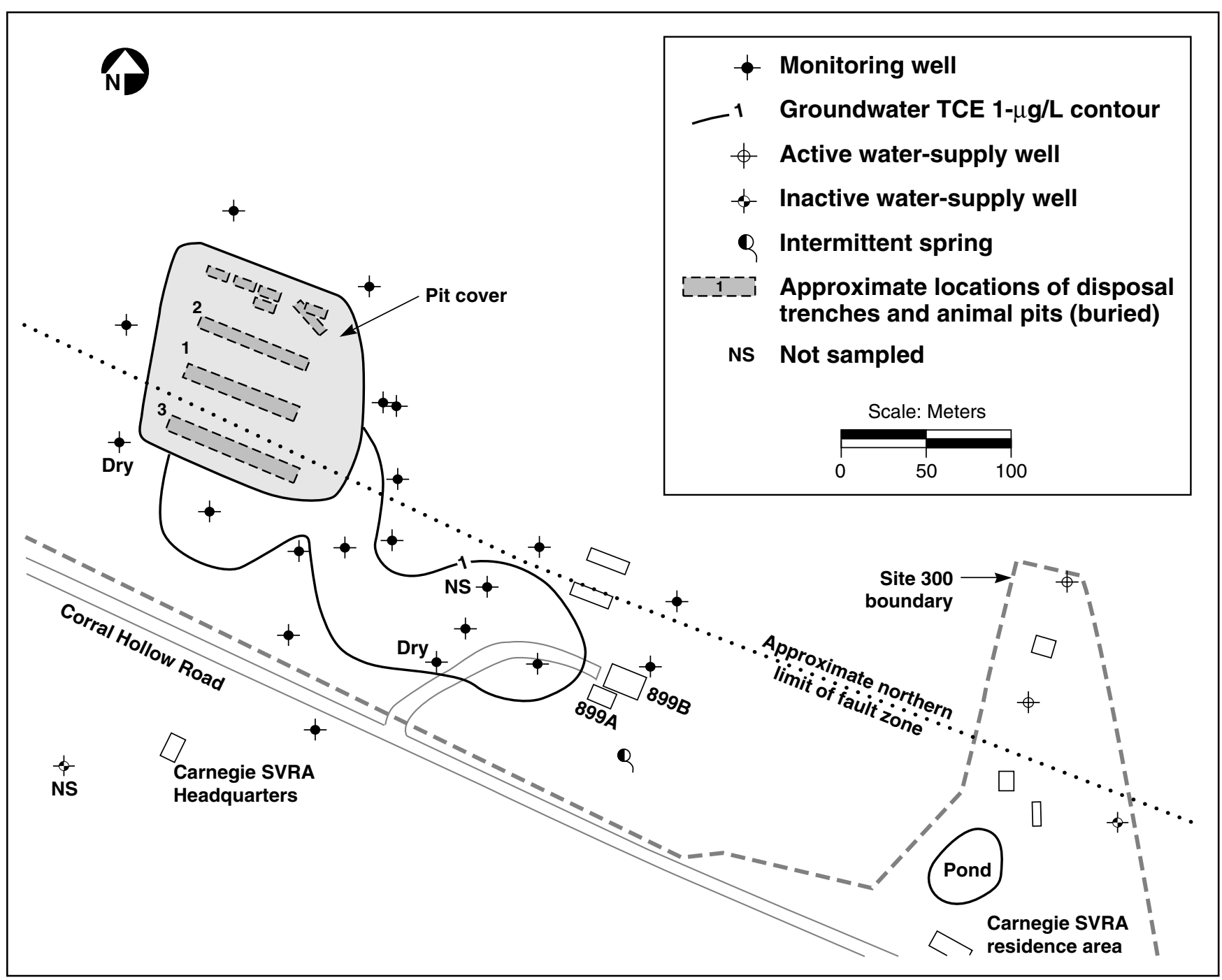

Figure 8-19. Distribution of TCE in groundwater in the Pit 6 area (4th quarter, 2000)

has also been detected at a maximum concentration of $.023 \mathrm{mg} / \mathrm{L}$. Well drilling during 1999 and 2000 indicated that the TCE contaminant plume and the nitrate in groundwater, both emanating from the Building 832 complex, are likely merging with the TCE and nitrate in groundwater from the Building 830 area. Perchlorate has also been detected in groundwater samples from 15 monitor wells in the area.
A groundwater and soil vapor extraction and treatment system has been operating to remove contaminant mass at the Building 832 source area. Groundwater is extracted and treated to remove VOCs, nitrate and perchlorate at two remediation systems located downgradient of the Building 830 source area. 


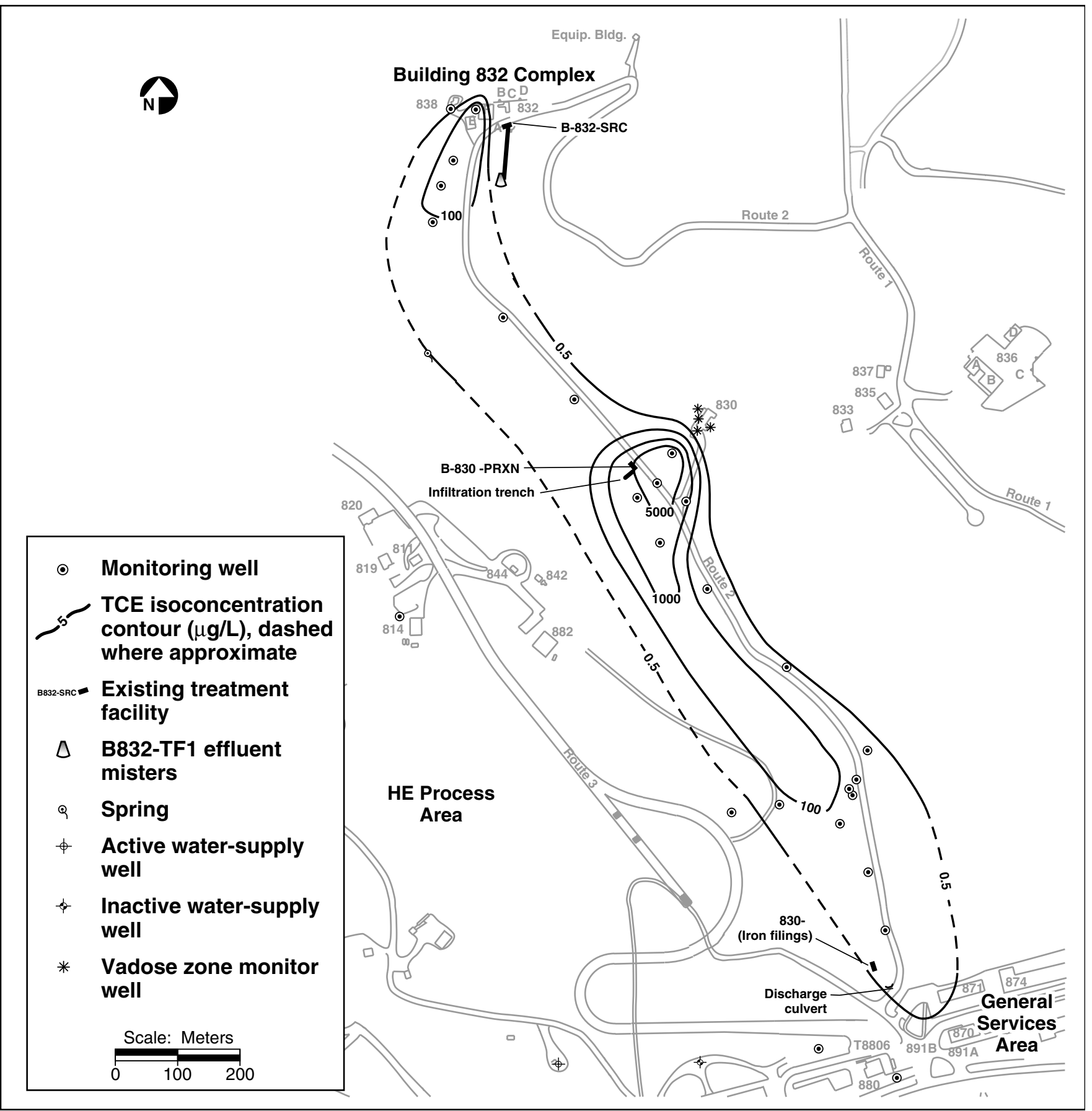

Figure 8-20. Distribution of TCE in groundwater in the Building 832 Canyon (4th quarter, 2000) 


\section{Site $\mathbf{3 0 0}$ Operable Unit}

The Site 300 OU consists of several small release sites where active remediation is not required, as well as several sites where characterization has yet to be completed including:

- Building 801 dry wells and Pit 8 Landfill

- Building 833

- Building 845 Firing Table and Pit 9 Landfill

- Building 851 Firing Table

- $\quad$ Building 812

- $\quad$ Building 865

- Sandia Test Site

VOCs have been detected in groundwater in the vicinity of the Building 801 dry wells; however, concentrations have declined to below drinking water standards in recent years. Debris from the Building 801 firing table was buried in the Pit 8 Landfill. No contaminants have been detected in the vicinity of the landfill. Groundwater monitoring will continue in this area to monitor the decreasing VOC concentrations and to detect any future releases from the landfill.

Contaminant releases, such as spills and leaching from a disposal lagoon adjacent to Building 833, resulted in VOC contamination of the emphemeral perched aquifer. VOC concentrations have decreased over time and the monitoring of groundwater will continue in this area.

Leaching of contaminants from the Building 845 firing table resulted in the contamination of subsurface soil with uranium, tritium, and HMX. The underlying groundwater has not been impacted.
Firing table debris from Building 845 was disposed in the Pit 9 Landfill in the late 1950's and early 1960's. No contamination has been detected in the vicinity of the landfill. Groundwater monitoring will continue in this area to detect any future releases of contaminants from soils under the firing table or the landfill.

Explosive experiments at the Building 851 firing table resulted in the release of low concentration of metals, RDX, tritium, and uranium to soil. Although isotopic ratios indicative of depleted uranium have been found in groundwater samples from one well, groundwater has not otherwise been impacted. Therefore, monitoring is being conducted to evaluate any future impacts to groundwater from soil contaminants.

LLNL continues to evaluate the nature and extent of Freon-113 at Building 865 (the closed Advanced Testing Accelerator). Freon-113 was used as a degreasing agent at the facility. Freon-113 was originally discovered in groundwater samples from wells in the Pit 1 monitoring network, downgradient and southeast of Building 865. Maximum Freon-113 concentrations in groundwater in this area are significantly less than the 1.2 ppm MCL for Freon-113.

During 2000, LLNL installed eight monitor wells at Building 812, a firing table where depleted uranium and thorium were used in explosives experiments. The maximum total calendar year 2000 uranium activity found in groundwater sampled from these wells is $1.33 \mathrm{~Bq} / \mathrm{L}$ (35.9 pCi/L). Further investigative work is planned for the future.

From 1959 to 1960, Sandia National Laboratory, Livermore, operated a small, temporary firing table in the East Firing Area of Site 300. Future characterization work is planned for this area. 


\section{Environmental Remediation at Site $\mathbf{3 0 0}$}

Dedicated groundwater and soil vapor extraction and treatment facilities operate at the eastern GSA, central GSA, and Building 834 areas. Eight treatment facilities that remove and treat VOCs operated throughout 2000. Additionally, three new treatment facilities were constructed and began operation at Site 300 during 2000. Fourteen wells that extract only groundwater, and 32 wells that extract both groundwater and soil vapor, operated during 2000 , treating about 102.5 ML of groundwater. The 32 wells that extract both vapor and groundwater removed $352,905 \mathrm{~m}^{3}$ of vapor. In 2000, the Site 300 treatment facilities removed approximately $27.7 \mathrm{~kg}$ of VOCs. Since remediation efforts began in 1990, more than $667 \mathrm{ML}$ of groundwater and approximately 1.61 million $\mathrm{m}^{3}$ of vapor have been treated, to yield about $168.7 \mathrm{~kg}$ of removed VOCs.

During 2000, a groundwater treatment system consisting of aqueous phase GAC and a fixed-film bioreactor was installed at the Building 815 (HE Process Area) source area, an aqueous phase GAC/ion exchange resin/containerized wetland system was installed at Building 854, and an aboveground iron filings treatment system was installed at Building 832 Canyon.

The central GSA, eastern GSA, and Building 815 treatment facilities discharge to surface drainage courses. The other treatment systems discharged to air by misting or, in the case of the new Building 854 system, discharge to an infiltration trench. Table 8-5 summarizes calendar year 2000 and cumulative totals of volumes and masses of contaminants removed from groundwater and soil vapor at Site 300 .

\section{General Services Area}

Compliance: During 2000, extraction and treatment systems were consistently maintained and operated. The soil vapor extraction and treatment system in the central GSA dry-well source area reduced VOC concentrations in soil vapors, remediated dense nonaqueous-phase liquids in the soil, and mitigated the VOC inhalation risk inside Building 875. The groundwater extraction and treatment systems in the central and eastern GSA area reduced VOC concentrations to drinking water maximum contaminant levels (MCLs), prevented further migration of the contaminant plume, and dewatered the shallow water-bearing zone in the Building 875 dry-well area to enhance soil vapor extraction. These wells are being considered as possible extraction wells for the expansion of the groundwater treatment facility.

Four quarterly reports were submitted to the EPA and RWQCB in 2000 that detail the performance of the treatment facilities (Lamarre 2000i, j, k, and 1). During 2000, the groundwater extraction system at the central GSA was expanded to further contain the contaminant plume, increase mass removal, and eliminate contaminant sources as part of a regulatory-driven milestone. Two monitoring wells located at known contaminant sources and one monitoring well located downgradient of the source were converted to extraction wells. With the increased flow, the existing treatment system was converted and upgraded from batch mode to continuous flow operation.

Permit requirements for the central and eastern GSA groundwater treatment system are listed in Table 8-6. Both the central and eastern GSA treatment systems operated in compliance with regulatory requirements during 2000. LLNL submitted quarterly reports for the GSA treatment 
Table 8-5. Volatile organic compounds (VOCs) removed from groundwater and soil vapor at Site 300

\begin{tabular}{|c|c|c|c|c|c|}
\hline \multirow{2}{*}{$\begin{array}{c}\text { Treatment } \\
\text { area }\end{array}$} & \multirow{2}{*}{$\begin{array}{l}\text { Startup } \\
\text { date }\end{array}$} & \multicolumn{2}{|c|}{2000} & \multicolumn{2}{|c|}{ Cumulative total } \\
\hline & & $\begin{array}{l}\text { Water treated } \\
(M L)^{(a)}\end{array}$ & $\begin{array}{c}\text { VOCs } \\
\text { removed }(\mathrm{kg})\end{array}$ & $\begin{array}{l}\text { Water treated } \\
\qquad(M L)^{(a)}\end{array}$ & $\begin{array}{c}\text { VOCs } \\
\text { removed }(\mathrm{kg})\end{array}$ \\
\hline \multicolumn{6}{|c|}{ General Services Area } \\
\hline Eastern GWTF(b) & 1991 & 83.5 & 0.35 & 640.9 & 6.21 \\
\hline Central GWTF & 1993 & 11.5 & 1.06 & 20.5 & 8.60 \\
\hline Building 834 & 1995 & 0.043 & 1.57 & $0.633^{(c)}$ & $27.2^{(\mathrm{c})}$ \\
\hline Building 815 & 1999 & 1.85 & 0.007 & 2.19 & 0.017 \\
\hline Building 832 & 1999 & 1.74 & 0.19 & 34.1 & 0.194 \\
\hline Building 854 & 1999 & 3.90 & 1.33 & 4.09 & 1.37 \\
\hline \multirow[t]{2}{*}{ Pit 6} & 1998 & $-^{(c)}$ & $-^{(c)}$ & 0.268 & 0.0014 \\
\hline & & $\begin{array}{c}\text { Soil vapor } \\
\text { treated } \\
\left(10^{3} \mathrm{~m}^{3}\right)\end{array}$ & $\begin{array}{l}\text { VOCs } \\
\text { removed }(\mathrm{kg})\end{array}$ & $\begin{array}{c}\text { Soil vapor } \\
\text { treated } \\
\left(10^{3} \mathrm{~m}^{3}\right)\end{array}$ & $\begin{array}{l}\text { VOCs } \\
\text { removed }(\mathrm{kg})\end{array}$ \\
\hline \multicolumn{6}{|c|}{ General Services Area } \\
\hline Central & 1994 & 97.3 & 2.46 & 1590 & 67.08 \\
\hline Building 834 & 1998 & 151 & 20.44 & $511^{(c)}$ & $73.66^{(c)}$ \\
\hline Building 832 & 1999 & 105 & 0.30 & 108 & 0.674 \\
\hline
\end{tabular}

a $\quad M L=1$ million liters

b GWTF = Groundwater treatment facility

c Pit 6 is not routinely used for groundwater treatment. A hydraulic pump test was conducted there in 1998.

systems to the California EPA and the RWQCB in accordance with the National Pollutant Discharge Elimination System Order No. 97-242 for the eastern GSA and the Substantive Requirements for Waste Discharge for the Central GSA (Lamarre 2000i, j, k, and l).

Eastern GSA: The eastern GSA groundwater treatment system operates under NPDES Permit No. CA0082651, issued by the Central Valley RWQCB for discharges into Corral Hollow Creek. The system operated under WDR91-052 until December 5, 1997, when WDR 97-242 was issued. Based on the NPDES permit five-year review, sampling requirements were reduced at the eastern GSA groundwater treatment facility. The eastern GSA treatment facility employs granular activated carbon (GAC) canisters to remove VOCs from extracted groundwater. In accordance with NPDES Permit No. CA0082651, groundwater treated at the eastern GSA groundwater treatment facility was discharged off site to Corral Hollow Creek. Table 8-5 shows the amount of the water treated and VOCs removed at the eastern GSA.

The length of the eastern GSA TCE plume with concentrations over the cleanup standard of $5 \mathrm{ppb}$ (MCL) has been reduced by more than $1400 \mathrm{~m}$. The off-site portion of the plume now extends $200 \mathrm{~m}$ beyond the site boundary. TCE concentrations in influent from the eastern GSA groundwater treatment system were reduced from $64 \mathrm{ppb}$ in January 1992 to 3.1 ppb in November 1999. 
Table 8-6. General Services Area groundwater treatment system surface discharge permit requirements

\begin{tabular}{|c|c|c|}
\hline \multirow{2}{*}{ Parameter } & \multicolumn{2}{|c|}{ Treatment facility } \\
\hline & Central General Services Area & Eastern General Services Area \\
\hline VOCs & Halogenated and aromatic VOCs & Halogenated VOCs \\
\hline Maximum daily & $5.0 \mu \mathrm{g} / \mathrm{L}$ & $5.0 \mu \mathrm{g} / \mathrm{L}$ \\
\hline Monthly median & $0.5 \mu \mathrm{g} / \mathrm{L}$ & $0.5 \mu \mathrm{g} / \mathrm{L}$ \\
\hline Dissolved oxygen & $\begin{array}{l}\text { Discharges shall not cause the concentrations } \\
\text { of dissolved oxygen in the surface water } \\
\text { drainage course to fall below } 5.0 \mathrm{mg} / \mathrm{L} \text {. }\end{array}$ & $\begin{array}{l}\text { Discharges shall not cause the concentrations } \\
\text { of dissolved oxygen in the surface water } \\
\text { drainage course to fall below } 5.0 \mathrm{mg} / \mathrm{L} \text {. }\end{array}$ \\
\hline $\mathrm{pH}$ (pH units) & $\begin{array}{l}\text { Between } 6.5 \text { and } 8.5 \text {, no receiving water alter- } \\
\text { ation greater than } \pm 0.5 \text { units }\end{array}$ & $\begin{array}{l}\text { Between } 6.5 \text { and } 8.5 \text {, no receiving water alter- } \\
\text { ation greater than } \pm 0.5 \text { units }\end{array}$ \\
\hline Temperature & $\begin{array}{l}\text { No alteration of ambient receiving water } \\
\text { conditions more than } 3^{\circ} \mathrm{C}\end{array}$ & $\begin{array}{l}\text { No alteration of ambient receiving water } \\
\text { conditions more than } 3^{\circ} \mathrm{C}\end{array}$ \\
\hline Place of discharge & $\begin{array}{l}\text { To groundwater during dry weather and to } \\
\text { surface water drainage course in eastern GSA } \\
\text { canyon during wet weather. }\end{array}$ & Corral Hollow Creek \\
\hline Flow rate & $\begin{array}{l}272,500 \mathrm{~L} \text { ( } 30 \text {-day average daily dry weather } \\
\text { maximum discharge limit) }\end{array}$ & $272,500 \mathrm{~L}$ per day \\
\hline Mineralization & $\begin{array}{l}\text { Mineralization must be controlled to no more } \\
\text { than a reasonable increment. }\end{array}$ & $\begin{array}{l}\text { Mineralization must be controlled to no more } \\
\text { than a reasonable increment. }\end{array}$ \\
\hline $\begin{array}{l}\text { Methods and detec- } \\
\text { tion limits for VOCs }\end{array}$ & $\begin{array}{l}\text { EPA Method } 601 \text {-detection limit of } 0.5 \mu \mathrm{g} / \mathrm{L} \\
\text { EPA Method } 602 \text {-method detection limit of } \\
0.3 \mu \mathrm{g} / \mathrm{L}\end{array}$ & EPA Method 601 -detection limit of $0.5 \mu \mathrm{g} / \mathrm{L}$ \\
\hline
\end{tabular}

No off-site wells in the eastern GSA yielded groundwater TCE concentrations in excess of the cleanup standard of $5 \mathrm{ppb}$ (MCL).

Central GSA: The central GSA groundwater treatment system is operating under substantive requirements for wastewater discharge issued by the Central Valley RWQCB. The central GSA treatment facility discharges to bedrock in the eastern GSA canyon, where the water percolates into the ground. Extracted central GSA groundwater runs through an air-sparging PTU to remove VOCs. Extracted soil vapor at the central GSA runs through GAC canisters to remove VOCs. In accordance with the substantive requirement for wastewater discharge, treated groundwater at the central GSA was collected and batch-discharged in a remote Site 300 canyon.

TCE concentrations in central GSA groundwater treatment system (GWTS) influent have been reduced from $9400 \mathrm{ppb}$ in 1993 to $51 \mathrm{ppb}$ in 2000. Volumes of water extracted and masses of VOCs removed from Central GSA groundwater are tabulated in Table 8-5. 
Soil vapor extraction and treatment of VOCs began in 1994, following dewatering of bedrock through groundwater extraction. Table 8-5 shows the amounts of soil vapor treated and VOCs removed at the central GSA. From 1994 through the end of 2000, VOC concentrations in the central GSA soil vapor extraction influent stream were reduced from 450 parts per million by volume (ppmv) to 5.5 ppmv. VOC concentrations in individual central GSA soil vapor extraction wells have also been significantly reduced.

After the central GSA well field expansion increased flow rate, the existing treatment system was converted and upgraded from batch mode to continuous flow operation. An additional interlock was added to stop groundwater extraction from all wells with pneumatic and electrical pumps during system shutdown. To increase accuracy in measuring extracted air flow, a new vortex meter was installed at the soil vapor extraction and treatment system. A new 1000-gallon polyethylene effluent surge tank with liquid level switches replaced the Baker tank at the central GSA groundwater extraction and treatment system.

\section{Building 834 Complex}

In 2000, the GWTS was operated at full scale for only the month of January. From February through June 2000, the GWTS was off-line to conduct a groundwater rebound study, to test the performance of the soil vapor extraction system in various configurations, and to evaluate the effectiveness of in situ bioremediation via reductive dechlorination of VOCs. For the remainder of 2000 , the GWTS and the soil vapor extraction (SVE) and treatment system operated periodically to continue testing the facility performance under various configurations, and to continue evaluating the effectiveness of in situ bioremediation.
Treatment facility performance under these various extraction well configurations is currently being evaluated to optimize our cleanup operations. Data collected during bioremediation monitoring strongly indicates that during periods when the SVE, and to a lesser extent groundwater extraction, is not in operation, anaerobic microbial dehalogenation is taking place. A peer-reviewed publication reported on the novel microbial process that exploits alkoxysiloxane lubricants as drivers for TCE bioattenuation at Building 834 (Halden et al. 1999).

Because of reduced operations in 2000, and to a lesser extent declining VOC concentrations, overall mass removal was down by $42 \%$ from 1999 , when the combined groundwater and soil vapor VOC mass removal at Building 834 was $52.5 \mathrm{~kg}$. During 2000 , the combined VOC mass removal at Building 834 was $22.0 \mathrm{~kg}$. Additional VOC mass was destroyed during 2000 through in situ bioremediation, although the amount was not quantified.

Table 8-5 shows the amounts of water and soil vapor treated and VOCs removed at Building 834 . Quarterly reports for the Building 834 treatment facility were submitted to the California EPA and the RWQCB in accordance with the Substantive Requirements for Waste Discharge (Lamarre 2000e, $\mathrm{f}, \mathrm{g}$, and $\mathrm{h}$ ). Because treated groundwater is discharged to misters and is not discharged to the ground, there are no treatment system surface discharge permit requirements for Building 834 .

\section{High Explosives Process Area}

The final Action Memorandum for the Building 815 Operable Unit Removal Action at Lawrence Livermore National Laboratory Site 300 (Ziagos and Jakub 1998) was submitted to the regulatory 
agencies on August 17, 1998. This report describes the main components of the removal action, estimates removal action costs, and addresses all verbal and written comments submitted by the community during the public workshop. The Building 815 Removal Action Design Workplan for the High Explosives Process Area at Lawrence Livermore National Laboratory Site 300 (Ziagos and Reber-Cox 1998a) was submitted to the regulatory agencies on November 15, 1998. This report describes the removal action in more detail and provides a contingency plan to address foreseeable problems that may arise during this removal action.

Treatability testing began in 1998 to evaluate costeffective groundwater treatment technologies for the second phase of groundwater cleanup. Removal and destruction technologies are being considered to remediate nitrates and HE compounds, including perchlorate. These technologies use granular-activated carbon or ionexchange for contaminant removal and ex situ bioremediation for contaminant destruction. Phytoremediation, using indigenous grasses, is also being evaluated for treating nitrate-bearing groundwater.

In 1999, a groundwater treatment facility (B815TF1) was installed near the Site 300 boundary to prevent off-site migration of VOCs in groundwater. Using granular-activated carbon, the system pumps and treats water from an existing groundwater monitoring well that was converted to an extraction well. Depending on the performance from these two wells, additional wells may be added. A second monitor well will be converted to an extraction well and connected to this treatment facility in 2001. In 2000, a groundwater treatment system (B815-SRC) consisting of aqueous phase GAC and a fixed-film bioreactor was installed at the Building 815 source area. This treatment system is designed to treat VOCs, RDX, and perchlorate and to reduce nitrate concentrations to levels permissible for discharge (i.e., $<45 \mathrm{mg} / \mathrm{L}$ ). Table 8-5 shows amounts of water treated and VOCs removed in the treatment system.

\section{Building 854 Area}

In December 1999, a groundwater treatment facility (B854-SRC) was installed near the TCE source area at Building $854 \mathrm{~F}$ as a part of a groundwater treatability study. The facility uses granular activated carbon to treat VOCs in groundwater. In March 2000, a second groundwater treatment facility (B854-PRXN) began operation. This system uses granular activated carbon to remove VOCs, resins to remove perchlorate, and containerized wetlands to remove nitrate. Both systems are operating under waste discharge requirements that were finalized in 2000. Table 8-5 shows amounts of water treated and VOCs removed in the treatment systems. Treated groundwater from B854-SRC is misted to air; treated effluent from B854-PRXN is discharged to an infiltration trench. Progress of the pump-and-treat systems and groundwater monitoring results are published quarterly (Lamarre 2000a, b, c, and d).

\section{Building 832 Canyon}

The Building 832 Canyon OU Treatability Study Workplan sets forth plans for groundwater and soil vapor TCE extraction and treatment, using portable treatment units, solar-powered water activated-carbon treatment units, and soil vapor extraction systems. Additionally, an aboveground iron filings treatment system is being employed in the lower canyon area to treat extracted TCE-laden groundwater, destroy the TCE and degradation products, and help control the migration of the TCE plume off-site.

In 1999, the Building 832 Canyon groundwater and soil vapor treatment system, B832-TF1, began continuous operation. In June 2000, the Building 830 portable groundwater treatment 
system (B830-PRXN) began operation. This system uses a PTU outfitted with GAC treatment. The iron filings treatment unit (B830-DISS), located near the mouth of the Building 832 Canyon, was completed and began operation in July 2000. This system also includes a containerized wetland unit for the treatment and removal of nitrate. The waste discharge requirements for these facilities were finalized during 2000. Table 8-5 shows volume of water treated and mass of VOCs removed in the treatment systems. The treated water is discharged into the canyon. Progress of the pump-and-treat systems and groundwater monitoring results are published quarterly (Lamarre 2000a, b, c, and d).

\section{East and West Firing Areas}

To determine the appropriate remediation strategy for the Pits 3 and 5 landfills, LLNL is currently conducting an evaluation of tritium, depleted uranium, and metal sources within the landfills and is continuing to build and calibrate a three-dimensional geological structural model and a finite element model of groundwater flow and contaminant transport. Additionally, LLNL is evaluating several remediation strategies to keep water from entering the landfills. These techniques include subsurface groundwater interceptor trenches, landfill freezing and other forms of permeability reduction, and geochemical techniques to immobilize uranium in groundwater. LLNL is also conducting a water budget and field studies to elucidate how water recharges the perched water-bearing zone and enters the landfills.

\section{Community Relations}

During 2000, LLNL met quarterly with members of Tri-Valley Citizens Against a Radioactive Environment and their technical advisor as part of the activities funded by an EPA Technical Assistance Grant. On May 5, 2000, the remedial project managers held a public meeting to present to the community the preferred remedial alternatives outlined in the Final Proposed Plan for Environmental Cleanup at Lawrence Livermore National Laboratory Site 300 (Dresen et al. 2000). 


\section{GroundWATER MONITORING}

\section{Introduction}

Lawrence Livermore National Laboratory regularly samples and analyzes groundwaters in the Livermore Valley and in the Altamont Hills. LLNL maintains multiple groundwater monitoring programs to comply fully with environmental regulations, applicable U.S. Department of Energy (DOE) orders, and the requirements of the Groundwater Protection Management Program (GWPMP). The objectives of the groundwater monitoring programs described in this chapter are to measure compliance with waste discharge requirements and postclosure plans and to assess the impact, if any, of current LLNL operations on groundwater resources.

DOE Order 5400.1 requires all DOE facilities to prepare a GWPMP that describes the site's groundwater regime, areas of known contamination, remediation activities, programs to monitor groundwater, and the means to monitor and control potential sources of groundwater contamination. Considerable groundwater monitoring and remediation, discussed in Chapter 8 , are carried out under Comprehensive Environmental Response, Compensation and Liability Act (CERCLA) restoration efforts. Soil and sediment surveillance monitoring under the GWPMP is described in Chapter 10. Additional programs address the sanitary sewer system, building drains, and underground storage tanks.

\section{Surveillance Monitoring}

Groundwater monitoring at LLNL complies with DOE Order 5400.1, which affirms DOE's commitment to protect the environment. LLNL conducts surveillance monitoring of groundwater in the Livermore Valley and in the Altamont Hills through networks of wells and springs that include private wells off site and DOE CERCLA wells on site. The two monitored areas are not connected 
hydrologically; they are separated by a major drainage divide and numerous faults. The Livermore site in the Livermore Valley drains to San Francisco Bay via Alameda Creek. Most of Site 300 drains to the San Joaquin River Basin via Corral Hollow Creek, with a small undeveloped portion in the north draining to the north and east toward Tracy. To maintain a comprehensive, costeffective monitoring program, LLNL determines the number and locations of surveillance wells, the analytes to be monitored, the frequency of sampling, and the analytical methods to be used.

A wide range of analytes is monitored to assess the impact, if any, of current LLNL operations on local groundwater resources. Because surveillance monitoring is geared to detecting substances at very low concentrations in groundwater, it can detect contamination before it significantly impacts groundwater resources. Wells at the Livermore site, in the Livermore Valley, and at Site 300 in the Altamont Hills are included in LLNL's surveillance monitoring plan. Historically, the surveillance and compliance monitoring programs have detected relatively elevated concentrations of various metals, nitrate, perchlorate, and depleted uranium (uranium-238) in groundwater at Site 300. Subsequent CERCLA studies have linked several of these contaminants to past operations, while others are the objects of continuing study. Present-day administrative, engineering, and maintenance controls in place at both LLNL sites are specifically tailored to prevent damage to the environment.

\section{Compliance Monitoring}

The Compliance Groundwater Monitoring Program complies with numerous federal and state controls (see Table 2-5, for a summary of LLNL permits). Compliance monitoring of groundwater is conducted at Site $\mathbf{3 0 0}$ to satisfy state-issued permits associated with closed landfills containing solid wastes, and with continuing discharges of liquid waste to surface impoundments, sewage ponds, and percolation pits. Groundwater compliance monitoring at Site 300 is specified in Waste Discharge Requirement (WDR) orders issued by the Central Valley Regional Water Quality Control Board (CVRWQCB) and in landfill closure and postclosure monitoring plans. The WDRs and postclosure plans specify wells and effluents to be monitored, constituents of concern (COCs) and parameters to be measured, frequency of measurement, inspections to be conducted, and the frequency and form of required reports. These monitoring programs include quarterly and semiannual monitoring of groundwater, monitoring of various influent waste streams, and visual inspections. LLNL performs the maintenance necessary to ensure the integrity of the closed facilities and their monitoring networks. LLNL conducts additional operational monitoring of wastewater effluents discharged to surface impoundments and sewage evaporation and percolation ponds to comply with WDRs issued under California's Porter-Cologne Water Quality Control Act. Quarterly and annual written reports of analytical results, inspection findings, and maintenance activities are required for each monitoring network.

Table 9-1a and 9-1b in the Data Supplement shows the analytical methods and reporting limits for inorganic constituents (including specific radioisotopes analyzed by alpha spectroscopy and other sensitive methods), and organic constituents in groundwater.

\section{Livermore Site and Environs}

\section{Livermore Valley}

LLNL has monitored tritium in water hydrologically downgradient of the Livermore site since 1988. Tritiated water (HTO) is potentially the most mobile groundwater contaminant emanating from LLNL. Rain and storm water runoff in the Livermore Valley, which recharges local aquifers, 
contains small amounts of tritium from natural sources, past worldwide atmospheric nuclear weapons tests, and atmospheric emissions from LLNL. (See Chapters 4, 5, and 7 for further discussion of air emissions, rain, and storm water runoff.) Groundwater samples were obtained during 2000 from 20 of 23 wells in the Livermore Valley (see Figure 9-1) and measured for tritium activity.

Groundwater is recharged at the Livermore site, primarily from arroyos by rainfall (see also Chapter 7). Groundwater flow at the Livermore site, which is generally westward, is discussed generally in Chapter 1 and in detail in the
CERCLA Remedial Investigation Report for the LLNL Livermore Site (Thorpe et al. 1990) and the annual LLNL Groundwater Project reports (Aarons et al. 2001).

\section{Livermore Site Perimeter}

LLNL designed a surveillance monitoring program to complement the Livermore Groundwater Project (discussed in Chapter 8). The intent of this network is to monitor for potential groundwater contamination from continuing LLNL operations. The perimeter portion of this surveillance groundwater monitoring network makes use of three background monitoring wells (wells W-008, $\mathrm{W}-221$, and W-017) near the eastern boundary of

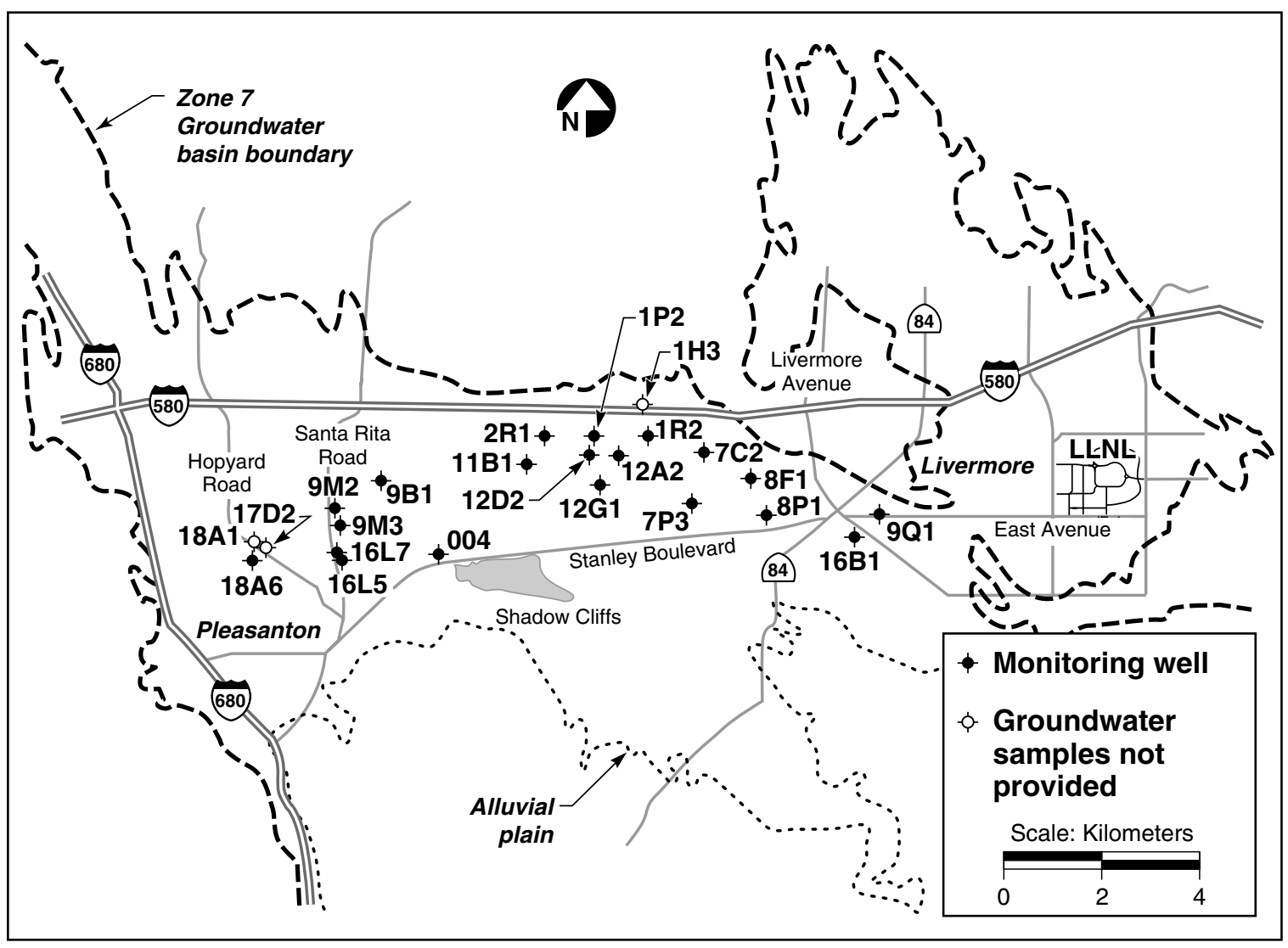

Figure 9-1. Locations of off-site tritium monitoring wells in the Livermore Valley 
the site and of the seven monitoring wells located near the western boundary (wells 14B1, W-121, W-151, W-1012, W-571, W-556, and W-373) (see Figure 9-2). These seven wells, located in the regions of treatment Facilities A, B, and C (see Figure 8-1), meet the requirements of DOE Order 5400.1. These western wells are screened in the uppermost aquifers for COCs that are outside but very near the areas where groundwater is being treated.
The screened interval for each surveillance monitoring well is in the uppermost saturated aquifer (or aquifers) at that well location. As discussed in Chapter 8, the alluvial sediments have been divided into seven hydrostratigraphic units (HSUs), which are shown in Figure 8-1. Screened intervals for these monitoring wells range from the shallow HSU $1 \mathrm{~B}$, in which some of the western monitoring wells are screened, to the deeper HSU 5, in which background well W-017 (and some wells around Buildings 514 and 612) is screened.

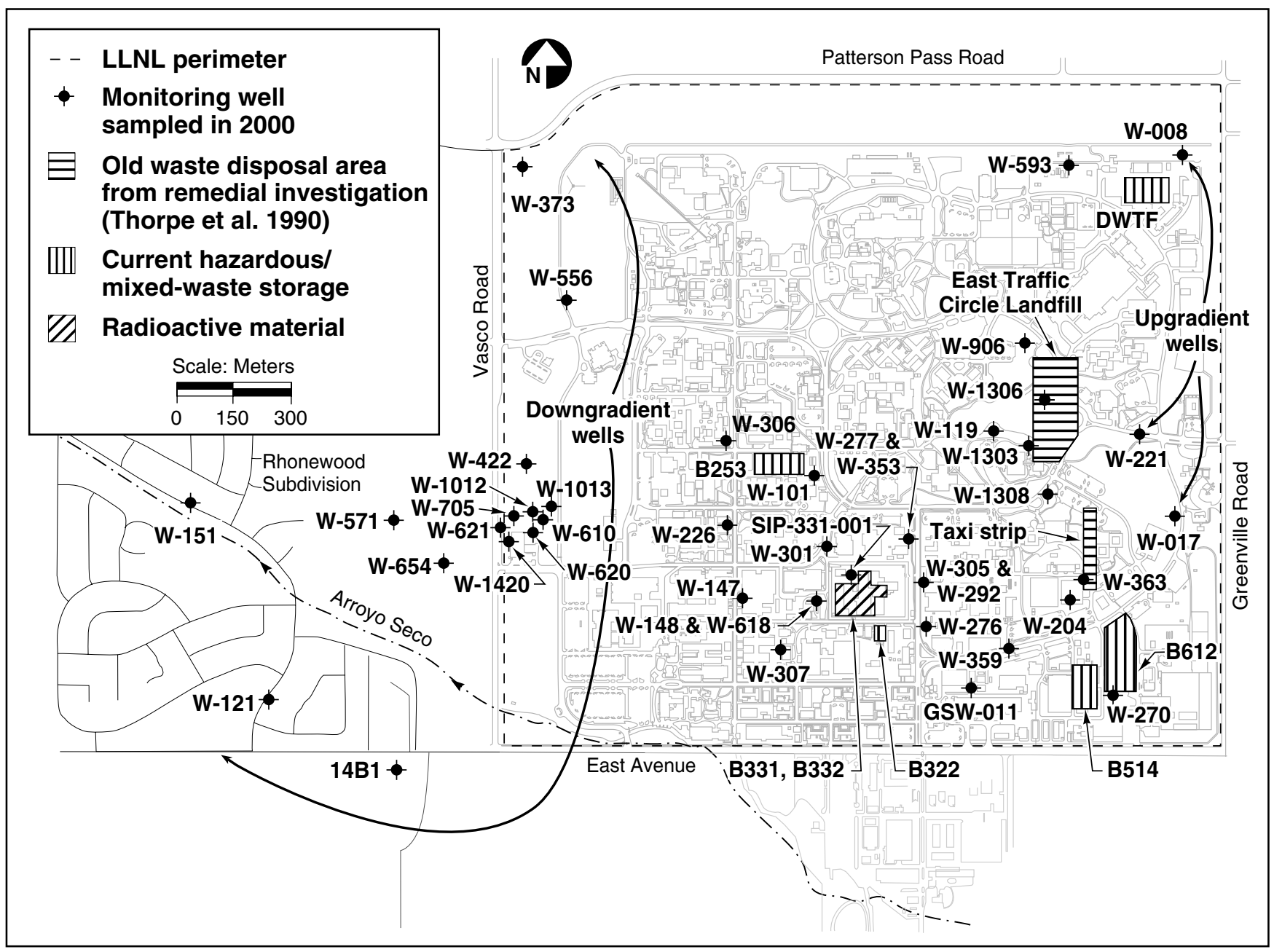

Figure 9-2. Locations of routine surveillance groundwater monitoring wells at the Livermore site 
Two of the background wells, W-008 (screened in H SU s 3A/ 3B) and W-221 (screened in H SU 3A), were sampled and analyzed twice for pesticide and herbicide compounds used on site and once for all trace metals. They were also sampled and analyzed semiannually for minerals and quarterly for several radioactive constituents. Well W-017 is considered a background well for the deeper H SU 5 because it is screened in that H SU. It was sampled and analyzed once during the fourth quarter for minerals, hexavalent chromium, selected trace metals, and radioactive constituents. Sampling and analysis were carried out during the third quarter for the commonly used herbicides diuron and glyphosate.

The seven western downgradient wells screened in shallower H SU S 1B and 2 were sampled and analyzed annually for nonradioactive constituents and quarterly for many radioactive constituents. (Because it was originally a production well, well 14B1 is screened over three depth intervals in H SU s 2, 3A, and 3B.) E ach well was sampled and the water analyzed for metals and minerals, pesticides and herbicides, gross al pha and beta, tritium, and other radioisotopes. Sampling and analysis were carried out during the third quarter for the commonly used herbicides diuron and glyphosate. Fourth-quarter sampling and analysis of groundwater from western wells were performed only at those wells and for those analytes that had previously been detected at concentrations that might be of concern. Routine surveillance monitoring data for 2000 are presented in the Data Supplement (Tables 9-2 through 9-11). These monitoring results help establish baseline conditions for future monitoring and detect the presence of any COCs that may adversely affect public health or the environment.
Livermore Site

Groundwater sampling locations within the L ivermore site include areas where releases to the ground may have occurred in the recent past or where previously detected CO C s have low concentrations that do not require CERCLA remedial action. M onitoring wells that are screened in the uppermost aquifers are situated downgradient from and as near as possible to the potential release locations.

The Taxi Strip Area and the East Traffic Circle Landfill are two potential sources of groundwater contamination. Surveillance monitoring wells for these two sites were added to the surveillance monitoring network in 1997 (see Figure 9-2). Samples from monitoring wells screened in H SU S 2 (W-204) and 3A (W-363) downgradient from the Taxi Strip Area were analyzed in 2000 for copper, lead, zinc, polychlorinated biphenyls (PCBs), radium-226, radium-228, and tritium. Samples from monitoring wells screened at least partially in H SU 2 (W-119, W-906, W-1303, W-1306, and W-1308) within and downgradient from the East Traffic Circle $L$ andfill were analyzed for americium, plutonium, radium-226, radium-228, tritium, copper, lead, zinc, and PCBs. The locations of all of these wells are shown in

Figure 9-2. All surveillance monitoring analytical data for the Taxi Strip Area and the East Traffic Circle L andfill are presented in D ata Supplement Tables 9-12 through 9-18.

A nother potential source of ground water contamination is the $D$ econtamination and Waste Treatment Facility (DWTF) in the northeastern portion of L LN L. Samples were obtained downgradient from this facility from well W-593 during 2000 and were analyzed for the same suite of analytes as the East Traffic C ircle L andfill, except for PCBs (see D ata Supplement Table 9-19). 
The hazardous waste/mixed waste storage facilities around Buildings 514 and 612 are monitored by wells W-270 and W-359 screened in HSU 5 and well GSW-011 screened in HSU 3B. These wells were sampled and analyzed for selected trace metals, general minerals, and radioactive constituents in 2000. All surveillance monitoring analytical data from the Hazardous Waste Management Area are presented in Data Supplement Tables 9-20 through 9-22.

Groundwater samples were also obtained downgradient from areas where minor releases of metals to the ground have occurred. Samples were obtained from monitoring well W-307 (screened in HSU 1B), downgradient from a fume hood vent on the roof of Building 322, a metal plating shop. Soil samples obtained from the area show elevated concentrations (in comparison with LLNL's site background levels) of chromium, copper, lead, nickel, zinc, and occasionally other metals. LLNL removed contaminated soils near Building 322 in 1999 and replaced them with clean fill. The area was then paved over, making it less likely that metals will migrate from the site. Analytical results for dissolved metals in 2000 groundwater samples are presented in Data Supplement Table 9-23.

Groundwater samples were also obtained downgradient from a location where sediments containing metals (including cadmium, copper, lead, mercury, and zinc) had accumulated in a storm water catch basin near Building 253 (Jackson 1997). These samples were obtained from monitoring wells W-226 and W-306 screened in HSUs $1 \mathrm{~B}$ and 2, respectively. Analytical results for dissolved metals in these samples are presented in Data Supplement Tables 9-24 and 9-25.

Additional surveillance groundwater sampling locations established in 1999 surround the area of the Plutonium Facility (Building 332) and the Tritium Facility (Building 331) (see Figure 9-2). Possible contaminants include plutonium-239 and americium-24l from the Plutonium Facility and tritium from the Tritium Facility. Both plutonium and americium are much more likely to bind to the soils, rather than to migrate into the groundwater. Tritium, in contrast, could migrate into groundwater if spilled in sufficient quantities. Upgradient of these facilities, well W-305 is screened in HSU 2, downgradient well W-148 is screened in HSU 1B, and SIP-331-001 is screened in HSU 2. Radiological analytical results are presented in Data Supplement Tables 9-26 through 9-28.

LLNL sampled and analyzed additional monitoring wells for tritium in the area surrounding the Tritium Facility in 2000 because of the very high activities of tritium detected in storm water (see Chapter 7) and because tritium was detected at $110 \mathrm{~Bq} / \mathrm{L}(3100 \mathrm{pCi} / \mathrm{L})$ in a groundwater sample collected from well W-148 in August 2000. The locations of these wells are also shown in Figure 9-2. Tritium activities analyzed in groundwater samples collected from these wells and the HSU within which each well is screened are listed in the Data Supplement in Table 9-29.

\section{Site 300}

For surveillance and compliance groundwater monitoring at Site 300, LLNL uses DOE CERCLA wells on site and private wells and springs off site. Representative groundwater samples are obtained at least once per year; they are routinely measured for various elements (primarily metals), a wide range of organic compounds, nitrate, general radioactivity (gross alpha and gross beta), uranium activity, and tritium activity. Typically, analytical methods approved by the Environmental Protection Agency (EPA) are used because they are both accurate and sensitive. (See Data Supplement Table 9-1 for a complete list of COCs and for the EPA or other standard analytical methods used to measure them.) 
Figure 9-3 shows the wells and springs at Site 300 that are groundwater surveillance sampling locations. Although groundwater from the uppermost water-bearing zone is the target of most of the sampling, deeper water-bearing zones are sampled at several locations by means of multiplecompletion installations fitted with Barcad devices. Barcads are identified in Figure 9-3 by the capital letters $\mathrm{A}, \mathrm{B}$, and $\mathrm{C}$ at the end of a monitoring installation's identifier code. (" $\mathrm{A}$ " is assigned to the Barcad that samples the deepest of three, or deeper of two, water-bearing zones.)

Twelve groundwater monitoring locations are off-site. Two are springs, identified as MUL2 and VIEl, which are located near the northern boundary of Site 300. Off-site surveillance well VIE2 is located $6 \mathrm{~km}$ west of Site 300 in the upper

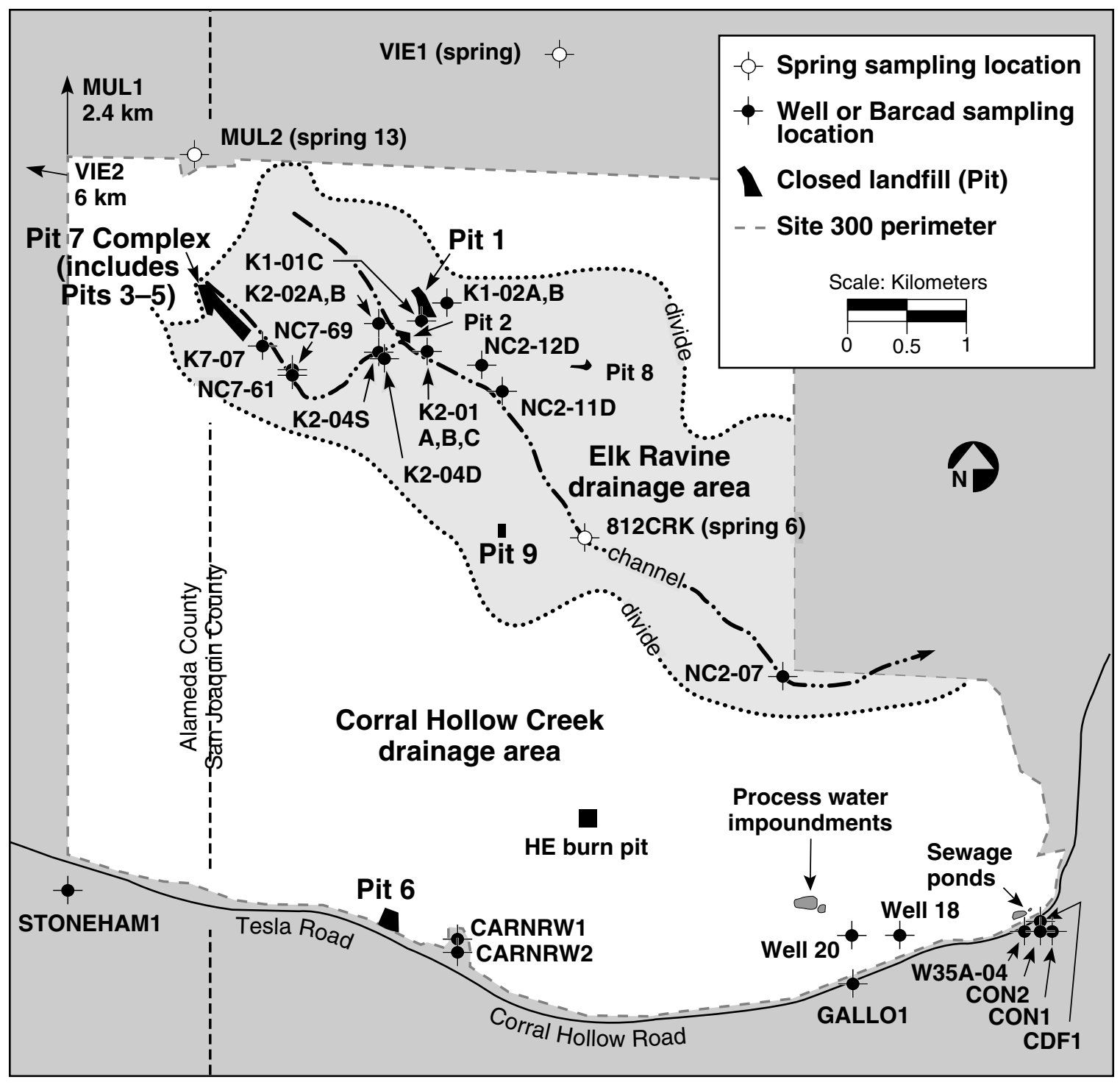

Figure 9-3. Locations of surveillance groundwater wells, Barcads, and springs at Site 300 
reaches of the Livermore Valley watershed. Eight off-site surveillance locations are wells located near the southern boundary of Site 300 in or adjacent to the Corral Hollow Creek floodplain.

On-site wells installed for CERCLA characterization studies during the 1980s continue to be used to monitor the closed landfills, a former open-air burn pit, two connected surface water impoundments, and two connected sewer ponds. The closed landfills-identified as Pit 1, Pit 2, Pit 7 Complex, Pit 8, and Pit 9-are located in the northern portion of Site 300 in the Elk Ravine drainage area, while Pit 6 , the former burn pit, the two surface impoundments, and the sewage ponds are located in the southern portion of Site 300 in the Corral Hollow Creek drainage area (Figure 9-3). Two on-site water supply wells, identified as well 18 and well 20, are also used for surveillance monitoring purposes. Well 20 provides potable water to the site. Well 18 is maintained as a standby supply well.

Brief descriptions of the Site 300 groundwater monitoring networks are given below. Networks within the Elk ravine drainage area are described first, followed by the networks in the Corral Hollow creek drainage area. CERCLA wells within Site 300 have been selected for compliance and surveillance monitoring use, based on their locations and our general understanding of local geologic and hydrogeologic conditions at Site 300 as described in Webster-Scholten (1994). (Also see Chapter 8 for a summary of Site 300 stratigraphy and hydrogeology.) With the exception of the monitoring data for the former burn pit near Building 829, groundwater measurements made during 2000 and published elsewhere are not listed in tables in the Data Supplement. References to the publications containing the remaining groundwater data collected during 2000 are cited in the References at the end of this volume.

\section{Elk Ravine Drainage Area}

The Elk Ravine drainage area, a branch of the Corral Hollow Creek drainage system, includes most of northern Site 300 (see Figure 9-3).

Storm water runoff from closed landfills within the Elk Ravine drainage area (Pits 1-5 and 7-9) collects in arroyos and quickly infiltrates into the ground. Groundwater from wells that lie within the Elk Ravine drainage area are monitored for COCs because of the system of surface and underground flows that connects the entire Elk Ravine drainage area. The area contains Pits $1-5$ and 7-9 and many firing tables where explosives tests are conducted. The following descriptions of monitoring networks within Elk Ravine begin with the headwaters area and proceed downstream. (See Chapter 8 for a review of groundwater contamination in this drainage area as determined from numerous CERCLA investigations.)

Pit 7 Complex: Monitoring requirements for the closed Pit 7 landfill in the Elk Ravine drainage area are specified in Waste Discharge Requirements Order 93-100 (WDR 93-100), administered by the CVRWQCB (1993 and 1998) and in LLNL Site 300 RCRA Closure and Post-Closure PlansLandfill Pits 1 and 7 (Rogers/Pacific Corporation 1990).

The Pit 7 Complex area is located at an elevation of about $400 \mathrm{~m}$ in the most elevated portion of the Elk Ravine drainage area. The complex consists of four adjacent landfills identified as Pits 3, 4, 5, and 7 (see Figure 9-4). From 1963 to 1988, the landfills received waste gravels and debris from hydrodynamic tests of explosive devices conducted on firing tables at Site 300. The gravels contained concrete, cable, plastic, wood, tritium, depleted uranium (uranium-238), beryllium, lead, and other metals in trace amounts. In 1988, $9440 \mathrm{~m}^{3}$ of gravel were removed from six firing tables at 


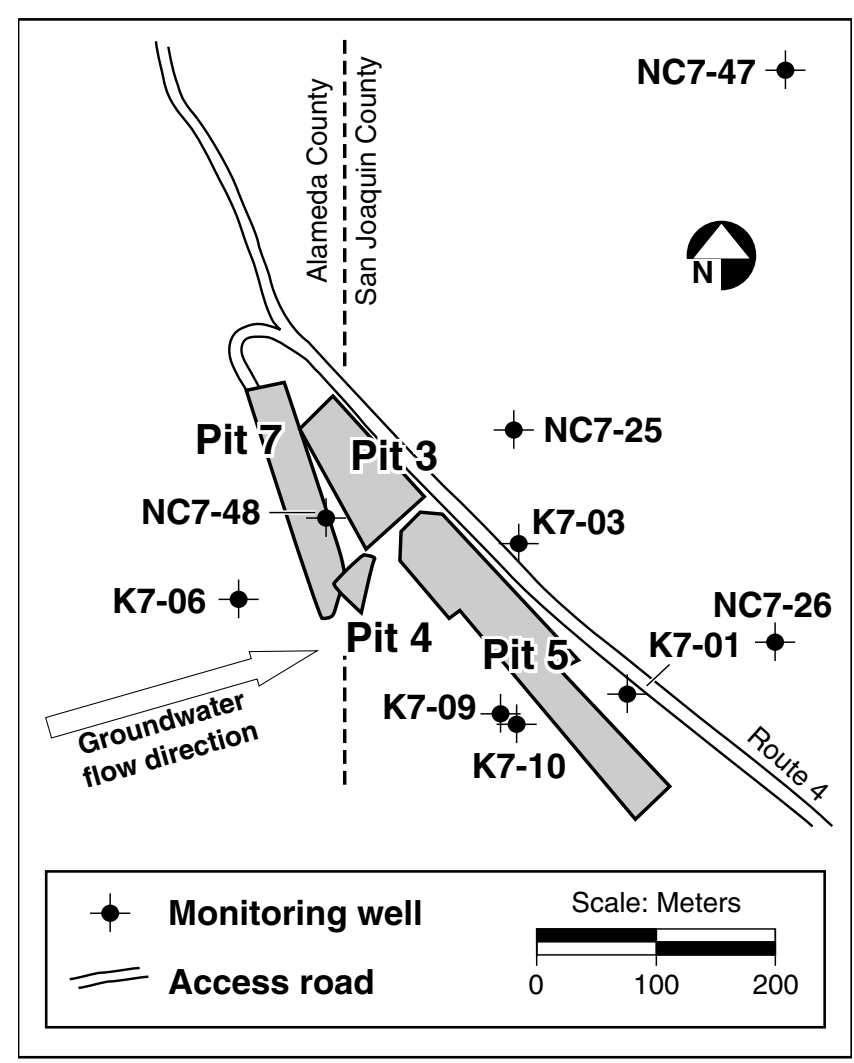

Figure 9-4. Locations of Pit 7 compliance groundwater monitoring wells

Site 300 and placed in Pit 7 (Lamarre and Taffet 1989). These were the last solid wastes to be placed in a landfill at Site 300 .

The main objective of monitoring is the early detection of any release of COCs from Pit 7 to groundwater. All detected COCs are investigated. Most of the COCs detected by the Pit 7 monitoring network have been previously linked to historical releases from other pits near Pit 7. Detected COCs such as arsenic, barium, and uranium are released from the underlying rocks and sediments where they occur naturally. Comparison of new data with historical data helps analysts identify releases from wastes buried in Pit 7, versus releases from sources other than Pit 7 , including natural sources. Most of the COCs detected during 2000 in the groundwater near Pit 7 were released historically from Pits 3 and 5 (WebsterScholten 1994). (See Chapter 8 for a review of the stratigraphy, hydrogeology, and groundwater contamination in the Pit 7 area.)

As required by the monitoring and reporting program contained in WDR 93-100, LLNL obtained groundwater samples quarterly from Pit 7 monitoring wells during 2000 and analyzed them for inorganic COCs (mostly metallic elements), general radioactivity (gross alpha and beta), activity of certain radioisotopes (tritium, radium, uranium, and thorium), explosive compounds (HMX and RDX), and volatile organic compounds (VOCs) (EPA Method 601). Field measurements of groundwater depth, temperature, $\mathrm{pH}$, and specific conductance were obtained at each well at the time of sample collection. Three quarterly reports and one annual report covering monitoring activities at Pit 7 during 2000 have been published previously (Christofferson and MacQueen 2000a, 2000b, 2000c, 2001). Tables and graphs of Pit 7 groundwater data for 2000 can be found in LLNL Experimental Test Site 300 Compliance Monitoring Program for RCRA-Closed Landfill Pits 1 and 7, Annual Report for 2000 (Christofferson and MacQueen 2001).

Elk Ravine: Groundwater samples were obtained twice during 2000 from the widespread Elk Ravine surveillance monitoring network. Samples were analyzed for inorganic constituents (mostly metallic elements), general radioactivity (gross alpha and beta), tritium and uranium activity, explosive compounds (HMX and RDX), and, where possible, VOCs (EPA Method 601).

Pit 2: The closed Pit 2 landfill lies in the upper portion of Elk Ravine, about $320 \mathrm{~m}$ above sea level (Figures 9-3 and 9-5). The landfill contains primarily gravels and debris from hydrodynamic tests of explosive devices conducted at the Building 801 and 802 firing tables. The buried 


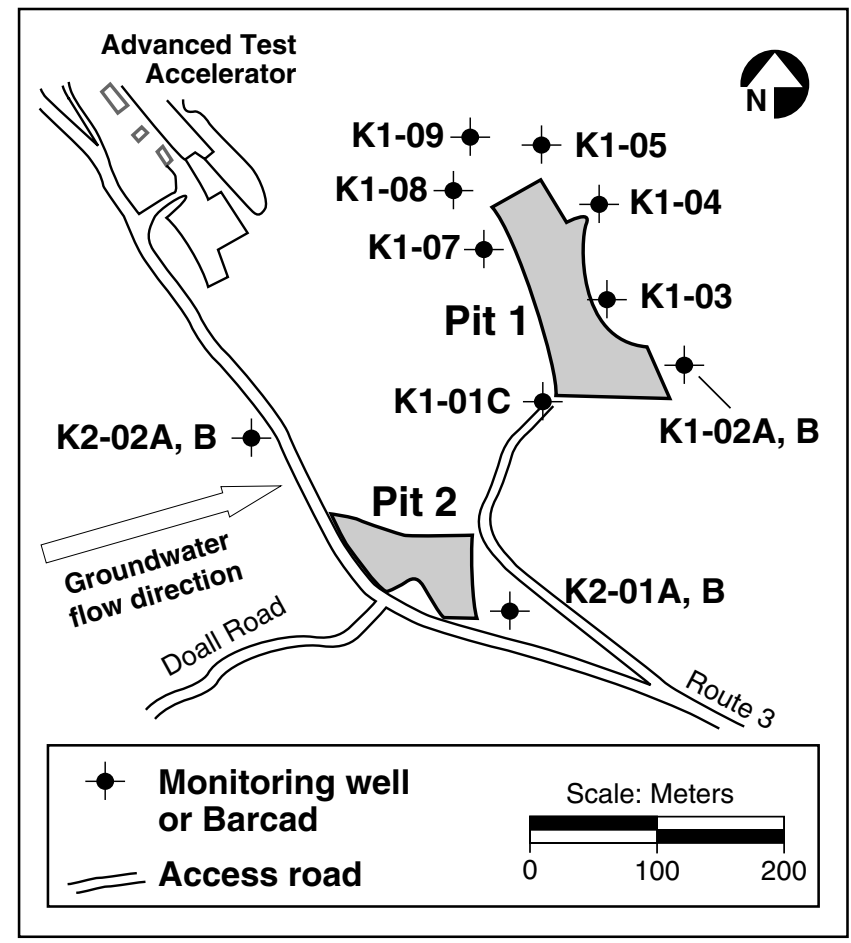

Figure 9-5. Locations of Pit 1 and Pit 2 groundwater monitoring wells

waste material contains depleted uranium (uranium-238), and trace amounts of beryllium, thorium, and possibly tritium.

As planned for surveillance purposes, LLNL obtained groundwater samples twice during 2000 from the Pit 2 monitoring network (comprising mostly Barcad installations) and analyzed them for inorganic COCs (mostly metallic elements), general radioactivity (gross alpha and beta), activity of certain radioisotopes (tritium and uranium), and explosive compounds (HMX and RDX).

Pit 1: Monitoring requirements for the Pit 1 landfill, which was closed under the Resource Conservation and Recovery Act (RCRA), are specified in Waste Discharge Requirements Order 93-100 (WDR 93-100) administered by the CVRWQCB (1993 and 1998) and in LLNL Site 300 RCRA
Closure and Post-Closure Plans-Landfill Pits 1 and 7 (Rogers/Pacific Corporation 1990).

Pit 1 lies in the Elk Ravine drainage area about $330 \mathrm{~m}$ above sea level. The Pit 1 landfill and the positions of the eight groundwater wells used to monitor it are shown in Figure 9-5.

As required by the monitoring and reporting program contained in WDR 93-100, LLNL obtained groundwater samples from Pit 1 monitoring wells every quarter during 2000. Samples were analyzed for inorganic COCs (mostly metallic elements), general radioactivity (gross alpha and beta), activity of certain radioisotopes (tritium, radium, uranium, and thorium), explosive compounds (HMX and RDX), and VOCs (EPA Method 601). Every other quarter, analyses were conducted for an additional seven elements. Additional annual analyses were conducted on fourthquarter samples for extractable organics (EPA Method 625), pesticides and PCBs (EPA Method 608), and herbicides (EPA Method 615). Field measurements of groundwater depth, temperature, $\mathrm{pH}$, and specific conductance were obtained at each well at the time of quarterly sample collection. Three quarterly reports and one annual report covering monitoring activities at Pit 1 during 2000 have been published previously (Christofferson and MacQueen 2000a, 2000b, 2000c, 2001). Tables and graphs containing Pit 1 groundwater data for 2000 can be found in LLNL Experimental Test Site 300 Compliance Monitoring Program for RCRA-Closed Landfill Pits 1 and 7, Annual Report for 2000 (Christofferson and MacQueen 2001).

Pit 8: The closed Pit 8 landfill is located in the Elk Ravine drainage area adjacent to the Building 801 firing table. Explosives experiments were conducted there from 1958 to 1998, at which time construction of a new enclosed firing facility began. Construction continued through 2000. 
Approximately $40 \mathrm{~m}^{3}$ of untreated debris from the firing table were placed in the pit until 1974 when the pit was closed. The debris buried there may contain trace amounts of tritium, depleted uranium (uranium-238), lead, and beryllium.

Figure 9-6 shows the Building 801 and Pit 8 areas and the locations of the monitoring wells. The pit is located in a narrow ravine within the Elk Ravine drainage area about $350 \mathrm{~m}$ above sea level. Chemical analysis of soil and rock samples obtained from this area during CERCLA remedial investigations detected no COCs above background level concentrations (Webster-Scholten 1994). However, low concentrations of trichloroethylene (TCE) have been detected in groundwater samples from Pit 8 surveillance monitoring wells, including upgradient well K8-01, since 1987. Previous remedial investigation links the TCE to a dry well near Building 801 that was once used to dispose liquid wastes (Webster-Scholten 1994).
Because of construction activities in the vicinity of Pit 8 during 2000, groundwater samples could be obtained only from surveillance monitoring wells K8-01 and K8-02B. Groundwater samples from the two surveillance wells were analyzed for inorganic COCs (mostly metallic elements), general radioactivity (gross alpha and beta), activity of certain radioisotopes (tritium and uranium), explosive compounds (HMX and RDX), pesticides (EPA Method 608), PCBs (EPA Method 8082A), and VOCs (EPA Method 601).

Pit 9: The Pit 9 landfill is centrally located within Site 300 about $340 \mathrm{~m}$ above sea level. Similar to the other closed landfills in Elk Ravine, the closed Pit 9 landfill contains firing table gravels and debris from explosives experiments conducted on the Building 845 firing table nearby.

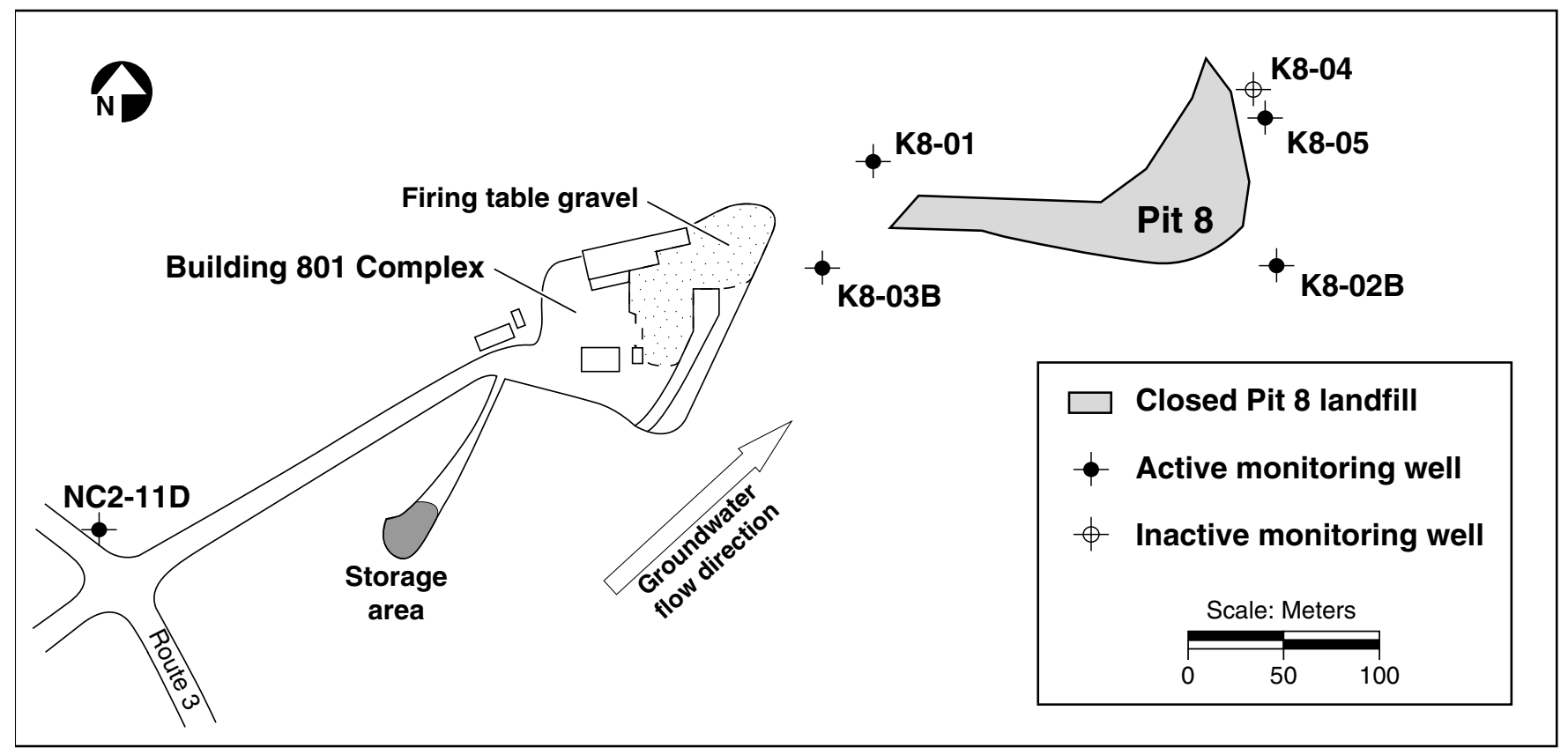

Figure 9-6. Locations of Pit 8 surveillance groundwater monitoring wells 
Figure 9-7 shows the locations of the four surveillance wells used to monitor the groundwater in the vicinity of Pit 9. Groundwater flows east-northeasterly beneath Pit 9 in the Neroly lower blue sandstone unit $\left(\mathrm{Tnbs}_{1}\right)$. The water table lies about $40 \mathrm{~m}$ below the ground surface at Pit 9. Monitoring well K9-02 is hydrologically upgradient from Pit 9, and wells K9-01, K9-03, and K9-04 are downgradient.

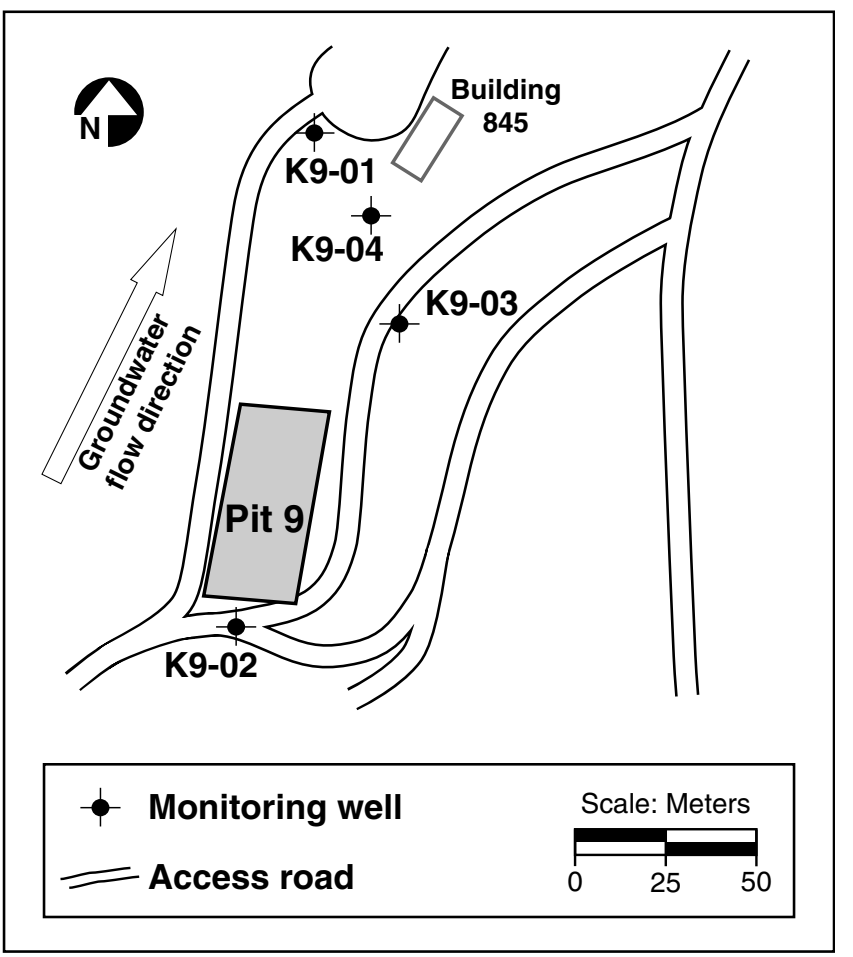

Figure 9-7. Locations of Pit 9 surveillance groundwater monitoring wells

As planned for surveillance purposes, the four Pit 9 monitoring wells were sampled once during 2000. Groundwater samples from the four wells were analyzed for inorganic COCs (mostly metallic elements), general radioactivity (gross alpha and beta), activity of certain radioisotopes (tritium and uranium), explosive compounds (HMX and RDX), and VOCs (EPA Method 601).

\section{Corral Hollow Creek Drainage Area}

This section describes the groundwater monitoring networks that are located in the southern half of Site 300 where runoff and groundwater flow south to Corral Hollow creek. (See Chapter 8 for a review of groundwater contamination in this drainage area as determined from numerous CERCLA investigations.)

Pit 6: Compliance monitoring requirements for the closed Pit 6 landfill in the Corral Hollow Creek drainage area are specified in the Post-Closure Plan for the Pit 6 Landfill Operable Unit Lawrence Livermore National Laboratory Site 300 (Ferry et al. 1998). The closed Pit 6 landfill covers an area of about 1 hectare ( 2.5 acres), at an elevation of approximately $215 \mathrm{~m}$ above sea level. From 1964 to 1973 , approximately $1500 \mathrm{~m}^{3}$ of solid wastes were buried there in nine separate trenches. The trenches were not lined, consistent with historical disposal practices. Three larger trenches contain $1300 \mathrm{~m}^{3}$ of solid waste that includes empty drums, glove boxes, lumber, ducting, and capacitors. Six smaller trenches contain $230 \mathrm{~m}^{3}$ of biomedical waste, including animal carcasses and animal waste. Minor releases of VOCs, primarily the solvent TCE and tritium, occurred prior to closure. During 1997, a multilayered cap was constructed over all the trenches, and a drainage control system was installed around the cap. The cap and the drainage control system are engineered to keep rainwater from contacting the buried waste (Ferry et al. 1998).

The Pit 6 disposal trenches were constructed in Quaternary terrace deposits (Qt) above and north of the Corral Hollow Creek flood plain. Surface runoff from the pit area flows southward to Corral Hollow Creek. The Carnegie-Corral Hollow Fault zone extends beneath the southern third of Pit 6 . The northern limit of the fault zone is shown in Figure 9-8. Beneath the northern two-thirds of Pit 6, groundwater flows south-southeast, following the inclination (dip) of the underlying 


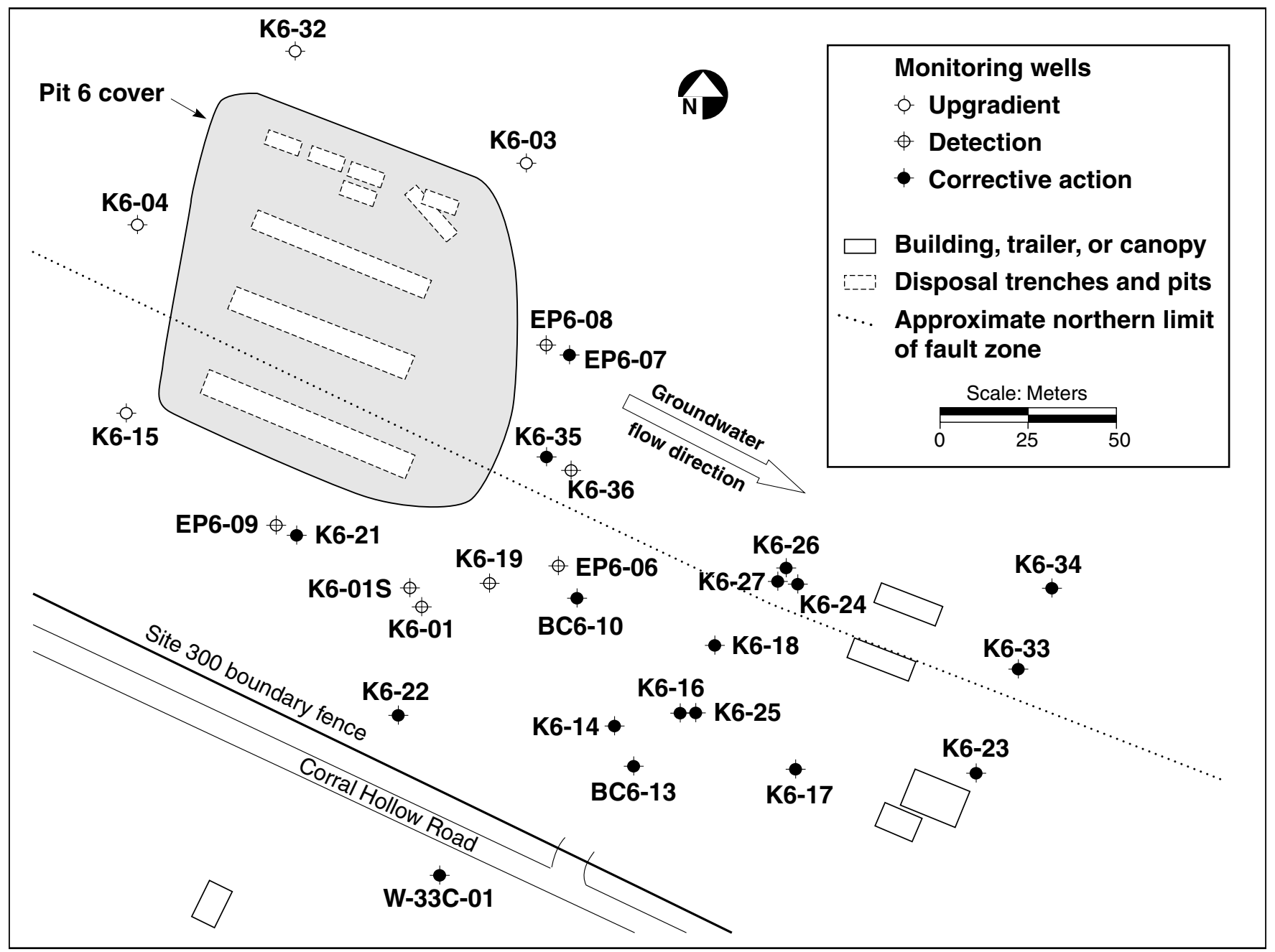

Figure 9-8. Locations of Pit 6 groundwater wells

sedimentary rocks. Groundwater seepage velocities are less than $10 \mathrm{~m} / \mathrm{y}$. Depths to the water table range from 10-20 m. Beneath the southern third of Pit 6 , a trough containing terrace gravel within the fault zone provides a channel for groundwater to flow southeast, parallel to the Site 300 boundary fence (Webster-Scholten 1994). (See Chapter 8 for a review of the stratigraphy, hydrogeology, and groundwater contamination in the Pit 6 area.)

Two groundwater monitoring programs were implemented at the Pit 6 landfill during 1998 to ensure compliance with all regulations: (1) the
Detection Monitoring Program (DMP), designed to detect any new release of COCs to groundwater from wastes buried in the Pit 6 landfill, and (2) the Corrective Action Monitoring Program (CAMP), which operates under CERCLA and monitors the movement and fate of existing releases (see Chapter 8 for a summary of CAMP monitoring results for Pit 6). During 2000, perchlorate was added to the list of $24 \mathrm{COCs}$, which include VOCs and radioisotopes, that are monitored in groundwater near Pit 6 (Ferry et al. 1998).

Figure 9-8 shows the locations of Pit 6 and the wells used to monitor groundwater there. 
As required by the monitoring program contained in the postclosure plan, groundwater at the Pit 6 monitoring wells was sampled quarterly during 2000. Samples were analyzed for inorganic COCs (mostly metals), general radioactivity (gross alpha and beta), tritium activity, uranium activity, VOCs (EPA Method 624), extractable organics (EPA Method 625), pesticides (EPA Method 608), and PCBs (EPA Method 8082A). Field measurements of groundwater depth, temperature, $\mathrm{pH}$, and specific conductance were obtained at each well at the time of sample collection. Three quarterly reports and one annual report covering monitoring activities at Pit 6 during 2000 have been published previously (Christofferson and Taffet 2000, Christofferson et al. 2000a, 2000b, 2001). Tables listing the groundwater data obtained during year 2000 for Pit 6 can be found in Christofferson et al. 2001.

HE Process Area Closed Burn Pits: Compliance monitoring requirements for the closed burn pits in the Corral Hollow Creek drainage area are specified in the Final Closure Plan for the HighExplosives Open Burn Treatment Facility at Lawrence Livermore National Laboratory Experimental Test Site 300 (Mathews and Taffet 1997) and in the Post-Closure Permit Application for the Building 829 HE Open Burn Facility - Volume 1. (LLNL 2000).

The former High-Explosives (HE) Open Burn Treatment Facility, part of the Building 829 Complex, is located on a ridge within the southeast portion of Site 300 at an elevation of about $320 \mathrm{~m}$ $(1050 \mathrm{ft})$ (see Figure 9-9). The facility included three shallow unlined pits constructed in unconsolidated sediments that cap the ridge (Tps formation). The former burn facility was covered with an impervious cap during 1998 following RCRA guidance. The facility was used to thermally treat explosives waste generated by research operations at Site 300. Surface water drains southward from the facility toward Corral Hollow Creek. The nearest site boundary lies about $1.6 \mathrm{~km}(4500 \mathrm{ft})$ to the south at Corral Hollow Road. Stratified rocks of the Neroly ( $\mathrm{Tn}$ ) formation underlie the facility and dip southeasterly. Two water-bearing zones exist at different depths beneath the facility. The shallower zone, at a depth of about $30 \mathrm{~m}$ $(100 \mathrm{ft})$, is perched within the Neroly upper siltstone/claystone aquitard $\left(\operatorname{Tnsc}_{2}\right)$. The deeper zone, at a depth of about $120 \mathrm{~m}(400 \mathrm{ft})$, represents a regional aquifer within the Neroly upper sandstone member $\left(\mathrm{Tnbs}_{2}\right)$. (See Chapter 8 for a review of the stratigraphy, hydrogeology, and groundwater contamination in this area.)

Based on groundwater samples recovered from boreholes, previous CERCLA remedial investigations determined that the perched groundwater beneath the burn facility was contaminated with VOCs, primarily TCE, but that the deeper regional aquifer was free of any contamination stemming from operation of the facility (Webster-Scholten 1994). Subsequent assays of soil samples obtained from shallow boreholes prior to closure revealed that low concentrations of HE compounds, VOCs, and metals exist beneath the burn pits (Mathews and Taffet 1997). Conservative transport modeling indicates that the shallow contamination will not adversely impact the regional aquifer, primarily because its downward movement is blocked by a 100 -m-thick intervening aquitard. However, beginning in 1999, LLNL implemented the intensive groundwater monitoring program for this area described in the postclosure plan (Mathews and Taffet 1997) to track the fate of contaminants in the perched water-bearing zone and to watch the deep regional aquifer for the appearance of any potential contaminants from the closed burn facility. 


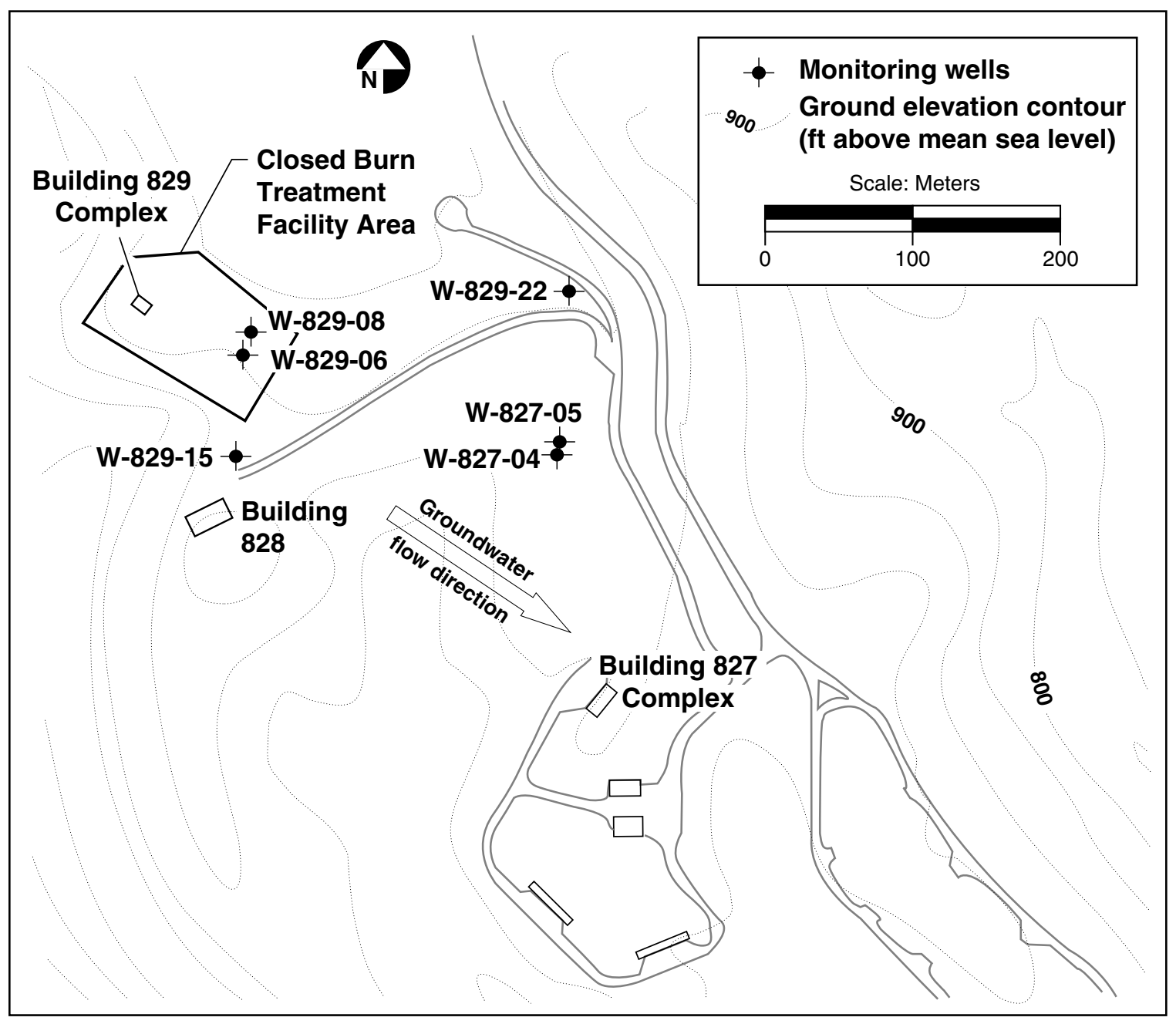

Figure 9-9. Locations of monitoring wells in Building 829 closed burn facility area

Figure 9-9 shows the locations of the closed burn treatment facility area and the six wells used to monitor the groundwater. Two wells, W-829-06 and $\mathrm{W}-829-08$, are screened in the perched waterbearing zone beneath the former burn facility. The remaining four wells are screened in the deep regional aquifer downgradient of the closed facility. During 2000, quarterly samples were obtained from five of the six monitoring wells. One of the deep wells, W-827-04, was dry during 2000. Groundwater samples from the wells screened in the deep regional aquifer were analyzed quarterly for inorganic COCs (mostly metals), general minerals, explosive compounds (HMX, RDX, and TNT), VOCs (EPA Method 624), extractable organics (EPA Method 625), general radioactivity (gross alpha and beta), activity of certain radioisotopes (tritium and radium), total organic carbon (TOC), total organic halides (TOX), and coliform bacteria. Groundwater samples from the two wells screened in the shallow perched water-bearing zone were analyzed quarterly for explosive compounds and VOCs during 2000. 
Water Supply Wells: Water supply wells 18 and 20 are located in the southeastern part of Site 300 (Figure 9-3). Both are deep, high-production wells. Well 20 supplied potable water at the site during 2000, while well 18 was maintained as a standby water supply well. Both wells are screened in the Tnbs ${ }_{1}$. The well 18 screen extends upward into the aquitard unit $\left(\mathrm{Tnsc}_{1}\right)$ that separates the upper $\left(\mathrm{Tnbs}_{2}\right)$ and lower blue sandstone units of the Neroly Formation. Each well can produce up to $1500 \mathrm{~L} / \mathrm{min}$ of potable water. For many years, well 18 groundwater samples have shown trace amounts of TCE. CERCLA studies have not yet determined the source of the TCE in well 18 (see Chapter 8 for the locations of TCE plumes at Site 300).

As planned for surveillance purposes, groundwater samples were obtained quarterly from these two on-site supply wells. Groundwater samples from well 20 were analyzed for inorganic COCs (mostly metals), VOCs (EPA Method 502.2), explosive compounds (HMX, RDX), general radioactivity (gross alpha and gross beta), and tritium activity. Groundwater samples from standby well 18 were analyzed for VOCs, general radioactivity (gross alpha and gross beta), and tritium.

Explosives Process Area: WDR Order No. 96-248 establishes the basis for compliance monitoring of the two adjacent surface impoundments (see Figure 9-10). This includes quarterly monitoring of the groundwater, monitoring of various influent waste streams to the surface impoundments, and visual observations of leachate collection and removal systems. Influent wastewater monitoring complements administrative controls that regulate the discharge of chemicals that could degrade the polyethylene liners of the impoundments. A three-tiered monitoring program comprising weekly visual inspections of the leachate collection and removal systems, quarterly inspections of lysimeters, and quarterly sampling of monitoring wells is in place to detect any release of chemicals from the surface impoundments in the Explosives Process Area.

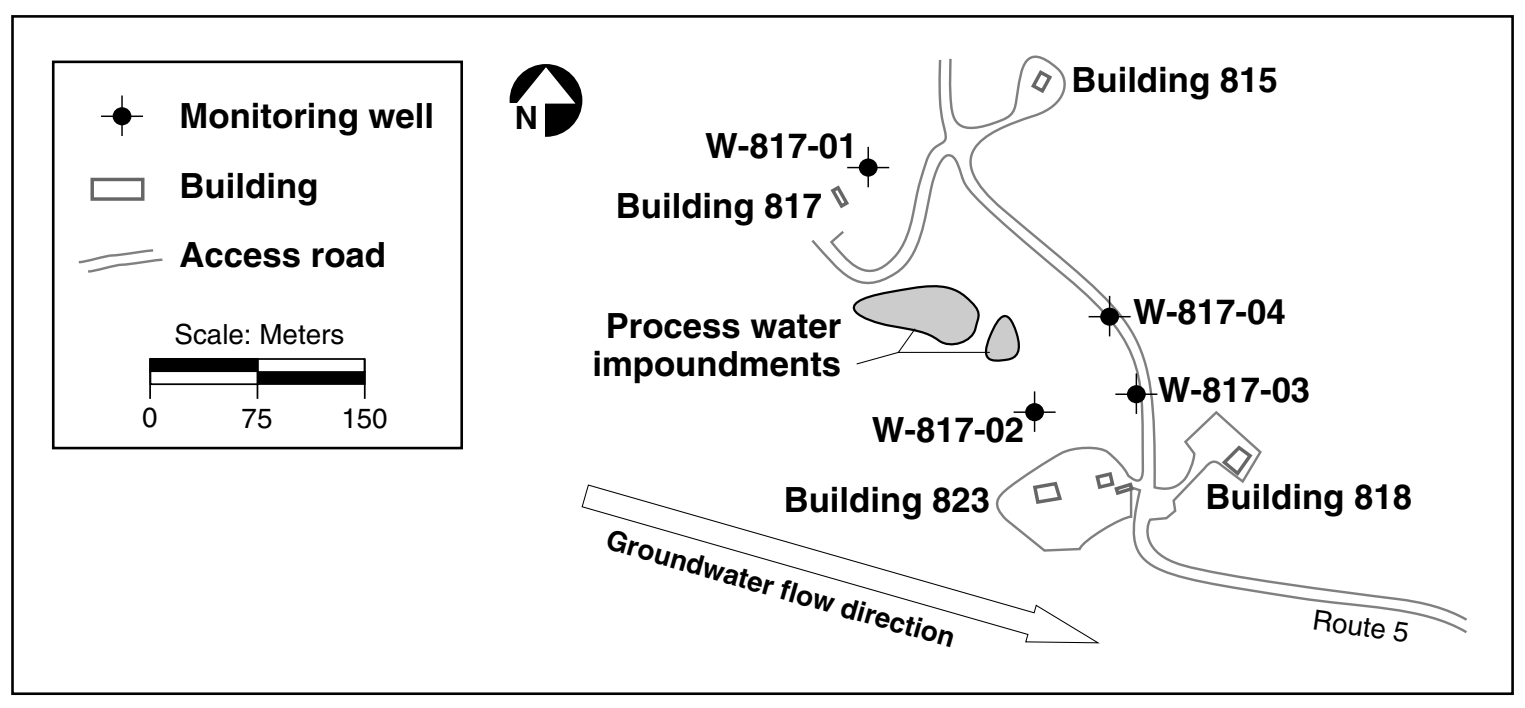

Figure 9-10. Locations of compliance groundwater monitoring wells in the Explosives Process Area 
LLNL is required to obtain groundwater samples quarterly from four monitoring wells (see

Figure 9-10) and to establish statistical concentration limits for COCs in groundwater beneath the surface impoundments. These requirements are part of the Monitoring and Reporting Program (MRP) for the surface impoundments detailed in WDR 96-248.

WDR 96-248 establishes limits for discharges of COCs into the surface impoundments and requires monitoring of the photographic process and chemistry area wastewater retention tanks that discharge to the surface impoundments as well as direct discharges to the surface impoundments from explosives processing. Influent streams are monitored at a prescribed frequency for area-specific COCs.

Retention tanks containing photographic process rinsewater from Buildings 801, 823, and 851 are sampled to confirm that discharges are consistent with effluent discharge limits specified in WDR 96-248. Discharges to the surface impoundments occur after samples are obtained, except for rinsewater from the Building 823 retention tanks, which is discharged automatically to the surface impoundments and sampled quarterly.

Samples of process wastewater from the Chemistry Area (Buildings 825, 826, and 827 Complex) are collected when the retention tanks are ready for discharge to the surface impoundments. The wastewater is held in retention tanks until analytical results indicate compliance with WDR 96-248.

Process water discharges to the surface impoundments are analyzed for COCs that have been found (or are likely to be found) in the process water from each specified building within the Explosives Process Area. This monitoring program includes process wastewater from Buildings 806/807, 809, and 817. WDR 96-248 requires annual analysis of this waste stream.

Percolation Pits: Percolation pits that are designed to accept discharges from mechanical equipment are located at Site 300 Buildings 806A, $827 \mathrm{~A}, 827 \mathrm{C}, 827 \mathrm{D}$, and $827 \mathrm{E}$. In other remote Site 300 facilities, these types of waste streams are discharged to septic systems. These discharges are permitted by WDR 96-248, which specifies monthly observations and monitoring requirements for overflows. Overflows of the percolation pits, should they occur, are sampled and analyzed to determine if any metals are present.

\section{Sewage Evaporation and Percolation Ponds:}

Site 300 is not serviced by a publicly owned treatment works (POTW) as is the Livermore site; therefore, alternate methods of treating and disposing of sanitary waste are necessary. Sewage generated at buildings in the General Services Area is discharged into a lined evaporation pond. The wastewater is disposed of through evaporation from the pond. However, during rare periods of high rainfall, treated wastewater may overflow into an unlined percolation pond, where it enters the ground and the shallow groundwater.

The environmental monitoring requirements for the sewage evaporation and percolation ponds (hereafter sewage ponds) are specified in MRP 96-248. The monitoring requirements include both wastewater monitoring and monitoring of the groundwater to detect potential impacts of the sewage on groundwater quality.

Wastewater is sampled quarterly at an influent location (ISWP) and within the pond (ESWP). Overflows are sampled as needed at location DSWP. The sampling locations are shown in Figure 9-11. 


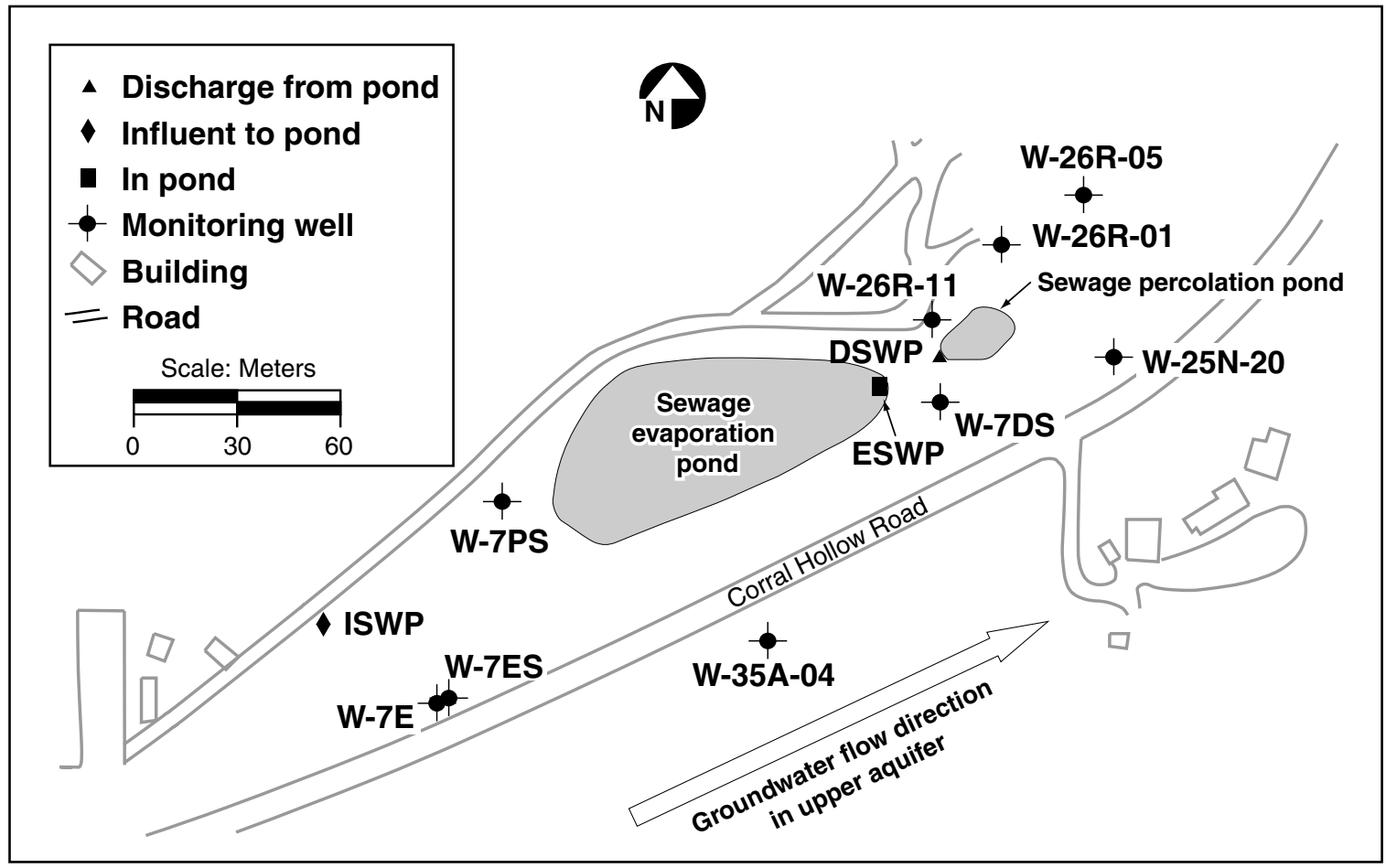

Figure 9-11. Sewage evaporation and percolation ponds, compliance groundwater monitoring wells, and wastewater monitoring locations

Nine groundwater monitoring wells are sampled semiannually to provide information on the groundwater quality in the vicinity of the sewage ponds (Figure 9-11). The wells are screened in three different geological formations: Qal, $\mathrm{Tnbs}_{1}$,

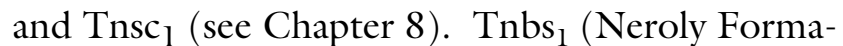
tion lower blue sandstone unit) is the regional aquifer.

\section{Off-site Surveillance Wells and Springs: As} planned for surveillance purposes, groundwater samples were obtained from two off-site springs and ten off-site wells during 2000. With the exception of one well, all off-site monitoring locations are near Site 300. The exception, well VIE2, is located at a private residence $6 \mathrm{~km}$ west of the site. It represents a typical Altamont Hills potable water supply well. One stock watering well, MUL1, and two stock watering springs, MUL2 and VIE1, are adjacent to Site 300 on the north. Eight wells, CARNRW1, CARNRW2, CDF1, CON1, CON2, GALLO1, STONEHAM1, and W-35A-04, are adjacent to the site on the south (Figure 9-3). Seven of the wells to the south are privately owned and were constructed to supply water for human consumption, stock watering, or fire suppression. The exception is well W-35A-04, which is a DOE CERCLA well that was installed for monitoring purposes only.

Groundwater samples were obtained quarterly during 2000 at six off-site surveillance well locations south of Site 300 . Of these, CARNRW1 and CON2 samples were analyzed for VOCs (EPA Method 601) and tritium. Samples from CARNRW2, CDF1, CON1, and GALLO1 were analyzed quarterly for inorganic COCs (mostly metals), general radioactivity (gross alpha and 
beta), tritium activity, explosive compounds (HMX and RDX), and VOCs (EPA Method 502.2).

Additional analyses were conducted on thirdquarter samples for uranium activity and extractable organics (EPA Method 625).

Groundwater samples were obtained once (annually) during 2000 from six off-site surveillance monitoring locations-MUL1, MUL2, VIE1, and VIE2 (north and west of Site 300) and STONEHAMI and W-35A-04 (south of Site 300). Samples were analyzed for inorganic COCs (mostly metals), general radioactivity (gross alpha and beta), tritium and uranium activity, explosive compounds (HMX and RDX), VOCs (EPA Method 502.2), extractable organics (EPA Method 625), and pesticides (EPA Method 608).

\section{Sampling and Analytical Methods}

Representative samples of groundwater were obtained from monitoring wells in accordance with the LLNL Livermore Site and Site 300 Environmental Restoration Project Standard Operating Procedures (SOPs) (Dibley and Depue 2000).

These protocols cover sampling techniques and specific information concerning the chemicals that are routinely searched for in groundwater. Different sampling techniques were applied to different wells depending on whether they were fitted with submersible pumps, had to be bailed, or contained Barcad devices. See the Data Supplement for sampling details.

At Site 300, wastewater samples from the photographic and explosives process areas, sewage evaporation pond influent, water in the pond, and overflow water from the percolation pits pond were obtained in accordance with the standardized procedures of the Operations and Regulatory Affairs Division (Tate et al. 1999). Standard sample handling and hygiene procedures were employed to prevent cross-contamination (e.g., wearing disposable gloves, decontaminating equipment between uses, and maintaining samples at $4 \pm 2^{\circ} \mathrm{C}$ ). Replicates, field blanks, and trip blanks were obtained for quality assurance/quality control purposes. Analyses were performed by state-certified contract analytical laboratories.

Technologists collected wastewater samples from retention tanks in the Chemistry Area associated with Buildings 825, 826, and 827 using Hazardous Waste Management Procedure 411. Wastewater was held in retention tanks until analytical results were reviewed for compliance with WDR 96-248. Some of the analyses were performed by LLNL, which is state-certified for some analyses. The remainder of the analyses were done by off-site contract laboratories late in the year.

\section{Results}

This section presents the monitoring results for the Livermore site and environs as well as Site $\mathbf{3 0 0 .}$

\section{Livermore Site and Environs}

\section{Livermore Valley}

Measurements of water samples obtained during the summer of 2000 from 20 wells (some of the wells were either dry or not sampled for some other reason in 2000) in the Livermore Valley continue to show very low tritium levels compared with the $740 \mathrm{~Bq} / \mathrm{L}(20,000 \mathrm{pCi} / \mathrm{L})$ maximum contaminant level (MCL) established by the California Department of Health Services. For 2000, the highest tritium activity measured off site was $5.0 \pm 2.0$ $\mathrm{Bq} / \mathrm{L}$ in a groundwater sample from well $12 \mathrm{D} 2$ (see Figure 9-1), located about $10 \mathrm{~km}$ west of LLNL (results are reported in Data Supplement Table 9-30). Figure 9-12 shows the trend in maximum tritium activity in the Livermore Valley wells sampled. The maximum Livermore Valley tritium activity was measured in samples collected from well 11Bl from 1988 through 1996; the 


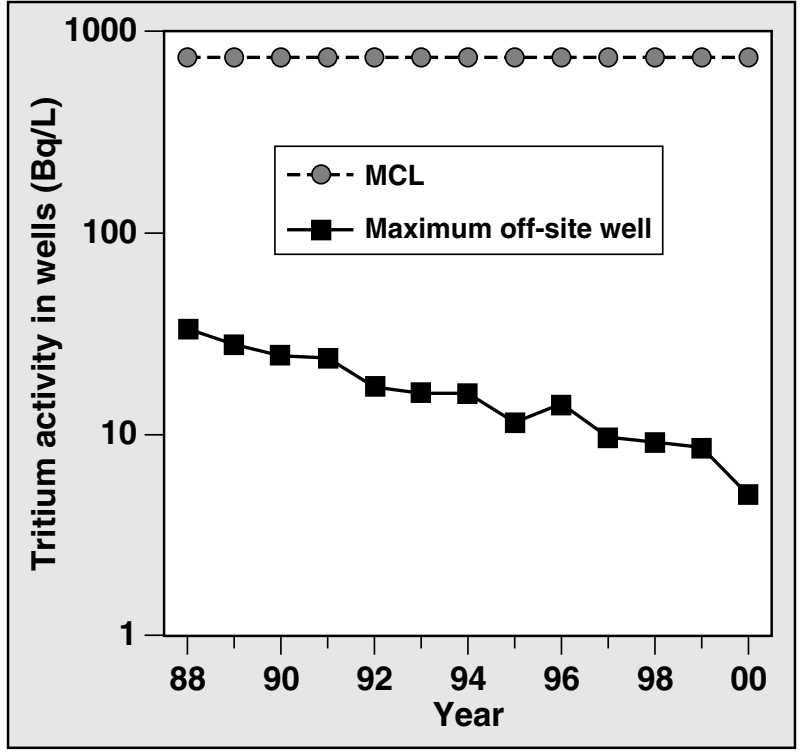

Figure 9-12. Trend of tritium activity in Livermore Valley wells, 1988 to 2000 . Drinking water MCL of $740 \mathrm{~Bq} / \mathrm{L}$ is also shown

maximum has varied between wells $11 \mathrm{Bl}$ and 12D2 from 1997 through 2000. Even the highest activity of $32.9 \mathrm{~Bq} / \mathrm{L}$ for a water sample collected from well $11 \mathrm{Bl}$ in 1988 was less than $5 \%$ of the California's MCL.

Overall tritium activity has been decreasing in Livermore Valley groundwaters downgradient of LLNL. The median activities of tritium in groundwater samples from these downgradient wells decreased from $3.00 \mathrm{~Bq} / \mathrm{L}$ in 1988 to $0.65 \mathrm{~Bq} / \mathrm{L}$ in 2000 .

\section{Livermore Site Perimeter}

Tritium activity ranged from -2.1 (calculated) $\mathrm{Bq} / \mathrm{L}$ to $5.6 \mathrm{~Bq} / \mathrm{L}$ in groundwater samples from on-site background monitoring wells and from -2.5 (calculated) to $13.1 \mathrm{~Bq} / \mathrm{L}$ in western perimeter monitoring wells.
No pesticide or herbicide semivolatile organic compounds were detected in the groundwater during 2000.

The inorganic compounds detected, including dissolved trace metals and minerals, occur naturally in the groundwater at variable concentrations.

Table 9-1 shows the three anions with the highest

Table 9-1. Concentration ranges for three major anions in shallow background and western perimeter monitoring wells

\begin{tabular}{|l|c|c|}
\hline \multirow{2}{*}{$\begin{array}{c}\text { Concentration range } \\
(\mathrm{mg} / \mathrm{L})\end{array}$} & \multicolumn{2}{|c|}{ Hydrologic flow } \\
\cline { 2 - 3 } & Background & $\begin{array}{c}\text { Western } \\
\text { perimeter }\end{array}$ \\
\hline $\begin{array}{l}\text { Bicarbonate }\left(\mathrm{HCO}^{3-}\right) \\
\text { Range }\end{array}$ & $230-340$ & $190-280$ \\
Median & 290 & 240 \\
\hline $\begin{array}{l}\text { Chloride (Cl-) } \\
\text { Range } \\
\text { Median }\end{array}$ & $300-510$ & $75-150$ \\
\hline Sulfate (SO $\left.{ }_{4}{ }^{2-}\right)$ & 385 & 87 \\
Range & $97-340$ & $26-64$ \\
Median & 214 & 38 \\
\hline
\end{tabular}

concentrations in the two shallower background wells, W-008 and W-221, and the seven western wells at LLNL. Concentrations of these major anions are higher in the background wells than in the western wells (see Tables 9-2 through 9-11 in the Data Supplement). Concentrations of chloride in shallow background wells W-008 and W-221 (Tables 9-2 and 9-3 in the Data Supplement) are higher than California's recommended secondary MCL of $250 \mathrm{mg} / \mathrm{L}$, while chloride concentrations in none of the western wells exceed $250 \mathrm{mg} / \mathrm{L}$. Likewise, sulfate concentrations in background well W-008 exceed California's recommended 
secondary MCL of $250 \mathrm{mg} / \mathrm{L}$, while sulfate concentrations in none of the western wells exceed $250 \mathrm{mg} / \mathrm{L}$. Additionally, the boron concentration of $8.7 \mathrm{mg} / \mathrm{L}$ in background monitoring well W-008 in February 2000 is an order of magnitude higher than it is in the western wells. Poor groundwater quality in the background (eastern, especially northeastern) portions of the site has been described previously in the remedial investigations (Thorpe et al. 1990).

In March 1996, nitrate was first detected at concentrations greater than the MCL of $45 \mathrm{mg} / \mathrm{L}$ $(75 \mathrm{mg} / \mathrm{L})$ in a groundwater sample obtained from western perimeter monitoring well W-1012 (screened in HSU 2) (see Figure 9-2). From a groundwater sample collected in May 2000, the concentration of nitrate for this well was $97 \mathrm{mg} / \mathrm{L}$ (see Data Supplement Table 9-9). This is the highest nitrate concentration measured in any surveillance monitoring well during 2000. Because of the hydrologic influence of Treatment Facility B that pumps and treats groundwater from HSUs $1 B$ and 2 (see Chapter 8), groundwater with high nitrate concentrations is restrained from moving off site to the west. The highest concentration measured in an off-site well was at or below the MCL at $37 \mathrm{mg} / \mathrm{L}$, in downgradient monitoring wells W-151 and W-571 (see Data Supplement Tables 9-7 and 9-8). Monitoring well W-571 is off-site and downgradient from well $\mathrm{W}-1012$, but is screened in HSU $1 \mathrm{~B}$; monitoring well $\mathrm{W}-151$ is off-site and downgradient to the southwest, along Arroyo Seco, and is screened in HSU 2. During 2000 , concentrations of nitrate in on-site shallow background wells $\mathrm{W}-008$ and $\mathrm{W}-221$ ranged from $19 \mathrm{mg} / \mathrm{L}$ to $34 \mathrm{mg} / \mathrm{L}$. Detected concentrations of nitrate in western wells, with the exception of well $\mathrm{W}-1012$, ranged from 12 to $37 \mathrm{mg} / \mathrm{L}$.

LLNL sampled and analyzed for nitrate eight additional wells surrounding well W-1012 during the fourth quarter in order to better define the elevated nitrate concentrations. Monitoring wells W-1013, W-1420, W-422, W-610, W-620, W-621, W-654, and $\mathrm{W}-705$ were sampled in addition to wells W-1012 and W-571. Each of the additional monitoring wells is screened in either HSU $1 \mathrm{~B}$ or HSU 2. All nitrate monitoring results for that area in 2000 are presented in Data Supplement Table 9-31. Nitrate was not detected at concentrations greater than the MCL in any other surveillance monitoring well during 2000. Fluctuations in nitrate concentrations have occurred since regular surveillance monitoring began in 1996, but nitrate concentrations have not increased overall in groundwater from the western monitoring wells since 1996. The nitrate may originate as an agricultural residue (Thorpe et al. 1990).

Of the 21 trace metal analytes, seven - barium, chromium, copper, hexavalent chromium, nickel, selenium, and zinc - were detected in western perimeter surveillance wells during 2000. Only chromium and hexavalent chromium exceeded California's MCL of $50 \mu \mathrm{g} / \mathrm{L}$ in groundwater samples collected from western perimeter well W-373 in February (see Data Supplement Table 9-11). Groundwater samples collected from this well are from HSU 1B, and the nearby Treatment Facility C (see Figure 8-1) treats groundwater from HSU $1 \mathrm{~B}$ for chromium. Consequently, concentrations of chromium (including hexavalent chromium) have been continually decreasing (see Data Supplement Tables 9-2 through 9-11).

A groundwater sample collected from on-site well W-1012 $(0.49 \pm 0.03 \mathrm{~Bq} / \mathrm{L}$, or $13.3 \pm 0.92 \mathrm{pCi} / \mathrm{L})$ exceeded the MCL for total radium of $0.185 \mathrm{~Bq} / \mathrm{L}(5 \mathrm{pCi} / \mathrm{L})$ (see Data Supplement Table 9-9). It is now the routine procedure at LLNL to collect and analyze two retest samples when such an overage occurs. The first retest sample was collected in October with an analytical result of $0.003 \pm 0.004 \mathrm{~Bq} / \mathrm{L}$ (see Data Supplement Table 9-9). The second was collected 
early in 2001 and had an analytical result of $<0.009 \mathrm{~Bq} / \mathrm{L}$. Therefore, the original result greater than the MCL was not confirmed.

Activities of naturally occurring total uranium (uranium-234 $+235+238$ ) continued to be highest in the shallow background wells W-008 and W-221 during 2000. Activities of total uranium in those wells were measured as $0.20 \pm 0.04 \mathrm{~Bq} / \mathrm{L}$ to $0.25 \pm 0.05 \mathrm{~Bq} / \mathrm{L}$ (34\% of California's MCL of $0.74 \mathrm{~Bq} / \mathrm{L}$, or $20 \mathrm{pCi} / \mathrm{L})$. (See Data Supplement Tables 9-2 and 9-3). Activities of total uranium are lower, from $0.024 \pm 0.013 \mathrm{~Bq} / \mathrm{L}$ (in well W-121) to $0.23 \pm 0.04 \mathrm{~Bq} / \mathrm{L}$ (31\% of California's MCL in well W-1012), in groundwater from each of the western monitoring wells (Data Supplement Tables 9-6 and 9-9). Uranium and its radioactive daughters, thorium-230, radium-226, and radon-222, occur naturally in the sediments and rock layers beneath and surrounding LLNL. Uranium activities did not exceed drinking water limits.

\section{Livermore Site}

Groundwater downgradient of potential sources showed possible impact from two releases of metals to the ground. Groundwater at well W-307 near Building 322 showed a maximum concentration of hexavalent chromium at $14 \mu \mathrm{g} / \mathrm{L}$, slightly greater than $10 \mu \mathrm{g} / \mathrm{L}$, the highest concentration of hexavalent chromium measured in shallow background well W-008 at various times from 1996 through 1999. Hexavalent chromium was detected at elevated concentrations in groundwater samples from wells W-226 and W-306, downgradient from the Building 253 catch basin. Concentrations were measured as $26 \mu \mathrm{g} / \mathrm{L}$ and $27 \mu \mathrm{g} / \mathrm{L}$ (at well W-226) and $40 \mu \mathrm{g} / \mathrm{L}$ and $41 \mu \mathrm{g} / \mathrm{L}$ (at well W-306) (see Data Supplement Tables 9-24 and 9-25). The accumulated sediment in the catch basin is a potential source of several metals (Jackson 1997). No concentrations of hexavalent chromium exceeded the MCL of $50 \mu \mathrm{g} / \mathrm{L}$ for chromium in drinking water.
The initial analytical results from well W-148, downgradient from both the Plutonium and Tritium Facilities, show radium-226 detected from a sample collected in March 2000 to be $0.30 \pm 0.07 \mathrm{~Bq} / \mathrm{L}(8.0 \pm 1.8 \mathrm{pCi} / \mathrm{L})$, which is above the MCL for total radium. LLNL again employed the retest procedure with two retest groundwater samples collected in August and October 2000. Analytical results for the retest samples were $0.048 \pm 0.015 \mathrm{~Bq} / \mathrm{L}$ and $0.008 \pm 0.004 \mathrm{~Bq} / \mathrm{L}$, respectively. The original analytical result for radium-226 that was greater than the MCL was not confirmed.

In August 2000, the tritium activity was $115 \pm 5.0 \mathrm{~Bq} / \mathrm{L}$ (about $15 \%$ of the MCL) in the groundwater sampled at well W-148, downgradient from the Tritium Facility (Building 331). This relatively elevated tritium activity triggered additional sampling of groundwater from wells in the vicinity of Building 331 during the fourth quarter of 2000, including monthly samples from wells W-148 and W-301 (see Figure 9-2). The tritium activities of these additional groundwater samples are listed in Table 9-29 of the Data Supplement. Groundwater tritium activities were at or near background level by December 2000 in all the wells sampled downgradient of Building 331. The relatively elevated tritium activity in the groundwater sampled at well 148 in August 2000 is most likely related to local infiltration of storm water containing elevated tritium activity (see Chapter 7). No radioactivity of concern was detected for americium or plutonium radioisotopes in the groundwater sampled at the routine monitoring wells in this area (see Data Supplement Tables 9-26 through 9-28). LLNL continues to collect groundwater samples from these wells periodically for surveillance purposes, primarily to demonstrate that their tritium, americium, and plutonium contents remain below any environmental levels of concern. 


\section{Site 300}

The following are summaries of Site 300 groundwater surveillance and compliance monitoring results for 2000. Site 300 compliance monitoring results for 2000 have been published previously (Brown 2000a, b, c, and 2001; Christofferson and MacQueen 2000a, b, c, and 2001; Christofferson and Taffet 2000; Christofferson et al. 2000a, 2000 b, 2001). Compliance monitoring results for Site 300 are discussed again in the following summaries. Surveillance monitoring results for 2000 have not been published elsewhere.

\section{Elk Ravine Drainage Area}

Pit 7: Data collected during 2000 show no new release of constituents of concern (COCs) to groundwater from Pit 7. The few COCs detected in the groundwater are mostly from sources other than Pit 7 that were seasonally exposed to infiltrating stormwater or to rising groundwater. Groundwater elevations beneath the closed landfills have been generally falling since they peaked in 1998 , because of reduced rainfall and recharge. Pits 3 and 5, which are adjacent to and downgradient from Pit 7 are the primary sources of the COCs detected by the network of Pit 7 monitoring wells. The COCs detected include metals, depleted uranium, tritium, and several volatile organic compounds (VOCs). Natural sources in the rocks and sediments surrounding Pit 7 have also contributed uranium and other elements to the groundwater.

Compliance monitoring results for 2000 suggest that zinc was released to groundwater from the RCRA-closed Pit 7 landfill. However, it is more likely that it came from waste buried in one of the other closed landfills nearby. Well K7-03 is located hydraulically downgradient of all four closed landfills constituting the Pit 7 Complex. It is improbable that there has been a postclosure release of zinc from Pit 7 because zinc was not detected at well NC7-48, which is located immediately downgradient of Pit 7 (Figure 9-4). It was likely released from waste buried in the closed Pit 5 landfill, which is upgradient and adjacent to well K7-03. Both Pits 3 and 5 are known to have been partially inundated by rising groundwater during the El Niño winter of 1997-1998, when the site received more than double the average seasonal rainfall (Ziagos and Reber-Cox 1998b), which likely released zinc and other COCs to groundwater.

As in the past, tritium activity in groundwater sampled at Pit 7 monitoring wells K7-01, K7-03, and NC7-25 remained above the MCL of $740 \mathrm{~Bq} / \mathrm{L}$ throughout 2000. However, tritium activities generally decreased during 2000 , following a peak activity of $28,500 \mathrm{~Bq} / \mathrm{L}$ $(770,000 \mathrm{pCi} / \mathrm{L})$ measured in groundwater sampled at well NC7-25 during fourth quarter 1999. As in the past, the groundwater immediately downgradient of Pit 7 at well NC7-48 showed very low tritium activity. Historical tritium activity measurements of groundwater sampled at well NC7-48 indicate that no release of tritium has occurred from Pit 7 to groundwater since the well was completed in 1986.

The rising trend in tritium activity in the groundwater at well NC7-25 began in 1995. CERCLA investigations link the rising trend to seasonal releases of tritium in Pit 3, which began during the winter of 1992-93 and continued during successive winters through 1997-98, at which time Pit 3 was partially inundated from beneath by rising groundwater. (Taffet et al. 1996, Ziagos and Reber-Cox 1998b).

As in the past, three VOCs were detected in the groundwater sampled at Pit 7. Trichloroethene (TCE), which has an MCL of $5.0 \mu \mathrm{g} / \mathrm{L}$, ranged between 2.0 and $5.6 \mu \mathrm{g} / \mathrm{L}$ in groundwater sampled at Pit 7 monitoring wells K7-01 and K7-03. The TCE is associated with past releases 
from Pit 5 (Webster-Scholten 1994, Taffet et al. 1996). 1,1-Dichloroethene (1,1-DCE), which has an MCL of $6.0 \mu \mathrm{g} / \mathrm{L}$, was detected each quarter at Pit 7 monitoring well K7-03 at low concentrations ranging from $1.0 \mu \mathrm{g} / \mathrm{L}$ to $1.6 \mu \mathrm{g} / \mathrm{L}$. 1,1-DCE was detected in the fourth quarter at a concentration of $0.7 \mu \mathrm{g} / \mathrm{L}$ in groundwater sampled at well K7-01. If TCE or 1,1-DCE were released from Pit 7, we would expect to detect them in the groundwater sampled at well NC7-48, but we do not. Only one VOC, trichlorofluoromethane (Freon 11), which has an MCL of $150 \mu \mathrm{g} / \mathrm{L}$, has been detected in groundwater sampled at well NC7-48. The maximum concentration measured during 2000 is $1.0 \mu \mathrm{g} / \mathrm{L}$. Pit 7 is the probable source of the Freon 11, because it is the only landfill upgradient of monitoring well NC7-48.

Elk Ravine: Analytical results for the Elk Ravine drainage area surveillance monitoring network for 2000 are listed in Data Supplement Table 9-32 (see Figure 9-3). As in past years, arsenic, barium, chromium, selenium, vanadium, and zinc were detected at low concentrations typical of groundwater elsewhere in the Altamont Hills.

Tritium activity was above background level in many of the shallow groundwater surveillance samples obtained during 2000 from Elk Ravine. Tritium, as tritiated water (HTO), has been released in the past in the vicinity of Building 850 (Taffet et al. 1996). The HTO plumes at Site 300 are limited to shallow depths in the Neroly lower blue sandstone unit and overlying alluvium (see Figure 8-12 for the CERCLA map of tritium plumes). As in past years, tritium activity was not discernible in groundwater samples from the deeper water-bearing zone monitored at surveillance well NC7-69.

The majority of the Elk Ravine surveillance network tritium measurements made during 2000 support earlier CERCLA studies that show that, despite additional releases, the tritium contents and extents of the plumes are generally diminishing over time because of natural decay and dispersion (Ziagos and Reber-Cox 1998b). LLNL observed small increases in tritium activity at the distal end of the plume (wells K2-01C, NC2-11D, and NC212D), while those wells monitoring the bulk of the plume (NC7-61, K2-04D, and K2-04S) show relatively large decreases in tritium activity over the past several years. For example, tritium activity in groundwater at well NC7-61 decreased from $6500 \mathrm{~Bq} / \mathrm{L}$ in 1996 to $2500 \mathrm{~Bq} / \mathrm{L}$ in 2000.

Surveillance measurements in Elk Ravine of gross alpha, gross beta, and uranium radioactivity were all low and indistinguishable from background levels. (Note that gross beta measurements do not detect the low-energy beta emission from tritium decay.)

Pit 2: No release of a COC from Pit 2 to groundwater is indicated by the surveillance monitoring data obtained during 2000. Analytical results for the Pit 2 surveillance monitoring network are presented in Data Supplement Table 9-33. Several metals were detected at low concentrations. Most were below analytical reporting limits, which are in the parts per billion (ppb) range. None exceeded an MCL. Arsenic and barium concentrations were within the range of natural (background level) concentrations in groundwaters at Site 300 (Webster-Scholten 1994). The radioactivity measurements show only low background-level activities for gross alpha, gross beta, and tritium. Anomalous tritium activities were measured in the fourth quarter for Barcad locations Kl-02A $(620 \mathrm{~Bq} / \mathrm{L})$ and $\mathrm{K} 2-01 \mathrm{~A}(210 \mathrm{~Bq} / \mathrm{L})$, but these were not confirmed by two sets of retest samples obtained from those locations. All four retest samples had tritium activities below the analytical reporting limit of about $4 \mathrm{~Bq} / \mathrm{L}$. 
Pit 1: No new release of constituents of concern (COCs) to groundwater from Pit $\mathrm{l}$ is evident in the data collected during 2000.

Tritium activity measured above background levels in the groundwater at Pit 1 monitoring wells $\mathrm{Kl}-01 \mathrm{C}, \mathrm{Kl}-02 \mathrm{~B}, \mathrm{Kl}-03$, and $\mathrm{Kl}-08$ during 2000 (see Figure 9-5). However, no release of tritium from Pit 1 is indicated by these measurements. Rather, the tritium activity represents a distal lobe of the Building 850 tritium plume, which extends eastward more than $1 \mathrm{~km}$ to Pit 1 (see Figure 8-17 for a CERCLA map of the Building 850 tritium plume extending to Pit 1).

Measurements of radium, thorium, and uranium made during 2000 in groundwater samples from Pit 1 compliance monitoring wells all showed low activities indistinguishable from background levels.

The VOC 1,1,2-trichloro-1,2,2-trifluoroethane (Freon 113) decreased from a maximum concentration of $140 \mu \mathrm{g} / \mathrm{L}$ in 1999 to $80 \mu \mathrm{g} / \mathrm{L}$ in 2000 in groundwater at Pit 1 monitoring wells Kl-05, Kl-08, and Kl-09. The drinking water MCL for this VOC is $1200 \mu \mathrm{g} / \mathrm{L}$. Previous CERCLA investigations have linked the Freon 113 detected in Pit 1 monitoring wells to past spills of Freon in the Advanced Test Accelerator area, about 200 m west and cross-gradient from the affected wells (Webster-Scholten 1994, Taffet et al. 1996).

Pit 8: No release of a COC to groundwater from Pit 8 is indicated by the surveillance monitoring data obtained during 2000. Analytical results for the Pit 8 surveillance monitoring network are presented in Data Supplement Table 9-34. Two VOCs, TCE and 1,2-dichloroethane (1,2-DCA) were detected below their $5 \mu \mathrm{g} / \mathrm{L}$ MCLs. A relatively small VOC plume exists beneath this area (see Chapter 8), which originated prior to 1981 from waste discharged to a dry well upgradient of Pit 8, near Building 801 (Webster-Scholten 1994).
Arsenic, chromium, selenium, and vanadium were detected in concentrations similar to their natural levels in groundwater elsewhere in the Altamont Hills.

Pit 9: No evidence for a release from Pit 9 is indicated by the surveillance monitoring data obtained during 2000. Analytical results for the Pit 9 surveillance monitoring network are presented in Data Supplement Table 9-35. COCs were either not detected or were indistinguishable from natural background level concentrations. Since annual surveillance monitoring of groundwater began there more than a decade ago, no evidence of a release of any COCs from Pit 9 has been recorded.

\section{Corral Hollow Creek Drainage Area}

Pit 6: No new release of COCs from Pit 6 is indicated by the DMP groundwater data collected during 2000. Designated COCs, including several VOCs and tritium that were released prior to pit closure, continued to be detected in the groundwater at low concentrations. Only two COC measurements exceeded statistical limits during 2000 , and those were invalidated by retesting (total uranium, well EP6-09, and benzene, well EP6-06, third quarter 2000).

In 1998, detections of the VOC 1,2-DCA were reported as statistically significant evidence of a postclosure release from Pit 6 (Galles 1998). During the fall of 1998, water was pumped from well EP6-09 and VOCs were removed by airsparging. Evidence of the success of this action was the decrease in TCE concentration to below the MCL in the groundwater at well EP6-09 and the subsequent disappearance of detectable concentrations of 1,2-DCA through 2000.

During 2000, only one measurement of TCE in groundwater at a DMP monitoring well exceeded the MCL of $5 \mu \mathrm{g} / \mathrm{L}$ for TCE in drinking water. That was the fourth-quarter measurement of 
$5.1 \mu \mathrm{g} / \mathrm{L}$ TCE in the groundwater sample from well K6-19. However, the groundwater sampled at this well continues to follow an historically decreasing trend of TCE concentration.

As in the past, the organic compound bis(2-ethylhexyl) phthalate, which is not a designated COC, was detected at concentrations up to $14 \mu \mathrm{g} / \mathrm{L}$ in groundwater sampled at two upgradient wells (K6-03 and K6-04) and at two downgradient wells (K6-19 and K6-36). The compound has been sporadically detected upgradient and downgradient of Pit 6 since postclosure monitoring began in 1998. The source of this compound is unknown. There is no record of it being placed in the pit, but it is known to have been used historically in explosives at Site 300. It may also have served as a dielectric in transformers and capacitors. The California state MCL for this compound is $4 \mu \mathrm{g} / \mathrm{L}$. All of the detections are above the MCL.

Relatively elevated tritium activity is contained within a small volume of groundwater that is adjacent to and downgradient (southeast) of Pit 6. Monitoring of the small tritium plume is being conducted by LLNL under CERCLA auspices. Tritium activity remained above background levels in groundwater sampled at downgradient wells K6-19 and K6-36. The maximum activity recorded was $2160 \mathrm{pCi} / \mathrm{L}(80 \mathrm{~Bq} / \mathrm{L})$, which is less than $11 \%$ of the $20000 \mathrm{pCi} / \mathrm{L}(740 \mathrm{~Bq} / \mathrm{L}) \mathrm{MCL}$ for tritium in drinking water. This represents a decrease since 1999 when the maximum tritium activity measured at the point of compliance was $2500 \mathrm{pCi} / \mathrm{L}(93 \mathrm{~Bq} / \mathrm{L})$, or 13\% of the MCL.

The decrease can be attributed to dilution and to natural decay of tritium (12.3-yr half-life). Continued monitoring of tritium in the vicinity of Pit 6 is being conducted by LLNL under CERCLA auspices (see Figure 8-12 for a CERCLA map of the small tritium plume).
Building 829 Closed HE Burn Facility: Analyses of groundwater samples obtained quarterly from the deep regional aquifer downgradient of the closed HE burn facility show no consistent evidence of contamination from past operation of the facility. The analytical results represent background level concentrations of substances dissolved from natural sources in the underlying rocks. Analytical results for 2000 for three of the four wells that are used to monitor the deep regional aquifer are listed in Data Supplement Table 9-36. (A fourth deep well, W-827-04, was dry during 2000.)

As in the past, analyses of groundwater samples obtained from the shallower perched groundwater beneath the closed facility do show evidence of contamination. Analytical results for 2000 for the two wells that are used to monitor the perched groundwater are listed in Data Supplement Table 9-37. The primary contaminant in the perched groundwater is TCE. TCE concentrations up to $330 \mu \mathrm{g} / \mathrm{L}$ were measured during 2000. A second contaminant is 1,2-DCE. The maximum 1,2-DCE concentration measured during 2000 is $2.6 \mu \mathrm{g} / \mathrm{L}$. The perched water has a high total concentration of dissolved substances. Many of the inorganic analytes measured have natural sources in the surrounding rocks. The perched groundwater does not contain clearly anthropomorphic chemicals such as pesticides, PCBs, herbicides, or the explosives compounds that were burned at the facility and that are known to exist at shallow depth in the soil above the perched groundwater.

Water Supply Wells: Analytical results for Site 300 water supply wells 18 and 20 are presented in Data Supplement Tables 9-38 and 9-39. As in past years, TCE was detected during 2000 in surveillance groundwater samples from standby well 18 at a maximum concentration of $0.5 \mu \mathrm{g} / \mathrm{L}$, which is $10 \%$ of the MCL of $5 \mu \mathrm{g} / \mathrm{L}$ for 
TCE. The source of the TCE has not yet been identified. Gross alpha, gross beta, and tritium activities in water samples from both production wells are very low and are indistinguishable from natural background level activities. Lead was detected in the second quarter at a concentration of $9 \mu \mathrm{g} / \mathrm{L}$ in the routine well 20 water sample. However, the presence of lead was not confirmed by the analyses of the third and fourth quarter routine groundwater samples from well 20 in which lead was not detectable $(<2 \mu \mathrm{g} / \mathrm{L})$.

Explosives Process Area: The two leachate collection and removal systems were monitored weekly for the presence of liquids. In 2000, no water was recovered from the leachate collection and removal system. However, a potential leak was detected in the polyethylene liner of the lower surface impoundment by experimental electrical resistance tomography late in 1999 . The presence of a hole in the liner was visually confirmed and repairs to the liner were made in January 2000 (Brown 2000a). No water has been observed in the leachate collection and removal system since liner repairs were made in 1997. No water was found in five lysimeters. Analytical results for all monitored constituents in Site 300 groundwater beneath the surface impoundments are contained in the LLNL Experimental Test Site 300 Compliance Monitoring Report for Waste Discharge Requirements 96-248, Annual/Fourth Quarter Report 2000 (Brown 2001).

The explosive compounds (HMX, RDX, and TNT) and perchlorate are the compounds most indicative of discharges to groundwater from the Explosives Process Area surface impoundments. However, prior to 1985, explosives wastewater was discharged into unlined ponds in the vicinity of the surface impoundments, where it infiltrated the soil and some reached groundwater. Because of this past practice, it is necessary to discriminate between new releases from the surface impoundments and past releases from the unlined ponds. Analyses of groundwater from upgradient monitoring well W-817-01 during 2000 showed HMX concentrations between 17.5 and $23.4 \mu \mathrm{g} / \mathrm{L}$ (see Figure 9-10). HMX was not detected above the analytical reporting limit that varied from 0.1 to $1.0 \mu \mathrm{g} / \mathrm{L}$ in any of the groundwater samples from the downgradient monitoring wells. Groundwater samples from all four wells contained detectable concentrations of the explosive compound RDX above the analytical reporting limit of $0.85 \mu \mathrm{g} / \mathrm{L}$. The groundwater samples containing RDX were from upgradient well W-817-01 (from 48.0 to $61.7 \mu \mathrm{g} / \mathrm{L}$ ) and lower concentrations in downgradient wells W-817-02, W-817-03 and W-817-04. The RDX and HMX originated at closed disposal sites upgradient of the present surface impoundments (Raber and Carpenter 1983, WebsterScholten 1994). Other explosive compounds or components of explosive compounds, 4-amino2,6-dinitrotoluene and perchlorate, were detected in upgradient well W-817-01 and in two downgradient wells in this monitoring network. Another component of explosive compounds, 2 -amino4,6-dinitrotoluene, was also detected sporadically in this monitoring network during 2000. The concentrations observed in the downgradient wells do not exceed their permitted limits, but concentrations of perchlorate often exceeded the California Department of Health Services' recommended limit of $18 \mu \mathrm{g} / \mathrm{L}$ in drinking water. The remediation of these compounds is discussed in Chapter 8 .

As in the past, groundwater concentrations of nitrate continued to exceed the drinking water MCL in samples from all surface impoundment monitoring wells during 2000. Concentrations of arsenic continue to be detected at concentrations at or near its drinking water MCL in these same wells during 2000. Concentrations of both arsenic and nitrate in groundwater have historically exceeded their respective MCLs $(0.050 \mathrm{mg} / \mathrm{L}$ for arsenic and $45 \mathrm{mg}$ /L for nitrate) in this area. Background 
level concentrations of arsenic in groundwater monitoring wells upgradient from the surface impoundments have been measured at concentrations above the drinking water MCL (WebsterScholten 1994). Although the distribution of arsenic over time and throughout the area suggests a natural source, the occurrence and concentration of arsenic at Site 300 is the subject of a continuing CERCLA study. The remediation of all of these compounds (except for the element arsenic) is discussed in Chapter 8 of this document.

During 2000, all discharges into the surface impoundments were in compliance with discharge concentration limits with one exception: an inadvertent discharge of 2-butanone (methyl ethyl ketone, or MEK) on August 7, 2000, at a concentration above permitted effluent limits into the upper surface impoundment. LLNL took a grab sample from the upper surface impoundment three days after the discharge that verified that MEK was not present in the upper surface impoundment at the elevated concentration. LLNL notified the CVRWQCB by letter (Galles 2000a) and took the corrective actions specified in that letter to minimize the likelihood of such an occurrence in the future. Those corrective actions taken were discussed in the third quarter monitoring report under WDR 96-248 (Brown 2000c). See the LLNL Experimental Test Site 300 Compliance Monitoring Report for Waste Discharge Requirements 96-248, Annual/Fourth Quarter Report 2000 (Brown 2001).

Percolation Pits: During 2000, the percolation pits at Buildings 806A, 827D, and 827E operated normally with no overflows. Standing water was regularly noted in the Building $827 \mathrm{C}$ percolation pit inspections (Brown 2001).

\section{Sewage Evaporation and Percolation Ponds:}

All wastewater parameters for the sewage evaporation and percolation ponds complied with permit provisions and specifications throughout 2000, and there were no overflows to the percolation pond.

All of the groundwater monitored constituents were also in compliance with permitted limits. Nitrate concentrations in downgradient monitoring well W-26R-05 decreased to $6.0 \mathrm{mg} / \mathrm{L}$ during the third quarter. LLNL has not been able to determine the origin of elevated nitrate concentrations, but a sitewide study of nitrate at Site $\mathbf{3 0 0}$ is continuing, and LLNL continues to monitor these wells and nearby off-site wells for nitrate concentrations (see also Chapter 8).

Off-Site Water Supply Wells: Analytical results for the off-site water supply wells for 2000 are presented in Data Supplement Tables 9-40 to 9-46. Generally, no COC attributable to LLNL activities was detected in the off-site groundwater samples. Arsenic and barium were widely detected at these locations, but their concentrations were below MCLs and consistent with natural sources in the rocks. Scattered detections of metals were all below MCLs and were probably related to metals used in pumps and supply piping.

As in past years, TCE was detected at concentrations up to $0.6 \mu \mathrm{g} / \mathrm{L}$ in the groundwater samples obtained from well GALLOl (see Figure 9-3). Previous CERCLA remedial investigations concluded that the TCE in the GALLOl well water was likely caused by a localized surface spill on the property, possibly solvents used to service the private well (Webster-Scholten 1994). (Surveillance monitoring of a similarly sited well, GALLO2, was terminated in 1991 because of 
contamination from chemicals leaking from the pumping apparatus.) Radioactivity measurements of off-site groundwater are all indistinguishable from natural background activities.

\section{Environmental Impacts}

The overall impact of Livermore site and Site 300 operations on off-site groundwaters is minimal. With the exception of VOCs being remediated under CERCLA at both sites, current LLNL operations have no measurable impact on groundwaters beyond the site boundaries.

\section{Livermore Site and Environs}

Groundwater monitoring at the Livermore site and in the Livermore Valley indicates that LLNL operations have minimal impact on groundwater beyond the site boundary. (See Chapter 8 for CERCLA remediation activities with VOCs.) During 2000, neither radioactivity nor concentrations of elements or compounds detected in groundwater from any off-site monitoring well were confirmed as exceeding primary drinking water MCLs. The maximum tritium activity of 13.1 Bq/L (355 pCi/L), only $1.8 \%$ of the MCL, in any Livermore site perimeter well was detected in the groundwater sample collected from on-site well W-373 in July (see Figure 9-2). The maximum tritium activity measured off site in the Livermore Valley was even lower, $5.0 \mathrm{~Bq} / \mathrm{L}$ (134 pCi/L), in well 12D2 (see Figure 9-1).

Of the Livermore on-site monitoring wells, no inorganic data exceeded primary MCLs, with the exceptions of chromium in monitoring well W-373 and nitrate in monitoring well W-1012 (see Figure 9-2). Hexavalent chromium in groundwater in the vicinity of monitoring well W-373 is being removed at Treatment Facilities B and C.
The LLNL Ground Water Project reports on the treatment of groundwater in the vicinity of the treatment facilities (see Chapter 8). Concentrations of nitrate in groundwater samples collected from well W-1012 throughout 2000 exceeded California's MCL of $45 \mathrm{mg} / \mathrm{L}$. Nitrate above the MCL has not yet migrated off site. LLNL continues to monitor this well and monitoring well W-571, which is off-site and about 350 meters downgradient from well W-1012, to determine if nitrate migrates off site at concentrations above the MCL.

The arroyo sediment data in Chapter 10 indicate no potential adverse impact on groundwater through the arroyos that cross the Livermore site.

\section{Site $\mathbf{3 0 0}$}

Groundwater monitoring at Site 300 and adjacent properties in the Altamont Hills shows minimal impact of LLNL operations on groundwater beyond the site boundaries.

Within Site 300, the chemicals detected in groundwater beneath the High Explosives Process Area will not migrate off site. Plans to remediate TCE, explosive compounds such as RDX, perchlorates, and nitrate are currently being implemented under CERCLA auspices (see Chapter 8). Additionally, LLNL is investigating the distribution and origins of arsenic and zinc in this area.

VOCs, primarily the solvent TCE, have been released historically to shallow groundwater at numerous locations at Site 300 (see Chapter 8 and references cited therein). With the exceptions of a small plume in the General Services Area area that extends minimally off site along Corral Hollow Road, all of the TCE-bearing groundwater is onsite. The plume extending off site from the Eastern 
GSA area is being drawn back to the site by pumping, and the TCE is being removed from the groundwater.

Tritiated water (HTO) has been released to groundwater from several landfills and a firing table in the northwestern part of Site 300. The boundary of the slowly moving HTO plume lies entirely within the site boundaries. CERCLA modeling studies indicate that, given tritium's short half-life of 12.3 years, and the relatively slow rate of groundwater flow $(5-15 \mathrm{~m} / \mathrm{yr})$, the activity of the released HTO will decrease to several orders of magnitude below the MCL of $740 \mathrm{~Bq} / \mathrm{L}$ $(20,000 \mathrm{pCi} / \mathrm{L})$ before it can reach a site boundary and travel off site (Taffet et al. 1996). 


\section{SOIL AND SEDIMENT MONITORING}

Gretchen M. Gallegos Richard A. Brown

\section{Introduction}

The soil and sediment monitoring analysis that Lawrence Livermore National Laboratory performed in 2000 included work in three areas: surface soil in the Livermore Valley and at Site 300, sediment at the Livermore site, and vadose zone soils at the Livermore site.

Soil is weathered material, mainly composed of disintegrated rock and organic material that sustains growing plants. Soil can contain pollutants originally released directly to the ground, to the air, or through liquid effluents. Department of Energy (DOE) guidance for environmental monitoring states that soil should be sampled to determine if there is measurable, long-term buildup of radionuclides in the terrestrial environment and to estimate environmental radionuclide inventories (U.S. DOE 1991). The guidance recommends monitoring for radionuclides specific to a particular operation or facility as well as those that occur naturally. Particulate radionuclides are of major interest in the LLNL soil monitoring program because airborne particulate releases are the most likely pathway for LLNL-induced soil contamination.

Sediments are defined for the purposes of this chapter as finely divided, solid materials that have settled out of a liquid stream or standing water. The accumulation of radioactive materials in sediment could lead to exposure of humans through their ingestion of aquatic species, sediment resuspension into drinking water supplies, inhalation of dust particles, or as an external radiation source (U.S. DOE 1991). However, the Livermore site and Site 300 do not have habitats for aquatic species that are consumed by people, nor do they have surface drainage that directly feeds drinking water supplies. 
Soils in the vadose zone-the region below the land surface where the soil pores are only partially filled with water-are collected in arroyo channels at the Livermore site as part of the Ground Water Protection Management Program (GWPMP). Infiltration of natural runoff through arroyo channels is a significant source of groundwater recharge, accounting for an estimated $42 \%$ of resupply for the entire Livermore Valley groundwater basin (Thorpe, et al. 1990). Soils in the shallow vadose zone are collected and analyzed to provide information about possible constituents that may be dissolved as runoff water infiltrates through the arroyo to the groundwater.

\section{Sampling Locations}

Since 1971, surface soil sampling near the LLNL Livermore site and Site 300 has been part of a continuing LLNL monitoring program designed to measure any changes in environmental levels of radioactivity and evaluate any increase in radioactivity that might have resulted from LLNL operations. These samples have been analyzed for plutonium and gamma-emitting radionuclides, such as depleted uranium used in some explosive tests at Site 300. The inclusion of other gammaemitting, naturally occurring nuclides (potassium40 and thorium-232) and the long-lived fission product, cesium-137, provides background information and baseline data on global fallout from historical aboveground nuclear weapons testing. In addition, LLNL analyzes Site 300 soils for beryllium, a potentially toxic metal used at this site. Soils in the Livermore vicinity were analyzed for beryllium from 1991 to 1994 . However, analysis for beryllium was discontinued at the Livermore site in 1995, because it was never measured above background values.

Surface soil samples are collected at 19 locations in the Livermore Valley (Figure 10-1) and 14 locations at or near Site 300 (Figure 10-2). The locations were selected to represent background concentrations (distant locations unlikely to be affected by LLNL operations) as well as areas where there is the potential to be affected by LLNL operations. Areas with known contaminants, such as the Livermore Water Reclamation Plant (LWRP), are also sampled.

Site $\mathbf{3 0 0}$ soil sampling locations are established around firing tables and other areas of potential soil contamination. PRIM location, east of Site 300, became inaccessible and was removed from the sampling program in 2000 because the site owner discontinued operations.

Sediment samples have been collected from selected arroyos and other drainage areas at and around the Livermore site since 1988; these locations largely coincide with selected storm water sampling locations (see Chapter 7). The sediment sampling location, CDB, was removed in the year 2000; the surface drainage and settling basin at that location had been removed and storm drainage pipe installed, thereby preventing any meaningful sediment sampling. However, four additional samples were collected in the shelf areas of the Drainage Retention Basin, when the basin was partially emptied for the addition of a frog habitat. These samples were available for collection because the water level was maintained during the habitat construction at a level sufficient for sampling.

Sediment sampling locations have not been established at Site 300. The drainage courses at Site 300 are steep, causing flowing water to scour the drainages and preventing the accumulation of sediment. Because of these conditions, sediment sampling at Site 300 is not warranted.

Vadose zone soil sampling has been conducted since 1996. These sampling locations correspond to the same selected storm water sampling locations as the sediment sampling locations (see 


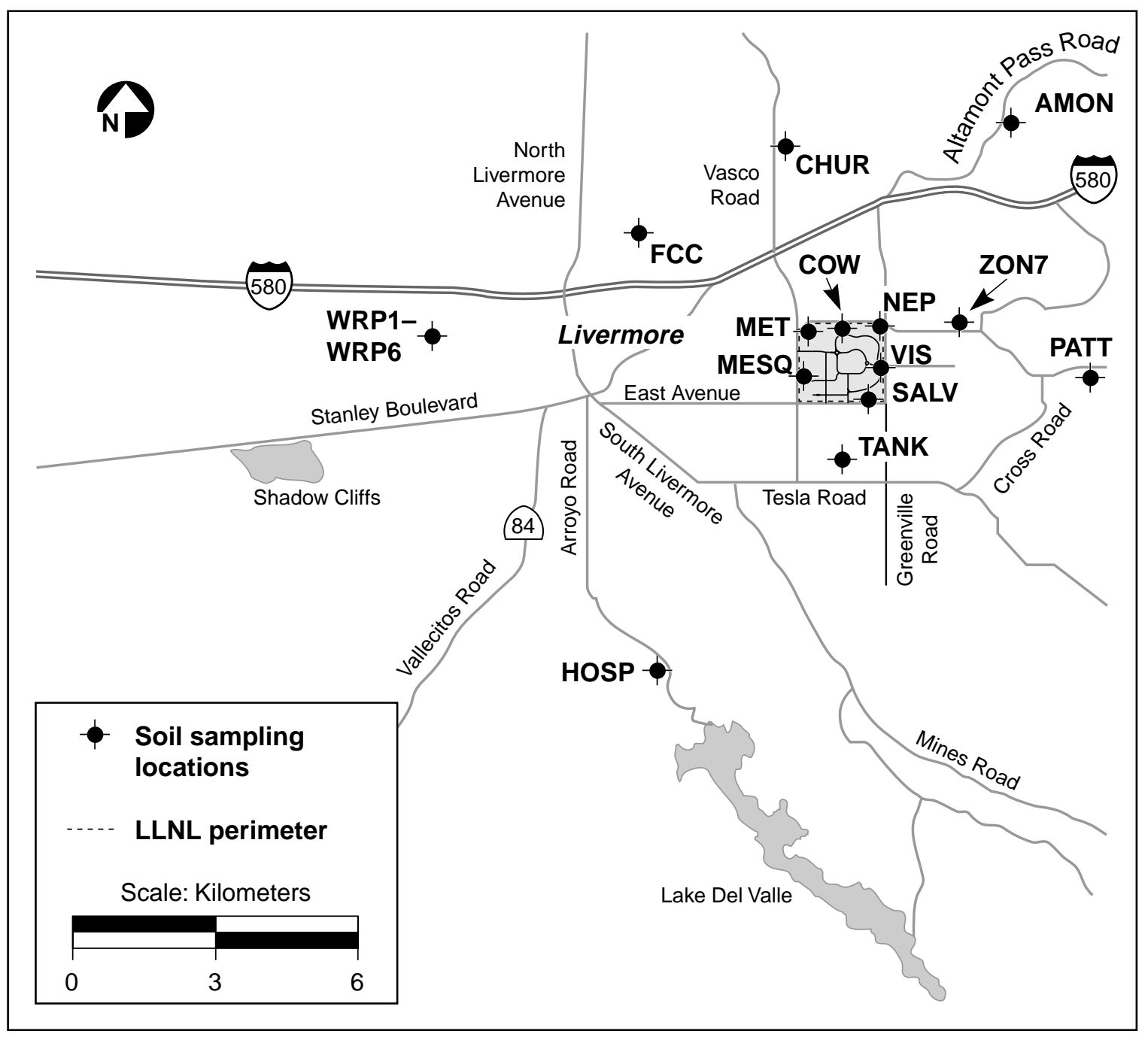

Figure 10-1. Surface soil sampling locations, Livermore Valley, 2000

Figure 10-3). Vadose zone samples were not collected in the D rainage Retention Basin because the liner for the basin prevents migration of materials to the groundwater. The collocation of sampling for these three media facilitates comparison of analytical results. As with sediment samples, vadose zone samples are not collected at Site 300 .

Approximately $10 \%$ of locations are sampled in duplicate; two identical samples are collected at each location chosen for this sampling. All soil and sediment sampling locations have permanent location markers for reference.

\section{Methods}

Surface soil, sediment, and vadose zone soil sampling is conducted according to written, standardized procedures (Tate et al. 1999). Soil samples are collected from undisturbed areas near permanent location markers. These areas are generally level, free of rocks, and unsheltered by trees or buildings. Surface soil samples are 


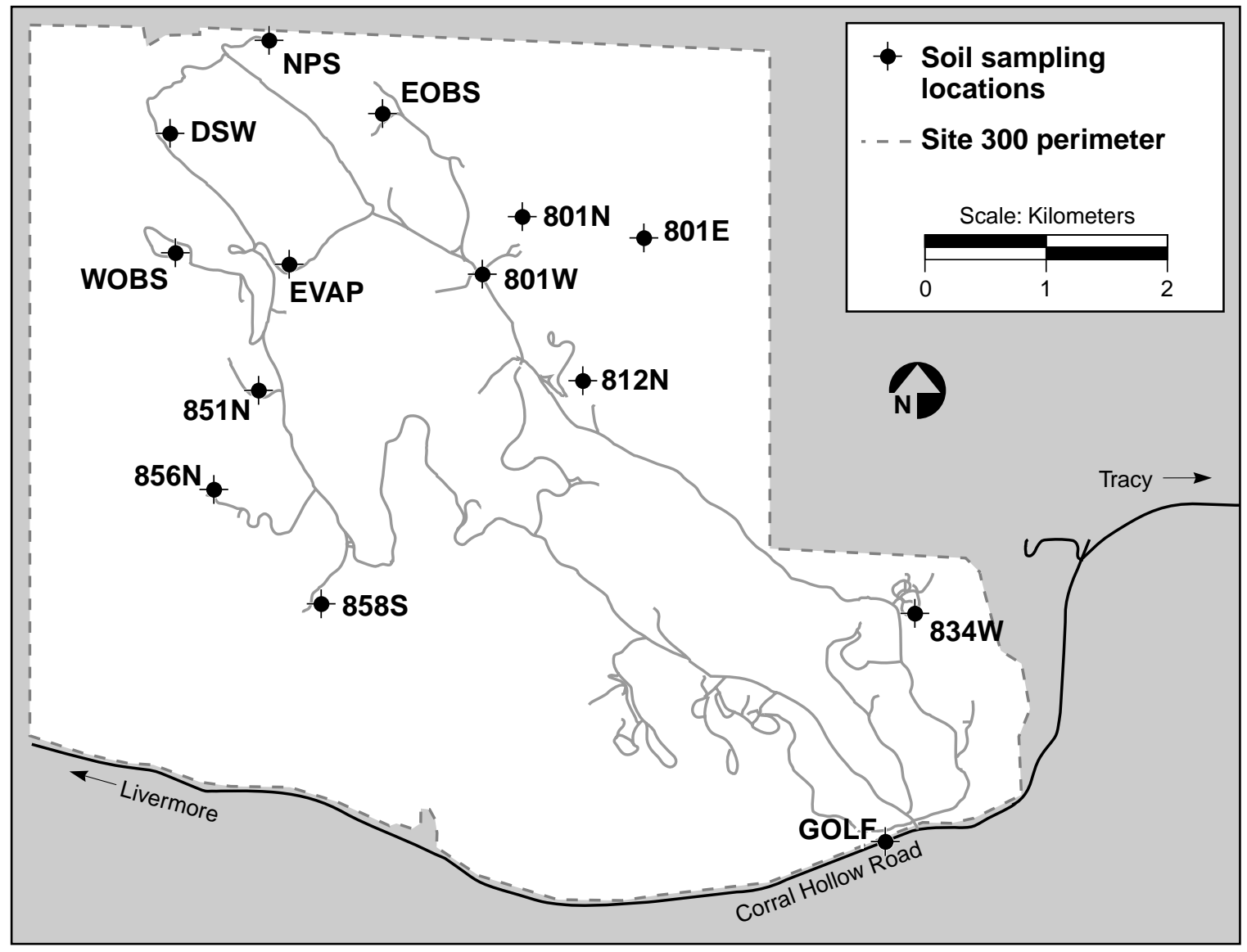

Figure 10-2. Site 300 surface soil sampling locations, 2000

collected from the top $5 \mathrm{~cm}$ of soil because aerial deposition is the primary pathway for potential contamination, and resuspension of materials from the surface into the air is the primary exposure pathway to nearby human populations. Sediments are collected annually from drainages at and around the LLN L Livermore site after the cessation of spring runoff. Samples to be analyzed for particulate radionuclides are collected from the top $5 \mathrm{~cm}$ of soil. Samples to be analyzed for tritium are collected 5-15 cm deep to obtain sufficient water in the sample for analysis. Vadose zone soil samples are collected at 30-45 cm deep for metals analysis, and at 45-65 cm deep for analysis of soluble volatile organic compounds and for polychlorinated biphenyls (PCBs).
In 2000, surface soil samples in the Livermore Valley were analyzed for plutonium and gammaemitting radionuclides. Samples from Site 300 were analyzed for gamma-emitting radionuclides and beryllium. Analysis of Site 300 soil samples for plutonium was discontinued in 1997 because plutonium has not been used at the site, and sample results have continuously been at background levels since sampling began in 1972. Annual sediment samples collected at the Livermore site were analyzed for plutonium and gamma-emitting radionuclides and tritium. Because the four additional samples from the drainage retention basin were of interest due to the potential for the settling of particulate materials, these samples were analyzed for plutonium and gamma-emitting radionuclides, 


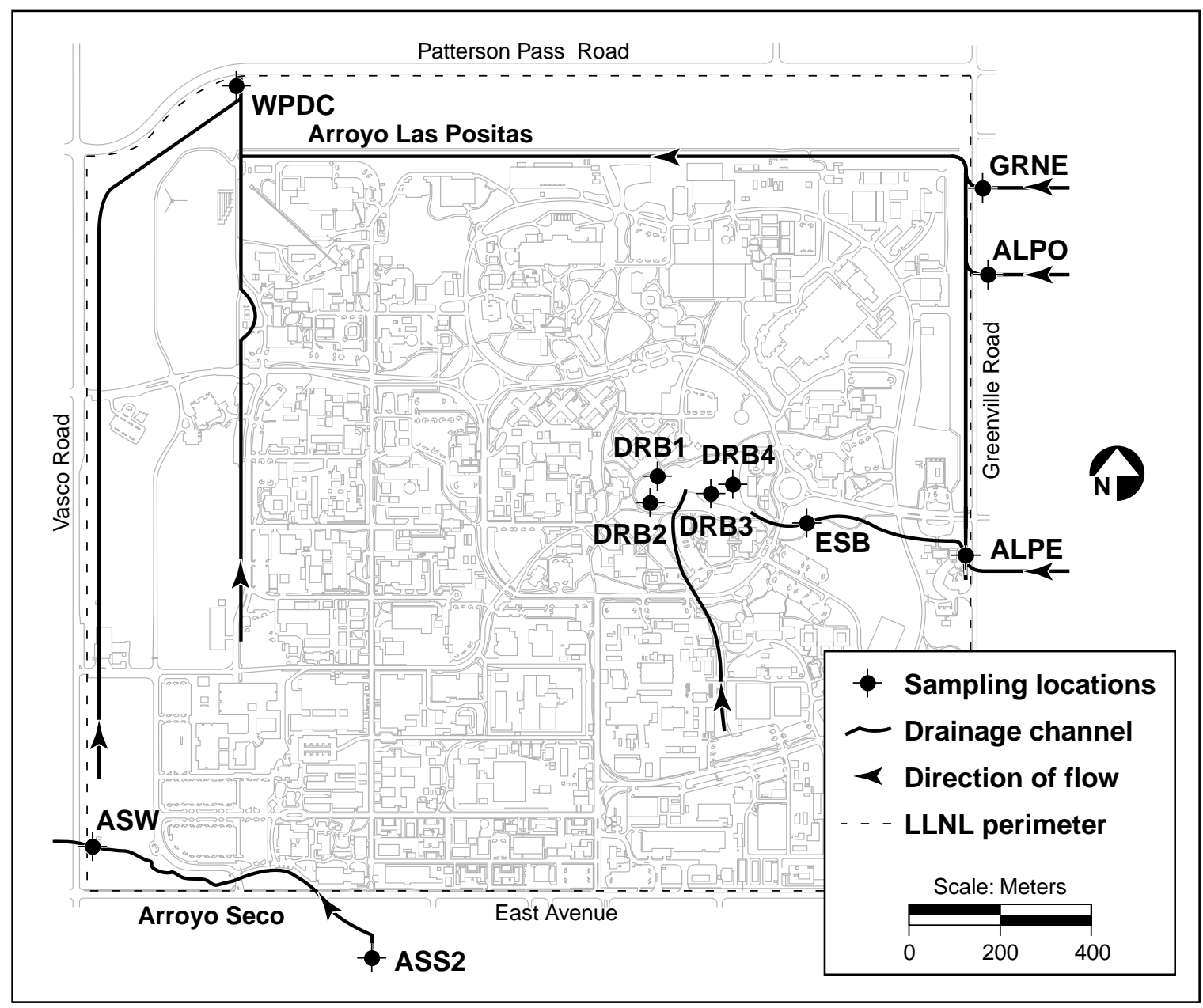

Figure 10-3. Sediment and vadose zone sampling locations on or near the Livermore site, 2000

but not for tritium. Vadose zone samples were analyzed for total and soluble metals and for soluble volatile organic compounds.

Prior to radiochemical analysis, surface soil and sediment samples are dried, ground, sieved, and homogenized. The samples are analyzed by L LN L's $C$ hemistry and $M$ aterials Science Environmental Services (CES) laboratory. The plutonium content of a 100-g sample aliquot is determined by al pha spectroscopy. O ther sample aliquots (300-g) are analyzed for more than 150 radionuclides by gamma spectroscopy using a high-purity germanium (H PGe) detector ( $\mathrm{H}$ all and Edwards 1994a, $b$, and c). The 10-g subsamples for beryllium analyses are sent to a contract analytical laboratory and are analyzed by graphite-furnace atomic absorption spectroscopy. For sediment samples collected for tritium analyses, CES uses freezedrying techniques to recover water from the samples and determines the tritium content of the water by liquid-scintillation counting.

Vadose zone soil samples are analyzed by a contract laboratory. The analytical methods include the toxicity characteristic leaching procedure (TCLP) followed by EPA M ethod 8240 for volatile organic compounds, and total metals by EPA M ethods 
200.7, 245.2, 7471A, and 6010B. The procedure for determining soluble metals includes the

California Waste Extraction Test, followed by the same analytical methods for metals applied to the leachates. In 2000, a vadose zone soil sample from location ESB (Figure 10-3) was also analyzed for PCBs by EPA Method 8082. Chain-of-custody procedures are followed throughout the sampling, delivery, and analytical processes.

\section{Livermore Valley Surface Soil Results}

Table 10-1 presents summary data on the concentrations of plutonium-239+240, plutonium-238, americium-241, cesium-137, potassium-40, thorium-232, uranium-235, and uranium-238 in surface soils from the Livermore Valley sampling locations. Complete data for 2000 soil and sediment sampling are presented in Table 10-1 of the Data Supplement.

Table 10-1. Summary of surface soil and sediment radioanalytical data, 2000

\begin{tabular}{|c|c|c|c|c|}
\hline Analyte and location & $\begin{array}{l}\text { Detection } \\
\text { frequency }(a)\end{array}$ & Median & $I Q R^{(b)}$ & Maximum \\
\hline \multicolumn{5}{|l|}{ Plutonium-238 ( $\mu \mathrm{Bq} / \mathrm{dry} \mathrm{g})$} \\
\hline Livermore Valley soils & $12 / 13$ & 2.70 & 3.65 & 19.5 \\
\hline LWRP(c) soils & $6 / 6$ & 128 & 173 & 377 \\
\hline Livermore site sediments & $6 / 10$ & 6.53 & 11.8 & 174 \\
\hline \multicolumn{5}{|l|}{ Plutonium-239+240 $(\mu \mathrm{Bq} / \mathrm{dry} \mathrm{g})$} \\
\hline Livermore Valley soils & $13 / 13$ & 61.1 & 60.3 & 352 \\
\hline LWRP soils & $6 / 6$ & 2410 & 3370 & 6440 \\
\hline Livermore site sediments & $10 / 10$ & 78.9 & 105 & 1740 \\
\hline \multicolumn{5}{|l|}{ Cesium-137 (mBq/dry g) } \\
\hline Livermore Valley soils & $13 / 13$ & 1.39 & 0.960 & 7.1 \\
\hline LWRP soils & $6 / 6$ & 1.04 & 1.89 & 4.07 \\
\hline Livermore site sediments & $10 / 10$ & 0.184 & 0.330 & 1.11 \\
\hline Site 300 soils & $13 / 14$ & 1.56 & 1.60 & 5.00 \\
\hline \multicolumn{5}{|l|}{ Potassium-40 (Bq/dry g) } \\
\hline Livermore Valley soils & $13 / 13$ & 0.470 & 0.129 & 0.551 \\
\hline LWRP soils & $6 / 6$ & 0.358 & 0.045 & 0.411 \\
\hline Livermore site sediments & $10 / 10$ & 0.391 & 0.270 & 0.470 \\
\hline Site 300 soils & $14 / 14$ & 0.414 & 0.107 & 0.551 \\
\hline \multicolumn{5}{|l|}{ Thorium-232 $(\mu \mathrm{g} / \mathrm{dry} \mathrm{g})^{(\mathrm{d})}$} \\
\hline Livermore Valley soils & $13 / 13$ & 6.73 & 1.12 & 8.68 \\
\hline LWRP soils & $6 / 6$ & 6.32 & 0.06 & 6.45 \\
\hline Livermore site sediments & $10 / 10$ & 3.16 & 1.50 & 6.81 \\
\hline Site 300 soils & $14 / 14$ & 8.08 & 1.21 & 11.1 \\
\hline
\end{tabular}


Table 10-1. Summary of surface soil and sediment radioanalytical data, 2000 (continued)

\begin{tabular}{|c|c|c|c|c|}
\hline Analyte and location & $\begin{array}{l}\text { Detection } \\
\text { frequency }(a)\end{array}$ & Median & $I_{Q} R^{(b)}$ & Maximum \\
\hline \multicolumn{5}{|l|}{ Uranium-235 $(\mu \mathrm{g} / \mathrm{dry} \mathrm{g})^{(\mathrm{e})}$} \\
\hline Livermore Valley soils & $13 / 13$ & 0.0190 & 0.0057 & 0.0272 \\
\hline LWRP soils & $6 / 6$ & 0.0190 & 0.0030 & 0.0237 \\
\hline Livermore site sediments & $10 / 10$ & 0.0106 & 0.0039 & 0.0175 \\
\hline Site 300 soils & $14 / 14$ & 0.0301 & 0.0117 & 0.0690 \\
\hline \multicolumn{5}{|l|}{ Uranium-238 $(\mu \mathrm{g} / \mathrm{dry} g)^{(\mathrm{f})}$} \\
\hline Livermore Valley soils & $13 / 13$ & 1.78 & 0.750 & 2.87 \\
\hline LWRP soils & $6 / 6$ & 1.94 & 0.435 & 2.74 \\
\hline Livermore site sediments & $10 / 10$ & 1.02 & 0.464 & 1.57 \\
\hline Site 300 soils & $14 / 14$ & 1.90 & 1.41 & 29.3 \\
\hline \multicolumn{5}{|l|}{ Tritium (Bq/L extracted water) ${ }^{(g)}$} \\
\hline Livermore site sediments & $4 / 6$ & 4.53 & 1.84 & 14.1 \\
\hline \multicolumn{5}{|l|}{ Americum-241 (mBq/dry g) ${ }^{(h)}$} \\
\hline LWRP soils & $2 / 6$ & 1.00 & -(i) & 3.17 \\
\hline \multicolumn{5}{|l|}{ Beryllium (mg/kg) ${ }^{(i)}$} \\
\hline Site 300 soils & $9 / 14$ & 0.36 & -(i) & 1.10 \\
\hline
\end{tabular}

a The detection frequency is the fraction of samples having a measured value above the detection limit.

b IQR = Interquartile range; the difference between the top of the third and the top of the first quartiles of the data

c $\quad$ LWRP $=$ Livermore Water Reclamation Plant

d Thorium-232 activities in Bq/dry g can be determined by dividing the weight in $\mu \mathrm{g} / \mathrm{dry} \mathrm{g}$ by 247.3 , and $\mathrm{pCi} / \mathrm{dry} \mathrm{g}$ can be determined by dividing by 9.15 .

e Uranium-235 activities in Bq/dry g can be determined by dividing the weight in $\mu \mathrm{g} / \mathrm{dry} \mathrm{g}$ by 12.5 , and $\mathrm{pCi} / \mathrm{dry} \mathrm{g}$ can be determined by dividing by 0.463 .

$\mathrm{f}$ Uranium-238 activities in Bq/dry $\mathrm{g}$ can be determined by dividing the weight in $\mu \mathrm{g} / \mathrm{dry} \mathrm{g}$ by 80.3 , and $\mathrm{pCi} / \mathrm{dry} \mathrm{g}$ can be determined by dividing by 2.97 .

g Only sediment samples are analyzed for tritium. The samples collected within the Drainage Retention Basin were not analyzed for tritium because only particulate materials were of interest in these samples.

$\mathrm{h}$ Americium-241 is detected only in LWRP soil samples.

i IQR is not calculated because of high incidence of reported values below detection limits.

j Only Site 300 samples are analyzed for beryllium.

The concentrations and distributions of all observed radionuclides in soil for 2000 are within the ranges reported in previous years and generally reflect worldwide fallout and naturally occurring concentrations. The ratio of uranium-235 to uranium-238 generally reflects the natural ratio of $0.7 \%$; however, there is significant uncertainty in the uranium-235/uranium-238 ratio because of the difficulty in measuring small quantities of uranium-238 by gamma spectroscopy.

Plutonium has, in the past, been detected at levels above background at VIS, a perimeter sampling location near the east boundary of the Livermore site. Since 1980, soil samples at this location have generally shown plutonium-239+240 values higher 
than background. H owever, in 2000, the measured plutonium-239+240 value for VIS was within the range of background, $352 \mu \mathrm{Bq} /$ dry $\mathrm{g}$ $\left(9.51 \times 10^{-3} \mathrm{pCi} /\right.$ dry g). The slightly higher values at and near the L ivermore site have been attributed to historic operations, including the operation of solar evaporators for plutoniumcontaining liquid waste in the southeast quadrant (Silver et al. 1974). L LN L no longer operates the solar evaporators or engages in any other open-air treatment of plutonium-containing waste. N onetheless, plutonium- $239+240$ from historic operations can be carried off site by resuspension of soil by wind. Similarly, elevated levels of plutonium-239+240 (resulting from an estimated $1.2 \times 10^{9} \mathrm{~Bq}$ [32 $\mathrm{mCi}$ ] plutonium release to the sanitary sewer in 1967 and earlier releases) were first observed in soils near LWRP during the early 1970s, and were again detected at LWRP sampling locations. As in 1997 through 1999, americium-241 was detected in LWRP samples; it is most likely caused by the natural decay of the trace concentrations of plutonium-241 that were present in the release.

$\mathrm{H}$ istorical plots of median plutonium-239+240 concentrations in soil in the Livermore Valley upwind and downwind of the center of the LLNL Livermore site, at Site 300, and at LWRP are shown in Figure 10-4. Livermore Valley upwind and Site 300 concentrations have remained relatively constant since monitoring began and generally are indicative of worldwide fallout. G reater variation can be noted in the downwind concentration data, which in 2000 included sampling locations VIS, PATT, NEP, COW, $A M O N$, and ZON 7, compared with the upwind and historic Site 300 data. The concentrations of plutonium at the downwind locations reflect resuspension of low-level plutonium contamination from soils in the southeast quadrant of the Livermore site. Greater variability in plutonium- $239+240$ is seen in samples from LWRP.
Because the plutonium $-239+240$ is likely to be present in discrete particles, the random presence or absence of the particles dominates the measured plutonium-239+240 in any given sample.

\section{Livermore Site Sediment Results}

Table 10-1 presents summary data on radionuclides detected in the sediment samples; a complete presentation of 2000 sediment data is found in Table 10-1 of the $D$ ata Supplement. The levels of plutonium-239+240 were generally at background concentrations, reflective of worldwide fallout.

Sampling location ESB (see Figure 10-3) shows a moderately higher value for plutonium than values at other locations. The value may be attributed to historic actions because this location is in a drainage area for the so utheast quadrant at $L L N L$. M ost other radionuclides were detected at levels similar to those reported from 1988 through 1999: cesium-137 (a fission product) was found at worldwide background concentrations; potassium-40, thorium-232, uranium-235, and uranium-238 (naturally occurring radionuclides) were detected at background concentrations. Tritium concentrations were within the range of previous data. Tritium in sediments will continue to be evaluated as long as the measured values remain above the detection limits of the liquid scintillation analytical method.

\section{Livermore Site Vadose Zone Soil Results}

A nalytical results for vadose zone soil samples are compared with soil reuse standards developed by LLNL and approved by the San Francisco Bay Regional Water Q uality Control Board (SFBRWQ CB) (Folks 1997, M arshack 2000). $M$ etals background concentrations are based on naturally occurring levels in the soil, considering first the results for total metals and then the soluble metals test. There are no background levels for organic compounds or tritium. Soils containing 


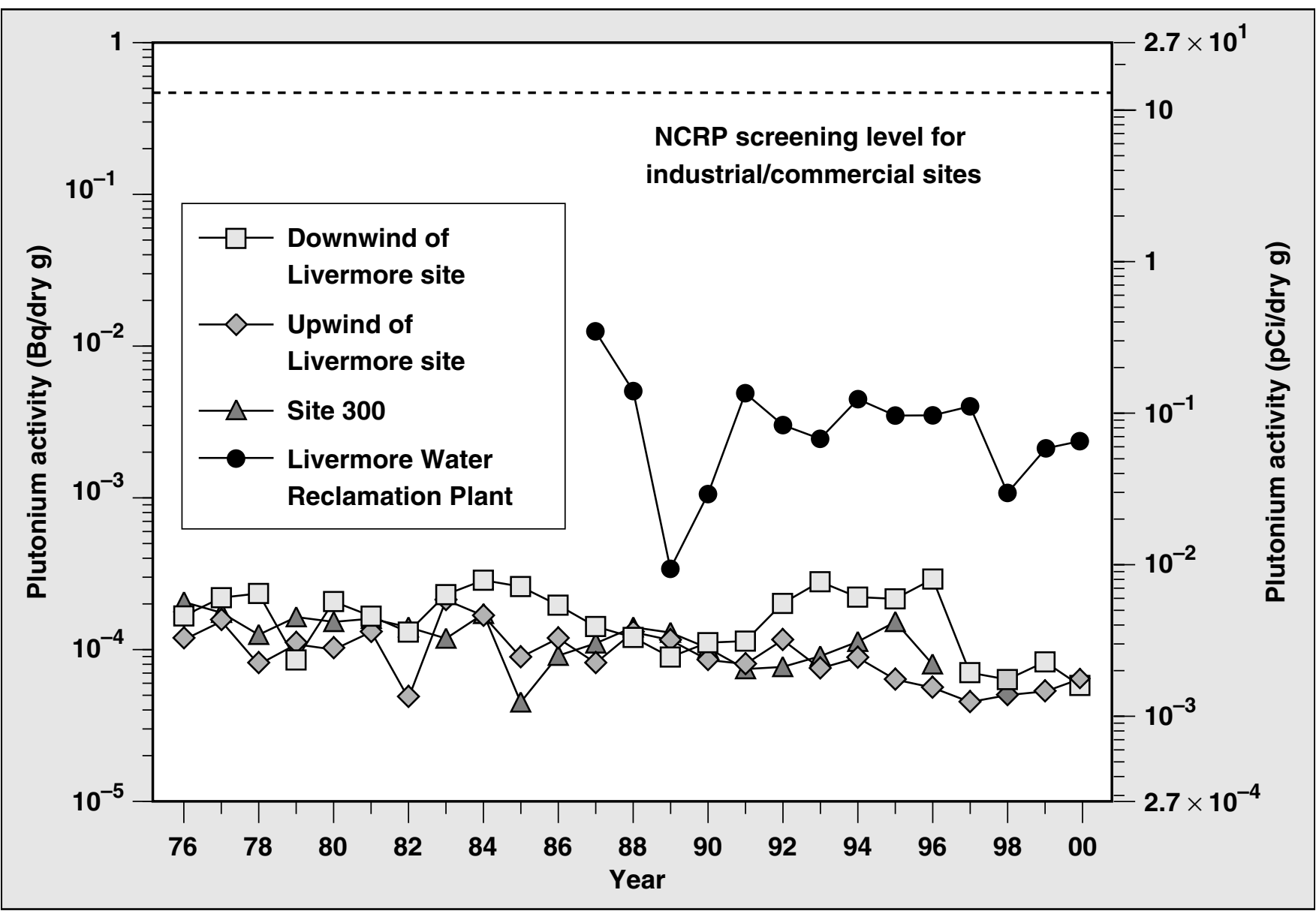

Figure 10-4. Median plutonium-239+240 activities in surface soils, 1976-2000. Upwind and downwind designations are relative to the center of the Livermore site.

materials at levels above background still may not adversely affect the groundwater. If there are any detected organic compounds or tritium, the designated level methodology (DLM) (i.e., application of a simple attenuation factor and specific water quality objectives) is used to determine the soluble levels of contaminants that would not adversely impact groundwater beyond its beneficial uses. (Background and DLM de minimis values are presented in Tables 10-3 and 10-4 in the Data Supplement.)

All analytical results for soluble VOCs were below detection limits, except for chloroform, a common laboratory contaminant. Chloroform was also detected in the laboratory's method blank samples. All total metals concentrations were within site background. See Tables 10-5 to 10-7 in the Data Supplement for analytical results for VOCs and metals. A PCB, Arochlor 1260, was detected at $14 \mathrm{mg} / \mathrm{kg}$ at location ESB. The presence of PCBs suggests that this sample represents residual lowlevel contamination from the 1984 excavation of the former East Traffic Circle landfill (see Chapter 9). Further confirmatory investigations are underway. (The analytical results for approximately the same location sampled in 2001 was $2.1 \mathrm{mg} / \mathrm{kg}$.) The detected concentrations are below the federal and state hazardous waste limits. Tritium results from the sediment sampling were evaluated by the DLM 
method and were all below de minimis levels (see the Data Supplement, Table 10-1).

\section{Site 300 Results}

Table 10-1 presents summary data on the concentrations of cesium-137, potassium-40, thorium232, uranium-235, uranium-238, and beryllium in soil from the Site 300 sampling locations; a complete presentation of 2000 soils data for
Site 300 is found in Table 10-2 of the Data Supplement. The concentrations and the distributions of all observed radionuclides in Site 300 soil for 2000 lie within the ranges reported in all years since monitoring began. The ratio of uranium-235 to uranium-238 generally reflects the natural ratio of $0.7 \%$. Historical trends of uranium-238 concentrations from both the Livermore Valley and Site 300 are shown in Figure 10-5. Median values have remained relatively constant for both places.

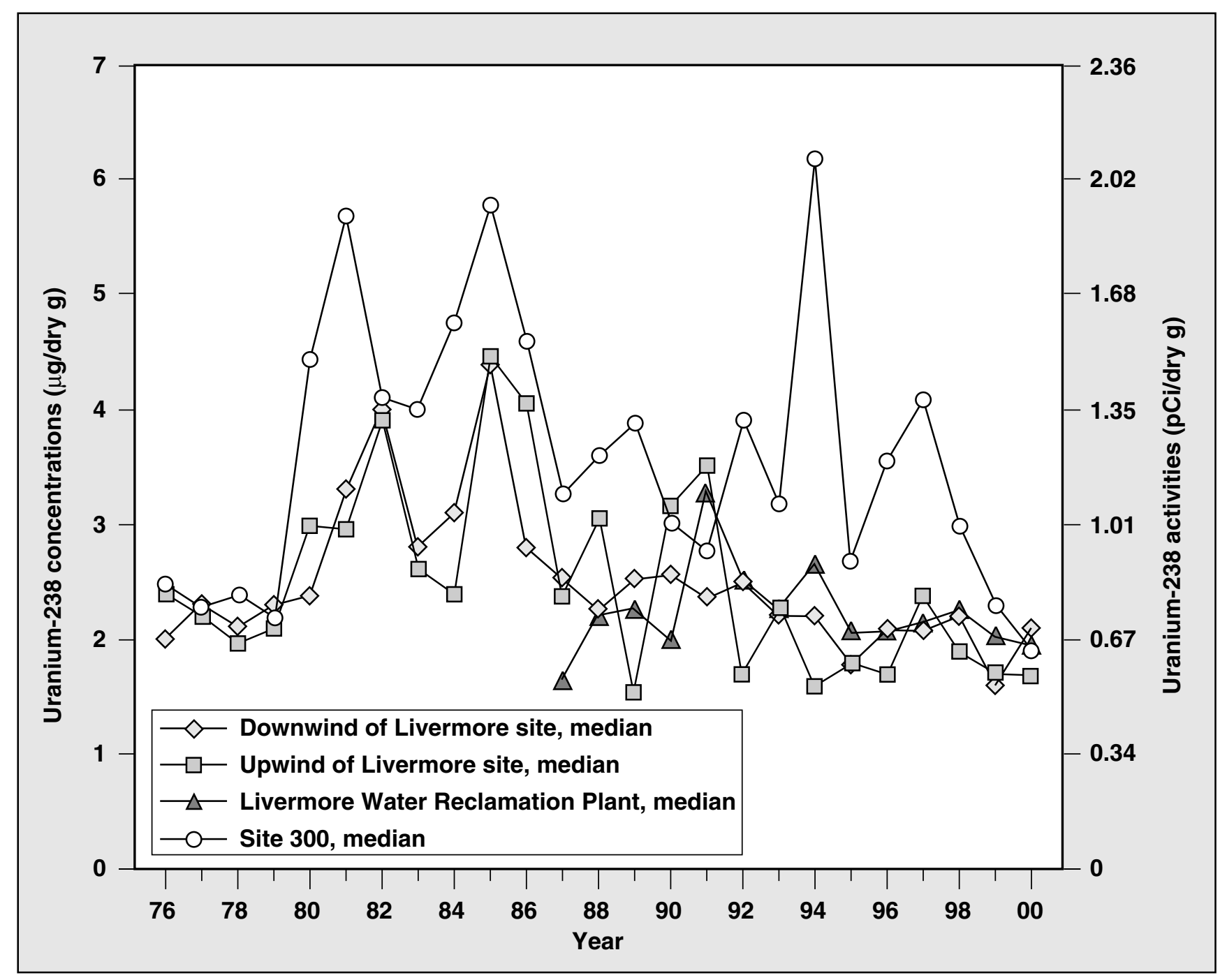

Figure 10-5. Uranium-238 concentrations in surface soils, 1976-2000 
The highest values at Site 300 result from the use of depleted uranium in explosive experiments.

\section{Environmental Impact}

This section discusses the environmental impacts of operations at the LLNL Livermore site and Site 300 inferred from soil, sediment, and vadose zone soil monitoring.

\section{Livermore Site}

Routine surface soil, sediment, and vadose zone soil sample analyses indicate that the impact of LL N L operations on these media in 2000 has not changed from previous years and remains insignificant. M ost analytes of interest or concern were detected at background concentrations or in trace amounts, or could not be measured above detection limits.

The highest value of $6.4 \mathrm{mBq} / \mathrm{dry} \mathrm{g}$ $(0.17 \mathrm{pCi} /$ dry g) for plutonium-239+240 measured at LWRP is $1.3 \%$ of the $\mathrm{N}$ ational Council on Radiation Protection (NCRP) recommended screening limit of $470 \mathrm{mBq} / \mathrm{g}$ (12.7 pCi/g) for property used for commercial purposes (N CRP 1999). Statistical analysis shows no general increase or decrease in plutonium$239+240$ values with time.

$O$ ver the years, $L L N L$ has frequently investigated the presence of radionuclides in local soils. Several of the studies are listed in Table 10-2. LLN L sampling of surface soil, sediment, and vadose zone soil will continue on an annual basis.

Table 10-2. Special soil studies

\begin{tabular}{|c|c|c|}
\hline Year & Subject & Reference \\
\hline 1971-1972 & Radionuclides in Livermore Valley soil & $\begin{array}{l}\text { Gudiksen et al. 1972; } \\
\text { Gudiksen et al. } 1973\end{array}$ \\
\hline 1973 & Radionuclides in San Joaquin Valley soil & Silver et al. 1974 \\
\hline 1974 & Soil study of southeast quadrant of Livermore site & Silver et al. 1975 \\
\hline 1977 & Sediments from LLN L to the San Francisco Bay & Silver et al. 1978 \\
\hline 1980 & Plutonium in soils downwind of the Livermore site & Toy et al. 1981 \\
\hline 1990 & 195 samples taken in southeast quadrant for study & Gallegos et al. 1992 \\
\hline 1991 & Drainage channels and storm drains studied & Gallegos 1991 \\
\hline 1993 & EPA studies southeast quadrant & Gallegos et al. 1994 \\
\hline 1993 & Historic data reviewed & Gallegos 1993 \\
\hline 1995 & LLN L, EPA, and DHS sample soils at Big Trees Park & MacQ ueen 1995 \\
\hline 1999 & Summary of results of 1998 sampling at Big Trees Park & Gallegos et al. 1999 \\
\hline 2000 & $\begin{array}{l}\text { Health Consultation, Lawrence Livermore National } \\
\text { Laboratory, Big Trees Park } 1998 \text { Sampling }\end{array}$ & $\begin{array}{l}\text { Agency for Toxic Substances } \\
\text { Disease Registry } 2000\end{array}$ \\
\hline
\end{tabular}




\section{Site 300}

The concentrations of radionuclides and beryllium observed in soil samples collected at Site $\mathbf{3 0 0}$ are within the range of previous data and are generally representative of background or naturally occurring levels. The uranium-235/uranium-238 ratios that are indicative of depleted uranium occur near active and inactive firing tables at Buildings 801 and 812 . There they represent a small fraction of the firing table operations that disperse depleted uranium. The uranium-238 concentrations are below the NCRP recommended screening level for commercial sites of $313 \mu \mathrm{g} / \mathrm{g}(3.9 \mathrm{~Bq} / \mathrm{g}$ or $105 \mathrm{pCi} / \mathrm{g})$. Historically, some measured concentrations of uranium-238 near Building 812 have been greater than the screening level. The investigation and characterization planned for the area surrounding Building 812 will clarify the nature and extent of the contamination in the area. 


\section{VEgETATION AND FoOdstuff Monitoring}

S. Ring Peterson

\section{Introduction}

Lawrence Livermore National Laboratory has a vegetation and foodstuff monitoring program to comply with U.S. Department of Energy (DOE) guidance. This guidance (U.S. DOE 1991) states that periodic sampling and analysis of vegetation should be performed to determine if there is measurable, long-term buildup of radionuclides in the terrestrial environment.

Tritium is the nuclide of major interest in the LLNL vegetation and foodstuff monitoring program. LLNL has historically released tritium to the air accidentally and during routine operations, and tritium is the only radionuclide released from LLNL activities that occurs in detectable concentrations in vegetation and foodstuff. Tritium moves through the food chain as tritiated water and can be rapidly assimilated into plant water and then incorporated into the organic matter of plants through photosynthesis. It can contribute to human radiation dose if it is inhaled, absorbed through the skin, or ingested via vegetables or via milk and meat from animals that have eaten tritiated vegetation.

LLNL has been monitoring tritium in vegetation to some extent since 1966 and has performed vegetation sampling in the vicinity of the Livermore site and Site 300 as part of a continuing monitoring program since 1971. The monitoring program is designed to measure changes in the environmental levels of radioactivity, to evaluate the environmental effect of LLNL operations, and to calculate potential human doses from radionuclides in the food chain.

In 1977, LLNL added wine to the LLNL monitoring program. Wine is now the most important agricultural product in the Livermore Valley, representing an approximately $\$ 80$-million annual industry, based on sales. Although the tritium concentrations in all wines are low, the sampling data indicate that Livermore Valley wines contain statistically more tritium than do wines from other California wine-producing regions.

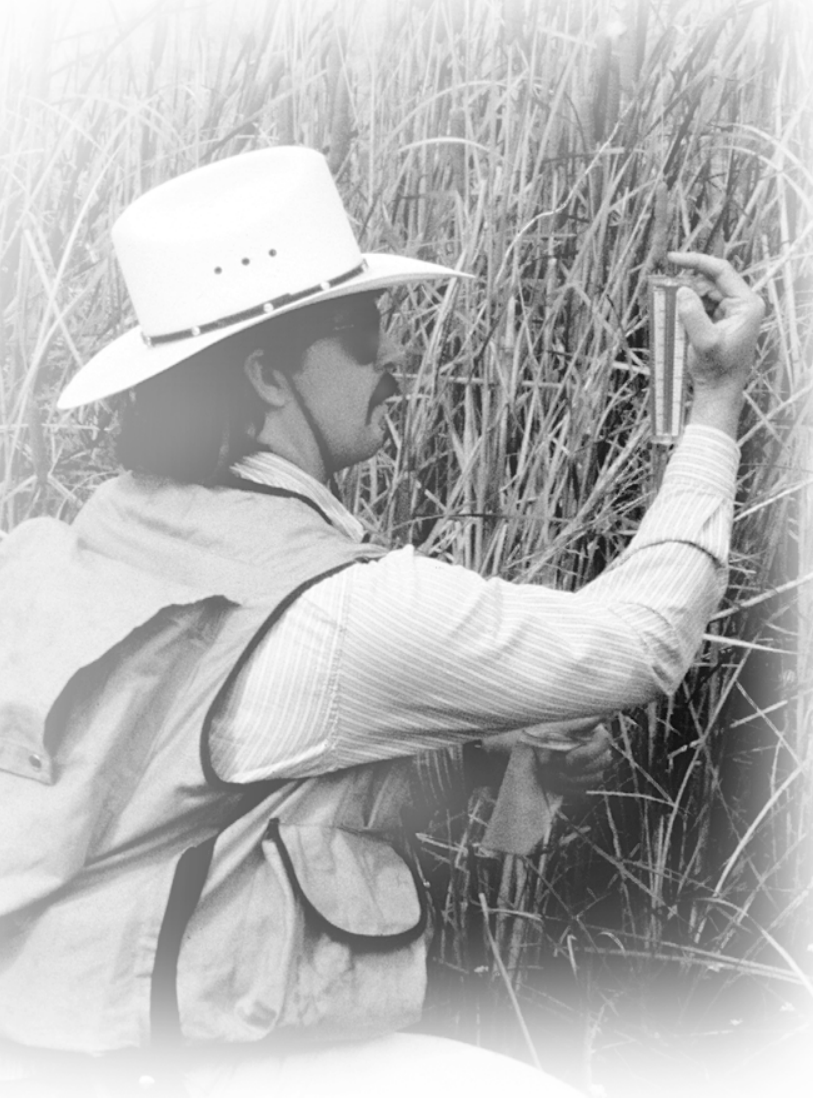


In the past, other foodstuffs (cow milk, goat milk, and honey) leading to potential dose were also monitored for tritium. At present, however, only tritium concentrations in vegetation and wine are used to assess potential ingestion dose from tritium emitted during LLNL operations. During 2000, LLNL collected and analyzed samples of herbaceous vegetation and wine. Potential human doses from these foodstuffs were calculated using the monitoring data and the dose models presented in Appendix A. In addition, as part of a continuing study, LLNL determined the potential tritium dose to the maximally exposed individual from a pine tree at the Livermore site. This tree serves as a diffuse source of tritium because it loses tritium to the air through evapotranspiration of tritiumcontaminated water in the root zone. The dose was calculated using the U.S. Environmental Protection Agency (EPA) model CAP88-PC.

\section{Methods}

The methods used for monitoring vegetation and wine are presented briefly in the following sections and in more detail in the Data Supplement. All vegetation and wine sampling was conducted according to written and approved standardized procedures (Tate et al. 1999).

\section{Vegetation}

LLNL staff collected vegetation samples, usually annual grasses, quarterly from 22 fixed locations in the Livermore Valley, San Joaquin County, and Site 300. The samples were then analyzed for tritium.

Location maps are provided in Figures 11-1 and 11-2. Sample locations were selected to represent vegetation from locations near LLNL that can be affected by LLNL operations, background locations where vegetation is unlikely to be affected by LLNL operations, and areas of known or suspected
LLNL-induced contamination. In 2000, the location COHO, at Site 300, replaced PRIM after the first quarter; all other sampling locations were the same as those in 1999.

\section{Wine}

Three types of wine samples were collected and analyzed for tritium concentrations: wine produced from grapes grown in the Livermore Valley, wine produced from grapes grown in California outside the Livermore Valley, and wine produced from grapes grown in Europe (France, Germany, and Italy). The wines were purchased from local retailers to represent what the general public could buy and drink during 2000 .

Data from the analysis of tritium in wine can be used to estimate the potential tritium dose received by consumers during the year of purchase. However, because wines purchased in 2000 are from grapes that were harvested in 1997, 1998, and 1999, the 2000 sampling data cannot be used to indicate how LLNL's operations affected concentrations of tritium in wines produced from grapes grown in 2000. To analyze trends and help determine the impact of LLNL operations on tritium in wine for the year of harvest, LLNL corrects the wine concentrations for radiological decay that has occurred between the approximate date of the grape harvest and the date when the wine was analyzed in the laboratory. Comparisons can then be made of wine concentrations that represent the year when the grapes were exposed to the tritium.

\section{Results}

The results of vegetation monitoring for the Livermore site and Site 300 and the results of wine monitoring are presented in the following sections. 


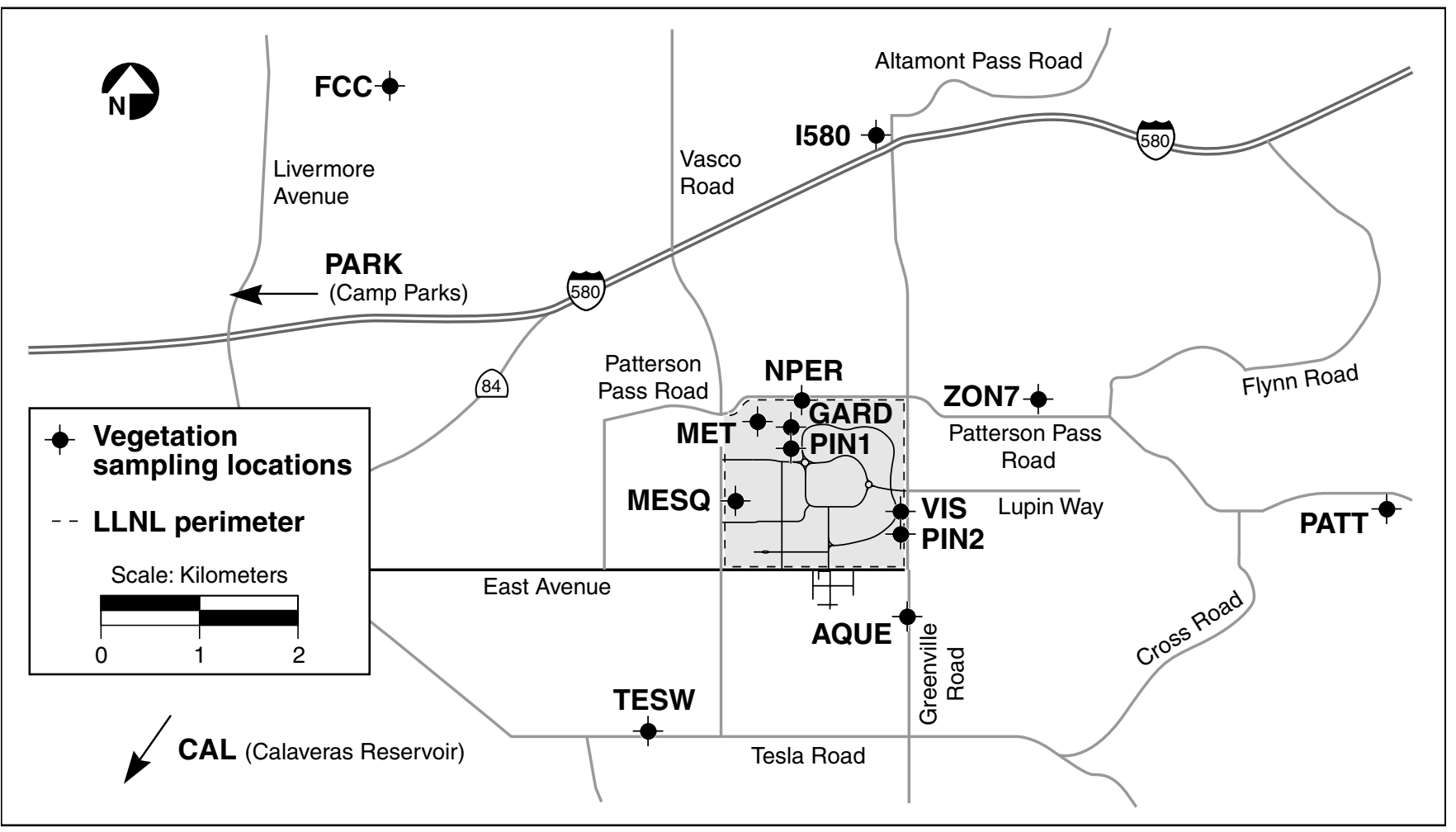

Figure 11-1. Livermore site and Livermore Valley vegetation sampling locations, 2000

\section{Livermore Site}

\section{Vegetation}

The Livermore site and Livermore Valley vegetation locations are put into four groups for statistical evaluation:

- Near: locations within $1 \mathrm{~km}$ of the Livermore site perimeter. Near locations include AQUE, GARD, MESQ, NPER, MET, PIN2, and VIS.

- Intermediate: locations in the Livermore Valley 1-5 km from the Livermore site perimeter that are often downwind and, thus, potentially under the influence of tritium releases at the site. The intermediate locations are I580, PATT, TESW, and ZON7.
- Far: locations unlikely to be affected by LLNL operations. One background location (CAL) is more than $25 \mathrm{~km}$ away. The other two (FCC and PARK), although in the Livermore Valley, are unlikely to be affected by LLNL operations because they are more than $5 \mathrm{~km}$ from the Livermore site and are generally upwind.

- PIN1: location of a pine tree rooted in an area of known tritium contamination on the Livermore site.

Table 11-1 shows summary tritium data for vegetation collected for the LLNL vegetation monitoring program in 2000 (individual sampling values are presented in the Data Supplement of this report). Figure 11-3 shows the 2000 medians 


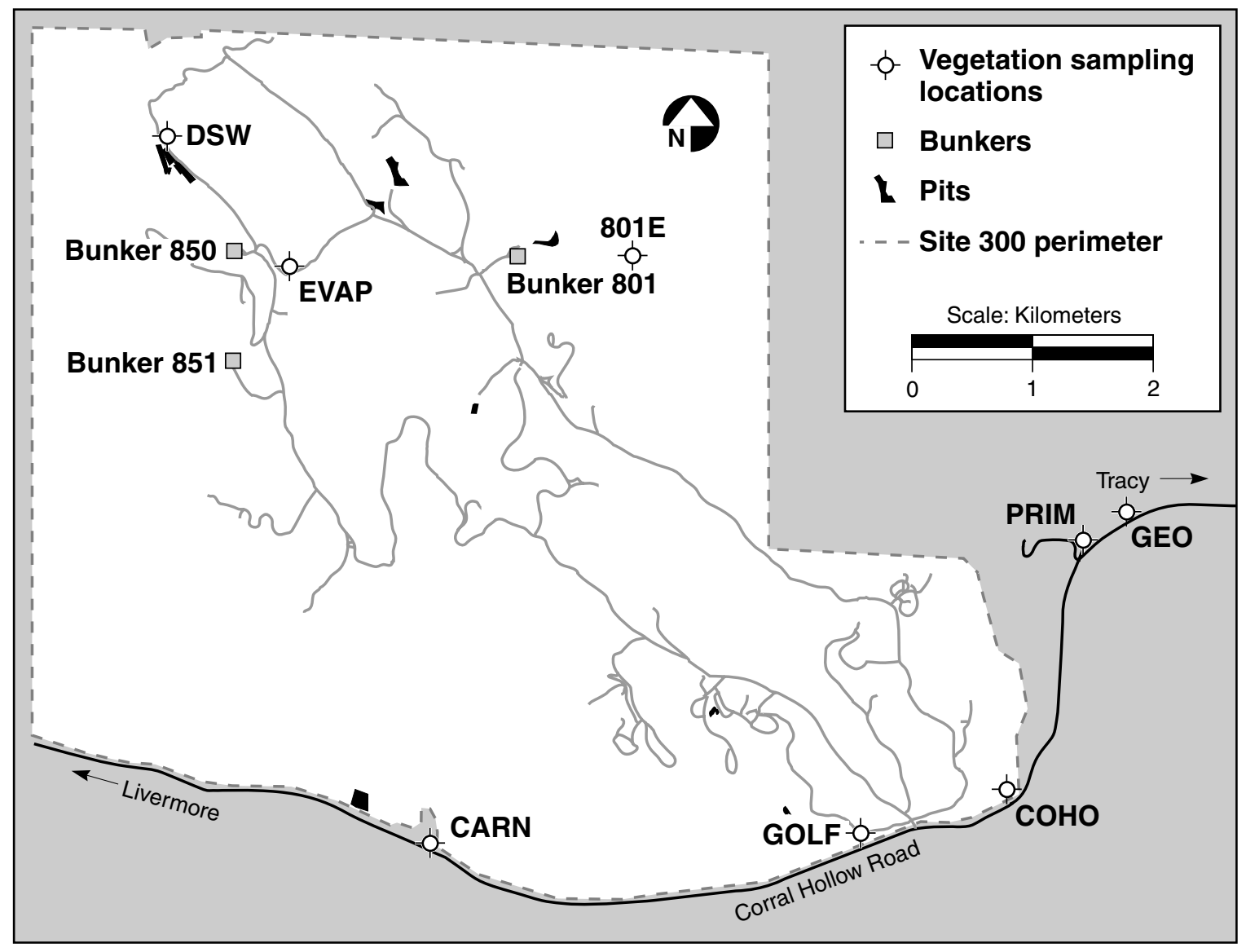

Figure 11-2. Site 300 vegetation sampling locations, 2000

of the tritium concentrations for PIN1, Near, Intermediate, and Far Livermore locations as a continuation of historic median concentrations from 1971 to 1999. For 1998 and 1999, the medians for the Far locations were negative; therefore, because negative numbers cannot be plotted on a logarithmic scale, the lowest positive measured concentrations were plotted instead. Although the concentration in Far vegetation appears to drop by about a factor of 10 in 1998 and to rise sharply in 2000 , it is highly unlikely that these apparent changes represent concentrations different from recent preceding years. The apparent difference in the Intermediate and Far observations since 1998 is caused by a change in how the analytical laboratory reported concentrations less than the detection limit. All Far vegetation samples were below the detection limit of the analysis in 1999 and 2000 .

For 2000, the data for tritium in vegetation were compared using Scheffé's $F$ and Games/Howell multiple comparisons (Scheffé 1953; Games and Howell 1976). These tests are the most appropriate tests for these distributions of data. Once again, as in 1999, the Near group was not found to be significantly different from the Intermediate and Far groups. This is due to many low observed tritium concentrations in the Near samples. For example, the first quarter sample for VIS was below the detection limits for the first time since sampling began there in 1991 (see Table 11-1 in the Data 
Table 11-1. Concentrations of tritium in plant water (Bq/L), 2000

\begin{tabular}{|c|c|c|c|c|c|c|}
\hline \multirow{2}{*}{ Location ${ }^{(a)}$} & \multirow{2}{*}{$\begin{array}{c}\text { Detection } \\
\text { Frequency } \\
\text { (b) }\end{array}$} & \multirow{2}{*}{ Median } & \multirow{2}{*}{$\begin{array}{l}\text { Inter- } \\
\text { quartile } \\
\text { Range }\end{array}$} & \multirow{2}{*}{ Maximum } & \multicolumn{2}{|c|}{ Dose $(\mathrm{nSv} / \mathrm{y})^{(\mathrm{c})}$} \\
\hline & & & & & Median & Maximum \\
\hline Livermore site near locations ${ }^{(d)}$ & $23 / 28$ & 2.4 & 4.0 & 12 & 12 & 59 \\
\hline Livermore site PIN1 (e) & $4 / 4$ & 59 & 68 & 240 & $0.0045^{(f)}$ & $0.018^{(f)}$ \\
\hline Livermore site intermediate locations & $6 / 16$ & 1.2 & 2.1 & 8.3 & 5.9 & 41 \\
\hline Livermore site far locations & $0 / 12$ & 0.48 & 1.6 & 1.9 & 2.4 & 9.3 \\
\hline Location DSW at Site $300^{(e)}$ & $3 / 4$ & 5.8 & 320 & 1300 & 28 & 6400 \\
\hline Location EVAP at Site $300^{(e)}$ & $3 / 4$ & 160 & 170 & 290 & 780 & 1400 \\
\hline All other locations at Site 300 & $2 / 20$ & 0.21 & 1.0 & 1.8 & 1.0 & 8.8 \\
\hline
\end{tabular}

Note: Radioactivities are reported as the measured concentration and an uncertainty ( $\pm 2 \sigma$ counting error). If the concentration is less than or equal to the uncertainty the result is considered to be a nondetection. See Chapter 14.

a See Figures 11-1 and 11-2 for sampling locations.

b Detection frequency means the fraction of samples taken having a measured value above the detection limit.

c Ingestion dose is calculated based on conservative assumptions that an adult's diet is exclusively vegetables with this tritium concentration and that meat and milk are derived from livestock fed on grasses with the same concentration of tritium. See Appendix A. Note that doses are reported in $\mathrm{nSv} / \mathrm{y}\left(1 \times 10^{-9} \mathrm{~Sv} / \mathrm{y}\right)$ rather than the $\mu \mathrm{Sv} / \mathrm{y}\left(1 \times 10^{-6} \mathrm{~Sv} / \mathrm{y}\right)$ of earlier years.

d Includes PIN2; plant water concentrations are similar among plant types

e Sampling location in area of known contamination

f For this dose calculation PIN1 is treated as a diffuse source of tritium (since pine needles are not eaten by human beings). Dose calculated using CAP88-PC is to the maximally exposed individual (see Chapter 13).

Supplement). The highest median tritium results for individual vegetation sampling locations were found at the Near locations, NPER and VIS, both of which were lower than in 1999.

In 1997 PINl, a pine tree growing in a known area of tritium contamination at the Livermore site, was monitored on a monthly basis to estimate emissions for compliance with National Emissions Standards for Hazardous Air Pollutants (NESHAPs). In 1998, the tree sampling was coordinated with the quarterly vegetation sampling. Since 1998, NESHAPs calculations to the maximally exposed individual (MEI) have been based on quarterly observations. To assess the contribution of soil water tritium to PIN1, LLNL also sampled a second tree (PIN2) which is not growing in tritium-contaminated soil. Concentrations of tritium in PIN2, like in all other vegetation sampled near the Livermore site, are from air and soil water in quasi-equilibrium with air. When samples from PINl were compared with samples from each Near location for 2000 using Scheffé's F procedure, concentrations of tritium in PINl were found to be significantly higher than concentrations at all other locations at the $5 \%$ significance level.

\section{Wine}

The results from the 2000 wine tritium analyses are shown in Table 11-2. Tritium concentrations are within the range of those reported in previous years and remain low in wines from all areas. The data for the 2000 sampling year were analyzed using Scheffé's $F$ and Games/Howell multiple comparisons. The results of the comparisons are the same as in previous years. Both analyses show that the tritium concentrations of Livermore Valley wines are higher than those of the six California 


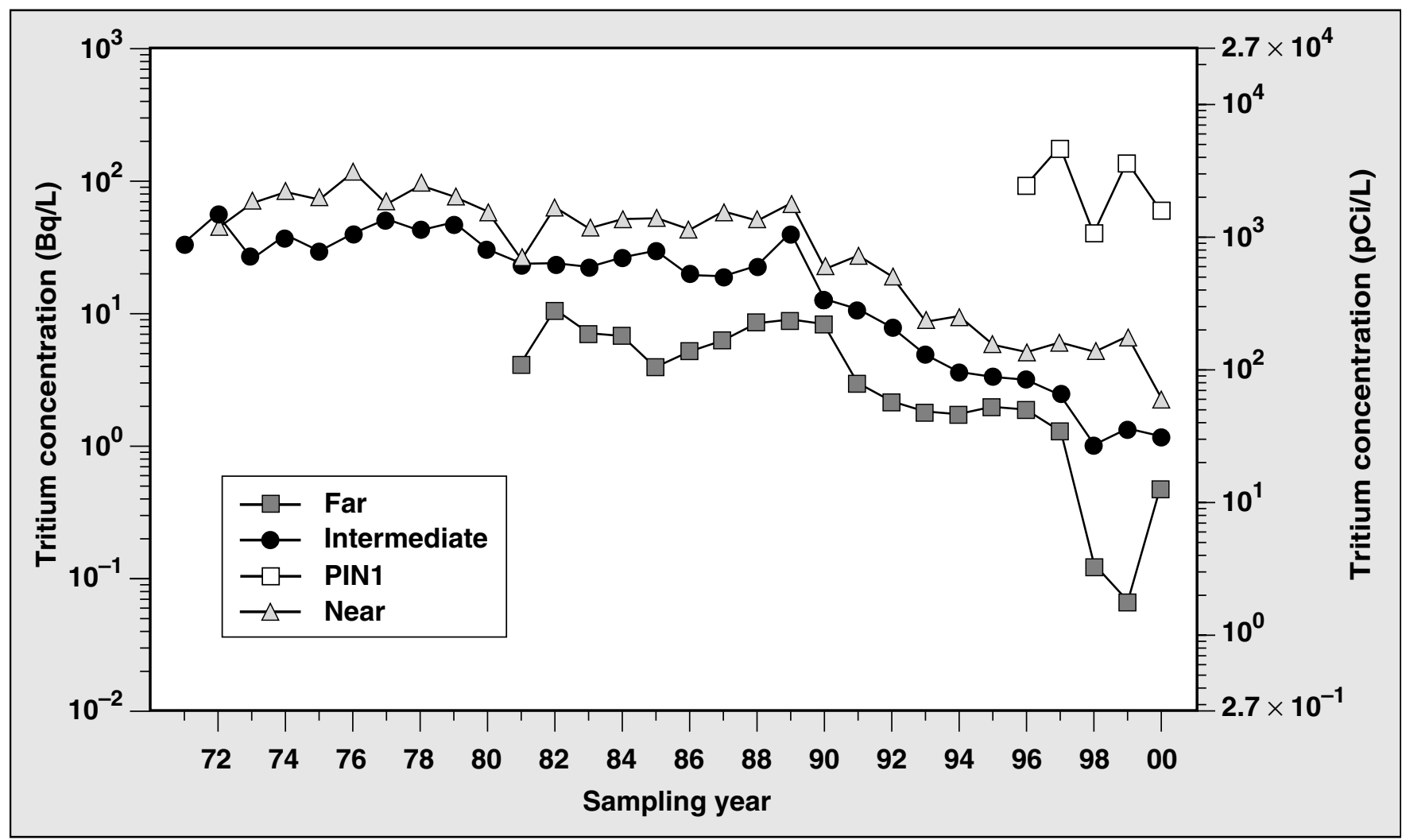

Figure 11-3. Median tritium concentrations in Livermore site and Livermore Valley plant water samples, 1971-2000 (For Far vegetation for 1998 and 1999, the values are the lowest positive.)

Table 11-2. Tritium in retail wine (Bq/L), 2000(a)

\begin{tabular}{|l|c|c|c|l|l|c|}
\hline \multicolumn{1}{|c|}{ Region } & $\begin{array}{c}\text { Detection }^{(b)} \\
\text { frequency }\end{array}$ & Median & $\begin{array}{c}\text { Interquartile } \\
\text { range }\end{array}$ & Mean & Maximum & $\begin{array}{c}\text { Dose } \\
\text { nSv/y }\end{array}$ \\
\hline Livermore Valley & $12 / 12$ & 1.80 & 0.523 & 1.75 & 2.62 & 1.6 \\
California & $6 / 6$ & 0.424 & 0.0340 & 0.449 & 0.584 & 0.40 \\
Europe & $4 / 4$ & 1.15 & 0.615 & 1.18 & 1.61 & 1.1 \\
\hline
\end{tabular}

Note: Radioactivities are reported as the measured concentration and an uncertainty ( $\pm 2 \sigma$ counting error). If the concentration is less than or equal to the uncertainty, the result is considered to be a nondetection. See Chapter 14.

a Wines from a variety of vintages were purchased and analyzed in 2000. The concentrations reported are those at the time the bottle was opened.

b Detection frequency means the fraction of samples taken having a measured value above the detection limit.

c This dose is calculated from assumption of drinking $52 \mathrm{~L}$ wine/year and using the mean concentration of sampled wines. 
wines at the $5 \%$ significance level. The Scheffés $F$ test, which can be used when the number of samples is fewer than six, also demonstrated that the California wines sampled have significantly lower tritium concentrations than the European wines sampled.

There is remarkably little variability in Livermore Valley wines collected for 2000, although the vintage years represented are 1997, 1998, and 1999.

Concentrations of tritium in wine corrected to vintage year are plotted in Figure 11-4. The downward trend seen in wines from all locations between 1982 and 1999 exhibits approximately a five-year half-life. The radiological half-life of tritium is 12.32 years. An environmental half-life shorter than the radiological half-life would be expected for tritium in Livermore Valley wines, since concentrations in grapes are driven by emissions from LLNL, and emissions have dropped since 1988, with a significant reduction after 1992 (see Chapter 4). What is surprising is the observation that Californian and European wines exhibit a similar half-life. The locations where the grapes were grown and the corresponding driving concentrations of tritium (e.g., fallout for California, unknown for Europe) only seem to affect the magnitude of the tritium concentrations, not the rate of loss from the environment. This observed loss-rate of tritium from wines is most likely due to the transfer of tritium to the oceans, which are a sink for tritium, and is similar to the loss-rate of tritium from precipitation observed in similar years after the cessation of bomb tests (Östlund, 1973; Momoshima et al. 1991).

The 1996 Livermore Valley wines were significantly higher in tritium than those from both 1997 and 1998 using both Scheffé's F procedure and the Games/Howell test. Data from 1999 could not be included because the sample comprised only two

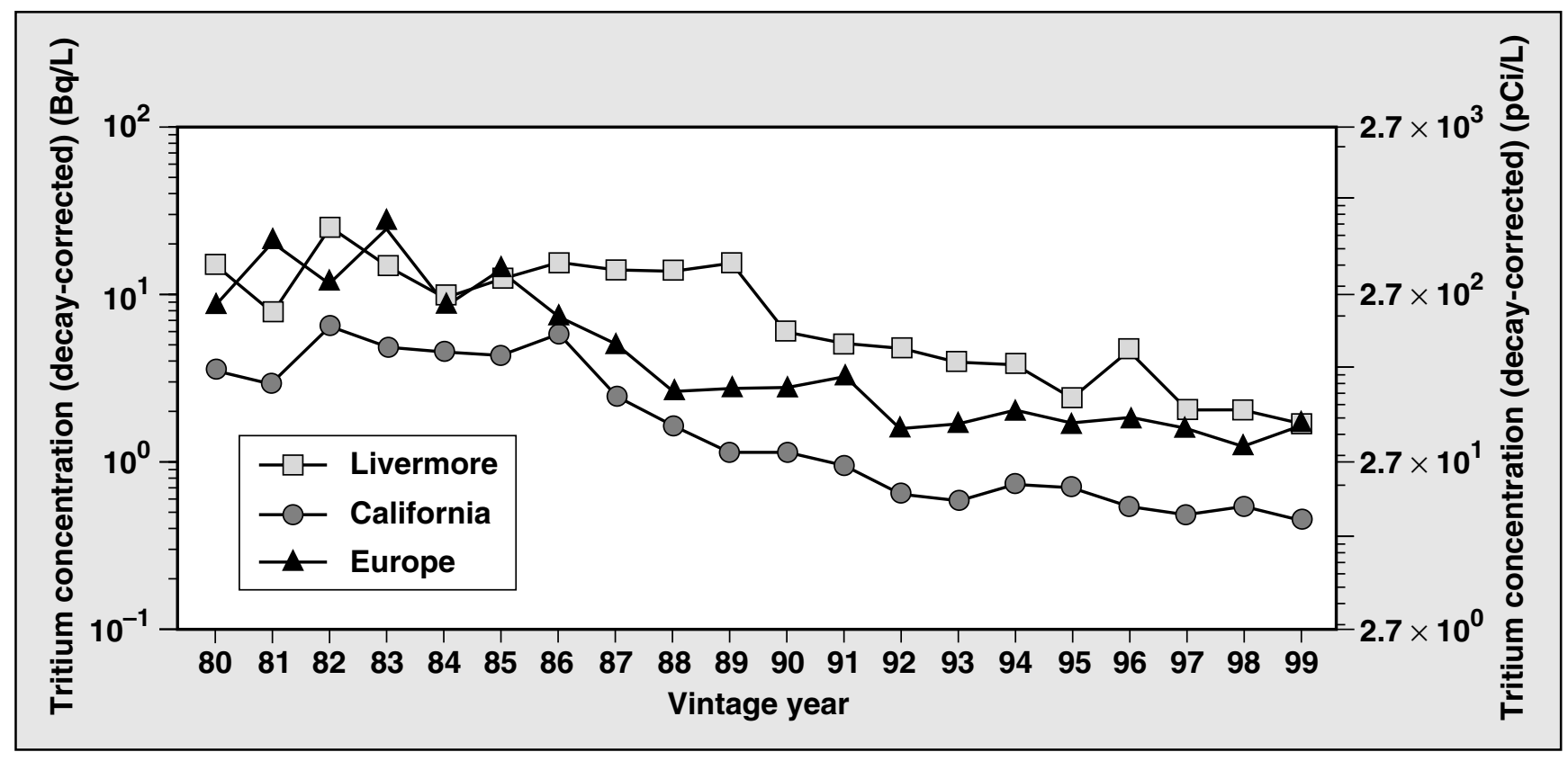

Figure 11-4. Mean tritium concentrations in retail wines decay-corrected from the sampling year to the vintage year 
bottles. As mentioned, wines are sampled randomly. Q uite by chance, the 1996 wines unequally represent vineyards close to $L L N L$ and therefore exhibited higher values.

\section{Site 300}

\section{Vegetation}

There are seven monitoring locations for vegetation at Site 300. Of these, five (CARN, GOLF, GEO , 801E, and PRIM / COH O) detect changes in atmospheric tritium concentrations. Vegetation from locations DSW and EVAP grows in areas of known groundwater contamination. Plants can take up tritiated water from two sources: air moisture and soil moisture. When soil water available to the plant is contaminated with tritium and there is little tritium in the air moisture, the concentrations in the plant water will be somewhat lower than those of soil water, but will be much higher than concentrations in air moisture.

Table 11-1 shows summary tritium data for vegetation collected at Site 300 during 2000. H istoric values for tritium at Site 300 sampling locations are shown in Figure 11-5. Of the seven sampling locations at Site 300, five yielded results in 2000 at or near the detection limits. Two locations, EVAP and D SW, yielded results above detection limits. EVAP's median tritium concentration is similar to that of 1999. DSW's median value is similar to recent years (excepting 1998). The extremely low concentrations from 1998 to the present for locations other than DSW and EVAP are caused by a change in how the analytical laboratory reported concentrations lower than detection limit and do not reflect a real difference in concentrations.

The highest tritium result ( $1300 \mathrm{~Bq} / \mathrm{L}$ ) for a single vegetation sample occurred at location D SW (see Table 11-1). This sampling location is adjacent to a landfill area that contains debris contaminated with tritium from past experiments. Tritium concentrations in vegetation are also above background levels at location EVAP, which is near a spring where groundwater flows near the surface and evaporates. Groundwater near EVAP is contaminated with tritium from Pit 3 , Pit 5 , and the firing table at Building 850. The DSW and EVAP locations are both within the East and West Firing Area (EFA/ WFA) Study Area of the Comprehensive Environmental Response, Compensation and Liability Act (CERCLA) environmental restoration study areas ( see C hapter 8 , Groundwater I nvestigation and Remediation). Tritium is one of the contaminants of concern in this area. R elatively high concentrations of tritium in plants at DSW and EVAP are observed only sporadically when conditions result in contaminated soil water being translocated by vegetation. Evaluation of the 2000 data for Site 300 using Scheffé's $F$ procedure yielded no significant differences among the various sampling locations, a result of the high variability of the data and the low number of data points.

\section{Environmental Impact}

In 2000, the environmental impacts of LLN L operations on vegetation and wine, presented below, were small.

\section{Livermore Site}

LLN L impacts on vegetation in the Livermore Valley remained minimal in 2000 . The effective dose equivalents shown in Table 11-1 were derived using the dose conversion factors provided by DOE (U.S. DOE 1988) and the dose pathway model from U .S. N uclear Regulatory Commission (NRC) Regulatory Guide 1.109 (U.S. N RC 1977). Appendix A provides a detailed discussion of dose calculation methods. The dose from ingested tritium is based on the conservative assumptions that an adult's diet (Table A-2, N RC maximum) consists exclusively of leafy vegetables 


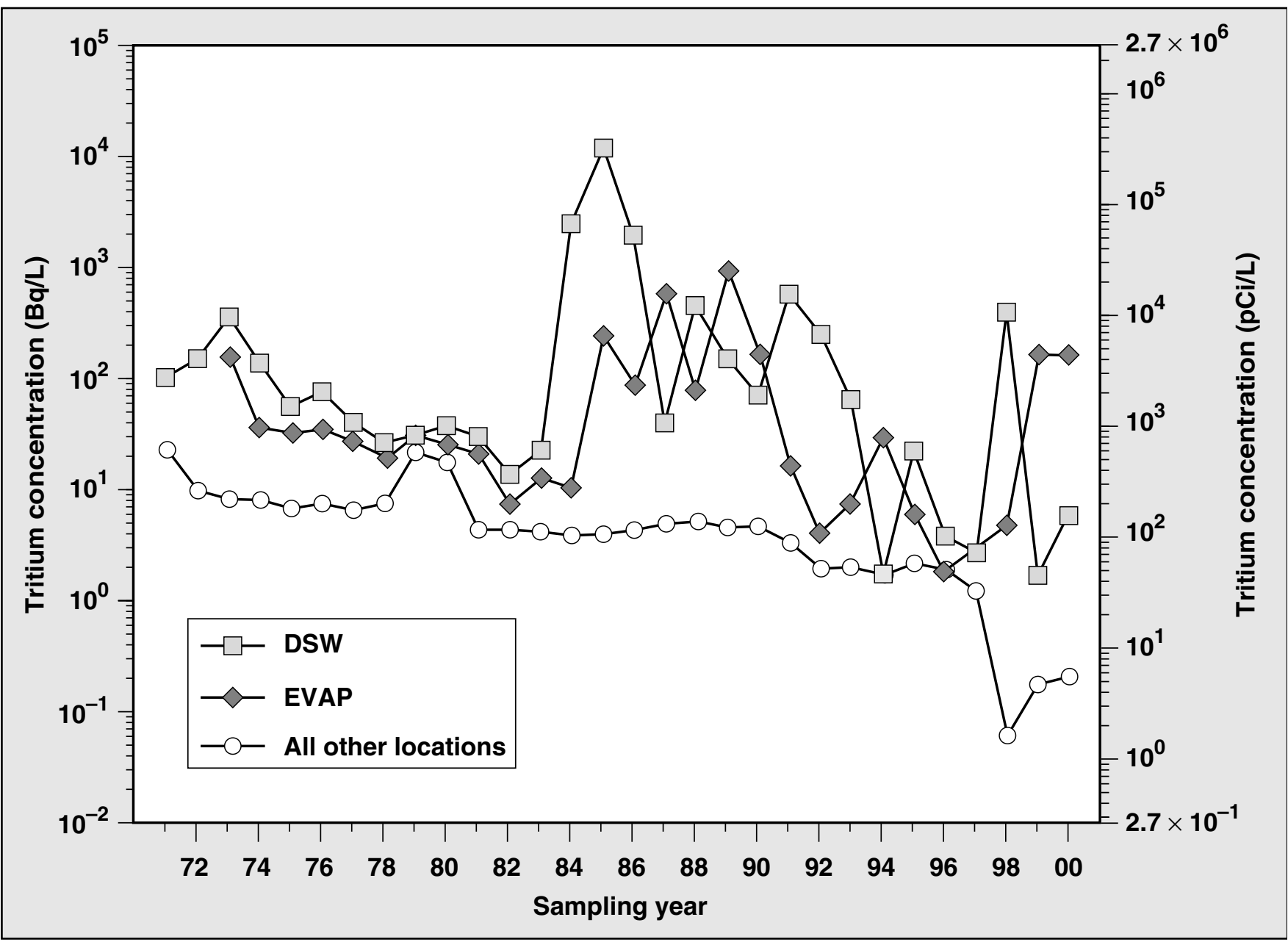

Figure 11-5. Median tritium concentrations in plant water at Site 300 sampling locations, 1971-2000. When the median is negative (e.g., all other locations for 1998 and 1999), the lowest positive concentration has been substituted.

with the measured tritium concentrations, as well as meat and milk from livestock fed on grasses with the same concentrations. In actuality, the vegetables consumed by an adult contain tritium at lower levels than those reported because most vegetables are imported from other areas. Similarly, tritium concentrations in food consumed by local livestock are at or below the concentrations in vegetation measured at the Intermediate and the Far locations. Nevertheless, based on these extremely conservative assumptions, the maximum potential dose from ingestion of affected vegetation for 2000 for the Livermore Valley is $58 \mathrm{nSv} / \mathrm{y}(0.058 \mu \mathrm{Sv}$ or (0.0058 mrem).

Doses are calculated based on measured tritium in plant water without considering the contribution of organically bound tritium (OBT). Dose conversion factors of $1.8 \times 10^{-11} \mathrm{~Sv} / \mathrm{Bq}$ for tritium in the plant or animal water (HTO) and $4.2 \times 10^{-11}$ $\mathrm{Sv} / \mathrm{Bq}$ for OBT have been established by the International Commission on Radiological Protection 
(1996). These show the relative importance of ingested HTO and OBT to dose. When vegetables are ingested, the dose from the HTO contribution is greater than the dose from the OBT contribution because the fraction of the vegetable that is organic matter is quite small (10-25\%). For example, about $10 \%$ of the ingestion dose from leafy vegetables (about 10\% dry matter) is contributed by OBT. OBT becomes increasingly important to dose when the fraction of dry matter increases. Pork, for example, has a dry-matter content of about $30-50 \%$ (Ciba-Geigy Ltd. 1981), and the resulting ingestion dose from pork is about half from OBT and half from HTO. The OBT in grain, which is $88 \%$ dry matter, contributes nearly $90 \%$ of the dose from ingested grain. Given the different fractions of OBT in different foods, the importance of OBT to ingestion dose depends on what quantities of what kinds of foods are consumed. An extremely unlikely diet very high in OBT would, at most, give an OBT contribution to dose equal to that of HTO. Thus, conservatively, the maximum total tritium dose from ingestion of vegetables and foodstuffs from the Livermore Valley for 2000 could be $120 \mathrm{nSv}(0.12 \mu \mathrm{Sv}$ or $0.012 \mathrm{mrem}$ ), which is more than a factor of eight below the estimate for 1999 and well below any level of concern.

The dose values for PINl shown in Table 11-1 were calculated in a different manner from those for edible vegetation, because it is unreasonable to assume that any person is directly ingesting pine needles. The pine tree is treated as a diffuse source of tritium to the atmosphere via the contaminated transpirational stream. LLNL used an estimated tritium transpiration rate from the tree as input data to the EPA regulatory model CAP88-PC. LLNL modeled air dispersion of the transpired tritium and calculated a resulting dose from inhalation, skin absorption, and potential ingestion from air concentrations at the location of the maximally exposed individual. This total dose is based on the conservative assumptions that $100 \%$ of the individual's time is spent at this location and that his/her diet consists exclusively of vegetables with the measured tritium concentration and meat from livestock fed on grasses with the same concentration. The resulting maximum dose for PINl of $0.018 \mathrm{nSv} / \mathrm{y}\left(1.8 \times 10^{-5} \mu \mathrm{Sv}\right.$ or $\left.1.8 \times 10^{-6} \mathrm{mrem}\right)$ is considerably lower than ingestion doses calculated directly from measured concentrations in vegetation because the tree is only an indirect source of air/vegetation contamination.

No health standards exist for radionuclides in wine. However, all the wine tritium levels were far below drinking water standards. In fact, even the highest detected Livermore Valley value $(2.3 \mathrm{~Bq} / \mathrm{L}$ or $62 \mathrm{pCi} / \mathrm{L})$ represents only $0.3 \%$ of the California drinking water standard $(740 \mathrm{~Bq} / \mathrm{L}$ or $20,000 \mathrm{pCi} / \mathrm{L})$. Doses from wine consumption can be calculated according to methods for water ingestion, as described in Appendix A.

Based on the conservative assumption that wine is consumed at the same rate as the average consumption of water $(370 \mathrm{~L} /$ year or about $1 \mathrm{~L} /$ day $)$, the annual dose that corresponds to the highest detected 2000 Livermore Valley tritium value in wine is $15 \mathrm{nSv}(1.5 \mu \mathrm{rem})$. Assuming a more realistic average wine consumption $(52 \mathrm{~L} /$ year or $1 \mathrm{~L} /$ week of wine) and the mean tritium values from the three sampling areas, the annual doses from Livermore, European, and California wines would be $1.6 \mathrm{nSv}(0.16 \mu \mathrm{rem}), 1.0 \mathrm{nSv}$ $(0.10 \mu \mathrm{rem})$, and $0.40 \mathrm{nSv}(0.040 \mu \mathrm{rem})$, respectively.

The potential ingestion dose from all foodstuffs grown near the Livermore site for 2000 was realistically below $120 \mathrm{nSv}(0.12 \mu \mathrm{Sv}$ or $0.012 \mathrm{mrem})$. This estimate is as high or higher than dose estimates calculated using other assumptions (see Appendix A). This estimate is a factor of 25,000 lower than an annual background dose $(\sim 3000 \mu \mathrm{Sv}$ 
or $300 \mathrm{mrem}$ ) and a factor of 800 lower than the dose from a typical chest $\mathrm{x}$-ray $(100 \mu \mathrm{Sv}$ or $10 \mathrm{mrem}$ ) (Shleien and Terpilak 1984). Therefore, although tritium levels are elevated slightly near the Livermore site, doses from tritium ingestion are negligible.

\section{Site 300}

In general, LLNL impacts on tritium concentrations in vegetation at Site 300 for 2000 were insignificant. With the exception of vegetation from previously identified sites of contamination, the tritium levels at Site $\mathbf{3 0 0}$ were at or near the limits of detection and comparable to those observed in previous years. The areas where tritium is known to be present in the subsurface soil are well delineated and localized.
The calculated maximum potential annual ingestion dose from vegetation at sampling location DWS, based on the maximum value of $1300 \mathrm{~Bq} / \mathrm{L}$ $(35,000 \mathrm{pCi} / \mathrm{L})$, is $6.2 \mu \mathrm{Sv}(0.62 \mathrm{mrem})$. This dose, based on the conservative modeling assumptions described above, is theoretical-but nevertheless small- because vegetation at Site 300 is not ingested either by people or by livestock. 



\section{ENVIRONMENTAL Radiation Monitoring}

\section{Introduction}

In accordance with federal regulations and applicable portions of Department of Energy (DOE) Orders 5400.1 and 5400.5, Lawrence Livermore National Laboratory monitors gamma radiation to establish radiation levels in its vicinity and to determine the direct environmental radiological impact of its operations. Gamma radiation in the environment primarily occurs naturally from terrestrial and cosmic sources. Because environmental radiological monitoring is used as one measure of the potential radiation dose that the public may receive as the result of LLNL operations, LLNL has developed an extensive radiological monitoring network for the Livermore site perimeter, Site 300 perimeter, and off-site locations. Gamma radiation has been measured at the Livermore site since 1973 and at Site 300 since 1988.

The absorbed gamma radiation dose imparted to thermoluminescent dosimeters (TLDs) is the result of TLD exposure from both terrestrial and cosmic radiation sources as well as LLNL sources, if any.

\section{Cosmic Radiation Component}

Gamma radiation in air is produced by the interaction of cosmic rays. Cosmic rays consist of high-energy particles and emanate primarily from beyond the solar system. Radiation observed in the lower atmosphere and at the earth's surface are secondary radiations formed in the reaction of these high-energy particles with nuclei in the upper atmosphere. The cosmic radiation component accounts for about half the observed site annual average gamma radiation.

\section{Terrestrial Radiation Component}

Terrestrial gamma radiation is caused by naturally occurring isotopes of the uranium (uranium-238 parent), thorium (thorium-232 parent), and actinium (uranium-235 parent) decay series that are present in soil worldwide and that produce 
gamma radiation during radioactive decay. The concentration of naturally occurring radionuclides in soil is variable and is determined by the ratio of thorium-232 to uranium-238 (present in these regions at the time of the earth's formation over four billion years ago), which ranges from 3 to 4 around the world. By characterizing the natural background radiation, LLNL can determine whether or not there is a contribution to gamma exposure from Laboratory operations.

\section{General Methods}

LLNL deploys TLDs in the field to assess the environmental impact of laboratory operations at both the Livermore site and Site 300. This assessment is done by comparing the gamma radiation data acquired from the Livermore perimeter site locations to various locations monitored in the Livermore Valley, and gamma-radiation data from Site 300 perimeter locations to locations in the City of Tracy and near Site 300 .

As previously mentioned, the variability of the naturally occurring radioisotopes present in the soil due to geological formations is the largest contributor to variations in measurements. Meteorological conditions contribute to seasonal variability, as does cosmic variation.

LLNL deploys TLDs at the beginning of each quarter of the year and retrieves them from the monitoring locations as near to the end of the quarter as possible in order to have a 90-day exposure period. All data are normalized to a 90-day standard quarter basis in order to make valid comparisons for the measurement period.

Details of the TLD calculations are described in an Operations and Regulatory Affairs Division (ORAD) procedure. Reporting of external gamma radiation dose may be found in the Data Supplement.

\section{Monitoring Locations}

In 2000 , external doses from gamma radiation were monitored at 14 Livermore site perimeter locations (shown in Figure 12-1) and at 23 Livermore Valley locations (Figure 12-2), which are used for background comparison to perimeter location data. Similarly, gamma doses are monitored at eight perimeter monitoring locations at Site 300 (Figure 12-3). Additionally, five off-site locations near Site 300 and two locations in nearby Tracy are also monitored for comparison to the Site 300 data. Summary dose calculations for all gamma-monitoring locations are presented in Table 12-1.

\section{Collocated Monitoring Locations}

The State of California Department of Health Services, Radiological Health Branch (CDHS$\mathrm{RHB}$ ) performs routine, independent gamma monitoring at several sites collocated with LLNL's TLD network. CDHS-RHB site locations correspond to several Livermore site perimeter, valley, Site 300, and off-site locations near Site 300.

\section{Locations at Site 300}

During the second quarter collection/third quarter deployment, all second quarter samples with the exception of 86 and 121 were damaged due to an accident involving a vehicle fire enroute. For the safety of the personnel involved in future deployments, east and north perimeter sites were eliminated in the third quarter and additional locations were supplemented, following an examination of the incident safety measures taken in an attempt to prevent future occurrences of this nature. The original locations initially removed were reinstated in the fourth quarter in order to preserve historical data. 


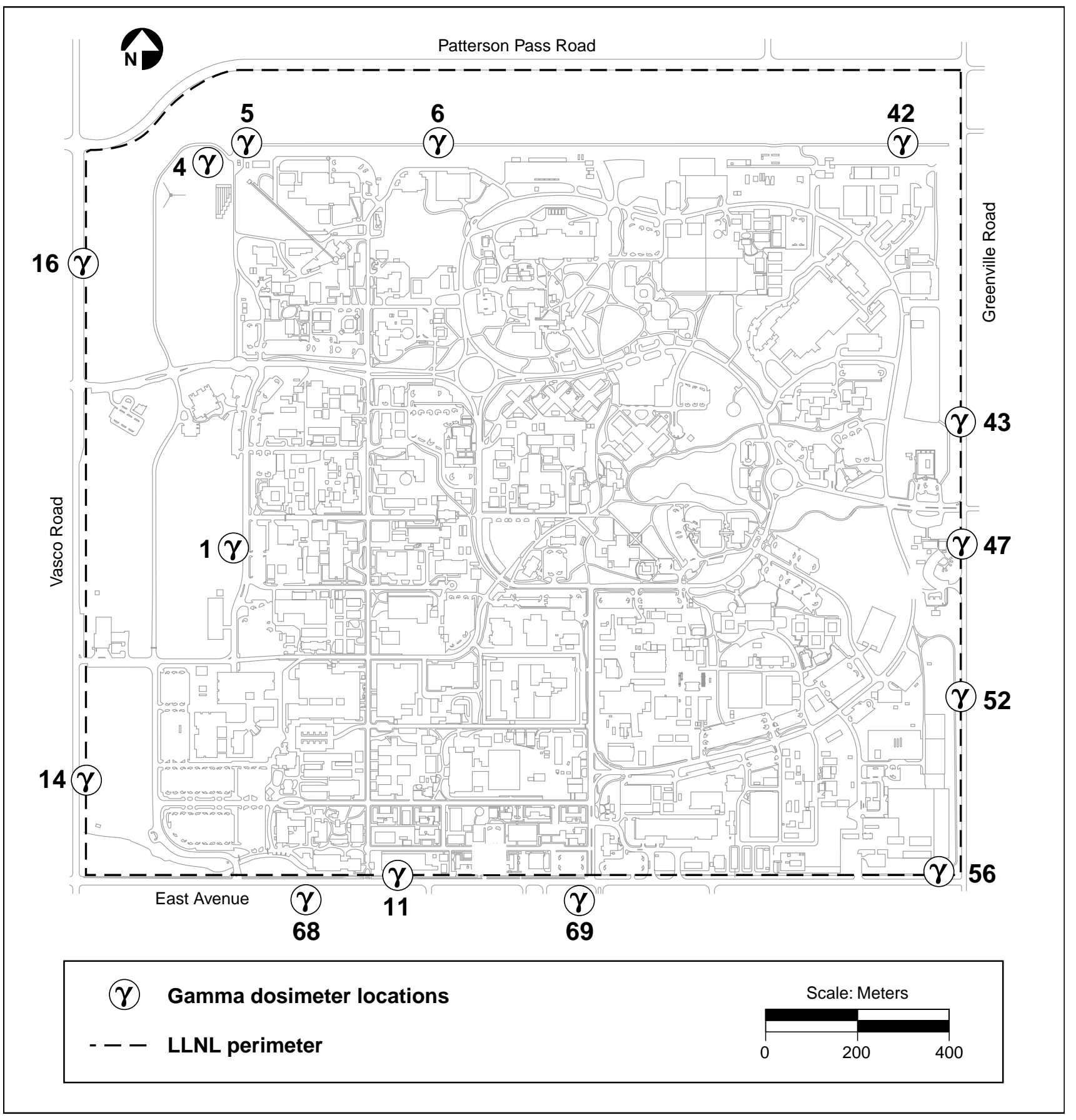

Figure 12-1. Gamma dosimeter locations, Livermore site, 2000 


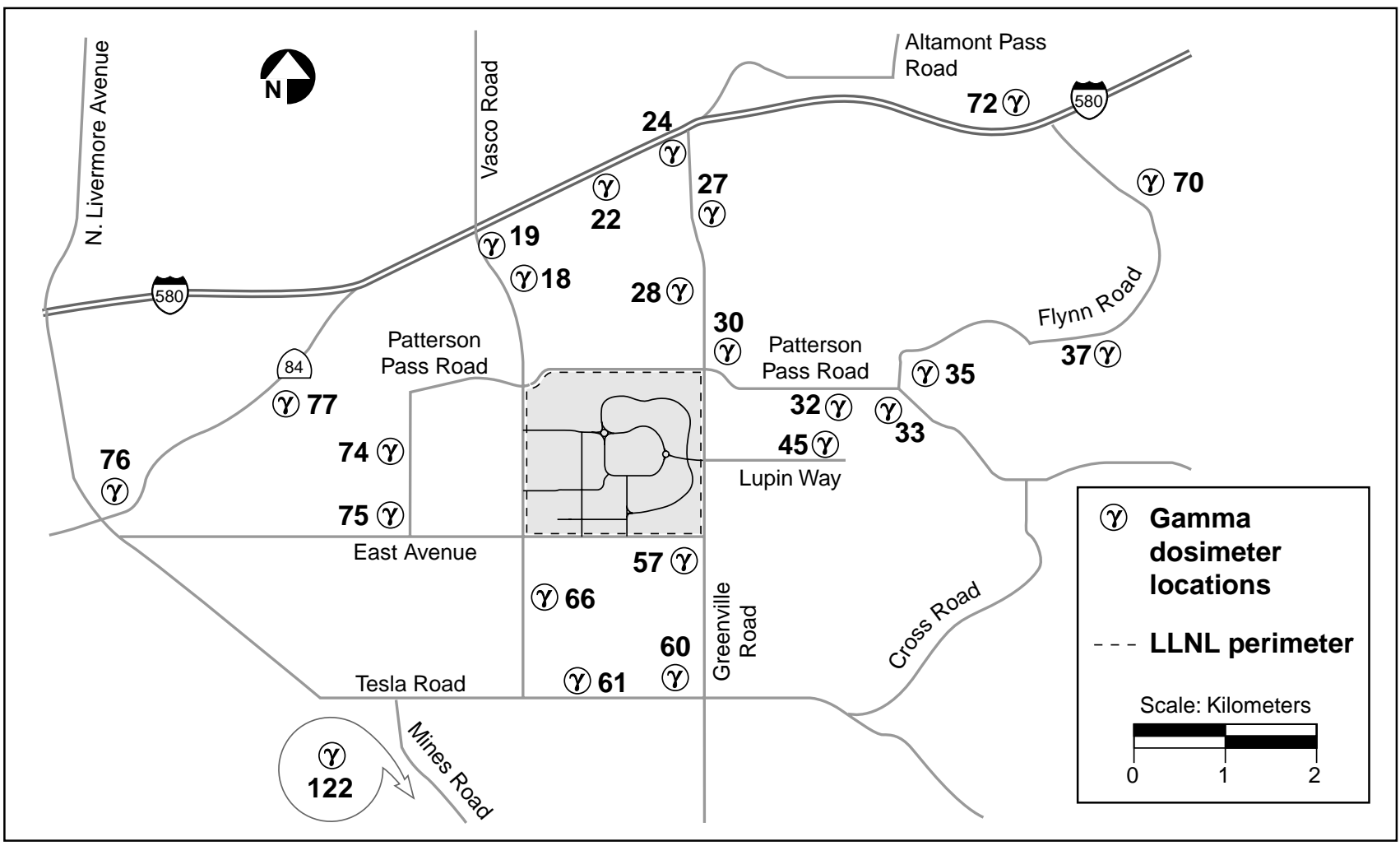

Figure 12-2. Gamma dosimeter locations, Livermore Valley, 2000

\section{Results of Gamma Monitoring}

Figure 12-4 shows gamma doses for the Livermore site perimeter, Livermore Valley, and Site 300 from 1988 through 2000. Beginning in 1995, all quarterly gamma radiation data points were normalized to standard, 90-day quarters, as is the practice of the $\mathrm{N}$ uclear R egulatory Commission (N RC) (Struckmeyer 1994). Correcting the data to standard quarters to normalize the data to the same number of days deployed reduces the variability caused by exposure duration.

\section{Livermore Site}

Table 12-1 presents a summary of the quarterly and annual TLD gamma radiation dose equivalents for the Livermore site perimeter locations and
L ivermore Valley off-site locations. The annual 2000 dose equivalent from external, direct-radiation exposure at the Livermore site perimeter, $0.571 \mathrm{mSv}$, is statistically the same as the background external dose measured in the Livermore Valley, $0.565 \mathrm{mSv}$. Table 12-2 lists the yearly doses due to direct gamma radiation at the L ivermore site perimeter. All doses fall within the predicted range for background radiation, and no LLN L operational impacts are discernible.

Site 300

As seen in Table 12-1, the measured Site 300perimeter annual average dose in 2000 was $0.644 \mathrm{mSv}$. The measured dose at the off-site locations near Site 300 was $0.559 \mathrm{mSv}$. H istorically, the off-site dose near Site 300, though 


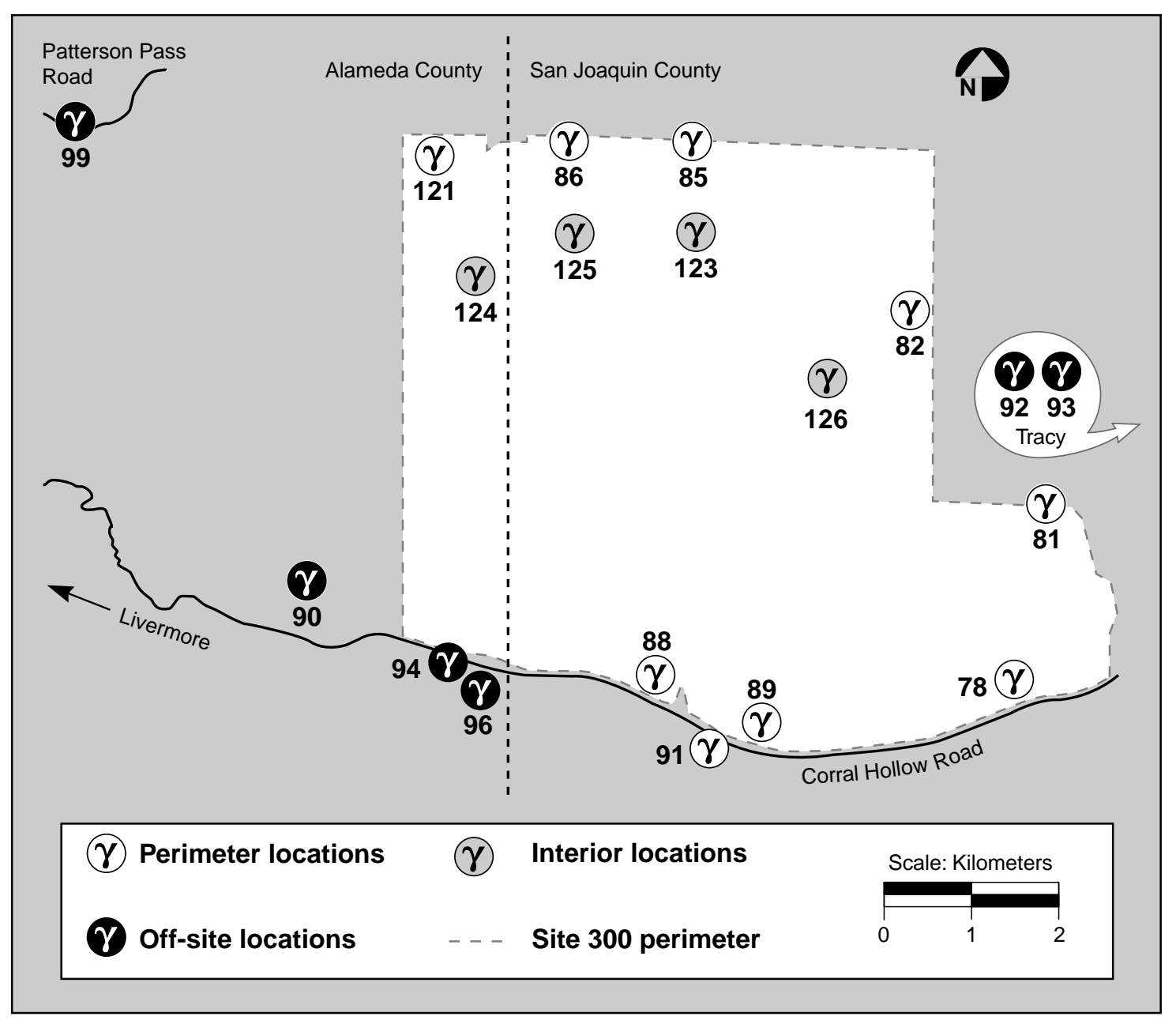

Figure 12-3. Gamma dosimeter locations, Site 300 and vicinity, 2000.

slightly higher, is statistically equivalent to the on-site measured dose. The annual off-site dose reported this year is represented by only three quarters due to the lost samples in the second quarter. The on-site dose is represented by the sum of four quarterly doses measured and therefore yields a higher annual dose this year. The annual dose measured for Tracy was $0.590 \mathrm{mSv}$ and is similar to the annual dose for 1999. All doses are within the predicted range for background radiation, and no LLNL operational impacts are discernible.
The region around Site 300 has higher levels of naturally occurring uranium present in the local geological area called the N eroly Formation. Although this year's annual dose for off-site 300 location was reduced by missing samples, 4 interior locations were added for safety concerns as a result of the fire in the second quarter and will likely impact the data set in the year 2001 by comparison.

The off-site locations have historically represented the high end of background radiation due to the geological substrate mentioned above. Samples collected for the Tracy area, with a measured 
Table 12-1. Summary of dose calculations for gamma-monitoring locations (mSv) ${ }^{(a)}$ at all LLNL sites, 2000

\begin{tabular}{|c|c|c|c|c|c|}
\hline \multirow{3}{*}{ Quarter } & \multicolumn{5}{|c|}{ Location } \\
\hline & Livermore site & Livermore Valley & Site $300^{(b)}$ & Tracy & Near Site $300^{(b)}$ \\
\hline & Mean $2 \mathrm{SE}^{(\mathrm{c})}$ & Mean $2 \mathrm{SE}^{(\mathrm{c})}$ & Mean $2 \mathrm{SE}^{(\mathrm{c})}$ & Mean $2 \mathrm{SE}^{(\mathrm{c})}$ & Mean $2 \mathrm{SE}^{(\mathrm{c})}$ \\
\hline First & $0.145 \pm 0.006$ & $0.144 \pm 0.007$ & $0.172 \pm 0.006$ & $0.156 \pm 0.001$ & $0.186 \pm 0.032$ \\
\hline Second & $0.141 \pm 0.007$ & $0.137 \pm 0.007$ & $0.159 \pm 0.014$ & $0.138 \pm 0.010$ & $-^{(d)} \pm-^{(e)}$ \\
\hline Third & $0.140 \pm 0.006$ & $0.140 \pm 0.007$ & $0.154 \pm 0.010$ & $0.142 \pm 0.014$ & $0.189 \pm 0.030$ \\
\hline Fourth & $0.145 \pm 0.006$ & $0.144 \pm 0.006$ & $0.159 \pm 0.012$ & $0.154 \pm 0.023$ & $0.184 \pm 0.037$ \\
\hline Annual dose & $0.571 \pm 0.002$ & $0.565 \pm 0.003$ & $0.644 \pm 0.007$ & $0.590 \pm 0.013$ & $0.559 \pm 0.002$ \\
\hline
\end{tabular}

a $1 \mathrm{mSv}=100 \mathrm{mrem}$

b Six of nine Site 300 perimeter samples and three of four near Site 300 samples were lost due to fire.

c $\mathrm{SE}=$ Standard Error (standard deviation of the mean)

d Insufficient number of samples to calculate the mean

e Insufficient number of samples to calculate the SE

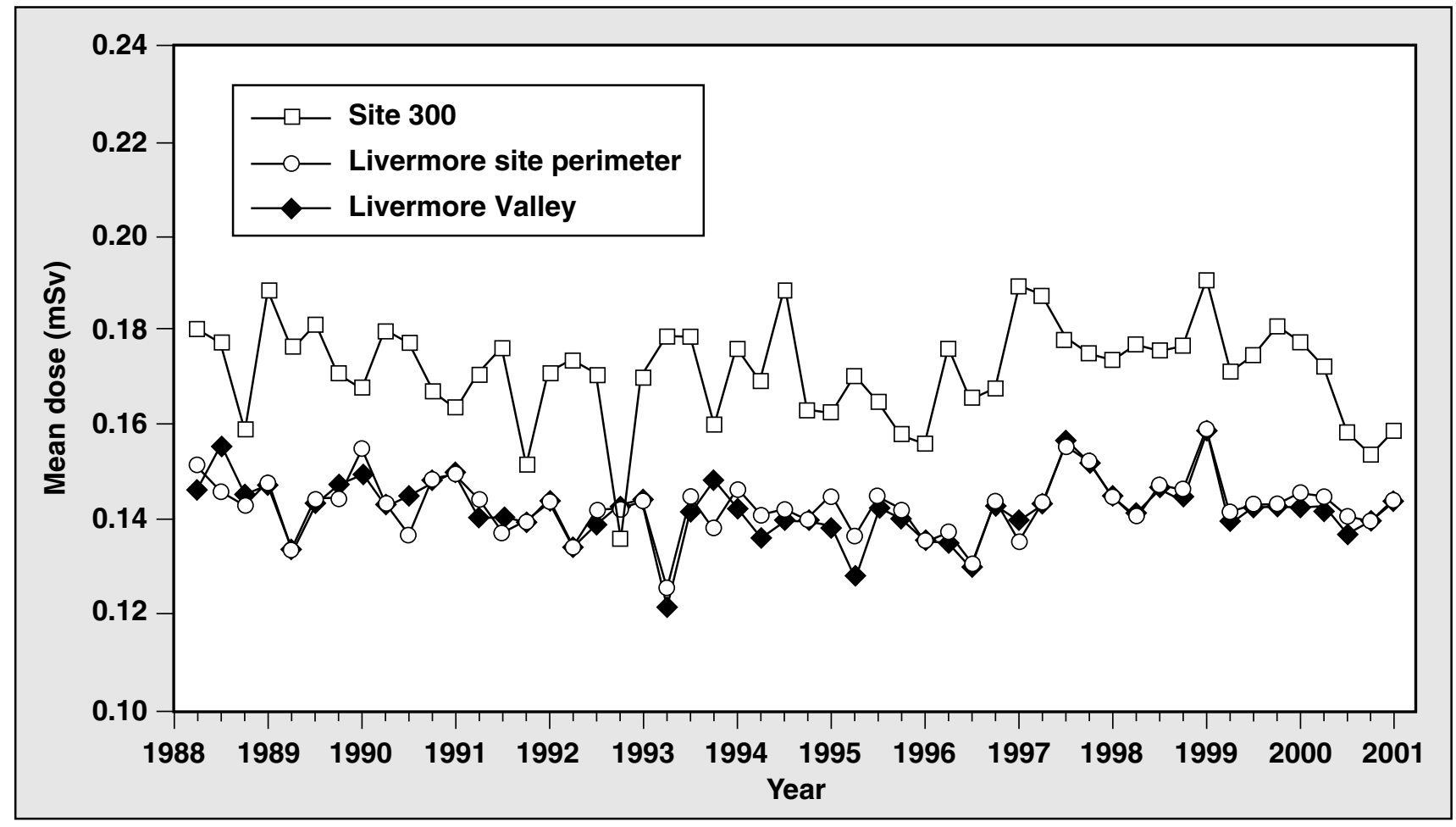

Figure 12-4. Quarterly gamma dose measurements at the Livermore site perimeter, Livermore Valley, and Site 300, 1988-2000 
annual dose of $0.590 \mathrm{mSv}$ were not affected by the 2 nd quarter loss. This area is underlain by a geological substrate composed of alluvial deposits of clays, sands, and silts overlying bedrock. The difference in the doses can be directly attributed to the difference in geologic substrates.

Table 12-2. Annual dose by year at the Livermore site perimeter caused by direct gamma radiation. $(a)$

\begin{tabular}{|c|c|c|}
\hline Year & mSv & mrem \\
\hline 1988 & 0.59 & 59 \\
1989 & 0.58 & 58 \\
1990 & 0.58 & 58 \\
1991 & 0.56 & 56 \\
1992 & 0.56 & 56 \\
1993 & 0.57 & 57 \\
1994 & 0.56 & 56 \\
1995 & 0.56 & 56 \\
1996 & 0.55 & 55 \\
1997 & 0.59 & 59 \\
1998 & 0.60 & 60 \\
1999 & 0.58 & 58 \\
2000 & 0.57 & 57 \\
\hline
\end{tabular}

a Data normalized to standard 90 days per quarter (360 days per year).

The doses at the Livermore-site perimeter and in the Livermore Valley are comparable from 1988 to 2000. However, while Site 300 doses are similarly comparable, TLDs there continue to record slightly higher direct gamma doses than do the Livermore site and the Livermore Valley, which is expected, given the differences in geology among these sites.

\section{Environmental Impact}

Although the contribution of cosmic radiation may vary due to the sun cycle, the sum of the measured terrestrial and cosmic radiation dose has been observed to range from 0.6 to $0.7 \mathrm{mSv} / \mathrm{y}$. In addition, variability due to the local geology and meteorology will also affect this range slightly. Direct radiation doses measured at the Livermore site perimeter in 2000 are near these predicted values and are statistically equivalent to the Livermore Valley doses, which are considered natural background levels. Although measured gamma exposure at Site 300 and the local vicinity are slightly higher than reported for the Livermore site and Livermore Valley, their range is attributed primarily to the variation of the geological substrate containing radionuclides of natural origin. The annual gamma radiation measured by the TLD network indicates that the exposure level is not elevated above natural background for any of the monitoring sites due to LLNL operations. 



\section{Radiological Dose AsSESSMENT}

\section{Introduction}

Radiological doses to the public result from both natural and man-made radiation. The doses received by individuals and populations can be determined by measurements and calculations. This chapter describes Lawrence Livermore National Laboratory's radiological dose assessments, which are made to determine the impact of LLNL operations on the public and the environment. It includes a discussion of the analyses performed to demonstrate LLNL's compliance with the radiological National Emission Standards for Hazardous Air Pollutants (NESHAPs; Title 40 Code of Federal Regulations [CFR], Part 61, Subpart H).

\section{Background Information}

Because this chapter is written for a diverse readership, from scientists and regulators to interested citizens with limited scientific training, a description is given of concepts, methods, tools, and other basic material in the first few sections as well as in Appendix D. Part D-1, Radiation Basics, covers the different sources and types of radiation and the units used to quantify radiation, and it provides perspective on the wide range of radiation levels that people commonly encounter. Part D-2, Radiation Control Measures at LLNL, sketches the standard operating procedures used to protect employees, the public, and the environment from uncontrolled releases and unsafe levels of radiation.

A discussion of sources, principal public receptors, and other aspects of modeling and monitoring follows the introductory material in the main text, leading to a presentation of key results on dose impacts from operations conducted in 2000. Readers desiring to go directly to these principal new results can turn to the section "Radiological Doses to the Public from 2000 LLNL Operations.” 


\section{Releases of Radioactivity to Air}

Releases to the air are by far the major source of public radiological exposures from LLNL operations. In contrast, releases to groundwater, surface water, and sewerable water are not sources of direct public exposures because these waters are not directly consumed or used by the public. Water releases can cause indirect exposures, which are treated as special cases; for example, a recent case considered the possible dose to the public from inhalation and ingestion of soil contaminated by sewer effluent containing radioactivity (U.S. Department of Health and Human Services 1999). Apart from such unusual occurrences, measurements and modeling of releases to air determine LLNL's radiological dose to the public.

Data are gathered by three principal means: routine surveillance air monitoring for radioactive particles and gases, both on and off Laboratory property (described in Chapter 5); continuous monitoring of stack effluent at selected facilities at the Livermore site (described in Chapter 4); and usage inventories at all noncontinuously monitored or unmonitored facilities housing radioactive materials management areas and for radioactive materials used in explosive experiments at Site 300 (described in LLNL's NESHAPs annual reports [e.g., Gallegos et al. 2001]).

Despite this emphasis on air monitoring, it should be noted that LLNL's extensive environmental monitoring program encompasses a variety of media and a wide range of potential contaminants; it is not limited to radioactive ones. In addition to air monitoring and the three categories of water monitoring already mentioned, the Laboratory samples soil, sediment, vegetation, and wine, and measures environmental (gamma) radiation. Monitoring has been described extensively since 1971 in LLNL's environmental reports (e.g., Larson et al. 2000; see also Chapters 4 through 12 in the present report) and in LLNL's triennially updated Environmental Monitoring Plan (e.g., Tate et al. 1999) and its associated procedures and guidance documents.

\section{Air Dispersion and Dose Models}

Theoretical/calculational models are needed to describe the transport and dispersion in air of contaminants and the doses received by exposed persons. Various factors dictate this need for modeling: (1) the amounts of LLNL-generated radioactive material dispersed into the atmosphere cause doses thousands of times smaller than those caused by natural background radiation (arising from irradiation by cosmic rays, inhalation of radon gas, exposure to radioactive materials in soil and rock, and ingestion of naturally occurring radionuclides present in our food and water; see Appendix D, Part D-1), so it is difficult to demonstrate compliance with standards through physical measurements alone; (2) all potentially significant exposure pathways need to be taken into account when estimating dose impacts; and (3) the U.S. Department of Energy (DOE) and the U.S. Environmental Protection Agency (EPA) sanction the use of specific computer codes that implement their approved dosimetry and dispersion models for evaluating potential doses to the public from both routine and unplanned releases. Advantages of a well-developed modeling capability include its utility in source design and optimization (e.g., estimating effects of hypothetical and/or dangerous sources) and in interpreting past events (e.g., in dose reconstruction).

The computer programs used at LLNL to model air releases and their impacts feature idealized, Gaussian-shaped plumes and can be run on personal computers. The CAP88-PC code (Parks 1992), in particular, incorporates dosimetric and health effects data and equations that are mandated by EPA to be used in compliance assessments. 
Furthermore, CAP88-PC accommodates sitespecific input data files to characterize meteorological conditions and population distributions for both individual and collective dose evaluations, and the code is relatively easy to use and understand. For these reasons, CAP88-PC has been the "workhorse" modeling tool for LLNL's regulatory compliance assessments since its availability in March 1992, particularly as applied to chronic releases of radioactivity to air occurring in the course of routine operations.

\section{Radiation Protection Standards}

The release of radionuclides from operations at LLNL and the resultant radiological impact to the public are regulated by both DOE and EPA.

DOE environmental radiation protection standards, provided under the authority of the Atomic Energy Act of 1954 and the DOE Organization Act of 1977 (both as amended), are defined in DOE Order 5400.5, Radiation Protection of the Public and the Environment. The standards for controlling exposures to the public from operations at DOE facilities that are incorporated in this order are based on recommendations by the International Commission on Radiological Protection (ICRP). The radiological impact to the public is assessed in accordance with the applicable portions of DOE Order 5400.1, General Environmental Protection. Current indices and links to DOE orders appear on the Department of Energy Directives website: http://www.directives.doe.gov.

The primary DOE radiation standards for protection of the public are 1 millisievert per year $(1 \mathrm{mSv} / \mathrm{y})$ or 100 millirem per year $(100 \mathrm{mrem} / \mathrm{y})$ whole-body effective dose equivalent (EDE) for prolonged exposure of a maximally exposed individual in an uncontrolled area and $5 \mathrm{mSv} / \mathrm{y}$ (500 mrem/y) EDE for occasional exposure of this individual. (EDEs and other technical terms are discussed in Appendix D, Part D-1 and defined in the glossary of this report.) These limits pertain to the sum of the EDE from external radiation and the committed 50-year EDE from radioactive materials ingested or inhaled during a particular year that may remain in the body for many years.

Radionuclide emissions to the atmosphere from DOE facilities are further regulated by the EPA, under the authority of Section 112 of the Clean Air Act. Subpart H of NESHAPs, under 40 CFR 61, sets standards for public exposure to airborne radioactive materials (other than radon) released by DOE facilities; radon is regulated by Subparts Q and T. NESHAPs implements the dosimetry system recommended by the ICRP in Publication 26 (ICRP 1977).

The EPA's radiation dose standard, which applies only to air emissions, limits the EDE to members of the public caused by activities/operations at a DOE facility to $100 \mu \mathrm{Sv} / \mathrm{y}(10 \mathrm{mrem} / \mathrm{y})$. EPA regulations specify not only the allowed levels, but also the approved methods by which airborne emissions and their impacts must be evaluated. With respect to all new and/or modified projects, NESHAPs compliance obligations define the requirements to install continuous air effluent monitoring and to obtain EPA approval for startup of operations. NESHAPs regulations require that any operation with the potential to produce an annual-averaged off-site dose greater than or equal to $1 \mu \mathrm{Sv} / \mathrm{y}(0.1 \mathrm{mrem} / \mathrm{y})$, taking full credit for emission-abatement devices, such as high-efficiency particulate air (HEPA) filters, must obtain EPA approval prior to startup of operations. This same calculation, but without taking any credit for emission abatement devices, determines whether or not continuous monitoring of emissions to air from this project is required. These requirements are spelled out in LLNL's online Environment, Safety, and Health (ES\&H) Manual in Document 31.1, "Air Quality Compliance," which can be found at the 
following Internet address:

http://www.llnl.gov/es_and_h/hsm/doc_31.01/ doc31-01.html.

\section{Reporting Requirements}

All DOE facilities that conduct significant environmental protection programs are required by $\mathrm{DOE}$ to prepare an annual environmental report for the site, covering activities of the previous calendar year involving releases to all media via all pathways. Because DOE facilities and operations are subject to the regulatory requirements of EPA, in particular 40 CFR 61, Subpart H, DOE facilities are further required to submit an annual report to the EPA, via DOE, showing compliance with NESHAPs (addressing only releases to air).

Details on reporting requirements and citation of pertinent DOE orders and federal regulations are available in the chapter on radiological dose assessment in earlier environmental reports (e.g., Harrach et al. 1997) or LLNL's radiological dose assessment guidance document (Harrach 1998).

\section{Evaluation of Sources of Radioactive Emissions}

The starting point for an assessment of radiological dose is to identify and properly characterize all significant sources of radioactive emissions at a site. LLNL's sources are determined in three principal ways: (1) by an inventory process, (2) by direct measurement of the emission rate at the source (continuous effluent monitoring), and (3) by monitoring airborne gases and particulate matter at selected field points in and around the Livermore site and Site 300 (continuous surveillance air monitoring).

\section{Inventoried Sources}

Radiological operations areas are any locations where radioactive materials are used or stored, or where activation products occur. Several such areas at the Livermore site have effluent monitoring systems in place in their exhaust pathways, allowing a direct measurement of their emission rates. For unmonitored or noncontinuously monitored radiological operations areas, source terms for potential releases are inferred from radionuclide inventories, in accordance with EPA methods.

Experimenters and facility managers provide inventory data, following a protocol designed and administered by LLNL's Environmental Protection Department. A full (100\%) inventory is conducted every three years, including 1994, 1997, and 2000. Only the key Livermore site facilities, defined as those in a ranked list that collectively accounted for $90 \%$ or more of the previous year's Livermore site radiological dose to members of the public, are reinventoried annually. In addition, all new radiological operations areas (ones that commenced operations in the year under evaluation) are inventoried, and data on radionuclides used in all Site 300 explosives experiments are provided each year. A description of LLNL's inventory process, including examples of the inventory form and accompanying instructions, is given in the guidance document for preparation of NESHAPs annual reports (Gallegos 1998).

For dose-assessment modeling of unmonitored or noncontinuously monitored sources, the effective emission rate is calculated from radiological usage inventories by applying EPA-specified fractions for potential release to air of materials in different physical states (solid, liquid, powder, or gas) for each radioisotope. The inventory quantity (in becquerels or curies) is multiplied by a state-dependent release fraction to give the potential annual release to air, i.e., the effective emission rate, in 
accordance with 40 CFR 61, Appendix D. If the material is an unconfined gas, the release fraction is 1.0; for liquids and powders, $1.0 \times 10^{-3}$ is used; and for solids, $1.0 \times 10^{-6}$. In the same way, if the radioactive material is encapsulated or sealed for the entire year (i.e., it was not used and release to air was prevented), then its release fraction is considered to be zero. For materials that were encapsulated or sealed for part of the year, or that resided in different facilities over the course of the year, time weighting factors are introduced to properly account for the release potential. Information on inventories and descriptions of the diffuse sources can be found in the guidance document (Gallegos 1998) and in NESHAPs annual reports.

\section{Monitored Sources}

\section{Stack Effluent Monitoring}

Actual measurements of radionuclides in effluent flow are the basis for reported emissions from continuously monitored sources. Six buildings at the Livermore site had continuously monitored discharge points in 2000: Buildings 175, 177, $251,331,332$, and 491; taken together, these buildings feature 76 continuously operating monitors. The monitoring systems are described in the LLNL NESHAPs 2000 Annual Report (Gallegos et al. 2001), as well as in Chapter 4.

The most significant monitored source in terms of public dose impact is the Tritium Facility, Building 331, at the Livermore site. Each of the two 30-m stacks on this facility has both a continuous-monitoring ion-chamber alarm system and continuous molecular-sieve samplers (see Chapter 4 in the Data Supplement). The sieve samplers, which can discriminate between tritiated water vapor (HTO) and molecular tritium gas (HT), provide the values used for environmental reporting. The alarmed ion chambers provide real-time tritium concentration for significant releases (HT plus HTO).
Monitoring of these stacks provides an accurate measure of the total quantity (in becquerels or curies) of tritium released to the environment, time-resolved over the course of the year. Because the stacks have known properties (height, flow rate, and diameter) and the wind field properties (wind speed, direction, and fluctuation characteristics) are continuously monitored, these data are optimal inputs to modeling, and the quality of these data affects the accuracy of air dispersion and dose assessment modeling more than any other input factors.

Discharge points at Buildings 175, 177, 251, 332, and 491 are monitored for gross alpha and gross beta radioactivity. Air samples for particulate emissions are extracted downstream of HEPA filters and prior to the discharge point to the atmosphere. Particles are collected on membrane filters. Sample results are generally found to be below the minimum detectable concentration (MDC) of the analysis; for details, see Chapter 4 in this report and the LLNL NESHAPs 2000 Annual Report

(Gallegos et al. 2001).

Among the six continuously monitored facilities at the Livermore site, only the Plutonium Facility (Building 332) requires monitoring under the EPA's 0.1-mrem/y standard alluded to in the subsection Radiation Protection Standards. The other five are continuously monitored for programmatic or other reasons. For example, continuous monitoring is maintained at the Tritium Facility (Building 331) to provide the most dependable and accurate information on stack releases of tritium, the most significant radionuclide at the Livermore site in terms of potential public dose impact. Continuous monitoring is maintained at the Heavy Elements Facility (Building 251) in lieu of undertaking a modeling and measurement effort that would be required to demonstrate that monitoring is not needed. 
Dose calculations based on effluent monitoring data are expected to be considerably more accurate than those relying on usage-inventory data, physical-state release-to-air fractions, emission-abatement factors, and time factors.

\section{Surveillance Air Monitoring}

To provide wide-area coverage complementing the stack effluent monitoring, surveillance air monitors are placed at selected locations at the Livermore site and Site 300 and in their vicinities to detect radioactive gases and particulate matter in ambient air. In addition, dose rates from external penetrating radiation (gamma rays) are measured using thermoluminescent dosimeters (TLDs). Siting of the air monitors and TLDs is done in accordance with the LLNL Environmental Monitoring Plan (Tate et al. 1999). Surveillance air monitors are also placed in the vicinity of known diffuse (extended area) emission sources at the Livermore site, specifically those associated with Buildings 292, 331, 514, and 612. Such monitors are also located in and around the Livermore site's southeast quadrant, and at on-site locations that provide wide coverage of Site 300. These special monitors measure the concentrations of radionuclides present in the air near the sources and allow a direct determination of their environmental impact (see Chapter 5). The surveillance air monitors not only are useful in gauging releases from routine operations; they have also proven valuable in quantifying the magnitude of accidental releases and their dose impacts.

\section{Determinations of Dose}

This section briefly describes the way LLNL estimates doses to the public for compliance purposes. It touches on the main modeling approaches, identifies the key hypothetical receptors that represent the most exposed public individuals, discusses some important aspects regarding the modeling of tritium, and briefly notes some of the special modeling challenges raised by diffuse sources and explosives experiments.

\section{Principal Modeling Approaches}

LLNL's primary calculational tool for estimating dose and risk to the public from routine operations and most unplanned releases is the computer code CAP88-PC. The user's guide (Parks 1992) provides useful information on the code, including discussions of the basic equations and key input and output files. Additional information, for example, about LLNL-site-specific data files and several important caveats on use of the code, has been presented in earlier environmental reports (e.g., Harrach et al. 1998) and more fully in the LLNL radiological dose assessment guidance document (Harrach 1998).

Other codes such as EPA's INPUFF code (Peterson and Lavdas 1986) or LLNL's HOTSPOT code (Homann 1994) can be used as needed to address unplanned releases or transient releases from normal operations or accidents. In 2000 the EPA granted regulatory "guideline model" status to two codes - the AERMOD and CALPUFF codeswhich are of considerably greater complexity than CAP88-PC, INPUFF, and HOTSPOT. Many other Gaussian-plume-type computer models are available for modeling various types of releases; see, for example, the annotated lists in Atmospheric Dispersion Modeling Resources (Oak Ridge 1995) and Supplement B to the Guideline on Air Quality Models (Revised) (U.S. EPA 1993).

A complementary approach to deriving EDEs using the built-in dosimetry model in CAP88-PC or other codes is to explicitly calculate them using mathematical formulas from, for example, the Nuclear Regulatory Commission's Regulatory 
Guide 1.109 (U.S. NRC 1977), which incorporate dose conversion factors consistent with those in the International Commission on Radiation Protection's Publication 30 (ICRP 1980). This approach, outlined in Appendix A of this report, has been used historically at LLNL (since 1979) and can be used to evaluate annual doses to the public inferred from sampling of local environmental media (air, water, vegetation, and wine).

\section{Identification of Key Receptors}

When assessing probable off-site impacts, LLNL pays particular attention to three potential doses. First is the dose to the sitewide maximally exposed individual member of the public (SW-MEI; defined below). Second is the dose to the maximally exposed individual (MEI) member of the public from a given emission point. Third is the collective or population dose received by people residing within $80 \mathrm{~km}$ of either of the two LLNL sites, adding the products of individual doses received and the number of people receiving them.

The SW-MEI is defined as the hypothetical member of the public at a single, publicly accessible location (where members of the public reside or abide) who receives the greatest LLNL-induced EDE from all sources at a site (e.g., the Livermore site). This dose sums the contributions of all emission points for evaluation under the EPA's $100 \mu \mathrm{Sv} / \mathrm{y}(10 \mathrm{mrem} / \mathrm{y})$ standard. Public facilities that could be the location of the SW-MEI include schools, churches, businesses, and residences. This hypothetical person is assumed to reside at this location 24 hours per day, 365 days per year, continuously breathing air having the ground-level radionuclide concentration, and consuming a specified fraction of food and drinking water that is affected by the releases of radioactivity from the site. Thus, the SW-MEI dose is not received by any actual individual and is used as a health-conservative estimate (i.e., overestimate) of the highest possible dose to any member of the public. The location of the SW-MEI is sensitive to the frequency distribution of wind speeds and directions and locations of key sources in a given year and can change from one year to the next. At the Livermore site, evaluation showed that the SWMEI in 2000 was, as in previous years, located at the UNCLE Credit Union, about 10 m outside the controlled eastern perimeter of the site. This location lies $948 \mathrm{~m}$ from the Tritium Facility (Building 331), in an east-northeast direction (the typical prevailing wind direction). At Site 300, the 2000 SW-MEI occupied a new position, on the south-central boundary of the site bordering the Carnegie State Vehicular Recreation Area, approximately $3.2 \mathrm{~km}$ south-southeast of the firing table at Building 851. For the past several years the Site 300 SW-MEI location was an experimental area termed "Bunker 2," operated by Primex Physics International, just outside the east-central boundary of Site 300; Primex terminated operations at this facility.

The location of the MEI is generally different for each emission point. The MEI dose is used to evaluate whether continuous monitoring of each particular emission point is required and whether it is necessity to petition the EPA for permission to start up an activity (new or modified project), as discussed in the Reporting Requirements section.

Doses to the MEI, with and without allowance for abatement, are a major consideration when new projects or changes to existing projects (in which releases of radioactivity to the environment may occur) are reviewed for joint compliance with NESHAPs and the National Environmental Policy Act (NEPA). The possible environmental and worker safety issues raised by each proposed activity or project are examined from several different points of view in a process coordinated by LLNL's Environmental Protection Department, including a review and evaluation of potential emissions of 
radionuclides and air toxics. Air-quality compliance requirements for projects are described in Document 31.1, "Air Quality Compliance," of LLNL's online ESerH Manual at the Internet address:

http://www.llnl.gov/es_and_h/hsm/doc_31.01/ doc31-01.html.

\section{Assessment Assumptions Regarding Tritium}

Several aspects of tritium dose estimates based on CAP88-PC should be noted.

\section{Relative Contributions to Dose from HTO and HT Emissions}

Tritium $\left({ }^{3} \mathrm{H}\right)$ emissions account for the major dose from operations at the Livermore site. These emissions exist in two major chemical forms: tritium oxide or tritiated water vapor (HTO) and tritium gas (HT). The doses received by exposure to these two forms differ greatly. HTO enters the body by ingestion, inhalation, and dermal absorption; HT enters by inhalation. Ingested HTO is distributed throughout the entire body and eliminated at the same rate as body water (apart from the small fraction metabolized). Inhaled HTO dissolves in the fluids of the lung and is absorbed. In contrast, very little of the HT that enters the body via inhalation is retained; most is exhaled. The EDE from inhalation of tritium gas is lower by a factor of about 10,000 than that from tritium oxide inhalation (ICRP 1994 and 1996), and, overall, HTO is traditionally considered to be 25,000 times more toxic than HT (Eckerman et al. 1988; ICRP 1979). HT requires conversion to HTO (oxidation) to produce significant dose.

Emissions of HTO are expected to be the major contributor to the tritium dose, particularly for nearby individual receptors, such as the MEI and SW-MEI; historically, LLNL's standard procedure has been to enter into CAP88-PC only the curies of HTO released to air, disregarding the HT component. A more conservative approach would be to treat all HT as HTO in tritium dose calculations. In April 1999, EPA mandated that LLNL do exactly that when calculating dose to the public for NESHAPs compliance purposes. It should be noted that this HT "dual" doses problem concerns only the Livermore site; at Site 300, tritium makes a negligible contribution to the public dose.

Whether the Livermore site SW-MEI dose and population dose are much affected by the different ways of including HT emissions depends on the balance of curies released as HT vs. HTO, and the degree to which tritium dominates other radionuclides in the calculation of potential dose. For example, in 1999, Tritium Facility emissions were divided between 214 curies of HTO and 67 curies of HT, HTO accounted for about $92 \%$ of the total dose, and the result of treating HT as HTO for the 1999 assessment was to increase the Livermore site dose to the SW-MEI by about $21 \%$, compared to the value obtained by neglecting the contribution of HT to the SW-MEI dose. The 1999 population dose from Livermore site operations, which gives greater weight to the emissions from the tall stacks of the Tritium Facility than does the SW-MEI dose, was increased by $28 \%$ when treating HT as though it were HTO. However, in 2000 these stacks released 35.4 curies as HTO and only 4.8 curies as HT, and HTO accounted for about $75 \%$ of the total dose. As reported below in the section on Radiological Doses to the Public from 2000 LLNL Operations, the SW-MEI dose for 2000 was increased less than $3 \%$ by treating HT as though it were HTO, and the population dose increased by less than $11 \%$. This chapter emphasizes doses excluding contributions from HT, both to provide continuity with doses reported in this annual environmental report in the past, and because we believe it is more accurate to do so than to represent HT as fully converted to HTO. 


\section{Dose-Rate-Conversion Factor for Tritium}

The dose-rate-conversion factor that CAP88-PC uses for inhalation-plus-dermal-absorption of tritium is outdated and more conservative than the values quoted in recent literature. The ICRP in its Publication 30 (ICRP 1979) recommended that skin intake should be $50 \%$ of lung intake, revising its earlier recommendation stated in Publication 2 (ICRP 1959) that skin intake equals lung intake. The CAP88-PC dose-rate-conversion factor for tritium contains the 1959 recommendation, producing an inhalation-plus-dermal-absorption dose that is too large by a factor $4 / 3$ relative to the more recent recommendation; see Attachment 3 in the NESHAPs 1995 Annual Report (Gallegos et al. 1996).

\section{Overestimate of Ingestion Dose for Tritium} CAP88-PC overestimates the ingestion dose from tritium in a manner that depends on input selections, according to a recent article by Barry Parks (Parks 1999). The cause can be traced to three key assumptions implicit in the software that may not be immediately apparent to the user: (1) the contribution of homegrown food, (2) the distances at which food is produced, and (3) the number of people consuming locally produced food. Documentation on how these overestimates can occur is also available on the Internet at the following address: http://www.er.doe.gov/production/er-80/cap88/tritium.html.

\section{Contribution from Ingestion of Organically Bound Tritium}

The dose-rate-conversion factor for ingestion of organically bound tritium (OBT) is 2.3 times larger than that for ingestion of the same concentration of tritium in the free water of plants and animals. However, because the concentration of free-water tritium exceeds the concentration of tritium in organic matter for most dietary components (per kilogram) in LLNL's ingestion dose assessment, free-water tritium makes the dominant contribution to dose. LLNL's standard operating procedure has been to disregard the OBT contribution.

\section{New LLNL Tritium Model That Distinguishes Doses from HTO, HT, and OBT}

A new model, called NEWTRIT, was developed at LLNL in 2000 to better evaluate the dose from tritium releases. The CAP88-PC model, as noted above, treats only the dispersion and dose consequences of the tritiated water vapor form of tritium (HTO). The new model distinguishes between releases to air of HT and HTO and takes into account the effects on dose of conversion of HT to HTO in the environment. NEWTRIT also accounts for dose from organically bound tritium in the diet. The NEWTRIT model was programmed into CAP88-PC and used to generate dose results for comparison with default CAP88-PC model runs. NEWTRIT uses the latest dose coefficients for HT, HTO, and OBT of the International Commission on Radiological Protection (ICRP 1995, 1996). This new model is discussed in the LLNL NESHAPs 2000 Annual Report (Gallegos et al. 2001).

The NEWTRIT model has been described in detail by its authors in a paper accepted for publication in Health Physics (Peterson and Davis 2001). It will be presented to the EPA and DOE for consideration of its use in regulatory compliance modeling.

\section{Special Modeling Problems}

Nonstack releases may require special measurements and calculations to characterize the source. Both the Livermore site and Site 300 provide important examples in this regard.

\section{Diffuse Sources}

Nonstack releases often fall into the classification of "diffuse sources." One example is the leakage of tritium-contaminated water from an underground 
retention tank at Building 292 at the Livermore site, which results in the release of tritium to the atmosphere via soil moisture evaporation and rootuptake and transpiration by plants - from one pine tree in particular. A discussion of this source appears in the Livermore Site Diffuse Sources section in the NESHAPs 1993 Annual Report (Harrach et al. 1994); subsequent NESHAPs annual reports provide updates. Emissions from certain difficult-to-characterize sources sometimes can be inferred from data obtained by LLNL's routine surveillance air monitoring program, in which the ambient air at selected locations within and outside Laboratory boundaries is continuously monitored for tritiated water vapor and radioactive particles. For example, the operations in the Building 612 waste storage yard at the Livermore site are characterized using data from an air monitor in the yard. Another example is the diffuse source caused by resuspension of depleted uranium in soil at Site 300; an air monitor at the location of the SW-MEI measures the annualaverage concentration of uranium in air. A theoretical model described in the NESHAPs 1995Annual Report (Gallegos et al. 1996) was developed to distinguish between the contribution made to these Site 300 data by LLNL-operations-contributed uranium, compared to the considerably larger contribution from naturally occurring uranium. The routine air surveillance monitoring program also has been particularly useful in registering the magnitude of unplanned releases; an example of this type is provided by the accidental release of curium-244 from Building 513 in 1997, discussed in the Executive Summary, Chapter 2, and Chapter 12 of LLNL's Environmental Report 1997 (Harrach et al. 1998), as well as in the NESHAPs 1997 Annual Report (Gallegos et al. 1998).

\section{Modeling Dose Impacts from Explosives Experiments at Site $\mathbf{3 0 0}$}

Special consideration must be given to modeling releases of radionuclides into the atmosphere from explosive tests at Site 300, compared to conventional stack or area sources. During experiments, an explosive device, which may contain depleted uranium, is placed on an open-air firing table and detonated. A cloud of explosive decomposition products forms promptly (on a roughly 1 -minute time-scale) over the firing table, typically reaching a height of several hundred meters, and disperses as it is carried downwind. (The depleted uranium does not contribute to the explosive energy, which is entirely of chemical origin.)

In the absence of measurements of the cloud properties, we assume for compliance modeling purposes that it instantaneously reaches an initial height and size governed by known empirical scaling laws for detonations, in which the scaling parameter is the TNT-equivalent explosive mass. The specific equations we use for the maximum elevation, $\mathrm{H}_{\max }$, reached by the plume and the diameter, D, of the cloud of decomposition products have been described elsewhere (Harrach et al. 1998, Harrach 1998).

Transport and dispersion of the quickly formed cloud are modeled using a Gaussian-plume airdispersion code. A puff-code-based modeling methodology was submitted to EPA for approval in 1992 (Biermann et al. 1993). It would treat these transient explosive events as short-duration bursts or puffs, would incorporate some of the effects of the hilly terrain at Site 300 , and would use meteorological data appropriate to the cloud-dispersal period. EPA decided that, from the standpoint of regulatory compliance, the use of CAP88-PC to model these explosives experiments was adequate, despite the recognized difficulties. CAP88-PC simulates each explosive experiment or shot as a continuous, year-long, stack-type emission (i.e., the total activity released in a time period of order 1 minute in the explosion is treated as though it were released gradually over the course of an entire year), with meteorological data corresponding to 
annual-average conditions at Site 300. As inputs to the code, the scaling results for $\mathrm{H}_{\max }$ and $\mathrm{D}$ are used as a fixed plume height and stack diameter.

LLNL uses isotopic ratios for depleted uranium and determines the contribution of each isotope to dose. The isotopes uranium-238, uranium-235, and uranium-234 occur in the weight-fractions $0.998,0.002$, and $5 \times 10^{-6}$, respectively. The inventory for each explosive experiment specifies the mass of depleted uranium used: $\mathrm{M}_{\mathrm{DU}}(\mathrm{kg})$. The number of curies for each isotope in the cloud is then given by the product of its weight fraction, the mass of depleted uranium, and the specific activity (number of curies per kilogram) of the isotope. Uranium-235 has a specific activity of $2.14 \times 10^{-3} \mathrm{Ci} / \mathrm{kg}$, so that multiplying by the weight fraction 0.002 gives the number of curies of uranium-235 in the cloud to be $4.28 \times 10^{-6}(\mathrm{Ci} / \mathrm{kg}) \times \mathrm{M}_{\mathrm{DU}}(\mathrm{kg})$. The corresponding expressions for uranium-238 and uranium-234 are $3.32 \times 10^{-4}(\mathrm{Ci} / \mathrm{kg}) \times \mathrm{M}_{\mathrm{DU}}(\mathrm{kg})$ and $3.10 \times 10^{-5}(\mathrm{Ci} / \mathrm{kg}) \times \mathrm{M}_{\mathrm{DU}}(\mathrm{kg})$, respectively.

In the absence of detailed data about the explosive experiments, several highly conservative assumptions are made in our calculations. These assumptions are (1) 100\% of the depleted uranium present in the experiment is completely aerosolized and dispersed as a cloud (i.e., the release-to-air fraction is 1$)$; (2) the median particle size is the CAP88-PC default value of $1 \mu \mathrm{m}$; and (3) the lung clearance class for inhaled material is class Y. (Note: Clearance of inhaled material from the lung to the blood or to the gastrointestinal tract depends on the chemical form [e.g., $\mathrm{U}_{3} \mathrm{O}_{8}$ ] of the radionuclide and is classified as D, W, and $\mathrm{Y}$, respectively, for clearance times of order days, weeks, and years.) These assumptions may produce a dose that is too high by a factor of 10 or more. We believe a more realistic release-to-air fraction for the uranium is no greater than 0.2 , but we lack sufficient documentation to use a value other than 1.0. Also, the median particle size may be much larger than $1 \mu \mathrm{m}$, and a sizable fraction of the aerosolized particles might be more properly characterized by lung clearance class $\mathrm{D}$, which produces a dose by inhalation of depleted uranium that is smaller by a factor of about 16 compared to class Y. Even with these assumptions, the MEI and SW-MEI individual doses as well as the collective or population dose that we calculate annually for the explosive experiments are very small compared with natural background levels and regulatory standards (see the "Summary and Conclusions" section of this chapter).

\section{Radiological Doses to the Public from 2000 LLNL Operations}

Nearly 170 emission points were evaluated in the 2000 modeling runs. These emission sources were of several types: stacks and other exhaust pathways from buildings, diffuse area sources generally located external to buildings, and open-air firing tables at Site 300 where explosives experiments were conducted.

The principal diffuse sources at the Livermore site in 2000 were the waste storage, management, and drum sampling areas at the Building 612 Yard, a waste accumulation area located outside the Tritium Facility (Building 331), and the Building 514 Evaporator. The principal diffuse source at Site 300 was resuspension of depleted uranium over the total land area of the site.

This section summarizes the main results of LLNL's calculations for 2000 operations and exhibits the trends in these results over recent years. For further details, especially regarding the diffuse sources at the two sites, see the $L L N L$ NESHAPs 2000 Annual Report (Gallegos et al. 2001). 


\section{Dose Breakdown by Facility}

Table 13-1 lists all LLNL facilities and diffuse sources having the potential to release radioactivity into the environment during 2000. For each facility or building, the table gives the number of stacks or other exhaust avenues discharging radionuclides; lists the dose to the SW-MEI caused by the single, most dominant emission point at each facility; and identifies the types of operations occurring in the building or facility or the nature of the diffuse source. Corresponding data are included for the Site 300 explosive experiments. Facilities in which no operations using radionuclides took place in 2000 or in which any radionuclides present were encapsulated or sealed for the entire year are excluded from Table 13-1.

A principal feature shown in Table 13-1 is that LLNL has a large number of very small radioactive sources and only a few that could be considered significant. As shown more clearly in subsequent tables, about a half-dozen sources account for nearly all of the dose to members of the public, and the total dose is quite small compared with federal standards for radiation protection of the public.

\section{Unplanned Releases}

There were no unplanned atmospheric releases at the Livermore site or Site 300 in 2000.

\section{Doses to Public Site-Wide Maximally Exposed Individuals}

Total dose to the site-wide maximally exposed (public) individual (SW-MEI) at the Livermore site in 2000 was $0.37 \mu \mathrm{Sv}(0.037 \mathrm{mrem})$, divided $43 \%-$ $57 \%$ between point and diffuse (extended area) source emissions. This sort of division between dose levels attributed to these two types of sources contrasts with previous years, when doses to the public from stack emissions at the Livermore site considerably exceeded those from diffuse sources. Furthermore, in 2000, for the first time, a diffuse source-the Building 612 Yard for waste storage and management-was the single largest contributor to the SW-MEI dose, accounting for $0.15 \mu \mathrm{Sv}$ $(0.015 \mathrm{mrem})$, or more than $40 \%$ of the total. Emissions from the two 30-m stacks at the LLNL Tritium Facility (Building 331), historically the leading source, accounted for an unusually small $23 \%$ of the total dose.

The 2000 Livermore site SW-MEI dose is down by a factor of 2.7 from the previous year's value, principally owing to a nearly sixfold decrease in HTO emissions from the stacks of the Tritium Facility (Building 331): $1.3 \times 10^{12} \mathrm{~Bq}(35.4 \mathrm{Ci})$ of HTO in 2000 , compared to $7.9 \times 10^{12} \mathrm{~Bq}(214 \mathrm{Ci})$ the previous year. Emissions of HT from these stacks were also low in 2000, amounting to less than $1.8 \times 10^{11} \mathrm{~Bq}(4.8 \mathrm{Ci})$, which is about $7 \%$ of the previous year's value.

The foregoing dose numbers were obtained by neglecting contributions to dose from HT releases, relative to HTO releases; see the section on Assessment Assumptions Regarding Tritium. Calculating dose as recently directed by EPA (treating HT as though it were HTO in CAP88-PC model runs) only slightly increases the total annual dose to the SW-MEI from Livermore-site operations in 2000, to $0.38 \mu \mathrm{Sv}(0.038 \mathrm{mrem})$, since little HT was released.

The calculated EDE to the SW-MEI at Site 300 in 2000 was $0.19 \mu S_{v}(0.019 \mathrm{mrem})$. Seventy-nine percent, or $0.15 \mu \mathrm{Sv}(0.015 \mathrm{mrem})$, was attributed to releases to air of depleted uranium in explosives experiments conducted at the Building 851 firing table. The remaining $21 \%$ of the total was attributed to Site 300 diffuse sources. Resuspension of operations-contributed uranium in Site 300 surface soils (i.e., uranium deposited into the soils by LLNL experiments and other activities as opposed 
Table 13-1. Sources of radiation dose from LLNL releases (measured and potential) to air: stacks and other exhaust pathways from buildings containing radiological operations, and diffuse area sources $^{(a, b)}$

\begin{tabular}{|c|c|c|c|c|}
\hline Bldg & Facility & $\begin{array}{l}\text { Potential } \\
\text { emission } \\
\text { points }\end{array}$ & $\begin{array}{l}\text { Maximum } \\
\operatorname{EDE}^{(\mathrm{c})} \\
(\mu \mathrm{Sv} / \mathrm{y})\end{array}$ & Operations \\
\hline \multicolumn{5}{|c|}{ Livermore site point sources } \\
\hline $\begin{array}{l}131 \\
\text { Highbay }\end{array}$ & $\begin{array}{l}\text { Offices and laboratories, } \\
\text { Mechanical \& Electrical } \\
\text { Engineering }\end{array}$ & 3 & $8.6 \times 10^{-10}$ & Storage and display of post-test materials \\
\hline $132 \mathrm{~N}$ & $\begin{array}{l}\text { Offices and laboratories; } \\
\text { Chemistry \& Materials } \\
\text { Sciences; Nonproliferation, } \\
\text { Arms Control \& International } \\
\text { Security (NAI); and others }\end{array}$ & 6 & $1.0 \times 10^{-3}$ & $\begin{array}{l}\text { Preparation of samples for radiochemical analysis; } \\
\text { analysis of aqueous solutions and waste samples }\end{array}$ \\
\hline $132 S$ & See Building $132 \mathrm{~N}$ & 1 & $2.1 \times 10^{-10}$ & Transfer of uranium \\
\hline 151 & $\begin{array}{l}\text { Isotope Sciences Chemistry \& } \\
\text { Materials Science Environ- } \\
\text { mental Services Laboratory }\end{array}$ & 33 & $3.4 \times 10^{-3}$ & $\begin{array}{l}\text { Application of nuclear and isotope sciences to a } \\
\text { wide range of research; sample analysis of waste } \\
\text { streams and environmental media for radionuclide } \\
\text { content }\end{array}$ \\
\hline 175 & Space Action Team & 6 & $0.0^{(\mathrm{d})}$ & Operations discontinued \\
\hline 177 & Space Action Team & 1 & $0.0^{(\mathrm{d})}$ & Operations discontinued \\
\hline 194 & Physics \& Space Technology & 4 & $5.2 \times 10^{-5}$ & $\begin{array}{l}\text { High-energy linear accelerator, positron beam } \\
\text { generation and experiments; materials science } \\
\text { experiments }\end{array}$ \\
\hline 212 & Physics \& Space Technology & 2 & $8.5 \times 10^{-11}$ & $\begin{array}{l}\text { Physics experiments, residual contamination from } \\
\text { previous operation of rotating target neutron source } \\
\text { (no longer operating) }\end{array}$ \\
\hline 231 & $\begin{array}{l}\text { Chemistry \& Materials Science; } \\
\text { Engineering, Weapons Engi- } \\
\text { neering; Safeguards \& Security }\end{array}$ & 17 & $1.4 \times 10^{-6}$ & $\begin{array}{l}\text { Materials research and testing, metals processing } \\
\text { and characterization, electron-beam welding, } \\
\text { grinding/ polishing, casting, microscopy, sample } \\
\text { preparation, storage }\end{array}$ \\
\hline 235 & Chemistry \& Materials Science & 5 & $3.7 \times 10^{-7}$ & $\begin{array}{l}\text { Material structure studies, precision cutting, ion } \\
\text { implantation, metallurgical studies, sample prepara- } \\
\text { tion }\end{array}$ \\
\hline 241 & Chemistry \& Materials Science & 6 & $1.8 \times 10^{-4}$ & $\begin{array}{l}\text { Materials properties research and testing on } \\
\text { uranium; hybridization studies with nucleic acids } \\
\text { from soil bacteria }\end{array}$ \\
\hline \multirow[t]{3}{*}{251} & $\begin{array}{l}\text { Heavy Elements Facility, Physics } \\
\text { \& Space Technology }\end{array}$ & & & Storage of transuranic isotopes prior to disposal \\
\hline & Seismically hardened area & 4 & $0.0^{(\mathrm{d})}$ & \\
\hline & Unhardened areas & 28 & $1.4 \times 10^{-5}$ & \\
\hline 253 & Hazards Control & 10 & $2.8 \times 10^{-8}$ & Radiochemical analysis and counting of samples \\
\hline 254 & Hazards Control & 4 & $5.0 \times 10^{-10}$ & $\begin{array}{l}\text { Bioassays; analytical services; urine analyses for } \\
\text { radionuclides }\end{array}$ \\
\hline 255 & Hazards Control & 2 & $9.9 \times 10^{-5}$ & Radiation standards and instrument calibration \\
\hline 281 & Energy \& Environmental & 5 & $4.0 \times 10^{-7}$ & $\begin{array}{l}\text { Sample preparation, radioactivity migration studies, } \\
\text { tracers, flow studies }\end{array}$ \\
\hline 282 & Energy \& Environmental & 1 & $6.2 \times 10^{-12}$ & Residual tritium contamination from past activities \\
\hline
\end{tabular}


Table 13-1. Sources of radiation dose from LLNL releases (measured and potential) to air: stacks and other exhaust pathways from buildings containing radiological operations, and diffuse area sources $^{(a, b)}$ (continued)

\begin{tabular}{|c|c|c|c|c|}
\hline Bldg & Facility & $\begin{array}{l}\text { Potential } \\
\text { emission } \\
\text { points }\end{array}$ & $\begin{array}{l}\operatorname{Maximum} \\
\operatorname{EDE}^{(\mathrm{c})} \\
(\mu \mathrm{Sv} / \mathrm{y})\end{array}$ & Operations \\
\hline 292 & Environmental Programs & 3 & $3.9 \times 10^{-5}$ & Tritium contamination from prior operations \\
\hline 298 & NIF Programs Research & 3 & $5.7 \times 10^{-6}$ & Laser fusion targets research and development \\
\hline 321 & $\begin{array}{l}\text { Mechanical Engineering, } \\
\text { Materials Fabrication }\end{array}$ & 6 & $3.4 \times 10^{-7}$ & $\begin{array}{l}\text { Milling, shaping, heat treating, and machining } \\
\text { depleted uranium parts }\end{array}$ \\
\hline 322 & Mechanical Engineering & 1 & $5.0 \times 10^{-9}$ & Cleaning and plating of depleted uranium \\
\hline 327 & Mechanical Engineering & 1 & $1.9 \times 10^{-7}$ & Nondestructive ultrasonic material evaluation \\
\hline 331 & $\begin{array}{l}\text { Tritium Facility, Defense \& } \\
\text { Nuclear Technologies }\end{array}$ & 2 & $7.4 \times 10^{-2(d, e)}$ & $\begin{array}{l}\text { Tritium research and development, facility decon- } \\
\text { tamination and decommissioning operations }\end{array}$ \\
\hline 332 & $\begin{array}{l}\text { Plutonium Facility, Defense } \\
\text { Sciences Program }\end{array}$ & 8 & $0.0^{(\mathrm{d})}$ & Plutonium research \\
\hline 341 & Laser Directorate & 1 & $1.1 \times 10^{-9}$ & Equipment decontamination \\
\hline 361 & $\begin{array}{l}\text { Biology and Biotechnology } \\
\text { Research }\end{array}$ & 9 & $1.0 \times 10^{-7}$ & $\begin{array}{l}\text { DNA labeling, hybridization, and enzyme assay; } \\
\text { human genome research; P-32 labeling; DNA } \\
\text { protein interaction studies }\end{array}$ \\
\hline 362 & $\begin{array}{l}\text { Biology and Biotechnology } \\
\text { Research }\end{array}$ & 2 & $4.6 \times 10^{-7}$ & Characterization of metabolic pathways \\
\hline 363 & $\begin{array}{l}\text { Biology and Biotechnology } \\
\text { Research }\end{array}$ & 2 & $1.6 \times 10^{-13}$ & $\begin{array}{l}\text { Human urine sample project, high pressure liquid } \\
\text { chromatography (HPLC) analysis }\end{array}$ \\
\hline 364 & $\begin{array}{l}\text { Biology and Biotechnology } \\
\text { Research }\end{array}$ & 3 & $8.6 \times 10^{-8}$ & $\begin{array}{l}\text { DNA and protein extraction, accelerator mass } \\
\text { spectrometry (AMS) sample preparation }\end{array}$ \\
\hline 365 & $\begin{array}{l}\text { Biology and Biotechnology } \\
\text { Research }\end{array}$ & 2 & $2.0 \times 10^{-13}$ & $\begin{array}{l}\text { Housing research animals, animal research, equip- } \\
\text { ment decontamination }\end{array}$ \\
\hline 366 & $\begin{array}{l}\text { Biology and Biotechnology } \\
\text { Research }\end{array}$ & 1 & $3.2 \times 10^{-7}$ & DNA labeling \\
\hline 378 & $\begin{array}{l}\text { Energy \& Environment } \\
\text { Directorate }\end{array}$ & 2 & $2.6 \times 10^{-8}$ & Radioactive tracer handling \\
\hline 491 & Site Action Team & 1 & $0.0^{(\mathrm{d})}$ & Operations discontinued \\
\hline 513 & Hazardous Waste Management & 2 & $4.3 \times 10^{-5}$ & $\begin{array}{l}\text { Sampling, treatment, and storage of hazardous, } \\
\text { mixed, and radioactive waste; process optimization } \\
\text { and treatability studies }\end{array}$ \\
\hline 514 & Hazardous Waste Management & 3 & $6.0 \times 10^{-2}$ & Waste consolidation, waste treatment \\
\hline 612 & Hazardous Waste Management & 3 & $5.9 \times 10^{-3}$ & $\begin{array}{l}\text { Waste sampling; analysis of waste treatment and } \\
\text { treatability samples }\end{array}$ \\
\hline \multicolumn{5}{|c|}{ Site $\mathbf{3 0 0}$ point sources } \\
\hline 801 & Flash x-ray (FXR) machine & 1 & $1.8 \times 10^{-7}$ & Flash x-ray photography of explosives experiments \\
\hline $810 \mathrm{~A}$ & Site 300 firing table support & 3 & $2.8 \times 10^{-6}$ & Assembly of explosives test devices \\
\hline $810 B$ & Site 300 firing table support & 3 & $7.8 \times 10^{-7}$ & Assembly of explosives test devices \\
\hline 851 & $\begin{array}{l}\text { Site } 300 \text { firing table at } \\
\text { Building } 851\end{array}$ & $\boldsymbol{-}^{(\mathrm{f})}$ & $1.5 \times 10^{-1}$ & Detonation of explosives \\
\hline 851 & Linear accelerator & 1 & $1.6 \times 10^{-5}$ & Research \\
\hline
\end{tabular}


Table 13-1. Sources of radiation dose from LLNL releases (measured and potential) to air: stacks and other exhaust pathways from buildings containing radiological operations, and diffuse area sources $^{(a, b)}$ (continued)

\begin{tabular}{|c|c|c|c|c|}
\hline Bldg & Facility & $\begin{array}{l}\text { Potential } \\
\text { emission } \\
\text { points }\end{array}$ & $\begin{array}{c}\text { Maximum } \\
\text { EDE }^{(c)} \\
(\mu S v / y)\end{array}$ & Operations \\
\hline \multicolumn{5}{|c|}{ Livermore site diffuse sources ${ }^{(\mathrm{g})}$} \\
\hline 223 & Contaminated facility & 1 & $1.2 \times 10^{-6}$ & Decontamination and decommissioning activities \\
\hline 292 & Spill area & 1 & $7.2 \times 10^{-7}$ & $\begin{array}{l}\text { Evaporation and transpiration of tritiated water from } \\
\text { underground tank leakage }\end{array}$ \\
\hline 331 & Tritium Facility (external) & 1 & $4.4 \times 10^{-2}$ & $\begin{array}{l}\text { Outdoor temporary placement of contaminated } \\
\text { parts and equipment awaiting transport and storage }\end{array}$ \\
\hline 514 & $\begin{array}{l}\text { Hazardous Waste Management } \\
\text { Tank Farm }\end{array}$ & 1 & $9.2 \times 0^{-3}$ & $\begin{array}{l}\text { Processing of liquid hazardous, mixed, and radioac- } \\
\text { tive wastes in open-topped tanks }\end{array}$ \\
\hline 612 & $\begin{array}{l}\text { Hazardous Waste Management } \\
\text { storage yard }\end{array}$ & 1 & $1.5 \times 10^{-1}$ & Storage of low-level tritium waste \\
\hline 612 & $\begin{array}{l}\text { Hazardous Waste Management } \\
\text { waste areas }\end{array}$ & 1 & $8.5 \times 0^{-8}$ & $\begin{array}{l}\text { Drum sampling in Building } 612 \text { yard and all LLNL } \\
\text { waste accumulation areas (WAAs) }\end{array}$ \\
\hline 614 & $\begin{array}{l}\text { Hazardous Waste Management } \\
\text { yard }\end{array}$ & 1 & $1.3 \times 10^{-7}$ & Repackaging of waste scintillation cocktail \\
\hline - & $\begin{array}{l}\text { Southeast quadrant of } \\
\text { Livermore site }\end{array}$ & 1 & $4.5 \times 10^{-3}$ & $\begin{array}{l}\text { Ground contaminated with plutonium-239 from } \\
\text { past waste management operations }\end{array}$ \\
\hline \multicolumn{5}{|c|}{ Site 300 diffuse sources $(\mathbf{g})$} \\
\hline - & All Site 300 land area & 1 & $3.7 \times 10^{-2}$ & Resuspension of uranium in contaminated soil \\
\hline 804 & Open area & 1 & $2.1 \times 10^{-6}$ & Low-level waste staging area \\
\hline
\end{tabular}

a LLNL NESHAPs 2000 Annual Report (Gallegos et al. 2001)

b Areas in which no operations using radionuclides took place in 2000 or in which all radionuclides were encapsulated or sealed for the entire year are not included in this table. Table entries refer to routine operations, not unplanned releases.

c The maximum EDE to the SW-MEI member of the public from the single most dominant emission point for the indicated facility or building. The SW-MEI is defined in the Identification of Key Receptors section.

d The effluents from the facility are monitored. Zeroes refer to monitored values below the minimum detectable concentration, as discussed, for example, in the Air-Emission Data section of the LLNL NESHAPs 2000 Annual Report (Gallegos et al. 2001).

e This dose takes into account only HTO emissions from the Tritium Facility stacks. If, instead, the emissions of HTO and HT are combined, and the sum treated as though it were entirely HTO for purposes of evaluating the maximum potential dose to the public, the dose from the principal stack was $0.085 \mu \mathrm{Sv} / \mathrm{y}$, rather than $0.074 \mu \mathrm{Sv} / \mathrm{y}$. (See the "Assessment Assumptions Regarding Tritium" section of this chapter.)

f Open-air dispersal in 2000

g Diffuse sources are described briefly in the "Special Modeling Problems" section of this chapter and more fully in the LLNL NESHAPs 2000 Annual Report (Gallegos et al. 2001). 
to natural background amounts), was responsible for $0.037 \mu S_{v}(0.0037 \mathrm{mrem})$, which was nearly all of the dose from diffuse sources. Table 13-2 summarizes doses to the SW-MEIs for the Livermore site and Site 300 over the past eleven years.

Table 13-3 shows the Site 300 SW-MEI dose values attributed to firing table experiments for 1990 through 2000, exhibited along with the total amounts of depleted uranium and the total quantity of high explosives used each year in the experiments. (Only explosives experiments that included depleted uranium are considered here; most have none.) The 2000 total is indicative of reduced firing table activity compared to typical levels in the past decade (see also the "point source dose" column for Site 300 in Table 13-2). The Table 13-3 data indicate that the SW-MEI dose is increased by using more depleted uranium and smaller quantities of explosives (producing lower debris-cloud heights) in the experiments.

The facilities that were primarily responsible for the LLNL doses to the public are listed in Table 13-4. These facilities collectively accounted for approximately $91 \%$ of the total dose resulting from Livermore site operations and for more than 99\% of the total from Site 300 operations. The principal radionuclide(s) are indicated for each facility. Tritium was the overall dominant radionuclide at the Livermore site, as usual, accounting for almost $75 \%$ of the Livermore site dose. Also as usual, practically the entire dose from Site 300 operations was attributed to the isotopes present in depleted uranium having atomic numbers 238, 235, and 234 .

Regarding dose pathways of the dominant radionuclides, the relative significance of inhalation and ingestion depends on the assumptions made about the origin of food consumed. For the conditions assumed when assessing individual LLNL doses- namely that milk is imported while the remainder of the food is produced locally-ingestion dose is larger than inhalation dose in the case of tritium, approximately in the ratio $80 \%$ to $20 \%$. For uranium, these numbers are nearly reversed: $17 \%$ by the ingestion pathway versus $83 \%$ via inhalation. For both uranium and tritium, external doses from air immersion and ground irradiation are negligible.

\section{Comparison of Modeling Results to Monitoring Data}

Comparisons were made between measured and modeled values of annual-average tritium concentrations (specifically HTO) in air at the Livermore site in 2000 (Gallegos et al. 2001). CAP88-PC model runs used source terms representing the three principal tritium sources at the site: the Building 331 (Tritium Facility) stacks, the Building 612 Yard waste storage area, and an area outside Building 331. Data on concentrations of HTO were collected biweekly throughout the year from LLNL's set of tritium surveillance air monitors; see the maps showing monitor locations in Figures 5-1 and 5-2 in this report. For the calculation-data comparison, 1 offsite monitor (designated ZON7, notable because it is in the prevailing downwind direction from the sources and is the site of a drinking water supply for the area), and 11 onsite monitors (designated VIS, SALV, POOL, CAFE, MESQ, MET, COW, B331, B514, B624, and B292) were included.

The source terms representing HTO emissions from the Tritium Facility stacks and the area outside Building 331 were determined directly, independent of surveillance air monitoring data, by using continuous stack-effluent-monitoring data and inventory estimates, respectively. However, the Building 612 Yard emission rate was indirectly inferred from a self-consistent back calculation, in which the HTO release rate from the Building 612 
Table 13-2. Doses calculated for the SW-MEI for the Livermore site and Site 300, 1990 to 2000

\begin{tabular}{|c|c|c|c|}
\hline Year & $\begin{array}{l}\text { Total dose } \\
\qquad(\mu \mathrm{Sv})\end{array}$ & $\begin{array}{l}\text { Point source dose } \\
(\mu \mathrm{Sv})\end{array}$ & $\begin{array}{c}\text { Diffuse source dose } \\
\qquad(\mu \mathrm{Sv})\end{array}$ \\
\hline \multicolumn{4}{|c|}{ Livermore site } \\
\hline 2000 & $0.37^{(a)}$ & $0.16^{(\mathrm{a})}$ & 0.21 \\
\hline 1999 & $1.0^{(\mathrm{a})}$ & $0.73^{(a)}$ & 0.28 \\
\hline 1998 & 0.49 & 0.25 & 0.24 \\
\hline 1997 & 0.97 & 0.78 & 0.19 \\
\hline 1996 & 0.93 & 0.48 & 0.45 \\
\hline 1995 & 0.41 & 0.19 & 0.22 \\
\hline 1994 & 0.65 & 0.42 & 0.23 \\
\hline 1993 & 0.66 & 0.40 & 0.26 \\
\hline 1992 & 0.79 & 0.69 & 0.10 \\
\hline 1991 & 2.3 & - (b) $^{\text {(b) }}$ & - (b) $^{(b}$ \\
\hline 1990 & 2.4 & $-^{(b)}$ & $-^{(b)}$ \\
\hline \multicolumn{4}{|c|}{ Site 300} \\
\hline 2000 & 0.19 & 0.15 & 0.037 \\
\hline 1999 & 0.35 & 0.34 & 0.012 \\
\hline 1998 & 0.24 & 0.19 & 0.053 \\
\hline 1997 & 0.20 & 0.11 & 0.088 \\
\hline 1996 & 0.33 & 0.33 & 0.0045 \\
\hline 1995 & 0.23 & 0.20 & 0.03 \\
\hline 1994 & 0.81 & 0.49 & 0.32 \\
\hline 1993 & 0.37 & 0.11 & 0.26 \\
\hline 1992 & 0.21 & 0.21 & -(c) $^{(c)}$ \\
\hline 1991 & 0.44 & 0.44 & - (c) $^{\text {(c) }}$ \\
\hline 1990 & 0.57 & 0.57 & - (c) $^{\text {(c) }}$ \\
\hline
\end{tabular}

a Calculating dose by the alternative method as directed by EPA, the total dose for 2000 was $0.38 \mu$ Sv and the point source dose was $0.17 \mu \mathrm{Sv}$; similarly, the total dose for 1999 was $1.2 \mu \mathrm{Sv}$ and the point source dose was $0.94 \mu \mathrm{Sv}$ (see the discussion in the "Assessment Assumptions Regarding Tritium" section of this chapter).

b Point source and diffuse source doses were not reported separately from the total dose for the Livermore site for 1990 and 1991.

c No diffuse emissions were reported at Site 300 for years prior to 1993. 
Table 13-3. Annual dose to the SW-MEI from explosives experiments on firing tables at Site 300, 1990-2000, related to the total quantity of depleted uranium used in the experiments and the total quantity of high explosives driving the detonations

\begin{tabular}{|c|c|c|c|c|}
\hline \multirow{2}{*}{ Year } & \multicolumn{2}{|c|}{ Dose to SW-MEI } & $\begin{array}{c}\text { Total depleted uranium } \\
\text { used in experiments (kg) }\end{array}$ & $\begin{array}{c}\text { Total HE (a) used in depleted } \\
\text { uranium experiments (kg) }\end{array}$ \\
\cline { 2 - 5 } 2000 & $(\mu \mathrm{Sv})$ & $(\mathrm{mrem})$ & 43 & 34 \\
1999 & 0.15 & 0.015 & 216 & 168 \\
1998 & 0.34 & 0.034 & 230 & 192 \\
1997 & 0.19 & 0.019 & 163 & 122 \\
1996 & 0.11 & 0.011 & 272 & 112 \\
1995 & 0.33 & 0.033 & 165 & 199 \\
1994 & 0.20 & 0.020 & 230 & 134 \\
1993 & 0.49 & 0.049 & 99 & 74 \\
1992 & 0.11 & 0.011 & 151 & 360 \\
1991 & 0.21 & 0.021 & 221 & 330 \\
1990 & 0.44 & 0.044 & 340 & 170 \\
\hline
\end{tabular}

a $\mathrm{HE}=$ high explosives

Yard diffuse source was adjusted to force agreement with the data provided by the tritium surveillance air monitor in closest proximity (the B624 monitor). The modeling results then agree, by design, with the B624 monitor data, and the meaningful comparison between modeling and measurements involves only the eleven other monitor locations. The results are displayed in Table 13-5. The main conclusion was that CAP88-PC air dispersion modeling, taking into account the three leading sources of HTO emissions at the Livermore site and using site-specific meteorological data for 2000, gave results in fairly good agreement with annual-average surveillance air monitoring data. CAP88-PC assumes "flat" terrain, which is appropriate for the Livermore site, but the code's neglect of terrain features such as trees and buildings is expected to produce discrepancies with measurements, even with long-time (one-year) averaging of winds. Generally speaking, the modeling predicted higher concentrations of
HTO than were measured (see the "ratio" column in Table 13-5). This is a desirable result, particularly for offsite locations such as ZON7 where public exposures could occur, erring on the side of more conservative modeling for regulatory compliance.

The modeled concentration levels were in the right "ball park," agreeing with the data within a factor of five at all but three locations, despite the fact that the emissions and consequently the concentrations were quite low. In the case of two monitors (B331 and CAFE), the difference was approximately a factor of six, and at one monitor (SALV) the difference was almost a factor of eleven. These results are consistent with those found in similar comparisons made the previous three years; see the NESHAPs Annual Reports for 1997 through 1999 (Gallegos et al. 1998; Biermann et al. 1999; Gallegos et al. 2000). 
Table 13-4. Major contributors to LLNL's radiation dose to the site-wide maximally exposed (public) individual (SW-MEI) via releases to air, 2000

\begin{tabular}{|c|c|c|c|}
\hline \multirow{2}{*}{$\begin{array}{l}\text { Facility or } \\
\text { operation }^{(a)}\end{array}$} & \multirow{2}{*}{$\begin{array}{c}\text { Dominant } \\
\text { radionuclide(s) }\end{array}$} & \multicolumn{2}{|c|}{ EDE at SW-MEI(b) } \\
\hline & & $\mu \mathrm{Sv} / \mathrm{y}$ & mrem/y \\
\hline \multicolumn{4}{|l|}{ Livermore site } \\
\hline B612 Yard Area(c) & Tritium & 0.15 & 0.015 \\
\hline B331/Tritium Facility & Tritium & $0.084^{(\mathrm{d}, \mathrm{e})}$ & $0.0084^{(\mathrm{d}, \mathrm{e})}$ \\
\hline B514 Evaporator & Various & 0.060 & 0.0060 \\
\hline B331 External Waste Accumulation Area ${ }^{(c)}$ & Tritium & 0.044 & 0.0044 \\
\hline Sum of all other sources & Various & 0.027 & 0.0027 \\
\hline Total & & $0.37^{(e, f)}$ & $0.037^{(e, f)}$ \\
\hline \multicolumn{4}{|l|}{ Site 300} \\
\hline B851/firing table & $\begin{array}{l}\text { Uranium-238 } \\
\text { Uranium-234 } \\
\text { Uranium-235 }\end{array}$ & 0.15 & 0.015 \\
\hline Soil resuspension ${ }^{(c)}$ & $\begin{array}{l}\text { Uranium-238 } \\
\text { Uranium-234 } \\
\text { Uranium-235 }\end{array}$ & 0.037 & 0.0037 \\
\hline Total & & $0.19^{(f)}$ & $0.019^{(f)}$ \\
\hline
\end{tabular}

a The facilities cited here are discussed in the text of this report and in more detail in the LLNL NESHAPs annual reports.

b The SW-MEI is defined in the Identification of Key Receptors section.

c Diffuse sources (see text)

d The dose quoted for the Building 331 Tritium Facility is the collective result of emissions from both stacks.

e Calculating dose as directed by EPA yields $0.095 \mu \mathrm{Sv} / \mathrm{y}$ for the Tritium Facility, which raises the total dose to $0.38 \mu \mathrm{Sv} / \mathrm{y}$. (See the "Assessment Assumptions Regarding Tritium" section of this chapter.)

f These Livermore site and Site 300 totals represent $0.37 \%$ and $0.19 \%$, respectively, of the federal standard.

\section{Temporal Trends in Dose to the SW-MEI}

The trends in dose to the SW-MEI from emissions at the Livermore site and Site 300 over the last 11 years are shown graphically in Figure 13-1 (see also Table 13-2). The general pattern, particularly over the last nine years, shows year-to-year fluctuations around a quite low dose level, staying at or below about $1 \%$ of the federal standard.

The SW-MEI dose estimates are intentionally conservative, predicting potential doses that are several times higher than would actually be experi- enced by any member of the public. Potential doses from Site 300 firing table operations are especially so, as explained in the "Special Modeling Problems" section of this chapter.

\section{Collective Doses to Potentially Exposed Populations}

Population doses, or collective EDEs, for both the Livermore site and Site 300 were evaluated using CAP88-PC, taking into consideration persons living within an EPA-specified 80-kilometer $(50-\mathrm{mi})$ radius of the site centers. The highest 
Table 13-5. Comparison of measured and modeled annual-average concentrations of tritiated water vapor (HTO) in air at selected Livermore site locations, 2000

\begin{tabular}{|c|c|c|c|c|c|c|}
\hline \multirow{2}{*}{$\begin{array}{l}\text { Air } \\
\text { monitor } \\
\text { (name) }\end{array}$} & \multirow{2}{*}{$\begin{array}{l}\text { Measured } \\
\text { concentration } \\
\left(\mathrm{pCi} / \mathrm{m}^{3}\right)\end{array}$} & \multirow{2}{*}{$\begin{array}{l}\text { Modeled }^{(a)} \\
\text { concentration } \\
\left(\mathrm{pCi} / \mathrm{m}^{3}\right)\end{array}$} & \multirow{2}{*}{$\begin{array}{c}\text { Ratio of } \\
\text { modeled-to- } \\
\text { measured } \\
\text { concentrations }\end{array}$} & \multicolumn{3}{|c|}{$\begin{array}{l}\text { Modeled concentration of tritium in air } \\
\text { contributed by the indicated source } \\
\qquad\left(\mathrm{pCi} / \mathrm{m}^{3}\right)\end{array}$} \\
\hline & & & & $\begin{array}{l}\text { B331 } \\
\text { Stacks }\end{array}$ & $\begin{array}{l}\text { B612 } \\
\text { Yard }\end{array}$ & $\begin{array}{c}\text { B331 } \\
\text { Outside }\end{array}$ \\
\hline B624 & 88.6 & 89.9 & 1.01 & 0.48 & 89 & 0.41 \\
\hline B331 & 12.1 & 68.9 & 5.69 & 0.054 & 1.8 & 67 \\
\hline B514 & 50.0 & 49.7 & 0.99 & 0.23 & 49 & 0.42 \\
\hline VIS & 1.28 & 3.79 & 2.96 & 1.4 & 1.7 & 0.69 \\
\hline POOL & 2.07 & 9.02 & 4.35 & 0.72 & 1.8 & 6.5 \\
\hline CAFE & 1.09 & 6.68 & 6.13 & 0.68 & 2.4 & 3.6 \\
\hline cow & 0.908 & 0.95 & 1.05 & 0.22 & 0.25 & 0.48 \\
\hline B292 & 1.49 & 1.70 & 1.14 & 0.25 & 0.45 & 1.0 \\
\hline SALV & 0.738 & 7.99 & 10.8 & 0.18 & 7.6 & 0.21 \\
\hline MESQ & 0.565 & 2.80 & 4.96 & 0.17 & 0.53 & 2.1 \\
\hline MET & 0.484 & 1.14 & 2.36 & 0.18 & 0.26 & 0.70 \\
\hline ZON 7 & 0.381 & 1.14 & 2.99 & 0.73 & 0.18 & 0.23 \\
\hline (CRED) & $-^{(b)}$ & 4.99 & $-^{(\mathrm{b})}$ & 1.5 & 2.7 & 0.79 \\
\hline
\end{tabular}

a This result takes into account the three most significant tritium sources; it is the sum of the three contributions shown in the far-right column.

b The CRED location does not have a tritium surveillance air monitor, but is included since it marks the location of the SW-MEl.

population concentrations in this range are found in the cities of Livermore, Tracy, M odesto and Stockton, and the large urban centers of $O$ akland, San Francisco, and San Jose. U pdated population distributions centered on the two sites were prepared in 2001, as described in Section VI of the LLN L N ESH A Ps2000 A nnual R eport (Gallegos et al. 2001). The circles of $80-\mathrm{km}$ radius envelope 6.9 million residents for the Livermore site and 6.0 million for Site 300 .

The population dose or collective EDE attributed to 2000 Livermore site operations was 0.0047 person-Sv (0.47 person-rem). This is about 3.6-times lower than the 1999 result of
0.017 person-Sv (1.7 person-rem). The decrease compared to 1999 was principally due to the previously noted factor-of-six reduction in emissions of $\mathrm{H}$ TO from the Tritium Facility stacks in 2000. When calculated as directed by EPA (i.e., treating $\mathrm{HT}$ as though it were $\mathrm{HTO}$ ), the 2000 population dose from Livermore site operations is increased about $11 \%$, to 0.0052 person-Sv (0.52 person-rem).

The population dose from Site 300 operations in 2000 was 0.025 person-Sv (2.5 person-rem). This is lower by a factor of 4.4 than the value registered in each of the previous two years, corresponding 


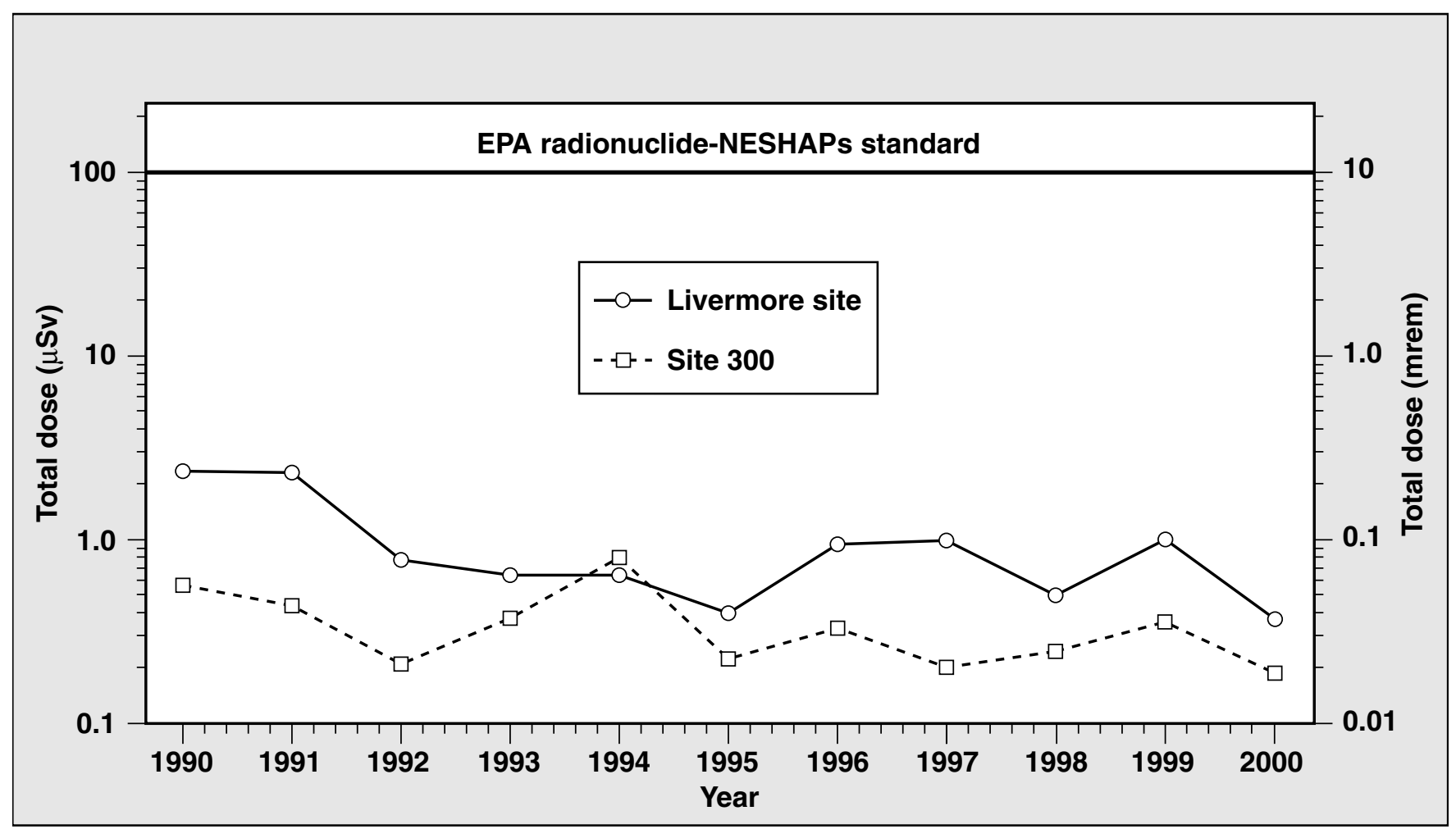

Figure 13-1. Annual dose to the site-wide maximally exposed individual member of the public, 1990 to 2000

primarily to the reduction in quantity of depleted uranium used in explosives experiments (see

Table 13-3).

\section{Doses to the Public Placed in Perspective}

These levels of variation in population and SW-

MEI doses from one year to the next are within the expected range of operations-driven fluctuations in small radiation quantities. A frame of reference to gauge the magnitude of these LLNL doses is provided in Table 13-6. The table compares the conservatively estimated population doses and doses to the maximally exposed public individuals caused by LLNL operations against average doses received in the United States from exposure to natural background radiation and medical treatments. The population doses attributed to LLNL operations in 2000 are more than 750,000-times smaller than ones from natural background radiation; the estimated maximum potential doses to individual members of the public from operations at the two LLNL sites in 2000 are 8000 -times smaller than ones from background radiation in the natural environment.

\section{Estimate of Dose to Biota}

DOE has worked the past six years to develop standards for protection of the natural environment from the effects of ionizing radiation, culminating in its detailed (draft) guidance document "DOE Standard (Proposed): A Graded Approach for Evaluating Radiation Doses to Aquatic and Terrestrial Biota" (U.S. DOE 2000). The operating principle used for radiological protection in 
Table 13-6. Comparison of background (natural and man-made) and LLNL radiation doses, 2000

\begin{tabular}{|c|c|c|c|c|}
\hline \multirow{2}{*}{ Location/source } & \multicolumn{2}{|c|}{ Individual dose $e^{(a)}$} & \multicolumn{2}{|c|}{ Population dose $e^{(b)}$} \\
\hline & $(\mu \mathrm{Sv})$ & (mrem) & (person-Sv) & (person-rem) \\
\hline Livermore site sources & & & & \\
\hline Atmospheric emissions & $0.37^{(c)}$ & $0.037^{(c)}$ & $0.0047^{(c)}$ & $0.47^{(c)}$ \\
\hline Site $\mathbf{3 0 0}$ sources & & & & \\
\hline Atmospheric emissions & 0.19 & 0.019 & 0.025 & 2.5 \\
\hline Other sources $(d)$ & & & & \\
\hline Natural radioactivity ${ }^{(e, f)}$ & & & & \\
\hline Cosmic radiation & 300 & 30 & 1,900 & 190,000 \\
\hline Terrestrial radiation & 300 & 30 & 1,900 & 190,000 \\
\hline Internal (food consumption) & 400 & 40 & 2,500 & 250,000 \\
\hline Radon & 2,000 & 200 & 12,500 & $1,250,000$ \\
\hline $\begin{array}{l}\text { Medical radiation (diagnostic } \\
\text { procedures) }^{(f)}\end{array}$ & 530 & 53 & 3,300 & 330,000 \\
\hline Weapons test fallout ${ }^{(f)}$ & 11 & 1.1 & 68 & 6,800 \\
\hline Nuclear fuel cycle & 4 & 0.4 & 25 & 2,500 \\
\hline
\end{tabular}

a For LLNL sources, this dose represents that experienced by the SW-MEI member of the public.

b The population dose is the collective (combined) dose for all individuals residing within an 80-km radius of LLNL (approximately 6.9 million people for the Livermore site and 6.0 million for Site 300), calculated with respect to distance and direction from each site.

c Calculating dose by the alternative method as directed by EPA, the individual dose was increased to $0.38 \mu \mathrm{Sv}(0.038 \mathrm{mrem})$, and the population dose to 0.0052 person-Sv (0.52 person-rem); see the "Doses to Public Site-Wide Maximally Exposed Individvals" and "Collective Doses to Potentially Exposed Populations" sections.

d From National Council on Radiation Protection and Measurements (NCRP 1987a, b)

e These values vary with location.

$f$ This dose is an average over the U.S. population.

the past - that by protecting man, other living things are also likely to be sufficiently protected-is no longer considered adequate.

The guidance includes a biota manual, spreadsheets, and a database giving biota concentration guides (BCGs). Cases where human access to an area of exposure is restricted or exposure pathways favor biota exposure are especially important to consider. The effort required to show compliance is minimized by several features of the guidance: its use of a graded approach; its allowance of use of existing generic and site-specific data (not requiring new monitoring programs tailored to biota); and the fact that current and proposed standards are not very restrictive. Regarding the latter, the limit on absorbed dose is $10 \mathrm{mGy} / \mathrm{d}(1 \mathrm{rad} / \mathrm{d})$ for aquatic animals and terrestrial plants, and $1 \mathrm{mGy} / \mathrm{d}$ $(0.1 \mathrm{rad} / \mathrm{d})$ for terrestrial animals. See Appendix D, Part D-1, Radiation Basics, and the Glossary for a discussion of radiation units.

Screening calculations for LLNL impacts were performed in 2000 using the spreadsheet provided with the guidance. Each radionuclide in each medium (soil, sediment, surface water) is assigned a 
derived concentration limit in the guidance. For each measured maximum concentration input to the spreadsheet, a fraction of the derived concentration limit for that radionuclide is automatically calculated, and the fractions summed for each medium. For aquatic biota, the sum of the fractions for water exposure are added to the sum of the fractions for sediment exposure. Similarly, the fractions for water and soil are summed for terrestrial biota. If the sums for the aquatic and terrestrial biota are both less than 1.0, the site has passed the screening analysis, and the biota are assumed to be protected without further analysis.

In the LLNL assessment, the maximum concentration of each radionuclide measured in soils, sediments, and surface waters during 2000, whether measured on the Livermore site, offsite in the Livermore Valley, or at Site 300, was entered into the screening calculation. Principal measured radionuclides were cesium-137, tritium, plutonium-239, thorium-232, uranium-234, uranium-235 and uranium-238. For LLNL, the sum of the fractions for aquatic biota was 0.0724, and the sum for terrestrial biota was 0.0165 . Both are indicative of doses to aquatic and terrestrial biota from LLNL operations that are well below allowable dose limits.

\section{Summary and Conclusion}

The annual radiological dose from all emissions at the Livermore site and Site 300 in 2000 was found to be well below the applicable standards for radiation protection of the public, in particular the NESHAPs standard. This standard limits to $100 \mu \mathrm{Sv} / \mathrm{y}(10 \mathrm{mrem} / \mathrm{y})$ the EDE to any member of the public, arising as a result of releases of radionuclides to air from DOE facilities. Using EPAmandated computer models, actual LLNL meteorology, and population distributions appropriate to the two sites, the potential doses to the LLNL SW-MEI members of the public from operations in 2000 were evaluated, with the following results:

- Livermore site: $0.37 \mu \mathrm{Sv}(0.037 \mathrm{mrem})-43 \%$ from point-source emissions, $57 \%$ from diffusesource emissions - calculated by neglecting the dose contribution of HT releases relative to $\mathrm{HTO}$ releases. If $\mathrm{HT}$ is treated as though it were HTO, as directed by EPA, the total annual dose to the SW-MEI from Livermore site operations is increased slightly to $0.38 \mu \mathrm{Sv}$ (0.038 mrem).

- Site 300: $0.19 \mu \mathrm{Sv}(0.019 \mathrm{mrem})-79 \%$ from explosive experiments, which are classified as point-sources, $21 \%$ from diffuse-source emissions.

The major radionuclides accounting for the doses were tritium at the Livermore site and the three isotopes in depleted uranium (uranium-234, uranium-235, and uranium-238) at Site 300. The only significant exposure pathway was release of radioactive material to air, leading to doses by inhalation and ingestion.

The collective EDE or population dose attributable to LLNL operations in 2000 was estimated to be 0.0047 person-Sv $(0.47$ person-rem $)$ for the Livermore site and 0.025 person-Sv $(2.5$ personrem) for Site 300. Calculating dose as directed by EPA, the Livermore site value was 0.0052 person-Sv ( 0.52 person-rem). These doses include potentially exposed populations of 6.9 million people for the Livermore site and 6.0 million people for Site 300 living within a distance of $80 \mathrm{~km}$ from the site centers, based on an updated population analysis. 
The doses to the MEI members of the public resulting from Livermore site and Site 300 operations in 2000 were below $0.4 \%$ of the federal standard and were about 8,000 times smaller than the dose from background radiation. The population doses from LLNL operations in 2000 were more than 750,000 times smaller than those caused by natural radioactivity in the environment (see Table 13-6).

Potential doses to aquatic and terrestrial biota from LLNL operations were assessed and found to be well below DOE allowable dose limits.
We conclude that the potential radiological doses from LLNL operations were well below regulatory standards and were very small compared with doses normally received by these populations from natural background radiation sources, even though highly conservative assumptions were used in the determinations of LLNL doses. These maximum credible doses to the public indicate that LLNL's use of radionuclides had no significant impact on public health during 2000 . 


\section{Quality Assurance}

Lucinda M. Clark Donald H. MacQueen

\section{Introduction}

Quality assurance (QA) is a system of activities and processes put in place to ensure that monitoring and measurement data meet user requirements and needs. Quality control (QC) consists of procedures used to verify that prescribed standards of performance in the monitoring and measurement process are met. U.S. Department of Energy (DOE) orders and guidance mandate QA requirements for environmental monitoring of DOE facilities. DOE Order 5400.1 identifies QA requirements for radiological effluent and surveillance monitoring and specifies that a QA program consistent with the DOE order addressing quality assurance is established. This order sets forth policy, requirements, and responsibilities for the establishment and maintenance of plans and actions that assure quality in DOE programs.

Lawrence Livermore National Laboratory conducted QA activities in 2000 at the Livermore site and Site 300 in accordance with the Environmental Protection Department Quality Assurance Management Plan (Revision 3), based on DOE Order 5700.6C, which meets the intent of DOE Order 0-414.1A and prescribes a risk-based, graded approach to QA. This process promotes the selective application of QA and management controls based on the risk associated with each activity in order to maximize effectiveness and efficiency in resource use.
The DOE Environmental Regulatory Guide for Radiological Effluent Monitoring and Environmental Surveillance (U.S. DOE 1991) requires that an environmental monitoring plan be prepared. LLNL environmental monitoring is conducted according to procedures published in Appendix B of the LLNL Environmental Monitoring Plan (Tate et al. 1999). 
LLNL or commercial laboratories analyze environmental monitoring samples using U.S. Environmental Protection Agency (EPA) standard methods, when available. When EPA standard methods are not available, custom analytical procedures (usually developed at LLNL) are used. The radiochemical methods used by LLNL laboratories are described in procedures unique to the laboratory performing the analyses. LLNL uses only State of California-certified laboratories to analyze its environmental monitoring samples. In addition, LLNL requires all analytical laboratories to maintain adequate QA programs and documentation of methods.

\section{Quality Assurance Activities}

Nonconformance reporting and tracking is an LLNL QA process for ensuring that Environmental Protection Department (EPD) activities meet the department's QA requirements and that problems are found, identified, resolved, and prevented from recurring. LLNL generated 76 Nonconformance Reports (NCRs) related to environmental monitoring in 2000 compared to 111 in 1999 and 92 in 1998. The number of NCRs decreased in 2000 because of a change in EPD reporting requirements. Beginning in the summer of 2000 , EPD no longer required the documentation of samples that were planned but not successfully collected and analyzed. The reason for lost samples is documented on paperwork completed during sampling, and a summary of these results appears in Table 14-1.

Thirty-nine of the 76 NCRs generated in 2000 were due to problems with analytical laboratories. Twenty-one were due to documentation or procedural errors. Three were related to minor problems with air-monitoring equipment, and another five were due to minor problems with sewer monitoring equipment. The remaining NCRs were related to location changes (4) and shipping problems (1).
LLNL addresses analytical laboratory problems with the appropriate laboratory as they arise. Many of the NCRs written in response to problems with the laboratories concerned minor documentation or paperwork errors, which were corrected soon after they were identified. Other problems — such as missed holding times, late analytical results, and typographical errors on data reports-accounted for the remaining NCRs related to the analytical laboratories. The majority of these problems were corrected by reanalysis, resampling, reissued reports, or corrected paperwork and associated sample results were not affected.

LLNL addresses internal documentation, training, and procedural errors by conducting formal and informal training. These errors generally do not result in lost samples, but may require extra work on the part of sampling and data management personnel to resolve or compensate for the errors.

\section{Analytical Laboratories}

LLNL continued to operate under the Blanket Service Agreements (BSAs) put into place with seven analytical laboratories in March 1999. LLNL continues to work closely with these analytical laboratories to minimize the occurrence of problems.

\section{Participation in Laboratory Intercompar- ison Studies}

The LLNL Chemistry and Materials Science Environmental Services' (CES) Environmental Monitoring Radiation Laboratory (EMRL) and the Hazards Control Department's Analytical Laboratory (HCAL) participated in the DOE Environmental Monitoring Laboratory (EML) intercomparison studies program. A review of the EML studies indicates that 45 of 46 results reported by CES and 10 of 10 results reported by HCAL fell within the established acceptance control limits. 
Table 14-1. Sampling completeness in $\mathbf{2 0 0 0}$ for the Livermore site and Site $\mathbf{3 0 0}$

\begin{tabular}{|c|c|c|c|c|}
\hline Environmental monitoring network & $\begin{array}{l}\text { Number of } \\
\text { analyses } \\
\text { planned }\end{array}$ & $\begin{array}{l}\text { Number of } \\
\text { analyses } \\
\text { completed }\end{array}$ & $\begin{array}{c}\text { Complete- } \\
\text { ness (\%) }\end{array}$ & Reason(s) for lost samples \\
\hline \multicolumn{5}{|l|}{ Air particulate (Livermore site) } \\
\hline Radiological parameters & 1208 & 1182 & 98 & $\begin{array}{l}\text { Lost power due to auto accident } \\
\text { (23), unacceptable flow rate (2), } \\
\text { motor failure (1) }\end{array}$ \\
\hline Beryllium & 96 & 96 & 100 & \\
\hline \multicolumn{5}{|l|}{ Air particulate (Site 300) } \\
\hline Radiological parameters & 715 & 691 & 97 & $\begin{array}{l}\text { Lost power due to electrical } \\
\text { upgrade (18), unit off on arrival } \\
(4) \text {, no access to area (2) }\end{array}$ \\
\hline Beryllium & 72 & 69 & 96 & $\begin{array}{l}\text { Lost power due to electrical } \\
\text { upgrade (3) }\end{array}$ \\
\hline \multicolumn{5}{|l|}{ Air tritium } \\
\hline Livermore site and vicinity & 476 & 445 & 93 & $\begin{array}{l}\text { Lost power due to auto accident } \\
\text { (9), flask broke (12), insufficient } \\
\text { run time (6), excessive flow (4) }\end{array}$ \\
\hline Site 300 & 26 & 25 & 96 & Insufficient run time (1) \\
\hline \multicolumn{5}{|l|}{ Soil } \\
\hline Livermore & 42 & 42 & 100 & \\
\hline Site 300 & 30 & 30 & 100 & \\
\hline Arroyo sediment (Livermore site only) & 63 & 51 & 81 & $\begin{array}{l}\text { Could not access sampling } \\
\text { location (12) }\end{array}$ \\
\hline \multicolumn{5}{|l|}{ Vegetation } \\
\hline Livermore site and vicinity & 70 & 70 & 100 & \\
\hline Site 300 & 32 & 32 & 100 & \\
\hline Wine & 25 & 25 & 100 & \\
\hline \multicolumn{5}{|l|}{ Rain } \\
\hline Livermore site & 118 & 97 & 82 & $\begin{array}{l}\text { Insufficient rainfall (20) bucket } \\
\text { stolen (1) }\end{array}$ \\
\hline Site 300 & 24 & 10 & 42 & Insufficient rainfall (14) \\
\hline \multicolumn{5}{|l|}{ Storm water runoff } \\
\hline Livermore site & 458 & 218 & 48 & $\begin{array}{l}\text { Two storms not sampled due to } \\
\text { lack of runoff }(226) \text {, sampler } \\
\text { error (8), analytical lab error (6) }\end{array}$ \\
\hline Site 300 & 148 & 82 & 55 & No flow at locations (66) \\
\hline
\end{tabular}


Table 14-1. Sampling completeness in $\mathbf{2 0 0 0}$ for the Livermore site and Site $\mathbf{3 0 0}$ (continued)

\begin{tabular}{|c|c|c|c|c|}
\hline Environmental monitoring network & $\begin{array}{l}\text { Number of } \\
\text { analyses } \\
\text { planned }\end{array}$ & $\begin{array}{l}\text { Number of } \\
\text { analyses } \\
\text { completed }\end{array}$ & $\begin{array}{l}\text { Complete- } \\
\text { ness (\%) }\end{array}$ & Reason(s) for lost samples \\
\hline \multicolumn{5}{|l|}{ Drainage Retention Basin } \\
\hline Field measurements & 886 & 835 & 94 & $\begin{array}{l}\text { Lake drained (48), sampler } \\
\text { error (3) }\end{array}$ \\
\hline Samples & 90 & 86 & 96 & Sampler error (4) \\
\hline Releases & 63 & 63 & 100 & \\
\hline Other surface water (Livermore only) & 60 & 60 & 100 & \\
\hline \multicolumn{5}{|l|}{ Groundwater } \\
\hline Livermore site & 488 & 470 & 96 & Missed samples (18) \\
\hline Site 300 & 2069 & 1933 & 93 & $\begin{array}{l}\text { Well dry (72), equipment } \\
\text { problems (42), well inacces- } \\
\text { sible because of construction } \\
\text { (14), sampler error (9) }\end{array}$ \\
\hline Livermore Valley wells & 29 & 24 & 83 & $\begin{array}{l}\text { Sample not provided (4), well } \\
\text { not operational (1) }\end{array}$ \\
\hline \multicolumn{5}{|l|}{ Sewage } \\
\hline B196 & 912 & 910 & 99.8 & Loss of flow (2) \\
\hline $\mathrm{C} 196$ & 329 & 329 & 100 & \\
\hline LWRP(a) effluent & 128 & 128 & 100 & \\
\hline Digester sludge & 80 & 80 & 100 & \\
\hline \multicolumn{5}{|l|}{ WDR-96-248 } \\
\hline Surface impoundment wastewater & 60 & 58 & 97 & Missed sampling event (2) \\
\hline Surface impoundment groundwater & 105 & 105 & 100 & \\
\hline Sewage ponds wastewater & 45 & 45 & 100 & \\
\hline Sewage ponds groundwater & 144 & 144 & 100 & \\
\hline \multicolumn{5}{|l|}{ Thermoluminescent dosimeters (TLDs) } \\
\hline Livermore site & 76 & 76 & 100 & \\
\hline Livermore Valley & 100 & 95 & 95 & $\begin{array}{l}\text { Samples missing at time of } \\
\text { pickup }\end{array}$ \\
\hline Site 300 & 74 & 65 & 88 & Samples lost due to vehicle fire \\
\hline Cooling towers (Site 300 only) & 40 & 38 & 95 & Tower off-line (2) \\
\hline
\end{tabular}

a LWRP = Livermore Water Reclamation Plant 
CES EMRL participated in two DOE Mixed Analyte Performance Evaluation Program (MAPEP) studies in 2000. Twenty-one of twentytwo analytes reported fell within acceptable limits.

CES has implemented changes that are intended to address the root causes of unacceptable intercomparison study results and prevent future results from falling outside the acceptance control limits.

Details of the intercomparison study results, including the follow-up explanation and response for data that fell outside the acceptance control limits, are presented in the Data Supplement. Although contract laboratories are also required to participate in laboratory intercomparison programs, permission to publish their results for comparison purposes was not granted for 2000 .

LLNL uses the results of intercomparison program data to identify and monitor trends in performance and to solicit corrective action responses for unacceptable results. If a laboratory performs unacceptably for a particular test in two consecutive performance evaluation studies, LLNL may choose to select another laboratory to perform the affected analyses until the original laboratory can demonstrate that the problem has been corrected. Continued unacceptable performance could result in formal notification or suspension, depending on the type of laboratory. If an off-site laboratory continues to perform unacceptably or fails to prepare and implement acceptable corrective action responses, the LLNL Procurement Department will formally notify the laboratory of its unsatisfactory performance. If the problem persists, the offsite laboratory's BSA could be terminated. If an on-site laboratory continues to perform unacceptably, use of that laboratory could be suspended until the problem is corrected.
A joint performance evaluation committee composed of members from EPD, CES, and Lawrence Berkeley National Laboratory is creating a systematic process for evaluating laboratory performance using performance evaluation samples. A method for evaluating the results of intercomparison studies will be developed by that committee.

\section{Duplicate Analyses}

Duplicate or collocated samples are distinct samples of the same matrix collected as closely to the same point in space and time as possible. Collocated samples processed and analyzed by the same laboratory provide intralaboratory information about the precision of the entire measurement system, including sample acquisition, homogeneity, handling, shipping, storage, preparation, and analysis. Collocated samples processed and analyzed by different laboratories provide interlaboratory information about the precision of the entire measurement system (U.S. EPA 1987). Collocated samples may also be used to identify errors such as mislabeled samples or data entry errors.

Tables 14-2 through 14-4 present statistical data for collocated sample pairs, grouped by sample matrix and analyte. Samples from both the Livermore site and Site 300 are included.

Tables 14-2 and 14-3 are based on data pairs in which both values are detections (see Statistical Methods in this chapter). Table 14-4 is based on data pairs in which either or both values are nondetections.

Precision is measured by the percent relative standard deviation (\%RSD); see the EPA's Data Quality Objectives for Remedial Response Activities: Development Process, Section 4.6 (U.S. EPA 1987). Acceptable values for $\%$ RSD vary greatly with matrix, analyte, and analytical method; 
Table 14-2. Quality assurance collocated sampling. Summary statistics for analytes with more than eight pairs in which both results were above the detection limit.

\begin{tabular}{|c|c|c|c|c|c|c|}
\hline Matrix & Analyte & $N^{(a)}$ & $\%$ RSD $^{(b)}$ & Slope & $r^{2(c)}$ & Intercept \\
\hline \multirow[t]{6}{*}{ Air } & Gross beta & 14 & 9.17 & 1.09 & 0.87 & $-0.000112 \mathrm{~Bq} / \mathrm{m}^{3}$ \\
\hline & Beryllium & 16 & 13.7 & 1.02 & 0.99 & $-1.44 \mathrm{pg} / \mathrm{m}^{3}$ \\
\hline & Uranium-234+233(d) & 12 & 37.7 & 0.15 & 0.1 & $3.17 \times 10^{-7} \mathrm{~Bq} / \mathrm{m}^{3}$ \\
\hline & Uranium-235+236 $(\mathrm{e})$ & 11 & 78.3 & 1.1 & 0.52 & $-2.03 \times 10^{-8} \mathrm{~Bq} / \mathrm{m}^{3}$ \\
\hline & Uranium-238 ${ }^{(d)}$ & 12 & 45.6 & 0.194 & 0.13 & $2.62 \times 10^{-7} \mathrm{~Bq} / \mathrm{m}^{3}$ \\
\hline & Tritium & 20 & 20.7 & 0.904 & 1.0 & $0.00278 \mathrm{~Bq} / \mathrm{m}^{3}$ \\
\hline \multirow[t]{10}{*}{ Groundwater } & Gross beta & 19 & 12.5 & 1.01 & 0.98 & $0.00858 \mathrm{~Bq} / \mathrm{L}$ \\
\hline & Arsenic & 20 & 13.3 & 1.03 & 0.99 & $-0.000658 \mathrm{mg} / \mathrm{L}$ \\
\hline & Barium & 10 & 8.29 & 1.02 & 0.98 & $0.00383 \mathrm{mg} / \mathrm{L}$ \\
\hline & Nitrate (as $\mathrm{NO}_{3}$ ) & 24 & 2.86 & 0.96 & 0.98 & $2.82 \mathrm{mg} / \mathrm{L}$ \\
\hline & Potassium & 30 & 3.51 & 0.958 & 0.98 & $0.168 \mathrm{mg} / \mathrm{L}$ \\
\hline & Trichloroethene & 11 & 3.1 & 1.0 & 1.0 & $0.276 \mu \mathrm{g} / \mathrm{L}$ \\
\hline & Tritium & 15 & 5.81 & 1.01 & 1.0 & $25.1 \mathrm{~Bq} / \mathrm{L}$ \\
\hline & Uranium-234+233 & 20 & 7.7 & 1.02 & 0.99 & $0.00506 \mathrm{~Bq} / \mathrm{L}$ \\
\hline & Uranium-238 & 18 & 8.15 & 0.994 & 0.99 & $0.00716 \mathrm{~Bq} / \mathrm{L}$ \\
\hline & Vanadium & 9 & 1.43 & 0.787 & 0.84 & $0.0123 \mathrm{mg} / \mathrm{L}$ \\
\hline \multirow[t]{2}{*}{ Sewer } & Gross alpha $^{(e)}$ & 9 & 24.8 & 0.192 & 0.05 & $0.000121 \mathrm{~Bq} / \mathrm{mL}$ \\
\hline & Gross beta & 52 & 10.2 & 0.976 & 0.97 & $8.33 \times 10^{-6} \mathrm{~Bq} / \mathrm{mL}$ \\
\hline
\end{tabular}

a Number of collocated pairs included in regression analysis

b $75^{\text {th }}$ percentile of percent relative standard deviations (\%RSD) where \%RSD $=\left(\frac{200}{\sqrt{2}}\right) \frac{\left|x_{1}-x_{2}\right|}{x_{1}+x_{2}}$ and $x_{1}$ and $x_{2}$ are the reported

c Coefficient of determination

d Outside acceptable range of slope or $r^{2}$ because of outliers

e Outside acceptable range of slope of $r^{2}$ because of variability

however, lower values represent better precision. The results for $\%$ RSD given in Table 14-2 are the $75^{\text {th }}$ percentile of the individual precision values.

Regression analysis consists of fitting a straight line to the collocated sample pairs. Good agreement is indicated when the data lie close to a line with slope equal to 1 and intercept equal to 0 , as illustrated in Figure 14-1. Allowing for normal analytical variation, the slope of the fitted line should be between 0.7 and 1.3 , and the absolute value of the intercept should be less than the detection limit. The coefficient of determination $\left(\mathrm{r}^{2}\right)$ should be greater than 0.8 . These criteria apply to pairs in which both results are above the detection limit.

When there were more than eight data pairs with both results in each pair considered detections, precision and regression analyses were performed; 
Table 14-3. Quality assurance collocated sampling. Summary statistics for selected analytes with eight or fewer pairs in which both results were above the detection limit.

\begin{tabular}{|c|c|c|c|c|c|}
\hline Matrix & Analyte & $\mathbf{N}$ & Mean ratio & Minimum ratio & Maximum ratio \\
\hline Aqueous & Gross beta & 1 & 1.1 & 1.1 & 1.1 \\
\hline \multirow[t]{6}{*}{ Groundwater } & Gross alpha & 7 & 1.3 & 0.88 & 2.1 \\
\hline & Americium-241 & 1 & 1.3 & 1.3 & 1.3 \\
\hline & Plutonium-238 & 1 & 1.1 & 1.1 & 1.1 \\
\hline & Plutonium-239+240 & 2 & 1.5 & 1.5 & 1.5 \\
\hline & Radium-226 & 5 & 1.1 & 0.62 & 2.0 \\
\hline & Uranium-235+236 & 7 & 1.0 & 0.84 & 1.3 \\
\hline \multirow[t]{4}{*}{ Runoff (from rain) } & Gross alpha & 3 & 0.63 & 0.39 & 0.96 \\
\hline & Gross beta & 5 & 1.0 & 0.94 & 1.2 \\
\hline & Uranium-234+233 & 1 & 0.89 & 0.89 & 0.89 \\
\hline & Uranium-238 & 1 & 0.93 & 0.93 & 0.93 \\
\hline \multirow[t]{9}{*}{ Soil } & Beryllium-7 & 1 & 0.94 & 0.94 & 0.94 \\
\hline & Cesium-137 & 4 & 1.6 & 0.85 & 3.7 \\
\hline & Potassium-40 & 4 & 0.96 & 0.88 & 1.0 \\
\hline & Plutonium-239+240 & 3 & 1.2 & 0.92 & 1.5 \\
\hline & Radium-226 & 4 & 0.97 & 0.95 & 1.0 \\
\hline & Radium-228 & 4 & 0.97 & 0.91 & 1.0 \\
\hline & Thorium-232 & 4 & 0.98 & 0.92 & 1.1 \\
\hline & Uranium-235 & 4 & 1.0 & 0.92 & 1.2 \\
\hline & Uranium-238 & 4 & 0.93 & 0.66 & 1.3 \\
\hline \multirow[t]{2}{*}{ Sewer } & Tritium & 8 & 1.0 & 0.83 & 1.6 \\
\hline & Plutonium-239+240 & 2 & 1.2 & 1.2 & 1.2 \\
\hline Vegetation & Tritium & 2 & 0.86 & 0.85 & 0.87 \\
\hline
\end{tabular}

those results are presented in Table 14-2. When there were eight or fewer data pairs with both results above the detection limit, the ratios of the individual duplicate sample pairs were averaged; the average, minimum, and maximum ratios for selected analytes are given in Table 14-3. The mean ratio should be between 0.7 and 1.3 .
When one of the results in a pair is a nondetection, then the other result should be less than two times the detection limit. Table 14-4 identifies the sample media and analytes for which at least one pair failed this criterion. Analytes with fewer than four pairs are omitted from the table. 
Table 14-4. Quality assurance duplicate sampling. Summary statistics for analytes with at least four pairs in which one or both results were below the detection limit.

\begin{tabular}{|c|c|c|c|c|}
\hline Media & Analyte & $\begin{array}{c}\text { Number of } \\
\text { inconsistent } \\
\text { pairs }\end{array}$ & $\begin{array}{l}\text { Number } \\
\text { of } \\
\text { pairs }\end{array}$ & $\begin{array}{l}\text { Percent of } \\
\text { inconsistent } \\
\text { pairs }\end{array}$ \\
\hline Air & Tritium & 1 & 28 & 3.6 \\
\hline Groundwater & $\begin{array}{l}\text { Gross alpha } \\
\text { Gross beta } \\
\text { Americium-241 } \\
\text { 2-Amino-4,6-dinitrotoluene } \\
\text { Lead } \\
\text { Methylene chloride } \\
\text { Nitrite (as N) } \\
\text { Nitrite (as NO}{ }_{2} \text { ) } \\
\text { Plutonium-238 } \\
\text { Plutonium-239+240 } \\
\text { Plutonium-239+240 } \\
\text { Zinc }\end{array}$ & $\begin{array}{l}2 \\
1 \\
2 \\
2 \\
1 \\
1 \\
1 \\
1 \\
4 \\
8 \\
8 \\
1\end{array}$ & $\begin{array}{r}19 \\
7 \\
8 \\
5 \\
26 \\
26 \\
6 \\
4 \\
20 \\
44 \\
44 \\
25\end{array}$ & $\begin{array}{r}11 \\
14 \\
25 \\
40 \\
3.8 \\
3.8 \\
17 \\
25 \\
20 \\
18 \\
18 \\
4\end{array}$ \\
\hline Rain & Tritium & 1 & 5 & 20 \\
\hline Sewer & $\begin{array}{l}\text { Gross alpha } \\
\text { 1,1,1-Trichloroethane }\end{array}$ & $\begin{array}{c}16 \\
1\end{array}$ & $\begin{array}{r}43 \\
7\end{array}$ & $\begin{array}{r}2.3 \\
14\end{array}$ \\
\hline
\end{tabular}

Collocated sample comparisons are more variable when the members of the pair are analyzed by different methods or with different criteria for analytical precision. For example, radiological analyses using different counting times or different laboratory aliquot sizes will have different amounts of variability.

These analyses show generally good agreement between routine samples and QA duplicates: 90\% of the pairs have a precision better than $26 \%$. Data sets not meeting our precision criteria fall into one of two categories. The first category, outliers, can occur because of data transcription errors, measure- ment errors, or real but anomalous results. Of the 18 data sets reported in Table 14-2, 2 did not meet the criterion for acceptability because of outliers. Figure 14-2 illustrates a set of collocated pairs with one outlier.

The other results that do not meet the criterion for acceptability consist of data sets where there is a lot of scatter. This tends to be typical of nondetections and measurements at extremely low concentrations, as illustrated in Figure 14-3. Low concentrations of radionuclides on particulates in air highlight this effect, because one or two radionuclide-containing particles on an air filter can 


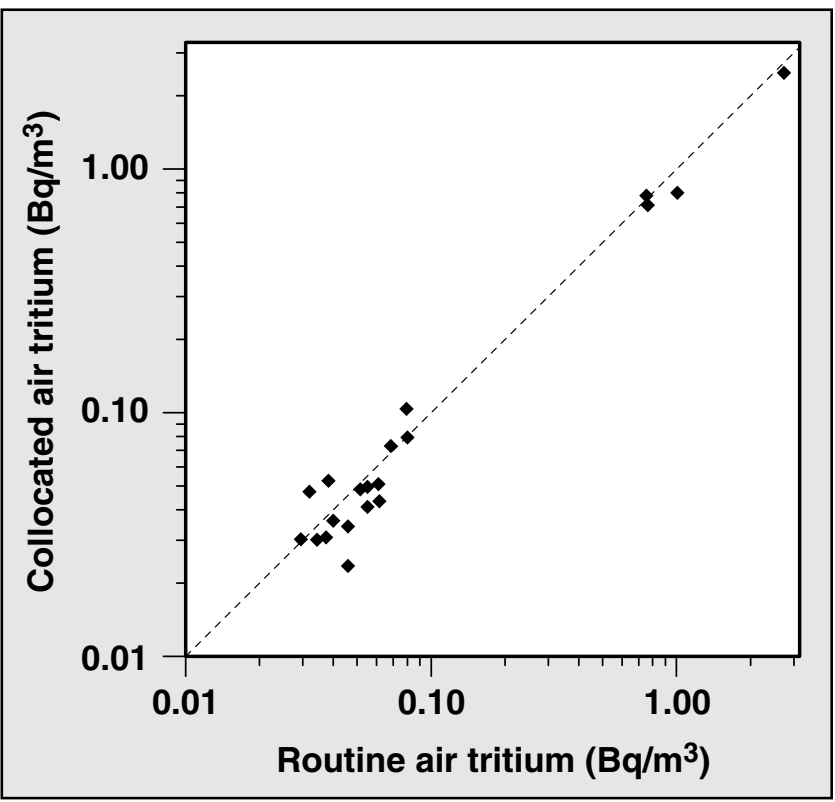

Figure 14-1. Air tritium concentrations from collocated samples. These samples lie close to a line with slope equal to 1 and intercept equal to 0 .

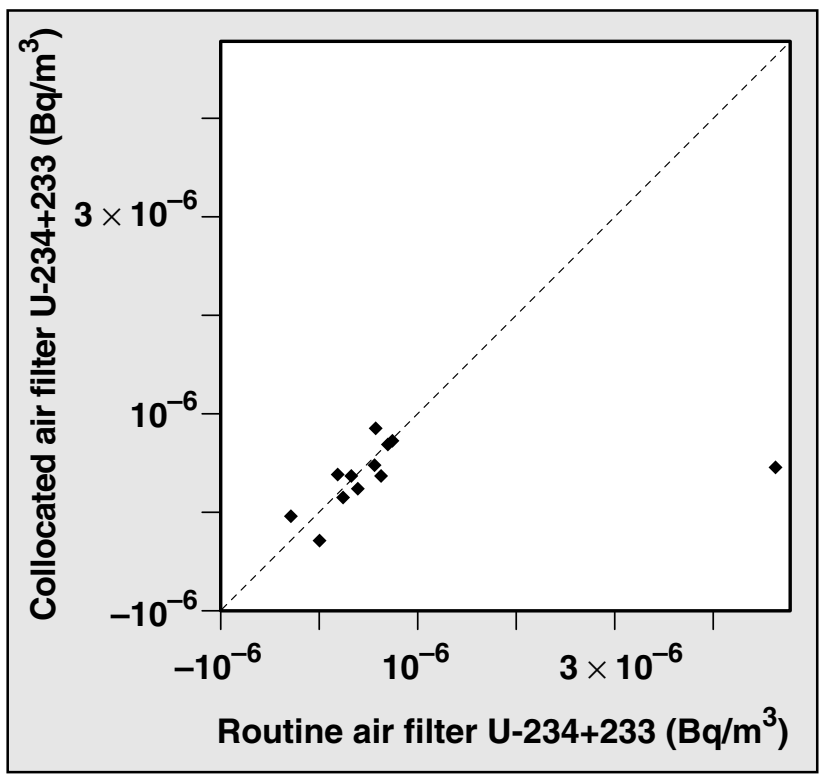

Figure 14-2. Air uranium concentrations from collocated samples showing an outlier

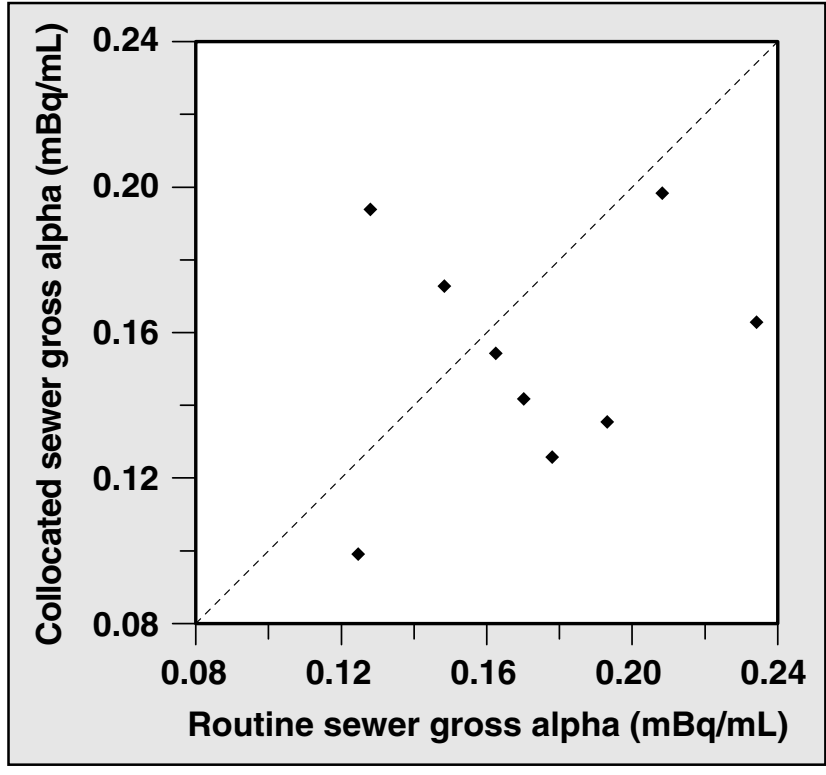

Figure 14-3. Sewer gross alpha concentrations from collocated samples showing a lot of scatter

significantly affect results. Other causes of high variability are sampling and analytical methodology. Analyses of total organic carbon and total organic halides in water are particularly difficult to control. Of the 18 data sets in Table 14-2, two show sufficient variability in results to make them fall outside the acceptable range.

\section{Statistical Methods}

Statistical methods used in this report have been implemented in accordance with the Environmental Monitoring Plan (Tate et al. 1999). These methods reduce the large volumes of monitoring data to summary estimates suitable for temporal and spatial comparisons. Attention is given to estimating accuracy, bias, and precision of all data.

Data review and analysis are conducted in accordance with the Environmental Monitoring Plan (Tate et al. 1999) and the data analysis procedure developed by EPD's Operations and Regulatory 
Affairs Division. These documents contain detailed information regarding the acceptability of data and the procedures that are followed for the identification, notification, and correction of suspect data.

\section{Radiation Units}

Data for 2000 have been reported in Système Internationale (SI) units to conform with standard scientific practices and federal law. Values in the text are reported in becquerels (Bq) and millisieverts $(\mathrm{mSv})$; equivalent values in picocuries $(\mathrm{pCi})$ and millirems (mrem) are given in parentheses.

\section{Radiological Data}

The precision of radiological analytical results is displayed in the Data Supplement tables as the $2 \sigma$ counting uncertainty. The counting uncertainties are not used in summary statistic calculations. Any radiological result exhibiting a $2 \sigma$ counting uncertainty greater than or equal to $100 \%$ is considered to be a nondetection. The reported concentration is derived from the number of sample counts minus the number of background counts. Therefore, a sample with a low concentration may have a negative value; such results are reported in the tables and used in the calculation of summary statistics and statistical comparisons.

Some Data Supplement tables provide radioactivity sensitivity values instead of a reported concentration when the radiological result is below the detection criterion. Such results are displayed in the tables with a less-than symbol. These values can be described as a concentration of radioactive material that can be detected (distinguished from background) with a large degree of confidence. These radioactivity sensitivity values are referred to as minimum detectable concentrations (MDC) in Chapters 4 and 5, limits of sensitivity (LOS) in Chapter 6, and detection limits (DL) in Chapters 7 and 9.

\section{Nonradiological Data}

Nonradiological data reported as being below the reporting limit are also displayed in the tables with a less-than symbol. The reporting limit values are used in the calculation of summary statistics, as explained below.

\section{Statistical Comparisons}

Standard comparison techniques (such as regression, $\mathrm{t}$-tests, and analysis of variance) have been used where appropriate to determine the statistical significance of trends or differences between means. When such a comparison is made, it is explicitly stated in the text as being "statistically significant" or "not statistically significant." Other uses of the word "significant" in the text do not imply that statistical tests have been performed. Instead, these uses relate to the concept of practical significance and are based on professional judgment.

\section{Summary Statistics}

Determinations of measures of central tendency and associated measures of dispersion are calculated according to the Environmental Monitoring Plan (Tate et al. 1999). For data sets that do not contain values below the detection criterion, the measures of central tendency and dispersion are the median and interquartile range (IQR). The IQR is the range that encompasses the middle $50 \%$ of the data set. The IQR is calculated by subtracting the 25th percentile of the data set from the 75 th percentile of the data set. When necessary, the percentiles are interpolated from the data. Software vendors may use slightly different formulas for calculating percentiles. Radiological data sets that include values less than zero may have an IQR greater than the median. 
For data sets with one or more, but fewer than one-half, of the values below the detection criterion, the measure of central tendency is the median. If the values of the detection limits and the number of values below the detection limit permit (determined on a case-by-case basis), dispersion is reported as the IQR. Otherwise, no measure of dispersion is reported. Statistics are calculated using the reported detection limit value for nonradiological data or the reported value for radiological data.

For data sets with one-half or more of the values below the detection criterion, the central tendency is reported as less than the median value. Dispersion is not reported.

\section{Quality Assurance Process for the Environmental Report}

Unlike the preceding discussion, which focused on standards of accuracy and precision in data acquisition and reporting, a discussion of QA/QC procedures for a technical publication per se must deal with how to retain content accuracy through the publication process. Because publication of a large, data-rich document like this site annual environmental report involves many operations and many people, the chances of introducing errors are great. At the same time, ensuring quality is more difficult because a publication is less amenable to the statistical processes used in standard quality assurance methods.

The QA procedure we used concentrated on the tables and figures in the report and enlisted 40 authors, contributors, and technicians to check the accuracy of sections other than those they had authored or contributed to. In 2000, the 92 illustrations and 66 tables in the main volume and the 117 tables in the Data Supplement were checked. Checkers were assigned illustrations and tables and given a copy of each item they were to check along with a quality control form to fill out as they checked the item. Items to be checked included figure captions and table titles for clarity and accuracy, data accuracy and completeness, figure labels and table headings, units, significant digits, and consistency with text. When checking numerical data, checkers randomly selected $10 \%$ of the data and compared it to values in the master database. If all $10 \%$ agreed with the database, further checking was considered unnecessary. If there was disagreement in the data, the checker compared another $10 \%$ of the data with the database values. If more errors were found, the checker had then to verify every piece of data in the table or illustration.

A coordinator guided the process to ensure that forms were tracked and the proper approvals were obtained. Completed quality control forms and the corrected illustrations or tables were returned to the report editors, who were responsible for ensuring that changes, with the agreement of the original contributor, were made. This QA check resulted in the correction of data errors and omissions on $10 \%$ of the illustrations, $33 \%$ of the tables in the main volume, and $39 \%$ of the tables in the Data Supplement. Other corrections were made to footnotes, headings, titles in tables, graph axes, callouts, and captions in figures. 



\section{Appendix A. \\ S. Ring Peterson Methods of Dose Calculations}

\section{Introduction}

Lawrence Livermore National Laboratory calculates doses to the public for radiation protection purposes using the U.S. Environmental Protection Agency's (EPA's) model, CAP88-PC (Parks 1992, 1997), and discusses them in detail in Chapter 13. Emission rates of radionuclides from stacks and diffuse sources are used as input to CAP88-PC. Alternatively, doses may be calculated from concentrations in air, vegetation, water, and wine measured during routine monitoring. Because CAP88-PC is expected to overestimate doses to the public, doses calculated from environmental measurements should be lower, even when assumptions about intake rates are conservative. Calculating dose from measured environmental concentrations will reduce the uncertainty and increase the accuracy of the dose assessment.

Although various radionuclides are released to the environment in small quantities by LLNL activities, tritium is the only radionuclide that can be measured in the local food chain. Furthermore, tritium is the radionuclide primarily responsible for the low dose received by the public. Thus, although some of the equations presented in this chapter can be applied to any radionuclide, only the dose from tritium will be calculated and discussed here.

In this appendix, two different models that may be used to calculate dose from measured environmental concentrations are presented. One model, the Nuclear Regulatory Commission's (NRC) Regulatory Guide 1.109 (U.S. NRC 1977), has been used by LLNL since 1979 (Silver et al. 1980) to calculate ingestion doses from measured environmental concentrations of tritiated water (HTO). Doses have been based on the assumption of maximum annual intake of water, leafy vegetables, milk and meat. Inhalation doses have also been calculated based on measured air concentrations. Equations that derive bulk transfer parameter values used in Chapters 5, 7, and 11 to calculate doses from inhalation and ingestion of water and locally produced foodstuffs based on measured concentrations in the various media are presented here as they have been for twenty-one years. In addition, for comparison, bulk transfer parameter values based on the NRC 1.109 equations with different assumptions are derived. Similarly, bulk transfer parameter values are derived to calculate inhalation dose from predicted air concentrations of tritiated hydrogen gas (HT) and immersion dose from swimming. Using NRC 1.109 with various assumptions, including that of dose from organically bound tritium (OBT), doses based on 2000 environmental measurements are calculated. These doses are compared with those predicted for 2000 by NEWTRIT, the other model used to calculate doses from environmental measurements in this appendix. NEWTRIT has been recently developed and proposed as an improved regulatory model (Peterson and Davis, in press). NEWTRIT accounts for dose contributions from OBT and doses from releases of both HTO and HT. 


\section{Overview of CAP88-PC, NRC 1.109 and NEWTRIT}

The annual whole-body dose rate from ingestion of a particular food or drink is expressible as a product of three factors, regardless of model. These three factors are (1) the rate at which the food or drink is consumed (e.g., kg/y), (2) the radionuclide concentration in the food or drink (e.g., Bq/kg), and (3) the dose coefficient for the radionuclide (e.g., $\mu \mathrm{Sv} / \mathrm{Bq}$ ). Calculating the dose contribution from inhalation will be similar (e.g., $\left.\mathrm{m}^{3} / \mathrm{y} \times \mathrm{Bq} / \mathrm{m}^{3} \times \mu \mathrm{Sv} / \mathrm{Bq}\right)$. Each of the three models, CAP88-PC, NRC 1.109, and NEWTRIT, approaches this calculation of dose from exposure to environmental tritium in a somewhat different way.

CAP88-PC calculates the air concentration at a particular location using a Gaussian dispersion model. Assuming a default annual absolute humidity of $8 \mathrm{~g} / \mathrm{m}^{3}$, CAP88-PC calculates the concentration of HTO in air moisture. The HTO in vegetables, milk and meat is assumed in equilibrium with the HTO in air moisture. The daily diet is assumed to consist of $1560 \mathrm{~g}$ of water obtained from food and $1440 \mathrm{~g}$ of drinking water (Moore et al. 1979). The fractions of daily water obtained from food that represent vegetables, milk, and meat are $0.505,0.310$, and 0.185 respectively. For an atmospheric release of HTO, drinking water is assumed to have only $1 \%$ the tritium concentration of the air moisture.

Measured concentrations of HTO in air (for inhalation dose), water (for drinking water dose), and vegetation (for dose from food ingestion) can be used in NRC 1.109 to calculate doses from exposure to tritium. The equations, shown in detail in the next section, are not unique to tritium. They may be used to calculate the dose from any radionuclide if the appropriate transfer parameter values are known. Historically at LLNL, concentrations in milk and meat have been calculated based on the assumption that pasture ingested by animals has the same tritium concentration as the median measured concentration of HTO in vegetation. Ingestion dose to man was then calculated based on maximum annual intake rates of leafy vegetables, milk, and meat. This approach, although still used for calculations in Chapter 11 and demonstrated in the equations presented here, ignored the important contribution of tritium in the animal's drinking water to the concentration in the animal product. It also ignored the potential contribution to dose from vegetables other than leafy ones. Furthermore, the assumption of maximum annual intake is highly unrealistic. For comparison with doses based on these assumptions that are reported in Chapters 5, 7 , and 11, dose calculations using NRC 1.109 will be presented that are based on an average annual intake of a fairly complete diet. The milk and meat concentrations that make up that diet include the contributions from HTO in both ingested vegetation and drinking water. Doses based on NRC 1.109 concentrations in vegetables, milk, and meat that account for a fraction of intake being due to OBT (based on estimated HTO concentrations of foodstuff) will also be presented.

NEWTRIT calculates doses from releases of HT and HTO based on predicted or measured air concentrations. The default absolute humidity, like that in CAP88-PC, is $8 \mathrm{~g} / \mathrm{m}^{3}$, but a site-specific absolute humidity may be substituted. The model is formulated in terms of the tritium-to-hydrogen ratio in each environmental compartment. However, with each transfer, a small reduction in the ratio is introduced to reflect dilution observed in nature. Drinking water for animals is assumed to have half the concentration of air moisture, because small bodies of water exhibit that level of contamination near an atmospheric source of tritium. Drinking water for people is assumed to have $10 \%$ the HTO concentration of air moisture, which 
is the concentration of tritium expected in a large body of water near an atmospheric source of tritium. NEWTRIT accounts for dose from ingested OBT, as well as HTO. Based on experimental data, NEWTRIT accounts for the conversion of HT to HTO in the soil and the re-emission of HTO to the atmosphere from the soil. Doses calculated from a release of HT include inhalation of HT, inhalation and skin-absorption of HTO, ingestion of HTO from drinking water and foods, and ingestion of OBT from foods. Doses from a unit release of HT are expected to be about 10\% those from a unit release of HTO. The diet in NEWTRIT is the same as that in GENII (Napier et al. 1988), and it is assumed that the all the food ingested has been grown at the location at which the air concentrations have been estimated.

Each model recommends different consumption rates (see Table A-1). In Appendix E of the NRC Regulatory Guide 1.109, two annual diets are recommended, one for maximum intake and one for average intake. The diet shown for CAP88-PC is based on the assumption that the daily intake of $1560 \mathrm{~g}$ of water obtained from food accounts for a complete diet. Values for fresh weight, protein, carbohydrate, and fat fractions, used to derive the annual ingestion rates $(\mathrm{kg} / \mathrm{y})$ of vegetables, milk and meat based on water equivalent, come from Ciba-Geigy (1981). Assumptions about the fractions of fruit, grain, root crops, and fruit vegetables that make up "produce" come from NRC Regulatory Guide 1.109. Clearly, based on consumption alone (see Table A-1), doses from these models will be different.

Table A-1. Examples of annual inhalation and ingestion rates

\begin{tabular}{|l|c|c|c|c|}
\hline & $\begin{array}{c}\text { NRC 1.109 } \\
\text { maximum }\end{array}$ & $\begin{array}{c}\text { NRC 1.109 } \\
\text { average }\end{array}$ & CAP88-PC & NEWTRIT \\
\hline $\begin{array}{l}\text { Leafy vegetables/other plant } \\
\text { products }(\mathrm{kg})\end{array}$ & $64 / 520$ & - (a) $/ 190$ & - (a) $/ 333$ & $15 / 276$ \\
\hline Milk (L) & 310 & 110 & 183 & 230 \\
\hline Meat (kg) & 110 & 95 & 113 & 98.5 \\
\hline Drinking water (L) & 730 & 370 & 526 & 440 \\
\hline Inhalation $\left(\mathrm{m}^{3}\right)$ & 8000 & 8000 & 8038 & 8521 \\
\hline
\end{tabular}

a Leafy vegetables are included with the other plant products.

Each of the three models uses different dose coefficients. The dose coefficients used in the calculations of HTO dose from NRC 1.109 were obtained from the committed dose equivalent tables for DOE dose calculations (U.S. DOE 1988). They are similar to those specified in ICRP 72, Age dependent doses to members of the public from intake of radionuclides (ICRP 1996), which are used in NEWTRIT. The dose calculation for inhalation of tritiated hydrogen (HT) gas uses a dose coefficient from ICRP 71, (ICRP 1995). A comparison of dose coefficients is shown in Table A-2.

Assumptions play such a very important part in predicting dose that assumptions must be clearly elucidated, so that the apparent differences in dose predictions may be understood. 
Table A-2. Comparison of dose coefficients for tritium ( $\mu \mathrm{Sv} / \mathrm{Bq})$

\begin{tabular}{|l|c|c|c|}
\hline & DOE & CAP88-PC(a) & ICRP \\
\hline HTO (inhalation, skin absorption) & $1.73 \times 10^{-5}$ & $3.41 \times 10^{-5}$ & $1.8 \times 10^{-5}$ \\
\hline HT (inhalation) & $3.31 \times 10^{-13(b)}$ & - (c) $^{\text {(b) }}$ & $1.8 \times 10^{-9}$ \\
\hline HTO (ingestion) & $1.73 \times 10^{-5}$ & $2.43 \times 10^{-5}$ & $1.8 \times 10^{-5}$ \\
\hline OBT (ingestion) & -(c) $^{\text {(c) }}$ & (c) $^{\text {(c) }}$ & $4.2 \times 10^{-5}$ \\
\hline
\end{tabular}

a Computer code required by the EPA for modeling air emissions of radionuclides

b Units are $\mu \mathrm{Sv} / \mathrm{Bq} \times \mathrm{s} / \mathrm{m}^{3}$ because dose is considered external from air submersion.

c Not taken into account

\section{Dose Calculation Methods}

Although the analytical laboratories report concentrations in $\mathrm{pCi}$ and the DOE's dose coefficients have units of mrem/pCi, LLNL uses Système Internationale (SI) units of becquerel (Bq) for concentration and millisievert $(\mathrm{mSv})$, microsievert $(\mu \mathrm{Sv})$, or nanosievert $(\mathrm{nSv})$ for dose in compliance with Presidential Executive Order 12770, Metric Usage in Federal Government Programs (July 25, 1991). The conversion factors are as follows:

$1 \mathrm{~Bq}=27 \mathrm{pCi}$

$1 \mathrm{mSv}=100 \mathrm{mrem} ; \mathrm{l} \mu \mathrm{Sv}=0.1 \mathrm{mrem} ; \mathrm{lnSv}=0.1 \mu \mathrm{rem}$

All units have been converted to SI units in the following dose calculations.

Note: In some of the following equations, the dimensions associated with a multiplicative factor are not shown explicitly; the dimensions of the dependent variable and measured quantity are shown explicitly.

\section{Dose Calculation Methods for Chapters 5, 7, and 11 Using NRC 1.109}

In the following subsections, equations from NRC 1.109 provide guidance to estimate the annual dose from inhalation and from tritium ingested from water (or wine) and food (e.g., leafy vegetables, milk, and meat).

\section{Calculating Annual Dose from Potable Water (Chapter 7)}

The effective dose equivalent for tritium in drinking water $\left(D_{\text {water }}\right)$ in $\mu \mathrm{Sv} / \mathrm{y}$ is calculated using the following equation:

$$
D_{\text {water }}(\mu \mathrm{Sv} / \mathrm{y})=U_{\mathrm{w}} \times D C_{\mathrm{HTO}} \times C_{\mathrm{w}}
$$


where

$$
\begin{aligned}
& U_{\mathrm{w}}=\text { water consumption rate }(\mathrm{L} / \mathrm{y}) \\
& D C_{\mathrm{HTO}}=\text { dose coefficient for } \mathrm{HTO}(\mu \mathrm{Sv} / \mathrm{Bq}) \\
& C_{\mathrm{w}}=\text { concentration of tritium measured in drinking water }(\mathrm{Bq} / \mathrm{L})
\end{aligned}
$$

The tritium dose from ingestion of potable water, assuming maximum intake of water, is then

$$
\begin{aligned}
\mathrm{D}_{\text {water }}(\mu \mathrm{Sv} / \mathrm{y}) & =730(\mathrm{~L} / \mathrm{y}) \times 1.73 \times 10^{-5}(\mu \mathrm{Sv} / \mathrm{Bq}) \times C_{\mathrm{w}}(\mathrm{Bq} / \mathrm{L}) \\
& =1.3 \times 10^{-2} \times C_{\mathrm{w}}(\mathrm{Bq} / \mathrm{L})
\end{aligned}
$$

In Chapter 7, this equation is used to estimate doses from drinking water. Assuming different quantities are consumed, this equation can also be used to calculate the effective dose equivalent from wine (see Chapter 11).

\section{Calculating Annual Dose from Food Ingestion (Chapter 11)}

The effective dose equivalent from ingestion of food $\left(D_{\text {food }}\right)$ is calculated by summing the contributions from leafy vegetables, meat, and milk to the diet. The concentrations in these foodstuffs are based on measured tritium concentrations in annual grasses or weeds (see Chapter 11). Concentrations in milk and meat are calculated from measured concentrations in vegetation using the equations from NRC Regulatory Guide 1.109.

Leafy Vegetables: For dose calculations, we make the assumption that the leafy vegetables are $100 \%$ water; therefore, $\mathrm{Bq} / \mathrm{L}=\mathrm{Bq} / \mathrm{kg}$ fresh weight.

$$
D_{\text {veg }}(\mu \mathrm{sv} / \mathrm{y})=U_{\mathrm{veg}} \times D C_{\mathrm{HTO}} \times C_{\mathrm{veg}}
$$

where

$$
\begin{aligned}
& U_{\mathrm{veg}}=\text { intake rate of leafy vegetables }(\mathrm{kg} / \mathrm{y}) \\
& D C_{\mathrm{HTO}}=\text { dose coefficient for HTO }(\mu \mathrm{Sv} / \mathrm{Bq})(\mathrm{U} . S . \text { DOE } 1988) \\
& C_{\mathrm{veg}}=\text { concentration measured in annual grasses and weeds }(\mathrm{Bq} / \mathrm{L})
\end{aligned}
$$

The tritium dose from ingestion of leafy vegetables, assuming maximum intake, is then

$$
\begin{aligned}
D_{\text {veg }}(\mu \mathrm{Sv} / \mathrm{y}) & =64(\mathrm{~kg} / \mathrm{y}) \times 1.73 \times 10^{-5}(\mu \mathrm{Sv} / \mathrm{Bq}) \times C_{\text {veg }}(\mathrm{Bq} / \mathrm{kg}) \\
& =1.1 \times 10^{-3} \times C_{\text {veg }}(\mathrm{Bq} / \mathrm{L})
\end{aligned}
$$


Meat (Beef): To calculate dose from ingestion of meat, first the concentration of tritium in the meat must be calculated from the measured concentration in vegetation.

$$
C_{\text {meat_veg }}=F_{\mathrm{f}}(\mathrm{d} / \mathrm{kg}) \times Q_{\mathrm{f}}(\mathrm{kg} / \mathrm{d}) \times C_{\mathrm{veg}}(\mathrm{Bq} / \mathrm{kg}) \times \exp \left(-\lambda_{\mathrm{i}} t_{\mathrm{s}}\right)
$$

where

$F_{\mathrm{f}}=$ average fraction of an animal's daily intake of radionuclide appearing in each kilogram of animal flesh $[(\mathrm{Bq} / \mathrm{kg})$ in meat per $(\mathrm{Bq} / \mathrm{d})$ ingested by the animal $]=1.2 \times 10^{-2} \mathrm{~d} / \mathrm{kg}$

$Q_{f}=$ amount of feed consumed $=50 \mathrm{~kg} / \mathrm{d}$

$C_{\mathrm{veg}}=$ concentration measured in vegetation $(\mathrm{Bq} / \mathrm{kg})$

$\lambda_{\mathrm{i}}=$ radiological decay constant $=1.5 \times 10^{-4} \mathrm{~d}^{-1}$

$t_{\mathrm{s}}=$ time from slaughter to consumption $=20 \mathrm{~d}$

Therefore

$$
\begin{aligned}
C_{\text {meat_veg }} & =1.2 \times 10^{-2}(\mathrm{~d} / \mathrm{kg}) \times 50(\mathrm{~kg} / \mathrm{d}) \times C_{\text {veg }}(\mathrm{Bq} / \mathrm{kg}) \times \exp \left[\left(-1.5 \times 10^{-4}\right) \times 20\right] \\
& =0.6 \times C_{\text {veg }}(\mathrm{Bq} / \mathrm{kg})
\end{aligned}
$$

The dose from ingestion of meat is calculated:

$$
D_{\text {meat }}(\mu \mathrm{Sv} / \mathrm{y})=U_{\text {meat }} \times C_{\text {meat }} \times D C_{\mathrm{HTO}}
$$

where

$$
\begin{aligned}
& \begin{aligned}
U_{\text {meat }} & =\text { maximum intake rate }(\mathrm{kg} / \mathrm{y}) \\
C_{\text {meat }} & =\text { predicted concentration in meat at time of consumption from the contribution of vegetation } \\
& =C_{\text {meat_veg }}
\end{aligned} \\
& D C_{\text {HTO }}=\text { dose coefficient for } \mathrm{HTO}(\mu \mathrm{Sv} / \mathrm{Bq})
\end{aligned}
$$

The tritium dose rate from meat consumption is then

$$
\begin{aligned}
D_{\text {meat }}\left(\mu \mathrm{Sv}_{\mathrm{v}} \mathrm{y}\right) & =110(\mathrm{~kg} / \mathrm{y}) \times\left[0.6 \times C_{\mathrm{veg}}(\mathrm{Bq} / \mathrm{kg})\right] \times 1.73 \times 10^{-5}(\mu \mathrm{Sv} / \mathrm{Bq}) \\
& =1.1 \times 10^{-3} \times \mathrm{C}_{\mathrm{veg}}(\mathrm{Bq} / \mathrm{L})
\end{aligned}
$$


Cow Milk: To calculate dose from ingestion of milk, first the concentration of tritium in the milk must be calculated from the measured tritium concentration in vegetation.

$$
\mathrm{C}_{\text {milk_veg }}=\mathrm{F}_{\mathrm{m}}(\mathrm{d} / \mathrm{L}) \times \mathrm{Q}_{\mathrm{f}}(\mathrm{kg} / \mathrm{d}) \times \mathrm{C}_{\text {veg }}(\mathrm{Bq} / \mathrm{kg}) \times \exp \left(-\lambda_{\mathrm{i}} \mathrm{t}_{\mathrm{f}}\right)
$$

where

$\mathrm{F}_{\mathrm{m}}=$ average fraction of an animal's daily intake of radionuclide appearing in each kilogram of milk $[(\mathrm{Bq} / \mathrm{L})$ in milk per $(\mathrm{Bq} / \mathrm{d})$ ingested by the animal $]=1.0 \times 10^{-2} \mathrm{~d} / \mathrm{L}$

$Q_{\mathrm{f}}=$ amount of feed consumed by the milk cow $=50 \mathrm{~kg} / \mathrm{d}$

$C_{\mathrm{veg}}=$ concentration measured in vegetation $(\mathrm{Bq} / \mathrm{kg})$

$\lambda_{\mathrm{i}}=$ radiological decay constant $=1.5 \times 10^{-4} \mathrm{~d}^{-1}$

$t_{\mathrm{f}}=$ time from milking to milk consumption $=2 \mathrm{~d}$

Therefore

$$
\begin{aligned}
C_{\text {milk_veg }} & =1.0 \times 10^{-2}(\mathrm{~d} / \mathrm{L}) \times 50(\mathrm{~kg} / \mathrm{d}) \times C_{\text {veg }}(\mathrm{Bq} / \mathrm{kg}) \times \exp \left[\left(-1.5 \times 10^{-4}\right) \times 2\right] \\
& =0.5 \times C_{\text {veg }}(\mathrm{Bq} / \mathrm{L})
\end{aligned}
$$

The dose from consumption of milk is calculated:

$$
\mathrm{D}_{\text {milk }}(\mu \mathrm{Sv} / \mathrm{y})=\mathrm{U}_{\text {milk }} \times \mathrm{C}_{\text {milk }} \times \mathrm{DC}_{\mathrm{HTO}}
$$

where

$\mathrm{U}_{\text {milk }}=$ maximum intake $\operatorname{rate}(\mathrm{L} / \mathrm{y})$

$\mathrm{C}_{\text {milk }}=$ predicted concentration in milk at time of consumption from the contribution of vegetation $=\mathrm{C}_{\text {milk_veg }}$

$\mathrm{DC}_{\mathrm{HTO}}=$ dose coefficient for $\mathrm{HTO}(\mu \mathrm{Sv} / \mathrm{Bq})$

The tritium dose rate from directly consumed milk is then

$$
\begin{aligned}
D_{\text {milk }}(\mu \mathrm{Sv} / \mathrm{y}) & =310(\mathrm{~L} / \mathrm{y}) \times\left[0.5 \times \mathrm{C}_{\mathrm{veg}}(\mathrm{Bq} / \mathrm{kg})\right] \times 1.73 \times 10^{-5}(\mu \mathrm{Sv} / \mathrm{Bq}) \\
& =2.7 \times 10^{-3} \times C_{\mathrm{veg}}(\mathrm{Bq} / \mathrm{L})
\end{aligned}
$$


Total Food Ingestion: The annual dose from food ingestion as calculated in Chapter 11 based on measured $\mathrm{HTO}$ in vegetation is then:

$$
D_{\text {food }}(\mu \mathrm{Sv} / \mathrm{y})=D_{\text {veg }}+D_{\text {meat }}+D_{\text {milk }}
$$

where

$D_{\text {veg }}=$ dose from ingestion of leafy vegetables $(\mu \mathrm{Sv} / \mathrm{y})$

$D_{\text {meat }}=$ dose from ingestion of meat $(\mu \mathrm{Sv} / \mathrm{y})$

$D_{\text {milk }}=$ dose from ingestion of milk $(\mu \mathrm{Sv} / \mathrm{y})$

Therefore

$$
\begin{array}{rlr}
D_{\text {food }}(\mu \mathrm{Sv} / \mathrm{y}) & =1.1 \times 10^{-3} \times C_{\mathrm{veg}}(\mathrm{Bq} / \mathrm{L}) \quad & (\text { dose from leafy vegetables }) \\
+ & 1.1 \times 10^{-3} \times C_{\mathrm{veg}}(\mathrm{Bq} / \mathrm{L}) \quad(\text { dose from meat }) \\
+ & 2.7 \times 10^{-3} \times \mathrm{C}_{\mathrm{veg}}(\mathrm{Bq} / \mathrm{L}) & (\text { dose from milk }) \\
& =4.9 \times 10^{-3} \times C_{\mathrm{veg}}(\mathrm{Bq} / \mathrm{L}) &
\end{array}
$$

\section{Calculating Annual Inhalation and Skin Absorption Doses of HTO (Chapter 5)}

Doses caused by inhalation of radionuclide-contaminated air can be estimated in a way analogous to the preceding treatment of ingestion doses. The starting point is to evaluate the radionuclide concentration in air, $\chi\left(\mathrm{Bq} / \mathrm{m}^{3}\right)$, at the location of interest. Measurements of tritium in air are found in Chapter 5 .

The dose from HTO arises from the processes of inhalation and skin absorption. For inhalation/skin absorption dose, the known concentration of tritium in air is multiplied by the inhalation rate of a human to obtain the number of becquerels of tritium inhaled. Dose coefficients provided by the DOE (U.S. DOE 1988) are used to relate the intake of radioactive material into the body to dose commitment. The dose coefficient for inhalation is the same as for ingestion. However, to account for skin absorption, the inhalation factor is multiplied by 1.5. These dose factors provide estimates of the 50 -year dose from a oneyear intake of radioactivity.

The inhalation/skin absorption dose is expressible as

$$
D_{\text {inh } / \mathrm{sa}}(\mu \mathrm{Sv} / \mathrm{y})=1.5 \times U_{\text {air }} \times C_{\text {air }} \times D C_{\mathrm{HTO} \_ \text {inh }}
$$


where

1.5 factor that accounts for skin absorption

$U_{\text {air }}=$ air intake rate $\left(\mathrm{m}^{3} / \mathrm{y}\right)$

$C_{\text {air }}=$ HTO concentration measured in air at the receptor $\left(\mathrm{Bq} / \mathrm{m}^{3}\right)$

$D C_{\mathrm{HTO} \_ \text {inh }}=$ dose coefficient for inhalation $(\mu \mathrm{Sv} / \mathrm{Bq})$

The whole-body inhalation dose rate from HTO is then

$$
\begin{aligned}
D_{\text {inh } / \mathrm{sa}}(\mu \mathrm{Sv} / \mathrm{y}) & =1.5 \times 8000 \mathrm{~m}^{3} / \mathrm{y} \times C_{\text {air }} \times 1.73 \times 10^{-5} \mu \mathrm{Sv} / \mathrm{Bq} \\
& =0.21 \times C_{\text {air }}\left(\mathrm{Bq} / \mathrm{m}^{3}\right)
\end{aligned}
$$

Doses in Chapter 5 are calculated as shown here. The breathing rate of $8000 \mathrm{~m}^{3} / \mathrm{y}$ was corrected in 1999 from the $8400 \mathrm{~m}^{3} / \mathrm{y}$ used in previous years to conform to NRC 1.109 .

\section{Guidance to Calculate Annual Ingestion Dose with NRC 1.109 Using Modified Assumptions: Drinking Water for Animals and Annual Average Ingestion Rates for People}

The calculations of ingestion dose for Chapter 11 (shown above) do not account for ingestion of tritiated drinking water by animals, and yet drinking water is an important pathway. In 1998, in this appendix, a new approach to calculating the ingestion dose using NRC 1.109 was introduced that included drinking water for animals. In 1999 two further changes were made: (1) the annual ingestion rate for an individual was changed to include produce as well as leafy vegetables and (2) average ingestion rates, rather than maxima, were used (see Table A-1).

To calculate concentrations of tritium in meat and milk resulting from ingestion of water, the contribution of drinking water must be calculated using eqs A-3 and A-5 with two substitutions: (1) the daily intake of water $(50 \mathrm{~L} / \mathrm{d}$ for beef cattle and $60 \mathrm{~L} / \mathrm{d}$ for milk cows) must replace daily intake of pasture and (2) the measured concentration in potable water must replace the measured concentration in vegetation. When dose is calculated using eqs A-4 and A-6, the tritium contributed by drinking water must be added to the tritium contributed by the vegetation to obtain the concentration in meat or milk from both ingestion sources.

To calculate dose from average rather than maximum ingestion rates, the average NRC 1.109 consumption rates from Table A-1 are substituted into eqs A-1, A-2, A-4, and A-6. 
Complete equations that account for these assumptions may be found in Larson et al. (2000). Bulk transfer factor parameter values based on these assumptions have been calculated using eqs A-2, A-3, A-4, A-5, and A-6. They are summarized and compared in Table A-3 with the values used for the calculations in Chapters 5, 7 and 11 .

Table A-3. Comparison of the two sets of bulk transfer factors based on different assumptions to calculate doses using NRC 1.109

\begin{tabular}{|c|c|c|c|}
\hline Doses & Assumptions for SAER & \multicolumn{2}{|c|}{$\begin{array}{l}\text { Alternate assumptions: tritium in milk and meat comes from } \\
\text { pasture and drinking water; average annual diet }\end{array}$} \\
\hline $\mathrm{D}_{\text {inh/sa }}$ & $\begin{array}{l}\text { Chapter } 5 \\
\text { Inhalation and skin absorption: } \\
0.21 \times \mathrm{C}_{\text {air }}\left(\mathrm{Bq} / \mathrm{m}^{3}\right)\end{array}$ & \multicolumn{2}{|c|}{ Inhalation and skin absorption: } \\
\hline $\mathrm{D}_{\text {water }}$ & $\begin{array}{l}\text { Chapter } 7 \\
\text { Drinking water: } \\
1.3 \times 10^{-2} \times C_{w}\end{array}$ & \multicolumn{2}{|l|}{$\begin{array}{l}\text { Drinking water: } \\
6.4 \times 10^{-3} \times C_{w}\end{array}$} \\
\hline & $\begin{array}{l}\text { Chapter } 11 \text { Calculations - food } \\
\text { ingestion: }\end{array}$ & \multicolumn{2}{|c|}{$\begin{array}{l}\text { Calculations assuming drinking water for animals and average } \\
\text { annual intake for people - food ingestion: }\end{array}$} \\
\hline & Factor $\times \mathrm{C}_{\mathrm{veg}}(\mathrm{Bq} / \mathrm{kg})$ & Factor $\times \mathrm{C}_{\mathrm{veg}}(\mathrm{Bq} / \mathrm{kg})$ & Factor $\times C_{w}(B q / L)$ \\
\hline$D_{\text {veg }}$ & $1.1 \times 10^{-3}$ & $3.7 \times 10^{-3}$ & NA \\
\hline$D_{\text {meat }}$ & $1.1 \times 10^{-3}$ & $9.9 \times 10^{-4}$ & $9.9 \times 10^{-4}$ \\
\hline $\mathrm{D}_{\text {milk }}$ & $2.7 \times 10^{-3}$ & $9.5 \times 10^{-4}$ & $1.1 \times 10^{-3}$ \\
\hline
\end{tabular}

\section{Method to calculate dose from ingestion of OBT}

Models that account only for dose from HTO have come under attack in recent years. As shown in Table A-2, the dose coefficient for OBT is 2.3 times greater than that of HTO. When it is assumed (as in CAP88PC and NRC 1.109) that all ingested tritium is HTO, there is a possibility, depending on other assumptions in the models, that dose may be under-estimated. It is easy enough to calculate the probable contribution of OBT to dose, even from a model that only calculates concentrations of HTO and dose from HTO.

At LLNL, the HTO concentration of the plant water is measured in Bq/L. The concentration of tritium in fresh weight plant is the sum of the tritium in the water fraction (HTO) plus the tritium in the dry matter fraction $(\mathrm{OBT})$ :

$\mathrm{Bq} / \mathrm{kg}$ fresh weight plant $=\left(\mathrm{Bq} / \mathrm{L}(\right.$ measured $\left.\mathrm{HTO}) \times \mathrm{F}_{\mathrm{fw}}\right)$

$$
+\left(\mathrm{Bq} / \mathrm{L}(\text { measured HTO }) \times \mathrm{F}_{\mathrm{dm}} \times \mathrm{W}_{\mathrm{eq}}\right)
$$

where

$\mathrm{F}_{\mathrm{fw}}=$ water fraction of the plant $(\mathrm{L} / \mathrm{kg})$ 
$\mathrm{F}_{\mathrm{dm}}=$ dry matter fraction of the plant $(\mathrm{kg} / \mathrm{kg})$

$\mathrm{W}_{\mathrm{eq}}=$ water equivalent factor $(\mathrm{L} / \mathrm{kg})=$ amount of water generated through the combustion of the dry material in the sample $=[($ percent protein $\times 0.07)+($ percent fat $\times 0.12)+($ percent carbohydrate $\times 0.062)] / 100 \times(1 /$ fraction of mass of water that is hydrogen $)$

where

$0.07=$ fraction of hydrogen in proteins

0.12 fraction of hydrogen in fats

$0.062=$ fraction of hydrogen in carbohydrates

$2 / 18=$ fraction of mass of water that is hydrogen

Values of water fractions and fractions of protein, fat, carbohydrate, and ash for a wide variety of foodstuffs can be found in Ciba-Geigy Ltd. (1981). The $\mathrm{W}_{\mathrm{eq}}$ varies with the type of food and can be calculated from these data. A median value of $\mathrm{W}_{\mathrm{eq}}$ for a normal array of foodstuffs is about $0.6 \mathrm{~L} / \mathrm{kg}$.

Similarly, concentrations of HTO and OBT per kilogram milk or meat can be estimated based on the total concentrations of milk and meat calculated using eqs A-3 and A-5 and accounting for the contribution of drinking water.

Examples of concentrations of various foodstuffs based on the 2000 median tritium concentrations in plant water $(6.2 \mathrm{~Bq} / \mathrm{L})$ and rain water $(3.0 \mathrm{~Bq} / \mathrm{L})$ at VIS (Table A-4) are shown below. These equations follow the format of eq A-9, where the total concentration of tritium per kilogram edible food is the sum of the HTO and OBT contributions, respectively.

Lettuce $\quad(6.2 \times 0.948)+(6.2 \times 0.052 \times 0.602)=5.88+0.19=6.07 \mathrm{~Bq} / \mathrm{kg}$ fresh weight

Potato $\quad(6.2 \times 0.798)+(6.2 \times 0.202 \times 0.568)=4.95+0.7 \mathrm{l}=5.66 \mathrm{~Bq} / \mathrm{kg}$ fresh weight

Whole milk $(4.9 \times 0.885)+(4.9 \times 0.115 \times 0.746)=4.34+0.42=4.76 \mathrm{~Bq} / \mathrm{kg}$ fresh weight

Lean sirloin $(4.6 \times 0.718)+(4.6 \times 0.282 \times 0.724)=3.30+0.94=4.24 \mathrm{~Bq} / \mathrm{kg}$ fresh weight

To calculate dose that accounts for OBT, the concentration of HTO or OBT in each foodstuff must be multiplied by the appropriate dose coefficient (Table A-2) and by the quantity consumed. The total food ingestion dose is then the sum of the HTO and OBT dose contributions. 


\section{Method to calculate dose from inhalation of HT}

In the recent past, HT doses were treated as immersion doses (Eckermann and Ryman 1993), because H T has a low-energy beta particle and behaves similarly to ${ }^{41} \mathrm{Ar}$. $\mathrm{H}$ owever, the dose from $\mathrm{HT}$ is dominated by the small fraction that is metabolized. HT is therefore treated as a soluble gas (ICRP 1994), and an inhalation dose is calculated.

For tritium gas (H T), an inhalation dose is expressible as

$$
\mathrm{D}_{\text {inh_H }} \text { T }(\mu \mathrm{Sv} / \mathrm{y})=\mathrm{C}_{\text {air_H }} \mathrm{T} \times \mathrm{U}_{\text {air }} \times \mathrm{DC} \mathrm{C}_{\mathrm{HT}}
$$

where

$$
\begin{aligned}
& \mathrm{C}_{\text {air_H }} \mathrm{H}=\text { concentration of } \mathrm{HT} \text { in air at location } X_{\text {; }} \text { estimated by dispersion modeling }\left(\mathrm{Bq} / \mathrm{m}^{3}\right) \\
& \mathrm{U}_{\text {air }}=\text { air intake rate }\left(\mathrm{m}^{3} / \mathrm{y}\right) \\
& D C_{H T}=\text { effective dose per unit intake }(\mu \mathrm{Sv} / \mathrm{Bq})
\end{aligned}
$$

Therefore

$$
D_{\text {inh_HT }}(\mu \mathrm{SV} / \mathrm{y})=\mathrm{C}_{\text {air_HT }}\left(\mathrm{Bq} / \mathrm{m}^{3}\right) \times 8000 \mathrm{~m}^{3} / \mathrm{y} \times 1.8 \times 10^{-9} \mu \mathrm{SV} / \mathrm{Bq}
$$

The tritium dose rate from inhalation of $\mathrm{H} T$ is then (based on predicted $\mathrm{H} T$ in air):

$$
D_{\text {inh_H }}(\mu \mathrm{Sv} / \mathrm{y})=1.44 \times 10^{-5} \times \mathrm{C}_{\text {air_HT }}\left(\mathrm{Bq} / \mathrm{m}^{3}\right)
$$

\section{Method to calculate dose from swimming}

Immersion in water is another pathway to dose from tritium because tritium can be absorbed through the skin. The intake of water by skin diffusion is $0.4 \mathrm{~mL} / \mathrm{min}$ (O sborne 1968). A high estimate of time spent swimming in the LLNL would be 250 hours a year. The amount of water absorbed through the skin in this period would be $6 \mathrm{~L}$.

D ose from immersion in water can be expressed as:

$$
D_{\text {imm_HTO }}(\mu \mathrm{Sv} / \mathrm{y})=\mathrm{C}_{\text {pool }}(\mathrm{Bq} / \mathrm{L}) \times \mathrm{U}_{\text {pool }}(\mathrm{L} / \mathrm{y}) \times \mathrm{D} \mathrm{C}_{\text {HTO }}(\mu \mathrm{SV} / \mathrm{Bq})
$$

where

$\mathrm{C}_{\text {pool }}=$ median annual concentration of $\mathrm{HTO}$ in the $L L N L$ swimming pool $(\mathrm{Bq} / \mathrm{L})$

$\mathrm{U}_{\text {pool }}=$ intake rate of water through the skin $(\mathrm{L} / \mathrm{y})$

$D C_{H T O}=$ effective dose per unit intake $\mathrm{HTO}(\mu \mathrm{Sv} / \mathrm{Bq})$ 
The whole-body skin absorption dose from swimming is:

$$
\begin{aligned}
D_{\text {imm_HTO }}(\mu \mathrm{Sv} / \mathrm{y}) & =\mathrm{C}_{\text {pool }} \times 6 \mathrm{~L} / \mathrm{y} \times 1.8 \times 10^{-5} \mu \mathrm{Sv} / \mathrm{Bq} \\
& =1.1 \times 10^{-4} \mathrm{C}_{\text {pool }}(\mathrm{Bq} / \mathrm{L})
\end{aligned}
$$

\section{Dose Predictions}

\section{Regulatory Dose Predictions}

\section{Observed and Predicted Input to Models}

Concentrations of tritium in air (Chapter 5 ) are monitored at 11 on-site locations, including the Visitor's Center (VIS), which is a convenient location for comparing doses from different modeling approaches, because measurements of tritium in vegetation and rainfall are also taken at VIS. Furthermore, VIS is close to the location of the site-wide maximally exposed individual. M edian concentrations measured in air, vegetation (Chapter 11) and rainwater (Chapter 7) for VIS are shown in Table A-4 along with predicted air concentrations at VIS for releases from the Tritium Facility using CAP88-PC. If the contribution of all LLNL sources of tritium had been estimated at VIS, the predicted concentrations of tritium in air would be higher. The concentration of tritium in wine (Chapter 11) and the LLNL swimming pool (Chapter 7) are also shown in Table A-4.

Table A-4. Observed tritium concentrations in various environmental media at VIS and in the vicinity of Livermore, and concentrations of HTO and HT in air at VIS predicted by CAP88-PC from releases from the Tritium Facility. All data are for 2000.

\begin{tabular}{|l|c|c|}
\hline & $\begin{array}{c}\text { Median Observed HTO } \\
\text { Concentrations }\end{array}$ & $\begin{array}{c}\text { Predicted Tritium } \\
\text { Concentrations }\end{array}$ \\
\hline $\begin{array}{l}\text { Air concentration }\left(\mathrm{Bq} / \mathrm{m}^{3)}\right. \\
\text { HTO } \\
\text { HT }\end{array}$ & 0.047 & 0.059 \\
\hline Vegetation (Bq/L) & 6.2 & 0.0070 \\
\hline Rain (Bq/L) & 3.0 & $\mathrm{n} / \mathrm{a}$ \\
\hline Livermore Valley Wine (Bq/L) & 2.3 & $\mathrm{n} / \mathrm{a}$ \\
\hline LLNL Swimming Pool (Bq/L) & 2.8 & $\mathrm{n} / \mathrm{a}$ \\
\hline
\end{tabular}

$\mathrm{n} / \mathrm{a}=$ not applicable

CAP88-PC doses are calculated based on measured source terms. D oses using N EWTRIT can be estimated using either the observed or predicted air concentrations at VIS. M easured concentrations in vegetation, air, and rainfall at VIS can be used as input to NRC 1.109 to calculate doses. The assumption for all calculations is that the exposed person never leaves the Visitor's C enter and is entirely self-sufficient in that all vegetables (including grain) ingested are grown at the Visitor's C enter. Furthermore, all animals used for food live there too and consume pasture grown there. D rinking water for both animals and people (in N RC 1.109) is rainwater at the median concentration for the entire year. The assumption that drinking water has the concentration of rain water is extremely conservative and will result in a very high estimate of dose 
compared with the true probable dose in the Livermore Valley, because no drinking water supplies were above the detection limit for 2000 (Table 7-13). The use of different models and different assumptions will result in very different dose predictions (Tables A-5 and A-6). Because the protection of the public is paramount, it should be shown by more than one model and more than one set of assumptions that the dose to the public is acceptably low.

Comparison of Model Predictions for inhalation and ingestion of HTO: CAP88-PC and NRC 1.109

Results in Table A-5 compare doses predicted by CAP88-PC and the N RC 1.109 model with two different sets of assumptions. Results for N RC 1.109 in the middle column of Table A-5 were calculated using the historical assumptions that have been used in the SAER for dose calculations in the appropriate chapters (i.e., no drinking water for animals and maximum annual ingestion rates of leafy vegetables, milk and meat). N umbers for N RC 1.109 in the right-hand column were calculated based on the assumption of drinking water for animals and an annual average diet. All results are based on the assumption that ingested tritium is only H TO.

The CAP88-PC predictions are all higher than either set of NRC results except for drinking water. The default assumption in CAP88-PC is that drinking water is only $1 \%$ as contaminated as air moisture; in N RC 1.109 , the assumption has been made that the individual is drinking water with a concentration of $3.0 \mathrm{~Bq} / \mathrm{L}$ (equal to rain water). Thus, for 2000, the dose from drinking water in NRC 1.109 can be as much as nearly $50 \%$ of the total dose, depending upon other assumptions, while in CAP88-PC, the drinking water contribution is less than $1 \%$ of the total dose. This illustrates the importance of tritium concentrations in drinking water to total dose.

Table A-5. Comparison of hypothetical annual doses from only HTO at the Visitor's Center

\begin{tabular}{|l|c|c|c|}
\hline \multicolumn{1}{|c|}{$\begin{array}{c}\text { Dose } \\
\text { (nSv/y) }\end{array}$} & $\begin{array}{c}\text { CAP88-PC (a) } \\
\text { (from predicted air } \\
\text { concentrations) }\end{array}$ & $\begin{array}{c}\text { NRC 1.109 } \\
\text { (from observed } \\
\text { concentrations)- } \\
\text { SAER assumptions }\end{array}$ & $\begin{array}{c}\text { NRC 1.109 (from } \\
\text { observed } \\
\text { concentrations)- } \\
\text { new assumptions }\end{array}$ \\
\hline Inhalation and skin absorption & 16. & 9.8 & 9.8 \\
\hline Vegetables & 52. & 6.8 & 9.2 \\
\hline Milk & {$[32]$.} & 17. & 9.1 \\
\hline Meat & 19. & 6.8 & 19. \\
\hline Drinking water & 0.95 & 39. & 58. \\
\hline Total ingestion dose (food and water) & $72 .[104]$. & 70. & 67. \\
\hline Total dose from HTO & $88 .[120]$. & 79. & 20. \\
\hline
\end{tabular}

a N umbers in brackets (e.g., dose from milk) are not calculated for reported LLNL doses. See LLNL NESHAPs 1999 Annual Report (Gallegos et al. 2000), Guidance for Radiological Dose Assessment (Harrach 1999), and Chapter 13. 
Comparison of Model Predictions for HTO inhalation and ingestion and OBT ingestion: NRC 1.109 and NEWTRIT

$\mathrm{U}$ sing the assumptions of the NRC 1.109 model (animals drink rainwater and the annual diet is average) and estimated concentrations of $\mathrm{HTO}$ and $\mathrm{OBT}$ in $\mathrm{Bq} / \mathrm{kg}$ fresh weight of food, doses for total tritium (H TO and OBT) can be calculated for NRC 1.109 (Table A-6). The contribution of OBT increases the

Table A-6. Comparison of hypothetical annual doses from HTO and OBT at the Visitor's Center

\begin{tabular}{|l|c|c|c|c|}
\hline $\begin{array}{c}\text { Dose } \\
\text { (nSV/y) }\end{array}$ & $\begin{array}{c}\text { NRC 1.109 } \\
\text { (from observed } \\
\text { air and } \\
\text { vegetation } \\
\text { concentrations) }\end{array}$ & $\begin{array}{c}\text { NEWTRIT(a) for } \\
\text { released HTO } \\
\text { (from observed } \\
\text { air } \\
\text { concentrations) }\end{array}$ & $\begin{array}{c}\text { NEWTRIT } \\
\text { released HTO } \\
\text { (from predicted } \\
\text { air } \\
\text { concentrations) }\end{array}$ & $\begin{array}{c}\text { NEWTRIT(a) } \text { for }^{(2)} \\
\text { released HT } \\
\text { (from predicted } \\
\text { air } \\
\text { concentrations) }\end{array}$ \\
\hline Inhalation & 9.8 & 11. & 12. & 0.045 \\
\hline Vegetables ${ }^{(b)}$ & 27. & 28. & 31. & 0.48 \\
\hline Milk & 11. & 18. & 19. & 0.23 \\
\hline Meat & 13. & 8.9. & 10. & 0.11 \\
\hline Drinking water & 19. & 4.7 & 5.1 & 0.10 \\
\hline Total ingestion (food and water) & 70. & 60. & 65. & 0.92 \\
\hline Total dose from HTO and OBT & 80. & 71. & 77. & 0.97 \\
\hline
\end{tabular}

a The total tritium dose predicted by NEWTRIT for HT and HTO released from the Tritium Facility will be the sum of the NEWTRIT results for predicted air concentrations of HT and HTO or the sum of the HT results for predicted air concentrations plus the HTO results based on observed air concentrations.

b Includes leafy vegetables, fruit, fruit vegetables, root vegetables and grain

doses over those shown in Table A-5 by 35\%, 20\%and 43\% for vegetables (including grain), milk and meat respectively. In Table A-6, doses from NRC 1.109 that account for O BT are compared with doses calculated from NEWTRIT. Differences are due to different assumptions about diets (see Table A-1) and the fact that NEWTRIT's concentrations in vegetables, milk and meat are lower than those of N RC 1.109. The drinking water tritium contribution to milk and meat is about the same in both models. The contribution of drinking water to human dose in N RC 1.109 is much higher than in NEWTRIT with its default assumption that the concentration of the individual's drinking water is just $10 \%$ of the concentration of air moisture. $10 \%$ of the median air moisture concentration measured at VIS is $0.59 \mathrm{~Bq} / \mathrm{L}$, which is about a factor of 5 lower than the concentration of rainwater. This concentration is also non-detectable using scintillation counting. This estimate is nevertheless conservative, since drinking water in the Livermore Valley does not come from surface water, and it is higher than the prediction of CAP88-PC (see Table A-5). 
Also shown in Table A-6 is the estimated dose from the release of $\mathrm{H} \mathrm{T}$ from the Tritium Facility. A tiny contribution to total dose from inhalation $\left(1.3 \times 10^{-8} \mathrm{nSv} / \mathrm{y}\right.$, not shown explicitly) arises from air concentrations of tritiated hydrogen $(\mathrm{H} \mathrm{T})$ gas, based on an air concentration of $0.007 \mathrm{~Bq} / \mathrm{m}^{3}$ estimated by the dispersion model in CAP88-PC. The inhalation dose shown from the release of $\mathrm{HT}$ is due to conversion of HT to HTO in the soil and the re-emission of HTO to air. Re-emitted HTO is incorporated into plants. For 2000, the release rate of $\mathrm{H} \mathrm{T}$ was small relative compared with the release of $\mathrm{H} \mathrm{TO}$ from the Tritium Facility. As a result, the dose from $\mathrm{HT}$ is only about $1 \%$ that of the dose from the released $\mathrm{HTO}$. The measured H TO concentrations in air and vegetation account for the dose from any H T that has been converted to H TO in the environment.

The assumptions behind the models in Tables A-5 and A-6 are all designed to predict highly conservative doses for regulatory purposes that will not be exceeded by any member of the public. Even the lowest dose from Tables A-5 and A-6 (67 nSv/ y for NRC 1.109, assumptions of animal drinking water and average diet) is less than a factor of two below the highest dose, which was calculated with CAP88-PC.

\section{Realistic Dose Estimates}

NEWTRIT is the model best suited for a realistic dose assessment because it accounts for doses from releases of HT and H TO separately and determines the contribution of OBT to dose. Furthermore, its default parameter values may be altered to account for site-specific data. For example, in this calculation, the average absolute humidity for 2000 at $L L N L\left(7.6 \mathrm{~g} / \mathrm{m}^{3}\right)$ was used instead of the default $\left(8 \mathrm{~g} / \mathrm{m}^{3}\right)$. If it were possible for a person to live at the Visitor's Center, it would still be highly unlikely that they would spend all their time there, or that all their food would be homegrown. This person also might drink local wine and swim in the LLNL swimming pool; these doses can be calculated with the equations presented in this appendix. Realistic, yet still conservative, doses are shown in Table A-7.

Table A-7. Realistic, yet conservative, assumptions and consequent doses for the tritium exposure of an individual living at Visitor's Center in 2000 based on observed HTO in air concentrations and predicted $\mathrm{HT}$ in air concentrations

\begin{tabular}{|l|c|l|}
\hline \multicolumn{1}{|c|}{ Source of dose } & $\begin{array}{c}\text { Annual dose } \\
\text { (nSV) }\end{array}$ & \multicolumn{1}{|c|}{ Assumption } \\
\hline Inhalation & 7.3 & Breathes air at VIS 16 hours a day, all year \\
\hline $\begin{array}{l}\text { Ingesting food, } \\
\text { including OBT }\end{array}$ & 13.0 & $\begin{array}{l}\text { Raises and eats 50\% homegrown leafy vegetables, fruit vegetables, fruits and } \\
\text { root crops, no homegrown milk and 20\% homegrown meat (chickens and } \\
\text { eggs). Assume the feed for the chickens is 50\% homegrown; chickens drink } \\
\text { water from puddles at 50\% air moisture. }\end{array}$ \\
\hline Drinking water & 0.50 & Drinks well water at 1\% the concentration of air moisture. \\
\hline Drinking wine & 2.1 & Drinks one bottle of Livermore Valley wine each week \\
\hline Immersion & 0.12 & Swims in the LLN L pool 100 hours per year \\
\hline
\end{tabular}

The total annual "realistic" dose from Table A-7 is therefore 23 nSv/ y, a factor of about 5.2 below the maximum dose predicted by CAP88-PC, and a factor of 3.1 below the dose predicted by N EWTRIT, neither of which accounts for wine or swimming. 
All calculated doses presented here are about $1 \%$ or less of the EPA's radiation dose limit to the member of the public from an atmospheric release ( $100 \mu \mathrm{Sv} / \mathrm{y}$ ). CAP88-PC's dose, by far the highest, is just $1.2 \%$ of an annual effective dose equivalent of $10 \mu \mathrm{Sv}$, which corresponds to the $\mathrm{N}$ ational Council on Radiation Protection and M easurements' (1987a) concept of N egligible Individual Risk Level. Thus, even though artificially high, this dose is still small. 



\section{Appendix B. \\ ENVIRONMENTAL DOE ORDERS IN WORK SMART STANDARDS}

\begin{tabular}{|c|c|c|}
\hline Topic & Order number and title & Relevant portion \\
\hline \multirow[t]{3}{*}{ Sanitary Sewer Discharges } & \multirow{3}{*}{$\begin{array}{l}\text { DOE O } 5400.5 \text { Chg. } 2 \text {, } \\
\text { Radiation Protection of the } \\
\text { Public and the Environment }\end{array}$} & $\begin{array}{l}\text { Chapter I, Paragraph 5.b., Treatment of Liquid Radioactive } \\
\text { Waste Streams (using BAT) }\end{array}$ \\
\hline & & Chapter I, Paragraph 7, Discharges to Sanitary Sewer \\
\hline & & $\begin{array}{l}\text { Chapter II, Paragraph 3.d.2, Controlling Long-term Buildup of } \\
\text { Radionuclides in Solids }\end{array}$ \\
\hline CERCLA:Site Remediation & $\begin{array}{l}\text { DOE O } 414.1 \\
\text { Quality Assurance }\end{array}$ & Attachment 1, Contractor Requirements Document \\
\hline \multirow[t]{5}{*}{ Environmental Monitoring } & $\begin{array}{l}\text { DOE O } 231.1 \text {, } \\
\text { Environment, Safety, and } \\
\text { Health Reporting }\end{array}$ & $\begin{array}{l}\text { Paragraph 5.d.2, Annual Site Environmental Reports (requires } \\
\text { report on annual basis)-included in DOE O 231.1 Chg. 2, } \\
\text { ES\&H Reporting, Paragraph 3. Applicability, and Attachment 1, } \\
\text { Contractor Requirements Document }\end{array}$ \\
\hline & $\begin{array}{l}\text { DOE O } 5400.1 \\
\text { General Environmental } \\
\text { Protection Program }\end{array}$ & $\begin{array}{l}\text { Chapter III, Paragraph 4.a., Groundwater Protection Manage- } \\
\text { ment Program, and Chapter IV, paragraph 1.a. Requirement } \\
\text { for Environmental Monitoring, 3. Preoperational Monitoring of } \\
\text { Facilities, Sites, and Opertions, 4. Environmental Monitoring } \\
\text { Plan, 5. Environmental Monitoring General Requirements, } 6 \text {. } \\
\text { Meteorological Monitoring Requirements, and 10.c. Labora- } \\
\text { tory Quality Assessment-included in DOE O 5400.1 Chg. 1, } \\
\text { Chapter III, Paragraph 4(a), 4(b), } 4 \text { (c) and Chapter IV, } \\
\text { Paragraph } 1 \text { (a), 3, 4, 5, 6, and } 10 \text { (c) }\end{array}$ \\
\hline & \multirow[t]{3}{*}{$\begin{array}{l}\text { DOE O } 5400.5 \text { Chg. } 2 \text {, } \\
\text { Radiation Protection of the } \\
\text { Public and the Environment }\end{array}$} & $\begin{array}{l}\text { Chapter II, Requirements for Radiation Protection of the Public } \\
\text { and the Environment, Paragraph } 1 \text { (except 1.a.3.c. and 1.c), } \\
\text { Public Dose Limits, 2. ALARA, 5. Release of Property Having } \\
\text { Residual Radioactive Material, 6. Demonstration of } \\
\text { Compliance with the Dose Limits, and 8.a. Record Content }\end{array}$ \\
\hline & & Chapter III, Derived Concentration Guides for Air and Water \\
\hline & & Chapter IV, Residual Radioactive Material \\
\hline $\begin{array}{l}\text { Water Discharges - } \\
\text { Storage Tanks }\end{array}$ & $\begin{array}{l}\text { DOE O } 420.1 \text { Chg } 2 \text {, } \\
\text { Facility Safety }\end{array}$ & $\begin{array}{l}\text { § } 4.4 \text { Natural Phenomena Hazards Mitigation for DOE } \\
\text { facilities-included in DOE O } 420.1 \text { Chg. 2, Facility Safety, } \\
\text { Attachment 2, Contractor Requirments Document, Paragraph } \\
4 \text { (except } 4.1 .2,4.1 .3 \text {, and excluding the invocation of ANS } \\
\text { 8.9, ANS 8.10, and ANS 8.17) }\end{array}$ \\
\hline Waste-Radioactive & $\begin{array}{l}\text { DOE O } 435.1 \text {, } \\
\text { Radioactive Waste } \\
\text { Management }\end{array}$ & Attachment 1, Contractor Requirements Document \\
\hline $\begin{array}{l}\text { Waste Minimization/ } \\
\text { Pollution Prevention }\end{array}$ & $\begin{array}{l}\text { DOE O } 5400.1 \text { Chg. } 1, \\
\text { General Environmental } \\
\text { Protection Program }\end{array}$ & $\begin{array}{l}\text { Chapter III, Paragraph 4.a, 4.b, 4.c and Chapter IV, Paragraph } \\
1 . a, 3,4,5,6 \text {, and } 10 . c\end{array}$ \\
\hline
\end{tabular}





\section{APPENDix C. \\ Reports for Regulatory Agencies}

\begin{tabular}{|c|c|c|}
\hline Title & Agency & Frequency \\
\hline AB2588 Emissions Report & $\begin{array}{l}\text { Bay Area Air Quality Management District } \\
\text { San Joaquin Valley Unified Air Pollution Control } \\
\text { District }\end{array}$ & Every 2 years \\
\hline $\begin{array}{l}\text { Air Emission Permit Renewals and Emissions } \\
\text { Report }\end{array}$ & $\begin{array}{l}\text { Bay Area Air Quality Management District } \\
\text { San Joaquin Valley Unified Air Pollution Control } \\
\text { District }\end{array}$ & Yearly \\
\hline Recycling Unit Contingency/Business Plans & Department of Toxic Substances Control & As required \\
\hline Conditional Exemption Unit Contingency Plans & Department of Toxic Substances Control & As required \\
\hline PCB Annual Report & Environmental Protection Agency & Yearly \\
\hline Medical Waste Permit & $\begin{array}{l}\text { Alameda County Emergency Health Services and } \\
\text { Department of Public Health Services, San } \\
\text { Joaquin County }\end{array}$ & As required \\
\hline $\begin{array}{l}\text { Explosive Waste Treatment Facility_Site } 300 \\
\text { Permit }\end{array}$ & Department of Toxic Substances Control & Every 10 years \\
\hline $\begin{array}{l}\text { Main Site Part A\&B Hazardous Waste Permit } \\
\text { (includes contingency plans and closure plans) }\end{array}$ & Department of Toxic Substances Control & Every 10 years \\
\hline $\begin{array}{l}\text { Site } 300 \text { Container Storage Area (B883) and } \\
\text { Explosive Waste Storage Facility Permit }\end{array}$ & Department of Toxic Substances Control & Every 10 years \\
\hline Cultural Resource Management Plan & $\begin{array}{l}\text { Department of Energy } \\
\text { California State Historic Preservation Officer }\end{array}$ & As required \\
\hline $\begin{array}{l}\text { RCRA Section } 3016 \text { Report, Inventory of Federal } \\
\text { Agency Hazardous Waste Facilities }\end{array}$ & $\begin{array}{l}\text { Department of Energy } \\
\text { Environmental Protection Agency }\end{array}$ & As required \\
\hline $\begin{array}{l}\text { Less-than-90-Day Waste Accumulation Area } \\
\text { Contingency Plans }\end{array}$ & Department of Toxic Substances Control & As required \\
\hline SB14 Documentation Plan & Department of Toxic Substance Control & Every 4 years \\
\hline Ozone Depleting Chemicals Phase Out Report & $\begin{array}{l}\text { Department of Energy } \\
\text { Environmental Protection Agency }\end{array}$ & Yearly \\
\hline DOE Annual Waste Minimization Report & Department of Energy & Yearly \\
\hline Waste Minimization Certification for Site 300 & Department of Toxic Substances Control & Yearly \\
\hline $\begin{array}{l}\text { NEPA Reviews, Proposed LLNL/Department of } \\
\text { Energy Projects }\end{array}$ & Department of Energy & As required \\
\hline
\end{tabular}




\begin{tabular}{|c|c|c|}
\hline Title & Agency & Frequency \\
\hline $\begin{array}{l}\text { CEQA Review for Department of Energy/UC } \\
\text { Contract Renewal }\end{array}$ & University of California & $\begin{array}{l}\text { Before } \\
\text { contract } \\
\text { renewal }\end{array}$ \\
\hline CEQA Reviews, Proposed LLNL/UC Projects & University of California & As required \\
\hline $\begin{array}{l}\text { Spill Prevention Control and Countermeasures } \\
\text { Plans (Livermore Site and Site 300) Plan }\end{array}$ & $\begin{array}{l}\text { Environmental Protection Agency } \\
\text { San Francisco Bay Regional Water Quality } \\
\text { Control Board } \\
\text { Central Valley Regional Water Quality Control } \\
\text { Board } \\
\text { Alameda County Environmental Health Services } \\
\text { or Department of Public Health Services, } \\
\text { San Joaquin County }\end{array}$ & $\begin{array}{l}\text { Every } 3 \text { years } \\
\text { or when there } \\
\text { are significant } \\
\text { changes }\end{array}$ \\
\hline $\begin{array}{l}\text { Closure Plans for any hazardous waste/product } \\
\text { underground storage tanks (USTs) removed from } \\
\text { service }\end{array}$ & $\begin{array}{l}\text { Alameda County Environmental Health Services } \\
\text { or Department of Public Health Services, } \\
\text { San Joaquin County }\end{array}$ & As required \\
\hline $\begin{array}{l}\text { Closure Reports for any hazardous waste/product } \\
\text { USTs removed from service }\end{array}$ & $\begin{array}{l}\text { Alameda County Environmental Health Services } \\
\text { or Department of Public Health Services, } \\
\text { San Joaquin County }\end{array}$ & As required \\
\hline $\begin{array}{l}\text { Monitoring Program and Emergency Response } \\
\text { Plan for any hazardous waste/ product USTs }\end{array}$ & $\begin{array}{l}\text { Alameda County Environmental Health Services } \\
\text { or Department of Public Health Services, } \\
\text { San Joaquin County }\end{array}$ & As required \\
\hline $\begin{array}{l}\text { Closure Reports for greater than } 90 \text {-day } \\
\text { hazardous waste aboveground storage tanks } \\
\text { (ASTs) operated under Interim Status and } \\
\text { removed from service }\end{array}$ & Department of Toxic Substances Control & As required \\
\hline $\begin{array}{l}\text { Engineering Assessments for RCRA hazardous } \\
\text { waste tanks }\end{array}$ & $\begin{array}{l}\text { Alameda County Environmental Health Services } \\
\text { or Department of Public Health Services, } \\
\text { San Joaquin County }\end{array}$ & As required \\
\hline $\begin{array}{l}\text { Installation Plans for new hazardous waste/ } \\
\text { product UST }\end{array}$ & $\begin{array}{l}\text { Alameda County Environmental Health Services } \\
\text { or Department of Public Health Services, } \\
\text { San Joaquin County }\end{array}$ & As required \\
\hline Hazardous Waste/Product UST Operating Permit & $\begin{array}{l}\text { Alameda County Environmental Health Services } \\
\text { or Department of Public Health Services, } \\
\text { San Joaquin County }\end{array}$ & Annually \\
\hline $\begin{array}{l}\text { Less-than-90-Day Hazardous Waste Tank } \\
\text { Contingency Plans (for Hazardous Tank Systems } \\
\text { at Livermore Site) }\end{array}$ & Department of Toxic Substances Control & As required \\
\hline $\begin{array}{l}\text { Tank Monitoring Program for Hazardous Waste } \\
\text { ASTs }\end{array}$ & $\begin{array}{l}\text { Alameda County Environmental Health Services } \\
\text { or Department of Public Health Services, } \\
\text { San Joaquin County }\end{array}$ & $\begin{array}{l}\text { Prior to new } \\
\text { tank use }\end{array}$ \\
\hline $\begin{array}{l}\text { Tank Modification/Approval Plans for hazardous } \\
\text { waste/product USTs }\end{array}$ & $\begin{array}{l}\text { Alameda County Environmental Health Services } \\
\text { or Department of Public Health Services, } \\
\text { San Joaquin County }\end{array}$ & As required \\
\hline Monthly Sewer Monitoring Report & Livermore Water Reclamation Plant & Monthly \\
\hline
\end{tabular}




\begin{tabular}{|c|c|c|}
\hline Title & Agency & Frequency \\
\hline $\begin{array}{l}\text { Site } 300 \text { Pits } 1 \text { and } 7 \text { Compliance Monitoring } \\
\text { Reports }\end{array}$ & $\begin{array}{l}\text { Central Valley Regional Water Quality Control } \\
\quad \text { Board } \\
\text { Environmental Protection Agency } \\
\text { Department of Toxic Substances Control }\end{array}$ & $\begin{array}{l}\text { Quarterly and } \\
\text { yearly }\end{array}$ \\
\hline $\begin{array}{l}\text { Site } 300 \text { Quarterly Cooling Tower Discharge } \\
\text { Report }\end{array}$ & $\begin{array}{l}\text { Central Valley Regional Water Quality Control } \\
\text { Board }\end{array}$ & Quarterly \\
\hline $\begin{array}{l}\text { Wastewater Point-Source Monitoring Semi- } \\
\text { Annual Report }\end{array}$ & Livermore Water Reclamation Plant & Twice a year \\
\hline $\begin{array}{l}\text { Storm Water Pollution Prevention Plans (Liver- } \\
\text { more Site and Site 300) }\end{array}$ & $\begin{array}{l}\text { San Francisco Bay Regional Water Quality } \\
\text { Control Board } \\
\text { Central Valley Regional Water Quality Control } \\
\text { Board }\end{array}$ & As required \\
\hline $\begin{array}{l}\text { Storm Water Pollution Prevention Plans for } \\
\text { Construction (Livermore Site and Site 300) }\end{array}$ & $\begin{array}{l}\text { San Francisco Bay Regional Water Quality } \\
\text { Control Board } \\
\text { Central Valley Regional Water Quality Control } \\
\text { Board }\end{array}$ & As required \\
\hline Ground Water Protection Management Program & Department of Energy & $\begin{array}{l}\text { Every } 3 \text { years } \\
\text { or as required }\end{array}$ \\
\hline $\begin{array}{l}\text { Storm Water Monitoring Programs (Livermore Site } \\
\text { and Site 300) }\end{array}$ & $\begin{array}{l}\text { San Francisco Bay Regional Water Quality } \\
\text { Control Board } \\
\text { Central Valley Regional Water Quality Control } \\
\text { Board }\end{array}$ & As required \\
\hline $\begin{array}{l}\text { Industrial Storm Water Discharge Annual Reports } \\
\text { (Livermore Site and Site 300) and } \\
\text { Site } 300 \text { Cooling Tower Annual Report }\end{array}$ & $\begin{array}{l}\text { San Francisco Bay Regional Water Quality } \\
\text { Control Board } \\
\text { Central Valley Regional Water Quality Control } \\
\text { Board }\end{array}$ & Yearly \\
\hline $\begin{array}{l}\text { Storm Water Pollution Prevention Annual Certifi- } \\
\text { cations for Construction Projects } \\
\text { (Livermore Site and Site 300) }\end{array}$ & $\begin{array}{l}\text { San Francisco Bay Regional Water Quality } \\
\text { Control Board } \\
\text { Central Valley Regional Water Quality Control } \\
\text { Board }\end{array}$ & Yearly \\
\hline $\begin{array}{l}\text { Quarterly and Annual Compliance Reports for } \\
\text { Explosive Process Area Surface Impoundments, } \\
\text { Sewage Evaporation and Percolation Ponds, and } \\
\text { Percolation Pits }\end{array}$ & $\begin{array}{l}\text { Central Valley Regional Water Quality Control } \\
\text { Board }\end{array}$ & $\begin{array}{l}\text { Quarterly and } \\
\text { yearly }\end{array}$ \\
\hline DRB Quarterly/Annual Monitoring Reports & $\begin{array}{l}\text { Department of Toxic Substances Control } \\
\text { San Francisco Bay Regional Water Quality } \\
\quad \text { Control Board } \\
\text { Environmental Protection Agency } \\
\text { Department of Energy }\end{array}$ & $\begin{array}{l}\text { Quarterly and } \\
\text { yearly }\end{array}$ \\
\hline $\begin{array}{l}\text { Hazardous Material Business Plan and Chemical } \\
\text { Inventory }\end{array}$ & $\begin{array}{l}\text { Alameda County Health Care Services Agency } \\
\text { and San Joaquin County Office of Emergency } \\
\text { Services }\end{array}$ & $\begin{array}{l}\text { Yearly or as } \\
\text { required }\end{array}$ \\
\hline $\begin{array}{l}\text { SARA } 311 \text { /Material Safety Data Sheet (MSDS) } \\
\text { Reporting }\end{array}$ & $\begin{array}{l}\text { California Emergency Planning and Response } \\
\text { Commission }\end{array}$ & As required \\
\hline
\end{tabular}




\begin{tabular}{|c|c|c|}
\hline Title & Agency & Frequency \\
\hline SARA 313/Toxic Release Inventory & Department of Energy/State and Federal EPA & Yearly \\
\hline Beryllium in Ambient Air Monitoring & Bay Area Air Quality Management District & Quarterly \\
\hline Radiological NESHAPs Annual Report & Environmental Protection Agency & Yearly \\
\hline Environmental Monitoring Plan & Department of Energy & $\begin{array}{l}\text { Every three } \\
\text { years }\end{array}$ \\
\hline Site Annual Environmental Report & Department of Energy & Yearly \\
\hline Biennial Hazardous Waste Report & $\begin{array}{l}\text { Department of Toxic Substances Control (under } \\
\text { Environmental Protection Agency delegated } \\
\text { authority) }\end{array}$ & Every 2 years \\
\hline Annual Hazardous Waste Report & Department of Toxic Substances Control & Yearly \\
\hline $\begin{array}{l}\text { Conceptual Site Treatment Plan (CSTP) } \\
\text { Draft Site Treatment Plan (DSTP) } \\
\text { Final Site Treatment Plan (FSTP) }\end{array}$ & $\begin{array}{l}\text { Department of Toxic Substances Control } \\
\text { Environmental Protection Agency } \\
\text { Department of Energy }\end{array}$ & As required \\
\hline Safety Analysis Report & Department of Energy & As required \\
\hline Contingency Plans & Department of Toxic Substances Control & As required \\
\hline Closure Plans & Department of Toxic Substances Control & As required \\
\hline EIR Mitigation Monitoring Annual Report & University of California & Yearly \\
\hline FFA-CERCLA Reports & $\begin{array}{l}\text { Environmental Protection Agency } \\
\text { Department of Toxic Substances Control } \\
\text { San Francisco Bay Regional Water Quality } \\
\text { Control Board } \\
\text { Central Valley Regional Water Quality Control } \\
\text { Board } \\
\text { Department of Energy/EM-40 }\end{array}$ & As required \\
\hline $\begin{array}{l}\text { Wastewater Discharge/Chemical Storage Permit } \\
\text { Application }\end{array}$ & Livermore Water Reclamation Plant & Yearly \\
\hline $\begin{array}{l}\text { Ground Water Discharges to Sanitary Sewer } \\
\text { Annual Self-Monitoring Report }\end{array}$ & Livermore Water Reclamation Plant & Yearly \\
\hline Above Ground Petroleum Tank Storage Statement & State Water Resources Control Board & Every 2 years \\
\hline Arroyo Maintenance Monitoring Report & $\begin{array}{l}\text { San Francisco Bay Regional Water Quality } \\
\text { Control Board }\end{array}$ & $\begin{array}{l}\text { Annually } \\
\text { when there is } \\
\text { an exceed- } \\
\text { ance of a } \\
\text { receiving } \\
\text { water limit }\end{array}$ \\
\hline $\begin{array}{l}\text { Blue Elderberry Bush Cuttings Report pursuant to } \\
\text { Biological Assessment for Fire Trail Grading at } \\
\text { Site } 300\end{array}$ & $\begin{array}{l}\text { San Francisco Bay Regional Water Quality } \\
\text { Control Board }\end{array}$ & $\begin{array}{l}\text { As required if } \\
\text { cutting is } \\
\text { needed }\end{array}$ \\
\hline $\begin{array}{l}\text { WDR 99-086 for Arroyo Las Positas Maintenance; } \\
\text { Provision 20: Maintenance Impact Study Results }\end{array}$ & $\begin{array}{l}\text { San Francisco Bay Regional Water Quality } \\
\text { Control Board }\end{array}$ & $\begin{array}{l}\text { January 16, } \\
2006\end{array}$ \\
\hline
\end{tabular}




\begin{tabular}{|c|c|c|}
\hline Title & Agency & Frequency \\
\hline $\begin{array}{l}\text { Annual report for Arroyo Las Positas } \\
\text { Maintenance: Biological Assessment/Biological } \\
\text { Opinion Section } 7 \text { consultation }\end{array}$ & United States Fish and Wildlife Service & $\begin{array}{l}\text { Yearly if } \\
\text { applicable }\end{array}$ \\
\hline Building 829 Closure Monitoring Report & Department of Toxic Substances Control & Annually \\
\hline Pit 6 Closure Monitoring Report & $\begin{array}{l}\text { Department of Toxic Substances Control } \\
\text { Environmental Protection Agency } \\
\text { Central Valley Regional Water Quality Control } \\
\text { Board } \\
\text { Department of Energy }\end{array}$ & Quarterly \\
\hline Arroyo Las Positas Mitigation Monitoring & Army Corps of Engineers & Annually \\
\hline $\begin{array}{l}\text { Low Threat Discharges Quarterly Monitoring } \\
\text { Report }\end{array}$ & $\begin{array}{l}\text { Central Valley Regional Water Quality Control } \\
\text { Board }\end{array}$ & Quarterly \\
\hline
\end{tabular}





\section{Appendix D. Supplementary Topics on Radiological Dose}

\section{D-1: Radiation Basics}

\section{Natural and Man-Made Radiation}

By far, the greatest part of radiation received by the world's population comes from natural sourcesprimarily cosmic rays that impinge on the earth's atmosphere from space and radionuclides naturally present in our environment, such as radioactive materials in soil and rocks. Among these terrestrial sources are carbon-14, potassium-40, rubidium87, uranium-238, thorium-232, and other radioactive elements, such as radon, that arise from decay of uranium and thorium. The source of human exposure to natural radiation can be external (from substances staying outside the body) or internal (from substances inhaled in air or ingested in food and water). Individual doses vary with location. The level of cosmic radiation increases with altitude because less air is overhead to act as a shield. The earth's poles receive more cosmic radiation than the equatorial regions because the earth's magnetic field diverts the radiation. The levels of terrestrial radiation differ from place to place around the United States and around the world, mainly because of variations in soil and rock composition.

Adding to this pervasive natural or background radiation is man-made radiation from radionuclides used in medicine, consumer products, energy production, and nuclear weapons production. Exposure to man-made sources can be controlled more readily than exposure to most natural sources. However, nuclear explosives tested in the atmosphere in the 1950s and 1960s spread radioactivity across the surface of the globe, and the 1986 nuclear reactor accident at Chernobyl affected a large area. At present, medical treatment is the largest common source of public exposure to manmade radiation. Individual medical doses vary enormously - someone who has never had an x-ray examination may receive zero medical dose while patients undergoing treatment for cancer may receive many thousands of times the annualaverage dose they would receive from natural radiation. Another source of public exposure to manmade radiation is consumer products, including luminous-dial watches, smoke detectors, and tobacco products.

\section{Radioactivity}

Generally, naturally occurring isotopes are stable, but notable exceptions include carbon-14, potassium-40, thorium-232, uranium-235, and uranium-238, which occur naturally but are radioactive. There are three main categories of nuclear decay: alpha, beta, and gamma. Alpha decay is the spontaneous emission of an alpha particle (a bound state of two protons and two neutrons - the nucleus of a helium atom) from a nucleus containing a large number of protons (most commonly 82 or more). Beta decay is the spontaneous conversion of a neutron to a proton in the nucleus with the emission of an electron, and gamma decay is the spontaneous emission of highenergy photons (high-frequency electromagnetic radiation) by nuclei. 
Radioisotopes decay at quite different rates; the "half-life," or length of time for half of the atoms to decay, spans a wide range from small fractions of a second to millions of years. For example, tritium (the radioactive form of hydrogen) has a 12.3-year half-life, compared to 24,131 years for plutonium-239.

Some radioisotopes decay by forming radioisotopes that, in turn, decay into other radioisotopes until a stable state is achieved. For example, an atom of uranium-238 can undergo alpha decay, leaving behind a daughter, thorium-234, which is also radioactive. The transformations of the decay chain continue, ending with the formation of lead206 , a stable isotope.

Radioactivity can be hazardous because radiation (alpha particles, beta particles, gamma rays, and other subatomic particles such as neutrons) can be released with great energy. This energy is capable of altering the electronic configuration of atoms and molecules, especially by stripping one or more electrons off the atoms of the irradiated material, thereby disrupting the chemical activity in living cells. If the disruption is severe enough to overwhelm the normal restorative powers of the cell, the cell may die or become permanently damaged. Cells are exposed to many naturally occurring sources of disruption, including naturally toxic chemicals in food, microbes that cause disease, high-energy radiation from outer space (cosmic rays), and heat and light (including the sun's rays, which can cause sunburn and skin cancer). Consequently, cells and living organisms have evolved the capacity to survive limited amounts of damage, including that caused by radioactivity.

Three main factors determine the radiationinduced damage that might be caused to living tissue: the number of radioactive nuclei that are present, the rate at which they give off energy, and the effectiveness of energy transfer to the host medium, i.e., how the radiation interacts with the tissue. Alpha radiation can be halted by a piece of paper and can scarcely penetrate the dead outer layers of skin. Radioisotopes that give off alpha radiation are generally not health hazards unless they get inside the body through an open wound or are ingested or inhaled. In those cases, alpha radiation can be especially damaging because its disruptive energy can be deposited within a small distance, resulting in significant energy deposition in a few cells. Beta radiation from nuclear decay typically penetrates a centimeter or two of living tissue. It, therefore, deposits energy over many cells, decreasing the damage to any single cell. Gamma radiation is extremely penetrating and can pass through most materials, being significantly attenuated only by thick slabs of dense materials, such as lead.

\section{Measurement of Radioactivity and Dose}

The rate at which a nucleus decays is expressed in either units of becquerels (abbreviated Bq) where $1 \mathrm{~Bq}$ is one decay per second, or alternatively in curies (abbreviated $\mathrm{Ci}$ ), where $1 \mathrm{Ci}$ equals $3.7 \times 10^{10}$ (37 billion) decays per second, or $3.7 \times 10^{10} \mathrm{~Bq}$. (This is approximately equal to the decay rate of 1 gram of pure radium). Becquerels and curies are not measures of the effect of radiation on living tissue; the effect on living tissue depends on the efficiency of energy deposition as the radiation traverses matter.

The amount of energy deposited in living tissue is called the "dose." The amount of radiation energy absorbed per gram of tissue is called the "absorbed dose" and is expressed in units of rads or grays (Gy), where 1 Gy equals 100 rads; 1 Gy equals 1 joule per kilogram. Because an absorbed dose produced by alpha radiation is more damaging to living tissue than the same dose produced by beta or gamma radiation, the absorbed dose is multiplied by a quality factor to 
give the dose equivalent. The quality factor for alpha radiation is 20 ; for beta and gamma, 1 . The dose equivalent is measured in units of rem or sieverts $(\mathrm{Sv})$ with $1 \mathrm{~Sv}$ equal to $100 \mathrm{rem}$. Also commonly used are millirem (mrem) and millisievert $(\mathrm{mSv})$, which are one-thousandth of a rem and sievert, respectively.

Just as one type of radiation can be more damaging than others, some parts of the body are potentially more vulnerable to radiation damage than are others; therefore, the different parts of the body are given weightings. For example, a radiation dose from iodine-131 is more likely to cause cancer in the thyroid than in the lung. The reproductive organs are of particular concern because of the potential risk of genetic damage. Once particular organs are weighted appropriately, the dose equivalent becomes the "effective dose equivalent" (EDE), also expressed in rem or sievert. This allows dose equivalents from nonuniform exposure of the body to be expressed in terms of an EDE that is numerically equal to the dose from uniform exposure of the whole body that entails the same risk as the nonuniform exposure.

The EDE describes doses to individuals. When individual EDEs received by a group of people are summed, the result is called the "collective effective dose equivalent," often referred to as the "population dose," and is expressed in person-sievert or person-rem. Finally, to account for the long-term effects of radionuclides as they continue to decay and affect generations of people, we calculate the dose over many years, summing the effect over time. This is termed the "collective effective dose equivalent commitment." Most of our discussion in this chapter deals with the EDE and the collective EDE.

\section{Doses from Natural and Man-Made Radioactivity}

Annual average radiation doses from natural and other common sources in the United States have been estimated by the National Council on Radiation Protection and Measurement (1987b). The average radiation dose from natural sources is $3.0 \mathrm{mSv} / \mathrm{y}(300 \mathrm{mrem} / \mathrm{y})$. Approximately $0.3 \mathrm{mSv} / \mathrm{y}$ (30 mrem/y) of this exposure comes from high-energy radiation from outer space (cosmic rays). Terrestrial sources, mainly radionuclides in rock and soil, also account for approximately $0.3 \mathrm{mSv} / \mathrm{y}(30 \mathrm{mrem} / \mathrm{y})$ of the average natural dose. Another significant part of the dose comes from radionuclides ingested through food and drink, resulting in approximately $0.4 \mathrm{mSv} / \mathrm{y}$ (40 mrem/y). Potassium-40 and carbon-14 are common radionuclides in food.

The remaining $2.0 \mathrm{mSv} / \mathrm{y}(200 \mathrm{mrem} / \mathrm{y})$ or $67 \%$ of the average dose from natural sources in the United States comes from radon gas. Radon is one of the major radionuclides produced by uranium decay, and inhalation dose is dominated by radon's short-lived decay products.

As noted earlier, medical treatment is the largest common source of public exposure to man-made radiation, and most of it is delivered as medical $\mathrm{x}$-rays. These contribute $0.39 \mathrm{mSv}(39 \mathrm{mrem})$ to the average whole-body annual dose in the United States. Nuclear medicine contributes $0.14 \mathrm{mSv}$ (14 mrem) to the average dose, and consumer products add $0.1 \mathrm{mSv}(10 \mathrm{mrem})$. Thus, for a typical member of the public in the United States, radiation from medical procedures and consumer products results in a dose of approximately $0.63 \mathrm{mSv} / \mathrm{y}(63 \mathrm{mrem} / \mathrm{y})$. The annual average 
dose from other man-made sources, including fallout from nuclear testing, is less than $0.03 \mathrm{mSv}$ (3 mrem). As described in Chapter 13, the contributions from LLNL operations to the dose of even the most affected resident are on the order of $1 \mu \mathrm{Sv} / \mathrm{y}(0.1 \mathrm{mrem} / \mathrm{y})$, which is a small fraction of the average doses from natural and man-made radioactivity (see Table 13-6).

Deviations from the average levels can be quite large, depending on an individual's place of residency, occupation, eating habits, and other lifestyle choices, such as frequency of air travel. Radon dose, for example, varies significantly with geographic location; levels several times higher than the average occur in some regions of the United States. At LLNL and its environs, radoninduced doses as low as half the average are typical. Doses from cosmic rays increase with elevation above sea level, producing several tenths of $\mathrm{mSv}$ (tens of mrem) differences between cosmic-ray doses in coastal and mountain communities, and imparting a dose of about $0.05 \mathrm{mSv}$ ( $5 \mathrm{mrem}$ ) to a passenger flying round-trip between Los Angeles and New York City.

A useful Internet reference with links to a large quantity of material on effects and risks from radiation is the "Radiation Information Network" at the following Internet address: http://www.physics.isu.edu/radinf/.

\section{D-2: Radiation Control Measures at LLNL}

Radioisotopes used at LLNL include uranium, transuranics, biomedical tracers, tritium, and mixed-fission products. Protection of employees and the public from the uncontrolled release of radioactive materials into the environment is a primary consideration for LLNL. This effort takes several forms, as summarized here. More detailed information can be found in LLNL's online $E S \& \cdot H$ Manual; see, for example, Documents 2.01 and 2.02 at the following Internet addresses:

http://www.llnl.gov/es_and_h/hsm/doc_2.01/ doc2-01.html.

http://www.llnl.gov/es_and_h/hsm/doc_2.02/ doc2-02.html.

When an operation or facility is designed at LLNL, a thorough assessment of potential radiation hazards is conducted, and radioisotope-handling procedures and work enclosures are determined for each project, depending on the isotope, the quantity being used, and the type of operations being performed. Radioisotope handling and working environments include glove boxes, exhaust hoods, and laboratory bench tops. The controls might include limiting physical access and using shielding, filters, and remote handling equipment. Exhaust paths to the atmosphere include HEPA-filtered stacks, stacks without abatement devices, roof vents, and ordinary room air ventilation channels.

Appropriate monitoring, control, training, emergency response, and other requirements are called out in various facility documents related to each operation. These may include a discipline action plan (DAP), Integration Work Sheet (IWS), safety analysis report (SAR), operational safety plan (OSP), and/or facility safety plan (FSP), and will include a document reviewing the operation under the NEPA compliance guidelines. These documents are reviewed by environmental analysts, industrial hygienists, and health physicists to assess the safety of the operation, its compliance with current occupational and public health and environmental standards, the adequacy of proposed engineering and administrative controls, and the adequacy of proposed training requirements for personnel. This part of the control program 
enables LLNL personnel who work with radiation and radioactivity to recognize and prevent the execution of unsafe operations.

Another form of LLNL's radiation control program involves direct monitoring of the workplace environment. This monitoring includes sampling of the air and surfaces in the facilities where radioactive materials are handled, as well as the use of personal dosimetry and bioassay programs to monitor potential worker exposure to direct radiation and radioactive isotopes. Direct monitoring of the workplace environment helps to determine the effectiveness of a facility's radiation control program as well as providing information on worker exposures.

The surveillance and effluent monitoring of radiation in air, ground and surface waters, sewerable water, soil and sediment, and vegetation and foodstuff, as discussed in Chapters 2 and 4 through 11 of this report, play an important role in LLNL's program to control radiation releases. These measurements can signal anomalous releases, should they occur, and they directly gauge the degree of success of LLNL's radionuclide discharge control program in limiting exposures of the public. LLNL implemented a quality assurance/ quality control (QA/QC) process to ensure the accuracy, precision, and reliability of these monitoring data (see Chapter 14 of this report and the "Quality Control for 1999 Radiological Accounting Update and Modeling" section, in the LLNL NESHAPs 1999 Annual Report [Gallegos et al. 2000]).
In addition to routine QA/QC measures carried out each year, special audits by outside agencies and self-assessments are performed occasionally. Examples are the Safety Management Evaluation (SME) audit performed by DOE in 1996, the public health assessment conducted by the Agency for Toxic Substances and Disease Registry (ATSDR) at the Livermore site in 1999-2000, and the self-assessment by LLNL's Assurance Review Office (ARO) conducted during 1999.

Development of the Livermore Valley and the San Joaquin Valley has enlarged the populations and decreased the distance between sources of emissions and the residents who might be exposed. People live and work within several hundred meters of LLNL's boundaries. It is, therefore, increasingly important that the Laboratory's assessments provide the best information possible regarding the radiological impact of its operations. 



\section{Appendix E. ERrata to 1999 ENVIRONMENTAL REPORT}

\section{Protocol for Handling Errata in LLNL Environmental Reports}

The advent of readily accessible, electronic documents on the Internet has made the LLNL site annual environmental report (SAER) a truly dual publication with its bound, hard-copy and its Internet electronic forms. These two versions must be fully equivalent and, in fact, the content must be precisely the same, both in their original versions as first presented to the public, and as they are changed (noted as published errata) subsequent to publication.

In October 1998, LLNL developed a protocol for making post-publication revisions to the Internet versions of SAERs. The main criteria are that (1) the SAER home page must simply and clearly convey what revisions, if any, have been made to a particular report, and directly link to an errata information section; (2) credibility that the Internet version accurately represents each SAER must be maintained; (3) each SAER accessible on the Internet at any time shall be the most current version of the report, incorporating all revisions; and (4) the content of the electronic and hard copy versions of each SAER must be the same, in the sense that the hard copy version plus its errata, if any, must provide the same information as the current (revised) Internet version.

Presently SAERs covering calendar years 1994 through 1999 can be accessed on the Internet at the address of the LLNL SAER homepage: http://www.llnl.gov/saer. Both the main volume and data supplement volume of each individual report can be viewed in its fully corrected, most upto-date form. A link to an errata section provides a complete record of post-publication changes that have been made.

\section{Record of Changes to SAER for 1999}

The following changes have been made to the Internet version of Chapter 6 of the main volume.

In Table 6-4 on page 6-10:

- replaced the row label "DOE 5400.5 monthly

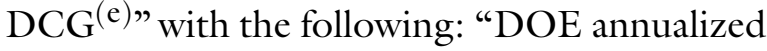
discharge limit for application of $\mathrm{BAT}^{(\mathrm{e})}$

$(\mathrm{Bq} / \mathrm{mL}) "$

- on same row, added footnote designator “(f)" to the data for LLNL maximum $\left(1.2 \times 10^{-4}\right)$ and LLNL median $\left(1.7 \times 10^{-5}\right)$

- replaced footnote (e) with the following: "The DOE annualized discharge limit for application of best available technology (BAT) is five times the Derived Concentration Guide (DCG; ingested water) for each radionuclide released."

- $\quad$ added footnote (f) as follows: "Monitoring results as a fraction of limit are calculated using LLNL monthly average results and the DOE annualized discharge limit." 
In Table 6-5 on page 6-12:

- changed the exponents for the ${ }^{137} \mathrm{Cs},{ }^{239} \mathrm{Pu}$, and Total quantities in the row labeled " $\mathrm{Bq} / \mathrm{y}$ " under "Annual total discharges by radioisotope" from negative to positive. The correct values are $1.2 \times 10^{6}, 6.8 \times 10^{4}$, and $1.3 \times 10^{6}$ for ${ }^{137} \mathrm{Cs},{ }^{239} \mathrm{Pu}$, and Total, respectively.

- replaced the row label "DOE 5400.5 monthly

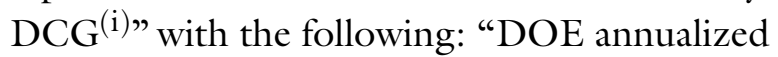
discharge limit for application of $\mathrm{BAT}^{(\mathrm{i})}$ ”

- deleted "monthly" in footnote (h) to read "....and the corresponding concentration-based limit ..." instead of "... and the corresponding monthly concentration-based limit..."

- replaced footnote (i) with the following: "The DOE annualized discharge limit for application of best available technology (BAT) is five times the Derived Concentration Guide (DCG; ingested water) for each radionuclide released."
On page 6-14:

- in the first sentence of the fourth paragraph, deleted the word "monthly" to make sentence read "...DOE Order 5400.5 concentrationbased limit for tritium ... “ instead of “...DOE Order 5400.5 monthly concentration-based limit for tritium ..."

- in the first sentence of the last paragraph, deleted "monthly average" to make the sentence read "In addition to the DOE concentration discharge limit..." instead of "In addition to the DOE monthly average concentration discharge limit..."

- in the second sentence of the last paragraph, replaced "monthly concentrations" with "an annualized concentration" to make sentence read "... applies to a daily rather than an annualized concentration." instead of “... applies to daily rather than monthly concentrations." 


\section{REFERENCES}

Aarons, J., M. D resen, L. Berg, F. H offman, G. H oward, R. Bainer, E. Folsom, R. Blake, Z. D emir, V. D ibley, K. Folks, B. H effner, J. Karachewski, M. M aley, W. M cC onachie, W.W. M cN abb, G. M etzger, C. N oyes, T. Pico, M. Ridley and S. Shukla, eds. (2000), LLN L Ground Water Project 1999 A nnual R eport, Lawrence Livermore N ational Laboratory, Livermore, CA (U CRL-AR-126020-99).

Aarons, J., M. D resen, L. Berg, F. H offman, G. H oward, R. Bainer, E. Folsom, R. Blake, Z. D emir, V. D ibley, K. Folks, B. H effner, J. Karachewski, M. M aley, K. M ansoor, W. M cC onachie, W. W. M cN abb, G. M etzger, C. N oyes, T. Pico, and M. Ridley (2001), LLN L Ground Water Project 2000 A nnual R eport, Livermore, CA (U CRL-AR-126020-00).

Agency for Toxic Substances D isease R egistry (2000), H ealth C onsultation, Lawrence Livermore N ati onal Laboratory, Big Trees Park 1998 Sampling, Livermore, California, Federal Facilities Assessment Branch, Division of H ealth Assessment and Consultation, Agency for Toxic Substances and D isease R egistry (CERCLIS N 0. CA2890012584).

Althouse, P. E. (1998), R adiological Background LevelsFound in GlassFiber Filters U sed for Low-Level Environmental Surveillance A ir Sampling, Lawrence Livermore N ational Laboratory, Livermore, CA (U CRL-JC-131844).

Bainer, R. W., and K. Abbott (2000a), Letter Report: LL L L Livermore Site Second Q uarter Self-M onitoring Report, dated August 31, 2000.

Bainer, R. W., and K. Abbott (2000b), Letter Report: LLN L Livermore Site Third Q uarter Self-M onitoring Report, dated N ovember 30, 2000.

Bainer, R. W., and K. Abbott (2001), Letter Report: LLN L Livermore Site Fourth Q uarter 2000 Self-M onitoring Report, dated February 28, 2001.

Bainer, R. W., and H . Joma (2000a), L etter Report: LLN L Livermore Site December 3, 1999, Remedial Program M anagers' M eeting Summary, Lawrence Livermore N ational Laboratory, Livermore, CA, dated February 2000.

Berg, L. L. (2000), Explanation of Significant Differences for the Trailer 5475 Ground Water R emediation, Lawrence Livermore $\mathrm{N}$ ati onal Laboratory, Livermore Site, Lawrence Livermore N ational Laboratory, Livermore, CA (U CRL-AR-136189).

Berg, L. L., E. N. Folsom, M . D. Dresen, R. W. Bainer, and A. L. Lamarre, eds. (1997), Explanation of Significant D ifferencesfor M etals D ischarge Limits at the Lawrence Livermore $N$ ati onal Laborator y Livermore Site, L awrence Livermore N ational Laboratory, Livermore, CA (U CRL-AR-125927).

Biermann, A. H ., G. M. Gallegos, R. J. H arrach, N. A. Bertoldo, L. C. H all, R. L. Berger, and K. A. Surano (1999), LLN L N ESH A Ps 1998 A nnual R eport, Lawrence Livermore N ational L aboratory, Livermore, CA (U CRL-ID 113867-99).

Biermann, H . H ., R. J. H arrach, R. L. Berger, and K. A. Surano (1993), LL L N ESH A Ps Project Quarterly Progress R eport, First Quarter 1993, Lawrence Livermore N ational Laboratory, Livermore, CA (U CRL-AR-108419-93-1).

Brandstetter, E. R. (1998), LivermoreSite A nnual Storm Water M onitoring R eport for WD R 95-174, Lawrence Livermore N ational Laboratory, Livermore, CA (U CRL-AR-126783-98).

Brown, R. (2000a), LLN L Experimental Test Site 300 Compliance M onitoring R eport for Waste Discharge R equi rements 96-248, First Quarter R eport 2000, Lawrence Livermore N ational Laboratory, Livermore, CA (U CRL-AR-125915-00-1). 
Brown, R. (2000b), LLN L Experimental Tet Site 300 Compliance M onitoring R eport for WasteD ischarge R equirements 96-248, Second Quarter R eport 2000, Lawrence Livermore N ational L aboratory, Livermore, CA (U CRL-AR125915-00-2).

Brown, R. (2000c), LLN L Experimental Test Site 300 Compliance M onitoring R eport for Waste Discharge R equirements 96-248, Third Quarter R eport 2000, Lawrence Livermore N ational Laboratory, Livermore, CA (U CRL-AR125915-00-3).

Brown, R. (2001), LLN L Experimental Test Site 300 Compliance M onitoring R eport for Waste Discharge R equirements 96-248, A nnual/ Fourth Quarter R eport 2000, L awrence Livermore N ational Laboratory, Livermore, CA (U CRL-AR-125915-00-4).

Campbell, B. (1995), Spill Prevention Control and Countermeasure (SPCC) Plan, Livermore Site, Lawrence Livermore N ational Laboratory, Livermore, CA (U CRL-M A-105699 Rev. 1).

Cantwell, B. and J. Celeste (1998), N ational I gnition Facility Pollution Prevention and Waste Minimization Plan, L awrence Livermore N ational Laboratory, Livermore, CA (U CRL-AR-131194).

Carlsen, T., E. Espeland and A. Smith (2001), R arePlant R estoration and M onitoring at LawrenceLivermore $N$ ational Laborator y Si te 300 Project Progress R eport Fiscal Year 2000 October 1999-September 2000. Lawrence Livermore $\mathrm{N}$ ational Laboratory, Livermore, CA (U CRL-AR-142408).

Carpenter, D. W., J. J. Sweeney, P. W. Kasameyer, N. R. Burkhard, K. G. Knauss, and R. J. Shelmon (1984), Geology of the Lawrence Livermore $N$ ational Laborator $y$ Si te and A djacent A reas, L awrence Livermore $N$ ational L aboratory, Livermore, CA (U CRL-53316).

Celeste, J., S. Coleman, B. N isbet, and B. Campbell (1998), A Comprehensive Opportunity A ssessment for Pollution Prevention at Lawrence Livermore $N$ ational Laboratory, L awrence Livermore $N$ ational L aboratory, Livermore, CA (U CRL-AR-127890).

CVRWQ CB (1993), Order N 0. 93-100, Waste Discharge R equirements for U niversity of C alifornia LawrenceLiver more $\mathrm{N}$ ational Laboratory Site 300 and U .S. D epartment of Energy, Landfill Pits 1 and 7, San J oaquin County, Central Valley Regional Water Q uality Control Board (J une 25, 1993).

CVRW Q CB (1998), R evised M onitoring and R eporting Programs N 0. 93-100 and 96-248, Lawrence Livermore $\mathrm{N}$ ational Laborator y Site 300 and U .S. D epartment of Energy, Landfill Pits 1 and 7, San J oaquin County, Central Valley Regional Water Q uality Control Board (J une 25, 1993).

Christofferson, E., and D. H . M acQ ueen (2000a), LLN L Experimental Test Site 300 Compliance M onitoring Program for R CR A-Closed Landfill Pits 1 and 7, First Quar ter R eport, January-M arch 2000, L awrence Livermore $\mathrm{N}$ ational L aboratory, Livermore, CA (U CAR-10191-00-1).

Christofferson, E., and D. H . M acQ ueen (2000b), LLN L Experimental Test Site 300 Compliance M onitoring Program for R CR A-Closed Landfill Pits 1 and 7, Second Quarter R eport, A pril-J une 2000, L awrence Livermore N ational Laboratory, Livermore, CA (U CAR-10191-00-2).

Christofferson, E., and D. H . M acQ ueen (2000c), LLN L Experimental Test Site 300 Compliance M onitoring Program for R CR A-Closed Landfill Pits 1 and 7, Third Quarter R eport, July-September 2000, Lawrence Livermore $N$ ational Laboratory, Livermore, CA (U CAR-10191-00-3).

Christofferson, E., and D. H . M acQ ueen (2001), LLN L Experimental Tet Site 300 Compliance M onitoring Program for R CR A-Closed Landfill Pits 1 and 7, A nnual R eport for 2000, Lawrence Livermore N ational Laboratory, Livermore, CA (U CAR-10191-00-4).

Christofferson, E., and M. J. Taffet (2000), LLN L Experimental Test Site 300 Compliance M onitoring Program for the CER CLA-C losed Pit 6 Landfill, First Q uarter R eport, J anuary-M arch 2000, Lawrence Livermore $\mathrm{N}$ ational L aboratory, Livermore, CA (U CRL-AR-132057-00-1). 
Christofferson, E., M. J. Taffet, W. A. M cConachie, and S. P. Vonder H aar (2000a), LLN L Experimental Test Site 300 Compliance M onitoring Program for the CER CLA -C losed Pit 6 Landfill, Second Quarter R eport, A pril-June 2000, L awrence Livermore N ational Laboratory, Livermore, CA (U CRL-AR-132057-00-2).

Christofferson, E., S. P. Vonder H aar, W. A. M cConachie, and M. J. Taffet (2000b), LL N L Experimental Test Site 300 ComplianceM onitoring Program for the CER C LA -C losed Pit 6 Landfill, Third Quarter R eport, J uly-September 2000, L awrence Livermore N ational L aboratory, Livermore, CA (U CRL-AR-132057-00-3).

Christofferson, E., S. P. Vonder H aar, W. A. M cConachie, and M . J. Taffet (2001), LLN L Experimental Test Site 300 Compliance M onitoring Program for the CER CLA-Closed Pit 6 Landfill, A nnual R eport for 2000, Lawrence Livermore N ational Laboratory, Livermore, CA (U CRL-AR-132057-00-4).

Ciba-Geigy Ltd. (1981), "U nits of M easurement, Body Fluids, Composition of the Body, N utrition." In Geigy Scientific Tables, Vol. 1, Eighth Edition, Basel, Switzerland.

Clough, R. E. (2000), Integrated Safety M anagement System D escription, Lawrence Livermore N ational Laboratory, Livermore, CA (U CRL-AR-132791 Rev. 3).

Cooperrider, A. Y., B. J. Boyd, and H . R. Stuart, eds. (1986), I nventory and M onitoring of Wildlife H abitat, U. S. D epartment of I nterior, Bureau of Land M anagement, Service Center, D enver, CO.

Dibblee, T. W., Jr. (1980), Preliminary Geologic M ap of the M idway Quadrangle, A lameda and San Joaquin Counties, California, U SGS O pen File Report 80-535.

Dibley, V., and R. Depue (2000), LLN L LivermoreSiteand Site 300 Environmental R estoration Project Standard O perating Procedures (SO Ps), Lawrence Livermore N ational Laboratory, Livermore, CA (U CRL-M A-109115 Rev. 7).

D resen, M . D ., L. Ferry, R. Ferry, and W. I sherwood (1999), D raft Final Proposed Plan for Environmental Cleanup at Lawrence Livermore N ati onal Laboratory Site 300, Lawrence Livermore $N$ ational L aboratory, Livermore, CA (UCRL-AR-136376 DR).

Dresen, M. D., L. Ferry, R. Ferry, and W. I sherwood (2000), Final Proposed Plan for Environmental Cleanup at Lawrence Livermore $N$ ational Laboratory Site 300, L awrence Livermore $N$ ational Laboratory, Livermore, CA (UCRL-AR-136376).

Eadie, G. G. and D. E. Bernhardt (1976), Sampling and D ata R eporting Considerations for A irborne Particulate R adioacti vity, U.S. Environmental Protection Agency, O ffice of Radiation Programs, Las Vegas, $\mathrm{N}$ evada (ORP/ LV-76-9).

Eccher, B., K. Folks, R. Goluba, M. Gonzalez, D. H ieb, W. I sherwood, M. Kelly, S. M athews, V. M ode, B. Schumacher, T. Schmiegel, and S. Thomson (1994a), Storm Water Pollution Prevention Plan (SWPPP) LivermoreSite, Lawrence Livermore N ational laboratory, Livermore, CA (U CRL-AR-110573-94).

Eccher, B., K. Folks, R. Goluba, M. Gonzalez, D. H ieb, W. I sherwood, M. Kelly, S. M athews, V. M ode B. Schumacher, T. Schmiegel, and S. Thomson (1994b), Storm Water Pollution Prevention Plan (SWPP), Experimental Test Site(Site 300), Lawrence Livermore $\mathrm{N}$ ational Laboratory, Livermore, CA (U CRL-AR-110572-94).

Eckerman, K. F., A. B. Wolbarst, and A. C. B. Richardson (1988), Limiting Values of R adionuclide Intakeand A ir Concentration and D ose Conversion Factors for I nhalation, Submersion, and I ngestion, U .S. Environmental Protection Agency, Washington, DC (Federal Guidance Report N 0. 11, EPA-520/ 1-88-020).

Eckerman, K. F., and J. C. Ryman (1993), External Exposureto R adionuclides in Air, Water and Soil, U .S. Environmental Protection Agency, Washington, DC (Federal Guidance Report N 0. 12, EPA 402-R-93-081). 
Environmental Laboratory (1987), U .S. A rmy Corps of Engineers Wetlands D elineation Manual, U .S. Army Engineer Waterways Experiment Station, Vicksburg, M ississippi (Technical Report Y-87-1).

EPD (1997), Transition Plan: Transer of Existing WasteTreatment U nitsto the D econtamination and WasteTreatment Facility, Lawrence Livermore N ational Laboratory, Livermore, CA (U CRL-AR-126352).

Ferry, L., T. Berry, and D. M acQ ueen (1998), Post-ClosurePlan for the Pit 6 Landfill O perable U nit, Lawrence Livermore $\mathrm{N}$ ati onal Laboratory, Site 300, Lawrence Livermore $\mathrm{N}$ ational Laboratory, Livermore, CA (U CRL-AR-128638).

Ferry, L., R. Ferry, W. I sherwood, R. Woodward, T. Carlsen, Z. Demir, R. Q adir, and M . D resen (1999a), D raft Final SiteWide Feasi bi lity Study for Lawrence Livermore N ational Laboratory Site 300, Lawrence Livermore N ational L aboratory, Livermore, CA (U CRL-AR-132609DR).

Ferry, L., R. Ferry, W. I sherwood, R. Woodward, T. Carlsen, Z. D emir, R. Q adir, and M. D resen (1999b), Final SiteWide Feas bi lity Study for Lawrence Livermore $\mathrm{N}$ ational Laboratory Site 300, Lawrence Livermore $N$ ational Laboratory, Livermore, CA (U CRL-AR-132609).

Folks, K. (1997), LLN L R eport of WasteD ischargefor Beneficial R euse of Soil at the Livermore Site, L awrence Livermore $\mathrm{N}$ ational Laboratory, Livermore, CA (U CRL-AR-126943).

Gallegos, G. M . (1991), A ssessment of Sediment M onitoring at LLN L, Lawrence Livermore N ational Laboratory, Livermore, CA (U CRL-ID-121236).

Gallegos, G. M . (1993), "Surveillance M onitoring of Soils for Radioactivity: L awrence Livermore N ational L aboratory 1976 to 1992," H ealth Physics 69(4), 487-493.

Gallegos, G. M . (1998), N ESH A PsA nnual R eport Guidance D ocument, L awrence Livermore N ational Laboratory, $O$ perations and Regulatory Affairs Division, Livermore, CA (EM P-N S-S).

Gallegos, G. M., A. H. Biermann, R. J. H arrach, N. A. Bertoldo, L. C. H all, R. L. Berger, and K. A. Surano (1998), LLN L N ESH A Ps 1997 A nnual Report, L awrence Livermore N ational Laboratory, Livermore, CA (U CRL-ID-113867-98).

Gallegos, G. M., A. H. Biermann, R. J. H arrach, N. A. Bertoldo, R. L. Berger, and K. A. Surano (2000), LLN L N ESH A Ps 1999 A nnual R eport, Lawrence Livermore N ational L aboratory, Livermore, CA (U CRL-ID-113867-00).

Gallegos, G. M., R. J. H arrach, R. L. Berger, N. A. Bertoldo, P. J. Tate, and S-R. Peterson (2001), LL N L N ESH A Ps 2000 A nnual R eport, Lawrence Livermore N ational Laboratory, Livermore, CA (U CRL-ID-113867-01).

Gallegos, G. M., B. K. Balke, K. A. Surano, W. G. H oppes, P. J. Tate, J. C. Steenhoven, B. C. Fields, L. M. Garcia, K. C. Lamson (1992), Environmental R eport 1991, Lawrence Livermore $N$ ational Laboratory, Livermore, CA (U CRL-50027-91).

Gallegos, G. M., R. J. H arrach, A. H. Biermann, F. J. Gouveia, P. J. Tate, B. C. Fields, and K. Surano (1996), LLN L N ESH A Ps 1995 A nnual R eport, Lawrence Livermore N ational Laboratory, Livermore, CA (U CRL-ID-113867-96).

Gallegos, G. M ., D. M acQ ueen, K. Surano (1999), LivermoreBig Trees Park: 1998 Summary R esults, L awrence Livermore N ational Laboratory, Livermore, CA (U CRL-ID-134581).

Gallegos, G. M., P. J. Tate, B. K. Balke, E. Christofferson, R. J. H arrach, W. G. H oppes, R. A. Failor, S. Wander, B. C. Fields, L. M. Garcia, and A. R. Grayson (1994), Environmental R eport for 1993, Lawrence Livermore $\mathrm{N}$ ational Laboratory, Livermore, CA (U CRL-50027-93). 
Galles, H .L. (1998), Letter to S. Timm re: Statistically Significant Evidence for a R elease of 1,2-D ichloroethane from Pit 6 (WGM G98:282, O ctober 13, 1998).

Galles, H . L . (1997), Letter to J. Cho re: Lawrence Livermore N ational Laboratory D rainage Retention Basin M onitoring Plan Amendment (WGM G 97-439, December 9, 1997).

Galles, H . L. (2000a), Letter to the Central Valley Regional Water Q uality Control Board re: Discharge of M ethyl Ethyl Ketone (2-butanone) Above Permitted Limits, August 24, 2000.

Galles, H.L. (2000b), Letter to K. Lichten re: Submission of the Water Diversion, Desilting, and Sediment Transport Best $M$ anagement Practice Plan for Arroyo Las Positas M aintenance Project and a Proposed M odification of the M aintenance Plan Regarding Fills, L awrence Livermore N ational Laboratory (WGM G00:084, J une 14, 2000).

Galles, H .L. (2000c), Letter to K. Lichten re: 2000 Annual Self-M onitoring Report, Lawrence Livermore N ational L aboratory, Livermore, CA (WGM G00:269, N ovember 14, 2000).

Galles, H . L., and K. V. Gilbert (2000a), A nnual H azardous WasteR eport-M ainsite, Lawrence Livermore N ational Laboratory, Livermore, CA.

Galles, H . L., and K. V. Gilbert (2000b), A nnual H azardous WasteR eport-Site 300, Lawrence Livermore N ational Laboratory, Livermore, CA.

Games, P. A. and J. F. H owell (1976), "Pairwise M ultiple Comparison Procedures with U nequal n's and/ or Variances. A M onte Carlo Study," J ournal of Educational Statistics 1:113-125.

Gouveia, F., and K. R. Chapman (1989), Climatology of Lawrence LivermoreN ational Laboratory, Lawrence Livermore $\mathrm{N}$ ational Laboratory, Livermore, CA (U CID-21686).

Grandfield, C. H . (1989), Guidelines for D ischarges to the Sanitary-Sewer System, Lawrence Livermore N ational Laboratory, Livermore, CA (U CAR-10235).

Gudiksen, P. H., C. L. Lindeken, C. Gatrousis, and L. R. Anspaugh (1972), Environmental Levels of R adioactivity in the Vicinity of the Lawrence Livermore L aboratory, J anuary through D ecember 1971, L awrence Livermore $N$ ational Laboratory, Livermore, CA (U CRL-51242).

Gudiksen, P. H., C. L. Lindeken, J. W. M eadows, and K. O. H amby (1973), Environmental Levels of R adi oactivity in the Vicinity of the Lawrence Livermore Laboratory, 1972 A nnual R eport, Lawrence Livermore N ational Laboratory, Livermore, CA (U CRL-51333).

H alden, R. U ., V. M adrid, P. D aley, M. Lima, S. G regory, and J. P. Ziagos (1999), “Silicon L ubricants Facilitate Bioattenuation of TCE at LLN L's Superfund Site 300," Fifth In Situ and On-Site Bioremediation Symposium, San Diego, CA.

H all, H . L., and W. L. Edwards (1994a), R adiation A nalytical Sciences Quality A ssurance Plan, Q uality I mplementing Proceduresand Quality A ssurance Project Plans, Vol. 1, L awrence Livermore N ational Laboratory, Livermore, CA (U CRL-M A-116560, Vol. 1).

H all, H . L., and W. L. Edwards (1994b), R adiation A nalytical Sciences I ntegrated Software D ocumentation, Vol 3, L awrence Livermore N ational Laboratory, Livermore, CA (U CRL-M A-116560, Vol. 3).

H all, H . L., and W. L. Edwards (1994c), R adiation A nalytical Sciences Technical I mplementing Procedures, Vol. 2A, L awrence Livermore $\mathrm{N}$ ational Laboratory, Livermore, CA (U CRL-M A-116560, Vols. 2A and 2B).

H arrach, R. J. (1998), Guidance for R adiological D ose A ssessment, O perations and Regulatory Affairs D ivision, L awrence Livermore $N$ ational L aboratory, Livermore, CA (EM P-R-DA). 
H arrach, R. J., K. A. Surano, A. H. Biermann, F. J. Gouveia, B. C. Fields, and P. J. Tate, (1994), LLN L N ESH A PS 1993 A nnual R eport, Lawrence Livermore N ational Laboratory, Livermore, CA (U CRL-ID-113867-94).

H arrach, R. J., G. M. Gallegos, R. A. Failor, E. Christofferson, P. J. Tate, E. R. Brandstetter, J. M. Larson, J. M cl ntyre, B. C. Fields, R. A. Brown, L. M. Garcia, and A. R. Grayson (1995), Environmental R eport 1994, Lawrence Livermore N ational Laboratory, L ivermore, CA (U CRL-50027-94), http:/ / www.llnl.gov/ saer/.

H arrach, R. J., R. A. Failor, G. M. Gallegos, P. J. Tate, E. Christofferson, E. R. Brandstetter, J. M . Larson, A. H. Biermann, R. A. Brown, B. C. Fields, L. M. Garcia, and A. R. Grayson (1996), Environmental R eport 1995, L awrence Livermore N ational Laboratory, Livermore, CA (U CRL-50027-95), http:/ / www.IInl.gov/ saer/.

H arrach, R. J., G. M. Gallegos, P. J. Tate, E. Christofferson, E. R. Brandstetter, J. M . Larson, A. H . Biermann, B. C. Fields, L. M. Garcia, and K. A Surano (1997), Environmental R eport 1996, L awrence Livermore N ational L aboratory, Livermore, CA (U CRL-50027-96), http:/ / www.IInl.gov/ saer/.

H arrach, R. J., J. M. Larson, G. M. Gallegos, E. Christofferson, E. R. Brandstetter, P. J. Tate, A. H . Biermann, B. C. Fields, L. M . Garcia, and P. Althouse (1998), Environmental R eport 1997, Lawrence Livermore N ational L aboratory, Livermore, CA (U CRL-50027-97), http:/ / www.Ilnl.gov/ saer/.

H omann, S. G. (1994), H OTSPOT H ealth PhysicsC odesfor the PC, Lawrence Livermore N ational Laboratory, Livermore, CA (U CRL-MA-10615).

H uey, A. S. (1948), "G eology of the Tesla Q uadrangle, California," California Division of M inesand Geology, Bulletin 140.

ICRP (1959), R ecommendations of the International Commission on R adiological Protection, R eport of Committee 2 on PermissibleD ose of I nternal R adiation, International Commission on Radiological Protection, Publication 2, Pergamon Press, N ew York, NY.

ICRP (1977), R ecommendations of the International Commission on R adiological Protection, International Commission on Radiological Protection, Publication 26, Pergamon Press, N ew York, NY.

ICRP (1979 et seq.), Limitsfor I ntakes of R adi onuclides by Workers, International Commission on Radiological Protection, Publication 30, Pergamon Press, N ew York, NY.

ICRP (1994), D ose C oefficients for I ntakes of R adi on uclides by Workers International Commission on Radiological Protection, Publication 68, Vol. 24, N 0. 4, Pergamon Press, 0 xford.

ICRP (1995), Age dependent doses to members of the public from intake of radionuclides, Part 4, Inhalation D ose Coefficients. Publication 71; Ann. ICRP 25(3\& 4), Pergamon Press, Oxford.

ICRP (1996), "Compilation of Ingestion and I nhalation D ose Coefficients." In A gedependent D osesto M embers of the Public from Intake of R adionudides. Part 5. Annals of the ICRP Vol. 26 N 0. 1. ICRP N 0. 72 ISSN 0146-6453, Pergamon Press, 0 xford.

I sherwood, W. F., C. H . H all, M. D. D resen, and A. J. Boegel (1991), CER C LA Feasibility Study R eport for the LLN L LivermoreSite, Lawrence Livermore N ational Laboratory, Livermore, CA (U CRL-AR-104040).

Jackson, C. S. (1997), Letter to the San Francisco Bay Regional Water Q uality Control Board re: L awrence Livermore N ational Laboratory Building 253 C atch Basin M ercury Residue, M ay 23, 1997.

Joma, H . (2000), Action Memorandum for a TimeCritical Removal Action at the East Traffic Circle, Lawrence Livermore $\mathrm{N}$ ati onal Laboratory, Livermore Site, Lawrence Livermore N ational Laboratory, Livermore, CA (UCRL-AR-136832).

Lamarre, A. L., and M . J. Taffet (1989), Firing Table Gravel Cleanup at Lawrence Livermore N ational Laboratory Site 300, Lawrence Livermore N ational L aboratory, Livermore, CA (U CAR-10282). 
Lamarre, A. L. (2000a), Compliance Report for the Building 832 Canyon and Building 854 Ground Water Treatment Systems, 4th Q uarter 1999, Lawrence Livermore N ational Laboratory Site 300, Livermore, California, M arch 30, 2000.

Lamarre, A. L. (2000b), Compliance Report for the Building 832 C anyon and Building 854 Ground Water Treatment Systems, 1st Q uarter 2000, L awrence L ivermore N ational L aboratory Site 300, Livermore, California, June 30, 2000.

Lamarre, A. L. (2000c), Compliance Report for the Building $832 \mathrm{C}$ anyon and Building 854 Ground Water Treatment Systems, 2nd Q uarter 2000, L awrence Livermore N ational Laboratory Site 300, Livermore, California, September 30, 2000.

Lamarre, A. L. (2000d), Compliance Report for the Building 832 Canyon and Building 854 Ground Water Treatment Systems, 3rd Q uarter 2000, L awrence Livermore N ational L aboratory Site 300, Livermore, California, D ecember 30, 2000.

Lamarre, A. L. (2000e), Q uarterly Compliance Report for the Building 834 G round Water Treatment System, 4th Q uarter 1999, L awrence Livermore N ational L aboratory Site 300, Livermore, California, M arch 30, 2000.

L amarre, A. L. (2000f), Q uarterly Compliance Report for the Building 834 Ground Water Treatment System, 1st Q uarter 2000, Lawrence L ivermore N ational Laboratory Site 300, Livermore, California, June 30, 2000.

Lamarre, A. L. (2000g), Q uarterly Compliance Report for the Building 834 Ground Water Treatment System, 2nd Q uarter 2000, L awrence Livermore N ational L aboratory Site 300, Livermore, California, September 30, 2000.

Lamarre, A. L. (2000h), Q uarterly Compliance Report for the Building 834 Ground Water Treatment System, 3rd Q uarter 2000, L awrence Livermore N ational Laboratory Site 300, Livermore, California, D ecember 30, 2000.

Lamarre, A. L. (2000i), Q uarterly Compliance Report for the Eastern and Central General Services Area Soil Vapor and Ground Water Treatment Systems, 4th Q uarter 1999, L awrence Livermore N ational L aboratory Site 300, Livermore, California, J anuary 30, 2000.

Lamarre, A. L. 2000j), Q uarterly Compliance Report for the Eastern and Central General Services Area Soil Vapor and Ground Water Treatment Systems, 1st Q uarter 2000, L awrence Livermore N ational L aboratory Site 300, Livermore, California, A pril 30, 2000.

Lamarre, A. L. (2000k), Q uarterly Compliance Report for the Eastern and Central General Services Area Soil Vapor and Ground Water Treatment Systems, 2nd Q uarter 2000, L awrence Livermore N ational L aboratory Site 300, Livermore, California, July 30, 2000.

Lamarre, A. L. (2000I), Q uarterly Compliance Report for the Eastern and Central General Services Area Soil Vapor and Ground Water Treatment Systems, 3rd Q uarter 2000, Lawrence Livermore N ational Laboratory Site 300, Livermore, California, O ctober 30, 2000.

Larson, J. M., R. J. H arrach, P. E. Althouse, N. A. Bertoldo, A. H. Biermann, R. G. Blake, E. R. Brandstetter, S. L. Brigdon, R. A. Brown, E. Christofferson, K. J. Folks, G. M. Gallegos, L. M. Garcia, T. A. Giesing, A. R. Grayson, L. C. H all, D. H. M acQ ueen, S. M athews, S. R. Peterson, M. J. Taffet, P. J. Tate, R. J. Vellinger, R. J. Ward (1999), Environmental R eport 1998, Lawrence Livermore N ational L aboratory, Livermore, CA, (U CRL-50027-98), http:/ / www.llnl.gov/ saer. 
Larson, J. M., A. H. Biermann, R. J. H arrach, P. E. Althouse, N. A. Bertoldo, R. G. Blake, E. R. Brandstetter, S. L. Brigdon, R. A. Brown, E. Christofferson, K. J. Folks, G. M. Gallegos, L. M. Garcia, T. A. Giesing, A. R. Grayson, L. C. H all, D. H. M acQ ueen, S. M athews, S. R. Peterson, M. J. Taffet, P. J. Tate, R. J. Vellinger, R. J. Ward, R. A. Williams (2000), Environmental R eport 1999, Lawrence Livermore N ational Laboratory, Livermore, CA, (U CRL-50027-99), http:/ / www.IInl.gov/ saer.

LLN L (2000), Post-Closure Permit A pplication for the Building 829 H E Open Burn Facility-Volume 1, Lawrence Livermore N ational Laboratory, Livermore, CA (U CRL-AR-139697).

Limnion Corporation, The (1991), The D rainage R etention Basin Management Plan, Lawrence Livermore $\mathrm{N}$ ational L aboratory, Livermore, CA.

Lindeken, C. L., R. O. M orgin, and K. F. Petrock (1963), “C ollection Efficiency of Whatman-41 Filter Paper for Submicron Aerosols," H ealth Physi cs 9:305-308.

Longley, K. E., H . V. J ohns, and H . A braham (1994), The Water Quality Control Plan (Basin Plan) for the California R egional Water Quality Control Board, Central Valley R egion, Sacramento and San Joaquin R iver Basins, Central Valley Regional Water Control Board, Sacramento, CA.

M acQ ueen, D. H . (1995), Livermore Big Trees Park J anuary 1995 Soil Sur vey R esults, Lawrence Livermore N ational Laboratory, Livermore, CA (U CRL-ID-121045).

M arshack, J.B. (2000), A C ompilation of Water Quality Goals, California Environmental Protection Agency Regional Water Q uality Control Board, Central Valley Region, August 2000.

M athews, S. (2000), Lawrence Livermore N ational Laboratory Site 300 Water Suppliers' Pollution Prevention and $M$ onitoring and R eporting Program, Lawrence Livermore $\mathrm{N}$ ational L aboratory, Livermore, CA (U CRL-AR-139704).

M athews, S., and M. Taffet (1997), Final ClosurePlan for the H igh-Explosives O pen Burn Facility at Lawrence Livermore $\mathrm{N}$ ational Laborator y Experimental Test Site 300, L awrence Livermore $\mathrm{N}$ ational L aboratory, Livermore, CA (U CRL-ID-111753 Rev. 1).

M cN ab, W. W. (1999), Evaluating the A pplication of Electroosmosis to the Cleanup of FineGrained Sedimentsin Contaminant Source A reas at Lawrence Livermore $\mathrm{N}$ ational Laborator $\mathrm{y}$, L awrence Livermore $\mathrm{N}$ ational Laboratory, Livermore, CA (U CRL-AR-136098).

M oore, R. E., C. F. Baes, III, L. M . M cD owell-Boyer, A. P. Watson, F. A. H offman, J. C. Pleasant, and C. W. M iller (1979), A IR D OS-EPA : A Computerized M ethodology for Estimating Envi ronmental Concentrati onsand D oseto M an from $A$ irborne $R$ eleases of $R$ adi onuclides. $O$ ak Ridge $N$ ational L aboratory, $O$ ak Ridge, TN (ORNL-5532).

M omoshima, T.O ., T. Kaji, and Y. Takashima, (1991) “D istribution and Transformation of Various Chemical Forms of Tritium in the Environment," R adiochimica Acta 54:129-132.

Napier, B. A., R. A. Peloquin, D.L. Strenge, and J. V. Ramsdell (1988), GEN II-TheH anford Environmental R adiation D osimetry Software System. Pacific N orthwest Laboratory, Richland, WA, (PN L-6584 Vol. U C-60).

NCRP (1987a), R ecommendations on Limits of Exposure to I onizing R adiation, Report N o. 91, N ational Council on Radiation Protection and M easurements, Washington, DC.

NCRP (1987b), I onizing R adiation Exposure of the Population of the U nited States, Report N 0. 93, N ational Council on Radiation Protection and M easurements, Washington, DC.

NCRP (1999), R ecommended Screening Limits for Contaminated Surface Soil and R eview of FactorsR elevant to Site-Specific Studies, Report N o. 129, N ational Council on Radiation Protection and M easurements, Bethesda, M D.

O ak Ridge Institute for Science and Education (1995), A tmospheric D ispersion M odeling R esources, Second Edition. 
O sborne, R. V. (1968), "I ntake of Tritium When Skin Is Splashed with Tritiated Water." H ealth Physics, 15:155-156.

Ö stlund, H . G. (1973), "T ritium in the Atmosphere and O cean." In Tritium. Proceedings of a Symposium, A. A. M oghissi and M.W. Carter, eds., M essenger Graphics, Phoenix. CONF-710809, TID O ak Ridge; 1973: 382-391.

Parkhurst, D . L., and C. A. J. Appelo (1999), U ser's Guideto PH R EEQ C - A Computer Program for Speciation, Batchreaction, O nedimensional Transport, and I nverse G eochemical Calculations, U.S. Geological Survey WaterResources I nvestigations Report 99-4259.

Parks, B. S. (1992), U ser's Guide for CA P88-PC, Version 1.0, U .S. Environmental Protection Agency, O ffice of Radiation Programs, Las Vegas, NV (EPA 402-B-92-001).

Parks, B. S. (1997), U ser's Guide for CA P88-PC, Version 2.0, U .S. Environmental Protection Agency, Germantown, $M D(E R-8 / G T N)$.

Parks, B. S. (1999), "T ritium D ose O verestimates by CAP88-PC." In Operational R adiation Safety. Supplement to H ealth Physics 76, N 0. 2, February 1999.

Pendleton, B., A. Giron, B. A. M illsap, K. W. Cline, and D. M. Bird, eds. (1987), R aptor M anagement Techniques Manual, N ational Wildlife Federation, Washington, DC.

Peterson, S-R. and P. A. D avis (2000), "Tritium D oses from Chronic Atmospheric Releases: A N ew M odel Proposed for Regulatory Compliance". Accepted upon revision by H ealth Physics. (U CRL-JC-141535).

Peterson, W. B. and L. G. Lavdas (1986), "IN PU FF 2.0-A M ultiple Source Gaussian Puff D ispersion Algorithm," In U ser's Guide, U.S. Environmental Protection Agency, Research Triangle, N C.

PRAG (Permits and Regulatory Affairs Pollution Prevention Team)(2001), 1999 Comprehensive O ppor tunity A ssessment for Pollution Prevention, Energy Efficiency, and Water Conservation at Lawrence Livermore N ational Laboratory, Livermore Site, Lawrence Livermore N ational Laboratory, Livermore, CA (U CRL-AR127890-99). Forthcoming.

Raber, E., and D. W. Carpenter, eds. (1983), A n Evaluati on of theH ydrogeology and Groundwater Chemistry A ssociated with Landfills at LLN L's Site 300, L awrence Livermore N ational Laboratory, Livermore, CA (U CRL-53416).

Rice, D. W., J r., and G. J. Cannon, eds. (1999), H ealth and Envi ronmental A ssessment of the U se of Ethan ol asa Fuel Oxygenate, Lawrence Livermore N ational Laboratory, Livermore, CA (U CRL-AR-135949), http:/ / www-erd.Ilnl.gov/ ethanol/.

Rogers/ Pacific Corporation (1990), Lawrence Livermore N ati onal Laboratory Site $300 \mathrm{R}$ esource Conservation and R ecover y A ct Closure and Post-Closure Plans - Landfill Pits 1 and 7, Vols. I and II, Van N uys, CA (California EPA N o. CA2890090002).

Rueth, L. S., R. A. Ferry, L. K. Green-H orner, and T. H . D eL orenzo (1998), R emedial D esign D ocument for the General ServicesA rea OperableU nit Treatment Facilities Lawrence Livermore N ational Laboratory, Site 300, L awrence Livermore N ational Laboratory, Livermore, CA (U CRL-AR-127465).

SFBRW Q CB (1982a), Water Quality C ontrol Plan, San Francisco Bay Basin, State of California, San Francisco Bay Regional Water Q uality Control Board, O akland, CA.

SFBRWQ CB (1982b), WasteD ischarge R equirements and N ational Pollutant Discharge Elimination System (N PDES) Storm Water Permit for: U.S. D epartment of Energy and Lawrence Livermore N ational Laboratory, San Francisco Bay R egional Water Q uality Control Board, O akland, CA. (O rder N 0. 95-174, N PDES N o. CA030023). 
SFBRWQ CB (1995), Water Quality Control Plan, San Francisco Bay Basin, State of California, San Francisco Bay Regional Water Q uality Control Board, O akland, CA.

Scheffé, H . (1953), "A M ethod for Judging All Contrasts in the Analysis of Variance," Biometrica, 40: 87-104.

Schemnitz, S. D., ed. (1980), Wildlife M anagement Techniques M anual, The Wildlife Society, Washington, DC.

Shleien, B., and M. S. Terpilak (1984), The H ealth Physics and R adiological H ealth $\mathrm{H}$ andbook, N ucleon Lectern Associates, Inc., Olney, M D.

Silver, W. J., C. L. Lindeken, J. W. M eadows, W. H. H utchin, and D. R. M cl ntyre (1974), Environmental Levels of $R$ adi oactivity in the Vicinity of the Lawrence Livermore Laboratory, 1973 A nnual R eport, Lawrence Livermore $\mathrm{N}$ ational Laboratory, Livermore, CA (U CRL-51547).

Silver, W. J., C. L. Lindeken, J. W. M eadows, W. H . H utchin, and D. R. M cl ntyre (1975), Environmental M onitoring at the Lawrence Livermore Laboratory, 1974 A nnual R eport, Lawrence Livermore N ational Laboratory, Livermore, CA (UCRL-50027-74).

Silver, W. J., C. L. Lindeken, K. M. Wong, E. H. Willes, and J. H. White (1978), Environmental M onitoring at the Lawrence Livermore Laboratory, 1977 A nnual R eport, Lawrence Livermore N ational Laboratory, Livermore, CA (U CRL-50027-77).

Silver, W. J., C. L. Lindeken, J. H . White, and R. W. Buddemeir (1980), Envi ronmental M onitoring at the Lawrence Livermore Laboratory, 1979 A nnual R eport, Lawrence Livermore N ational Laboratory, Livermore, CA (U CRL-50027-79).

SWRCB (1999), Waste D ischarge R equirementsfor Di scharges of Storm Water R un off A ssociated with C onstruction A ctivity. N PDES General Permit N o. CAS000002 (O rder N 0. 99-08-DWQ).

Stone, R., and M . R. Ruggieri (1983), Ground-Water Quality and M ovement at Lawrence Livermore N ati onal Laboratory, L awrence Livermore N ational Laboratory, Livermore, CA (U CRL-53474).

Struckmeyer, R. (1994), N R C TLD D irect R adiation M onitoring N etwork, Progress R eport, July-September, 1994, N uclear Regulatory Commission, Washington, DC (NUREG-0837, Vol. 14, N 0. 3).

Taffet, M . J., L. Green-H orner, L. C. H all, T. M. Carlsen, and J. A. O rberdorfer (1996), A ddendum to Site-Wide R emedial I nvestigation R eport, Building 850/ Pit 7 Complex Operable U nit, Lawrence Livermore $\mathrm{N}$ ational Laborator y Site 300, Lawrence Livermore N ational Laboratory, Livermore, CA (U CRL-AR-108131, Add. 1).

Tate, P., S. M athews, G. Gallegos, L. M Garcia, J. M . Larson, A. H. Biermann, E. R. Brandstetter, E. Christofferson, R. J. H arrach, D. Rueppel, F. Gouveia, P. Althouse, B. C. Fields, D. M acQ ueen, R. A. Brown, R. Vellinger, K. A. Surano, K. J. Folks, S. L. Brigdon, A. L. Grayson, W. G. Hoppes, R. L. Welsh, N. A. Bertoldo, G. J. Cannon, R. L. Berger, R. G. Blake, M . J. Taffet, R. A. Failor, C. Choate (1999), Environmental M onitoring Plan, Lawrence Livermore N ational Laboratory, Livermore, CA (U CRL-ID-106132 Rev. 2).

Thorpe, R. K., W. F. I sherwood, M . D. D resen, and C. P. Webster-Scholten (1990), CER CLA R emedial I nvestigation R eport for the LLN L LivermoreSite, Vols. 1-5, Lawrence Livermore N ational L aboratory, Livermore, CA (UCAR-10299).

Toy, A. J., C. L. Lindeken, K. S. Griggs, and R. W. Buddemeier (1981), Envi ronmental M onitoring at the Lawrence Livermore $\mathrm{N}$ ational Laboratory, $1980 \mathrm{~A}$ nnual R eport, L awrence Livermore $\mathrm{N}$ ational L aboratory, Livermore, CA (U CRL-50027-80).

U.S. D OE (1988), External D ose R ate Conversion Factorsfor C alculation of D ose to the Public, U.S. D epartment of Energy, Washington, DC (DOE/ EH-0070). 
U.S. D OE (1991), Environmental R egulator y Guide for R adiological Effluent M onitoring and Environmental Surveillance, U .S. D epartment of Energy, Washington, DC (DOE/ EH -0173T).

U.S. D OE (1993), R ecord of D ecision for the Lawrence LivermoreN ational Laboratory LivermoreSite, U .S. D epartment of Energy, Washington, DC (U CRL-AR-109105).

U.S. DOE (1999), Supplement A nalysisfor C ontinued Operation of Lawrence Livermore N ational Laboratory and Sandia $\mathrm{N}$ ational Laboratories, Livermore, Volumes I and II, $\mathrm{O}$ akland $\mathrm{O}$ perations $\mathrm{O}$ ffice, $\mathrm{O}$ akland, California (DOE/ EIS-0157-SA-01).

U.S. D OE (2000), D raft Final I nterim SiteWide R ecord of D ecision for Lawrence Livermore N ational Laboratory Site 300, Lawrence Livermore N ational L aboratory, Livermore, CA (U CRL-AR-138470DR).

U.S. D OE and U C (1992a), Final Environmental I mpact Statement and Environmental I mpact R eport for Continued Operation of Lawrence Livermore $\mathrm{N}$ ational Laboratory and Sandia N ational Laboratories, Livermore, Lawrence Livermore N ational Laboratory, Livermore, CA (D OE/ EIS-0157, SCH 90030847).

U.S. D OE and U C (1992b), Final Environmental I mpact Statement and Environmental I mpact R eport Executive Summary, Lawrence Livermore N ational Laboratory, Livermore, CA (D OE/ EIS-0157).

U.S. D epartment of $\mathrm{H}$ ealth and $\mathrm{H}$ uman Services (1999), H ealth Consultation: "Plutonium Contamination in Big Trees Park," L awrence Livermore N ational L aboratory, Public Service, Agency for Toxic Substances and D isease Registry, CERCLIS N o. CA28900125584, pp. 7-8.

U.S. EPA (1987), Data Quality Objectives for R emedial R esponse A ctivities: Development Process, U.S. Environmental Protection Agency, O ffice of Emergency and Remedial Response, Washington, DC (EPA 540/ G-87/ 003, OSWER Directive 9355-0).

U.S. EPA (1993), Supplement B to the Guideline on A ir Quality Models (R evised), U .S. Environmental Protection Agency, O ffice of Emergency and Remedial Response, Washington, DC (EPA Report N 0. EPA-450/ 2-78-027R Supplement B).

U .S. EPA (1995), “N otice: Final N ational Pollutant Discard Elimination System Storm Water M ulti-Sector General Permit for Industrial Activities, Environmental Protection Agency," Federal R egister, Volume 60, N o. 189 (September 29, 1995).

U .S. EPA (2000), "N otice: Final Reissuance of N ational Pollutant D ischarge Elimination System (N PDES) Storm Water M ulti-Sector General Permit for Industrial Activities," Environmental Protection Agency, Federal Register, Volume 65, No. 210 (O ctober 30, 2000).

U.S. N RC (1977), Calculation of A nnual D osesto M an from R outine R eleases of R eactor Effluent for the Purpose of Evaluation Compliance with 10 Code of Federal R egulations, Part 50, A ppendix 1, U.S. N uclear Regulatory Commission, Washington, DC (Regulatory Guide 1.109).

Webster-Scholten, C. P., and C. H . H all (1988), Work Plan, Lawrence Livermore N ational Laboratory, Livermore Site: CER CLA/SA R A R emedial I nvestigations/ Feasibility Studies, Lawrence Livermore $\mathrm{N}$ ational Laboratory, Livermore, CA (U CAR-10225).

Webster-Scholten, C. P., ed. (1994), Final Site-Wide R emedial I nvestigation R eport, Lawrence Livermore N ational Laborator y Site 300, Lawrence Livermore N ational Laboratory, Livermore, CA (U CRL-AR-108131).

Wilson, K. L. (1999), A ssessing the N onhazardous Solid Waste Stream at Lawrence Livermore N ational Laborator y, Lawrence Livermore N ational Laboratory, Livermore, CA (U CRL-AR-134220).

Ziagos, J., and E. Reber-Cox (1998a), Building 815 R emoval A ction D esign Workplan for the H igh Explosives Process A rea O perable U nit at Lawrence Livermore $N$ ational Laboratory Site 300, Livermore, CA, N ovember 17, 1998. 
Ziagos, J., and E. Reber-Cox (1998b), Ground Water Tritium Plume Characterization Summary R eport for the Building 850/ Pits 3 and 5 Operable U nit, Lawrence Livermore $N$ ational Laborator $y$ Site 300, Livermore, CA, O ctober 30, 1998.

Ziagos, J., and B. Jakub, (1998), A ction M emorandum for the Building 8150 perable U nit R emoval A ction at Lawrence Livermore $N$ ati onal Laboratory Site 300, Lawrence L ivermore $N$ ational L aboratory, Livermore, CA (U CRL-AR-130229). 


\section{Acronyms ANd Abbreviations}

\%RSD Percent relative standard deviation

A ACDEH

ACHCS

ACL

ACOE

ALARA

AMS

ANSI

ARO

AST

ATSDR

AVLIS

AWQC

B BAAQMD

BA/BO

BCG

BETX (or BTEX)

BMP

BOD

Bq

BSA

C CAM

CAMP

CAREs

CCR

CDFG
Alameda County Department of Environmental Health

Alameda County Health Care Services

Ambient concentration limit

Army Corps of Engineers

As low as reasonably achievable

Accelerator mass spectrometry

American National Standards Institute

Assurance Review Office at LLNL

Aboveground Storage Tank

Agency for Toxic Substances and Disease Registry

Advanced Laser Isotope Separation

Ambient water quality criteria

Bay Area Air Quality Management District

Biological Assessment/Biological Opinion

Biota concentration guide

Benzene, ethyl benzene, toluene, and xylene

Best management practice

Biochemical oxygen demand

Becquerel

Blanket Service Agreement

Continuous air monitor

Corrective Action Monitoring Program

(Tri-Valley) Communities Against a Radioactive Environment

California Code of Regulations

California Department of Fish and Game 


\begin{tabular}{|c|c|}
\hline CDHS & California Department of Health Services \\
\hline CDHS-RHB & California Department of Human Services, Radiological Health Branch \\
\hline CEI & Compliance Evaluation Inspection \\
\hline CEPRC & Chemical Emergency Planning and Response Commission \\
\hline CEQA & California Environmental Quality Act of 1970 \\
\hline CERCLA & Comprehensive Environmental Response, Compensation and Liability Act of 1980 \\
\hline CERCLA/SARA & Superfund Amendments and Reauthorization Act (SARA) \\
\hline CES & Chemistry and Materials Science Environmental Services \\
\hline CFC & Chlorofluorocarbon \\
\hline CFR & Code of Federal Regulations \\
\hline CHA & Critical habitat area \\
\hline CHP & California Highway Patrol \\
\hline $\mathbf{C i}$ & Curie \\
\hline COC & Constituent of concern \\
\hline CRD & Catalytic reductive dehalogenation \\
\hline CRMP & Cultural Resource Management Plan \\
\hline CRWQCB & California Regional Water Quality Control Board \\
\hline CVRWQCB & Central Valley Regional Water Quality Control Board \\
\hline CWG & Community Work Group \\
\hline DAP & Discipline Action Plan \\
\hline DC & Direct current \\
\hline DCG & Derived Concentration Guide \\
\hline DHS & Department of Health Services \\
\hline $\mathbf{D L}$ & Detection limits \\
\hline DLM & Designated level methodology \\
\hline $\mathbf{D M P}$ & Detection Monitoring Program \\
\hline DOE & U.S. Department of Energy \\
\hline DOE/OAK & DOE Oakland Operations Office \\
\hline DOT & U.S. Department of Transportation \\
\hline DRB & Drainage Retention Basin \\
\hline DTSC & $\begin{array}{l}\text { (California Environmental Protection Agency), Department of Toxic Substances } \\
\text { Control }\end{array}$ \\
\hline DWTF & Decontamination and Waste Treatment Facility \\
\hline E2 & Energy efficiency \\
\hline
\end{tabular}




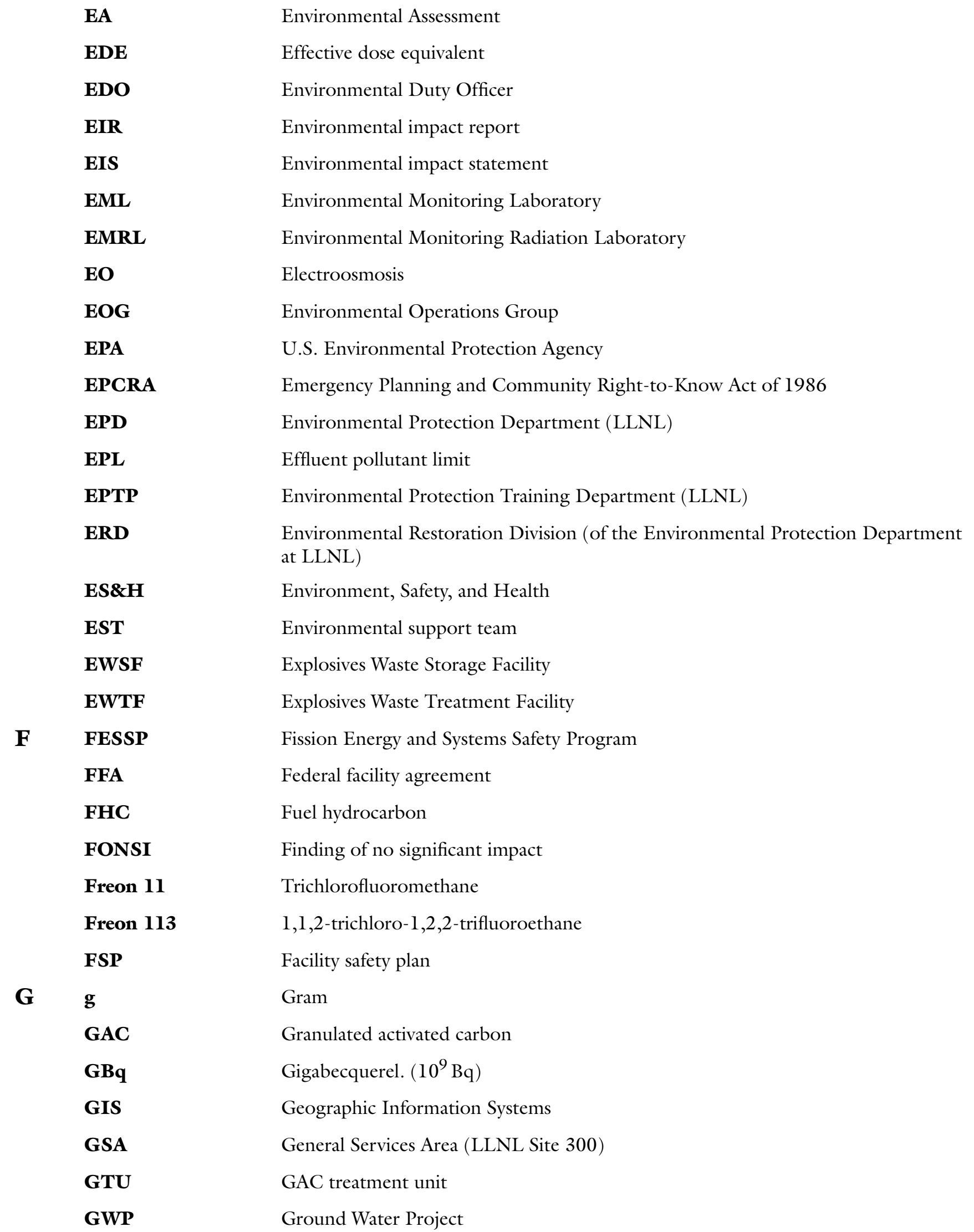


GWPMP

GWTF

GWTS

Gy

H HCAL

HCD

HCRML

HE

HEPA

HMX

HPGe

HPLC

HSU

HT

HTO

HWCA

HWM

I ICRP

IMS

IQR

ISMS

IWS

J JON

K $\quad \mathbf{k g}$

kCi

kBq

L LBNL

LEPC

LLNL

LOEC

LOS

LUFT
Ground Water Project Management Program

Ground Water Treatment Facility

Ground Water Treatment System

Gray

Hazards Control Department's Analytical Laboratory

Hazards Control Department (LLNL)

Hazards Control Radiological Measurements Laboratory

High explosives

High-efficiency particulate air (filter)

Cyclotetramethyltetramine. Also referred to as octahydro-1,3,5,7-tetranitro1,3,5,7-tetrazocine.

High-purity germanium

High Pressure Liquid Chromatography

Hydrostratigraphic unit

Tritiated hydrogen gas (See also tritium in Glossary.)

Tritiated water and water vapor (See also tritium in Glossary.)

(California) Hazardous Waste Control Act

Hazardous Waste Management Division (of the Environmental Protection

Department at LLNL)

International Commission on Radiological Protection

Instrumented membrane system

Interquartile range

Integrated Safety Management System

Integration work sheet

Judgement of Need

Kilogram

Kilocurie $\left(10^{3} \mathrm{Ci}\right)$

Kilobequerel $\left(10^{3} \mathrm{~Bq}\right)$

Lawrence Berkeley National Laboratory

Local Emergency Planning Committee

Lawrence Livermore National Laboratory

Lowest observed effect concentration

Limit of sensitivity

Leaking underground fuel tank 
LWRP

M

MAPEP

mCi

MCL

MDC

MDL

MEI

MEK

mGy

ML

$\mathbf{m L}$

MPN

$\mathbf{m R}$

mrem

MRF

MRP

MSDS

mSv

MTBE

MTU

N NCRP

NEPA

NESHAPs

NHPA

NIF

NIST

NOEC

NOI

NOV

NPDES

NPL

NRC

nSv
Livermore Water Reclamation Plant

Mixed Analyte Performance Evaluation Program

Millicurie $\left(10^{-3} \mathrm{Ci}\right)$

Maximum contaminant level

Minimum detectable concentration

Minimum detection limit

Maximally exposed individual

Methyl ethyl ketone

Milligray $\left(10^{-3} \mathrm{~Gy}\right)$

Megaliter $\left(10^{6}\right.$ liters $)$

Milliliter $\left(10^{-3}\right.$ liter $\left.=1 \mathrm{~cm}^{3}\right)$

Most probable number

Milliroentgen $\left(10^{-3} \mathrm{R}\right)$

Millirem $\left(10^{-3} \mathrm{rem}\right)$

Materials Recovery Facility

Monitoring and Reporting Program

Material safety data sheet

Millisievert $\left(10^{-3} \mathrm{~Sv}\right)$

Methyl tertiary-butyl ether

Minature treatment unit

National Council on Radiation Protection

National Environmental Policy Act

National Emission Standards for Hazardous Air Pollutants

National Historical Preservation Act

National Ignition Facility

National Institute for Standards and Technology

No observed effect concentration

Notice of Intent

Notice of Violation

National Pollutant Discharge Elimination System

National Priorities List

Nuclear Regulatory Commission

Nanosievert $\left(10^{-9} \mathrm{~Sv}\right)$ 


\begin{tabular}{|c|c|c|}
\hline \multirow[t]{4}{*}{$\mathbf{O}$} & OBT & Organically bound tritium \\
\hline & ORAD & $\begin{array}{l}\text { Operations and Regulatory Affairs Division (of the Environmental Protection } \\
\text { Department at LLNL) }\end{array}$ \\
\hline & OSP & Operational safety plan \\
\hline & $\mathbf{O U}$ & Operable unit \\
\hline \multirow[t]{16}{*}{$\mathbf{P}$} & $\mathbf{P 2}$ & Pollution Prevention \\
\hline & PA & Programatic agreement \\
\hline & PCB & Polychlorinated biphenyl \\
\hline & PCE & $\begin{array}{l}\text { Perchloroethylene (or perchloroethene). Also called tetrachloroethylene (or } \\
\text { tetrachloroethene). }\end{array}$ \\
\hline & $\mathbf{p C i}$ & Picocurie $\left(10^{-12} \mathrm{Ci}\right)$ \\
\hline & pg & Picogram $\left(10^{-12} \mathrm{~g}\right)$ \\
\hline & PHA & Public Health Assessment \\
\hline & pHMS & $\mathrm{pH}$ Monitoring Station \\
\hline & $\mathbf{P M}$ & Performance measure \\
\hline & PMCL & Primary maximum contaminant level \\
\hline & POTW & Publicly owned treatment works \\
\hline & ppb & Parts per billion \\
\hline & ppm & Parts per million \\
\hline & ppmv & Parts per million by volume \\
\hline & PPOA & Pollution Prevention Opportunity Assessment \\
\hline & PTU & Portable treatment unit \\
\hline \multirow[t]{3}{*}{$\mathbf{Q}$} & QA & Quality assurance \\
\hline & QAP & Quality Assurance Plan \\
\hline & QC & Quality control \\
\hline \multirow[t]{9}{*}{$\mathbf{R}$} & $\mathbf{R}$ & Roentgen \\
\hline & RAIP & Remedial Action Implementation Plan \\
\hline & RCRA & Resource Conservation and Recovery Act of 1976 \\
\hline & RDX & Hexahydro-1,3,5-trinitro-1,3,5-triazine \\
\hline & RHB & Radiological Health Branch \\
\hline & $\mathbf{R L}$ & Reporting limit \\
\hline & $\mathbf{R M L}$ & Radiological Measurements Laboratory \\
\hline & ROD & Record of Decision \\
\hline & ROI & Return on investment \\
\hline
\end{tabular}




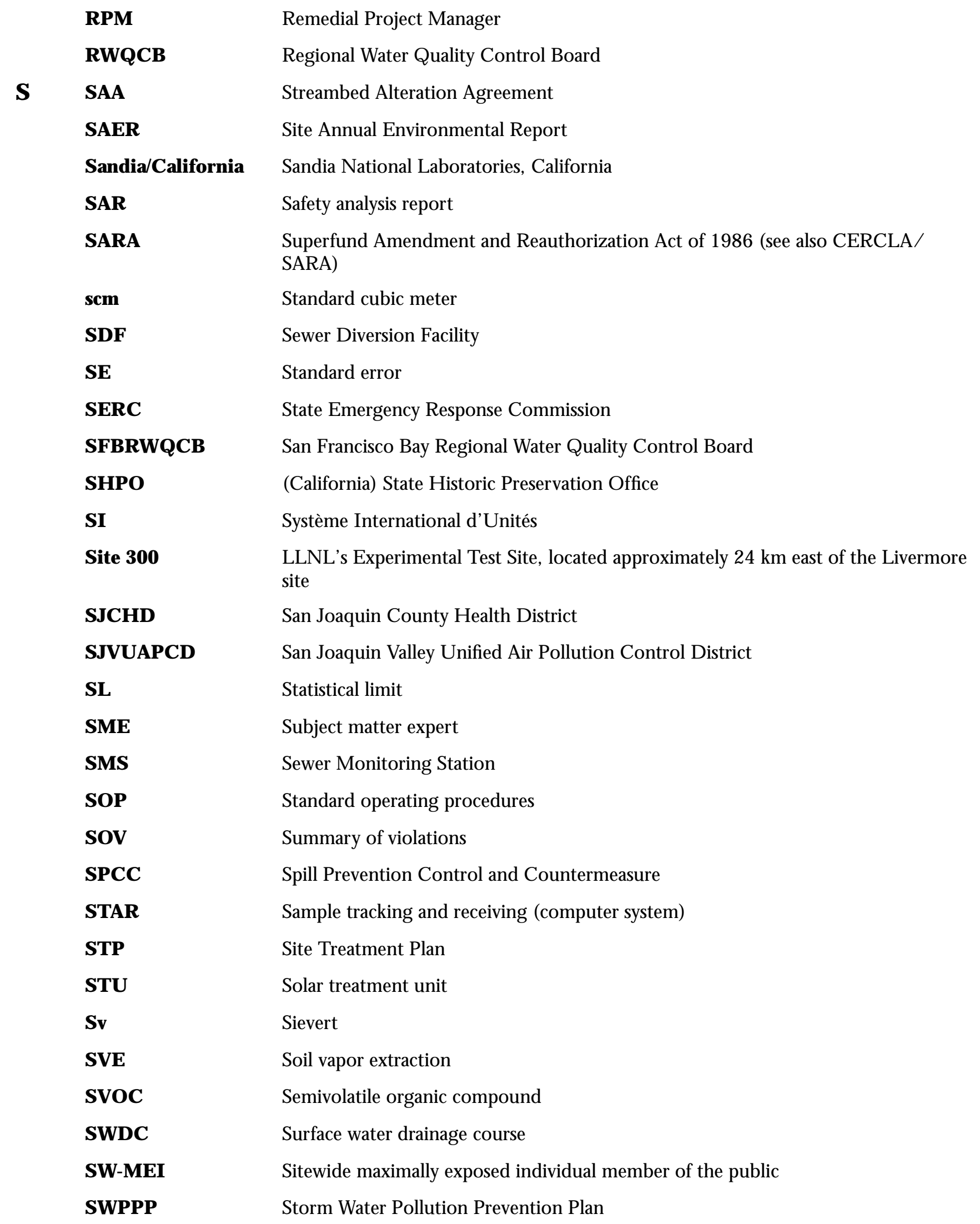


SWRCB (California) State Water Resources Control Board

T TBq Terabecquerel $\left(10^{12} \mathrm{~Bq}\right)$

TCE Trichloroethene (or trichloroethylene)

TCLP Toxicity characteristic leaching procedure

TDS Total dissolved solids

TLD Thermoluminescent dosimeter

TNT Trinitrotoluene

TOC Total organic carbon

TOX Total organic halides

TRI Toxic Reporting Inventory

TRU Transuranic waste

TSCA Toxic Substances Control Act

TSS Total suspended solids

TTO Total toxic organics

TWMS Total Waste Management System

U UC University of California

UST Underground storage tank

V VOC Volatile organic compound

VTF Vapor treatment facility

W WAA Waste accumulation area

WDR Waste Discharge Requirements

WSS Work Smart Standards

Z Zone $7 \quad$ Alameda County Flood Control and Conservation District, Zone 7 


\section{GLOSSARY}

A Absorbed dose: the amount of energy imparted to matter by ionizing radiation per unit mass of irradiated material, in which the absorbed dose is expressed in units of rad or gray ( $1 \mathrm{rad}=0.01$ gray)

Accuracy: the closeness of the result of a measurement to the true value of the quantity measured Action level: defined by regulatory agencies, the level of pollutants which, if exceeded, requires regulatory action

Aerosol: a gaseous suspension of very small particles of liquid or solid

Ag: silver

Alameda County Flood Control and Water Conservation District: also known as Zone 7, the water management agency for the Livermore-Amador Valley with responsibility for water treatment and distribution, and responsible for management of agricultural and surface water and the ground water basin

Alluvium: sediment deposited by flowing water

Alpha particle: a positively charged particle emitted from the nucleus of an atom, having mass and charge equal to those of a helium nucleus (two protons and two neutrons)

Ambient air: the surrounding atmosphere, usually the outside air, as it exists around people, plants, and structures; not considered in monitoring purposes when immediately adjacent to emission sources

Analysis of variance (ANOVA): a test of whether two or more sample means are statistically different

Analyte: the specific component measured in a chemical analysis

Anion: a negatively charged ion, such as $\mathrm{Cl}^{-}$

Aquifer: a saturated layer of rock or soil below the ground surface that can supply usable quantities of ground water to wells and springs, and be a source of water for domestic, agricultural, and industrial uses

Aquitard: low-permeability geologic formation that bounds an aquifer

As: arsenic

Atom: the smallest particle of an element capable of entering into a chemical reaction

Atomic absorption (AA) spectroscopy: a method used to determine the elemental composition of a sample, where the sample is vaporized and its light absorbance measured 
B Barcad: device that samples water in a well in which water, collected in a discrete water-bearing zone, is forced to the surface by pressurized nitrogen

Bay Area Air Quality Management District (BAAQMD): the local agency responsible for regulating stationary air emission sources (including the LLNL Livermore site) in the San Francisco Bay Area

Becquerel (Bq): the SI unit of activity of a radionuclide, equal to the activity of a radionuclide having one spontaneous nuclear transition per second

Beta particle: a negatively charged particle emitted from the nucleus of an atom, having charge, mass, and other properties of an electron

Biochemical (biological) oxygen demand (BOD): a measure of the amount of dissolved oxygen that microorganisms need to break down organic matter in water, used as an indicator of water quality

Blowdown: water discharged from cooling towers in order to control total dissolved solids concentrations by allowing make-up water to replenish cooling apparatuses

$\mathrm{C} \mathbf{C a C O}_{3}$ : calcium carbonate

California Code of Regulations (CCR): codification of regulations promulgated by the State of California

California Environmental Quality Act of 1970 (CEQA): statute that requires that all California state, local, and regional agencies document, consider, and disclose to the public the environmental implications of their actions

CAP88-PC: computer code required by the EPA for modeling air emissions of radionuclides

Categorical discharge: discharge from a process regulated by EPA rules for specific industrial categories

Cd: cadmium

Chain-of-custody: a method for documenting the history and possession of a sample from the time of its collection, through its analysis and data reporting, to its final disposition

Chemistry and Materials Science Environmental Services (CES): an LLNL laboratory that analyzes environmental samples

Chlorofluorocarbon (CFC): a compound that has fluorine and chlorine atoms on a carbon backbone, such as Freons

Chlorocarbon: a compound of carbon and chlorine, or carbon, hydrogen, and chlorine, such as carbon tetrachloride, chloroform, and tetrachloroethene

Code of Federal Regulations (CFR): a codification of all regulations promulgated by federal government agencies

Collective dose equivalent and collective effective dose equivalent: the sums of the dose equivalents or effective dose equivalents to all individuals in an exposed population within $80 \mathrm{~km}$ (50 miles) of the radiation source. These are evaluated by multiplying the dose received by an individual at each location by the number of individuals receiving that dose, and summing over all such products for locations within $80 \mathrm{~km}$ of the source. They are expressed in units of person-rem or person-sievert. The collective EDE is also referred to as the "population dose." 
Committed dose equivalent: the predicted total dose equivalent to a tissue or organ over a 50-year period after an intake of a radionuclide into the body. It does not include contributions from external dose. Committed dose equivalent is expressed in units of rem (or sievert; 100 rem equals one sievert).

Committed effective dose equivalent: the sum of the committed dose equivalents to various tissues in the body, each multiplied by an appropriate weighting factor representing the relative vulnerability of different parts of the body to radiation. Committed effective dose equivalent is expressed in units of rem or sievert.

\section{Comprehensive Environmental Response, Compensation and Liability Act of 1980}

(CERCLA): administered by EPA, this program, also known as Superfund, requires private parties to notify the EPA after the release of hazardous substances or conditions that threaten to release hazardous substances, and undertake short-term removal and long-term remediation.

Cosmic radiation: radiation with very high energies originating outside the earth's atmosphere; it is one source contributing to natural background radiation

Cr: chromium

Cu: copper

Curie (Ci): a unit of measurement of radioactivity, defined as the amount of radioactive material in which the decay rate is $3.7 \times 10^{10}$ disintegrations per second or $2.22 \times 10^{12}$ disintegrations per minute; one $\mathrm{Ci}$ is approximately equal to the decay rate of one gram of pure radium

D Daughter nuclide: a nuclide formed by the radioactive decay of another nuclide, which is called the parent

De minimis: shortened form of "de minimis non curat lex," which means, "The law does not care for, or take notice of, very small or trifling matters," meaning a level that is so inconsequential that it cannot be cause for concern

Depleted uranium: uranium having a lower proportion of the isotope ${ }^{235} \mathrm{U}$ than is found in naturally occurring uranium. The masses of the three uranium isotopes with atomic weights 238 , 235 , and 234 occur in depleted uranium in the weight-percentages $99.8,0.2$, and $5 \times 10^{-4}$, respectively. Depleted uranium is sometimes referred to as D-38.

Derived Concentration Guide (DCG): concentrations of radionuclides in water and air that could be continuously consumed or inhaled for one year and not exceed the DOE primary radiation standard to the public (100 mrem/y EDE)

Dose: the energy imparted to matter by ionizing radiation; the unit of absorbed dose is the rad, equal to 0.01 joules per kilogram for irradiated material in any medium

Dose commitment: the dose that an organ or tissue would receive during a specified period of time (e.g., 50 or 70 years) as a result of one year's intake of one or more radionuclides

Dose equivalent: the product of absorbed dose in rad (or gray) in tissue and a quality factor representing the relative damage caused to living tissue by different kinds of radiation, and perhaps other modifying factors representing the distribution of radiation, etc. expressed in units of rem or sievert $(1 \mathrm{rem}=0.01$ sievert $)$

Dosimeter: a portable detection device for measuring the total accumulated exposure to ionizing radiation 
Dosimetry: the theory and application of the principles and techniques of measuring and recording radiation doses

Downgradient: in the direction of groundwater flow from a designated area; analogous to downstream

Drainage Retention Basin (DRB): man-made, lined pond used to capture storm water runoff and treated water at the LLNL Livermore site

E Effective dose equivalent (EDE): an estimate of the total risk of potential effects from radiation exposure, it is the summation of the products of the dose equivalent and weighting factor for each tissue. The weighting factor is the decimal fraction of the risk arising from irradiation of a selected tissue to the total risk when the whole body is irradiated uniformly to the same dose equivalent. These factors permit dose equivalents from nonuniform exposure of the body to be expressed in terms of an effective dose equivalent that is numerically equal to the dose from a uniform exposure of the whole body that entails the same risk as the internal exposure (ICRP 1980). The effective dose equivalent includes the committed effective dose equivalent from internal deposition of radionuclides and the effective dose equivalent caused by penetrating radiation from sources external to the body, and is expressed in units of rem (or sievert).

Effluent: a liquid or gaseous waste discharged to the environment

Emergency Planning and Community Right-to-Know Act of 1986 (EPCRA): act that requires facilities that produce, use, or store hazardous substances to report releases of reportable quantities or hazardous substances to the environment

Environmental impact report (EIR): a detailed report prepared pursuant to CEQA on the environmental impacts from any action carried out, approved, or funded by a California state, regional, or local agency

Environmental impact statement (EIS): a detailed report, required by the National Environmental Policy Act, on the environmental impacts from a federally approved or funded project. An EIS must be prepared by a federal agency when a "major" federal action that will have "significant" environmental impacts is planned.

Evapotranspiration: a process by which water is transferred from the soil to the air by plants that take the water up through their roots and release it through their leaves and other aboveground tissue

F Federal facility: a facility that is owned or operated by the federal government, subject to the same requirements as other responsible parties when placed on the Superfund National Priorities List

Federal facility agreement (FFA): a negotiated agreement that specifies required actions at a federal facility as agreed upon by various agencies (e.g., EPA, RWQCB, and DOE).

Federal Register: a document published daily by the federal government containing notification of government agency actions, including notification of EPA and DOE decisions concerning permit applications and rule-making

Freon 11: trichlorofluoromethane

Freon 113: 1,1,2-trichloro-1,2,2-trifluoroethane; also known as CFC 113

G Gamma ray: high-energy, short-wavelength, electromagnetic radiation emitted from the nucleus of an atom, frequently accompanying the emission of alpha or beta particles 
Gram (g): the standard metric measure of weight approximately equal to 0.035 ounce

Gray (Gy): the SI unit of measure for absorbed dose; the quantity of energy imparted by ionizing radiation to a unit mass of matter, such as tissue. One gray equals 100 rads, or 1 joule per kilogram.

Groundwater: all subsurface water

H Half-life (radiological): the time required for one-half the radioactive atoms in a given amount of material to decay; for example, after one half-life, half of the atoms will have decayed; after two halflives, three-fourths; after three half-lives, seven-eighths; and so on, exponentially

Hazardous waste: hazardous wastes exhibit any of the following characteristics: ignitability, corrosivity, reactivity, or EP-toxicity (yielding toxic constituents in a leaching test), but other wastes that do not necessarily exhibit these characteristics have been determined to be hazardous by EPA. Although the legal definition of hazardous waste is complex, according to EPA the term generally refers to any waste that, if managed improperly, could pose a threat to human health and the environment.

(California) Hazardous Waste Control Act (HWCA): legislation specifying requirements for hazardous waste management in California

Hg: mercury

High-efficiency particulate air filter (HEPA): a throwaway, extended-media, dry type filter used to capture particulates in an air stream; HEPA collection efficiencies are at least $99.97 \%$ for 0.3 micrometer diameter particles

Hexahydro-1,3,5-trinitro-1,3,5-triazine (RDX): a high-explosive compound

High explosives (HE): materials that release large amounts of chemical energy when detonated

Hydraulic gradient: in an aquifer, the rate of change of total head (water-level elevation) per unit distance of flow at a given point and in a given direction

Hydrology: the science dealing with the properties, distribution, and circulation of natural water systems

I Inorganic compounds: compounds that either do not contain carbon or do not contain hydrogen along with carbon, including metals, salts, and various carbon oxides (e.g., carbon monoxide and carbon dioxide).

In situ: refers to the treatment of contaminated areas in place without excavation or removal, as in the in situ treatment of on-site soils through biodegradation of contaminants

Interim status: a legal classification allowing hazardous waste incinerators or other hazardous waste management facilities to operate while EPA considers their permit applications, provided that they were under construction or in operation by November 19, 1980 and can meet other interim status requirements

International Commission on Radiological Protection (ICRP): an international organization that studies radiation, including its measurement and effects

Interquartile range (IQR): the distance between the top of the lower quartile and the bottom of the upper quartile, which provides a measure of the spread of data

Isotopes: forms of an element having the same number of protons in their nuclei, but differing numbers of neutrons 
L Less than detection limits: a phrase indicating that a chemical constituent was either not present in a sample, or is present in such a small concentration that it cannot be measured by a laboratory's analytical procedure, and therefore is not identified or not quantified at the lowest level of sensitivity.

Liter (L): the SI measure of capacity approximately equal to 1.057 quart

Livermore Water Reclamation Plant (LWRP): the City of Livermore's municipal wastewater treatment plant, which accepts discharges from the LLNL Livermore site

Low-level waste: waste defined by DOE Order 5820.2A, which contains transuranic nuclide concentrations less than $100 \mathrm{nCi} / \mathrm{g}$

Lower limit of detection: the smallest concentration or amount of analyte that can be detected in a sample at a $95 \%$ confidence level

Lysimeter: an instrument for measuring the water percolating through soils and determining the dissolved materials

M Maximally exposed individual (MEI): a hypothetical member of the public at a fixed location who, over an entire year, receives the maximum effective dose equivalent (summed over all pathways) from a given source of radionuclide releases to air. Generally, the MEI is different for each source at a site.

Multiple completion: a borehole with water surveillance monitoring devices (Barcads) placed at various levels and separated by impermeable layers of material such as grout. Usually referred to as a well, the uppermost "completion" is accessible from the surface, making physical sample-taking possible (as opposed to Barcads).

Mixed waste: waste that has the properties of both hazardous and radioactive waste

N National Emission Standards for Hazardous Air Pollutants (NESHAPs): standards found in the Clean Air Act that set limits for hazardous air pollutants

National Environmental Policy Act (NEPA): federal legislation enacted in 1969 that requires all federal agencies to document and consider environmental impacts for federally funded or approved projects and the legislation under which DOE is responsible for NEPA compliance at LLNL

National Institute for Standards and Technology (NIST): the federal agency, formerly known as the National Bureau of Standards, responsible for reference materials against which laboratory materials are calibrated

National Pollutant Discharge Elimination System (NPDES): federal regulation under the Clean Water Act that requires permits for discharges into surface waterways

NEWTRIT: model used to calculate doses from environmental measurements

Ni: nickel

Nonpoint source: any nonconfined area from which pollutants are discharged into a body of water (e.g., agricultural runoff, construction runoff, and parking lot drainage), or into air (e.g., a pile of uranium tailings)

Nuclear Regulatory Commission (NRC): the federal agency charged with oversight of nuclear power and nuclear machinery and applications not regulated by DOE or the Department of Defense 
Nuclide: a species of atom characterized by the constitution of its nucleus. The nuclear constitution is specified by the number of protons, number of neutrons, and energy content; or, alternatively, by the atomic number, mass number, and atomic mass. To be regarded as a distinct nuclide, the atom must be capable of existing for a measurable length of time.

O Off-site: outside the boundaries of the LLNL Livermore site and Site 300 properties On-site: within the boundaries of the LLNL Livermore site or Site 300 properties

P Part B permit: the second, narrative section submitted by generators in the RCRA permitting process that covers in detail the procedures followed at a facility to protect human health and the environment

Parts per billion (ppb): a unit of measure for the concentration of a substance in its surrounding medium; for example, one billion grams of water containing one gram of salt has a salt concentration of one part per billion

Parts per million (ppm): a unit of measure for the concentration of a substance in its surrounding medium; for example, one million grams of water containing one gram of salt has a salt concentration of one part per million

Pb: lead

Perched aquifer: aquifer that is separated from another water-bearing stratum by an impermeable layer

Performance standards (incinerators): specific regulatory requirements established by EPA limiting the concentrations of designated organic compounds, particulate matter, and hydrogen chloride in incinerator emissions

pH: a measure of hydrogen ion concentration in an aqueous solution. Acidic solutions have a $\mathrm{pH}$ from 0 to 6; basic solutions have a $\mathrm{pH}$ greater than 7; and neutral solutions have a $\mathrm{pH}$ of 7 .

Piezometer: instrument for measuring fluid pressure used to measure the elevation of the water table in a small, nonpumping well

Pliocene: geological epoch of the Tertiary period, starting about 12 million years ago

PM-10: fine particulate matter with an aerodynamic diameter equal to or less than 10 microns

Point source: any confined and discrete conveyance (e.g., pipe, ditch, well, or stack)

Pretreatment: any process used to reduce a pollutant load before it enters the sewer system

Pretreatment regulations: national wastewater pretreatment regulations, adopted by EPA in compliance with the 1977 amendments to the Clean Water Act, which required that EPA establish pretreatment standards for existing and new industrial sources

Priority pollutants: a set of organic and inorganic chemicals identified by EPA as indicators of environmental contamination

Q Quality assurance (QA): a system of activities whose purpose is to provide the assurance that standards of quality are attained with a stated level of confidence

Quality control (QC): procedures used to verify that prescribed standards of performance are attained 
Quality factor: the factor by which the absorbed dose ( $\mathrm{rad})$ is multiplied to obtain a quantity that expresses (on a common scale for all ionizing radiation) the biological damage to exposed persons, usually used because some types of radiation, such as alpha particles, are biologically more damaging than others. Quality factors for alpha, beta, and gamma radiation are in the ratio 20:1:1.

Quaternary: the geologic era encompassing the last 2-3 million years

R Rad: the unit of absorbed dose and the quantity of energy imparted by ionizing radiation to a unit mass of matter such as tissue, and equal to 0.01 joule per kilogram, or 0.01 gray.

Radioactive decay: the spontaneous transformation of one radionuclide into a different nuclide (which may or may not be radioactive), or de-excitation to a lower energy state of the nucleus by emission of nuclear radiation, primarily alpha or beta particles, or gamma rays (photons)

Radioactivity: the spontaneous emission of nuclear radiation, generally alpha or beta particles, or gamma rays, from the nucleus of an unstable isotope

Radionuclide: an unstable nuclide. See nuclide and radioactivity.

Regional Water Quality Control Board (RWQCB): the California regional agency responsible for water quality standards and the enforcement of state water quality laws within its jurisdiction. California is divided into a number of RWQCBs; the Livermore site is regulated by the San Francisco Bay Region, and Site 300 is regulated by the Central Valley Region.

Rem: a unit of radiation dose equivalent and effective dose equivalent describing the effectiveness of a type of radiation to produce biological effects; coined from the phrase "roentgen equivalent man," and the product of the absorbed dose ( $\mathrm{rad})$, a quality factor $(\mathrm{Q})$, a distribution factor, and other necessary modifying factors. One rem equals 0.01-sievert.

Resource Conservation and Recovery Act of 1976 (RCRA): a program of federal laws and regulations that govern the management of hazardous wastes, and applicable to all entities that manage hazardous wastes

Risk assessment: the use of established methods to measure the risks posed by an activity or exposure by evaluating the relationship between exposure to radioactive substances and the subsequent occurrence of health effects and the likelihood for that exposure to occur

Roentgen (R): a unit of measurement used to express radiation exposure in terms of the amount of ionization produced in a volume of air

S Sampling and Analysis Plan: a detailed document that describes the procedures used to collect, handle, and analyze groundwater samples, and details quality control measures that are implemented to ensure that sample-collection, analysis, and data-presentation activities meet the prescribed requirements

San Francisco Bay Regional Water Quality Control Board (SFBRWCB): the local agency responsible for regulating stationary air emission sources (including the Livermore site) in the San Francisco Bay Area

San Joaquin County Health District (SJCHD): the local agency that enforces underground-tank regulations in San Joaquin County, including Site 300

San Joaquin Valley Unified Air Pollution Control District (SJVUAPCD): the local agency responsible for regulating stationary air emission sources (including Site 300) in San Joaquin County 
Sanitary waste: most simply, waste generated by routine operations that is not regulated as hazardous or radioactive by state or federal agencies

Saturated zone: a subsurface zone below which all rock pore-space is filled with water; also called the phreatic zone

Sensitivity: the capability of methodology or instrumentation to discriminate between samples having differing concentrations or containing varying amounts of analyte

Sewerage: the system of sewers

Sievert (Sv): the SI unit of radiation dose equivalent and effective dose equivalent, that is the product of the absorbed dose (gray), quality factor $(\mathrm{Q})$, distribution factor, and other necessary modifying factors. 1 Sv equals 100 rem.

Sitewide Maximally Exposed Individual (SW-MEI): a hypothetical person who receives, at the location of a given publicly accessible facility (such as a church, school, business, or residence), the greatest LLNL-induced effective dose equivalent (summed over all pathways) from all sources of radionuclide releases to air at a site. Doses at this receptor location caused by each emission source are summed, and yield a larger value than for the location of any other similar public facility. This individual is assumed to continuously reside at this location 24 hours per day, 365 days per year.

Specific conductance: measure of the ability of a material to conduct electricity; also called conductivity

Superfund: the common name used for the Comprehensive Environmental Response, Compensation and Liability Act of 1980 (CERCLA). California has also established a "State Superfund" under provisions of the California Hazardous Waste Control Act.

Superfund Amendments and Reauthorization Act (SARA): act enacted in 1986, which amended and reauthorized CERCLA for five years at a total funding level of $\$ 8.5$ billion

Surface impoundment: a facility or part of a facility that is a natural topographic depression, manmade excavation, or diked area formed primarily of earthen materials, although it may be lined with man-made materials. The impoundment is designed to hold an accumulation of liquid wastes, or wastes containing free liquids, and is not an injection well. Examples of surface impoundments are holding, storage, settling and aeration pits, ponds, and lagoons.

Système International d'Unités (SI): an international system of physical units which include meter (length), kilogram (mass), kelvin (temperature), becquerel (radioactivity), gray (radioactive dose), and sievert (dose equivalent)

T Thermoluminescent dosimeter (TLD): a device used to measure external beta or gamma radiation levels, and which contains a material that, after exposure to beta or gamma radiation, emits light when processed and heated

Total dissolved solids (TDS): the portion of solid material in a waste stream that is dissolved and passed through a filter

Total organic carbon (TOC): the sum of the organic material present in a sample

Total organic halides (TOX): the sum of the organic halides present in a sample

Total suspended solids (TSS): the total mass of particulate matter per unit volume suspended in water and wastewater discharges that is large enough to be collected by a 0.45 micron filter 
Tritium: the radioactive isotope of hydrogen, containing one proton and two neutrons in its nucleus, which decays at a half-life of 12.3 years by emitting a low-energy beta particle

Transuranic waste (TRU): material contaminated with alpha-emitting transuranium nuclides, which have an atomic number greater than 92 (e.g. ${ }^{239} \mathrm{Pu}$ ), half-lives longer than 20 years, and are present in concentrations greater than $100 \mathrm{nCi} / \mathrm{g}$ of waste

U Unsaturated zone: that portion of the subsurface in which the pores are only partially filled with water and the direction of water flow is vertical; is also referred to as the vadose zone.

U.S. Department of Energy (DOE): the federal agency responsible for conducting energy research and regulating nuclear materials used for weapons production

U.S. Environmental Protection Agency (EPA): the federal agency responsible for enforcing federal environmental laws. Although some of this responsibility may be delegated to state and local regulatory agencies, EPA retains oversight authority to ensure protection of human health and the environment.

V Vadose zone: the partially saturated or unsaturated region above the water table that does not yield water to wells

Volatile organic compound (VOC): liquid or solid organic compounds that have a high vapor pressure at normal pressures and temperatures and thus tend to spontaneously pass into the vapor state

W Waste accumulation area (WAA): an officially designated area that meets current environmental standards and guidelines for temporary (less than 90 days) storage of hazardous waste before pickup by the Hazardous Waste Management Division for off-site disposal

Wastewater treatment system: a collection of treatment processes and facilities designed and built to reduce the amount of suspended solids, bacteria, oxygen-demanding materials, and chemical constituents in wastewater

Water table: the water-level surface below the ground at which the unsaturated zone ends and the saturated zone begins, and the level to which a well that is screened in the unconfined aquifer would fill with water

Weighting factor: a tissue-specific value used to calculate dose equivalents which represents the fraction of the total health risk resulting from uniform, whole-body irradiation that could be contributed to that particular tissue. The weighting factors used in this report are recommended by the International Commission on Radiological Protection (ICRP 1980).

Wind rose: a diagram that shows the frequency and intensity of wind from different directions at a specific location

Z Zn: zinc

Zone 7: the common name for the Alameda County Flood Control and Water Conservation District 


\section{Reader Survey and Data Supplement Order Form}

Our goal in providing this report is to give you a clear accounting of the range of environmental activities we undertake, the methods we employ, and the degree of accuracy of our results. It is important that the information we provide is easily understood, is of interest, and communicates LLNL's efforts to protect human health and the environment and to comply with environmental regulations. We would like to know from you whether we are successful in these goals. Your comments are welcome.

1. Is the technical level $\square$ too high? $\square$ too low? $\square$ uneven?

2. Is the writing $\square$ too concise? $\square$ too verbose?

uneven? $\square$ just right?

3. Do the illustrations help you understand the text better?

Are there enough?

Too few?

Too many?

4. Is the background information sufficient?

5. Are the methodologies being described understandable? Interesting?

6. Are the glossaries and appendices useful?

7. Are the data tables of interest?

Would you prefer short summaries of data trends instead? Other comments:

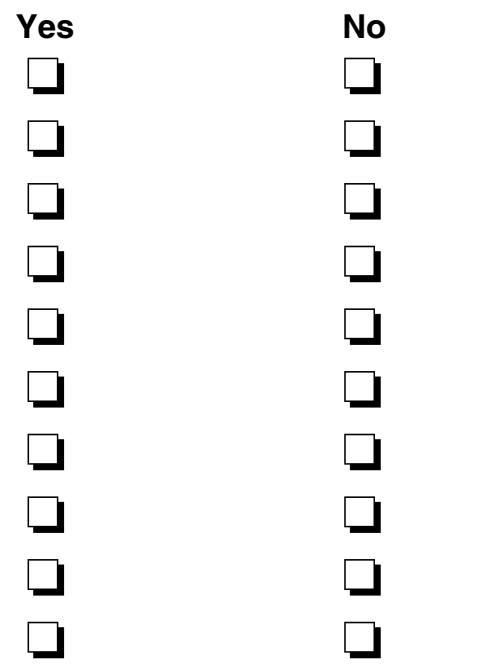

OPTIONAL: If you complete this reader survey but do not wish to order a Data Supplement, providing the following information here would be helpful:

Name: Occupation:

Address:

\section{Data Supplement Order Form}

$\square$ Please send me a copy of the LLNL Site Annual Environmental Report 2000 Data Supplement. My name and address are:

To return this reader survey and data supplement order form to the Laboratory, please detach it, fold it with this side in, tape it closed, and mail it. Laboratory staff may simply send their survey forms through Lab mail to Art Biermann, L-629. 
Please fold on dotted line and seal before mailing.

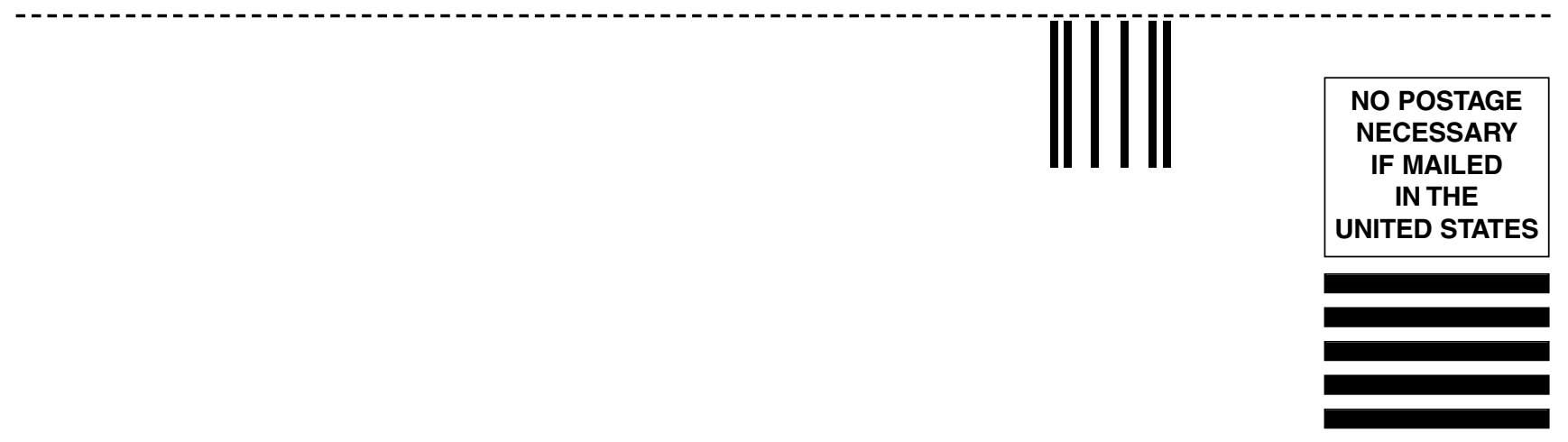

\section{BUSINESS REPLY MAIL}

FIRST-CLASS MAIL PERMIT NO. 16 LIVERMORE, CA

POSTAGE WILL BE PAID BY THE LLNL

University of California

Lawrence Livermore National Laboratory

Attn: Art Biermann

L-629

P.O. Box 808

Livermore, California 94551-0808

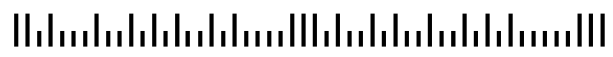





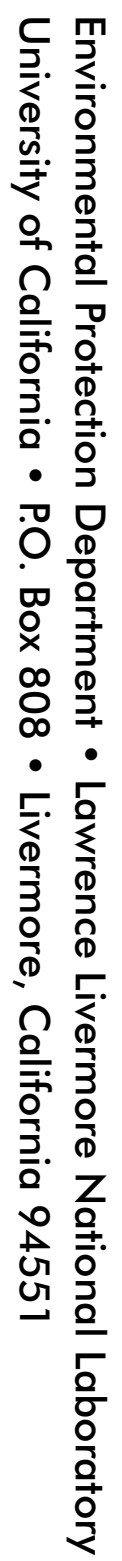

